\title{
ZARZĄDZANIE \\ OBSZARAMI METROPOLITALNYMI WOBEC GLOBALNYCH PROCESÓW URBANIZACJI
}


$\frac{3}{40}$ 


\author{
Justyna Danielewicz
}

\title{
ZARZĄDZANIE \\ OBSZARAMI METROPOLITALNYMI WOBEC GLOBALNYCH PROCESÓW URBANIZACJI
}

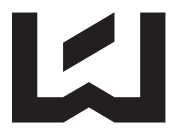

WYDAWNICTWO 
Justyna Danielewicz - Katedra Zarządzania Miastem i Regionem

Wydział Zarządzania, Uniwersytet Łódzki, 90-237 Łódź, ul. Matejki 22/26

\author{
RECENZENT \\ Florian Kuźnik \\ REDAKCJA TECHNICZNA I JĘZYKOWA \\ Bogustaw Pielat
}

SKŁAD I ŁAMANIE

Karolina Dmochowska-Dudek

OKŁADKĘ PROJEKTOWAŁA

Karolina Dmochowska-Dudek

Na okładce wykorzystano zdjęcie autorstwa Doroty Sikory-Fernandez

Wydrukowano z gotowych materiałów dostarczonych do Wydawnictwa UŁ

(C) Copyright by Uniwersytet Łódzki, Łódź 2013

Wydane przez Wydawnictwo Uniwersytetu Łódzkiego
Wydanie I. W.06276.13.0.H

ISBN (wersja drukowana) 978-83-7525-914-8

ISBN (ebook) 978-83-7969-313-9

Wydawnictwo Uniwersytetu Łódzkiego

90-131 Łódź, ul. Lindleya 8

www.wydawnictwo.uni.lodz.pl

e-mail: ksiegarnia@uni.lodz.pl

tel. (42) 6655863 , faks (42) 6655862 


\section{Spis treści}

WSTĘP . .9

I. GLOBALIZACJA A ROZWóJ OBSZARÓW ZURBANIZOWANYCH...................17

1. Obszary zurbanizowane wobec globalizacji ekonomicznej...................17

2. Globalizacja i polaryzacja przestrzeni ......................................................22

3. Zmiany w sferze politycznej a funkcjonowanie obszarów zur-

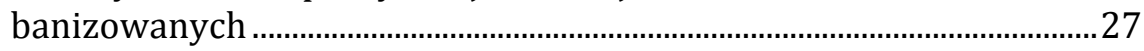

3.1. Malejąca suwerenność instytucji państwa ………………………….......31

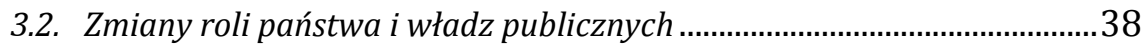

3.3. Miasta światowe jako „lokomotywy" rozwoju ............................................42

4. Nowe procesy urbanizacji w gospodarce globalnej ...................................48

5. Urbanizacja w Polsce ................................................................................52

6. Nowe podejście do zarządzania w miastach i ich otoczeniu .................57

\section{METROPOLIZACJA PRZESTRZENI I ROZWÓJ OBSZARÓW} METROPOLITALNYCH.........................................................................................

1. Definicje metropolii i obszaru metropolitalnego …………………….......71

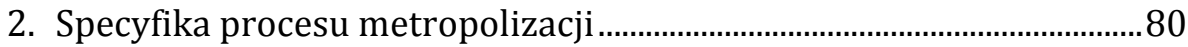

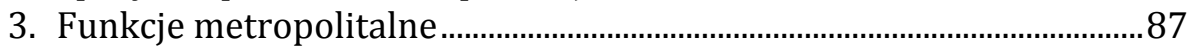

4. Delimitacja obszarów metropolitalnych....................................................89

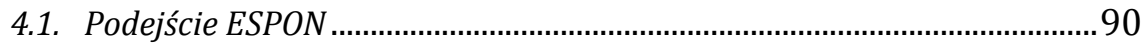

4.2. Szersze strefy miejskie według programu Urban Audit............................92

4.3. Delimitacja według Unii Metropolii Polskich............................................93

4.4. Delimitacja obszarów metropolitalnych według P. Śleszyńskiego............94

4.5. Delimitacja według Wojewódzkich Biur Planowania Przestrzennego....96

5. Problemy obszarów metropolitalnych ......................................................99

6. Polskie metropolie na tle metropolii światowych ................................... 107

\section{WSPÓŁCZESNE KONCEPCJE I KIERUNKI METROPOLITALNEGO} ZARZĄDZANIA..

1. Rola władz publicznych w świetle koncepcji zarządzania..................113

2. Corporate governance jako źródło koncepcji metropolitan governance.... 131 
3. Definicja zarządzania metropolitalnego (metropolitan governance)

4. Interesariusze metropolitan governance

5. Zasady zarządzania w obszarach metropolitalnych (metropolitan governance)

6. Cele metropolitan governance …………................................................155

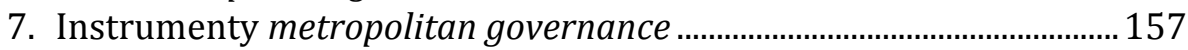

8. Mierniki efektywności metropolitan governance …………………….... 168

9. Bariery metropolitan governance ............................................................... 171

\section{METROPOLITALNE ZARZĄDZANIE W WYBRANYCH KRAJACH} EUROPY. 177

1. Współpraca na poziomie metropolitalnym we Francji .........................178

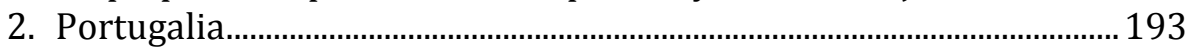

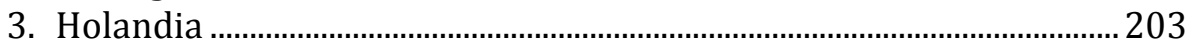

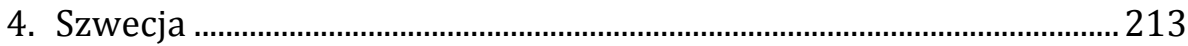

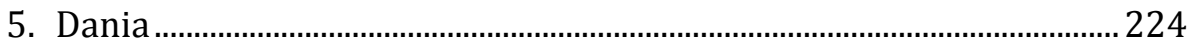

6. Niemcy - różne modele zarządzania obszarami metropolitalnymi .....232

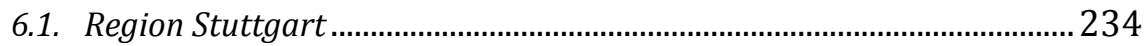

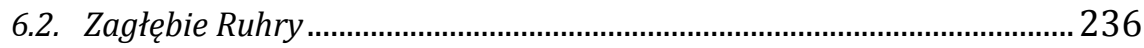

6.3. Obszar Metropolitalny Monachium ..................................................... 238

6.4. Region Metropolitalny Hamburga ……………………........................ 241

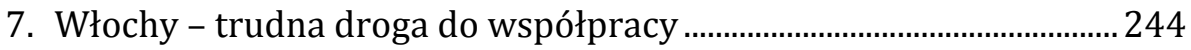

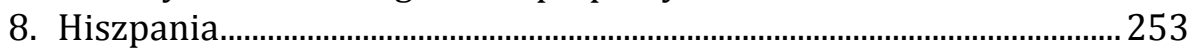

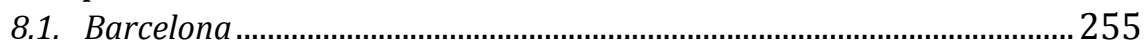

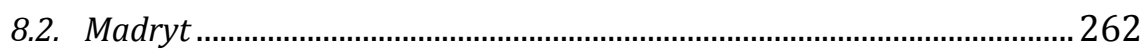

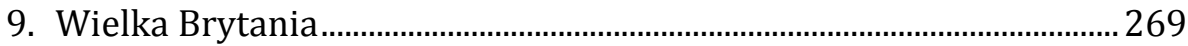

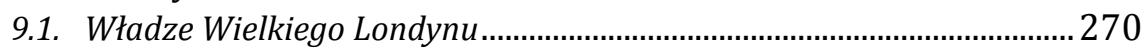

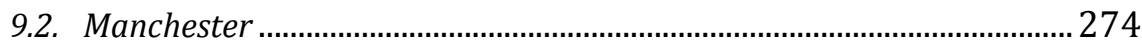

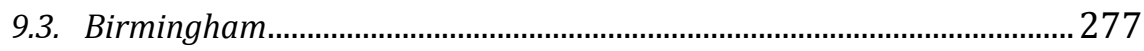

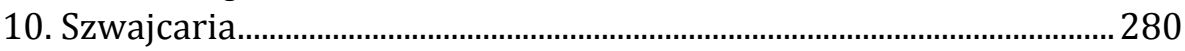

11. Podsumowanie sposobów zarządzania obszarami metropolital-

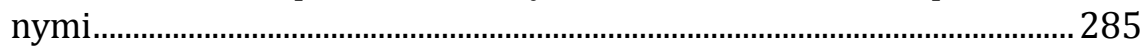

V. METROPOLITALNE ZARZĄDZANIE W POLSCE.............................................297

1. Obszary metropolitalne wobec procesów globalizacji .........................297

2. Podejście do obszarów metropolitalnych w dokumentach kra-

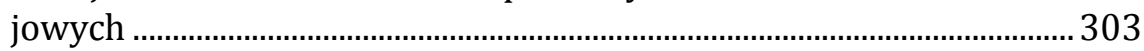

3. Projekty ustaw metropolitalnych ........................................................... 310

4. Doświadczenia obszarów metropolitalnych w zakresie współpracy

4.1. Formy wspótpracy dopuszczalne przez prawo

4.2. Analiza związków międzygminnych $w$ obszarach metropolitalnych ....322 


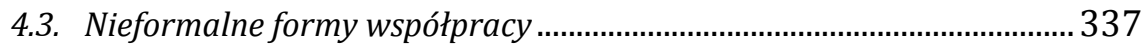

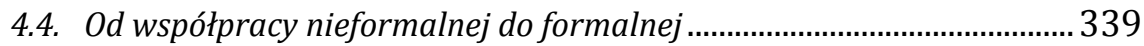

4.5. Szczególne problemy występujące w obszarach metropolitalnych........ 348

4.6. Wnioski z przeglądu studiów przypadku .........................................................352

5. Współrządzenie w obszarach metropolitalnych w świetle przeprowadzonych badań .................................................................................. 353

6. Potencjalne instrumenty metropolitalnego zarządzania w świetle zasad metropolitan governance .............................................................. 364

WNIOSKI I REKOMENDACJE_..........................................................................................369

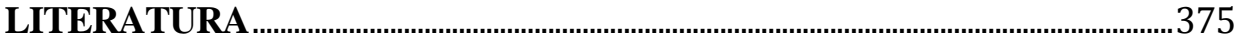

SPIS TABEL

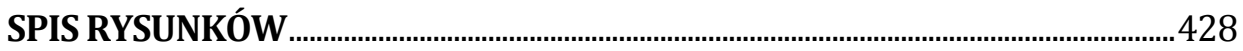

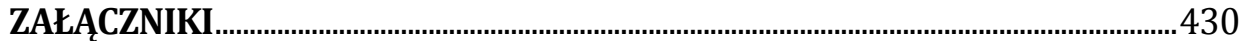





\section{WSTĘP}

Jednym z najważniejszych procesów kształtujących obecnie przestrzeń wielkich aglomeracji miejskich jest globalizacja oraz będąca jej konsekwencją metropolizacja. Procesy globalizacji i związana z nimi liberalizacja rynków spowodowały wzrost znaczenia czynników lokalizacji jednostek gospodarczych oraz ludności w wielkich obszarach zurbanizowanych. Konsekwencją tego procesu są przekształcenia wewnętrznych struktur miast, a nierzadko zmiany w kształtowaniu całych układów osadniczych. Są to następstwa nie tylko zjawisk i procesów gospodarczych, ale także przemian cywilizacyjnych, postępu techniczno-technologicznego, rozwoju komunikacji, ewolucji modelu konsumpcji, wzrostu poziomu wykształcenia, stylu życia, oczekiwań w zakresie warunków bytowych oraz zmieniającego się znaczenia dostępności przestrzennej. Zjawiskom tym towarzyszy wzrost i zróżnicowanie cen ziemi i nieruchomości zarówno w miastach, jak i w ich bezpośrednim otoczeniu. W miastach zmieniają się formy zagospodarowania, następuje rozwój funkcji dochodotwórczych, metropolitalnych oraz funkcji związanych z obsługą ludności. Wraz ze wzrostem poziomu dochodów ludności pogłębia się zjawisko zróżnicowania dochodów, a także, co jest oczywistym następstwem tego faktu, pojawiają się odmienności w zakresie preferencji miejsca zamieszkania.

Metropolizacja przestrzeni nie jest wynikiem świadomych działań planistycznych. Jest efektem procesów o podłożu ekonomicznym, w tym m.in. możliwości pozyskiwania czynników produkcji, obsługi instytucji otoczenia okołobiznesowego i niższych kosztów pozyskiwania siły roboczej o pożądanych kwalifikacjach. Metropolie odgrywają kluczową rolę w rozwoju społeczno-gospodarczym regionów i krajów. Będąc miejscami skupiającymi bogactwo i wiedzę, są głównymi podmiotami gospodarczego wzrostu i przyszłego dobrobytu społeczeństw. Spowodowane jest to wzrostem otwartości gospodarki na handel zagraniczny i swobodny przepływ kapitału, wysoką innowacyjnością, rozwojem nowych technologii, rozbudową wyspecjalizowanej infrastruktury, a także rosnącą skłonnością społeczeństwa do konsumpcji. Tutaj koncentrują się nowoczesne gałęzie produkcji i wysoko wykwalifikowani pracownicy, specjalistyczne usługi, instytucje finansowe, kulturalne i naukowe. Proces koncentracji funkcji i kapitału powoduje szereg interakcji między różnymi aktorami. Polegają one na 
wymianie informacji, dóbr, ludzi, komunikacji, kooperacji itp. Wymiana ta sprzyja budowaniu sieci, które stanowią podstawę innowacji, wzrostu gospodarczego i konkurencyjności obszarów metropolitalnych. Obszar metropolitalny stanowi funkcjonalnie powiązaną, wspólną przestrzeń działań społeczno-gospodarczych dla pewnej grupy podmiotów publicznych, prywatnych i społecznych. Procesy rozwoju obszarów metropolitalnych są wypadkową aktywności poszczególnych podmiotów funkcjonujących $w$ rozpatrywanych obszarach, których interesy, cele i dążenia nie zawsze pozostają zbieżne.

Obszar metropolitalny cechuje się dużym stopniem integracji gospodarczej, infrastrukturalnej, zwłaszcza komunikacyjnej oraz społecznokulturowej. Występują w nim naturalne ciążenia obszaru zewnętrznego do centrum metropolii, która oddziałuje na okoliczne obszary w sferze pracy, obsługi, kształcenia, kultury, opieki zdrowotnej. Obszary metropolitalne są również miejscami konfliktów różnych grup interesów i lokalnych władz.

W dobie postępującej globalizacji i metropolizacji obszary metropolitalne konkurują między sobą o uzyskanie wiodącej pozycji na arenie międzynarodowej. Aby to konkurowanie było skuteczne konieczne jest efektywne współzarządzanie terytorium, które składa się z wielu jednostek administracyjnych powiązanych ze sobą relacjami funkcjonalnymi. Każda z tych jednostek ma w pełni autonomiczne władze. Samorządy gmin, funkcjonujące w ramach jednego układu funkcjonalnego, często ze sobą konkurują (o kapitał, mieszkańców, środki finansowe) zamiast współpracować, przyczyniając się do polaryzacji rozwoju obszaru metropolitalnego. Sytuację dodatkowo komplikuje silna fragmentacja polityczna na wszystkich poziomach zarządzania oraz kadencyjność władzy. Ten stan rzeczy powoduje, że samorządy patrzą na rozwój jednostki terytorialnej przez pryzmat realizacji swoich własnych celów politycznych. Takie podejście w dłuższej perspektywie jest kosztowne społecznie, gdyż prowadzi do rozwoju chaotycznego, szeregu negatywnych zjawisk ekonomicznych, społecznych, przestrzennych i środowiskowych. Aby temu zapobiec konieczna jest współpraca interesariuszy, którzy funkcjonują w obszarze metropolitalnym - począwszy od władz (lokalnych, regionalnych i centralnych), poprzez sektor prywatny po organizacje społeczeństwa obywatelskiego.

Globalizacja spowodowała też zmiany w otoczeniu władz lokalnych. Po pierwsze, zwiększyła ich rolę i uwypukliła znaczenie lokalnych obszarów gospodarczych. Kapitał międzynarodowy woli nawiązywać kontakty gospodarcze z władzami lokalnymi, a nie z rządem centralnym, gdyż to one dysponują zasobami potrzebnymi do funkcjonowania przedsiębiorstw. Druga zmiana w otoczeniu wyraża się w rozwoju społeczeństwa obywatelskiego i demokracji, która została wzmocniona przez rozkwit organizacji 
pozarządowych i społecznych oraz daleko sięgające uczestnictwo społeczeństwa w administracji samorządowej.

Trzecia zmiana spowodowana jest wprowadzeniem do polityki gospodarczej liberalnej zasady konkurencyjności i wzmocnieniem rynkowości. Wiązało się to również z dostarczaniem usług publicznych, których koszt musieli ponosić beneficjenci. Ze względu na fakt, iż osłabione zostało znaczenie korzyści publicznych, zaczęto zwracać uwagę na ułomność rynku, spowodowaną przekonaniem, że jest on w stanie rozwiązywać wszelkie problemy. Znów pojawiło się zainteresowanie równością społeczną opartą na demokratycznych i publicznych wartościach.

Kolejną zmianą jest zmiana w strukturze popytu na usługi świadczone przez administrację samorządową. W wieku XXI administracja za główne cele stawia sobie dystrybucję dobrobytu i poprawę jakości życia. Dlatego pojawiły się nowe wymogi w zakresie dobrobytu, kultury i środowiska. Obecnie mieszkańcy zgłaszają większy popyt na edukację, miejsca pracy i zabezpieczenia socjalne. Rośnie również popyt na wysokie walory środowiska naturalnego oraz zapotrzebowanie w obszarze usług kulturalnych.

Nowe wymagania zmieniły katalog zadań władz lokalnych. Mimo tego, że zadania mające na celu zaspokojenie popytu na nowe dobra i usługi zajmują istotną pozycję w politykach większości samorządów, to obecne działania władz lokalnych mogą poprawić jakość życia mieszkańców tylko pod warunkiem stworzenia silnych powiązań między obywatelami a władzami lokalnymi. Potrzebę tę już dawno dostrzeżono w obszarach metropolitalnych Stanów Zjednoczonych i Europy Zachodniej, gdzie za najlepszą metodę zarządzania uznano zarządzanie metropolitalne (metropolitan governance) ukształtowane na gruncie nowego zarządzania publicznego. Zakłada ono włączenie w proces zarządzania rozwojem jak największej liczby podmiotów i podejmowanie decyzji na drodze szerokiego consensusu. Zaspokojenie różnorodnych, często sprzecznych ze sobą, interesów nie jest proste i wymaga długotrwałego nawiązywania relacji między poszczególnymi podmiotami, opartych na wzajemnym zaufaniu. Jest to szczególnie trudne w państwach, w których mamy do czynienia ze słabo rozwiniętymi instytucjami społeczeństwa obywatelskiego i niskim poziomem kapitału społecznego, do których zalicza się Polska.

Polskie obszary metropolitalne skupiają nie w pełni wykształcone funkcje metropolitalne. Ich konkurencyjność na arenie światowej jest słaba. Tylko Warszawa jest uznawana za metropolię europejską, pozostałe obszary metropolitalne mają charakter krajowy czy regionalny. W związku z tym należy dążyć do rozwoju i umacniania funkcji metropolitalnych w innych ośrodkach. Tymczasem w Polsce, zgodnie z polityką spójności, przez lata prowadzona była polityka równomiernego rozwoju wszystkich części kraju. Nie było jasno określonej polityki w odniesieniu do dużych aglomeracji. 
Dokumenty planistyczne i strategiczne jakie powstały w ostatnich latach na szczeblu centralnym wyraźnie wskazują, że rola miast i obszarów metropolitalnych jako centrów rozwoju społeczno-gospodarczego kraju była niedoceniana. Co za tym idzie, brak jest ukształtowanego, w pełni sprawnego i skutecznego systemu zarządzania rozwojem miast. Brak jest wielu uregulowań dotyczących współpracy różnych podmiotów, gospodarki ziemią, adekwatnego systemu podatków lokalnych, efektywnego zarządzania przestrzenią publiczną itp. Ta niekorzystna sytuacja wymaga podjęcia aktywnych działań zmierzających do uregulowania - zarówno od strony prawnej, jak i instytucjonalnej - sfery planowania i zarządzania obszarami zurbanizowanymi, ze szczególnym uwzględnieniem obszarów metropolitalnych.

Zarządzanie rozwojem kształtujących się obecnie regionów miejskich wymaga w szczególności odpowiedniej struktury instytucjonalnej, której dzisiejszym obszarom metropolitalnym w Polsce brakuje. Są one bowiem, $\mathrm{w}$ sensie administracyjnym, tworem nieupodmiotowionym, co stanowi istotny problem w koordynacji procesów sterowania rozwojem. W skład obszarów metropolitalnych (wytyczanych w Polsce według różnych kryteriów) wchodzi szereg niezależnych gmin lub powiatów, które zgodnie $\mathrm{z}$ istniejącym ustawodawstwem stanowią autonomiczne podmioty władzy samorządowej, niepodlegające żadnemu hierarchicznemu podporządkowaniu. Oznacza to, że nie ma jednego ośrodka władzy, który mógłby podejmować decyzje administracyjne i „narzucać” je wyodrębnionym, samorządnym gminom wchodzącym w skład obszaru metropolitalnego. Nie ma zatem metropolitalnego ośrodka zarządzania.

Gminy wprawdzie mogą ze sobą współpracować wykorzystując dopuszczalne prawem formy organizacyjne, jak porozumienia, związki międzygminne i stowarzyszenia, ale praktyka pokazuje, że nie są one stosowane do rozwiązywania problemów o zasięgu metropolitalnym.

Polska poszukuje nowego podejścia do zarządzania obszarami metropolitalnymi, które uwzględniałoby powiązania funkcjonalne zachodzące między poszczególnymi jednostkami i pozwalało na stworzenie elastycznych struktur ponad podziałami administracyjnymi.

Mając na uwadze powyższe problemy przyjęto hipotezę, iż zasady dotyczące tworzenia struktur metropolitalnych, wynikające z koncepcji governance, są $\mathrm{w}$ polskich warunkach właściwe. Sformułowano dwie hipotezy pomocnicze:

- Samorząd Polski nie jest jeszcze przygotowany do instytucjonalizacji obszarów metropolitalnych.

- System związków gminnych nie może być podstawą wdrożenia metropolitalnego zarządzania. 
Celem pracy jest przedstawienie przesłanek dla tworzenia modelu zarządzania obszarami metropolitalnym w Polsce i weryfikacja przydatności założeń modelu metropolitan governance, który funkcjonuje w krajach wysoko rozwiniętych do warunków polskich.

Celowi głównemu pracy podporządkowane są następujące cele szczegółowe:

- pokazanie związku między globalizacją a rozwojem obszarów metropolitalnych,

- identyfikacja systemów zarządzania obszarami metropolitalnymi w państwach europejskich,

- analiza form współpracy w polskich obszarach metropolitalnych,

- rozpoznanie uwarunkowań prawnych oddziałujących na zarządzanie polskimi obszarami metropolitalnymi.

Rozprawa składa się z pięciu części. Rozdział pierwszy, poświęcony jest analizie głównych zjawisk, będących przejawem wszechobecnej globalizacji, zwłaszcza w dziedzinie gospodarki i polityki. Szczególną uwagę zwrócono na oddziaływanie procesów globalizacji gospodarczej na konkurencyjność układów terytorialnych. W dalszej kolejności omówiono zjawisko urbanizacji zachodzące $w$ Polsce na tle analogicznych procesów obserwowanych na świecie, wskazując na potrzebę wprowadzenia zmian w zarządzaniu układami funkcjonalnymi, jakimi są obszary metropolitalne.

Rozdział drugi koncentruje się na identyfikacji podstawowych pojęć związanych z metropolizacją przestrzeni. Dokonano w nim analizy różnych podejść do delimitacji obszarów metropolitalnych, w kontekście ich przydatności do tworzenia systemu zarządzania metropolitalnego, uwzględniając problemy jakie występują w metropoliach. Na koniec ukazano pozycję polskich wielkich miast na tle metropolii światowych, głównie europejskich.

Rozdział trzeci jest rozdziałem ściśle teoretycznym i przedstawia ewolucję koncepcji metropolitan governance jako najlepiej przystającej do zarządzania obszarami metropolitalnymi. Wskazano główne zasady governance, których należy przestrzegać w zarządzaniu jednostkami administracji terytorialnej oraz bariery, które trzeba pokonać w celu wdrożenia modelu metropolitalnego zarządzania.

Tematyka rozdziału czwartego koncentruje się na analizie sposobów zarządzania w obszarach metropolitalnych $w$ wybranych państwach OECD. Prześledzono jak w czasie zmieniały się modele zarządzania metropoliami. Przedstawiono dziedziny tej współpracy i główne instrumenty stymulujące rozwój całych układów. Omówiono różne podejścia (oddolne i odgórne) do instytucjonalizacji obszarów metropolitalnych.

Ostatni rozdział stanowi empiryczną warstwę pracy i bezpośrednio dotyka polskich doświadczeń $\mathrm{w}$ zakresie zarządzania obszarami metropolitalnymi. Dokonano w nim analizy podejścia do zarządzania w układach funkcjonalnych od strony dokumentów tworzonych na szczeblu państwowym, uwzględniając 
również projekty ustaw metropolitalnych. Przedstawiono formy współpracy podejmowane przez samorządy wchodzące w skład obszaru metropolitalnego zarówno formalne, jak i nieformalne. Dokonano podsumowania przeprowadzonych badań oraz weryfikacji postawionych hipotez.

Całość rozważań kończy podsumowanie zawierające rekomendacje dla władz centralnych w zakresie wdrażania systemu zarządzania układami funkcjonalnymi oraz wskazujące kierunki dalszych prac badawczych. Podkreśla się konieczność odejścia od sektorowego planowania rozwoju na rzecz zintegrowanego terytorialnego podejścia w tworzeniu polityk i strategii rozwoju oraz znaczenie zachęt finansowych dla stymulowania współpracy w obszarach metropolitalnych.

Podstawową metodą badawczą zastosowaną w części teoretycznej jest analiza opisowa. Opierając się na analizie literatury dotyczącej globalizacji, metropolizacji oraz zarządzania w sektorze publicznym dokonano:

- wskazania jak globalizacja w sferze społeczno-gospodarczej wpływa na obszary metropolitalne,

- syntetycznej charakterystyki zjawisk metropolizacji przestrzeni,

- analizy rozwoju koncepcji mertropolitan governance,

- inwentaryzacji istniejących na świecie inicjatyw i dobrych praktyk związanych z zarządzaniem w obszarach metropolitalnych,

- analizy podejść do delimitacji obszarów metropolitalnych.

Część empiryczna pracy polegała na przeanalizowaniu realnych procesów zarządzania w wybranych obszarach metropolitalnych w Polsce. W ramach przeprowadzonych prac dokonano:

- inwentaryzacji podejmowanych w Polsce inicjatyw związanych z zarządzaniem w obszarach metropolitalnych,

- inwentaryzacji związków międzygminnych utworzonych przez gminy położone w obszarach metropolitalnych,

- analizy źródeł i dokumentów zastanych, takich jak: dokumenty Komisji Europejskiej, projekty ustaw metropolitalnych, dokumenty o charakterze strategicznym przyjęte bądź tworzone przez rząd, głównie przez Ministerstwo Rozwoju Regionalnego i Ministerstwo Administracji i Cyfryzacji.

Istotną część badań stanowiły badania ankietowe przeprowadzone w gminach funkcjonujących na terenach obszarów metropolitalnych. Miały one na celu zidentyfikowanie dziedzin i form współpracy podejmowanych przez gminy oraz opinii samorządów na temat instytucjonalizacji obszarów metropolitalnych.

Dziękuję Przedstawicielom Ministerstwa Rozwoju Regionalnego za pomoc w przeprowadzeniu badania ankietowego. Serdecznie dziękuję prof. zw. dr. hab. Tadeuszowi Markowskiemu za wsparcie i motywację do prowadzenia badań oraz za cenne rady, które wywarły istotny wpływ na ostateczny kształt pracy. Pragnę również wyrazić wdzięczność za pomoc 
i wsparcie współpracownikom z Katedry Zarządzania Miastem i Regionem UŁ. Szczególne słowa podziękowania kieruję do recenzenta pracy, prof. dr. hab. Floriana Kuźnika za życzliwość i trafne sugestie dotyczące treści niniejszego opracowania. Powstanie tej publikacji nie byłoby możliwe bez wsparcia mojej Rodziny i Przyjaciół za co jestem im niezmiernie wdzięczna. 



\section{GLOBALIZACJA A ROZWÓJ OBSZARóW ZURBANIZOWANYCH}

\section{Obszary zurbanizowane wobec globalizacji ekonomicznej}

Żyjemy w czasach globalizacji. Zjawisko to objęło wszelkie aspekty życia, we wszystkich krajach świata. W literaturze znajduje się różne definicje tego pojęcia. Jedna z nich mówi, iż globalizacja jest procesem, z jednej strony spowodowanym, a z drugiej prowadzącym do, rosnącymi przepływami między granicami państw produktów, usług, pieniędzy, ludzi, informacji i kultur [Held, McGrew, Goldblatt, Perraton 1999, s. 16]. Efektem rozwoju zaawansowanych technologii informacyjnych i komunikacyjnych są zwiększone przepływy technologii, ludzi, kapitału, towarów i idei ponad granicami1. Globalizacja powoduje „kompresję czasu i przestrzeni, kurczenie się świata" [Mitellman 1996]. G. Gereffi pisze o globalnych łańcuchach towarów przez co produkcja koordynowana jest w skali globalnej [Gereffi 1994]. S. Kobrin opisuje globalizację jako zjawisko spowodowane nie przez handel i inwestycje zagraniczne, lecz przez rosnącą skalę technologii i przepływy informacji [Kobrin 1997, s. 147-148]. R. Gilpin określa globalizację jako rosnącą współzależność gospodarek narodowych w dziedzinie handlu, finansów i polityki makroekonomicznej [Gilpin 1987, s. 389]. Socjolog R. Robertson twierdzi, iż globalizacja odnosi się zarówno do kurczenia się świata, jak i intensyfikacji poczucia jedności świata jako całości [Robertson 1992, s. 8]. M. Albrow definiuje globalizację jako rozprzestrzenienie się praktyk, wartości i technologii, które ma wpływ na życie ludzi na całym świecie [Albrow 1997, s. 88]. Z kolei M. Guillen uważa ją za proces prowadzący do większej współzależności i wzajemnej świadomości wśród ekonomicznych, politycznych oraz społecznych jednostek świata i generalnie wśród różnych podmiotów [Guillen 2001, s. 236]. Według Barbary Liberskiej

globalizacja gospodarki światowej jest procesem poszerzania i pogłębiania się współzależności między krajami i regionami wskutek rosnących przepływów międzynarodowych oraz działalności korporacji transnarodowych, co prowadzi do ja-

${ }^{1}$ Więcej na ten temat pisali: Castells 1996; Appadurai 2005; McMahon 2004. 
kościowo nowych powiązań między firmami, rynkami i gospodarkami. W tym ujęciu procesy globalizacji mają dwa ściśle ze sobą powiązane wymiary: ilościowy - gdy wskazuje się na zmiany w zasięgu i wielkości, intensywności czy szybkości różnego rodzaju przepływów globalnych (towarów, usług, technologii, kapitału, informacji) oraz jakościowy - gdzie wskazuje się na nowy charakter współzależności i powiązań strukturalnych oraz technologicznych między rynkami i gospodarkami [Liberska 2002, s. 20].

Międzynarodowy Fundusz Walutowy (MFW) definiuje globalizację jako historyczny proces będący wynikiem ludzkiej innowacji i postępu technologicznego. Odnosi się to do coraz większej integracji między gospodarkami świata, odbywającej się szczególnie poprzez handel i przepływy finansowe, ale również przepływy siły roboczej i wiedzy. MFW dostrzega także kulturowy, polityczny i środowiskowy wymiar globalizacji.

Istotę globalizacji sprowadzić można do wzrostu zasięgu, zakresu, wielości i intensywności wzajemnych przepływów, oddziaływań i współzależności w wymiarze przekraczającym granice państw, regionów i kontynentów. Kojarzona jest z usuwaniem granic, liberalizacją przepływów, dyfuzją obcych wpływów i deterytorializacją coraz większej liczby zjawisk i procesów [Polak 2009, s. 8].

Ideologicznym podłożem globalizacji jest neoliberalne podejście do kwestii gospodarczych [zob.: Nesadurai 2002]. Współczesna globalizacja nie byłaby możliwa bez promowania idei wolności i konkurencji.

Wspólnym mianownikiem wszystkich definicji globalizacji jest stwierdzenie, iż powoduje ona rosnące interakcje między państwami narodowymi i społecznościami (społeczeństwem) poprzez przepływ dóbr, pieniędzy, ludzi, idei i informacji w procesie, który powoduje, że granice terytorialne stają się mniej widoczne².

Obecnie globalizacja jest postrzegana jako ogólny paradygmat w wymiarze ekonomicznym, społecznym, kulturowym i politycznym, któremu towarzyszy poszerzenie, pogłębienie i przyśpieszenie powiązań o zasięgu światowym we wszystkich aspektach współczesnego życia [Oner et al. 2010, s. 2]. Z uwagi na te powiązania, globalizację można również definiować jako rozwój sieci o wielorakich relacjach między różnymi aktorami o multikontynentalnym zasięgu [Keohane, Nye 2000, s. 2]. Globalizacja jest najbardziej dynamiczna w sferze gospodarczej. Jej następstwem jest stopniowa integracja, standaryzacja, a nawet unifikacja gospodarki światowej. K. Zorska definiuje globalizację gospodarczą jako proces integrowania coraz większej liczby krajowych gospodarek ponad ich granicami, dzięki rozszerzeniu oraz intensyfikowaniu wzajemnych powiązań (inwestycyjnych, produkcyjnych,

2 Przeglądu definicji i przyczyn globalizacji dokonała A. Zorska, zob.: Zorska 2000, s. 13-43. 
handlowych, kooperacyjnych) [Zorska 2000]. L. Żabiński określa globalizację ekonomiczną jako

długotrwały proces integrowania, scalania działalności gospodarczej wielu podmiotów (organizacji gospodarczych, jak również organizacji non-profit) dla osiągania, efektywniejszego niż konkurenci, celów rozwojowych, społecznych, ekonomicznych, w tym celów rynkowych i finansowych. Podmiotami tymi mogą być odpowiednio gospodarki narodowe, regiony, sub- czy ponadnarodowe, przedsiębiorstwa. $\mathrm{W}$ wyniku tego procesu powstają globalne, często otwarte, wielopoziomowe systemy ponadnarodowe czy ponadkontynentalne, o współzależnościach wewnętrznych i zewnętrznych. Dzięki tym współzależnościom i odbywającej się syntezie wielu, nierzadko przeciwstawnych procesów, takich jak: uniwersalizacja vs. regionalizacja, integracja vs. fragmentacja, homogenizacja vs. dyferencjacja pojawiają się nieznane dotąd co do rozmiarów i zasięgu efekty synergii, dyfuzji, transferu, upodobniania, kompresji czasu i przestrzeni [Żabiński 2003, s. 119].

Z ekonomicznego punktu widzenia globalizacja oznacza, że granice między narodowymi państwami i różnice między rynkami finansowymi stały się dużo mniej ważne.

Do przyczyn tej sytuacji należą:

- globalizacja finansów,

- rosnące znaczenie przedsiębiorstw międzynarodowych,

- globalne bezpośrednie inwestycje zagraniczne (BIZ) z Ameryki Północnej, z Zachodniej Europy i Azji Wschodniej (głównie Japonii),

- globalna specjalizacja w lokowaniu produkcji (nowy międzynarodowy podział pracy),

- globalizacja trzeciego sektora gospodarki,

- globalizacja funkcji biurowych,

- globalna turystyka [Graizbord, Rowland, Aguilar 2003, s. 503].

Oprócz współzależności kolejną cechą globalizacji gospodarczej jest

rozszerzanie się skali ponadnarodowych operacji - sprzedaży towarów i usług, przepływu różnych form kapitału, inwestycji, transferu technologii, podróży biznesowych, połączeń komunikacyjnych, migracji związanych z pracą itd. [...] Towarzysząca temu homogenizacja wzorów i metod zarządzania prowadzi do konwergencji, czyli upodobniania się struktur gospodarczych [Waściński 2004, s. 20].

W kurczącym się świecie spadają koszty transportu i komunikacji ponieważ kompresja czasu i przestrzeni zbliża różne miejsca ${ }^{3}$. Jednym z przejawów globalizacji jest z jednej strony niespotykane na taką skalę rozprzestrzenianie się innowacji, a z drugiej strony absorpcja wszelkiego rodzaju nowości.

Globalne korporacje sprzedają standardowe produkty w taki sam sposób na całym świecie. Korporacje wielonarodowe, które działały w różnych

${ }^{3}$ Zob.: Harvey 1989; Krugman, Venables 1995. 
krajach i dostosowały swoją ofertę do oczekiwań danego społeczeństwa, stają się organizacjami przestarzałymi. Ogólnoświatowy przepływ informacji spowodował, że obecnie te same kraje, które apelują o uznanie i poszanowanie ich lokalnych tożsamości kulturowych, jednocześnie nalegają na sprzedawanie im tych samych nowoczesnych produktów, usług i technologii. Nawet w najbardziej odległych zakątkach świata oczekuje się takich samych produktów, które mają tę samą jakość, są tak samo zaawansowane technologicznie. Minęły czasy, kiedy przedsiębiorstwa mogły sprzedawać zeszłoroczne modele lub gorsze wersje zaawansowanych produktów w mniej rozwiniętych krajach. Oczywiście ma to również przełożenie na poziom kosztów funkcjonowania przedsiębiorstw, które w korporacjach globalnych są niższe niż w korporacjach wielonarodowych, dostosowujących swoją ofertę do rynków krajowych [Levitt 1983, s. 92-93]. Mechanizmem regulującym zachowania uczestników gry ekonomicznej jest konkurencja, a dokładniej rzecz ujmując, dążenie do wyeliminowania konkurentów po uzyskaniu korzystnej pozycji na rynku. Tradycyjne metody uzyskiwania przewag konkurencyjnych (przywództwo kosztowe, innowacyjność, marketing, reklama) nie wystarczają już na konkurencyjnym rynku. Elementem gry rynkowej staje się walka o redukcję własnych zobowiązań, uzyskanie uprzywilejowanych warunków działania i preferencyjnych regulacji prawnych oraz ograniczenie dostępu dla innych do poszczególnych rynków. Dotyczy więc ona nie tylko podmiotów gospodarczych, które zawsze między sobą rywalizowały, jej efekty coraz bardziej zależą od polityki państwa. Jednym z warunków globalizacji w gospodarce jest redukcja interwencjonizmu państwowego, deregulacja w zakresie gospodarczych i społecznych przepisów prawa oraz prywatyzacja sektora publicznego. Prywatyzacji ulegają tak nierynkowe dziedziny, jak energetyka, wodociągi, służba zdrowia, edukacja, transport miejski, więziennictwo, opieka społeczna [Polak 2009, s. 84]. Państwo wprowadza ulgi i zwolnienia podatkowe, składa zamówienia publiczne, przydziela subwencje, dysponuje narzędziami polityki handlowej, współfinansuje badania naukowe, stanowi przepisy gospodarcze, społeczne, pracownicze, ekologiczne itp. Twierdzi się wręcz, że korporacje nie mogą istnieć bez państwa [Bakan 2006, s. 176]. Państwa również zostały więc włączone $\mathrm{w}$ tę walkę konkurencyjną. W związku z rosnącą mobilnością, siłą i uniezależnieniem kapitału od lokalnych uwarunkowań są one zmuszone do ciągłych ustępstw i walki o jego pozyskanie [Polak 2009, s. 86]. Korporacje globalne przeciwstawiają konkurentom cały swój ogólnoświatowy system wyrobów i pozycji na rynku. W nowych warunkach tworzy się sieć powiązań produkcyjnych między przedsiębiorstwami w różnych krajach. Globalne strategie działania przedsiębiorstw pozwalają na rozdzielenie poszczególnych etapów produkcji oraz innych funkcji realizowanych $\mathrm{w}$ przedsiębiorstwie $\mathrm{w}$ zakresie tworzenia wartości 
dodanej na różnych rynkach. Prowadzi to często do ujednolicenia struktur organizacyjnych, metod zarządzania, systemów produkcji, sposobów przetwarzania danych, systemów prawnych oraz wzorów konsumpcji w skali całego świata. Znikają również odwieczne różnice w sposobach prowadzenia interesów. Jednolitość oczekiwań konsumentów prowadzi do standaryzacji produktów, metod produkcji oraz instytucji handlowych. Małe narodowe rynki zmieniają się i rozszerzają. Sukces osiągnięty w konkurencji światowej przekłada się na sprawność w produkcji, dystrybucji, marketingu, zarządzaniu i nieuchronnie znajduje odzwierciedlenie w cenie.

Pod wpływem globalizacji zmienia się rola poszczególnych czynników produkcji. Rośnie znaczenie kapitału a maleje - ziemi i pracy. Współczesny rozwój naukowo-techniczny, dominująca rola informacji, wiedzy i kwalifikacji tworzą nowy paradygmat rozwoju - gospodarkę opartą na wiedzy [Mączyńska 2003, s. 15]. Coraz większego znaczenia nabiera prawo do własności intelektualnej i jednym z kluczowych elementów nowego ładu międzynarodowego jest globalny system ochrony własności intelektualnej.

Globalizacja i wyzwania związane z gospodarką opartą na wiedzy wyznaczają nowe priorytety, do których należy nowoczesny system edukacyjny, szybki wzrost sektora badań i rozwoju, rozbudowa infrastruktury. Zglobalizowana konkurencyjna gospodarka coraz bardziej wymaga tworzenia nowych zasobów wiedzy obejmujących zarówno kreatywność, jak i systematyczne badania i rozwój nowych produktów i procesów. Wbrew niektórym teoriom, w tych obszarach nie zmniejsza się, lecz wzrasta rola państwa i władz lokalnych, ze względu na fakt, że te mające fundamentalne znaczenie dla dalszego rozwoju priorytety z reguły przynoszą korzyści w dłuższej perspektywie czasowej [Mączyńska 2003, s. 19] i często wymagają zainwestowania środków publicznych.

„Nowy paradygmat rozwoju wymusza zmiany w relacjach między biznesem a władzami oraz instytucjami" [Mączyńska 2003, s. 20]. W tej sytuacji tworzą się nowe teorie i kierunki badań w ekonomii, wśród których do ważniejszych należy ekonomia instytucjonalna. Ukazuje ona zależności między funkcjonowaniem tradycyjnych rynków a pozaekonomicznymi obszarami życia społecznego. Zakłada, iż sposób funkcjonowania gospodarki wyznaczony jest przez pewne ramy prawne zwane instytucjami ukształtowane normy i zasady postępowania o charakterze prawnym, społecznym lub ekonomicznym. Ich podstawową funkcją jest zmniejszanie nieprzewidywalności zachowań podmiotów gospodarczych i osób oraz ograniczanie deformacji strukturalnych i wynaturzeń rozwojowych ${ }^{4}$.

Atutem w globalnej gospodarce jest niezależność od konkretnego miejsca i lokalnych uwarunkowań, mobilność i elastyczność działania. Kosmo-

${ }^{4}$ Zob.: Mączyńska 2003; Wilkin 2012; Furubotn, Richter 2000; Hodgson 2003. 
polityzm przestał być domeną wykształconej części społeczeństwa (elity intelektualnej), stał się $\mathrm{w}$ zamian cechą wszystkich sektorów na całym świecie [Levitt 1983, s. 101]. Działalność gospodarcza w coraz większym stopniu dokonuje się $\mathrm{w}$ przestrzeni, a nie w miejscu. Właściwą dla niej formą organizacyjną staje się raczej wielopodmiotowa, wielocentryczna i wielowymiarowa sieć, nie zaś pojedyncza firma, nastawiona na efekty skali. W tej skomplikowanej i dynamicznej „nowej gospodarce” tradycyjne, scentralizowane, odgórne zarządzanie staje się coraz mniej przydatne „Globalizacja prowadzi do swoistej relatywizacji przestrzennego wymiaru działalności gospodarczej" [Hausner 2001, s. 7]. Skala krajowa przestaje być najważniejsza, a nie zyskuje tej rangi żadna inna - lokalna, regionalna, międzynarodowa czy globalna. Intensyfikacja działalności gospodarczej w wielkiej skali powoduje, że przeciwwagą dla niej staje się mobilizacja aktywności w skalach mniejszych - lokalnej i regionalnej. Współczesny regionalizm oznacza jednocześnie dostosowanie się do globalizacji, jak i opór wobec niej [Jessop 1999].

\section{Globalizacja i polaryzacja przestrzeni}

Mimo postępującej globalizacji gospodarki światowej nadal utrzymują się wyraźne różnice pomiędzy poszczególnymi krajami i narodami w zakresie ich systemów ekonomicznych, prawnych, społecznych oraz kulturowych [Jeżak 2010]. Korzyści z globalizacji rozkładają się nierównomiernie. Nie wszystkie kraje na niej zyskują. Globalizacji towarzyszy coraz silniejsza peryferyzacja, która ma dwa aspekty.

Po pierwsze następuje marginalizacja wielu krajów, które pozostają poza zasięgiem globalnych przepływów kapitału i technologii. Coraz głośniej mówi się o rosnącej przepaści między bogatą Północą a biednym Południem ${ }^{5}$.

Południe jest głównym dostawcą taniej siły roboczej na potrzeby Północy. Gospodarki krajów uprzemysłowionych coraz bardziej rozbudowując sektor usług, przenoszą produkcję wielu towarów do krajów rozwijających się w celu obniżenia kosztów siły roboczej [Berry, Conkling, Ray 1997; Bauman 1998; Held et al. 1999; Beck 2000]. Do krajów Południa przeniesiono nie tylko te gałęzie przemysłu przetwórczego, które bazują na intensywnym wykorzystaniu siły roboczej, ale również sektor usług oraz technologii informacyjno-komunikacyjnych (ICT). Nowy podział siły roboczej pociąga za sobą inwestycje kapitałowe na Południu (przejawia się to przede wszystkim w bezpośrednich inwestycjach zagranicznych w sektorze usług oraz $\mathrm{w}$ gałęziach przemysłu nastawionych na eksport), zagraniczne inwestycje pośrednie w przedsiębiorstwa państwowe, banki i budownictwo oraz

5 Zob.: Polak 2009. 
rosnącą podaż taniej siły roboczej dzięki międzynarodowym migracjom [Kampen, Naerssen 2008, s. 942]. Pomimo że więzi gospodarcze z krajami rozwijającymi się w ostatnich latach uległy wzmocnieniu, ciągle wielkich obszarów i skupisk ludzkich nie dotyczą główne procesy kreujące zjawisko globalizacji [Waściński 2004, s. 20]. Korzyści z globalizacji odnoszą państwa, które selektywnie przyjmują jej reguły gry, przy tym nie rezygnując z interwencjonizmu państwowego. Natomiast na zjawisku tym tracą państwa, które bezkrytycznie godzą się na zalecaną im "terapię szokową" (w przeszłości Rosja, Ameryka Łacińska), powodując gwałtowne zubożenie społeczeństw [Polak 2009, s. 30].

Po drugie marginalizacji ulegają regiony wewnątrz krajów, w których pojawia się mało nowych inwestycji kapitałowych. Zarówno w krajach OECD, jak i będących na przeciwnym biegunie rozwoju państwach Afryki Subsaharyjskiej wiele elit czerpie korzyści z globalizacji, podczas gdy w każdym z tych krajów istnieją społeczności, które czują się wykluczone $\mathrm{z}$ tego nurtu.

Uprzemysłowione regiony metropolitalne przyciągają kapitał i wykwalifikowaną siłę roboczą z regionów o słabszym poziomie rozwoju (zapóźnionych) [Chakravorty 2003, s. 358-360]. W rezultacie wzrost jest skoncentrowany w kilku miejscach na świecie i są nimi obszary metropolitalne. Globalizacja jest więc procesem wysoce asymetrycznym [McGrew 2009, s. 22].

Jednym z przejawów globalizacji jest segmentacja gospodarki globalnej, która polega - w uproszczeniu - na powstaniu dwóch segmentów:

- tzw. wysokiego, w którym przewagę konkurencyjną osiąga się dzięki innowacjom,

- tzw. niskiego - w którym źródłem przewag komparatywnych są niskie koszty wytwarzania produktów i usług, co przekłada się na ich niską cenę.

W segmencie wysokim następuje proces koncentracji, ponieważ wytwarzanie innowacji wymaga innowacyjnego środowiska, czyli odpowiednich warunków społecznych i gospodarczych, mogących zaistnieć tylko w miejscach już silnie rozwiniętych, które dzięki poniesionym dotąd inwestycjom dysponują bogatą infrastrukturą materialną i instytucjonalną oraz zapleczem badawczo-rozwojowym. W krajach relatywnie wyżej rozwiniętych kapitał zainwestowany w segmencie niskim, zazwyczaj ulokowany w regionach nieco słabiej rozwiniętych, ale z długimi tradycjami przemysłowymi, przenosi się do tańszych lokalizacji w innych krajach. Nie dotyczy to segmentu wysokiego, gdyż ten pozostaje w metropoliach. W rezultacie najbogatsze ośrodki metropolitalne powiększają swoją przewagę nad pozostałymi regionami, co prowadzi do dalszej peryferyzacji przestrzeni [Gorzelak 2008, s. 78]. 
Konwergencja zachodzi wśród krajów najbardziej rozwiniętych, podczas gdy w przypadku krajów o niższym poziomie rozwoju można mówić raczej o postępującej dywergencji.

Globalizacja zmniejszyła poczucie izolacji istniejące w wielu krajach rozwijających się i zapewniła ich mieszkańcom dostęp do wiedzy nieosiągalny wcześniej nawet $w$ krajach rozwiniętych, jednakże wielu ludziom z tych krajów nie przyniosła spodziewanych korzyści ekonomicznych. Pomimo licznych obietnic zmniejszenia ubóstwa w krajach Trzeciego Świata coraz większa liczba osób żyje w skrajnej nędzy, podczas gdy całkowity dochód światowy cały czas rośnie [Stiglitz 2004, s. 22-23].

Do najbardziej zauważalnych korzyści, jakie miasta czerpią z globalizacji, wskazywanych w literaturze, należą:

- wzrost bezpośrednich inwestycji zagranicznych,

- zwiększenie dostępności do innych ośrodków spowodowane obniżeniem kosztów transportu i czasu podróży,

- spadek kosztów telekomunikacji,

- dostęp do informacji, nowoczesnych technologii,

- powiększenie rynków zbytu,

- rozszerzenie rynkowej oferty produktów,

- zwiększenie presji na modernizację i wzrost efektywności działalności gospodarczej,

- ożywienie inwestycyjne,

- powstanie nowych miejsc pracy,

- pobudzenie eksportu,

- udział w międzynarodowym podziale pracy,

- wzrost gospodarczy,

- podniesienie poziomu życia,

- awans cywilizacyjny [Hansen, Andersen, Clark 2001; Kukliński et. al. 2000; Jałowiecki 2002].

Jednak globalizacja to nie tylko korzyści, ale również pewne koszty i ograniczenia, do których w sferze ekonomicznej możemy zaliczyć:

- rosnącą rolę pozapaństwowych, niewybieralnych i niedemokratycznych ośrodków władzy gospodarczej,

- koncentrację władzy wynikającą z dominacji jednego hipermocarstwa i coraz większej koncentracji bogactwa,

- groźbę niestabilności ekonomicznej w skali krajowej i międzynarodowej wynikającą z potęgi i rosnącej autonomii kapitału międzynarodowego,

- oddzielenie świata finansów od realnej gospodarki,

- wzrost dystansu pomiędzy poszczególnymi segmentami rynku pracy,

- ekonomiczną polaryzację społeczności międzynarodowej oraz poszczególnych państw i miast,

- uznanie rynku za jedyny sposób selekcji ludzi, 
- niekontrolowaną prywatyzację sektora publicznego i przestrzeni publicznej,

- prywatyzację problemów społecznych,

- zwiększenie kosztów społecznych,

- urbanizację (problem ten szerzej omówiono w dalszych częściach pracy),

- koncentrację, trwałość i izolację ubóstwa oraz konflikty z tym związane,

- dla państw przyjmujących kapitał zagraniczny:

- możliwość odpływu części zysków z działalności gospodarczej,

- niszczenie rodzimego przemysłu i sieci handlowych,

- unikanie płacenia podatków przez zagranicznych inwestorów,

- obciążenia bilansu płatniczego,

- wzrost bezrobocia,

- obciążenie budżetu państwa z powodu preferencyjnego traktowania zagranicznych firm,

- uzależnienie sfery gospodarczej i politycznej od kapitału ponadnarodowego [Jałowiecki 2007; Majer 2010; Polak 2009; Oduwaye 2006].

Podczas gdy w ciągu kilku ostatnich dekad rozwój technologii informacyjnych oraz transportu i komunikacji pomaga przezwyciężać bariery przestrzenne poprzez „zbliżenie” wszystkich części świata, na wszystkich kontynentach w dalszym ciągu rozrastają się i zyskują na znaczeniu gęste aglomeracje miejskie. Wzrost gospodarczy - $w$ tym pobudzony przez globalizację - prowadzi do urbanizacji, osłabiając tradycyjne społeczności wiejskie. Jednakże kluczowym efektem globalizacji jest pojawienie się globalnych miast - Nowy Jork, Miami, Londyn, Singapur - o roli i pozycji przewyższającej pozycję i rolę kraju, w którym te miasta powstały [zob.: Sassen 1991].

Miasta należą do obszarów strategicznych, w których szczególnie widoczne są efekty globalizacji. Saskia Sassen twierdzi, iż

Globalne miasta są ośrodkami obsługi i finansowania handlu międzynarodowego, inwestycji i operacji siedzib przedsiębiorstw. A zatem różnorodność wyspecjalizowanych czynności, które występują w miastach globalnych, odgrywa główną rolę w odniesieniu do waloryzacji czołowych sektorów dzisiejszego kapitału. I w tym właśnie sensie globalne miasta są strategicznymi obszarami produkcyjnymi dzisiejszych głównych sektorów gospodarczych. Niezwykle duże zagęszczenie, dające się zauważyć w centrach biznesowo-finansowych tych miast, jest jednym z przejawów przestrzennych tej logiki; innym przejawem jest decentralizacja wielu spośród tych czynności na szerszych obszarach metropolitalnych, a nie ich powszechne rozproszenie[Sassen 2007, s. 5].

Z jednej strony niezwykła mobilność informacji, siły roboczej i kapitału umożliwia maksymalne rozproszenie, $\mathrm{z}$ drugiej zaś rozwija się proces aglomeracji czynności centralizujących, które koncentrują się właśnie w miastach globalnych i w obszarach metropolitalnych. 
Zjawisko to świadczy o wzroście roli miejsc (miast i obszarów funkcjonalnych) w rozwoju gospodarczym i zaprzecza tezie o deterytorializacji gospodarki lansowanej przez licznych autorów [zob.: Appadurai 2005; Held et al. 1999; Holland 1991; Tomlinson 1999; Wojtyczek 2005]. Słuszne są ich twierdzenia mówiące o zanikaniu granic administracyjnych rozumianym jako zmniejszenie kosztów pokonania oporu powodowanych tymi granicami, natomiast błędne jest założenie o braku powiązań działalności gospodarczej z potencjałem miejsca.

Koncentracja działalności gospodarczych jest szczególnie widoczna w tych sektorach, w których jednocześnie występują trzy typy powiązań. Po pierwsze tam, gdzie koszty transakcji związane z pokonywaniem przestrzeni po stronie produkcyjnej są wyjątkowo wysokie, firmy działające w danej branży są skłonne lokować się wokół ich własnego środka ciężkości. Po drugie tam, gdzie koszty transakcji produktów uzależnione od przestrzeni są niskie, a rynki się rozrastają, pierwotne aglomeracje wykazują tendencje do wzrostu i pogłębiania lokalnego społecznego podziału pracy. Po trzecie, rosnące zyski spowodowane formalnymi i nieformalnymi współzależnościami producentów wzmacniają aglomeracje i dają gwarancję, że wzrost będzie prowadził do dalszego rozwoju [zob. Romer 1986]. We współczesnym świecie tego typu relacje stanowią jeden z głównych czynników prowadzących do formowania się superskupisk (superklastrów) przedsiębiorstw i pracowników, które formują ekonomiczne oblicze globalnych regionów miejskich. Rozwój miast i regionów na tak wielką skalę tworzy również negatywne efekty zewnętrzne, które jednak władze lokalne starają się ograniczać/kontrolować, aby nie zatrzymały one kolejnej fazy miejskiego rozwoju. Zatem obecnie obszary zurbanizowane mają większe znaczenie w geografii i gospodarce świata niż kiedykolwiek wcześniej w historii. W ciągu ostatnich kilku dekad wiele ośrodków miejskich na całym świecie przekształciło się w superklastry, których ekspansja na tak szeroką skalę wynika z faktu, iż wiele wiodących sektorów gospodarki kapitalistycznej jest zorganizowanych jako gęste i silnie zlokalizowane sieci producentów z silnymi endogenicznymi mechanizmami wzrostu i z rosnącym globalnym zasięgiem rynkowym (rosnącą pozycją na globalnym rynku).

Koncentracja ma istotnie pozytywny wpływ na zdolność miast do działania jako ośrodki kształcenia, kreatywności i innowacji ze względu na fakt, że miasta tworzone są jako silnie zagęszczone centra $\mathrm{z}$ wykorzystaniem intensywnych transakcji zachodzących między licznymi współzależnymi aktywnościami różnych podmiotów. Są również miejscami, w których bez końca pojawiają się nowe doświadczenia i w których codziennie tworzona i rozpowszechniana jest olbrzymia ilość informacji. Procesy te rozkładają się na wiele małych, często nie odnotowanych zdarzeń, ale skumulowane stanowią ważny fundament zlokalizowanej energii innowacyjnej i przedsię- 
biorczości. Dominują one w wielkich miastach ze względu na niezliczoną liczbę kombinacji, jakie mogą wystąpić w międzyludzkich relacjach, z których mogą wyniknąć niespodziewane i nieprzewidywalne formy kreatywnego działania [Scott 2001, s. 819]. W rezultacie wielkie miasta są zazwyczaj ważnymi ośrodkami przedsiębiorczości i innowacji dla wszystkich sektorów gospodarki6. I wreszcie ten "turbo" wzrost jest wzmocniony przez częste tworzenie wielu klastrów lub kompleksów w jednym regionie miejskim, zwłaszcza gdy występują tam silne efekty uboczne między różnymi sektorami wchodzącymi w ich skład. Regionalne skupianie się tworzy najlepsze ramy dla promocji, zlokalizowanego uczenia się, kreatywności i innowacji [Asheim, Clark 2001, s. 806].

\section{Zmiany w sferze politycznej a funkcjonowanie obszarów zurbani- zowanych}

Wraz ze wzrostem potęgi podmiotów ekonomicznych maleje znaczenie i siła organizacji politycznych. W sferze politycznej proces globalizacji zachodzi dużo wolniej niż w sferze ekonomicznej, jest on tylko częściowy i nieskończony. Jedną z kluczowych kwestii jest wpływ tego procesu na funkcjonowanie struktur politycznych. Międzynarodowy, terytorialnie zakorzeniony system polityczny wydaje się zagrożony, nie został on jednak jeszcze zastąpiony niczym zbliżonym do spójnego międzynarodowego porządku. Nie istnieje międzynarodowy system społeczny czy społeczność polityczna, w której można by osadzić zintegrowaną globalną gospodarkę [Kobrin 2009, s. 7]. Demokracja globalna wymagałaby ukształtowania globalnego społeczeństwa obywatelskiego i opinii publicznej, a może nawet „światowego rządu” [Olszewski 2009, s. 15]. O ile utworzenie globalnego rządu pozostaje raczej w sferze fantazji, o tyle w zakresie rządzenia światem obserwujemy rozwój tzw. global governance.

${ }^{6}$ Badacze procesów zachodzących $\mathrm{w}$ miastach postulują, by menadżerowie miast, którzy chcą uczestniczyć w globalnym wzroście i rozwoju, ulokowali je w tym globalnym systemie tak, aby ułatwić przepływy kapitału, towarów i ludzi. Miasta muszą być włączone w „przestrzeń przepływów”, w której tworzą kluczowe węzły w ogólnoświatowej sieci i funkcjonują jako punkty przekazu, łączące to, co globalne z poziomem regionalnym i lokalnym. Globalizujące się miasta muszą sprostać oczekiwaniom globalnego kapitału, jeśli chcą wykorzystać możliwość ekonomicznego wzrostu. Muszą więc wybudować odpowiednią infrastrukturę międzynarodowe lotniska, autostrady, przetwórcze strefy eksportowe czy pięciogwiazdkowe hotele. Jednocześnie muszą konkurować z innymi miastami, przez co są włączone $\mathrm{w}$ niekończący się proces restrukturyzacji infrastruktury fizycznej, rynku pracy i instytucji społecznych [Kampen, Naerssen 2008, s. 942]. 
Mnogość i różnorodność podmiotów uczestniczących w podejmowaniu decyzji o kierunkach rozwoju państw powoduje konieczność wprowadzenia tzw. zarządzania wielopoziomowego (multilevel governance) oraz tworzenia się w polityce układów sieciowych odzwierciedlających istnienie wielu autonomicznych i niezależnych, ale także wzajemnie na siebie oddziałujących centrów decyzyjnych zarówno w wymiarze państwowym, jak i międzynarodowym [Cini 2007, s. 177 i n.]. Poziomy governance odnoszą się do szczebli hierarchii, na które delegowana jest władza i pełnione są poszczególne funkcje. Począwszy od najniższego, aż do najwyższego szczebla można wyróżnić indywidualny, lokalny, regionalny i globalny poziom governan$c e$. Szczebel indywidualny jest zazwyczaj reprezentowany przez indywidualnych konsumentów czy społeczeństwo obywatelskie. Szczebel lokalny odnosi się do interakcji między władzami lokalnymi i regionami. Właśnie ten szczebel jest szczególnie istotny dla zarządzania rozwojem miast i obszarów zurbanizowanych. Władze lokalne i regionalne muszą stawić czoła wyzwaniom, jakie stawia przed nimi globalizacja w ramach kompetencji, które zostały im przekazane wskutek reform decentralizacyjnych państwa. Muszą z jednej strony sprostać oczekiwaniom mieszkańców, a z drugiej żądaniom firm, które chcą się lokować na ich terenie.

Coraz częściej głównym decydentem w zarządzaniu jednostkami lokalnymi staje się obcy kapitał, który ze względu na silną pozycję finansową przejmuje dominację w ustalaniu kierunków zagospodarowania przestrzeni. Ponadto władze lokalne, wybierane w drodze powszechnych wyborów, uwikłane są w różnego rodzaju koalicje polityczne. Prowadzi to do silnej fragmentacji zarówno poziomej, jak i pionowej. Tę sytuację podziałów politycznych wykorzystuje kapitał zagraniczny, który - odpowiednio wpływając na polityków, skłania ich do podejmowania korzystnych dla firm decyzji (np. zmiany przeznaczenia terenów). W takich warunkach konieczne jest poszukiwanie nowych modeli zarządzania dla obszarów miejskich, które włączałyby w ten proces wszystkich graczy. Poziom narodowy dotyczy władzy państwowej i jej polityk, regionalny - odzwierciedla integrację regionalną jako nowy sposób realizacji polityki transnarodowej [Hnat 2009, s. 35]. Global governance to koalicja najsilniejszych państw, korporacji, koncernów medialnych, działających na styku z kilkoma organizacjami międzynarodowymi, w ramach której, w sposób mniej lub bardziej formalny, zapadają decyzje o podstawowym znaczeniu dla kierunków rozwoju porządku międzynarodowego [Kuźniar 2003].

W warunkach politycznej globalizacji państwa stają się coraz bardziej „wmontowane” w gęstniejącą i zazębiająca się sieć o zasięgu ogólnoświatowym: instytucji multilateralnych, jak NATO czy Bank Światowy, transnarodowych stowarzyszeń i sieci (od Międzynarodowej Izby Handlu po Światowy Kongres Muzułmański), korporacyjnych i pozarządowych aktorów 
zajmujących się globalnymi kwestiami (Global AIDS Fund, Roll Back Malaria Initiative) oraz bardziej czy formalnych transrządowych sieci przedstawicieli państw, zajmujących się wspólnymi problemami globalnymi, włączając w to Bazylejski Komitet Nadzoru Bankowego, skupiający centralnych bankierów, czy Financial Action Task Force, zwalczający pranie brudnych pieniędzy [McGrew 2009, s. 25].

Działalność wielu organizacji pozarządowych (Czerwony Krzyż, Lekarze bez Granic, Care International itp.) można uznać za udział we wdrażaniu oficjalnej polityki rządów lub organizacji międzynarodowych. Niekiedy uczestniczą one w formułowaniu oficjalnej polityki (jako członkowie oficjalnych delegacji rządowych bądź eksperci) [Krzeczunowicz 2006, s. 41-42].

Takie koalicje powstają nie tylko w sferze globalnej gospodarki i polityki. Również miasta tworzą związki czy porozumienia dotyczące ich funkcjonowania. Wynika to z faktu, że skutki procesów globalizacji odbijają się na metropolizacji przestrzeni. Obecnie istnieją już różne sieci, których członkami są metropolie całego świata i które zajmują się istotnymi dla ich rozwoju problemami. Do najbardziej znanych należą METREX, URBACT, Eurocities.

METREX - Sieć Europejskich Obszarów i Regionów Metropolitalnych stanowi platformę wymiany wiedzy i doświadczeń w kwestiach metropolitalnych i wspólnych działań w sprawach leżących we wspólnym interesie. Sieć przyczynia się do ujmowania problemów metropolitalnych $\mathrm{w}$ formułowaniu polityk, programów i projektów o skali europejskiej. Jest partnerem instytucji europejskich, społeczności badawczej, organizacji pozarządowych i innych sieci. Jej członkami jest 50 obszarów i regionów metropolitalnych z Europy [http://www.eurometrex.org].

W roku 1986 powstała Sieć Miast Europejskich Eurocities, skupiająca obecnie ponad 140 samorządów miejskich z 30 krajów Europy. Sieć stanowi platformę wymiany wiedzy i idei. Współpracuje z Unią Europejską w kwestiach dotyczących życia w miastach. Jej głównym celem jest wzmocnienie roli władz lokalnych w wielopoziomowej strukturze zarządzania, kształtowanie poglądów interesariuszy w Brukseli oraz taka zmiana prawodawstwa Unii Europejskiej, która pozwoli władzom miast zmierzyć się ze strategicznymi wyzwaniami na poziomie lokalnym [http://www.eurocities.eu].

URBACT z kolei jest programem wymiany i nauki, który promuje zrównoważony rozwój obszarów miejskich. Został uruchomiony przez Unię Europejską w roku 2002 i umożliwia miastom współpracę w celu znalezienia i dzielenia się innowacyjnymi, zintegrowanymi i zrównoważonymi rozwiązaniami będącymi odpowiedzią na główne wyzwania miejskie. Program skupia ponad 270 partnerów (państwa, miasta, władze regionalne, uczelnie, organizacje prywatne, organizacje charytatywne) z 29 krajów. Od roku 2007 trwa II edycja programu [http://urbact.eu]. 
Zjednoczone Miasta i Władze Lokalne (United Cities and Local Governments - UCLG) jest międzynarodową organizacją, która reprezentuje i chroni interesy samorządów lokalnych na arenie międzynarodowej. Jej członkami są miasta i stowarzyszenia krajowe władz lokalnych. Do UCLG należy ponad 1000 miast z 95 krajów oraz 112 stowarzyszeń władz lokalnych. Jednym z głównych celów organizacji jest zwiększenie roli i wpływu samorządu terytorialnego i ich organizacji przedstawicielskich w systemie globalnego zarządzania [http://www.cities-localgovernments.org].

Rada Gmin i Regionów Europy (Council of European Municipalities and Regions - CEMR). Rada Gmin Europy została założona w roku 1951 przez grupę burmistrzów. Później rozszerzyła zakres działania na regiony i została Radą Gmin i Regionów Europy. Jej członkami jest ponad 50 krajowych stowarzyszeń miast, gmin i regionów z 40 krajów. Łącznie jest to około 100 000 przedstawicieli władz lokalnych i regionalnych. CEMR współpracuje blisko z Dyrekcją Generalną ds. Edukacji i Kultury Komisji Europejskiej w celu wspierania projektów partnerskich łączących miasta z całej Europy. Jest europejskim oddziałem nowej międzynarodowej organizacji Zjednoczonych Miast i Władz Lokalnych (UCLG). Obecnie przewodniczy CEMR burmistrz Stuttgartu [http://www.ccre.org]. Członkami z Polski są Związek Miast Polskich i Związek Powiatów Polskich.

Na powyższych przykładach widać, że o ile wcześniej sieci współpracy tworzyły państwa (ONZ, OECD, UE, NAFTA, ASEAN itp.), to obecnie takie działania podejmują miasta.

Za pośrednictwem tych sieci władze lokalne i regionalne próbują promować wspólne cele gospodarcze i polityczne. Nowe mechanizmy rozwoju spowodowały zmiany $\mathrm{w}$ relacji między wielkim miastem a regionem, w którym jest ono położone. Kiedyś miasta stanowiły podstawę gospodarki regionów. Relacje w tym układzie polegały na dwustronnej, w miarę ekwiwalentnej i intensywnej, wymianie. W gospodarce globalnej relacje metropolii z zapleczem ulegają segmentacji i przestrzennemu rozdzieleniu. Wielkie miasta kontaktują się $\mathrm{z}$ innymi metropoliami w obrębie światowego systemu miast globalnych, natomiast relacje $\mathrm{z}$ otoczeniem ulegają osłabieniu [Maik 2005, s. 29-31].

Pojawia się pytanie, czy w wyniku globalizacji zostaje podważona rola władz państwowych na rzecz nowych struktur współrządzenia międzynarodowym systemem państw? W literaturze przedmiotu obserwuje się tu dwa podejścia. Zwolennicy jednego z nich zakładają, że globalizacja powoduje coraz większe ograniczenie suwerenności większości państw. Według drugiego w dobie globalizacji następuje przekształcenie roli państwa, a nie jej zmniejszanie [Cox 1987]. 


\subsection{Malejąca suwerenność instytucji państwa}

Suwerenność państw usankcjonowana została przez Traktat Westfalski, w wyniku którego państwo zyskało niezależność od wszelkiej innej władzy $\mathrm{w}$ jego stosunkach $\mathrm{z}$ innymi podmiotami prawa międzynarodowego i samodzielność w regulowaniu spraw wewnętrznych [Pemberton 2009, s. 54-55]. Państwa narodowe w dalszym ciągu oficjalnie pełnią swoje główne funkcje, podczas gdy ich suwerenność jest stopniowo coraz bardziej ograniczana poprzez zastępowanie władzy państwowej władzą globalnych rynków i ponadnarodowych instytucji współrządzących [Keil 1998, s. 616]. W coraz mniejszym stopniu państwo realizuje prawa wynikające z zasady suwerenności w granicach swego terytorium poprzez autonomiczne decyzje najwyższych organów państwowych. Coraz częściej decyzje te są jedynie dostosowaniem do zewnętrznych tendencji, regulacji (np. Unii Europejskiej), oczekiwań lub presji. „Presję tę wywołują głównie korporacje ponadnarodowe, domagające się swobody przepływu kapitału i znoszenia przeszkód dla funkcjonowania wolnego handlu, uzależniając np. udzielenie pomocy finansowej od spełnienia tych warunków" [Olszewski 2009, s. 18]7. Obecnie suwerenność można rozumieć jako posiadanie maksymalnego wpływu na przyszły dobrobyt społeczeństwa [Camiller, Falk 1992, s. 47]. Scentralizowany i hierarchiczny porządek polityczny, charakterystyczny dla suwerennego państwa narodowego, zastępowany jest heterarchicznym układem koordynacji, obejmującym różnego rodzaju sieci organizacyjne, zróżnicowane formy partnerstwa i koordynacji działań zbiorowych [Jessop, 1999, s. 389]. Podejmowanie ważnych decyzji państwowych przesunęło się w kierunku menedżerów, zawodowych polityków i administratorów [Olszewski 2009, s. 17]. Wobec setek miliardów dolarów, które codzienne przepływają $\mathrm{z}$ giełdy na giełdę, z banku do banku, krążąc w gospodarce światowej, całoroczny budżet nawet dużego państwa narodowego wydaje się znikomy. Wielonarodowe korporacje i ponadnarodowe instytucje zwiększyły swoją władzę i zasoby, podczas gdy państwa narodowe zdają się zanikać8. Kompetencje i zasoby pozostające do dyspozycji rządu centralnego nie są wystarczające, aby zapewnić społeczny dobrostan i zapobiec społecznej marginalizacji [Hausner 2001, s. 7]. Wielkie korporacje najchętniej widziałyby państwo $w$ roli instytucji inwestującej w edukację, badania naukowe, rozwój infrastruktury [Arytmiak 2000, s. 147].

Globalizacja (...) często prowadzi do zastępowania starych dyktatur sprawowanych przez narodowe elity nowymi dyktaturami świata między-narodowych finansów. Państwa zmusza się do rezygnacji z części suwerenności na rzecz rynków kapitałowych, które decydują o dostarczeniu im pieniędzy"[Stiglitz 2004, s. 219].

7 Zob.: Scholte 2005; Baylis, Smith 2001.

8 Więcej: Dunning, Lundan 2008; Ohmae 2008. 
Rząd państwa nie może sprzeciwić się liberalnym regułom ekonomicznej gry, gdyż wtedy albo przegra $\mathrm{w}$ finansowym starciu z międzynarodowymi koncernami i finansistami, albo sprawi, że kapitał odpłynie, a tym samym szanse na rozwój gospodarczy państwa bardzo zmaleją. To wszystko drastycznie zmienia funkcje państwa i dostępne mu środki [Zorska 2002, s. 263-265].

Wymianę handlową i operacje finansowe na rynku zawsze kontrolowało państwo. Gracze ekonomiczni byli w znacznym stopniu ograniczeni wolą polityczną władz. Tymczasem globalizacja ekonomiczna sprawiła, że rola państwa narodowego bardzo zmalała. Państwo narodowe traci pełną kontrolę nad swym losem, potencjałem, polityką gospodarczą, socjalną, obronną i innymi dziedzinami. Następuje ograniczenie autonomii państwa w aspekcie wewnętrznym i zewnętrznym. Globalizacja powoduje obniżenie efektywności zarządzania gospodarką krajową przez państwo narodowe [Amin 1997, s. 32]. Przyczyniły się do tego same państwa. Rządy na całym świecie były aktywnymi uczestnikami neoliberalnej transformacji. Neoliberalne rządy $\mathrm{w}$ ciągu ostatnich trzech dekad angażowały się praktycznie w proces globalizacji poprzez obalenie międzynarodowych barier w handlu, przez deregulację narodowych systemów gospodarczych oraz poprzez próby złamania lokalnego oporu, gdzie to tylko było możliwe. Globalizacja jest przez te rządy przedstawiana jako bezwarunkowa korzyść dla światowych stowarzyszeń i dla ludzi [Keil 1998, s. 619]. W tym samym czasie, w którym globalizacja „wkroczyła do miast”, zaszły również zmiany w sferze politycznej, społecznej i przestrzennej, wpływając na rolę odgrywaną przez samorządy. Odejście od ekonomii dobrobytu w kierunku neoliberalnych reform spowodowało, że różnego rodzaju świadczenia dla mieszkańców stały się mniej dostępne i korzyści oraz usługi są słabiej dostosowane do potrzeb obywateli i nie wszystkich obejmują swoim zasięgiem. Również wyposażenie w infrastrukturę miejską stało się mniej uniwersalne i standardowe. Stworzyło to nowe wyzwania, z którymi muszą się zmierzyć władze lokalne. Przede wszystkim do władz tych należy prowadzenie polityki rozwoju, która uczyni obszar miasta atrakcyjnym dla różnych aktorów. Wymaga to, między innymi, skoordynowanej polityki przestrzennej, nawiązywania kontaktów z sektorem poza publicznym, mogącym pomóc $\mathrm{w}$ realizacji zadań władzy lokalnej, czy też bardziej prorynkowego podejścia do zarządzania miastem.

Rozważając procesy globalizacji, wielu autorów zwraca uwagę na aspekt tzw. deterytorializacji [zob.: Brenner 2004; Appadurai 2005]. Globalizacja jest synonimem kurczącego się świata, w którym nawet bardzo lokalne zdarzenia, od bezrobocia po konflikty etniczne, mogą wpływać na odległe uwarunkowania i decyzje. W tym kontekście globalizacja ucieleśnia proces deterytorializacji, ponieważ społeczne, polityczne i ekonomiczne działania coraz bardziej rozciągają się na cały świat i przestają być zorganizowane 
według ściśle terytorialnej logiki. Narodowa przestrzeń gospodarcza, $\mathrm{w}$ warunkach globalizacji, przestała być utożsamiana $\mathrm{z}$ narodową przestrzenią terytorialną [McGrew 2009, s. 18-19]. Granice są raczej niezauważane niż faktycznie przekraczane, relacje stają się coraz bardziej ponadterytorialne, ponieważ odległości, granice i przestrzeń geograficzna jako taka traci ekonomiczne i polityczne znaczenie [więcej: Scholte 1997]. M. Castells [2008] podkreśla, iż współczesny rozwój dokonuje się w przestrzeni przepływów, nie zaś, jak w przeszłości, w przestrzeni miejsc [Castells 2008]. Rynki nie muszą już być definiowane w kategoriach geograficznego położenia i w niektórych przypadkach umiejscowienie transakcji i organizacji pod względem geograficznym staje się niemożliwe.

Nie oznacza to wcale, że terytorium i granice są nieistotne, ale w warunkach globalizacji ich znaczenie jako ograniczeń dla działań społecznych oraz podziału władzy jest coraz mniejsze. W dobie natychmiastowej komunikacji i organizacji w czasie rzeczywistym, rozróżnienie między tym, co krajowe i międzynarodowe, między tym, co wewnątrz a co na zewnątrz państwa przestaje być możliwe. Maleje zatem rola granic, ale nie rola terytorium. Autorzy lansujący koncepcję deterytorializacji upraszczają pewne procesy, nie oddzielając kwestii znaczenia obszarów funkcjonalnych od barier administracyjnych. Przestrzeń jest w dalszym ciągu ważna z punktu widzenia działań gospodarczych. Procesy są skoncentrowane $w$ określonej przestrzeni i mimo że mówi się o deterytorializacji, czyli o oderwaniu przestrzeni, to wcale tak nie jest. Skupione systemy produkcyjne są jednocześnie areną rzeczywistych i potencjalnych synergii o zasięgu regionalnym. W zglobalizowanym świecie terytorium nie traci na znaczeniu, lecz, wręcz przeciwnie, globalizacja zwiększa jeszcze możliwości uwypuklenia różnic terytorialnych i lokalnej specyfiki [Scott 2001]. W gospodarce przepływów część gospodarki (produkty, kapitał i informacje) jest cały czas w ruchu, ale ruch ten jest napędzany przez węzły systemu gospodarczego. Tymi węzłami są pewne szczególne miejsca, głównie obszary metropolitalne. Gospodarka staje się „płynnym magazynem”, z którego czerpie się zasoby potrzebne w określonym czasie i miejscu. Filozofia just in time, funkcjonująca w przedsiębiorstwach, została przeniesiona na poziom globalny. Informacje, usługi, cały czas dostępne są w sieci.

Istnieje pewna specyfika zorganizowania życia w przestrzeni. Cechy przestrzeni i powiązania między nimi mają określony zasięg, a na to wszystko nakładają się podziały administracyjne. Gospodarka nie uznaje takich podziałów, natomiast każda działalność odbywa się na jakimś terytorium. Jeżeli spojrzymy na cechy terytorium ważne z punktu widzenia prowadzenia określonych działalności i decydujące o jego konkurencyjności, to widać, że nie da się ich przenieść, skopiować, powielać w każdym punkcie przestrzeni. Kon- 
kurencja polega na rywalizowaniu zasobami skoncentrowanymi na szczególnym terytorium o specyficznych powiązaniach funkcjonalnych.

W ciągu ostatnich dekad obserwuje się rosnącą skłonność różnych dziedzin aktywności gospodarczej (np. przetwórstwo, usługi) do skupiania się i tworzenia regionalnych klastrów lub skupisk. Bliskość przestrzenna (a zarazem w czasie) jest szczególnie istotna, stanowi źródło większych przewag konkurencyjnych dla wielu rodzajów firm i w efekcie wielkie regionalne kompleksy produkcyjne w coraz większym stopniu funkcjonują jako terytorialne platformy dla konkurujących globalnych rynków.

Porter podkreśla, że to, co dzieje się wewnątrz przedsiębiorstw, jest ważne, ale klastry pokazują, że otoczenie biznesu odgrywa równie istotną rolę. To znaczenie lokalizacji bardzo długo było niedoceniane, pomimo niezbitych dowodów, że innowacyjność i sukces konkurencyjny w wielu dziedzinach są uzależnione od położenia geograficznego [Porter 1998, s. 78]. Zlokalizowane uczenie się opiera się nie tyko na wiedzy formalnej, ale przede wszystkim na trudnej do zdefiniowania wiedzy, która jest mocno niemobilna $\mathrm{w}$ kategoriach geograficznych oraz na współzależnościach, które nie podlegają wymianie handlowej. Chodzi tu między innymi o technologiczne efekty zewnętrzne, mogące być wspólnym aktywem grupy firm/przemysłów skupionych $\mathrm{w}$ danym regionie i zgromadzone razem mogą stanowić ważne, regionalnie specyficzne warunki mające wpływ na innowacyjność i konkurencyjność regionalnych klastrów [Asheim, Cooke 1998]. Dlatego coraz częściej mówi się o terytorializacji, a właściwie reterytorializacji (por. tab. 1), prowadzącej do redefinicji terytorialności państwa i zmiany skali oddziaływań dużych miast.

Storper [1997, s. 170] przez terytorializację rozumie wyróżniający się subsystem terytorialnych skupisk (agglomerations), gdzie ekonomiczna żywotność (zdolność do przetrwania) wynika z aktywów (obejmujących praktyki i wzajemne relacje), które są nieosiągalne w wielu innych miejscach i których nie można łatwo i szybko stworzyć tam, gdzie ich nie ma [Storper 1997]. Przy czym coraz mniejsze znaczenie mają tu cechy fizyczne, geograficzne, posiadanie zasobów mineralnych (chociaż w dalszym ciągu są one istotne), natomiast na znaczeniu zyskują czynniki trwale związane z pewną specyfiką środowiska, wyznaczające dalsze procesy rozwoju i będące trwałymi źródłami przewagi konkurencyjnej. Regiony, które mają odpowiednie zasoby wiedzy i stosują właściwe rozwiązania organizacyjne oraz które są bardziej skuteczne w przetwarzaniu informacji w produkty, kupowane później na rynku, funkcjonują dużo lepiej niż regiony z mniej konkurencyjnymi technologiami i słabszym kapitałem ludzkim oraz społecznym [Domański 2001, s. 47]. Pewne relacje, powiązania i jakość zagospodarowania, razem z ludźmi tworzą bardzo istotny czynnik, który określa się kapitałem terytorialnym. Ten kapitał pojawia się w polskiej myśli plani- 
stycznej. Planiści zagospodarowania przestrzennego chcą go identyfikować w różnych układach przestrzennych, w tym w obszarach metropolitalnych [Storper 1997].

Tabela 1

Globalizacja jako reterytorializacja: zmiana skali państw i miast

\begin{tabular}{|c|c|c|c|}
\hline \multirow{2}{*}{$\begin{array}{c}\text { Formy } \\
\text { reterytorializacji }\end{array}$} & \multicolumn{3}{|c|}{ Skala przestrzenna akumulacji kapitału } \\
\hline & globalna & krajowa & miejska-regionalna \\
\hline $\begin{array}{l}\text { MIASTA } \\
\text { Zmiana skali } \\
\text { miasta. Po- } \\
\text { wstawanie } \\
\text { miast świato- } \\
\text { wych }\end{array}$ & $\begin{array}{l}\text { Formowanie się } \\
\text { światowej hierarchii } \\
\text { miast. } \\
\text { Intensyfikacja współ- } \\
\text { zawodnictwa miast } \\
\text { powiązana z rozwo- } \\
\text { jem światowej go- } \\
\text { spodarki }\end{array}$ & $\begin{array}{l}\text { Przejście z miejskich } \\
\text { systemów krajo- } \\
\text { wych w systemy } \\
\text { ponadkrajowe } \\
\text { i globalne. } \\
\text { Oddzielenie rozwoju } \\
\text { miast światowych } \\
\text { od rozwoju ich go- } \\
\text { spodarek narodo- } \\
\text { wych }\end{array}$ & $\begin{array}{l}\text { Kształtowanie się } \\
\text { „exopolis"9: re- } \\
\text { kompozycja form } \\
\text { miejskich: wyło- } \\
\text { nienie się policen- } \\
\text { trycznych regio- } \\
\text { nów miejskich } \\
\text { i nowych dzielnic } \\
\text { przemysłowych }\end{array}$ \\
\hline $\begin{array}{l}\text { PAŃSTWA } \\
\text { Restrukturyzacja } \\
\text { terytorialna } \\
\text { państwa. } \\
\text { Wyłonienie się } \\
\text { neoliberalnych } \\
\text { „państw glokal- } \\
\text { nych” }\end{array}$ & $\begin{array}{l}\text { Państwa narodowe } \\
\text { dokonały zwrotu na } \\
\text { zewnątrz: zmiana } \\
\text { skali w górę, w kie- } \\
\text { runku ponadnaro- } \\
\text { dowych poziomów } \\
\text { regulacji takich } \\
\text { instytucji, jak UE, } \\
\text { MFW, Bank Świato- } \\
\text { wy powoduje re- } \\
\text { strukturyzację prze- } \\
\text { strzeni państw }\end{array}$ & $\begin{array}{l}\text { „Denacjonalizacja” } \\
\text { skali narodowej. } \\
\text { Rząd centralny } \\
\text { przekazuje część } \\
\text { zadań na wyższy } \\
\text { szczebel agencji } \\
\text { ponadnarodowych, } \\
\text { a część w dół insty- } \\
\text { tucjom lokalnym i } \\
\text { regionalnym }\end{array}$ & $\begin{array}{l}\text { Państwa narodowe } \\
\text { dokonały zwrotu } \\
\text { do wewnątrz. } \\
\text { Zmiana skali w dół, } \\
\text { w kierunku pozio- } \\
\text { mów subnarodo- } \\
\text { wych. } \\
\text { Państwa promują } \\
\text { inwestycje korpo- } \\
\text { racji transnarodo- } \\
\text { wych w głównych } \\
\text { regionach miej- } \\
\text { skich. } \\
\text { Tworzenie „nowych } \\
\text { przestrzeni pań- } \\
\text { stwowych”, aby } \\
\text { regulować „nowe } \\
\text { przestrzenie prze- } \\
\text { mysłowe” }\end{array}$ \\
\hline
\end{tabular}

Źródło: [Brenner 1999, s. 442].

W tym kontekście coraz większego znaczenia nabierają regionalne systemy innowacji, które reprezentują planowe, interaktywne, wspierające przedsiębiorstwa podejście do polityki innowacyjnej, bazujące na bliskiej współpracy firm, wyższych uczelni, instytutów badawczych i agencji rzą-

9 Termin stworzony przez Edwarda Soję. Oznacza miasto jednocześnie zwrócone „na zewnątrz” i „do wewnątrz”. Zob.: Soja 1992. 
dowych. Taki układ aktorów, tworzących regionalny system innowacji, można zazwyczaj znaleźć w wielkich regionach miejskich, gdzie różnorodność korzyści z urbanizacji jest olbrzymia [Asheim, Clark 2001, s. 807-808]. To, wraz z innymi czynnikami, takimi jak rynek pracy charakteryzujący się znacznym popytem na wykwalifikowanych pracowników, zróżnicowanie kulturowe i tolerancja, niskie bariery wejścia i wysoki poziom usług publicznych w dużym stopniu determinuje geografię ekonomiczną talentów (economic geography of talent) ${ }^{10}$ i kreatywności, skoncentrowaną $\mathrm{w}$ wielkich miastach. Terytorializm gospodarki przejawia się $\mathrm{w}$ wykształcaniu trwałych cech regionów związanych z budowaniem przewag konkurencyjnych, których nie da się przenieść. Otoczenie, w jakim działają firmy, jakość środowiska antropogenicznego, przestrzennego i system relacji są zlokalizowane $\mathrm{w}$ określonym miejscu i są trwałymi cechami związanymi $\mathrm{z}$ budowaniem przewagi konkurencyjnej. To zakotwiczenie terytorialne związane z działalnością firm jest szczególnie ważne i trwałe i daje owe szczególne przewagi. Hasło terytorializacji gospodarki spowodowało, że zaczyna się mówić o wpływie miejsca na podstawy konkurencyjności. Jeśli potrafimy zbudować dobre otoczenie, infrastrukturę, sposób zagospodarowania, możemy mówić o rozwoju zrównoważonym, o wielu przewagach, korzyściach, oszczędnościach. I jeśli uzna się ten czynnik za ważny w kontekście uzyskiwania podstaw do budowania przewag konkurencyjnych, to bardzo ważną rolę w kształtowaniu otoczenia konkurencyjnego odgrywa planowanie przestrzenne i niepodważalna jest rola planistów/urbanistów. Jest to również wyzwanie dla tych grup zawodowych, aby zaczęły myśleć w sposób bardziej zintegrowany i zwróciły uwagę na relacje między sposobem zagospodarowania a funkcjonowaniem gospodarki [Markowski 2012].

Globalizujące się przedsiębiorstwa usług producenckich ${ }^{11}$ wykazują tendencję do skupiania się w wybranej grupie miast. Globalne przedsiębiorstwa usługowe (wytwarzające nowe produkty finansowe, nowe pakiety reklamowe, nowe formy usług prawniczych) mają jedną cechę wspólną, a mianowicie są uzależnione od specjalistycznej wiedzy. Ich najnowocześniejsze produkty są wytwarzane dzięki połączeniu różnej fachowej wiedzy, aby zaspokoić potrzeby klientów. Aby być w stanie stworzyć takie pakiety eksperckie, firmy muszą znajdować się $\mathrm{w}$ otoczeniu bogatym $\mathrm{w}$ wiedzę [Short 2004, s. 15]. Takie otoczenie można znaleźć w wielkich miastach. To one zapewniają tego typu otoczenie i kontakty "twarzą w twarz" między

10 Zob.: Florida 2000.

11 Usługi producenckie - świadczone na rzecz producentów, związane z obsługą procesów produkcyjnych i stanowiące pośredni wkład w proces wytwarzania dóbr materialnych [zob.: Dzieciuchowicz 2009, Sassen 1998] 
ekspertami są ułatwione dzięki skupianiu się w klastry bogatych w wiedzę jednostek [Sassen 1994].

Jest to szczególnie widoczne w przypadku efektów zewnętrznych, występujących $\mathrm{w}$ ograniczonej przestrzeni. Wiele korzyści zewnętrznych związanych $\mathrm{z}$ rozwojem wiedzy pojawia się $\mathrm{w}$ bardzo skoncentrowanych obszarach gospodarczych wewnątrz miast/obszarów metropolitalnych. Dobrami i usługami publicznymi zazwyczaj trudno jest handlować poza ograniczoną przestrzenią. Również efekty instytucjonalne częściowo pojawiają się na poziomie krajowym, ale również na poziomie regionów, miast czy specjalnych stref ekonomicznych [Venables 2009, s. 50-51]. Literatura bogato dokumentuje zewnętrzne korzyści produktywności, jakie generują wielkie centra urbanistyczne. Badania pokazują, że podwojenie rozmiarów miasta (pod względem liczby ludności) związane jest z 3-8\% wzrostem produktywności, przy czym analiza efektów przestrzennych pokazuje, że są to zjawiska skoncentrowane na ograniczonym obszarze. Oczywiście efekty te różnią się między branżami i zazwyczaj najsilniej występują w sektorach wysokich technologii ${ }^{12}$. W wielu krajach obserwujemy pogłębiające się procesy polaryzacji przestrzennej, narastające zróżnicowania między poszczególnymi regionami, a to oznacza, że cechy związane z zapleczem terytorialnym odgrywają istotną rolę. Dlatego należy wzmacniać terytoria, a nie pomagać bezpośrednio firmom - trzeba wzmacniać całe otoczenie. Powoduje to konieczność kompleksowego oddziaływania na cały lub na kilka powiązanych ze sobą układów terytorialnych, nie zaś na poszczególne jednostki administracyjne z osobna. Takie podejście prowadzi do zwiększenia spójności obszarów funkcjonalnych, a co za tym idzie podnosi konkurencyjność całego obszaru metropolitalnego, gdyż zmniejsza koszty transakcyjne przedsiębiorstw zlokalizowanych $\mathrm{w}$ regionie o dobrych powiązaniach komunikacyjnych $\mathrm{z}$ otoczeniem, wyposażonym w instytucje ułatwiające współpracę, zamieszkiwanym przez mobilne, dobrze poinformowane społeczeństwo [Gorzelak 2008, s. 80]. Aby to było możliwe konieczna jest współpraca między różnymi szczeblami władzy zarówno w układzie poziomym, jak i pionowym, ponieważ tylko wtedy można uzyskać efekt synergiczny dla całego obszaru funkcjonalnego. Ze względu na fakt, że zazwyczaj mamy małe organizacje administracji publicznej, często ze sobą skonfliktowane, a synergię możemy utworzyć poprzez układ współpracy i wspólne inwestycje dotyczące danego terytorium ${ }^{13}$, to $\mathrm{z}$ tego punktu widzenia nie

12 Więcej na ten temat: Rosenthal, Strange 2004; Rice, Venables, Pattachini 2006.

13 We Francji, żeby zmusić do współpracy podzielone sfragmentaryzowane układy administracji terytorialnej wprowadzono tzw. SCOT (Le Schéma de Cohérence Territoriale) - schematy rozwoju regionalnego, na które gminy dostaną pieniądze, jeżeli się między sobą dogadają, zrobią wspólny plan i dopasują swoje 
następuje deterytorializacja, lecz terytorializacja gospodarki, przedsiębiorstw, a maleje znaczenie podziałów administracyjnych w terytoriach wyznaczanych kryteriami politycznymi. Rośnie zaś rola poszczególnych podmiotów funkcjonujących na danym terenie i współdziałania między nimi ${ }^{14}$.

Zjawisko tworzenia struktur regionalnych czy nawet lokalnych obserwujemy jako przeciwwagę dla procesów globalizacji. Powstają one według kryteriów politycznych i ekonomicznych, ale również na podłożu kulturowym, religijnym, historycznym bądź cywilizacyjnym, ponieważ chronią tożsamość i różnorodność. Zjawisko to nazywane jest fragmentaryzacją i uczestniczy w nim również państwo, które jest jednym z uczestników tych struktur [Kuźniar 2000, s. 10].

\subsection{Zmiany roli państwa i władz publicznych}

Przeciwnicy teorii o zanikaniu państwa utrzymują, iż państwa nie tracą swojego znaczenia. Następuje raczej zmiana nowoczesnych cech suwerenności i terytorialności, która polega na „reprywatyzacji państwowego terytorium" [Sassen 1996]. Globalizacja wywołuje przekształcenie roli państwa, a nie jej zmniejszenie [Cox 1987, s. 254-259]. Stopford i Strange badali nowe możliwości działania państwa $\mathrm{w}$ gospodarce globalnej i doszli do wniosku, że jego rola stała się bardziej istotna i bardziej złożona [Stopford, Strange, Henley 1991, s. 1-2, 97-36] ${ }^{15}$. Globalizacja nie jest kresem istnienia państw narodowych, lecz tylko wymusza na nich nowe zadania. Przez wielu autorów traktowana jest jako przyczyna decentralizacji i rozproszenia władzy lub też jej niespotykanej w historii koncentracji [zob.: Polak 2009]. Powstawanie i funkcjonowanie nowych instytucji na poziomie ponadnarodowym i regionalnym prowadzi do decentralizacji kompetencji państwa oraz ograniczenia jego funkcji, co ma na celu ich racjonalizację. Instytucjonalizacja i regionalizacja powiązań ponadnarodowych stanowią brakujące

lokalne plany do tego nadrzędnego, który ma powiązać cały układ i stworzyć synergię.

${ }^{14} \mathrm{~W}$ tym kontekście warunkiem niezbędnym do stymulowania rozwoju całego obszaru jest wdrożenie koncepcji governance, która w praktyce pozwoli sterować kompleksowo całym układem funkcjonalnym. Jeżeli tych procesów nie uda się wywołać oddolnie ze względu na siły inercji występujące we władzach lokalnych bądź różnego rodzaju pułapki polityczne (troska o wygraną w kolejnych wyborach) czy pułapki społeczne, to wtedy, zgodnie z dynamiczną zasadą subsydiarności [Markowski 2011, s. 35], powinien reagować poziom regionalny, a może się okazać, że także rządowy, a nawet unijny. Jeżeli mówi się o spójności pewnych obszarów, to aby zmusić do współpracy poszczególne podmioty, trzeba pokazać, że taki układ terytorialny ma ze sobą coś wspólnego, może wykreować jakąś przewagę i podnieść atrakcyjność całego układu.

15 Zob.: Held 1999, s. 436-444. 
ogniwo koordynacji działań w ramach systemu gospodarki światowej" [Przygodzki 2007, s. 27-29].

Według większości politologów władza państwowa istnieje i nic jej nie zagraża. Obecnie suwerenność rozumiana jest jako dzielenie władzy publicznej między władze narodowe, regionalne i globalne [McGrew 2009, s. 24]. Podczas gdy struktury i same państwa w dalszym ciągu pozostają ważne, system światowy nie jest już systemem opartym na państwach (state-centric) [Kobrin 2009, s. 4]. Przejawem globalizacji jest zwiększająca się rola podmiotów eksterytorialnych, takich jak Unia Europejska, Bank Światowy, NATO, niezależnych od władzy państwowej, w kreowaniu rzeczywistości państw i ich społeczeństw. Są to różnego typu organizacje międzynarodowe stworzone przez państwa, które chcą za ich pomocą wprowadzić pewne standardy w stosunkach politycznych, społecznych, gospodarczych i handlowych, mające obowiązywać w skali globalnej, bez konieczności żmudnego budowania korzystnych stosunków za pomocą umów bilateralnych [Graniszewski 2009, s. 60]. Tym samym kształtuje się nowy ład międzynarodowy. $\mathrm{Z}$ jednej strony $\mathrm{w}$ dalszym ciągu mamy do czynienia z klasycznym systemem międzynarodowym złożonym z suwerennych państw, z drugiej zaś system ten jest wkomponowany w ponadpaństwową sieć instytucjonalnych i nieformalnych powiązań i zależności, złożoną z różnorodnych podmiotów i oddziaływań pozapaństwowych [Polak 2009, s. 23].

O realizację praw i interesów wynikających z suwerenności, państwa coraz bardziej zabiegają poprzez uczestnictwo w decyzjach podejmowanych na szczeblu organizacji wspólnotowych i licznych instytucji międzynarodowych [Staniszkis 2003, s. A8]. Mówi się o zdezagregowanym państwie, w którym tworzące je organy rządowe w coraz większym stopniu, w ramach zarządzania wspólnymi i globalnymi kwestiami, współdziałają z ich odpowiednikami za granicą, z organami międzynarodowymi i NGOs (non-governmental organizations) [Slaughter 2004, s. 171-172]. Dlatego też państwa muszą zaadaptować się do nowych realiów i zacząć rozumieć suwerenność państwową $\mathrm{w}$ kontekście nowych uwarunkowań. Obecnie suwerenność oznacza nie tyle niezależność państwa od czynników zewnętrznych, ile jego zdolność do stanowienia o swoim losie i do realizacji swoich interesów w warunkach globalizacji [Czaputowicz 2001, s. 31]. Państwo nie „więdnie”, lecz przyjmuje mnóstwo form na wielu poziomach przestrzenno-społecznych. Nie oznacza to jednak, że państwo jest wszędzie i że wszyscy politycy są wewnątrz państw. Wiele tradycyjnych funkcji państw narodowych zostało obecnie przesuniętych na niższe lub wyższe szczeble instytucji państwowych, które wcześniej albo nie istniały, albo zostały od podstaw zreformowane $\mathrm{w}$ trakcie tego procesu. Globalizacja tworzy państwa, ale inne niż te, do których byliśmy przyzwyczajeni [Keil 1998, 
s. 617]. „Państwo narodowe musi zaakceptować ten stan rzeczy i dostosować się do funkcjonowania w tym złożonym środowisku, akceptując fakt, że pewne rozstrzygnięcia, przybierające postać prawa, powstają jedynie z jego mniejszym lub większym udziałem, ale stosować je trzeba w całości ze względu na reguły wzajemności" [Graniszewski 2009, s. 61].

Nie oznacza to, że dotychczasowe instytucje państwowe przestają istnieć. $\mathrm{W}$ dalszym ciągu są one odpowiedzialne za tworzenie zasad, norm, praw, ale na poziomie ponadnarodowym. Zauważalne jest jednak przedefiniowanie ich kompetencji i zakresów działania. Kształtujące się organizacje ponadnarodowe nie budują nowej sieci powiązań, lecz wpisują się w istniejące już układy związków narodowych. Tworząc nowe ogniwa sieci przyczyniają się do jej rozbudowania, koordynują bowiem współdziałanie kilku lub kilkunastu podsieci narodowych.

Państwo nie ma już monopolu na tworzenie powszechnie obowiązujących przepisów, ale tylko państwo ma instrumenty, aby zapewnić egzekwowanie norm zawartych zarówno $\mathrm{w}$ prawie wewnętrznym, jak i przepisów zewnętrznych [Szczerski 2003, s. 39]. Podstawowym narzędziem regulacji sfery politycznej i społeczno-gospodarczej jest prawo, naturalne jest więc, że obowiązywanie obszernego, zewnętrznego systemu norm modyfikuje rolę państwa narodowego jako jedynego regulatora porządku społecznego. Prowadzi to nie tylko do ograniczenia zakresu jego suwerennej władzy, ale też generalnie zmienia sposób funkcjonowania państwa poprzez dyfuzję władzy, czyli przenoszenie kompetencji na poziom wyższy, ponadnarodowy, ale też upodmiotowienie wspólnot regionalnych i lokalnych.

Coraz większą rolę do odegrania mają władze regionalne i lokalne. Władze publiczne niższego szczebla odgrywają ważną rolę w budowaniu zaufania, będącego podstawą życia społecznego, niezbędnego, aby efektywnie konkurować na rynku bez względu na jego zasięg. Decentralizacja coraz szerzej postrzegana jest jako demokratyczna forma sprawowania władzy. Działa ona na podstawie zasady subsydiarności, która głosi, że to co można załatwić lokalnie nie powinno być przekazywane do rozwiązania wyższym szczeblom administracji [Krzeczunowicz 2006, s. 9]. Dyfuzja władzy oznacza też, że część kompetencji do stanowienia norm przenoszona jest na szczebel regionalny, lokalny oraz następuje włączenie $\mathrm{w}$ ten proces podmiotów niepublicznych w postaci tzw. zorganizowanego społeczeństwa obywatelskiego. Powstają liczne stowarzyszenia, w ramach których ludzie łączą swoje wysiłki, aby osiągnąć wspólne cele. Coraz większego znaczenia nabiera pozycja organizacji pozarządowych, często o globalnym zasięgu. Takimi organizacjami coraz bardziej zainteresowani są politycy. Wynika to przynajmniej $\mathrm{z}$ dwóch powodów. Po pierwsze obecna rekonstrukcja państw, zgodnie z ideologią neoliberalną, wiąże się ze zmniejszeniem liczby usług edukacyjnych i społecznych finansowanych przez państwo. Neoliberałowie 
postrzegają zapewnienie realizacji wielu tego typu usług jako zadanie dla organizacji pozarządowych. Po drugie coraz bardziej rośnie znaczenie polityczne tych organizacji (Amnesty International, Greenpeace). Rządy, a nawet ponadnarodowe korporacje, muszą liczyć się z ich zdaniem [Katus 2002]. Z globalizacją niektórzy wiążą również rosnącą liczbę partii politycznych.

Kolejnym przejawem globalizacji politycznej jest zacieranie się granic między sektorem prywatnym i publicznym. Niegdyś jasne różnice między sferą prywatną i publiczną, między politykami, prawem i przepisami z jednej strony a rynkiem i działalnością gospodarczą z drugiej - załamały się. Władze publiczne bezpośrednio angażują się w działalność gospodarczą poprzez należące do państwa bądź kontrolowane przez nie przedsiębiorstwa, natomiast firmy prywatne przejmują funkcje publiczne, np. zapewnienie opieki zdrowotnej. W wyniku zachodzących przemian następuje przesunięcie władzy z sektora publicznego do prywatnego (również NGOs, fundacje, stowarzyszenia), który nie podlega demokratycznej kontroli państwa [Polak 2009, s 21]. Wzrost konkurencyjności państw i gwałtowny rozwój społecznej odpowiedzialności biznesu zatarły te, jasne wcześniej, granice między sektorem prywatnym i publicznym. Okazało się, że sektor prywatny potrafi wiele problemów rozwiązać znacznie sprawniej niż skostniałe biurokracje państwowe. W dodatku odbywa się to bez komplikacji politycznych, które pojawiają się jako zagrożenie, gdy działania podejmują władze rządowe.

Rola firm międzynarodowych w polityce międzynarodowej nie jest już ograniczona do pośredniego oddziaływania poprzez lobbowanie rządów czy też prób oddziaływania na opinie polityków. Obecnie to one tworzą standardy, dostarczają dobra publiczne i uczestniczą w międzynarodowych negocjacjach. Stały się one międzynarodowymi aktorami, którzy dysponują prywatną władzą polityczną i są coraz bardziej zaangażowani w autorytatywne podejmowanie decyzji [Cutler, Haufler, Porter 1999, s. 16]. Uczestniczą $\mathrm{w}$ formułowaniu i wdrażaniu zasad w tych obszarach polityki, które niegdyś leżały jedynie w sferze odpowiedzialności państw lub międzynarodowych organizacji rządowych [Scherer, Palazzo, Baumann 2006, s. 506].

W stosunkach międzynarodowych efektem globalizacji jest centralizacja podejmowanych decyzji $w$ sprawach światowych przez nieliczne ośrodki państwowe i pozapaństwowe. W podejmowaniu tych decyzji zmniejsza się udział poszczególnych państw, w tym również w sprawach bezpośrednio ich dotyczących. Zmniejsza się poziom demokracji w społeczności międzynarodowej, coraz wyraźniejszy staje się podział na państwa tworzące politykę (policy-makers) i przyjmujące politykę (policy-takers) [Zorska 2001, s. 225].

Wszystko to nie oznacza, że narodowe interesy przestały istnieć. Kraje wyraźnie sobie uświadamiają swe narodowe interesy ekonomiczne, choć nadal inwestują poza swymi granicami. Czyniąc tak każdy kraj usiłuje za- 
dbać o dobrobyt i bezpieczeństwo własnych obywateli, a w związku z tym usiłuje zwiększyć potencjalną wartość tego, co jego obywatele mogą wnieść do globalnych sieci przedsiębiorczości [Reich 2000, s. 124]. Podobne zjawiska obserwuje się w miastach. Zmiany, które zaszły w ostatnich latach, spowodowały, że władze miast nie są dłużej w stanie, a przynajmniej nie w takim stopniu, jak wcześniej, kierować wydarzeniami. Przesunięcie w kierunku globalizacji gospodarki, włączające ruch kapitału inwestycyjnego, pojawienie się sektorów gospodarczych o zasięgu ogólnoświatowym i instytucji międzynarodowych, dla władz miejskich oznaczało utratę kontroli nad gospodarkami miast i nowe działania oraz nowe zakresy odpowiedzialności.

Coraz więcej obowiązków władz publicznych zostaje przekazanych innym podmiotom bądź to poprzez zastosowanie partnerstwa publicznoprywatnego, bądź przez zlecanie pewnych zadań innym organizacjom (fundacjom, NGOs itp). Zarządzanie miastem nie może być w dzisiejszych czasach rozumiane w kategoriach top down czy command and control modeli governance [Healey, Cameron, Davoudi et al. 1995, s. 18]. Obecnie znacznie częściej niż o zarządzaniu mówi się o współrządzeniu miastem.

Większość zmian politycznych, które obecnie zachodzą w wielkich regionach miejskich polega na poszukiwaniu struktur rządzenia zdolnych do zabezpieczenia i wzmocnienia ich przewag konkurencyjnych w gwałtownie globalizującym się ładzie gospodarczym. Malejąca zdolność władz centralnych do rozwiązywania różnych problemów regionów określonych administracyjnymi granicami oznacza, że wiele regionów stanęło w obliczu wyboru, czy biernie poddać się zewnętrznej międzygranicznej presji, czy też aktywnie tworzyć nowe instytucje, polityki i podjąć wysiłek potraktowania globalizacji jako szansy a nie zagrożenia. Regiony, które zdecydowały się na tę drugą opcję, muszą zmierzyć się z nowymi zadaniami politycznej koordynacji i reprezentacji. Zadanie to jest szczególnie pilne nie tylko ze względu na ich ekonomiczne znaczenie, ale z uwagi na fakt, iż wielkie regiony miejskie coraz silniej działają jako bieguny przyciągające nisko wynagradzanych emigrantów z całego świata, a co za tym idzie w ich populacji silnie wyróżniają się grupy językowe (polyglot) i często wykluczone społecznie. W efekcie wiele regionów miejskich stoi przed rozwiązaniem $\mathrm{z}$ jednej strony problemu politycznej partycypacji różnych środowisk, z drugiej zaś odbudowy lokalnej tożsamości i obywatelstwa [Scott 2001, s. 817].

\subsection{Miasta światowe jako „lokomotywy" rozwoju}

Wraz z postępem globalizacji tworzy się układ wielkich regionów miejskich i to te szczególne typy aglomeracji coraz bardziej funkcjonują jako fundamenty nowego światowego systemu, który kształtuje się od końca lat 70. wieku XX. To wielkie miasta uczestniczą w globalnej produkcji, global- 
nym przepływie dóbr, globalnych transakcjach finansowych, inwestycjach, globalnej współpracy naukowej, kulturalnej itp. Dzięki temu uzyskują dość szeroką autonomię, odgrywając główną rolę na scenie gospodarczej i społecznej współczesnego świata [Parysek 2008, s. 13]. Miasta te, zwane miastami światowymi, w pewnym stopniu weszły w sferę działań zastrzeżonych dotychczas dla państwa narodowego. To w nich tworzone są szczególne polityki miejskie dotyczące takich dziedzin, jak wzrost i rozwój; imigracje i prawa obywatelskie; tożsamość i polityka antyrasistowska; bezpośrednie sąsiedztwo versus kultura „światowa”; stosowanie i wymiana wartości; nowe formy walki klasowej; konsumpcja zbiorowa i trwałość (sustensywność). Wszystkie te obszary stanowią konkretną przestrzeń do mediacji i negocjacji, w której zazębiają się żądania różnych aktorów [Keil 1998, s. 631].

Istnieje bogata literatura na temat „miast światowych” i „miast globalnych", która koncentruje się przede wszystkim na koncepcji kosmopolitycznej metropolii jako „centrum dowodzenia” dla działań wielonarodowych korporacji, jako centrum zaawansowanych/wyższego rzędu usług oraz działań związanych z przetwarzaniem informacji oraz jako głęboko podzielonej przestrzeni społecznej, wyróżniającej się z jednej strony skrajnym ubóstwem, a $\mathrm{z}$ drugiej ogromnym bogactwem ${ }^{16}$. 0 miastach światowych pisał już w 1915 r. Geddes w swojej książce Miasta w procesie ewolucji (Cities in Evolution). W roku 1966 Hall zdefiniował je w kategoriach wielorakich ról, które odgrywają jako ośrodki władzy politycznej (zarówno krajowej, jak i międzynarodowej) i organizacji związanych z rządem (związki zawodowe, organizacje profesjonalistów, związki pracodawców, siedziby głównych koncernów międzynarodowych), ośrodki krajowego i międzynarodowego handlu pełniące funkcję magazynów dla swoich państw, ośrodki bankowości, ubezpieczeń i usług finansowych, ośrodki profesjonalnej działalności wszelkiego rodzaju (w dziedzinie medycyny, prawa, szkolnictwa wyższego) i stosowania wiedzy naukowej w technologiach, ośrodki zbierania i rozprzestrzeniania informacji za pośrednictwem największych wydawnictw i mass mediów, miejsca o wysokim poziomie konsumpcji zarówno dóbr luksusowych (przez mniejszą część społeczeństwa), jak i produktów masowych (konsumowanych przez większość), ośrodki kultury, sztuki i rozrywki [Hall 1966, s. 7-8]. Jak widać miasto światowe nie jest określane liczbą ludności, lecz funkcjami jakie pełni (tab. 2).

16 Zob.: Hall 1966; Castells 1996; Friedmann, Wolff 1982; Sassen 1991; Knox 1995. 
Cechy miasta globalnego według różnych autorów

\begin{tabular}{|c|c|c|}
\hline Hall (1966) & Friedmann (1986) & Sassen $(1991 ; 1995 ; 2000)$ \\
\hline $\begin{array}{l}\text { Główne ośrodki władzy } \\
\text { politycznej }\end{array}$ & $\begin{array}{l}\text { Włączenie w światową } \\
\text { gospodarkę jego funkcji } \\
\text { w nowy międzynarodowy } \\
\text { przestrzenny podział pracy }\end{array}$ & $\begin{array}{l}\text { Ośrodki polityczno- } \\
\text { gospodarczej kontroli } \\
\text { i oddziaływania na glo- } \\
\text { balny marketing i pro- } \\
\text { dukcję }\end{array}$ \\
\hline Narodowe ośrodki handlu & $\begin{array}{l}\text { Punkty, w których następuje } \\
\text { określenie profilów pro- } \\
\text { dukcji i rynków }\end{array}$ & $\begin{array}{l}\text { Węzły zarządzania } \\
\text { i regulacji nową ekono- } \\
\text { mią przestrzeni }\end{array}$ \\
\hline $\begin{array}{l}\text { Główne węzły sieci trans- } \\
\text { portowych }\end{array}$ & $\begin{array}{l}\text { Globalne funkcje sterujące } \\
\text { odzwierciedlone w struk- } \\
\text { turze i dynamice sektorów } \\
\text { gospodarki i zatrudnienia }\end{array}$ & $\begin{array}{l}\text { Siedziba czołowych firm } \\
\text { międzynarodowych } \\
\text { i ośrodki rozwoju zaa- } \\
\text { wansowanych usług } \\
\text { korporacyjnych } \\
\end{array}$ \\
\hline $\begin{array}{l}\text { Centra bankowości } \\
\text { i finansów }\end{array}$ & $\begin{array}{l}\text { Główne miejsca koncentracji } \\
\text { i akumulacji międzynaro- } \\
\text { dowego kapitału }\end{array}$ & $\begin{array}{l}\text { Miejsca produkcji usług dla } \\
\text { przedsiębiorstw }\end{array}$ \\
\hline $\begin{array}{l}\text { Centra profesjonalnych } \\
\text { usług }\end{array}$ & $\begin{array}{l}\text { Docelowy kierunek krajo- } \\
\text { wych i międzynarodowych } \\
\text { emigrantów }\end{array}$ & $\begin{array}{l}\text { Koncentracja funkcji } \\
\text { kontrolnych }\end{array}$ \\
\hline $\begin{array}{l}\text { Koncentracja wysokich } \\
\text { dochodów }\end{array}$ & $\begin{array}{l}\text { Przestrzenna i klasowa } \\
\text { polaryzacja }\end{array}$ & $\begin{array}{l}\text { Postindustrialne obiekty } \\
\text { wykorzystywane przez } \\
\text { wiodące przemysły, } \\
\text { finanse i specjalistyczne } \\
\text { usługi }\end{array}$ \\
\hline Przeludnienie i zatory & $\begin{array}{l}\text { Generatory kosztów społecz- } \\
\text { nych przekraczających } \\
\text { możliwości fiskalne pań- } \\
\text { stwa }\end{array}$ & $\begin{array}{l}\text { Krajowe i międzynarodo- } \\
\text { we rynki, na których } \\
\text { firmy i rządy mogą kupić } \\
\text { instrumenty finansowe } \\
\text { i specjalistyczne usługi }\end{array}$ \\
\hline
\end{tabular}

Źródło: [Richardson, Bae 2005, s. 151].

W większości publikacji termin miasto światowe jest stosowany wymiennie z określeniem miasto globalne [Lo, Yeung 1998, s. 2]. Terminy miasto globalne (global city) czy miasto światowe (world city) pojawiły się na określenie trzydziestu centrów miejskich, które są ze sobą połączone w sieć, łączącą kulę ziemską. W tym ujęciu miasta światowe są miejscami, w których ten nowy, zglobalizowany świat gospodarczy przyjmuje namacalną, konkretną postać. Globalne przepływy kapitału i pracy przechodzą przez te miasta i są przez nie kontrolowane [Keil 1998, s. 617]. Wikipedia definiuje „miasto globalne”, traktując je jako synonim dla world city, alpha city i world center, jako miasto uważane za ważny węzeł w globalnym systemie gospodarczym [http://en.wikipedia.org/wiki/Global_city]. Miasta globalne są interpretowane jako globalne centra usług świadczące usługi finansowe i biznesowe (księgowość, prawo, itp.) międzynarodowym korporacjom 
[Taylor 2003]. Są ośrodkami dowodzenia globalną gospodarką, punktami łączącymi globalne społeczeństwo i ważnymi miejscami przemian społecznych oraz gospodarczych [Short 2004, s. 3]. Friedmann zauważył, że miasta światowe tworzą większe narodowe, międzynarodowe i globalne jednostki gospodarcze, które są osadzone w hierarchii przestrzennej [Friedmann 1995, s. 23-24].

Scott [2001, s. 813] rozszerzył tę koncepcję na region jako tworzącą się polityczno-gospodarczą jednostkę z rosnącą autonomią działania na narodowej i światowej scenie, którą nazwał globalnym regionem miejskim. $\mathrm{Z}$ geograficznego punktu widzenia globalne regiony miejskie tworzą gęste, spolaryzowane skupiska kapitału, pracy i życia społecznego, które uwikłane są na wiele sposobów w zintensyfikowane i rozprzestrzenione pozanarodowe relacje. Jako takie powstają z wielkich obszarów metropolitalnych lub zespołu sąsiadujących obszarów metropolitalnych - wraz z otaczającymi je terenami sięgającymi w różnym stopniu w głąb kraju, na których pojawia się rozproszona zabudowa miejska. Równolegle do tych kierunków rozwoju, w wielu przypadkach następuje konsolidacja globalnych regionów miejskich w wyraźne polityczne całości, ponieważ sąsiadujące ze sobą władze lokalne (okręgów, gmin, obszarów metropolitalnych, itp.) tworzą przestrzenne koalicje $\mathrm{w}$ poszukiwaniu efektywnych podstaw dających możliwość niwelowania zagrożeń i wykorzystywania szans, które niesie globalizacja [Scott 2001, s. 817].

Pojawienie się nowych, globalno-lokalnych układów w miastach światowych powinno być postrzegane jako dynamiczny proces wzajemnego formowania się ugrupowań społecznych i jako rezultat faktycznych stosunków władzy. Możemy w nim wyróżnić dwa procesy: globalizacji regionów miejskich i fragmentacji miejskiego społeczeństwa obywatelskiego oraz fragmentacji politycznej [Keil 1998, s. 632].

Większość badaczy procesów, jakie zachodzą w związku ze zjawiskiem globalizacji, koncentruje się na relacjach zachodzących wewnątrz miast. W przeciwieństwie do podejścia, które wykorzystywało wskaźniki mierzalne do określenia rangi, jaką miasto zajmuje w globalnej hierarchii (np. liczba centrali firm transnarodowych, liczba pasażerów międzynarodowych rejsów lotniczych, mobilność ekspertów globalnych banków inwestycyjnych, globalna sieć biur międzynarodowych firm projektowo-architektonicznych), Taylor, wraz ze swymi współpracownikami z GAWC17, [2001; 2007] badał wewnętrzne relacje między miastami. $Z$ jego punktu widzenia istnieje wewnętrzne połączenie $w$ ramach sieci miast, nie uwzględniane w innych rankingach miast, które stanowi najważniejszą cechę wciąż podle-

17 Globalization and World Cities jest siecią badawczą koncentrująca się na powiązaniach zewnętrznych miast światowych., zob: http://www.lboro.ac.uk/gawc. 
gającego globalizacji światowego systemu miast. Aby określić usieciowienie miast światowych badali rozkład usług zaawansowanych wśród grupy miast. Stworzyli macierz składającą się z 315 miast i 100 przedsiębiorstw reprezentujących takie usługi, jak rachunkowość, reklama, banki, ubezpieczenia, kancelarie prawne i firmy konsultingowe.

Wybrali firmy, które miały co najmniej 15 filii w różnych miastach, w tym przynajmniej po jednym oddziale w najważniejszych obszarach globalizującego się świata (Ameryka Północna, Zachodnia Europa i Azja w rejonie Pacyfiku). Następnie określili połączenia między tymi miastami. Te, które miały co najmniej $20 \%$ połączeń w stosunku do najbardziej „usieciowionego" miasta, jakim okazał się Londyn, zostały określone jako miasta światowe. W sumie takich miast Taylor wyróżnił 123 . Po raz kolejny badania zostały powtórzone w roku 2009 i rozszerzone na 525 miast i 2000 firm [Taylor i in. 2010]. Najbardziej usieciowione miasta to Londyn, Nowy Jork i Hongkong. Wśród 25 miast europejskich, które osiągnęły najwyższy wskaźnik usieciowienia znalazła się również Warszawa (zał. 1).

Wcześniej mówiło się o miastach globalnych/światowych przeciwstawiając im bardziej współczesne określenie miasta w globalizacji. Dwadzieścia lat temu większość głównych siedzib korporacji transnarodowych znajdowała się w miastach globalnych. Obecnie, dzięki nowym technologiom komunikacyjnym, nie muszą one lokować się wyłącznie $w$ największych miastach. Od lat 90. obserwuje się wzrost znaczenia przepływów kapitałowych na tzw. wschodzących rynkach $\mathrm{z}$ pominięciem głównych siedzib zlokalizowanych $\mathrm{w}$ krajach zachodnich. W obecnej przestrzeni przepływów siedziba przedsiębiorstw transnarodowych nie jest konieczna do określenia miasta jako globalnego [Short 2004, s. 17]. Jak zauważają Taylor i in. wszystkie dzisiejsze miasta możemy nazwać zarówno światowymi, jak i globalnymi z natury, ponieważ wszystkie one są miastami w erze globalizacji [Taylor, Derudder, Saey, Witlox 2007, s. 13-14]. Współczesne procesy integracji geoekonomicznej przekształcają relacje między wszystkimi miastami i w konsekwencji zmieniają ważne aspekty wewnątrzmiejskiego (intra-urban) życia społecznego.

Między tymi ośrodkami pojawiają się interakcje, które prowadzą do wytworzenia globalnej sieci metropolii. W dobie globalizacji zachodzi proces osłabiania powiązań funkcjonalnych między miastami metropolitalnymi a ich zapleczem, na rzecz wzmocnienia związków z innymi metropoliami.

Wpływ globalizacji na miasta charakteryzuje kompleksowość. W przypadku obszarów metropolitalnych to oddziaływanie można obserwować na czterech różnych poziomach: międzynarodowym, krajowym, metropolitalnym i wewnątrzmiejskim.

Na poziomie międzynarodowym obszary metropolitalne stanowią atrakcyjną lokalizację dla większości krajowych i międzynarodowych korporacji 
działających w danym kraju. Są one miejscem, do którego i z którego kieruje się większość międzynarodowych lotów. W dobie gwałtownie rozwijającego się ruchu lotniczego metropolie wzmacniają swoją pozycję jako międzynarodowe centra lotnicze i dywersyfikują swoje powiązania z międzynarodową siecią lotniczą. Ma to odzwierciedlenie zarówno w rosnącej liczbie przewozów pasażerskich, jak i towarowych.

W skali krajowej, dla większości przedsiębiorstw obszary metropolitalne są głównymi rynkami zbytu, co umacnia ich pozycję w hierarchii miast.

Na poziomie metropolitalnym obserwujemy zmiany w strukturze miejskiej będące rezultatem dostosowania rynku nieruchomości i rynku pracy spowodowanego zmianami miejsca zamieszkania i dojazdów do pracy. W rezultacie pogłębia się przestrzenna segregacja terenów mieszkaniowych. Jednocześnie decentralizacja terenów mieszkaniowych i wzrost zatrudnienia $\mathrm{w}$ wysokodochodowych sektorach gospodarki doprowadziły do wydłużenia dojazdów do pracy dla znaczącej części populacji obszarów metropolitalnych. Obserwuje się przestrzenne rozrastanie się metropolii oraz postępującą suburbanizację spowodowaną przenoszeniem się bogatszej części społeczeństwa z centrum metropolii na przedmieścia. W statystykach miasta centralne wykazują ujemny bilans migracji, podczas gdy bilans codziennych dojazdów do pracy między miastem centralnym a otaczającymi je jednostkami terytorialnymi jest dodatni. To powoduje szereg problemów, które zostały szerzej opisane w dalszej części pracy. Przestrzenne wzory segregacji odzwierciedlają ludzkie zachowania będące wynikiem takich zmiennych, jak rodzina i pochodzenie, poziom dochodów, wykształcenie i in., jak również czynników zewnętrznych związanych $\mathrm{z}$ wizerunkiem kulturowym i warunkami codziennego życia. Jednakże obserwuje się generalną tendencję grup społecznych do wyboru miejsca zamieszkania w sąsiedztwie swoich rówieśników i do odróżnienia się od innych zarówno społecznie, jak i przestrzennie. Tworzenie takich skupisk społecznych jest bardziej widoczne wśród części mieszkańców osiągających najwyższe dochody. Biedniejsi pracownicy prezentują bardziej rozproszony wzorzec przestrzennego rozmieszczenia. Powszechnie mówi się o wykluczeniu, marginalizacji, gettoizacji (wcześniej była gettoizacja w sensie negatywnym (obszary biedy), teraz tworzy się getto dobrobytu) [Jałowiecki 2007].

Na szczeblu wewnątrzmiejskim, miasto można przedstawić jako przestrzennie zróżnicowaną pod względem społeczno-demograficznym mozaikę, będącą wynikiem społecznej polaryzacji i nierówności w dochodach. Charakterystyczną cechą dzisiejszego społeczeństwa są rosnące dysproporcje między jego poszczególnymi grupami, które szczególnie widoczne są na rynku pracy, między osobami zatrudnionymi a bezrobotnymi. Również rozwarstwienie społeczne przejawia się tym, że na rynku pracy poszukiwana jest tylko niewielka grupa wysoko wykwalifikowanych specjalistów, 
która może stawiać warunki przy ubieganiu się o pracę, natomiast większość osób ma problemy ze znalezieniem satysfakcjonującego zatrudnienia. Szansę na poprawę sytuacji społecznej mają jednostki mobilne, zdolne do zaadaptowania się w nowym miejscu pracy i uczestniczenia w sieci globalnych powiązań.

\section{Nowe procesy urbanizacji w gospodarce globalnej}

Urbanizacja to, w najogólniejszym sensie, proces tworzenia miast [Czornik 2004, s. 102]. Tradycyjnie oznaczała przeniesienie się ludności z obszarów wiejskich na obszary miejskie. Słownik języka polskiego definiuje urbanizację jako „proces społeczny i kulturowy wyrażający się w rozwoju miast, wzroście ich liczby, powiększaniu się obszarów miejskich i udziału mieszkańców miast w ogólnej liczbie ludności" [Dubisz 2003, s. 268]. Najczęściej stopień urbanizacji mierzony jest odsetkiem ludności mieszkającej na terenach zurbanizowanych [Woods 2003, s. 216]. Urbanizacja jest zjawiskiem demograficznym, ale powodującym fundamentalne konsekwencje ekonomiczne, społeczne, kulturowe i polityczne ${ }^{18}$. Urbanizacja jest jednym z krytycznych globalnych trendów kształtującym przyszłość.

Pod wpływem globalizacji zmieniają się miasta. Dziewiętnastowieczne miasta przemysłowe wyróżniały się koncentracją działalności biznesowych w centrum. Na taką rdzeniową strukturę miast wpływ miała potrzeba międzyregionalnego transportu surowców i produktów oraz struktura krańcowych kosztów transportu w miastach [Lim 2005, s. 21]. W epoce postindustrialnej procesy urbanizacji postępują dzięki rozwojowi usług, w których w krajach o nowoczesnej gospodarce pracuje najwięcej ludzi. Usługi wyższego rzędu decydują o metropolizacji miast powodując wzrost ich znaczenia na arenie międzynarodowej [Jakóbczyk-Gryszkiewicz 2005, s. 11].

Kolejną cechą współczesnej urbanizacji jest jej dwubiegunowy układ w postaci, z jednej strony, intensywnego pod względem demograficznym i przestrzennym rozwoju miast $w$ krajach rozwijających się. Zjawisko to określane jest mianem hiperurbanizacji. W roku 1950 na świecie były 83 miasta, których liczba ludności przekraczała 1 milion (2/3 z nich znajdowało się w krajach rozwiniętych gospodarczo). W roku 1990 były 272 takie miasta (aglomeracje), przy czym $2 / 3$ z nich położone było w krajach rozwijających się, a w dniu 1 stycznia 2013 r. takich aglomeracji było już 489 [The principal...]. Analiza trendów demograficznych w 30 największych obszarach metropolitalnych świata dokonana przez ONZ wskazuje, że tendencja ta $w$ ciągu najbliższych dziesięcioleci zostanie utrzymana. Jednakże nie

${ }^{18}$ Istnieje bogata literatura światowa i krajowa na temat urbanizacji i jej skutków, zob.: Puga 1998; Brunn, Hays-Mitchell, Zeigle 2012; Hugo, Champion 2004; Szymańska 2008; Jażdżewska 2003, 2005; Słodczyk, Śmigielska 2008. 
wszystkie wielkie obszary metropolitalne w tym samym stopniu podlegają wpływowi globalizacji i nie wszystkie globalne regiony miejskie można określić jako wielkie obszary metropolitalne [Scott 2001, s. 814]. Dynamika wzrostu ludności miejskiej jest większa w krajach rozwijających się i do roku 2030 prognozuje się tam tempo wzrostu ludności rzędu 2,27\% rocznie, podczas gdy w krajach rozwiniętych roczny przyrost ludności miejskiej szacuje się na poziomie $0,49 \%$. Z drugiej strony obserwujemy słabszy demograficznie, ale bardzo silny ekonomicznie i politycznie, rozwój miast w krajach wysoko rozwiniętych. Często obserwujemy zjawisko kurczenia się liczby ludności w niektórych miastach. Dotyczy to miast postindustrialnych oraz takich, których infrastruktura ulega zniszczeniu. Są one położone głównie w regionach rozwiniętych oraz przechodzących transformację.

Za rozwój miast w krajach rozwijających się odpowiadają głównie wysoki przyrost ludności oraz masowe migracje z terenów wiejskich do miast. Według prognoz liczba ludności miejskiej na świecie w roku 2030 może przekroczyć 5 mld, z czego 4 mld ma przypadać na miasta krajów rozwijających się [http://www.unfpa.org/pds/urbanization.htm]. Jednakże ta gwałtowna urbanizacja wywołuje również problemy. Po pierwsze chodzi o kwestię ochrony środowiska. Problemy środowiskowe są typowym przykładem negatywnych efektów zewnętrznych i konsekwencją obecnych wzorców konsumpcji i zwyczajów życiowych, które prowadzą do nadużywania zasobów naturalnych, niszczenia ekosystemów i zbyt gęstego zasiedlania terenów otwartych [Ambruosi et al. 2010, s.321] ${ }^{19}$.

Najsilniejsza urbanizacja zachodziła w wieku XX [Hartog 1999, s. 95]. Związane to było z korzystaniem na szeroką skalę z samochodu, co spotęgowało zjawisko codziennych dojazdów do pracy i aktywizację terenów poza miastem, położonych wzdłuż głównych szlaków komunikacyjnych. Samochód i elastyczność ludzkich zachowań (wzrost mobilności) sprzyjały urbanizacji i spowodowały, że nie ma już odwrotu od tego procesu. Według H. W. Eldredge'a [1967] urbanizacja jest procesem obejmującym cztery etapy:

1. Etap migracji z obszarów wiejskich do miasta;

2. Etap mniejszego odśrodkowego ruchu migracyjnego na obrzeża miasta;

3. Etap większego odśrodkowego ruchu migracyjnego na przedmieścia, rozszerzającego proces urbanizacyjny do wymiarów metropolitalnych;

4. Etap wyraźnego zwolnienia procesu koncentracji miejskiej, często na skutek zatarcia się granic między terenami miejskimi i wiejskimi w obszarze metropolitalnym [za: Herbst 2003, s. 107].

Zatem za początek procesów metropolizacji można uznać trzeci etap, związany z rozprzestrzenianiem się miasta.

19 Więcej o negatywnych efektach urbanizacji zob. rozdz. II. 
Proces metropolizacji przestrzeni nie może być utożsamiany z procesem urbanizacji. W wieku XX miasta rdzeniowe przekształciły się w rozprzestrzeniające się metropolie. Główne zmiany, które można było obserwować, to:

- suburbanizacja zarówno w odniesieniu do ludności, jak i miejsc pracy. W pierwszej kolejności, w poszukiwaniu miejsca do działalności w pobliżu szlaków komunikacyjnych, na przedmieścia zaczęła przenosić się rutynowa produkcja montażowa, następnie sektor badań i rozwoju oraz towarzyszące mu przedsiębiorstwa produkujące krótkoseryjne zaawansowane produkty, przenoszące się do miejsc o wysokim standardzie, często położonych w sąsiedztwie lotnisk ze względu na międzynarodową dostępność. Kolejne było zaplecze biurowe, wykonujące rutynowe działania związane z obsługą narodowych centrali przedsiębiorstw. Przenosiło się ono na przedmieścia z uwagi na dostęp do obszernych zasobów lokalnej siły roboczej. Temu wszystkiemu towarzyszył wzrost zatrudnienia w usługach (handel, szkolnictwo, itp.) rozproszonych $w$ regionie. $W$ końcowej fazie do tego trendu dołączyły centrale firm, które w pewnych przypadkach wyraźnie skłoniły do tego wysokie stawki podatków lokalnych w ośrodkach centralnych.

- masowa ekspansja obszarów metropolitalnych i powstawanie nowych miast. Konsekwencją suburbanizacji był wzmożony wzrost małych miast i ich otoczenia w szerszym obszarze metropolitalnym, zwłaszcza tych, które sąsiadowały z autostradami i/lub liniami kolejowymi [Hall 1989, s. 28-29].

- relatywny upadek miast centralnych - peryferializacja rdzenia miejskiego,

- rozlewanie się miast (urban sprawl),

- rozwój części zewnętrznych miast,

- dekoncentracja i rekoncentracja zabudowy i funkcji,

- powstawanie enklaw wewnątrzmiejskich,

- deindustrializacja i reindustrializacja,

- zacieranie się granic miasta [Parysek 2008, s. 13].

Zmiany te były związane:

- ze zwiększeniem liczby ludności,

- z migracją ze wsi do miast,

- z wielkoskalowymi działaniami przedsiębiorstw (ekonomia skali),

- z postępem technologicznym,

- z ulepszeniem systemów transportu,

- ze wzrostem dochodów,

- z polityką rządów odnośnie do rynku nieruchomości i zagospodarowania przestrzennego,

- z dyskryminacja etniczną, dochodową, itp.,

- z dysproporcjami w poziomie dochodów [Lim 2005, s. 21].

Współczesne procesy urbanizacji kształtują się pod wpływem wzajemnie powiązanych czynników: 
1. rosnącej roli informacji i innowacji, które dzięki nowym technikom informatycznym mogą docierać do wielu miejsc na świecie. Informatyzacja jest nie tylko efektem rozwoju technologii, ale i nowym paradygmatem cywilizacyjnym,

2. rozszerzającej się geograficznie i funkcjonalnie globalizacji, która innowacje rozpowszechnia, realizuje i wzmaga ich oddziaływanie w gospodarce. Globalizacja ekonomiczna stworzyła miasta w różnym stopniu włączone w globalną gospodarkę, natomiast globalizacja ideologiczna umacnia te rozbieżności, działając na niekorzyść peryferyjnych miast i regionów [Chakravorty 2003]. Globalizacja wpływa na zjawisko urbanizacji poprzez koncentrację zasobów gospodarczych, naukowych i kulturalnych w światowych metropoliach. Miasta, jako siedziby ponadnarodowych korporacji, rozwijają się w każdej dziedzinie życia intensywniej, stając się coraz nowocześniejsze i ciekawsze architektonicznie [Jakóbczyk-Gryszkiewicz 2005, s. 11],

3. zaostrzającej się konkurencji działającej ze szczególną siłą w rozwiniętej gospodarce rynkowej [Komorowski 2000, s. 62] i zmian w przewagach komparatywnych miast [Lim 2005, s. 22],

4. poszukiwania modelu sustensywnego rozwoju [Purchla, Sepioł 1998, s. 18].

Urbanizację w wieku XXI cechuje:

1. globalna skala zjawiska - liczba ludności w miastach rośnie znacznie szybciej niż ogólna populacja świata [Maik 2005, s. 27],

2. wzrost strategicznej roli wielkich miast $\mathrm{w}$ gospodarce światowej. Wielkie miasta stały się centrami zarządzania światową gospodarką, w których opracowywane są nowe strategie działania i rozwoju. Są one głównymi miejscami wyspecjalizowanych i najbardziej technologicznie zaawansowanych usług, które obecnie mają silniejszy wpływ na życie gospodarcze niż przemysł przetwórczy. Stanowią również rynki dla tych usług [Sassen 1994],

3. zmiana relacji między wielkimi ośrodkami miejskimi a otaczającymi je regionami. W rezultacie miasta na całym świecie przekształcają się w szersze regiony metropolitalne, które funkcjonują jako miejsca zintegrowanej gospodarczej produkcji i konsumpcji [Solecki, Leichenko 2006, s. 10],

4. wzrost kontrastów społecznych w wielkich miastach,

5. zróżnicowanie rozwoju współczesnej urbanizacji w dwubiegunowym układzie: „regiony rozwinięte-regiony rozwijające się” [Maik 2005].

We współczesnym świecie obserwujemy urbanizację na szeroką skalę i jest ona charakterystyczna zarówno dla gospodarczo rozwiniętych, jak i rozwijających się państw. Postępująca urbanizacja jest źródłem korzyści gospodarczych. Miasta są generatorami bogactwa, zatrudnienia, wzrostu produktywności i często są uważane za lokomotywy wzrostu krajowych gospodarek [Duranton 2000, s. 291-292]. Rośnie liczba obszarów metropolitalnych. Jednocześnie wielkie miasta na całym świecie powiększają swoje 
rozmiary. Obecnie połowa ludności $(50,46 \%)$ świata żyje na obszarach zurbanizowanych i liczba ta wykazuje tendencję rosnącą. Prognozy ONZ szacują, że w roku 2030 współczynnik urbanizacji osiągnie poziom 58,97\%, przy czym liczby te są wyższe dla krajów rozwiniętych i wynoszą odpowiednio: $75,16 \%$ oraz $80,88 \%$. Dla Europy ten wskaźnik jest jeszcze wyższy, gdyż $70 \%$ ludności Europy żyje na obszarach zurbanizowanych, a ponad $50 \% \mathrm{w}$ gęsto zaludnionym środowisku metropolitalnym, charakteryzującym się miejską i funkcjonalną ekspansją tradycyjnych miast poza ich granice administracyjne [AMB 2003, s. 151]. O ile liczba ludności w wielkich miastach generalnie spada, o tyle w większości przypadków rośnie liczba mieszkańców ich obszarów metropolitalnych.

Współcześnie urbanizację należy rozpatrywać poprzez pryzmat zmian, jakie zachodzą w już istniejących przestrzeniach miejskich [Smart, Smart 2003, s. 264]. Jest ona jednocześnie procesem i stanem. Współczesne procesy globalizacji powodują fundamentalne zmiany $\mathrm{w}$ formie miast, ich strukturze i organizacji. Z wprowadzeniem na szeroką skalę do gospodarki technologii informatycznych i telekomunikacyjnych w centrach wielkich miast zaobserwowano dwukierunkowe tendencje lokalizacyjne [Domański 2004, s. 155]. Z miast skupiających stare i mało konkurencyjne gałęzie przemysłu wyprowadzono wiele przedsiębiorstw, co pociągnęło za sobą masowy wzrost bezrobocia. Jednocześnie $w$ dzielnicach centralnych lokowały się nowe firmy z sektora finansowego i wyspecjalizowanych usług. Ich największe zagęszczenie nastąpiło w ośrodkach metropolitalnych [Maik 2005, s. 29].

\section{Urbanizacja w Polsce}

Również w Polsce proces urbanizacji uległ istotnym zmianom, zwłaszcza po transformacji w kierunku gospodarki rynkowej. Oprócz państwa, które było jedynym regulatorem kwestii społecznych, gospodarczych oraz zagospodarowania przestrzennego, pojawiły się nowe podmioty istotne dla gospodarki przestrzennej, takie jak władze samorządowe, prywatni właściciele oraz przedsiębiorstwa. W tej nowej sytuacji na rozwój społecznogospodarczy i zagospodarowanie przestrzenne, a co za tym idzie na kształt i charakter procesu urbanizacji, wpływ mają:

- przepisy prawa,

- polityka przestrzenna państwa, władz regionalnych i lokalnych,

- rynek nieruchomości,

- decyzje lokalizacyjne inwestorów,

- preferencje mieszkańców,

- tendencje rozwoju miast obserwowane w krajach wysoko rozwiniętych,

- uwarunkowania środowiskowe. 
Analiza danych statystycznych wyraźnie pokazuje, że w Polsce, podobnie jak na całym świecie, obserwujemy zjawisko gwałtownej urbanizacji (tab. 3).

Tabela 3

Procent ludności mieszkającej na terenach zurbanizowanych w latach 1950-2050

\begin{tabular}{|c|c|c|c|c|c|c|c|c|c|c|c|c|c|}
\hline \multirow{2}{*}{ Region, kraj } & \multicolumn{13}{|c|}{ Rok } \\
\hline & \begin{tabular}{|l|}
1950 \\
\end{tabular} & 1960 & \begin{tabular}{|l|}
1970 \\
\end{tabular} & 1980 & 1990 & 2000 & 2005 & 2010 & 2015 & 2020 & 2030 & 2040 & 2050 \\
\hline wiat & 29,4 & 33,6 & 36,6 & 39,4 & 43,0 & 46,7 & 49,1 & 51,6 & 53,9 & 56,0 & 59,9 & 63,5 & 67,2 \\
\hline Kraje & 4,5 & 60,9 & 66,6 & 70,1 & 72,3 & 4,1 & 75,9 & 77,5 & 78,8 & 80,0 & 82,1 & 34,1 & 35,9 \\
\hline Kraje rc & 7,6 & 21,8 & 25,3 & 29,5 & 34,9 & 40,1 & 3,0 & 46,0 & 48,7 & 51,3 & 5,8 & 0,0 & 4,1 \\
\hline Afryka & 14,4 & 18,6 & 23,5 & 27,8 & 32,0 & 35,6 & 37,3 & 39,2 & 41,1 & 43,2 & 47,7 & 2,6 & 57,7 \\
\hline zja & 7,5 & 21,1 & 23,7 & 27,1 & 32,3 & 7,4 & 40,9 & 44,4 & 47,6 & 50,5 & 65,5 & 60,0 & 64,4 \\
\hline Europa & 1,3 & 57,0 & 62,8 & 67,3 & 69,8 & 0,8 & 1,6 & 72,7 & 73,8 & 4,9 & 7,4 & 9,9 & 32,2 \\
\hline Europ & 39,7 & 48,9 & 56,6 & 63,8 & 68,0 & 68,2 & 68,2 & 68,9 & 69,7 & 70,6 & 2,9 & 5,6 & 78,2 \\
\hline Biał & 26,2 & 32,4 & 44,0 & 56,5 & 66,0 & 70,0 & 72,4 & 74,6 & 76,6 & 78,4 & 81,2 & 83,3 & 85,2 \\
\hline Buł & 7,6 & 37,1 & 52,3 & 62,1 & 66,4 & 68,9 & 70,2 & 72,5 & 75,3 & 77,6 & 1,0 & 3,3 & 85,2 \\
\hline $\mathrm{Cze}$ & 2 & 59,5 & 64,4 & 75,2 & 75,2 & 4,0 & 3,7 & 73,5 & 73,4 & 73,6 & 4,9 & 7,2 & 9,5 \\
\hline Mol & 16,5 & 23,4 & 32,1 & 40,4 & 46,8 & 4,6 & 43,2 & 46,9 & 50,5 & 53,9 & 9,8 & 4,8 & 9,6 \\
\hline Pols & 38,3 & 47,9 & 52,1 & 58,1 & 61,3 & 61,7 & 61,5 & 60,9 & 60,7 & 0,9 & 2,9 & 66,5 & 70,0 \\
\hline Ros & 4,1 & 53,7 & 62,5 & 69,8 & 73,4 & 3,4 & 2,9 & 73,7 & 74,5 & 75,5 & 7,6 & 9,8 & 81,9 \\
\hline $\mathrm{Ru}$ & & 34,2 & 40,3 & 46,1 & 53,2 & & 2,8 & 52,8 & 52,9 & 53,5 & 6,1 & 0,4 & 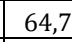 \\
\hline Sło &, 0 & 33,5 & 41,1 & 51,6 & 56,5 & 6,2 & 55,6 & 54,8 & 54,6 & 54,9 & 7,5 & 1,7 & 65,7 \\
\hline Ukr & 35,5 & 46,8 & 54,8 & 61,7 & 66,8 & 7,1 & 67,8 & 68,7 & 69,7 & 70,8 & 3,4 & 76,2 & 78,8 \\
\hline Wę & 3,0 & 55,9 & 60,1 & 64,2 & 65,8 & 4,6 & 6,4 & 69,0 & 71,3 & 73,4 & 6,8 & 79,5 & 81,9 \\
\hline Eur & & 71,6 & 73,8 & 76,4 & 77,1 & 7,9 & 8,3 & 79,0 & 79,7 & 80,5 & 2,3 & 34,1 & 85,7 \\
\hline $\mathrm{D}$ & 0 & 73,7 & 79,7 & 83,7 & 84,8 & 5,1 & 5,9 & 86,8 & 87,5 & 88,1 & 9,2 & 0,2 & 91,1 \\
\hline Est & 49,7 & 57,5 & 64,9 & 69,7 & 71,1 & 9,4 & 69,4 & 69,5 & 69,7 & 70,3 & 2,5 & 5,3 & 78,0 \\
\hline Fin & 3,0 & 55,3 & 63,7 & 71,7 & 79,4 & 2,2 & 2,9 & 83,6 & 84,2 & 84,9 & 6,2 & 37,5 & 88,7 \\
\hline & 1 & 45,8 & 51,7 & 55,3 & 56,9 & 59,1 & 0,5 & 61,9 & 63,4 & 65,1 & 8,6 & 72,2 & 75,4 \\
\hline Isl & 72,8 & 80,3 & 84,9 & 88,3 & 90,8 & 2,4 & 93,0 & 93,6 & 94,2 & 94,6 & 5,4 & 6,0 & 96,5 \\
\hline Litw & 28,8 & 39,5 & 49,6 & 61,2 & 67,6 & 7,0 & 66,6 & 67,0 & 67,6 & 68,4 & 0,8 & 3,8 & 76,7 \\
\hline Łotr & 46,4 & 52,9 & 60,7 & 67,1 & 69,3 & 68,1 & 68,0 & 67,7 & 67,7 & 68,1 & 0,1 & 73,0 & 75,8 \\
\hline & 0,5 & 49,9 & 65,4 & 70,5 & 72,0 & 6,1 & 77,5 & 79,1 & 80,5 & 81,7 & 33,8 & 85,4 & 86,9 \\
\hline Szy & 7 & 72,5 & 81,0 & 83,1 & 83,1 & 4,0 & 4,3 & 85,1 & 85,8 & 6,5 & 7,8 & 8,9 & 0,0 \\
\hline Wie & 79,0 & 78,4 & 77,1 & 78,5 & 78,1 & 8,7 & 79,0 & 79,5 & 80,1 & 80,9 & 2,7 & 34,4 & 85,9 \\
\hline Wys & 52,9 & 55,1 & 55,8 & 51,8 & 51,7 & 51,8 & 51,2 & 50,6 & 50,4 & 50,6 & 2,2 & 5,4 & 59,3 \\
\hline Wy & 4 & 38,7 & 36,1 & 32,2 & 31,4 & 0,5 & 30,6 & 31,1 & 31,8 & 32,7 & 35,5 & 39,3 & 43,4 \\
\hline Wys & 17,4 & 21,4 & 28,0 & 31,2 & 30,6 & 6,3 & 9,8 & 40,9 & 42,0 & 3,3 & 16,5 & 0,6 & 54,7 \\
\hline Euror & 45,1 & 50,4 & 57,6 & 62,1 & 63,8 & 65,5 & 66,5 & 67,7 & 68,9 & 70,3 & 73,5 & 76,5 & 79,2 \\
\hline Alba & 20,5 & 30,7 & 31,7 & 33,8 & 36,4 & 41,7 & 46,8 & 52,3 & 57,6 & 62,2 & 69,1 & 73,4 & 77,1 \\
\hline & 38,8 & 58,5 & 80,2 & 92,1 & 94,7 & 92 & 9 & 87,8 & 85,1 & 83,0 & 1,1 & 82,5 & 84,2 \\
\hline Bośni & 13,7 & 19,0 & 27,2 & 35,5 & 39,2 & 3,0 & 5,3 & 47,7 & 50,4 & 53,2 & 58,7 & 64,0 & 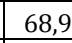 \\
\hline Chorn & 22,3 & 30,2 & 40,2 & 50,1 & 54,0 & 55,6 & 56,4 & 57,5 & 59,0 & 60,7 & 64,8 & 68,8 & 72,5 \\
\hline & 12,7 & 18,8 & 26,9 & 36,8 & 48,0 & 58,5 & 62,2 & 63,1 & 64,1 & 65,2 & 68,0 & 71,2 & 74,3 \\
\hline & 100,0 & 100,0 & 100,0 & 100,0 & 100,0 & 100,0 & 100,0 & 100,0 & 100,0 & 100,0 & 100,0 & 100,0 & 100,0 \\
\hline Grecj & 37,3 & 42,9 & 52,5 & 57,7 & 58,8 & 59,7 & 60,3 & 61,2 & 62,4 & 64,0 & 67,6 & 71,2 & 74,6 \\
\hline Hiszp & 51,9 & 56,6 & 66,0 & 72,8 & 75,4 & 76,3 & 76,7 & 77,3 & 78,0 & 78,9 & 80,9 & 82,8 & 84,5 \\
\hline Macedon & 23,4 & 34,0 & 47,1 & 53,5 & 57,8 & 59,4 & 59,1 & 59,2 & 59,8 & 60,9 & 64,5 & 68,2 & 71,8 \\
\hline
\end{tabular}


Tabela 3 c.d.

\begin{tabular}{|l|r|r|r|r|r|r|r|r|r|r|r|r|r|}
\hline Region, kraj & 1950 & 1960 & 1970 & 1980 & 1990 & 2000 & 2005 & 2010 & 2015 & 2020 & 2030 & 2040 & 2050 \\
\hline Malta & 88,9 & 90,1 & 89,7 & 89,8 & 90,4 & 92,4 & 93,6 & 94,7 & 95,4 & 96,0 & 96,7 & 97,2 & 97,6 \\
\hline Portugalia & 31,2 & 35,0 & 38,8 & 42,8 & 47,9 & 54,4 & 57,6 & 60,5 & 63,2 & 65,6 & 69,8 & 73,7 & 77,2 \\
\hline San Marino & 43,2 & 48,9 & 59,8 & 81,2 & 90,4 & 93,4 & 94,0 & 94,1 & 94,2 & 94,4 & 95,0 & 95,6 & 96,1 \\
\hline Serbia & 20,3 & 29,1 & 39,7 & 46,1 & 50,4 & 53,0 & 54,4 & 56,0 & 57,8 & 59,6 & 63,7 & 67,8 & 71,7 \\
\hline Słowenia & 19,9 & 28,2 & 37,0 & 48,0 & 50,4 & 50,8 & 50,5 & 50,0 & 49,8 & 50,3 & 53,0 & 57,5 & 62,1 \\
\hline Watykan & 100,0 & 100,0 & 100,0 & 100,0 & 100,0 & 100,0 & 100,0 & 100,0 & 100,0 & 100,0 & 100,0 & 100,0 & 100,0 \\
\hline Włochy & 54,1 & 59,4 & 64,3 & 66,6 & 66,7 & 67,2 & 67,6 & 68,2 & 69,1 & 70,3 & 73,2 & 76,0 & 78,7 \\
\hline Europa Zachodnia & 63,8 & 67,9 & 71,5 & 72,7 & 74,1 & 75,7 & 77,7 & 79,5 & 80,9 & 82,2 & 84,2 & 86,1 & 87,7 \\
\hline Austria & 63,6 & 64,7 & 65,3 & 65,4 & 65,8 & 65,8 & 66,5 & 67,5 & 68,5 & 69,7 & 72,5 & 75,5 & 78,2 \\
\hline Belgia & 91,5 & 92,5 & 93,8 & 95,4 & 96,4 & 97,1 & 97,3 & 97,5 & 97,6 & 97,7 & 97,9 & 98,1 & 98,2 \\
\hline Francja & 55,2 & 61,9 & 71,1 & 73,3 & 74,1 & 76,9 & 81,6 & 85,2 & 87,8 & 89,6 & 91,4 & 92,4 & 93,3 \\
\hline Holandia & 56,1 & 59,8 & 61,7 & 64,7 & 68,7 & 76,8 & 80,2 & 82,7 & 84,7 & 86,1 & 87,8 & 89,2 & 90,5 \\
\hline Liechtenstein & 19,9 & 20,4 & 18,5 & 18,3 & 16,9 & 15,1 & 14,7 & 14,4 & 14,3 & 14,4 & 15,5 & 17,7 & 20,3 \\
\hline Luxemburg & 67,2 & 69,6 & 74,4 & 80,0 & 80,9 & 83,8 & 83,9 & 85,2 & 86,3 & 87,3 & 89,0 & 90,4 & 91,7 \\
\hline Monako & 100,0 & 100,0 & 100,0 & 100,0 & 100,0 & 100,0 & 100,0 & 100,0 & 100,0 & 100,0 & 100,0 & 100,0 & 100,0 \\
\hline Niemcy & 68,1 & 71,4 & 72,3 & 72,8 & 73,1 & 73,1 & 73,4 & 73,8 & 74,5 & 75,3 & 77,4 & 79,7 & 81,8 \\
\hline Szwajcaria & 44,4 & 51,0 & 57,4 & 57,1 & 73,2 & 73,3 & 73,5 & 73,6 & 74,0 & 74,6 & 76,4 & 78,7 & 80,9 \\
\hline Ameryka Łacińska & 41,4 & 49,3 & 57,1 & 64,3 & 70,3 & 75,5 & 77,3 & 78,8 & 80,2 & 81,5 & 83,4 & 85,1 & 86,6 \\
\hline Ameryka Północna & 63,9 & 69,9 & 73,8 & 73,9 & 75,4 & 79,1 & 80,7 & 82,0 & 83,1 & 84,1 & 85,8 & 87,3 & 88,6 \\
\hline Australia/N. Zelandia & 76,2 & 80,5 & 84,5 & 85,3 & 85,3 & 86,9 & 87,8 & 88,6 & 89,2 & 89,8 & 90,7 & 91,6 & 92,4 \\
\hline
\end{tabular}

Źródło: [United... 2012].

W okresie powojennym liczba ludności w miastach systematycznie rosła do roku 2005, kiedy to sięgnęła 23,5 mln osób, co stanowiło prawie $62 \%$ ogółu. Co prawda od roku 1996 obserwujemy systematyczny spadek liczby ludności w miastach (do 23,28 mln w 2010 r.). Podczas gdy do roku 2007 spadek ten spowodowany był między innymi przez ujemny przyrost naturalny, to w ciągu ostatnich lat jest on skutkiem wyłącznie ujemnego salda migracji. Jest to rezultatem rozlewania się miast i wyprowadzania ludności miast rdzeniowych na przedmieścia. Proces zmian liczby ludności w poszczególnych obszarach metropolitalnych przedstawia tab. 4 .

Z zestawienia wyraźnie wynika, że nawet jeżeli maleje liczba ludności w mieście centralnym to przybywa mieszkańców w strefie podmiejskiej, niezależnie od tego, czy według statusu administracyjnego gmina należy do jednostki miejskiej czy wiejskiej20.

${ }^{20}$ Oficjalna statystyka prowadzona w Polsce nie pozwala na prawidłową ocenę procesu urbanizacji, gdyż zalicza ludność prowadzącą miejski tryb życia, a zameldowaną na terenach wiejskich do ludności wiejskiej. 
Tabela 4

Liczba ludności w miastach centralnych obszarów metropolitalnych

i w strefie podmiejskiej (w tys.)

\begin{tabular}{|c|c|c|c|c|}
\hline Miasta & 1995 & 2000 & 2005 & 2011 \\
\hline Warszawa & 1635 & 1672 & 1698 & 1708 \\
\hline Strefa podmiejska & 1168 & 1232 & 1284 & 1390 \\
\hline Ogółem OM & 2803 & 2904 & 2982 & 3098 \\
\hline Białystok & 278 & 289 & 292 & 294 \\
\hline Strefa podmiejska & 266 & 260 & 256 & 258 \\
\hline Ogółem OM & 544 & 549 & 548 & 552 \\
\hline Bydgoszcz & 386 & 376 & 366 & 363 \\
\hline Toruń & 205 & 210 & 208 & 205 \\
\hline Strefa podmiejska & 162 & 168 & 184 & 206 \\
\hline Ogółem OM & 753 & 754 & 758 & 774 \\
\hline Gdańsk & 463 & 463 & 458 & 461 \\
\hline Gdynia & 252 & 253 & 253 & 249 \\
\hline Sopot & 44 & 42 & 40 & 39 \\
\hline Strefa podmiejska & 618 & 635 & 664 & 727 \\
\hline Ogółem OM & 1377 & 1393 & 1415 & 1476 \\
\hline Katowice & 352 & 331 & 317 & 309 \\
\hline GZM & 2178 & 2066 & 2004 & 1928 \\
\hline Strefa podmiejska & 869 & 858 & 857 & 867 \\
\hline Ogółem OM & 3047 & 2924 & 2861 & 2795 \\
\hline Kraków & 745 & 759 & 757 & 759 \\
\hline Strefa podmiejska & 651 & 665 & 684 & 723 \\
\hline Ogółem OM & 1396 & 1424 & 1441 & 1482 \\
\hline Lublin & 355 & 359 & 355 & 349 \\
\hline Strefa podmiejska & 359 & 357 & 360 & 369 \\
\hline Ogółem OM & 714 & 716 & 715 & 718 \\
\hline Łódź & 823 & 798 & 768 & 725 \\
\hline Strefa podmiejska & 465 & 462 & 462 & 472 \\
\hline Ogółem OM & 1288 & 1260 & 1230 & 1197 \\
\hline Poznań & 581 & 582 & 568 & 554 \\
\hline Strefa podmiejska & 714 & 735 & 769 & 836 \\
\hline Ogółem OM & 1295 & 1317 & 1337 & 1390 \\
\hline Rzeszów & 160 & 161 & 159 & 180 \\
\hline Strefa podmiejska & 151 & 156 & 162 & 153 \\
\hline Ogółem OM & 311 & 317 & 321 & 333 \\
\hline Szczecin & 418 & 417 & 411 & 410 \\
\hline Strefa podmiejska & 197 & 200 & 206 & 218 \\
\hline Ogółem OM & 615 & 617 & 617 & 628 \\
\hline Wrocław & 642 & 641 & 636 & 631 \\
\hline Strefa podmiejska & 525 & 522 & 530 & 566 \\
\hline Ogółem OM & 1167 & 1163 & 1166 & 1197 \\
\hline
\end{tabular}

Źródło: [oprac. własne na podstawie danych GUS].

Proces urbanizacji, jaki obserwujemy w kraju, jest podobny do tego, co dzieje się na Zachodzie, chociaż zmiany te są mniej intensywne i zachodzą 
na mniejszą skalę. W rozwoju przestrzennym obserwuje się dwie przeciwstawne tendencje - koncentrację i dekoncentrację osadnictwa oraz działalności gospodarczej [Gorzelak 2008, s. 74]. Tendencja do koncentracji przeważa nad tendencją do dekoncentracji i szczególnie silna jest w obszarach metropolitalnych. Równocześnie obserwuje się zwiększanie bezpośredniego oddziaływania miasta na tereny przyległe, definiowane jako miejski obszar funkcjonalny. Zasięg tego obszaru wyznaczany jest przez rozlewanie się miasta (urban sprawl) zarówno form zabudowy, jak i miejskiego stylu życia oraz rosnący zakres dojazdów do pracy do centrów miast [MRR 2012].

Z coraz większą intensywnością zachodzi suburbanizacja przedmieść i rozlewanie się miast na skutek wynoszenia się ludności z centrów miast na tereny atrakcyjne przyrodniczo, pozostające jednocześnie w zasięgu codziennych dojazdów do pracy. $W$ dzielnicach peryferyjnych budowane są nowe mieszkania, centra handlowe, obiekty sportowo-rekreacyjne. Powstają tam również kampusy wyższych uczelni. Rdzeń miejski nie podlega jednak (jak dzieje się to w wielu miastach Zachodniej Europy) peryferyzacji. W Polsce obserwuje się proces przeciwny, polegający na zagęszczaniu istniejącej zabudowy oraz zmianie funkcji tej części miasta [Parysek, Mierzejewska 2005]. W dzielnicach centralnych budowane są nowoczesne biurowce, hotele, galerie handlowe, ekskluzywne mieszkania. Na coraz większą skalę prowadzona jest rewitalizacja zabytkowych budynków i starych zakładów przemysłowych, która ma prowadzić do ożywienia miast [Markowski, Stawasz 2007; Markowski, Kaczmarek, Olenderek 2010; Kaczmarek 2001]. Widoczna jest fragmentacja funkcjonalna przestrzeni miejskiej. Wyraźnie można w niej wyodrębnić centra administracyjnohandlowe, osiedla mieszkaniowe substandardowe i o wysokim standardzie (coraz częściej zamknięte i chronione), peryferyjne obszary budownictwa rezydencjonalnego, tereny magazynowo-składowe.

Intensyfikacja zabudowy przedmieść i bezpośredniego otoczenia miast powoduje zacieranie się widocznych granic między miastem a jego strefą zewnętrzną. Tereny rolne przekształcane są $w$ tereny magazynowe, przemysłowe, handlowe, rezydencjonalne, rekreacyjne i sportowe. $\mathrm{W}$ miastach zaczyna następować stratyfikacja społeczna. Bogatsza część społeczeństwa wyprowadza się ze starych bloków do miejsc oferujących lepsze warunki życia. Na terenach o starzejącej się zabudowie lokują się biedniejsze grupy społeczne, natomiast w dzielnicach, w których realizowane są nowe inwestycje mieszkaniowe koncentrują się mieszkańcy o wyższych dochodach. Powoduje to dalszą degradację substancji mieszkaniowej oraz rozwarstwienie społeczne (więcej na temat konsekwencji polaryzacji por. rozdz. II). To z kolei prowadzi do licznych napięć [Parysek 2008, s 15]. Mimo że polskie miasta coraz bardziej upodabniają się do miast Europy Zachodniej, 
w ich wyglądzie jeszcze długo będzie widoczny symbol minionego systemu, jakim są blokowiska [Parysek, Mierzejewska 2005, s. 52].

Jednocześnie pojawia się ogromna szansa rozwoju obszarów miejskich poszukujących nowej, konkurencyjnej pozycji, stwarzającej lepsze warunki rozwoju i dającej dobrobyt mieszkańcom [Parteka 2000a].

\section{Nowe podejście do zarządzania w miastach i ich otoczeniu}

Zarówno gwałtowna urbanizacja, jak i kurczenie się liczby ludności w miastach są testem dla władz na zdolność do tworzenia infrastruktury miejskiej oraz dla podatników na sfinansowanie tych usług. Jednocześnie zwiększają one prawdopodobieństwo wystąpienia katastrof naturalnych i kryzysów społecznych, których ograniczanie jest coraz trudniejsze [Harper et al. 2011, s. 4]. Gospodarka globalna funkcjonuje w warunkach silnej konkurencji między poszczególnymi aktorami. Konkurują ze sobą przedsiębiorstwa, gminy, miasta, regiony i państwa, a nawet bloki państw (np. Unia Europejska - Stany Zjednoczone i Japonia). W tym współzawodnictwie najważniejszą rolę odgrywają następujące czynniki:

- rozwój technologii i ścisły związek badań naukowych z procesem produkcji i zarządzania,

- dostęp do szerokiego, bogatego i zintegrowanego rynku, który jest głównym czynnikiem wpływającym na decyzje lokalizacyjne przedsiębiorstw,

- koszty produkcji,

- zdolność polityczna instytucji narodowych i ponadnarodowych do opracowania i realizacji strategii wzrostu gospodarczego krajów i regionów, którymi zarządzają [Jałowiecki 1999, s. 13].

Konkurencyjność zachodzi na dwóch płaszczyznach:

- konkurencyjności firm, zlokalizowanych na danym terytorium,

- konkurencyjności samych układów terytorialnych o nowy kapitał, tworzący miejsca pracy i przynoszący dochód.

Według J. Hausnera konkurencyjność układu terytorialnego należy rozumieć „jako zdolność do refleksyjnie uformowanej innowacyjności, na którą składają się kultura, wiedza, edukacja i informacja" [Hausner 1998, s. 35]. Obie płaszczyzny konkurencyjności są ze sobą ściśle powiązane. Warunki, jakie władze danego terytorium stwarzają dla prowadzenia działalności gospodarczej, są istotnym czynnikiem określającym konkurencyjność przedsiębiorstw. Niekorzystne warunki prowadzą do upadku przedsiębiorstw bądź ich przenoszenia się na inne obszary. Z kolei korzystne warunki, sprzyjający klimat inwestycyjny, są w stanie przyciągnąć nowe firmy i przedsięwzięcia oparte na wiedzy. To właśnie wiedza jest głównym czynnikiem produkcji, który koncentruje się w miastach. Zastępuje ona większość czynników produkcji, które miały dotychczas kluczowe znacze- 
nie dla gospodarki: energię, surowce, materiały, pracę, kapitał. Wiedza, informacja to specyficzne, całkiem odmienne od tradycyjnych źródła bogactwa: nie zużywają się, kto je sprzedaje, posiada je nadal. Tworzy to ogromny potencjał produktywności [Mączyńska 2003, s. 15]. Gospodarowanie w tych warunkach oparte jest na poszukiwaniu rozwiązań, które zagwarantowałyby wzrost efektywności, umożliwiałyby eliminację „wąskich gardeł”, przejrzystą organizację, wysoką efektywność produktów i usług oraz stworzyłyby możliwość uwzględniania w jak największym zakresie potrzeb i oczekiwań klienta [Skrzypek 2010]. Dostęp do wiedzy i informacji, umiejętność jej wykorzystania i możliwości jej rozwoju stały się podstawowym warunkiem uzyskania przewagi konkurencyjnej metropolii. Jednostki nie dysponujące nimi skazane są na wykluczenie.

Najcenniejsze dla danego obszaru firmy o wysokim potencjale innowacyjnym, tworzące nowe miejsca pracy wysokiej jakości i przynoszące znaczne dochody, mają w tym zakresie wysokie wymagania. Dlatego też władze terytorialne powinny robić wszystko, aby tym wymaganiom sprostać.

Miasta włączone do walki konkurencyjnej, aby się rozwijać muszą przyciągnąć na swoje terytorium podmioty gospodarcze i mieszkańców. Na arenie globalnej konkurencja następuje między obszarami metropolitalnymi, które są miejscem koncentracji kapitału, wiedzy, informacji, technologii i siły roboczej. Dlatego dążenie do konkurencyjności regionów miejskich stało się głównym celem lokalnych i krajowych polityk.

Ponadto rezygnuje się coraz częściej z zasady hierarchicznego organizowania przestrzeni na rzecz nowych, silnych powiązań między odległymi ośrodkami, co częściowo uniezależnia siłę oddziaływania jednostki od jej roli lokalnej oraz odległości fizycznej. Naturalną konsekwencją takich działań jest zmiana relacji pomiędzy ośrodkiem centralnym a otaczającym go regionem [Ładysz 2009, s. 45].

Nowa gospodarka generuje nowe formy nierówności. Według badań zachodnich ogromne inwestycje w branżach nieruchomości i telekomunikacyjnej w centrach globalnych miast i metropolitalnych centrach biznesu są skorelowane $\mathrm{z}$ niedoinwestowaniem ubogich dzielnic śródmiejskich. Bardzo wzrastają dochody wykształconych pracowników w wiodących sektorach, jak między innymi sektor finansów, podczas gdy płace pracowników niewykwalifikowanych, którzy sprzątają ich biura lub wykonują dla nich kserokopie pozostają na tym samym poziomie lub nawet ulegają obniżeniu [Appiah 2007]. Na rynkach pracy obserwuje się rosnącą polaryzację struktury zatrudnienia i dochodów z kurczącą się klasą średnią i powiększającą się przepaścią między najlepiej i najgorzej zarabiającymi [Harper et al. 2011, s. 5].

Strukturę zawodową światowych metropolii cechuje wysoka dynamika zmian. Ich przyczyną są sektorowe zmiany w zatrudnieniu, zmiany rozmiarów przedsiębiorstw i zmiany w kwalifikacjach siły roboczej. Wszystkie one 
powodują mniejszą stabilność zatrudnienia, zastępowanie stałej pracy pracą $\mathrm{w}$ niepełnym wymiarze godzin i rosnące wykorzystanie podwykonawstwa małych firm przez średnie i duże przedsiębiorstwa w celu ograniczenia kosztów wynikających z przepisów prawa pracy. Ogólne pogorszenie warunków pracy jest odzwierciedlone w rozwoju nieformalnej działalności gospodarczej, wykorzystywaniu pracowników, którym się nie płaci, wzroście zatrudnienia w sektorach wymagających niskich kwalifikacji (handlu, usługach i rolnictwie). Z drugiej zaś strony towarzyszy temu ekspansja stanowisk pracy wymagających wysoko wykwalifikowanych pracowników, w tym specjalistów, pracowników technicznych, menedżerów i kierowników najwyższego szczebla. Wszystko to tworzy coraz większe nierówności społeczne [Aguilar 1997, s. 375]. Następuje zwiększenie luki między sektorami gospodarki, grupami dochodów, wielkością przedsiębiorstw i zawodami.

Są one szczególnie widoczne w największych metropoliach świata (Nowy Jork, Meksyk, Rio de Janeiro, itd.). Jednak procesy polaryzacji w strukturze rynku pracy i niepewność części siły roboczej pokazują tylko jedną stronę medalu. Wzrost zatrudnienia w usługach produkcyjnych powoduje jednocześnie znaczący rozwój sektora produkcji z wysoko wykwalifikowanymi pracownikami o wysokich płacach, którzy mogą sobie pozwolić na mieszkanie w dzielnicach tzw. wyższej klasy średniej, konsumpcję dóbr luksusowych i kosmopolityczny styl życia. Usługi produkcyjne wykazują tendencję do lokalizowania się wzdłuż głównych ulic handlowych w wysokodochodowych obszarach miasta, odzwierciedlając wzrost natężenia usług w gospodarce i nadając formę przestrzenną procesowi globalizacji gospodarczej jako konkretne kompleksy gospodarcze umieszczone w konkretnych miejscach [Sassen 2000, s. 269]. Jednocześnie następuje gwałtowny rozwój szarej strefy we wszystkich ośrodkach miejskich, zwłaszcza w krajach rozwijających się [Harper et al. 2011, s. 5].

W regionach miejskich pojawiły się nowe formy przestrzenne powstałe poza kontrolą standardowych procesów planowania i projektowania miast przez władze lokalne. Zmiany te idą głównie w kierunku fragmentacji, separacji i specjalizacji funkcji i sposobów wykorzystania przestrzeni w miastach dotkniętych polaryzacją rynku pracy i nierównościami w dochodach, co znajduje odzwierciedlenie w rosnących różnicach między bogatszymi i biedniejszymi dzielnicami. Jasno widoczne kontrasty pojawiły się między zamożnymi dzielnicami, obszarami podmiejskimi i slumsami, enklawami zamieszkiwanymi przez mniejszości narodowe i gettami. Tym różnicom towarzyszą równolegle kontrasty między nowymi terenami przeznaczonymi na działalność sektorów zaawansowanych usług i produkcji, sprzedaż detaliczną dóbr luksusowych i sektor rozrywki a starymi dzielnicami z upadającym przemysłem, warsztatami i nieformalną działalnością gospodarczą. 
Wiele z tych różnic jest skutkiem gry rynkowej na rynku nieruchomości i kierunków rozwoju osiedli mieszkaniowych, ale zarazem stanowi konsekwencję polityk lokalnych, w ramach których miasta uczestniczące w globalnej konkurencji o kapitał próbowały wykreować się jako miejsca atrakcyjne dla inwestycji [Ibidem]. Te elementy różnorodności społecznej i zróżnicowania aktywności mają konsekwencje przestrzenne przynajmniej w dwóch zakresach. Po pierwsze zróżnicowaniu towarzyszy społeczno-przestrzenna polaryzacja i wykluczenie. W wielu miastach europejskich procesy wykluczenia społecznego doprowadziły do koncentracji ludzi w szczególnych dzielnicach. Odpowiedź governance na te okoliczności musi obejmować nowe kombinacje polityk zorientowanych na ludzi i miejsce [Madanipour 1998, s. 79].

Pogłębiają się nierówności i zagrożenia dla spójności społecznej spowodowane niewystarczającymi zasobami mieszkaniowymi, ograniczonymi możliwościami zatrudnienia, a co za tym idzie uzyskiwania dochodów, zwłaszcza na obszarach podmiejskich, gdzie rozwijają się slumsy i gdzie wskaźnik wzrostu populacji jest wyższy niż średnia dla obszaru metropolitalnego [Ambruosi et al. 2010, s. 321] (ta tendencja dotyczy głównie obszarów metropolitalnych w krajach rozwijających się).

Zarządzanie miastem stało się znacznie trudniejsze ze względu na rosnącą kompleksowość życia społecznego. Związek między ludźmi a miejscami jest bardziej rozproszony niż w przeszłości, miasto może więc być postrzegane jako „stanowisko zazębiających się sieci relacji o zróżnicowanym zasięgu przestrzennym" [Healey et al. 1995, s. 4]. Wewnątrz miasta jest większe zróżnicowanie społeczne, pojawiły się nowe style życia: ludzie żyją w inny sposób, podróżują w innych kierunkach, robią zakupy w innych godzinach. Zarządzanie podzieloną przestrzenią metropolii, podczas gdy stare zgodności i pewniki dotyczące stylu życia stały się nieaktualne, jest wyzwaniem [Kearns Paddison 2000, s. 846] i wymaga odpowiedniego systemu zarządzania metropoliami (metropolitan governance).

Po drugie, przestrzenne odzwierciedlenie zmian społeczno-ekonomicznych jest widoczne $w$ pojawianiu się nowych miejskich form przestrzennych. W Wielkiej Brytanii przyjmuje to formę coraz cieńszych (chudszych) wewnętrznych i środkowych obręczy, przepełnionych przedmieść i małych miasteczek oraz pełzającej urbanizacji obszarów wiejskich, przy jednoczesnym rozszerzaniu się miast, powstawaniu korytarzy miejskich i formacji nazywanych edge city.

Te zmiany można określić jako triumf chaosu i nieporządku. Odpowiedź governance zależy od tego, co jest rozumiane jako „dobre miasto”, w jaki sposób nierówności i otwartość miasta mają podlegać negocjacjom oraz jak zarządzać i regulować konflikty. To wymaga zrozumienia, że miasta obejmują różne formy porządku, które ze sobą kolidują i że relacje władzy 
istnieją i mają odzwierciedlenie w środowiskach miejskich oraz stosunkach przestrzennych, które wpływają na i tworzą to, co leży u podłoża związków społecznych [Mooney, Pile, Brook 1999].

Globalizacja rozumiana jako zwiększona świadomość szerszego świata, a jednocześnie jako eskalacja konkurencji między miastami, wprowadziła również nowe wymagania w stosunku do istniejących instytucji regulacyjnych i trybów postępowania. Jest ona nie tylko siłą zewnętrzną w stosunku do metropolitan governance: metropolitan governance brało czynny udział w tworzeniu i dyskursywnym wykorzystywaniu tej siły w realizacji zarówno dużych projektów infrastrukturalnych, jak i własnej transformacji politycznej [Hansen, Andersen, Clark 2001, s. 860].

Miasta dysponują olbrzymim potencjałem jako motory gospodarczego i społecznego rozwoju, tworząc miejsca pracy i generując pomysły dzięki ekonomii skali i kreatywnym oraz innowacyjnym kulturom obywatelskim. Jednak dzisiejsze miasta mogą też generować i wzmacniać społeczne wykluczenie, odbierając korzyści z życia w mieście biedakom, kobietom, osobom młodym i religijnym lub etnicznym mniejszościom, a także innym zmarginalizowanym grupom. Z trzydziestoletnich doświadczeń UNHABITAT $^{21}$ wynika, że kluczowym czynnikiem do stworzenia zintegrowanego społecznie miasta nie są pieniądze, technologie czy nawet fachowa wiedza (chociaż jest ważna), lecz dobry urban governance [UN-HABITAT 2002, s. 7].

Ewolucja metropolitalnych rozwiązań instytucjonalnych jest ściśle związana z kolejnymi fazami urbanizacji. Ponieważ odtwarzanie kapitału zaczęło bardziej zależeć od procesów miejskiego, podmiejskiego i regionalnego rozwoju, terytorialna konfiguracja obszarów metropolitalnych stała się przedmiotem społeczno-politycznych batalii, wystawiających do walki przeciwko sobie sojusze klasowe tworzone na podstawie miejsca, frakcji klasowych i innych sił społecznych w nieustannym wysiłku osiągnięcia sprzecznych celów w sferze produkcji, dystrybucji, odtwarzania i zarządzania. W miarę jak kapitalistyczny rozwój terytorialny uległ przyspieszeniu i zintensyfikowaniu w skali globalnej, geograficzna konfiguracja miejskich regionów również znacząco ewoluowała. W trakcie wieku XX monocentryczne regiony miejskie klasycznej ery przemysłowej zostały zastąpione przez policentryczne regiony metropolitalne, pola miejskie i megalopolie fordowskiego kapitalizmu. W latach 60. i 70. XX w. debata na temat zarządzania metropolitalnego koncentrowała się głównie na kwestiach efektywności administracyjnej, świadczenia usług lokalnych, planowania regionalnego i przestrzennej redystrybucji w ramach ustalonej na szczeblu krajo-

${ }^{21}$ United Nations Human Settlements Programme - Program Narodów Zjednoczonych ds. Osiedli Ludzkich. 
wym keynesistowskiej polityki państwa opiekuńczego [Brenner 2003, s. 300]. Większe jednostki administracji terytorialnej na obszarach miejskich były generalnie postrzegane jako analogiczne do form fordowskiej masowej produkcji, które miały przynieść korzyści skali w zakresie świadczenia usług publicznych [Keating 1991, s. 118]. Miejsko-regionalna sieć powojennej epoki została jeszcze bardziej przekształcona, tworząc jeszcze większe i bardziej zdecentralizowane układy rozwoju terytorialnego, które były określane jako exopolis [Soja 2000], miasta stumilowe, miastamultipleksy i mega miasta. Ponieważ tempo urbanizacji w okresie powojennym było bardzo szybkie, zaczęto coraz powszechniej tworzyć skonsolidowane instytucje metropolitalne, aby odróżnić funkcjonalne regiony miejskie w zakresie produkcji, budownictwa mieszkaniowego, transportu, rekreacji. Do ważniejszych instytucji metropolitalnych, które powstały w tym okresie w Europie Zachodniej należą: Greater London Council (1963), Madrid Metropolitan Area Planning and Coordinating Commission (1963), Greater Rotterdam Port Authority (1964), wspólnoty urbanistyczne we Francji, tj. Bordeaux, Lille, Lyon i Strasbourg (1966), Regionalverband Stuttgart (1972), powiaty metropolitalne w Wielkiej Brytanii (1974), Corporació Metropolitana de Barcelona (1974), Rada Wielkiej Kopenhagi (1974), Umlandverband Frankfurt (1974) i Kommunalverband Ruhr (1975) ${ }^{22}$.

Kryzys fiskalny państwa, wymagania i polityki organizacji ponadnarodowych i związane z nimi porozumienia oraz konkurencja gospodarcza na arenie międzynarodowej, doprowadziły do zmiany ról i kompetencji rządów centralnych. Ta rekonfiguracja otworzyła drogę dla nowych środków regulacyjnych, zwłaszcza w miastach, i przejście od urban government do urban governance [Pierre 1999]. Rządy centralne dokonały przedefiniowania swojej roli z bezpośredniej interwencji w kierunku sterowania społeczeństwem, aby osiągnąć wspólne cele [Pierre, Peters 2001].

Każdy z tych historycznych układów terytorialnej organizacji generował specyficzne problemy zarządzania i społeczno-polityczne konflikty w ramach wielkich regionów miejskich. W tej, wiecznie zmieniającej się, mozaice przestrzeni zurbanizowanych, inicjatywy w zakresie reform metropolitalnych mogą być postrzegane jako strategie podporządkowania kapitalistycznych procesów miejskich regionalnym formom państwowej kontroli [Brenner 2003, s. 299-300].

Reformowanie rządów i całej sfery publicznej, które w konsekwencji doprowadziło do powstania nurtu Nowego Zarządzania Publicznego, spowodowane było:

${ }^{22}$ Jak się kształtowały instytucje metropolitalne w różnych krajach przedstawiono w rozdz. IV. 
- wykształceniem się społeczeństwa obywatelskiego i kształtowaniem nowego typu relacji między władzą publiczną i obywatelami,

- zmianami spowodowanymi przejściem od ery industrialnej do ery wiedzy i informacji,

- wzrostem międzynarodowej konkurencyjności przedsiębiorstw,

- czynnikami instytucjonalnymi będącymi rezultatem wzrostu powiązań gospodarek narodowych oraz roli państw i organizacji międzynarodowych w globalnych stosunkach politycznych i społeczno-gospodarczych,

- rozwojem i wzrostem znaczenia w sferze publicznej tzw. trzeciego sektora,

- procesami decentralizacji [Kożuch 2004b, s. 17].

Władze miejskie muszą reagować na żądania wielu grup społecznych oraz zarządzać rozmieszczeniem zasobów, biorąc pod uwagę różne, często konkurujące ze sobą, wymagania. Jest to szczególnie trudne $\mathrm{w}$ wielkich miastach, gdyż stanowią one bardziej skomplikowany system powiązań niż mniejsze ośrodki. Dlatego też konieczne jest nowe podejście w ramach dialogu z mieszkańcami, przedsiębiorstwami i organizacjami społecznymi, które pozwoli na osiągnięcie rozwoju przy jednoczesnym zachowaniu zasad zrównoważonego rozwoju [Chądzyńska 2008, s. 28]. Miasta i obszary miejskie nie mogą być postrzegane jako zintegrowane jednostki/całości z pojedynczym czynnikiem rozwoju, ograniczone jasno zdefiniowanymi granicami przestrzennymi. Są one złożonymi konstrukcjami stworzonymi przez wzajemne relacje między aktorami, którzy tworzą złożone sieci i którzy inwestują w materialne projekty i nadają znaczenie walorom miejsc. Te sieci powiązań nie poddają się analitycznym próbom powiązania ich [Healey 2007, s. 2]. Miasta są nie tylko ogólnie złożone, ale dodatkowo są wplątane w nasilające się złożone procesy globalizacji. Planowanie rozwoju obszarów miejskich, w kategoriach społeczno-ekonomicznych i środowiskowych, musi się więc zmienić, tak by dostosować się do globalizacji, ale w dalszym ciągu jest bardzo ważne ze względu na rolę jaką może odegrać w globalnej konkurencji między miastami oraz na potencjał w wyciąganiu jak największych korzyści dla lokalnych obywateli [Newman, Thornley 2005, s. 277].

Odpowiedzią na restrukturyzację gospodarczą i społeczną jest rozwój lokalny poprzez działania organizacji społecznych. W obszarach metropolitalnych upadek sektora produkcji, wymagania odnośnie do większej elastyczności i cięcia w programach pomocy społecznej szczególnie wpływają na ludzi żyjących w niektórych dzielnicach miasta centralnego i mieszkańców niektórych starych przedmieść. W konsekwencji pogłębia się społeczno-ekonomiczne wykluczenie i ubóstwo. Obszary metropolitalne stają się coraz bardziej podzielone [Mollenkopf, Castells 1991]. Organizacje społeczne są kluczowymi podmiotami w reagowaniu na społeczny i gospodarczy upadek dzielnic zamieszkiwanych przez ludzi o niskich dochodach. W dzielnicach, 
gdzie występuje koncentracja ludzi biednych i bezrobotnych, organizacje społeczeństwa obywatelskiego są zaangażowane w praktyki rozwoju lokalnego [Clavel, Pitt, Yin 1997]. Rozwój lokalny można zdefiniować jako strategię, która ma na celu zmianę gospodarczej, społecznej, kulturowej, środowiskowej i politycznej sytuacji w celu poprawy warunków życia na lokalnym terytorium, poprzez mobilizację wewnętrznych i zewnętrznych podmiotów i zasobów [Stöhr 2003]. Definicja ta podkreśla, że proces rozwoju oznacza autonomię i udział indywidualnych i zbiorowych podmiotów i to nie tylko lokalnych. Lokalne organizacje są zaangażowane w mobilizowanie zasobów zarówno z wewnątrz, jak i spoza terytorium w celu świadczenia usług związanych z codziennym życiem oraz tworzenia miejsc pracy. Jednocześnie, wraz ze zmianą stanowiska rządu i odejściem od modelu keynesistowskiego w kierunku neoliberalnego systemu społecznej i gospodarczej organizacji, organizacje lokalne $\mathrm{w}$ większym stopniu przejęły odpowiedzialność za zabezpieczenie społeczne i rozwój gospodarczy. Jednakże wyższe szczeble władzy aktywnie uczestniczą w kształtowaniu tych praktyk (polityki sektorowe) [Ilcan, Basok 2004; Gough, Eisenschitz, McCulloch 2006].

Obserwuje się tu działania w dwóch kierunkach. Z jednej strony organizacje społeczne funkcjonują na zasadzie oddolnej, inicjując różnego rodzaju świadczenia i programy, z drugiej strony władze interweniują i tworzą programy, które kształtują lokalną aktywność społeczności jako odpowiedzialnej za szereg świadczeń i programów. W efekcie, te pionowe relacje prowadzą do coraz większej współpracy między społecznością i władzami, przy jednoczesnym zmniejszeniu konfliktów [Fisher, Shragge 2000; Hamel, Lustager-Thaler, Mayer 2000]. Oprócz współpracy z różnymi szczeblami władzy i prywatnymi fundacjami w celu uzyskania środków, rozpoczęcia działań i ich koordynacji, aby zapewnić efektywne świadczenie usług i realizację programów oraz przezwyciężyć barierę ograniczonych zasobów lokalnych nawiązywana jest współpraca pozioma między organizacjami społecznymi oparta na wzajemnej współpracy i negocjacjach. Te procesy współpracy między różnymi podmiotami dbającymi o rozwój społeczny i gospodarczy lokalnych jednostek wewnątrz obszaru metropolitalnego, tworzą formy metropolitan governance, w którym społeczeństwo obywatelskie za pośrednictwem organizacji społecznych odgrywa ważną rolę [Friedmann 1998]. Kluczem do powstania społeczeństwa obywatelskiego jest rozwinięty kapitał społeczny.

Spośród wielu definicji kapitału społecznego [Hanifan 1916; Coleman 1990; Bourdieu 1985; Portes 1998; Woolcock 1998] najtrafniejsza, w kontekście podnoszenia konkurencyjności obszarów metropolitalnych, wydaje się definicja Putnama mówiąca, iż kapitał społeczny to te cechy organizacji społecznych, takich jak sieci (układy) jednostek lub gospodarstw domo- 
wych oraz powiązanych z nimi norm i wartości, które kreują efekty zewnętrzne dla całej wspólnoty [Putnam 2008, s. 34-36].

Kapitał społeczny to przede wszystkim umiejętności społeczne, które pozwalają współpracować z innymi. Umiejętność współdziałania czy zaufanie do innych stają się jednymi z ważniejszych cech rozwoju w sytuacji, gdy rozwój w coraz mniejszym stopniu zależy od wysiłku pojedynczych osób, a jest efektem pracy zespołowej.

W literaturze wyróżnia się trzy typy kapitału społecznego: wiążący (bonding), pomostowy (bridging) i łączący (linking) [Cote, Healy 2001; Narayan, 1999; Putnam et al. 1993; Woolcock 2001]. Dla rozwoju społeczeństwa obywatelskiego kluczowe znaczenie ma kapitał pomostowy i łączący, z uwagi na relacje, jakie zachodzą między różnymi podmiotami funkcjonującymi we wspólnym otoczeniu ${ }^{23}$.

Należy podkreślić, że samo istnienie wysokiego kapitału społecznego, rozumianego jako silne więzi między jednostkami i podmiotami oraz wysoki poziom zaufania, nie zapewnia rozwoju ani wzrostu konkurencyjności jednostek terytorialnych [Działek 2008, s. 129]. Aby ten rozwój mógł wystąpić, konieczne są odpowiednie zasoby ekonomiczne i ludzkie, które dopiero w połączeniu z kapitałem społecznym powodują wzrost konkurencyjności. Dostęp do takich zasobów najłatwiejszy jest w obszarach metropolitalnych. Zatem można stwierdzić, że kluczem do rozwoju obszarów metropolitalnych, które są miejscami koncentracji wiedzy, kapitału (innego niż społeczny) jest wysoki poziom kapitału społecznego.

Spowodowana postępem procesów globalizacyjnych zdolność pracy czy bycia (elektronicznego) gdziekolwiek spowodowała, że coraz większe znaczenie dla ludzi ma miejsce, w którym żyją. Mieszkańcy tzw. klasy kreatywnej [zob.: Florida 2002; 2004] koncentrują się w miejscach, które wyróżniają się czynnikami jakości życia, są inne niż pozostałe miejsca. Tworzony powszechnie w miastach „klimat dla przedsiębiorczości” to już nie tylko ulgi podatkowe, infrastruktura, wykwalifikowana siła robocza, ale ośrodki kultury i sztuki (teatry, filharmonie, opery, galerie sztuki, muzea, festiwale), których działalność na terenie miasta nadaje mu rangę miasta światowego lub przynajmniej kontynentalnego. Miasta, które dysponują tymi cechami są lub pretendują do rangi metropolii [zob.: Jałowiecki 1999].

Na ten aspekt podnoszenia konkurencyjności również należy zwrócić uwagę. Nawet zagorzali globaliści, jak Porter (1990) czy Ohmae (2008), podkreślają potrzebę promowania przewag konkurencyjnych narodów czy regionów w celu maksymalizacji korzyści z globalizacji. Dzisiejsza gospo-

${ }^{23}$ Istnieje bogata literatia na temat kapitału społecznego. Zob.: Hanifan 1916; Coleman 1990; Bourdieu 1985; Portes 1998; Woolcock 1998; Sierocińska 2011; Putnam 1995; 2008; Fukuyama 1997; Seligman 1997; Sztompka 2007. 
darka, coraz bardziej oparta na wiedzy, wymaga zaangażowania, w procesie wytwarzania wysokiej jakości dóbr i usług, wykształconych, innowacyjnych i przedsiębiorczych pracowników, czyli kapitału ludzkiego. Kapitał ludzki staje się $\mathrm{w}$ dobie postępującej globalizacji i regionalizacji gospodarki światowej podstawowym źródłem przewagi konkurencyjnej państw i regionów [Trojan 2005, s. 61].

Ze zmniejszonymi kosztami transportu i komunikacji, podobnie jak globalizacja, wiąże się decentralizacja. W momencie, gdy spadają koszty, działalność produkcyjna ma większą swobodę lokalizacji. Konsekwencją tego jest wzrost konkurencyjności między obszarami metropolitalnymi. Firmy stają się coraz silniej zainteresowane znalezieniem lokalizacji charakteryzującej się dobrą dostępnością do transportu, dobrze wykształconej siły roboczej, wysokiej jakości uczelni i instytutów badawczych oraz przyjaznego dla życia otoczenia. Atrakcyjne miejsce do życia i mieszkania stało się kluczowym czynnikiem dla konkurencyjności regionów metropolitalnych. Innowacyjni pracownicy pozostają wrażliwi na wysokie płace, ale wydają się szczególnie przyciągani przez tętniące życiem środowisko [OECD 2006c, s. 76]. Praktycznym przejawem tych oczekiwań jest z jednej strony poszukiwanie przez międzynarodowe przedsiębiorstwa atrakcyjnych lokalizacji, z drugiej zaś - międzynarodowy marketing miast, który ma służyć przyciągnięciu firm na ich terytorium [Harsman, Olsson 2003, s. 102].

Obszary metropolitalne stają się źródłem konkurencyjności różnych podmiotów, w tym organizacji, chcących sprostać nasilającej się konkurencji [Przygodzki 2007, s. 14-15]. Mówiąc o konkurencji obszaru metropolitalnego powinno spojrzeć się na nią z dwóch perspektyw:

1. Przedmiotowej, która traktuje obszar metropolitalny jako szczególny układ przestrzenny oferujący atrakcyjne warunki do prowadzenia działalności gospodarczej czy jako atrakcyjne miejsce do życia.

2. Podmiotowej, która rozważa funkcjonowanie obszaru metropolitalnego poprzez układ instytucjonalny i jego zdolności do zarządzania rozwojem, obejmujące również stosowane strategie konkurencyjne wobec innych obszarów [Markowski 2005].

Dla budowania trwałych przewag konkurencyjnych obszarów metropolitalnych, obecnie kluczowe jest zbudowanie odpowiedniej struktury zarządzania. Dzisiejsze metropolie pokryte są gęstymi sieciami różnorodnych relacji (wymiana informacji, dobra i usługi, inwestycje, kontakty międzyludzkie, relacje finansowe itd.) i fakt ten stanowi dodatkową trudność w zarządzaniu złożonymi i wielorako uwarunkowanymi organizmami przestrzennymi.

Rozwijanie i efektywne wykorzystanie potencjału całego układu wymaga sprawnego zarządzania jego kapitałem, który stanowią zasoby ludzkie, potencjał gospodarzy oraz walory środowiska, co może prowadzić do osią- 
gnięcia zamierzonych celów [Chądzyńska 2008, s. 28-29]. Większość metropolii ma bardzo skomplikowaną sytuację instytucjonalną, na którą składa się duże rozdrobnienie terytorialnych jednostek administracyjnych oraz nakładanie się kompetencji różnych poziomów władzy i zakresów działania podmiotów publicznych, rzadko obejmujących skalę ważności spraw, którymi należy się zająć na poziomie metropolitalnym. Możliwie ścisła i jak najszersza współpraca między wszystkimi podmiotami publicznymi, prywatnymi oraz społeczeństwem jest obecnie niezbędna dla jakiegokolwiek rodzaju planowania (zarówno przestrzennego, jak i strategicznego) i jest kluczową kwestią konkurencyjności oraz sukcesu obszaru metropolitalnego.

Głównym celem ośrodków miejskich jest wzrost ich konkurencyjności, co prowadzi do wzrostu znaczenia miast i całych obszarów metropolitalnych, kosztem gospodarek narodowych jako podmiotów konkurencji gospodarczej. Prowadzi również do zastąpienia lokalnych rządów lokalnym rządzeniem (local governance) jako bardziej odpowiednią formą organizacji władzy na potrzeby promowania globalnej konkurencji [Sagan 2000, s. 142]. Na poziomie metropolitalnym konkurencja między aglomeracjami miejskimi motywuje przedstawicieli gmin i prywatnych korporacji do współpracy w celu wypracowania i wdrożenia strategii rozwoju, co można określić jako metropolitan governance [Fontan et al. 2009, s. 834].

Pojawia się tendencja do tworzenia międzysektorowych polityk, programów i działań, które obejmowałyby kwestie środowiskowe, gospodarcze, zdrowia i bezpieczeństwa, itp. Większość z nich ma wspólne następujące elementy:

- są bardziej strategiczne niż kompleksowe,

- są raczej elastyczne niż stałe i są zorientowane na efekt końcowy,

- są zorientowane na działanie i wdrożenie,

- są raczej prowadzone przez podmioty i społeczność niż (tylko) przez ekspertów,

- obejmują nowe cele odzwierciedlające pojawiające się w miastach problemy, np. pozycjonowanie miasta na arenie globalnej, ochrona środowiska, rozwój sustensywny, integracja społeczna i lokalna tożsamość,

- odgrywają rolę integracyjną $\mathrm{w}$ formułowaniu polityk i zarządzaniu miastem poprzez zachęcanie różnych wydziałów do koordynowania swoich planów w przestrzeni,

- są skoncentrowane na procesie planowania, którego efekty mogą być bardzo różne i zależą od wpływu zaangażowanych podmiotów czy kierunków lokalnej polityki [Harper et al. 2011, s. 6].

W miastach pozostających pod wpływem globalizacji, kluczową siłą jest zdolność do mobilizowania długookresowych koalicji, które są w stanie przeprowadzić zmiany od podstaw [Mossberger, Stoker 2001, s. 830]. 
Miasta mogą się dwojako odnaleźć w procesie globalizacji. Mogą stać się jej „ofiarą” (lub pasywnie czerpać korzyści z niej płynące, o ile ich pozycja na to pozwala), w sensie ponoszenia konsekwencji rosnącej migracji i decyzji nieskrępowanego kapitału i odpowiednio się do tej sytuacji dostosować. Mogą też stać się aktywnym czynnikiem (agent) w procesie globalizacji, wpływając wówczas na swój własny rozwój oraz przyczyniając się do globalizacji gdzie indziej.

Badania prowadzone przez Hardinga (1997) w pięciu miastach Europy wykazały, że efektem globalizacji jest rosnąca przedsiębiorczość miast, przyspieszone tworzenie sieci i aktywność obywatelska ze strony wybranych liderów biznesu na szczeblu lokalnym oraz tendencja do konkurowania o zasoby zewnętrzne (zarówno publiczne, jak i prywatne) w miejsce obserwowanego wcześniej wywierania presji na rząd centralny, aby wyrównał ich zasoby [Harding 1997].

Zmienił się kontekst społeczny i ekonomiczny współczesnego świata, w którym miasta walczą o swoją pozycję. Życie społeczne i polityka miasta, kiedyś definiowane terytorialnie, obecnie silnie zależą od procesów globalizacji produkcji i wymiany [Sagan 2000, s. 60]. Niemniej jednak cały czas miasta pozostają głównymi ośrodkami wzrostu (growth machine) ${ }^{24}$.

Pomimo procesów globalizacji i wynikającego z nich wzrostu bezpośredniej konkurencji między miastami, nie można analizy prowadzonej polityki władz miejskich wyabstrahować z kontekstu narodowego. Polityka państw wywiera zasadniczy wpływ na charakter procesów zachodzących w mieście. Zakres polityki lokalnej jest $w$ dużej mierze wyznaczany przez relacje między władzą lokalną a centralną władzą państwową, która zawsze buduje konkretny, specyficzny kontekst dla polityki w mieście [Sagan 2000, s. 138].

Tym, co pilnie muszą zrobić władze lokalne jest integracja globalizacji i lokalizacji ${ }^{25} \mathrm{w}$ strategiach rozwoju poprzez rozwój flagowych projektów

24 Po raz pierwszy określenia growth machine użył H. Moloch, zob.: Moloch 1976.

${ }^{25}$ Lokalizacja jest rozumiana częściowo jako przeciwdziałanie globalizacji. Miasta atrakcyjne koniecznie muszą odzwierciedlać oba te elementy - spełniać globalne standardy wymagane przez multinarodowe korporacje i mobilne talenty, jeśli chcą je przyciągnąć poprzez promocję miasta, z drugiej strony wyróżniająca lokalna tożsamość jest istotnym elementem odróżnienia miasta na światowym rynku. Dyskusja, która przede wszystkim koncentrowała się na przeciwstawianiu tego, co jest globalne kwestiom lokalnym, powinna raczej skupić się na "glokalizacji” [zob.: Swyngedouw 1997; Beauregard 1995]. Metropolie są często określane jako ośrodki glokalizacji, czyli miejsca, w których globalność przeplata się z lokalnością. To $\mathrm{w}$ nich następuje koncentracja instytucji związanych $\mathrm{z}$ umiędzynarodowieniem zarządzania i finansów, unifikacja w sferze kulturowej i wzorców życia oraz konkurencja o kontrolę nad gospodarką światową [Maik 2005, s. 12]. 
i klastrów kultury, w taki sposób, aby unikalne połączenie obu tych perspektyw wzmocniło odrębność i tożsamość, którą miasto już dysponuje. Tego typu działania mogą być osiągnięte poprzez staranne planowanie, które wykorzystuje zarówno wizerunek ekscytujących i dynamicznych środowisk miejskich i wyższy poziom jakości życia, jak i lokalną tożsamość zakorzenioną w aspiracjach obywateli [OECD 2007a, s. 46]. Globalizacja wzmacnia siłę ekonomiczną i polityczną miast, przekształcając je w tętniące życiem ośrodki gospodarki światowej [Maik 2005, s. 35].

Regiony metropolitalne, by skutecznie prowadzić politykę metropolitalną, muszą mieć:

- odpowiednie kompetencje (uprawnienia do przyjmowania, wdrażania i pilnowania metropolitalnej strategii),

- możliwości (wiedzę i zrozumienie w kontekście świadomego podejmowania decyzji). W tym celu organ władzy metropolitalnej musi mieć zdolność do planowania, monitorowania, przeglądu, ochrony i realizacji strategii metropolitalnych, a zatem musi dysponować:

- profesjonalnymi zasobami,

- dostępem do badań i danych,

- przewidywaniami i prognozami,

- oceną możliwości rozwoju miejskiego,

- analizą polityki na poziomie metropolitalnym,

- możliwościami przygotowania scenariuszy strategicznych i zintegrowanych strategii dla obszaru metropolitalnego,

- procesami (środkami do regularnego monitorowania, przeglądu i aktualizacji strategii).

Ciągły proces planowania, monitorowania i regularnych przeglądów pozwoli na utrzymanie strategii. Konieczne jest tu:

- proaktywne i przejrzyste podejście, zapewniające możliwość udziału społeczeństwa, w tym opinii publicznej,

- wdrażanie, monitorowanie i przegląd strategii (formalne umowy partnerskie z kluczowymi zainteresowanymi stronami, regularne rewizje strategii uwzględniające niezbędne zmiany, których konieczność pojawia się podczas przeglądu programów i projektów) [METREX 2004].

Pojawiła się potrzeba stworzenia efektywnego modelu zarządzania na poziomie metropolitalnym. Cele związane ze spójnością terytorialną ustanowione przez Unię Europejską mogą być najskuteczniej osiągane na poziomie metropolitalnym. Zarówno sustensywność, jak i policentryczność wymagają skutecznego metropolitalnego współrządzenia opartego na zintegrowanych gospodarczych, społecznych, środowiskowych i przestrzennych działaniach podejmowanych na szczeblu metropolitalnym [METREX 2004]. 



\section{METROPOLIZACJA PRZESTRZENI I ROZWÓJ OBSZARÓW METROPOLITALNYCH}

\section{Definicje metropolii i obszaru metropolitalnego}

Słowo metropolia pochodzi od greckiego metropolis, co oznaczało miasto-państwo, które założyło kolonie. Powstało z połączenia dwóch słów: meter - matka i polis - miasto [Dubisz 2003, s. 618]. Jest to więc miasto będące silnym ośrodkiem oddziałującym na region, którego jest stolicą. W Kościele metropolią jest „prowincja kościelna obejmująca kilka diecezji pod zwierzchnością arcybiskupa - metropolity" [Kopaliński 2000, s. 326]. Z definicji tych wynika, że metropolia jest ośrodkiem dominującym nad otaczającym ją regionem. Metropolia (w ujęciu historycznym) była strukturą, która organizowała przestrzeń i w dalszym ciągu tak się dzieje.

Kolejną cechą metropolii jest jej przodowanie w danym modelu rozwoju. Twórcą nowożytnego pojęcia metropolii był N. Gras. W latach 20. wieku XX sformułował teorię historycznych relacji między wpływową metropolią a otaczającym ją terytorium, nad którym dominuje, głównie za sprawą czynników ekonomicznych. Gras wyróżnił cztery fazy w przechodzeniu głównego miasta do metropolitalnej dominacji:

- skupienie życia handlowego z całego przylegającego terytorium,

- skoncentrowanie działalności przemysłowej,

- wybudowanie systemu transportu,

- dostarczanie usług finansowych dla otaczającego obszaru [Gras 1922].

Później okazało się, iż lepiej traktować to jako kluczowe czynniki gospodarczej metropolizacji niż fazy występujące w takiej kolejności. Koncepcja ta została rozszerzona o nieekonomiczne aspekty, takie jak: ośrodki władzy politycznej czy też społeczne, kulturalne i informacyjne struktury.

J. Parysek definiuje z kolei metropolię jako

duże miasto, o dość wyraźnej specyfice funkcji oraz charakterystycznym oddziaływaniu [...] o bardzo silnych powiązaniach zewnętrznych w sferze politycznej, ekonomicznej i kulturalnej [...]. z innymi ośrodkami o podobnej wielkości i podobnych funkcjach, czyli z innymi metropoliami [Parysek 2003, s. 21]. 
M. Bańczyk z zespołem przez metropolię rozumieją

organizm miejski, będący węzłem w sieci przepływów kluczowych procesów biznesowych i społecznych, którego oddziaływanie przebiega na trzech poziomach: municypalnym, regionalnym i sieciowym. Metropolia jest biegunem wzrostu i głównym producentem innowacji, wiedzy i dobrobytu [Bańczyk, Achrem, Mróz 2008, s. 5].

Koncepcja Przestrzennego Zagospodarowania Kraju 2030 definiuje metropolie jako

te ośrodki (wraz z ich obszarami funkcjonalnymi), które stanowią centra zarządzania gospodarczego na poziomie co najmniej krajowym, mają duży potencjał gospodarczy (ponadkrajową atrakcyjność inwestycyjną), oferują szereg usług wyższego rzędu i pełnią funkcje symboliczne, charakteryzują się wysoką zewnętrzną atrakcyjnością turystyczną, dużymi możliwościami edukacyjnymi i tworzenia innowacji (rozbudowane szkolnictwo wyższe, obecność jednostek naukowych i badawczorozwojowych), mają zdolność do utrzymywania relacji handlowych, naukowych, edukacyjnych, kulturowych z międzynarodowymi metropoliami oraz charakteryzują się wysoką wewnętrzna i zewnętrzną dostępnością transportową [MRR 2012a, s. 190].

$\mathrm{W}$ dyskusji na temat metropolizacji przestrzeni często wymiennie z pojęciem metropolii jest stosowane określenie aglomeracja. Takie podejście wydaje się błędne, gdyż o ile metropolia wiąże się z pewnym rodzajem funkcji skoncentrowanych $\mathrm{w}$ danym mieście, o tyle aglomeracja ma raczej wymiar ilościowy. Aglomeracją jest duże skupisko miejskie. Podczas gdy każda metropolia jest aglomeracją, to nie każda aglomeracja jest metropolią. Nie we wszystkich bowiem aglomeracjach wykształciły się struktury, funkcje i relacje z otoczeniem (często bardzo odległym) generujące funkcje metropolitalne ${ }^{26}$.

Jak zauważa Izdebski, metropolia (obszar metropolitalny)

stanowi organiczne zgrupowanie jednostek lokalnych łącznie stanowiących węzeł różnorodnych sieci światowych lub kontynentalnych (transportowych, naukowych, gospodarczych itp.), [natomiast] aglomeracja jest zgrupowaniem mechanicznym nastawionym na rozwiązanie określonego problemu czy grupy zbliżonych problemów (transport zbiorowy, zaopatrzenie w wodę i odprowadzanie ścieków, gospodarka odpadami itp.) [2010a, s. 16].

Z metropolią utożsamia się pojęcie obszaru metropolitalnego, wywodzące się ze Stanów Zjednoczonych, po raz pierwszy wprowadzone w trakcie spisu ludności w roku 1910 [Zborowski et al. 2012, s. 520].

Ch. Chute już w 1956 r. zauważył, że historyczne rozumienie obszaru metropolitalnego jako miasta centralnego otoczonego przez przedmieścia nie jest właściwe dla rozwiązywania problemów zarządzania w większości

\footnotetext{
${ }^{26}$ Analiza różnic między aglomeracja a metropolią, patrz: Smętkowski 2001.
} 
wielkich ośrodków miejskich. Twierdził, że należy wziąć pod uwagę wzajemne powiązania istotne dla zarządzania między sąsiadującymi obszarami metropolitalnymi a analizie poddać klastry obszarów metropolitalnych na takich samych zasadach, na jakich analizuje się klastry dużych miast czy innych ośrodków miejskich [Chute 1956, s. 274]. Miało to szczególne znaczenie w Stanach Zjednoczonych, gdzie mamy do czynienia z rządem federalnym, ponieważ należy ocenić, jaką rolę odgrywają władze poszczególnych stanów w takich obszarach. Należy przeprowadzić analizę korzyści i kosztów politycznej integracji jako odpowiedzi na problem zarządzania w obszarach metropolitalnych. W przypadku, gdyby się okazało, że polityczna integracja nie jest rozwiązaniem, trzeba się zastanowić jakie powinny być cele i polityki, które najlepiej rozwiążą problem zarządzania.

W polskiej literaturze również znaleźć można szereg definicji obszaru metropolitalnego. J. M. Chmielewski definiuje obszar metropolitalny jako

wysoce zurbanizowany układ osadniczy o dużym stopniu integracji społecznej, gospodarczej i przestrzennej, zdominowany przez jeden silny ośrodek wzrostu. Obszar ten poza terenami zurbanizowanymi obejmuje również strefy konieczne dla funkcjonowania jego systemów inżynieryjnych, komunikacyjnych i usługowych, a także przestrzenie, które stanowią z punktu widzenia przyrodniczego niezbędne dla niego zaplecze ekologiczne, przeznaczone na cele żywicielskie, rekreacyjne i klimatyczne [Chmielewski 1995].

\section{Według K. Trafasa i Z. Ziobrowskiego jest to}

ciągły przestrzennie, wielkomiejski układ osadniczy złożony z odrębnych jednostek osadniczych obejmujący duże miasto (metropolię) lub zwarty obszar miejski jako centrum (jądro) układu oraz powiązaną z nim funkcjonalnie strefę zurbanizowaną, o znacznym nasileniu konfliktów społecznych, gospodarczych i przestrzennych [Trafas b.d., s. 2].

\section{Dla J. Ziółkowskiego jest to}

złożony układ zróżnicowanych, współzależnych skupisk osadniczych typu miejskiego i wiejskiego, którego jądrem integrującym i ośrodkiem oddziaływania (dominacji) na szersze zaplecze jest duże miasto (metropolia). Strefa metropolitalna zawiera w sobie wszystkie możliwe twory osadnicze: wieś, osiedle zurbanizowane, strefę mieszaną, miasteczko, miasto, aglomerację, konurbację i metropolię. Powstanie strefy metropolitalnej jest zarazem wynikiem urbanizacji rolniczego regionu, jak i przyczyną dalszego postępowania tego procesu [za: Trafas b.d., s. 2].

Obszary metropolitalne charakteryzują w szczególności trzy zjawiska:

- obecność osób, które nie są ich mieszkańcami (mieszkańcy tymczasowi, osoby odwiedzające ten obszar w ciągu jednego dnia, w tym osoby dojeżdżające do pracy oraz osoby będące w podróży, przejeżdżające przez metropolię), obok stałych mieszkańców. Ich przebywanie tu ma poważne 
konsekwencje dla działań władzy, finansów metropolitalnych i demokracji lokalnej;

- obecność enklaw eksterytorialnych - dotyczy to sytuacji pionowego lub zewnętrznego podejmowania decyzji przez podmioty lub decydentów, którzy w dużej mierze znajdują się poza jurysdykcją władz lokalnych (międzynarodowe korporacje, Unia Europejska, rządy centralny i regionalne) podczas gdy efekty tych decyzji wchodzą w zakres kompetencji władz obszarów metropolitalnych;

- trudność w koordynowaniu nadzwyczajnych działań i projektów realizowanych na podstawie szczególnych przepisów (wielkie imprezy i działania podjęte przez innych administratorów, np. EURO 2012) ze zwykłą działalnością publiczną, co wywołuje konflikty, które tylko z pozoru wydają się biurokratyczne, natomiast $\mathrm{w}$ istocie są polityczne i gospodarcze [Ferri 2009, s. 372].

Wielu autorów jako metropolie definiuje miasta, które potrafiły stworzyć odpowiednie dla rozwoju sektora informacyjnego środowisko innowacyjne, będące wypadkową relacji gospodarczych, technologicznych, instytucjonalnych i społecznych. Najczęstszym, i najprostszym, kryterium metropolitalności ośrodka miejskiego jest liczba ludności wynosząca około 1 miliona. Nie jest to kryterium wystarczające. Musi ono być rozszerzone o pozostałe kryteria, do których należą:

- rozwinięty sektor usług,

- potencjał innowacyjny,

- wyjątkowość i specyfika miejsca [Gorzelak, Smętkowski 2005, s. 16].

Trzeba rozróżnić obszary miejskie od obszarów metropolitalnych. Obszarem miejskim (urban area) określamy przestrzeń charakteryzującą się ciągłym rozwojem miejskim. Przestrzeń ta staje się konurbacją, jeśli dwa lub więcej obszarów miejskich rośnie wspólnie (Osaka-Kobe-Kioto, Śląsk) [Ambruosi et al. 2010, s. 321].

W większości państw obszary metropolitalne definiowane są jako ośrodek centralny, ze znaczną koncentracją zatrudnienia lub ludności, i jego otoczenie, charakteryzujące się wysoką gęstością zaludnienia i bliskimi związkami z centrum [http://www.oecd.org/dataoecd/41/37/45511614.pdf]. Według OECD obszary metropolitalne są określane jako duże skupiska ludności i aktywności gospodarczej, które tworzą funkcjonalne układy gospodarcze, obejmujące zazwyczaj swoim zasięgiem kilka lokalnych jednostek terytorialnych z lokalnymi władzami [OECD 2006a, s. 31]. Są one określane według różnych kryteriów, takich jak liczba ludności, gęstość zaludnienia, działalność gospodarcza, rynek pracy, występowanie usług. Różne podejścia do delimitacji zostały opisane w dalszej części rozdziału.

Polskie prawo po raz pierwszy zdefiniowało pojęcie obszaru metropolitalnego w Ustawie o planowaniu i zagospodarowaniu przestrzennym z 27 
marca $2003 r$. Zgodnie z tą ustawą obszar metropolitalny to obszar wielkiego miasta oraz powiązanego z nim funkcjonalnie bezpośredniego otoczenia, ustalony w koncepcji przestrzennego zagospodarowania kraju [Ustawa... 2003]. Rada Unii Metropolii Polskich doprecyzowała tę definicję dodając kolejne słowa „zgodnie z zasadniczym podziałem terytorialnym państwa na powiaty, stanowiący kompleks osiedleńczy zamieszkany przez ponad 500 tys. osób, skupiający instytucje współpracy międzynarodowej" [Świetlik, Lubiatowski 2004]. Według T. Czyż obszar metropolitalny to terytorialny układ osadniczy o bardzo wyraźnie ujawniających się następujących aspektach systemowych:

- powiązaniach społeczno-gospodarczych nie tylko wokół ośrodka centralnego, ale w całym obszarze metropolitalnym,

- ukształtowanym podsystemie dziennych powiązań między ośrodkami zamieszkania, pracy, wypoczynku i współżycia zbiorowego,

- domkniętym zasięgu pewnych powiązań egzogenicznych ośrodka w obrębie sieci osadniczej tego obszaru,

- rozwiniętych powiązaniach zewnętrznych [Czyż 2009, s. 450].

Podstawową jego cechą jest integracja funkcjonalna - rozwój metropolitalnych funkcji wewnętrznych oraz zewnętrznych, zlokalizowanych w różnych częściach tego obszaru. Najtrafniejsza wydaje się definicja Markowskiego i Marszała [2006b, s. 328], według których obszar metropolitalny jest jednostką funkcjonalną tworzoną przez duży, złożony i spójny funkcjonalnie zespół miejski, którego istotną cechę stanowi występowanie funkcji metropolitalnych, a także powiązań funkcjonalnych. Obszar metropolitalny jest to wielkomiejski układ osadniczy (monocentryczny lub policentryczny) złożony z wielu jednostek osadniczych oraz terenów o wysokim stopniu zurbanizowania:

- obejmujący strefę o znacznym bezpośrednim zasięgu codziennego oddziaływania (miejsca pracy i zamieszkania) oraz tereny możliwości rozwojowych;

- gdzie zachodzą procesy metropolizacji i występuje wystarczające nagromadzenie działalności uzupełniających (substytucyjnych) metropolitalne funkcje ośrodka centralnego (lokalizacja funkcji metropolitalnych);

- o dużej skali wewnętrznej integracji funkcjonalnej (silnych powiązaniach funkcjonalnych);

- z dobrze rozwiniętą siecią transportową.

Obszary metropolitalne w Europie stanowią miasta „patchworkowe” składające się z funkcjonalnie wyspecjalizowanych przestrzeni. Cały obszar metropolitalny jest mozaiką miejsc, z których część skupia funkcje globalne (np. międzynarodowe finanse), część funkcje ważne w skali europejskiej, a część funkcje wyłącznie lokalne. Jednak wszystkie one są od siebie silnie współzależne i jedna przestrzeń funkcjonalna nie może przetrwać bez 
innych. Aby wzmocnić swoją międzynarodową pozycję konkurencyjną i czerpać korzyści ze swych lokalnych potencjałów obszary metropolitalne kładą nacisk na rozwój funkcji egzogenicznych, zazwyczaj kosztem innych funkcji, tworzą wyspecjalizowane instytucje badawcze i szkoleniowe oraz rozwijają globalne centra transportowe. W celu podniesienia konkurencyjności promują zarówno twarde, jak i miękkie czynniki lokalizacji. Próbują poprawić dostępność i standardy infrastrukturalne, walczą o przyciągnięcie międzynarodowych i krajowych instytucji i przedsiębiorstw w celu uzupełnienia lokalnego systemu, czują się zmuszone do inicjowania flagowych projektów w celu poprawy wizualnej jakości miasta i sponsorują wydarzenia, które mogą przyciągnąć globalnych gości, aby zademonstrować zaangażowanie w kulturę i obsłużyć wymagającą, wysoko wykwalifikowaną lokalną siłę roboczą. Aby to osiągnąć konieczna jest obecność międzynarodowych mediów [Kunzmann 1998, s. 60-61].

Najprostszą miarą rozwoju obszarów zurbanizowanych jest wzrost liczby ludności. W wiodących obszarach jest on wysoki (3\% i więcej rocznie) i jest efektem imigracji. W związku z tym głównym celem instytucji miejskich zajmujących się rozwojem jest zapewnienie dachu nad głową, usług i pracy tysiącom nowych ludzi, którzy stale napływają do miast. Jednocześnie instytucje te muszą skoncentrować się na przyciąganiu inwestycji, które mają stworzyć nowe miejsca pracy. Miasta, którym udaje się zarządzać tak, aby ten ruch przebiegał płynnie, utrzymywać niski poziom przestępczości, regularnie zbierać odpady i które do tego są w stanie zapewnić odpowiednie mieszkania (poprzez projekty sektora publicznego lub przez stworzenie instytucji, które upraszczają funkcjonowanie rynku nieruchomości) są miastami sukcesu - takimi, które dobrze zarządzają rozwojem, przez co przyciągają nowe możliwości tego rozwoju [Chakravorty 2003, s. 362].

W roku 1987 P. Soldatos przedstawił dziesięć cech miasta-metropolii:

1. Przyjmuje ono pochodzące z zagranicy czynniki produkcji, inwestycje, siłę roboczą oraz towary i usługi.

2. Gości zagraniczne firmy, siedziby i filie międzynarodowych korporacji, banków, instytucje pozarządowe, naukowe i oświatowe (szkoły) oraz uniwersytety o znacznym udziale studentów cudzoziemców, a także placówki dyplomatyczne.

3. Eksportuje czynniki produkcji - przedsiębiorstwa, banki i inne instytucje społeczno-gospodarcze, kulturalne i naukowe.

4. Jest bezpośrednio połączone siecią transportu i komunikacji z zagranicą, systemem autostrad, szybkiej kolei, lotniska międzynarodowego.

5. Ma rozbudowaną „infostrukturę” i cechuje się intensywną komunikacją z zagranicą przez ruch pocztowy, telekomunikacyjny i turystyczny.

6. Ma rozwinięty sektor usług nastawiony na zagranicznych klientów: centra kongresowe i wystawiennicze, luksusowe hotele, szkoły międzyna- 
rodowe, wysokiej jakości pomieszczenia biurowe, międzynarodowe kancelarie prawnicze, międzynarodowe instytucje naukowe.

7. Na jego obszarze znajdują się środki masowego przekazu o zasięgu międzynarodowym.

8. Organizowane są $\mathrm{w}$ nim regularnie różnego typu międzynarodowe spotkania: kongresy, wystawy, festiwale, imprezy sportowe i artystyczne.

9. Funkcjonują tu instytucje krajowe i regionalne zajmujące się relacjami zagranicznymi i mające międzynarodowa markę, jak np. stowarzyszenia, kluby sportowe.

10. Przez miejskie instytucje publiczne lub prywatne uprawiana jest, za pośrednictwem własnych przedstawicielstw w innych miastach za granicą, paradyplomacja, czemu służy także członkowstwo w organizacjach międzynarodowych, takich jak stowarzyszenia miast bliźniaczych, metropolii itp. [za: Jałowiecki, Szczepański 2006, s. 214].

Miasto uznane za metropolię powinno:

- mieć znaczny potencjał ekonomiczny oraz silnie rozwinięty sektor usług wyższego rzędu,

- charakteryzować się dużym potencjałem innowacyjnym, przez który rozumie się odpowiednią liczbę wysoko rozwiniętych jednostek naukowobadawczych,

- pełnić funkcje centralne wysokiego rzędu o zasięgu co najmniej krajowym,

- odgrywać kluczową rolę w systemie powiązań komunikacyjnych, organizacyjnych oraz informacyjnych i dzięki temu odznaczać się dużą dostępnością w różnych skalach przestrzennych [Markowski, Marszał 2006a, s. 12].

Ponadto, metropolię powinna charakteryzować wyjątkowość oraz specyfika miejsca, które powodowałyby subiektywne postrzeganie przez mieszkańców i przyjezdnych miasta jako metropolii [Ilnicki 2003, s. 62].

Powstawanie obszaru metropolitalnego jest konsekwencją rozwoju funkcji metropolitalnych, które z kolei powodują migrację ludności i przenoszenie działalności gospodarczej na peryferia dotychczasowych skupisk miejskich.

Obszary metropolitalne $w$ procesach polaryzacji przestrzeni stoją na uprzywilejowanej pozycji i są zdolne do konkurowania w warunkach globalizacji gospodarki, gdyż dysponują ukształtowanymi historycznie strukturami i możliwościami (warunkami) jej wzmacniania ze względu na:

- korzystne położenie geograficzne,

- rozwinięte węzły transportowe (lotniska, porty morskie, dworce kolejowe i autobusowe) i centra logistyczne,

- społeczne warunki kreowania innowacji (podatność gospodarki, administracji i społeczeństwa na innowację), jakość kapitału ludzkiego (po- 
ziom wykształcenia, stan zdrowia, struktura wieku itp.), koncentrację instytucji nauki, szkolnictwa wyższego i edukacji,

- sprawność funkcjonowania infrastruktury wewnętrznej (efektywny transport publiczny, bezpieczny i nieuciążliwy układ drogowy, niezawodna infrastruktura techniczna),

- efektywną sferę publiczną związaną z odpowiedzialną władzą samorządową (sprawność zarządzania, decyzyjność i zaufanie itp.),

- warunki umożliwiające uzyskanie wysokiego standardu życia i jakości środowiska przyrodniczego i antropogenicznego.

Metropolie stają się węzłami przepływów, rozciągającymi sieci między metropoliami i innymi miastami.

Obecnie tworzące się postmodernistyczne metropolie nie tylko różnią się formą od modernistycznych metropolii, w miejsce których powstają, ale kształtowane są przez nowe i zglobalizowane siły gospodarcze i polityczne [Amin, Thrift 2002; Gottdeiner 2002; Soja 2000]. Dlatego też należy zrewidować funkcjonujące teorie urbanistyczne i podejście do zarządzania, gdyż tylko wtedy będziemy w stanie zrozumieć miasta podzielonych przestrzeni (fragmented spatialities), wielu przepływów, dynamicznych sieci oraz otwarte w przestrzeni i czasie [Beauregard 2006, s. 218].

Relacje między miastem centralnym a otoczeniem przejawiają się również w:

- wzroście liczby miejsc pracy poza ośrodkiem centralnym zarówno w przemyśle, jak i usługach;

- codziennych dojazdach do miejsc pracy, usług i zamieszkania zarówno z obszaru podmiejskiego do miasta jak i w przeciwna stronę;

- braku zintegrowanego transportu publicznego obejmującego cały obszar metropolitalny;

- emigracji podatników poza miasto, w tym ludzi z wyższej grupy podatkowej, co powoduje wzrost dochodów gmin ościennych, przy jednoczesnym spadku dochodów miasta centralnego;

- utracie dochodów przez miasto centralne wskutek lokowania się przedsiębiorstw w strefie podmiejskiej [Kaczmarek 2010, s. 50]

- występowaniu zjawiska "gapowicza” (easy rider). Większość miast centralnych finansuje usługi, z których korzystają mieszkańcy gmin ościennych nie płacąc za nie.

Miasta metropolitalne charakteryzują również specyficzne struktury przestrzenno-funkcjonalne zlokalizowane $\mathrm{w}$ ich granicach administracyjnych. Wyróżnić wśród nich można:

- centrum administracyjno-gospodarcze z zespołem odpowiednich budynków (zazwyczaj wysokie, nowoczesne biurowce, czasami obiekty zabytkowe), w których swoje siedziby mają zarządy transnarodowych korporacji, banków, giełd, towarzystw transportowych, towarzystw ubezpieczenio- 
wych, agencji konsultingowych itp.) zlokalizowane w śródmieściu lub na „terenach nowych” (La Defense w Paryżu, Canary Wharf w dokach w Londynie);

- centrum kulturalno-artystyczne zlokalizowane zazwyczaj w starej, historycznej części miasta z licznymi zabytkami, galeriami, teatrami, salami koncertowymi itp. Zwykle znajdują się tam wysokiej klasy hotele, ekskluzywne restauracje, kluby. Obszar ten zlokalizowany jest z reguły w części śródmiejskiej, często uzupełniony rozległymi placami, parkami i małą architekturą;

- śródmiejskie centrum handlowe z ulicą prestiżowych sklepów, często o charakterze alei, czy bulwaru, wyłączoną z ruchu kołowego. Znajdują się tam liczne restauracje i kawiarnie, banki, biura podróży itp.;

- centrum komunikacyjno-komercyjne, w którym zlokalizowane są dworce kolejowy i autobusowy, parkingi, firmy wynajmu samochodów itp.;

- centrum władzy politycznej tworzone przez zespół obiektów państwowych i rządowych oraz organizacji międzynarodowych. Czasami jest to obszar rozproszony, często obejmuje tereny zielone;

- port lotniczy z całą przyległą infrastrukturą oferujący połączenia z całym światem, szczególnie z innymi metropoliami [Parysek 2000; 2003, s. 25-26].

Poziom wykształcenia powyższych układów przestrzennych decyduje (w powiązaniu z funkcjami) o hierarchii metropolii, a więc o sile powiązań i zasięgu oddziaływania.

W globalnym systemie miast odgrywających wiodącą rolę, oprócz metropolii i obszarów metropolitalnych, rozróżnia się jeszcze miasta globalne i światowe ${ }^{27}$. Czasami określenia te odnoszone są do tej samej kategorii miast, jednak nie każda metropolia jest miastem globalnym czy światowym, gdyż stopień koncentracji funkcji i zasięg oddziaływania jest w nich różny. Do miast globalnych można zaliczyć zaledwie kilka ośrodków takiej rangi jak: Nowy Jork, Londyn, Tokio i Paryż. Do grupy miast światowych wchodzi kolejnych kilkadziesiąt miast takich, jak np. Meksyk czy Pekin. Miasta światowe są wielkimi miastami włączonymi, jednakże luźno, w globalną sieć miejską przepływów ludzi, dóbr, idei i praktyk, natomiast miasta globalne są rdzeniem tych sieci [Short 2004, s. 2]. Jednak wielu badaczy wspomniane dwa terminy traktuje wymiennie [Taylor 2003; Lo, Yeung 1998; Kunzmann 1998]. Ranga metropolii nie zależy bezpośrednio od wielkości miasta i dlatego też pojawia się pojęcie megamiasta i miasta globalnego. Megamiasto jest wielkie ilościowo i liczba jego ludności nieustannie rośnie. ONZ za

${ }^{27}$ Obszerne badania na temat miast globalnych i światowych, zob.: Friedmann 1986, 1995; Sassen 1991, 2000; Knox 1995; Hall 1966; Taylor 2003; 2004. 
mega miasto uznaje miasto, którego liczba ludności przekracza 10 milionów [United Nations Population Division 2008, s. 13].

Trudno jest jednoznacznie zdefiniować metropolię. Rozumienie metropolii zmieniało się w czasie. Przytoczone definicje zwracają uwagę na takie cechy jak:

- silne oddziaływanie (dominacja) na otoczenie,

- specyficzne funkcje wielkomiejskie,

- węzeł w sieci przepływów,

- potencjał demograficzny,

- potencjał innowacyjny,

- potencjał gospodarczy,

- dostępność transportowa,

- atrakcyjność i wyjątkowość przestrzeni.

Podobne zróżnicowanie dotyczy obszaru metropolitalnego, który definiowany jest między innymi jako:

- miasto centralne otoczone przez przedmieścia,

- zurbanizowany/wielkomiejski układ osadniczy,

- obszar funkcjonalny.

Wspólny w większości definicji jest nacisk na rolę, jaką metropolia odgrywa w otoczeniu oraz na związki funkcjonalne pomiędzy poszczególnymi jednostkami tworzącymi obszar. Uzasadnione zatem wydaje się zdefiniowanie obszaru metropolitalnego jako powiązanego funkcjonalne układu terytorialnego obejmującego miasto centralne i otaczające je jednostki terytorialne, który skupia funkcje metropolitalne i odgrywa znaczącą rolę w systemie przepływów kapitału, informacji i ludzi na poziomie globalnym, kontynentalnym, regionalnym lub krajowym.

\section{Specyfika procesu metropolizacji}

Termin metropolizacja określony jest w Słowniku języka polskiego jako „skupianie [...] w dużych miastach obiektów przemysłowych, instytucji kulturalnych, społecznych itp." [Dubisz 2003, s. 618]. Według B. Jałowieckiego

metropolizacja oznacza wzrost nierówności przestrzennych i coraz bardziej zaznaczający się podział na metropolię i resztę. Jest to proces przekształcania się przestrzeni miejskich, polegający na zmianie relacji między miastem centralnym i jego bezpośrednim zapleczem oraz na nieciągłym sposobie użytkowania przestrzeni zurbanizowanych. Zmiana relacji polega na osłabieniu lub zerwaniu związków gospodarczych miasta z jego regionalnym zapleczem i zastąpieniu ich więziami z innymi metropoliami w skali kontynentalnej lub światowej. Rola regionu ogranicza się do pełnienia funkcji mieszkaniowych i rekreacyjnych dla mieszkańców metropolii, zaś nieciągłość przestrzeni oznacza, że sąsiadem w sensie gospodarczym i społecznym nie jest już otaczający region, ale odległa [...] inna metropolia [Jałowiecki 1999, s. 7, 29]. 
W innych publikacjach autor ten definiuje metropolizację jako: „proces przejmowania przez niektóre wielkie miasta funkcji kierowniczych w sferze gospodarczej oraz politycznej w przestrzeni ponadnarodowej” i/lub „funkcji wzorcotwórczych w kulturze" [Jałowiecki 2002; 2007, s. 36].

Zjawisko metropolizacji przestrzeni można powiązać z postępującą w międzynarodowej gospodarce globalizacją. [Gorzelak 2009, s. 12]. Proces metropolizacji przestrzeni jest swoistą odpowiedzią systemu osadniczego na zjawisko globalizacji. Wiąże się on z krystalizowaniem nowego typu struktury przestrzennej oraz skupianiem rozwoju w wybranych fragmentach przestrzeni, które uzyskują dzięki temu przewagę nad innymi jednostkami, a w konsekwencji uzyskują międzynarodową rangę. Takie ośrodki, wielkie miasta czy regiony:

- skupiają światowy potencjał gospodarczy, finansowy, naukowy, władzy, mediów i instytucji kulturalnych,

- przejmują nadrzędne funkcje w zarządzaniu gospodarką w skali ponadnarodowej,

- charakteryzują się dużą innowacyjnością i wysokim poziomem usług,

- są włączone w międzynarodowy układ powiązań, współpracy i zależności, w formie sieci miast pełniących najważniejsze funkcje [Markowski, Marszał 2006a, s. 10].

Metropolizacja od strony funkcjonalnej oznacza proces umiędzynarodowienia funkcji miejskich, tj. eliminowania barier w swobodnej wymianie dóbr i usług, a także współpracy międzynarodowej. Z drugiej strony należy oczekiwać, iż globalne procesy będą także rodziły określone skutki w przestrzeni lokalnej (nie zawsze pożądane) na tyle specyficzne, że można mówić o procesach nowej urbanizacji albo metropolizacji przestrzeni [Markowski, Marszał 2006b, s. 324].

Proces metropolizacji oznacza zmianę charakteru oraz siły powiązań pomiędzy ośrodkiem centralnym a otaczającym go regionem. Przekształcenie to związane jest z rozwojem systemu synergicznych zależności funkcjonalnych i przyjęciem miejskiego stylu życia na przyległych obszarach przy jednoczesnym zachowaniu zdecydowanej i wszechstronnej dominacji centrum.

Ponadto, analizowany proces prowadzi do przekształceń w użytkowaniu przestrzeni na obszarach miast oraz ich stref podmiejskich. W konsekwencji, jak już zauważono, krystalizuje się nowego typu struktura przestrzenna o charakterze dużego, złożonego zespołu osadniczego, który często ma policentryczny układ oraz niepewnie wytyczone, niemalże zatarte granice między miastem a strefą podmiejską. Oznacza rozwój przestrzeni zurbanizowanej, który prowadzi do ekspansji, eksportu i kopiowania rozwiązań miejskich stworzonych $\mathrm{w}$ metropoliach. Na takim obszarze obserwuje się procesy koncentracji ludności oraz wzrost potencjału ekonomicznego i społecznego [Markowski, Marszał 2006a, s. 10]. Warto zauważyć, iż pomimo powyższego 
stwierdzenia, że w wyniku procesów metropolizacji przestrzeni można rozpoznać nową formę jej organizacji, określenie „metropolizacja” nie ma charakteru morfologicznego. Jest to pojęcie zdecydowanie funkcjonalne i oznacza spełnienie określonych już wcześniej kryteriów.

Wskutek współczesnej rewolucji technologicznej miasta powracają do swej tradycyjnej roli - węzłów w globalnych sieciach przepływów. O ich rozwoju decyduje akumulacja i efektywność pracy kapitału [Bendyk 2010, s. 55].

Postępująca współcześnie metropolizacja przestrzeni znacznie różni się zarówno pod względem ilościowym, jak i jakościowym - od wcześniejszych procesów urbanizacji:

- związana jest z szybkim wzrostem znaczenia dużych układów miejskich we współczesnej gospodarce,

- oznacza odstępstwo od hierarchicznej organizacji przestrzeni w rozumieniu Christarella - wnosząc nowe silne powiązania między odległymi obszarami metropolitalnymi częściowo uniezależnia siłę oddziaływania ośrodka od jego "masy” i odległości fizycznej,

- zmienia relacje między miastem metropolitalnym a otaczającym je regionem,

- oznacza nowy sposób terytorialnego podziału pracy, kapitału, wiedzy i władzy [Markowski 2010].

Metropolizację przestrzeni można traktować jako współczesny wyraz procesów urbanizacji wielkich miast i stref ich oddziaływania pod wpływem procesów globalizacji [Markowski 2010]. Większość naukowców i praktyków badających procesy zachodzące w miastach zgodnie uznaje, że metropolizacja jest zestawem procesów, które wzmacniają wielkie układy zurbanizowane, charakteryzujących się zmianą systemów produkcyjnych analizowanych na szczeblu światowym, prowadzących do nowej organizacji i restrukturyzacji terytoriów i dotyczących ich relacji wewnętrznych oraz zewnętrznych [Gaussier, Lacour, Puissant 2003, s. 253].

Podobnie jak w przypadku procesu globalizacji, metropolizacja przestrzeni niesie za sobą niebywałe szanse rozwoju danych obszarów, ale także zagrożenia. Z jednej strony można powiedzieć, iż jedynie przestrzeń o wysokim poziomie metropolizacji może być $\mathrm{w}$ dobie obecnej innowacyjna i konkurencyjna, gdyż spełnia oczekiwania europejskie i globalne. Dzięki temu następuje otwarcie struktury miejskiej na relacje z całym kontynentem, a nawet światem, w konsekwencji czego główne miasta stają się węzłami sieci przepływów handlowych, finansowych, kulturalnych, informacyjnych czy naukowych o zasięgu ponadregionalnym i ponadnarodowym.

Z drugiej jednak strony szybka metropolizacja ośrodka, przy niewielkim zakresie i zasięgu przestrzennym jego rozprzestrzeniania, prowadzi do marginalizacji jego otoczenia regionalnego. Do tego typu rozwoju potrzebne są bowiem zasoby, które zazwyczaj nie występują w najbliższym sąsiedz- 
twie. Rola przyległych obszarów często ogranicza się do dostarczania wykwalifikowanego kapitału ludzkiego w formie migracji tygodniowych (na okres pracy lub nauki) lub stałych oraz zasobów środowiska w postaci wody pitnej czy przestrzeni rekreacyjnej. W zamian, otoczenie regionalne staje się odbiorcą negatywnych skutków rozwoju zespołów miejskich. To tu, ze względu na konkurencyjność cenową gruntów, lokują się niepożądane w mieście urządzenia infrastruktury technicznej (np. składowiska odpadów), transportowej i przemysłowej, centra dystrybucyjne czy pracochłonne branże działalności produkcyjnej. Obserwuje się również niekontrolowany wzrost budownictwa mieszkaniowo-rekreacyjnego, często zakłócającego ład przestrzenny lub niszczącego cenny pod względem przyrodniczym krajobraz. Ponadto zasoby, które wcześniej dostarczane były do miasta $\mathrm{z}$ regionu, w wyniku rozbudowania sieci powiązań na różnych płaszczyznach, zaczynają napływać również z innych, konkurencyjnych źródeł (np. żywność) lub zostały całkowicie przez nie wyparte (np. surowce) [Lendzion 2004, s. 7].

A zatem poważnym zagrożeniem, jakie niesie za sobą proces metropolizacji, jest swoista nieciągłość przestrzeni, co w praktyce oznacza, że „sąsiadem" w sensie gospodarczym i społecznym nie jest już otaczający region, a inny zespół miejski oddalony o setki lub nawet tysiące kilometrów.

Metropolizację należy zatem rozpatrywać w kategoriach efektów pozytywnych - rozwój funkcji metropolitalnych i np. rozwój lokalnych usług, jak i negatywnych: np. uboczne skutki alienacji funkcji metropolitalnych wpływających na przestrzeń w postaci tworzenia kosmopolitycznych miejsc pracy dla osób z zewnątrz - czy globalnej spekulacji gruntami [Markowski, Marszał 2006b, s. 327].

Następstwem metropolizacji rozumianej jako tworzenie się kreatywnych miast, tworzących środowisko nasycone kulturą, oświatą, nauką i informacją, zdolne do innowacyjnej refleksji jest innowacyjność przestrzeni. Miasta takie stanowią najwyżej zorganizowane centra informacji ekonomicznej [Amin, Graham 1997, s. 4-5]. Występujące w nich złożone sieci koordynacji działań są koniecznym instytucjonalnym warunkiem generowania, transferu i dyfuzji nowoczesnych technologii, co ma decydujące znaczenie także dla otoczenia miast. Miasta takie stają się metropoliami [Hausner 2001, s. 20]. O metropolitalnym charakterze miasta decyduje nie tylko siła oddziaływania i zasięg funkcji egzogenicznych, ale również ich zróżnicowanie. Na pełne miano metropolii zasługują tzw. diversified cities - miasta o funkcjach złożonych i znacznej komplikacji wypełnianych funkcji wyższego rzędu [Purchla, Sepioł 1998, s. 16]. Im bardziej złożony jest system, tym korzystniejsze są warunki do tworzenia relacji między nimi oraz pojawiania się efektów synergii [Domański 2001, s. 31]. Zróżnicowana gospodarka generuje bar- 
dziej kreatywne środowisko, a w efekcie gospodarkę odporniejszą na cykliczne wahania koniunktury.

W rezultacie w ostatnich latach obserwuje się wyraźną metropolizację rozwoju, czyli koncentrowanie się segmentu wysokiego $\mathrm{w}$ wielkich miastach, których cechy jakościowe pozwalają na zajęcie ważnego miejsca w światowej sieci metropolitalnej. Obszary metropolitalne notują najwyższe tempa wzrostu, powiększając i tak już istotną przewagę nad innymi regionami w swoich krajach. W przypadku Europy 67\% PKB wytwarzane jest w obszarach metropolitalnych, liczba ludności zamieszkującej te regiony stanowi zaś jedynie 59\% całkowitej populacji Europy [European Commission 2011, s. 2]. W ośmiu europejskich stolicach PKB na mieszkańca ponad dwukrotnie przewyższa średnią krajową. Dotyczy to nie tylko Londynu i Paryża, ale również stolic państw członkowskich UE, takich jak Warszawa, Bratysława, Sofia, Bukareszt, Praga, Budapeszt, Ryga i Tallin [Komisja Europejska 2010, s. 75].

Badania prowadzone przez Gorzelaka i Smętkowskiego [por. Gorzelak, Smętkowski 2009; Smętkowski, Wójcik 2009] w krajach Europy Środkowowschodniej wykazały, że w większości z nich, po wyeliminowaniu regionów, w których znajdują się obszary metropolitalne, w latach 1995-2005 zróżnicowanie międzyregionalne pozostawało na zbliżonym poziomie. Świadczy to o kluczowej roli metropolizacji w kształtowaniu się zróżnicowań przestrzennych. W Polsce zarówno województwa, jak i podregiony raczej względnie ubożały za sprawą znacznie szybszego niż przeciętny wzrostu dochodu w początkowo najbogatszych regionach (mazowieckie dla województw i podregiony będące dużymi miastami). Prowadziło to do dalszej polaryzacji regionalnej oraz wzmocnienia ośrodków metropolitalnych. We wszystkich krajach wielkie miasta umocniły swoją wiodącą pozycję pod względem PKB per capita, które było w nich wyższe niż średnia krajowa. Najszybciej rozwijające się regiony metropolitalne wykazywały tendencje do zwiększenia zróżnicowania wewnętrznego w wymiarze zrelatywizowanym średnią krajową. Proces metropolizacji i włączanie się regionów wielkich miast w główny nurt współczesnej gospodarki informacyjnej był przyczyną największych różnic między regionami Europy Środkowowschodniej. Z jednej strony najszybciej rozwijały się i rozwijać się będą najbogatsze regiony metropolitarne, o dużej koncentracji wykształconej i aktywnej siły roboczej, nowoczesnej strukturze gospodarczej, przejawiającej się we względnie dużym udziale sektora usług rynkowych. Według danych za 2009 rok, dochody per capita w dwunastu miastach należących do Unii Metropolii Polskich były o ponad 40\% wyższe niż średnia dla wszystkich gmin [Swianiewicz, Krukowska, Nowicka 2011, s. 9]. Jednocześnie na drugim biegunie znajdują się regiony o przewadze sektorów tradycyjnych, uzależnione od transferów publicznych, tkwiące w stagnacji 
i w małym stopniu uczestniczące w procesach rozwojowych i modernizacyjnych, przez co są i pozostaną biedne. Te dwa oddalające się od siebie bieguny będą powodowały narastanie rozwarstwienia, zwłaszcza w wymiarze wewnątrzkrajowym.

Cechą charakterystyczną metropolizacji jest również istotne ograniczenie przestrzeni publicznej charakterystycznej dla tradycyjnego miasta. Spowodowane jest to zmianą, przez wielkie międzynarodowe korporacje, wielofunkcyjnych centralnych dzielnic miast we względnie jednorodną przestrzeń biurową z niewielkimi aneksami usługowymi przeznaczonymi głównie dla pracowników i interesantów, a także budową peryferyjnych dzielnic biznesowych (często $\mathrm{w}$ pobliżu transkontynentalnych lotnisk). W niektórych miastach korporacje, w trosce o swój image, oddają w swoich kompleksach biurowych część prywatnej przestrzeni do użytku publicznego. Kolejną przyczyną ograniczenia przestrzeni publicznej w miastach jest zmiana organizacji handlu, który skupia się w specjalnie zaaranżowanych obiektach położonych na ogół poza centralnymi obszarami metropolii [Smętkowski, Jałowiecki, Gorzelak 2009, s. 13].

Proces metropolizacji obserwowany jest również na obszarach zurbanizowanych w Polsce [Jałowiecki 2000; Ilnicki 2003a; Parysek 2000; Juchnicka, Proniewski 2009]. Ma on swoje odzwierciedlenie w przemianach społeczeństw miast. Jednym z przejawów tego procesu jest tworzenie tzw. klasy metropolitalnej, wyróżniającej się zarówno rodzajem posiadanych kompetencji, jak i specyficznym stylem życia, przyjmowanym systemem wartości znajdującym wyraz między innymi w postrzeganiu miasta, w jego ocenie, identyfikacji z nim. Cechą klasy metropolitalnej, powstającej w Polsce, jest brak wielopokoleniowego dziedzictwa, brak historycznego zakorzenienia, kosmopolityzm oraz europejska lub światowa identyfikacja. Miasto, w którym jej członkowie mieszkają, często nie stanowi dla tej klasy istotnej wartości [Szkurłat 2003, s. 74].

Coraz większa liczebność i gospodarcza rola warstw wykształconych w społeczeństwie stwarza zapotrzebowanie na dobra kultury i wysokiej jakości rozrywkę, które z kolei przyciągają do metropolii ludzi o wysokich kwalifikacjach. W dużych miastach tworzy się nowa klasa społeczna obejmująca kreatywnych naukowców, inżynierów, architektów, nauczycieli, artystów i pisarzy. Jeżeli miasto ma się rozwijać, nie wystarczą nowe miejsca pracy, ale niezbędne jest tworzenie klimatu twórczego środowiska. Nową kreatywną klasę charakteryzuje duża dynamika działania, różnorodność i indywidualizm [Florida 2002; 2004; 2005]. Jej przedstawiciele nie korzystają z gotowych wzorców. Atrakcyjne są dla nich miejsca oferujące możliwość indywidualnego rozwoju. Są to ludzie w znacznym stopniu przyczyniający się do rozwoju miast, w których żyją i którzy przestrzeń współczesnych miast traktują jako atrakcyjne miejsce do życia [Chądzyńska 2008, s. 33]. 
Proces metropolizacji w Polsce już się rozpoczął i nie można go zatrzymać. Dlatego też, w obliczu identyfikacji szans i zagrożeń, jakie za sobą niesie, powinno się opracować narzędzia oraz instrumenty, których wdrożenie pozwoli na podjęcie niezbędnych działań mających na celu zminimalizowanie alienacji funkcjonalno-gospodarczej obszarów otaczających zespoły miejskie.

Jedną z cech współczesnej metropolizacji jest asymetria więzi metropolii z ich bezpośrednim zapleczem na rzecz umacniania relacji z innymi metropoliami [zob. Taylor 2003].

Metropolizacja przestrzeni tworzy metropolie, a metropolie tworzą obszar metropolitalny. Występowanie metropolii jest warunkiem koniecznym do rozpoczęcia procesu metropolizacji otoczenia. Metropolie są żywo zainteresowane dobrą kondycją gospodarczą otaczających je obszarów, gdyż są one pierwszym i najważniejszym odbiorcą metropolitalnych produktów i usług. Jak zauważa A. Klasik „nie ma metropolii bez regionu. Metropolia i jej otoczenie regionalne tworzą system posiadający wewnętrzne mechanizmy rozwoju i integracji" [Klasik 1998, s. 40], dzięki którym metropolie i ich obszary metropolitalne zajmują określoną pozycję na arenie krajowej i międzynarodowej.

Cechą charakterystyczną dla Europy jest fakt, że istnienie tzw. globalnych metropolii (Londyn, Paryż) stanowi raczej wyjątek niż regułę [Mieszkowska 2005, s. 36]. Występuje w niej jednak wiele miast, których znaczenie wynika $\mathrm{z}$ roli jaką odgrywają $\mathrm{w}$ systemie powiązań $\mathrm{z}$ innymi miejscami, w gospodarce światowej, ze znaczenia dla dziedzictwa cywilizacji.

Kształtowanie się metropolii i proces metropolizacji nie oznacza też, że nie ma już procesu urbanizacji. Urbanizacja postępuje nadal, ale jest zdominowana przez metropolizację. Proces metropolizacji powoduje zmiany całej tkanki społecznej i miejskiej nie tylko metropolii, ale także regionów od niej zależnych, których rola czasem ogranicza się do pełnienia funkcji mieszkaniowych i rekreacyjnych dla mieszkańców metropolii [Lendzion 2004, s. 9].

Metropolie, będąc atrakcyjnymi lokalizacjami biznesu i stwarzając dobre warunki życia, przyciągają nowych mieszkańców. Wzrostowi liczby ludności towarzyszy powiększanie się terytorium metropolii, głównie w wyniku suburbanizacji - nie tylko mieszkań, ale i usług. Coraz więcej gmin staje się częścią metropolii pełniąc funkcje produkcyjne, mieszkaniowe, dystrybucyjne, transportowe itp. To z kolei powoduje wydłużenie dojazdów do pracy, placówek handlowych i kulturalnych. Rozbudowie ulegają sieci infrastruktury komunalnej - energetyczne i wodno-kanalizacyjne, a gospodarka odpadami obejmuje większe obszary. Dotychczasowa terytorialna organizacja niemal każdego kraju nie jest już adekwatna do kształtujących się przestrzeni metropolitalnych obejmujących obszar funkcjonalny, powstają konflikty i trudności w zarządzaniu tymi obszarami, jak i w koordynacji inwestycji na tych terenach [Lendzion 2004, s. 45]. Wymaga to nowego sposobu zarządza- 
nia coraz większymi i coraz bardziej złożonymi organizmami miejskimi i poszerzającym się ich bezpośrednim zapleczem [Smętkowski, Jałowiecki, Gorzelak 2009, s. 3]. W tej sytuacji w wielu krajach Europy podejmuje się wysiłki mające na celu powołanie nowych struktur administracyjnych przystosowanych do zarządzania obszarami metropolitalnymi.

\section{Funkcje metropolitalne}

Nie każdy obszar silnie zurbanizowany jest obszarem metropolitalnym. 0 jego metropolitalności decyduje występowanie w nim pewnych szczególnych funkcji. Funkcje metropolitalne to funkcje społeczno-gospodarcze obszaru metropolitalnego oddziałujące na poziomie regionu, kraju, kontynentu, świata [Czyż 2009, s. 450]. W ciągu ostatnich lat coraz bardziej powszechnie wśród badaczy obszarów metropolitalnych panuje opinia, iż za obszar metropolitalny można uznać te tereny, które skupiają funkcje o zasięgu ponadkrajowym [Jałowiecki 1999; Korcelli-Olejniczak 2004; Parysek 2005]. Jest to podejście zawężające obszar metropolitalny, w systemie zarządzania metropoliami należy bowiem uwzględnić skutki zewnętrzne procesów globalizacji. Powodują one oddziaływanie funkcji metropolitalnych jednych metropolii na inne. Jeśli mówimy o sieci powiązań, to funkcje mogą stanowić skutek procesów metropolizacji i decydować o obszarze metropolitalnym. Niekoniecznie muszą to być funkcje egzogeniczne, zatem należy brać również pod uwagę skutki zewnętrzne funkcji endogenicznych obszaru oraz ich rozlokowanie, ponieważ to również będzie decydowało o charakterze obszaru metropolitalnego.

Obserwowaną tendencją jest wzrost stopnia złożoności systemów metropolitalnych. Widoczne jest zwiększenie liczby elementów i sieci powiązań między nimi. Jedną z charakterystycznych cech rosnącej złożoności systemów jest dywersyfikacja ich gospodarek, która jest procesem korzystnym dla miast i ich otoczenia. Rosnąca liczba elementów składowych tworzy warunki do większej liczby kombinacji. Wzajemne relacje między nimi ulegają rozgałęzieniom i intensyfikacji, co prowadzi do tworzenia złożonych sieci. Zróżnicowana gospodarka generuje bardziej kreatywne środowisko, a w efekcie gospodarkę odporniejszą na cykliczne wahania koniunktury. A zatem władze lokalne powinny dążyć do dywersyfikacji funkcji zarówno endogenicznych, jak i egzogenicznych oraz relacji między nimi [Domański 2001, s. 31].

W wielu obszarach metropolitalnych funkcje metropolitalne w pierwszej fazie rozwoju lokalizują się w rdzeniu obszaru, a gdy nie ma już w nim miejsca, zaczynają przemieszczać się do strefy zewnętrznej.

Każda jednostka samorządu terytorialnego została powołana w celu realizacji określonych zadań. Jednak nie wszystkie z nich, nawet te najwyższe- 
go szczebla, czyli mające pełnić z krajowego punktu widzenia najważniejsze funkcje, uznaje się za metropolie. Dlatego też dyskusyjne jest podejście niektórych badaczy problematyki miast [Maik 2003; Wolaniuk 1997], którzy utożsamiają funkcje metropolitalne z funkcjami wielkomiejskimi. Aby daną funkcję można było nazwać metropolitalną, powinna ona:

- zaliczać się do nowoczesnych (bazujących na wiedzy i najnowszych technologiach) działów gospodarki narodowej, bądź służyć bezpośrednio lub pośrednio obsłudze działalności gospodarczej lub też być rozumianą, jako wyspecjalizowana usługa wyższego rzędu, zaliczana do sektora IV;

- być egzogeniczna - służyć rozwijaniu sieci zewnętrznych powiązań, zwłaszcza w zakresie przepływu wiedzy, informacji, kapitału, dóbr kultury i ludzi, o zasięgu co najmniej ponadregionalnym;

- budować konkurencyjność ośrodka miejskiego w układach międzynarodowych [Markowski, Marszał 2006b, s. 325].

Warto podkreślić, iż o tym, czy dana funkcja będzie mogła odgrywać rolę metropolitalnej, nie decyduje jej rodzaj ani specjalizacja, a przede wszystkim zasięg oddziaływania (co najmniej krajowy) oraz powiązania z innymi metropoliami [Markowski, Marszał 2006a, s. 13]. Funkcje metropolitalne mogą być pojmowane jako funkcje dominujące (będące konsekwencją monopolistycznej pozycji na rynku oraz silnej dynamiki gospodarczej, technologicznej i kulturalnej), kontrolne (w sferze ekonomicznej, politycznej, społecznej, kulturalnej i technicznej) oraz funkcje budujące międzynarodowy charakter powiązań miasta i jego ponadregionalną rangę [Maik 2003, s. 13].

Możemy wyróżnić następujące funkcje metropolitalne:

- polityczną,

- administracyjną,

- kulturalną,

- naukową,

- turystyczną,

- edukacyjną,

- gospodarczą,

- finansową,

- komunikacyjną,

- finformacyjną,

- duchową [Hall 2001; Klasik 1998; Markowski, Marszał 2006a; b].

Funkcje metropolitalne charakteryzują te ośrodki, w których obecne są instytucje reprezentujące usługi wyższego rzędu, usługi unikalne, w tym ważniejsze instytucje administracji, wykraczają zasięgiem swej działalności poza granice administracyjne jednostki terytorialnej i doprowadzające do tworzenia się powiązań strukturalnych w otoczeniu [Wolaniuk 1997, s. 11]. Zatem do kreacji tych funkcji niezbędna jest obecność instytucji reprezentujących 
struktury kierowania i zarządzania międzynarodowych korporacji, struktury kierownictwa światowych instytucji finansowych i głównych regulatorów rynków kapitałowych, najwyższego standardu placówek naukowych i technologicznych, najwyżej rangi placówek kulturalnych oraz imprez czy festiwali artystycznych. Wytworzenie metropolitalnej roli danego ośrodka determinują również szybkie i częste połączenia komunikacyjne z głównymi ośrodkami życia gospodarczego oraz swoista wyjątkowość miasta [Parysek 2003, s. 24]. Tego typu kryteria metropolitalności spełnia duża liczba miast świata, część miast europejskich, w tym niektóre miasta polskie. ${ }^{28}$

Władze metropolii powinny się zastanowić jaka ma być relacja między funkcjami metropolitalnymi i endogenicznymi, zaspokajającymi potrzeby mieszkańców. Funkcje te mogą się wzajemnie wspomagać i wspierać lub mogą pozostawać ze sobą w sprzeczności. Mieszkańcy miasta mogą np. tracić na wydzieleniu znacznych części miasta dla realizacji funkcji egzogenicznych (hotele, placówki dyplomatyczne, itp.), ale mogą też zyskiwać na poprawie funkcjonalności miasta, dokonanej, w celu wzmocnienia jego funkcji egzogeniczne (np. lepszy system komunikacji, rozbudowa lotniska, utworzenie nowej atrakcyjnej galerii, czy centrum rozrywki). Szczególnie cenna przestrzeń powinna być $\mathrm{w}$ pierwszej kolejności przeznaczana na funkcje metropolitalne.

Władze miasta muszą brać pod uwagę funkcjonowanie całego układu metropolitalnego, gdyż oddziaływanie metropolii pod względem gospodarczym, przestrzennym i społecznym wykracza poza jego granice administracyjne i sięga często kilkudziesięciu kilometrów. Zarząd takiego obszaru metropolitalnego powinien przejąć, tak jak dzieje się to w obszarach metropolitalnych świata, planowanie przestrzenne, zarządzanie transportem, gospodarkę odpadami, zarząd infrastrukturą sieciową, bezpieczeństwo, promocję itd.

\section{Delimitacja obszarów metropolitalnych}

Jednym z podstawowych wyznaczników obszaru metropolitalnego jest liczba ludności, przy czym nie ma w tym zakresie jednolitego podejścia. W Stanach Zjednoczonych obszar metropolitalny wyznacza się wokół miast o liczbie ludności powyżej 50 tysięcy [Shaffer 2004, s. 114]. W krajach Unii Europejskiej obszar metropolitalny to funkcjonalna jednostka gospodarcza charakteryzująca się gęsto zamieszkanym rdzeniem i zapleczem, którego rynek pracy jest silnie powiązany z ośrodkiem centralnym. Ludność takiego

${ }^{28}$ Badaniu funkcji metropolitalnych w polskich miastach poświęcona jest obszerna literatura. Zob. m.in.: Wolaniuk 1997; Jażdżewska 2003; Matczak 1992; Kosiński 1958; Górka 1994; Maliszowa 1981; Dziewoński 1967; Węcławowicz 1992; Gawryszewski, Korcelli, Nowosielska 1998. 
obszaru przekracza 500 tys. mieszkańców [OECD 2012]. Ruch migracyjny w takich obszarach pomiędzy centrum metropolii a jej obrzeżami doskonale funkcjonuje w obu kierunkach.

Nieco inne kryteria delimitacji proponuje M. Bassand. Definiuje on metropolię jako aglomerację miejską liczącą około miliona lub więcej mieszkańców, ale równocześnie posługuje się trzema dodatkowymi miernikami, tj.:

- doskonałością usług, instytucji i wyposażenia,

- potencjałem innowacyjnym w zakresie technicznym, ekonomicznym, społecznym, politycznym i kulturalnym,

- wyjątkowością i specyfiką miejsca [za: Jałowiecki 2002, s. 39].

Biorąc pod uwagę te kryteria, trzeba stwierdzić, iż żadne polskie miasto nie spełnia wszystkich warunków, dlatego też kryteria owe, w odniesieniu do miast w Polsce, należy nieco zmodyfikować, biorąc pod uwagę cechy sieci osadniczej oraz poziom rozwoju gospodarczego.

Delimitacja obszarów metropolitalnych jest problem rozpatrywanym nie tylko w kontekście krajowym, ale również międzynarodowym, o czym świadczy fakt, że prób delimitacji podejmują się takie organizacje, jak Europejska Sieć Obserwacyjna Rozwoju Terytorialnego i Spójności Terytorialnej (ESPON), Organizacja Współpracy Ekonomicznej i Rozwoju (OECD) czy Komisja Europejska.

\subsection{Podejście ESPON}

Program ESPON na terytorium 29 państw Europy zidentyfikował funkcjonalne obszary miejskie (FUA), które składają się z miejskiego rdzenia oraz sąsiadującej i gospodarczo z nim zintegrowanej strefy (taką strefą jest np. lokalny rynek pracy). Głównym kryterium przy określaniu FUA był zasięg dojazdów do pracy. Funkcjonalne obszary miejskie zostały sklasyfikowane odpowiednio do ich znaczenia pod względem liczby ludności, transportu, turystyki, przemysłu, wiedzy i funkcji decyzyjnych. Jedną z grup w tej klasyfikacji stanowią tzw. MEGA, czyli europejskie metropolitalne obszary wzrostu. Koncepcja ESPON zakłada, iż na terenie objętym programem, znajduje się 76 europejskich metropolitalnych obszarów wzrostu. Ze względu na stopień wykształcenia oraz zasięg oddziaływania podzielono je na:

1. węzły globalne (Paryż i Londyn),

2. paneuropejskie: European engines (17),

3. silne MEGA (8),

4. potencjalne MEGA (25),

5. słabe MEGA (24) (rys. 1).

Wśród zidentyfikowanych obszarów metropolitalnych wyróżnia się osiem regionów miejskich Polski: Warszawę, zaklasyfikowaną jako potencjalne MEGA, oraz Łódź, Kraków, Wrocław, Poznań, Katowice, Gdańsk i Szczecin, uznawane za słabe MEGA [ESPON 2006, s. 26]. 
Delimitacja stosowana przez ESPON uznawana jest za nadmiernie skomplikowaną, słabo rozpowszechnioną oraz zbyt złożoną $\mathrm{w}$ kontekście powszechnego zastosowania.

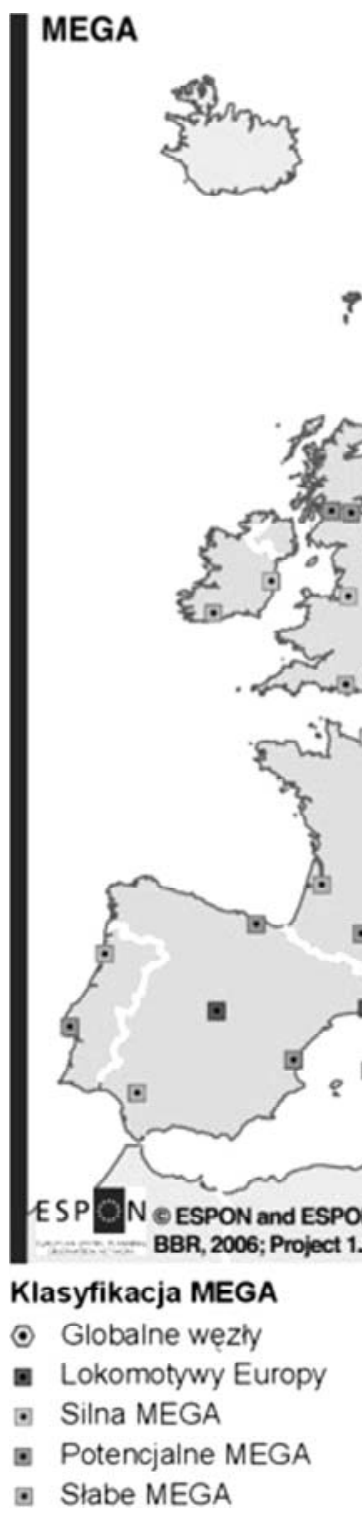

Rys. 1. Potencjalne i słabe MEGA w Polsce Źródło: [ESPON 2006] 


\subsection{Szersze strefy miejskie według programu Urban Audit}

Program Urban Audit jest wspólną inicjatywą Komisji Europejskiej i Eurostatu, której głównym celem jest dostarczenie obiektywnych i porównywalnych danych statystycznych o miastach europejskich, między innymi z zakresu demografii, struktury gospodarstw domowych, mieszkalnictwa, ochrony zdrowia, rynku pracy, działalności ekonomicznej, dochodów, zaangażowania społecznego, edukacji, ochrony środowiska, kultury i turystyki. Koordynatorem prac jest Eurostat, a wykonawcami krajowe urzędy statystyczne, urzędy miast oraz samorządy terytorialne [http://www.stat. gov.pl/gus/5840_13473_PLK_HTML.htm]. Delimitacja szerszych stref miejskich (Large Urban Zone - LUZ) została przeprowadzona na podstawie wyników badania Przepływy ludności zwiq̨zane z zatrudnieniem. Do LUZ zostały zaliczone gminy, z których ponad $15 \%$ pracujących dojeżdża do rdzenia i okalają miasta mające ponad 50 tys. mieszkańców. Liczba ludności szerszej strefy miejskiej musi wynosić co najmniej 500 tysięcy [Buciak 2012]. Efekt delimitacji przedstawia mapa (rys. 2).

Te same zasady delimitacji od roku 2011 przyjęła też OECD [zob.: OECD 2012].

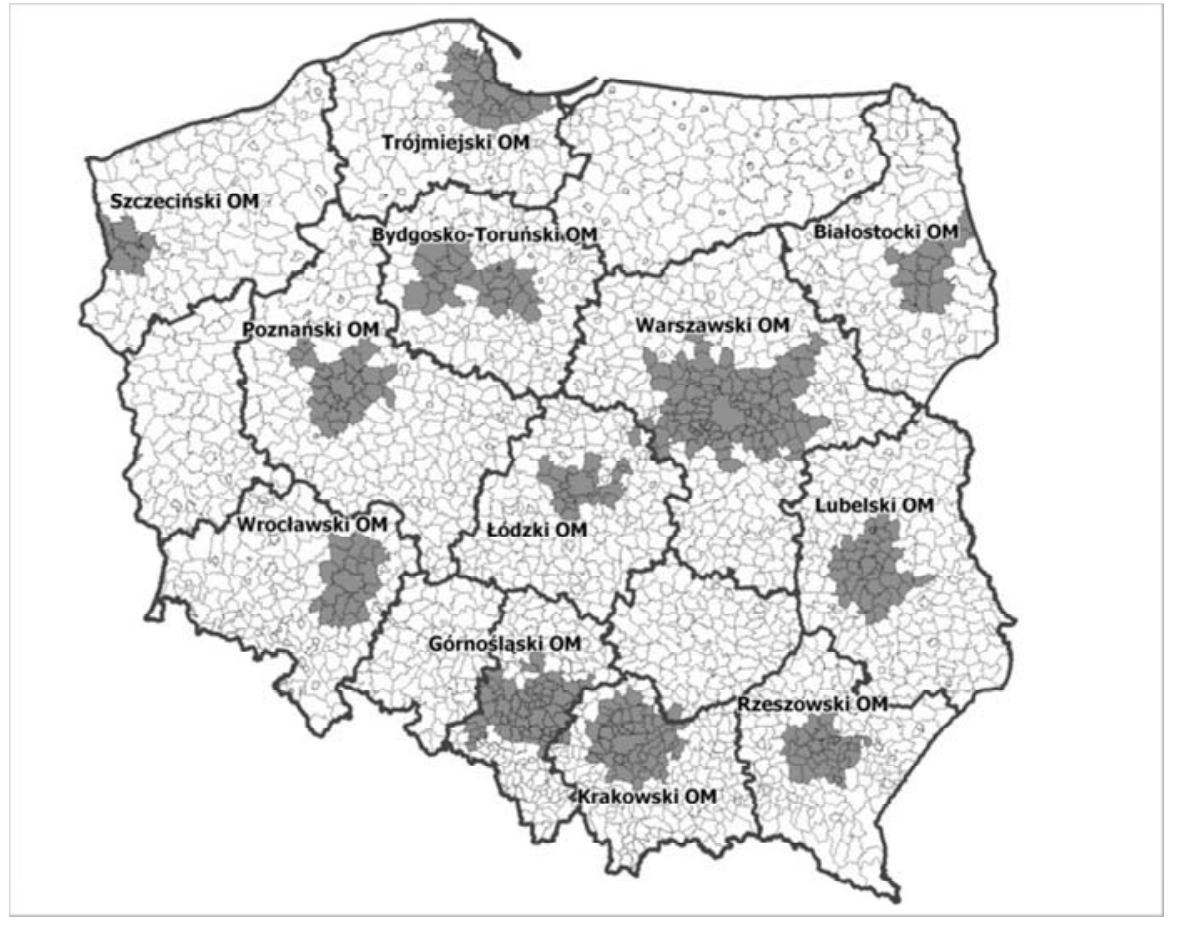

Rys. 2. Szersze strefy miejskie ośrodków metropolitalnych

Źródło: [oprac. własne na podstawie danych GUS] 


\subsection{Delimitacja według Unii Metropolii Polskich}

Unia Metropolii Polskich (UMP) jest organizacją założoną 11 października 1990 r. przez prezydentów pięciu miast: Gdańska, Krakowa, Poznania, Warszawy oraz Wrocławia. Obecnie współdziała w niej 12 głównych miast Polski (Białystok, Bydgoszcz, Gdańsk, Katowice, Kraków, Lublin, Łódź, Poznań, Rzeszów, Szczecin, Warszawa, Wrocław), których prezydenci stanowią jej Radę.

Wszystkie miasta UMP, poza Szczecinem, są członkami zwyczajnymi Stowarzyszenia Eurocities, zrzeszającego wielkie miasta europejskie. Natomiast od 2002 r. fundacja jest członkiem Światowego Stowarzyszenia Wielkich Metropolii „Metropolis”.

Unia Metropolii Polskich przyjmuje, iż każda polityka na szczeblu krajowym, a szczególnie polityka przestrzenna, musi brać pod uwagę podział na regiony statystyczne Unii Europejskiej. Jest to konieczne dla prowadzenia ewaluacji, obserwacji efektów gospodarczych i społecznych porównań międzynarodowych i międzyregionalnych. Polityka przestrzenna Polski musi być zbieżna $\mathrm{z}$ europejską polityką spójności i konkurencyjności, w której coraz ważniejszym czynnikiem stają się regiony metropolitalne i miejskie, w związku z ich rolą w globalnej, metropolizującej się gospodarce opartej na wiedzy.

Dlatego też za podstawę delimitacji obszarów metropolitalnych, przyjęto, że muszą one być wyznaczane w sposób zgodny z podziałem kraju na podregiony statystyczne NTS-3. Wykluczone jest wyodrębnianie według NTS-4 (pojedyncze powiaty) lub NTS-5 (mniejsze gminy), bowiem statystyka europejska nie schodzi na te poziomy, funkcjonują one jedynie w obiegu krajowym. Gdyby obszar metropolitalny został wyodrębniony niezgodnie z podziałem kraju na NTS-3, to nie można by operować takimi podstawowymi wskaźnikami do porównań, jak np. $\mathrm{PKB}^{29}$. Granice polskich obszarów metropolitalnych oparte na regionach statystycznych Unii Europejskiej przedstawiono na rys. 3.

Delimitacja obszarów metropolitalnych, przyjmująca za podstawową jednostkę podregion NTS-3, prowadzi do wyznaczenia obszarów o bardzo szerokim zasięgu, często obejmujących gminy nie wykazujące żadnych związków z ośrodkiem rdzeniowym obszaru.

\footnotetext{
${ }^{29}$ Materiały źródłowe udostępnione przez Unię Metropolii Polskich.
} 


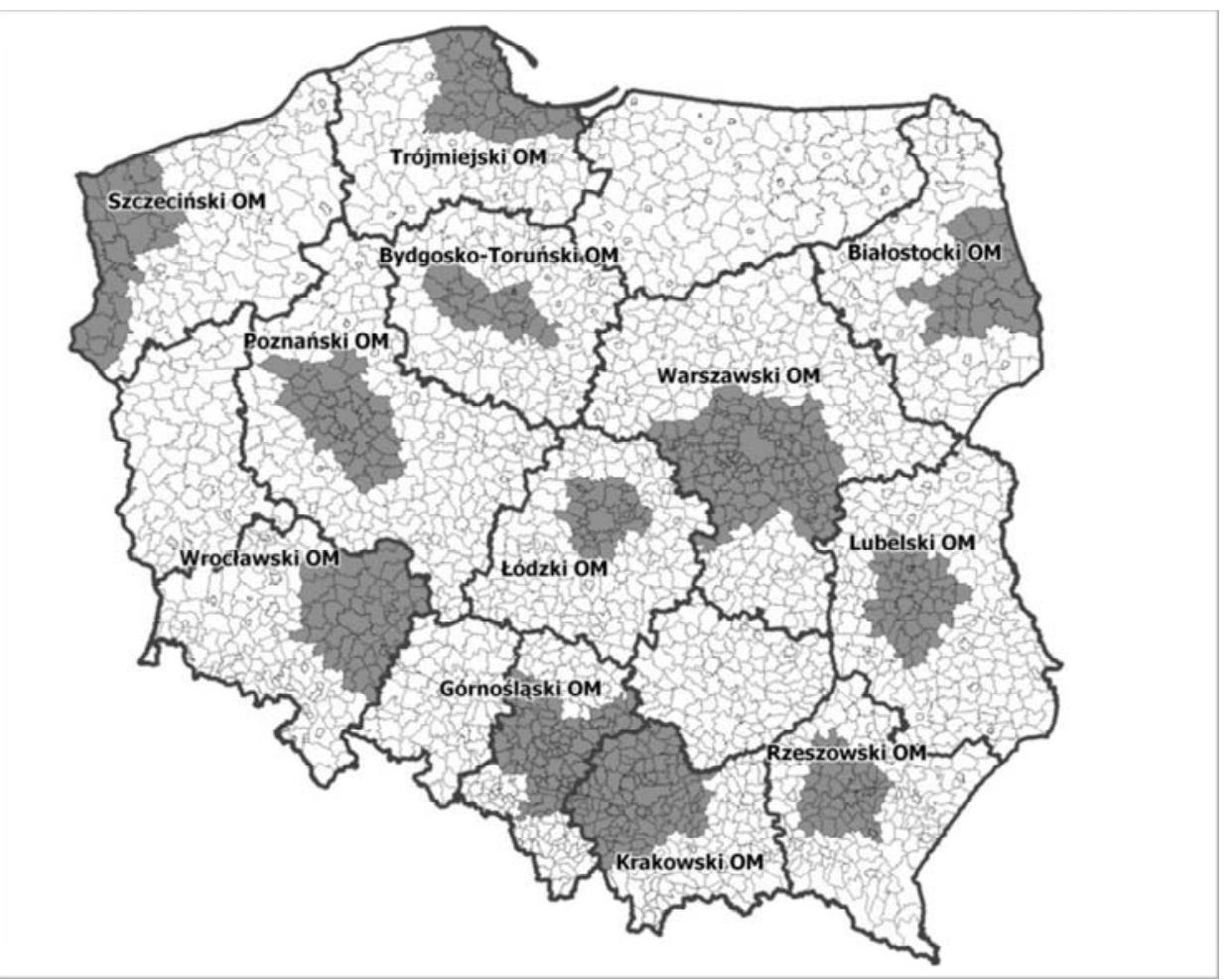

Rys. 3. Delimitacja obszarów metropolitalnych według UMP Źródło: oprac. własne

\subsection{Delimitacja obszarów metropolitalnych według P. Śleszyńskiego}

W Polsce, na poziomie rządowym, obecnie nie ma wiążącej delimitacji obszarów metropolitalnych. Jednak w Koncepcji Przestrzennego Zagospodarowania Kraju do roku 2030 przewidziano wyznaczenie miejskich obszarów funkcjonalnych stolic województw [MRRa 2012]. W związku z tym opracowywane są różnego rodzaju ekspertyzy mające w ostateczności doprowadzić do wyboru najlepszej, z punktu widzenia efektywnego zarządzania rozwojem tych obszarów, metod delimitacji. Najnowsza ekspertyza została sporządzona w październiku 2012 r. przez P. Śleszyńskiego. Opiera się ona na zestawie trzech rodzajów składników:

1. Funkcjonalnych:

- F1 - liczba wyjeżdżających do pracy najemnej do rdzenia MOF na 1000 mieszkańców w wieku produkcyjnym;

- F2 - liczba zameldowań z rdzenia MOF na 1000 mieszkańców.

2. Społeczno-gospodarczych: 
- S1 - udział pracujących w zawodach pozarolniczych, jako stosunek do analogicznego wskaźnika obliczonego dla całego województwa (czyli stosunek do średniej wojewódzkiej);

- S2 - liczba podmiotów gospodarczych na 1000 mieszkańców, jako stosunek do analogicznego wskaźnika obliczonego dla całego województwa;

- S3 - udział podmiotów gospodarczych w usługach wyższego rzędu, jako stosunek do analogicznego wskaźnika obliczonego dla rdzenia MOF.

3. Morfologicznych:

- M1 - gęstość zaludnienia (bez lasów i wód), jako stosunek do analogicznego wskaźnika obliczonego dla całego województwa;

- M2 - liczba mieszkań oddanych do użytku na 1000 mieszkańców, jako stosunek do analogicznego wskaźnika obliczonego dla całego województwa.

Ponadto przy delimitacji przyjęto zasady: spójności i rozłączności oraz spełnienia liczby minimalnych kryteriów. Do obszarów funkcjonalnych zostały zakwalifikowane gminy spełniające 5 z 7 minimalnych kryteriów (rys. 4).

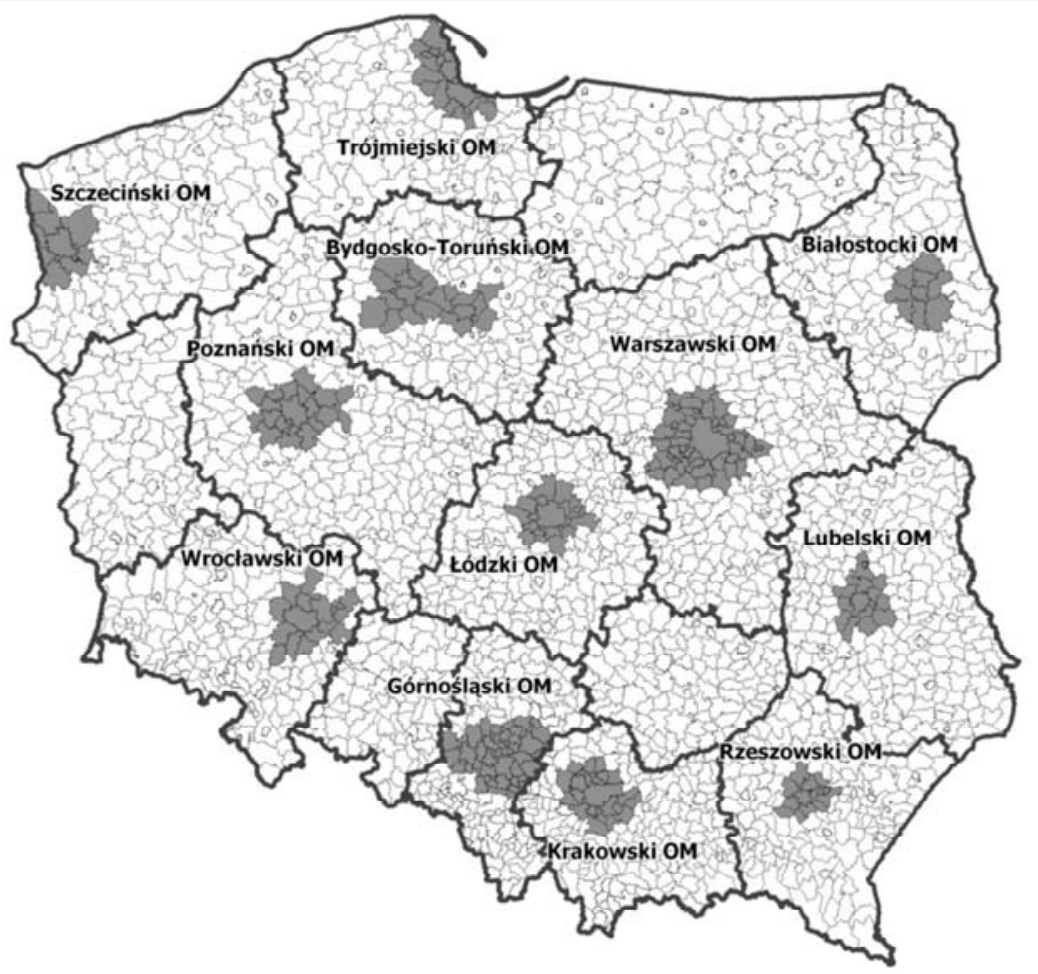

Rys. 4. Delimitacja obszarów metropolitalnych Źródło: oprac. własne 
Podstawową zaletą tej delimitacji jest porównywalność poszczególnych obszarów. Przy czym wskazuje ona minimalny zasięg obszaru funkcjonalnego, który może być zmieniany w zależności od potrzeb (w kierunku raczej rozszerzenia niż zmniejszenia) głównie przez Urzędy Marszałkowskie.

\subsection{Delimitacja według Wojewódzkich Biur Planowania Przestrzennego}

Zgodnie z zapisem ustawy o planowaniu przestrzennym „w planie zagospodarowania przestrzennego województwa [...] określa się w szczególności obszary problemowe wraz z zasadami ich zagospodarowania oraz obszary metropolitalne", dla których powinien zostać sporządzony plan zagospodarowania obszaru metropolitalnego jako część planu zagospodarowania województwa [Ustawa... 2003]. Urzędy marszałkowskie, które rozpoczęły pracę nad planami wojewódzkimi najczęściej dokonują własnej delimitacji obszarów metropolitalnych, zwłaszcza że żadna z przedstawionych powyżej delimitacji nie jest obowiązująca. W obowiązującej Koncepcji... jest wręcz powiedziane, iż ostateczna delimitacja powinna zostać przeprowadzona na poziomie regionalnym [MRR 2012a, s. 181].

Prace takie zostały podjęte przez Wojewódzkie Biura Planowania Przestrzennego w niektórych województwach, gdzie znajdują się obszary metropolitalne. Do najczęściej branych pod uwagę kryteriów należą:

- społeczno-gospodarcze,

- dostępności komunikacyjnej,

- zagospodarowania przestrzennego,

- prawno-polityczne,

- ekologiczne,

- funkcjonalno-techniczne,

- spójności infrastrukturalnej,

- mobilności ludności: dojazdy do pracy i migracje stałe.

Uwzględniane są też zasady bezpośredniego sąsiedztwa, ciągłości, zwartości oraz rozłączności, które brane były pod uwagę również w trakcie opracowywania Koncepcji Przestrzennego Zagospodarowania Kraju. W większości przypadków przyjęto, że granice obszaru metropolitalnego powinny być wyznaczone na podstawie granice gmin, ale są też przypadki, w których bazuje się na jednostce statystycznej NTS-3 i tworzy obszary metropolitalne $\mathrm{z}$ wykorzystaniem grupy powiatów bezpośrednio sąsiadujących z miastem centralnym (Wrocławski OM, Rzeszowski OM).

W celu wykazania różnic w poszczególnych delimitacjach, na mapie (por. rys. 5) przedstawiono delimitację Poznańskiego Obszaru Metropolitalnego według opisanych powyżej metod. 


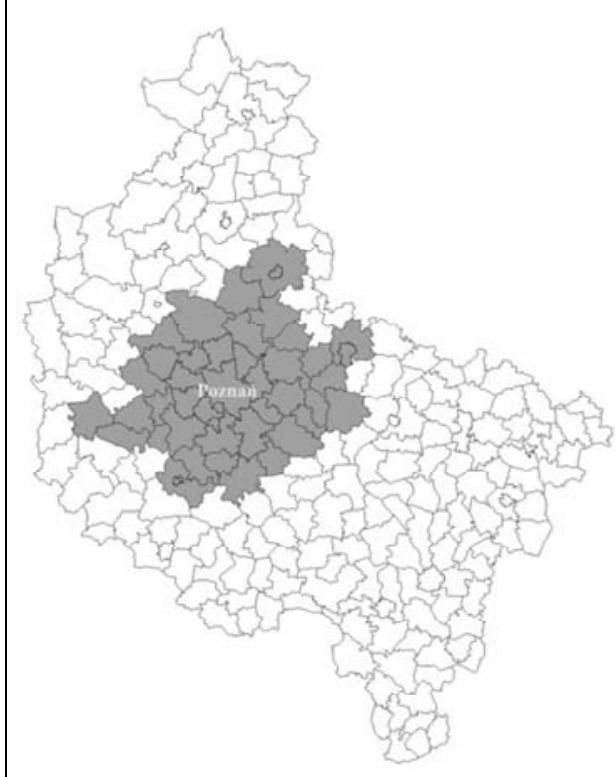

(1) Delimitacja wg Wielkopolskiego Biura Planowania Przestrzennego

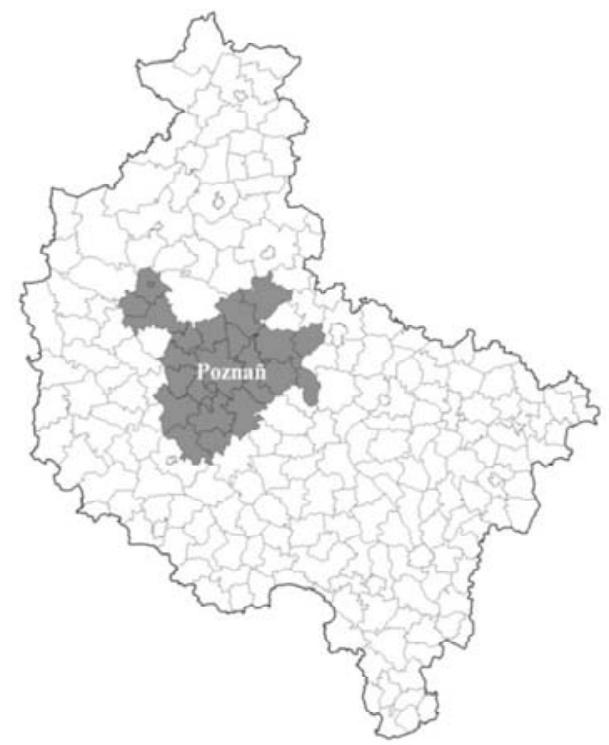

(3) Delimitacja według URBAN AUDIT

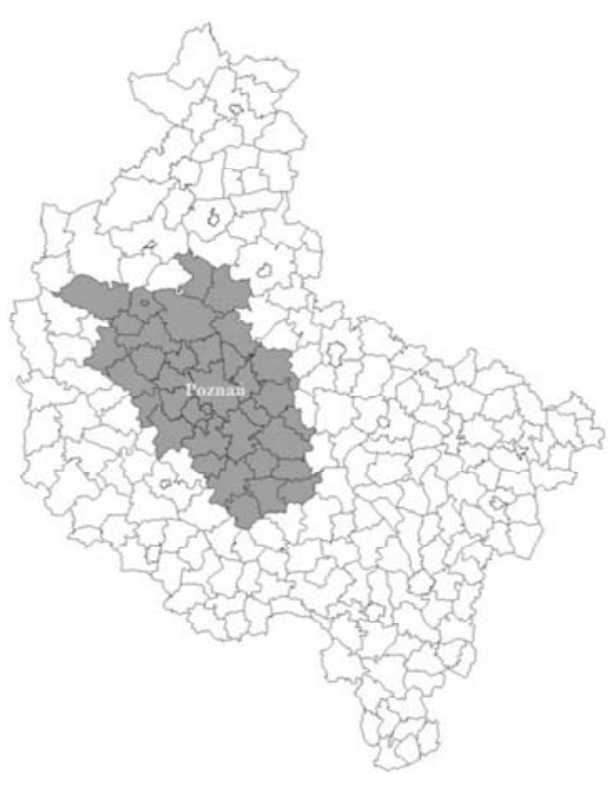

(2) Delimitacja wg Unii Metropolii Polskich

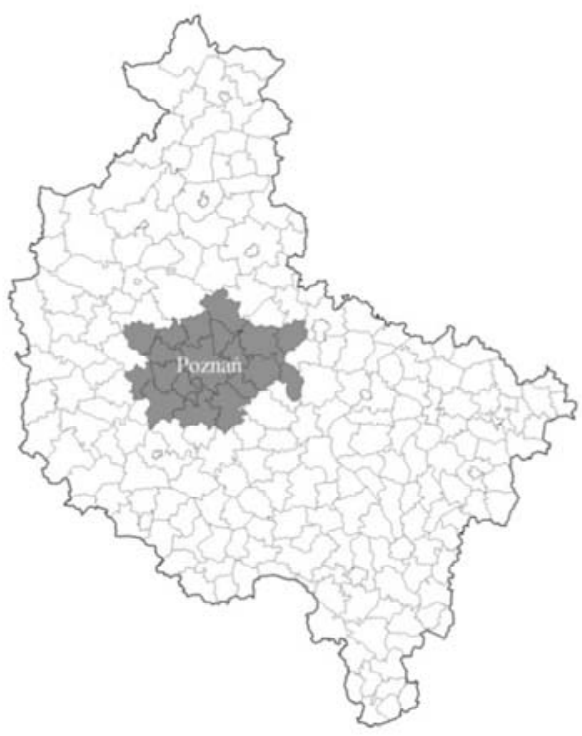

(4) Delimitacja wg Śleszyńskiego

Rys. 5. Poznański Obszar Metropolitalny według różnych metod delimitacji Źródło: oprac. własne 
Z informacji ukazanych na rysunku wynika, iż Poznański Obszar Metropolitalny (POM) wyznaczony przez Wielkopolskie Biuro Planowania Przestrzennego jest znacząco inny niż w przypadku pozostałych metod delimitacji. Należy podkreślić, że przedstawiona dla POM sytuacja stanowi ogólną tendencję, obserwowaną z różnym natężeniem we wszystkich obszarach metropolitalnych.

W zależności od przyjętej metody granice obszarów metropolitalnych, a co za tym idzie, liczba ludności i władz samorządowych, które wchodzą w ich skład są różne (por. tab. 5). W większości przypadków największe są obszary wyznaczone metodą zastosowaną przez Unię Metropolii Polskich, która za podstawową jednostkę delimitacji przyjmuje subregiony (NUT-3). Z punktu widzenia wdrażania koncepcji metropolitan governance nie wielkość obszaru jest istotna, lecz powiązania funkcjonalne między tworzącymi go jednostkami. Takie powiązania najlepiej można zidentyfikować na poziomie gmin. Na gminach opiera się zarówno metody zastosowane przez Eurostat i Śleszyńskiego, jak i metody delimitacji stosowane przez regionalne instytucje dokonujące delimitacji poszczególnych obszarów metropolitalnych.

Tabela 5

Liczba ludności i gmin obszarów metropolitalnych wyznaczanych według różnych delimitacji (w tys.)

\begin{tabular}{|c|c|c|c|c|c|c|c|c|c|c|}
\hline \multirow[t]{2}{*}{$\begin{array}{l}\text { Obszar } \\
\text { metropoli- } \\
\text { talny }\end{array}$} & \multicolumn{2}{|c|}{$\begin{array}{l}\text { ESPON } \\
2001\end{array}$} & \multicolumn{2}{|c|}{$\begin{array}{c}\text { Eurostat/OECD } \\
\text { (2011 r.) }\end{array}$} & \multicolumn{2}{|c|}{$\begin{array}{c}\text { UMP } \\
\text { (2011 r.) }\end{array}$} & \multicolumn{2}{|c|}{$\begin{array}{l}\text { Według } \\
\text { Śleszyńskiego } \\
\text { (2011 r.) }\end{array}$} & \multicolumn{2}{|c|}{$\begin{array}{l}\text { Według } \\
\text { Biura } \\
\text { planowania } \\
\text { (2011 r.) }\end{array}$} \\
\hline & \begin{tabular}{|c|} 
Liczba \\
ludności
\end{tabular} & $\begin{array}{c}\text { Liczba } \\
\text { gmin }\end{array}$ & \begin{tabular}{|c|} 
Liczba \\
ludności
\end{tabular} & $\begin{array}{l}\text { Liczba } \\
\text { gmin }\end{array}$ & $\begin{array}{c}\text { Liczba } \\
\text { ludności }\end{array}$ & $\begin{array}{c}\text { Liczba } \\
\text { gmin }\end{array}$ & $\begin{array}{c}\text { Liczba } \\
\text { ludności }\end{array}$ & $\begin{array}{l}\text { Liczba } \\
\text { gmin }\end{array}$ & $\begin{array}{c}\text { Liczba } \\
\text { ludności }\end{array}$ & $\begin{array}{l}\text { Liczba } \\
\text { gmin }\end{array}$ \\
\hline Warszawa & 2785 & & 3028 & 90 & 3272 & 107 & 2787 & 50 & 3098 & 81 \\
\hline Kraków & 1236 & & 1399 & 44 & 2097 & 93 & 1175 & 23 & 1428 & 50 \\
\hline Łódź & 1165 & & 1031 & 21 & 1109 & 28 & 1040 & 19 & 1197 & 32 \\
\hline Wrocław & 861 & & 850 & 19 & 1197 & 44 & 884 & 15 & 1197 & 44 \\
\hline Trójmiasto & 993 & & 1125 & 24 & 1289 & 41 & 1070 & 18 & 1476 & 47 \\
\hline Poznań & 919 & & 959 & 26 & 1156 & 38 & 912 & 21 & 1390 & 45 \\
\hline Górnośląski & 3029 & & 2560 & 60 & 2795 & 73 & 2473 & 46 & 2795 & 73 \\
\hline $\begin{array}{l}\text { Bydgoszcz } \\
\text {-Toruń }\end{array}$ & 721 & & 820 & 24 & 774 & 19 & 785 & 19 & 774 & 19 \\
\hline Szczecin & 610 & & 482 & 7 & 697 & 26 & 558 & 9 & 628 & 10 \\
\hline Lublin & 451 & & 674 & 33 & 717 & 42 & 539 & 15 & 718 & 41 \\
\hline Rzeszów & 314 & & 505 & 27 & 622 & 38 & 351 & 13 & 333 & 11 \\
\hline Białystok & 403 & & 424 & 13 & 510 & 26 & 387 & 9 & 552 & 33 \\
\hline
\end{tabular}

Źródło: oprac. własne.

Delimitacja oparta na gminach pozwala na uzyskanie mniejszego, bardziej spójnego pod względem powiązań funkcjonalnych, obszaru. Natomiast metody bazujące na subregionach i powiatach prowadzą do zaliczenia do 
obszarów metropolitalnych także takich gmin, które często nie są w żaden sposób funkcjonalnie związane z miastem centralnym. Taka sytuacja powoduje ograniczenia współpracy, a co za tym idzie wdrażania zasad metropolitan governance ze względu na niechęć lokalnych samorządów i obawy przed utratą części swoich kompetencji.

Z powyższych rozważań wynika podstawowy postulat wysuwany pod adresem metod delimitacji obszarów metropolitalnych: delimitacja powinna być przeprowadzana w oparciu o gminy.

Z punktu widzenia stosowanych kryteriów delimitacji trudno wskazać jeden uniwersalny ich zestaw, który mógłby z powodzeniem znaleźć zastosowanie w delimitacji obszarów metropolitalnych w Polsce i w Europie. Wydaje się, że różnorodność lokalnych uwarunkowań jest na tyle wielka, że uzasadnia nie tylko indywidualne krajowe podejścia do delimitacji, ale nawet dowolność wyboru kryteriów delimitacji przez poszczególne metropolie. Jednak takie rozwiązanie rodzić może problemy z prowadzeniem badań porównawczych $\mathrm{w}$ poszczególnych obszarach metropolitalnych krajów i świata.

Podejście funkcjonalne do delimitacji najpełniej odzwierciedla dynamikę powiązań między poszczególnymi jednostkami w regionie i najlepiej pozwala wyodrębnić poszczególne regiony wraz z ich metropoliami oraz na bieżąco mierzyć siłę i zasięg metropolitalnego oddziaływania poszczególnych ośrodków centralnych [Purchla, Sepioł 1998, s. 16]. Analizie powinno się poddać związki funkcjonalne ośrodka metropolitalnego z otoczeniem, wspólnie pełnione funkcje, powiązania gospodarcze i społeczne poszczególnych jednostek wchodzących w skład zespołu metropolitalnego, a także zakres, rodzaj i zasięg funkcji egzogenicznych.

Należy jednak pamiętać, że w obecnej sytuacji nie powinno się mówić o stanie polskich metropolii, lecz skupić się na analizie procesów metropolizacji. Dlatego też kwestia ostatecznych delimitacji poszczególnych obszarów jest wtórna, zwłaszcza, że powiązania funkcjonalne, które występują między poszczególnymi jednostkami administracyjnymi, ulegają zmianie, a co za tym idzie zmianom będą podlegać też zasięgi obszarów metropolitalnych. Z punktu widzenia zarządzania układami funkcjonalnymi kluczowe jest nie sztywne określenie granic przestrzennych, lecz elastyczna współpraca poszczególnych jednostek w zakresie problemów o zasięgu metropolitalnym.

\section{Problemy obszarów metropolitalnych}

Chociaż metropolie stanowią siłę napędową wzrostu, to właśnie w nich odnotowuje się największą koncentrację problemów, a w wielu przypadkach wysoką stopę bezrobocia. Proces globalizacji doprowadził do utraty 
licznych miejsc pracy, szczególnie w sektorze produkcyjnym. Likwidację miejsc pracy $\mathrm{w}$ przemyśle wytwórczym trudno zrekompensować tworzeniem nowych miejsc pracy, wymagających wysokich kwalifikacji i odznaczających się wysokim poziomem konkurencyjności. Przejście do korzystania z bardziej wykwalifikowanej siły roboczej nie jest łatwe, ponieważ bezrobotni o niskich kwalifikacjach, zwłaszcza osoby długotrwale bezrobotne, doświadczają szczególnych trudności przy podnoszeniu kwalifikacji i reintegracji na rynku pracy. Ponadto, obecny model wzrostu, zakładający oddzielenie wzrostu gospodarczego od zatrudnienia, doprowadził do zwiększenia części populacji wypychanej z rynku pracy lub zmuszonej do przyjmowania ofert niskopłatnej pracy w sektorze usług niewymagających kwalifikacji [European Commission 2011, s. 19]. Zjawisko to nasiliło się wskutek kryzysu gospodarczego. Redukcja publicznych finansów w wielu miastach doprowadziła do ograniczenia cyklicznych polityk, czego skutkiem jest dodatkowe pogorszenie sytuacji. Ograniczenie możliwości na rynku pracy wiąże się z ryzykiem wzrostu nietolerancji i polaryzacji między osobami zasilającymi fundusze socjalne i korzystającymi z nich.

Jednym z głównych problemów w obszarach metropolitalnych jest fragmentacja władzy. Kluczową rolę odgrywają tu partie polityczne i okresy wyborów samorządowych, co powoduje problemy w zarządzaniu całym obszarem. W celu uniknięcia otwartych konfliktów decyzje podejmowane są z dnia na dzień i towarzyszy im ciągły proces negocjacji z zainteresowanymi podmiotami. Autonomia władz lokalnych tworzy system rozdrobnionych kompetencji, w którym obszar metropolitalny jest podzielony na wiele mniejszych jurysdykcji bez żadnych władz, które troszczyłyby się o dobro całego regionu. Konsekwencje metropolitalnej fragmentacji są następujące:

- nierówności w ulokowaniu dochodów i zasobów w metropolii,

- ochrona przywilejów,

- wzrost władzy środowisk biznesowych,

- problem dostępności do mieszkań i bezdomności,

- brak racjonalnego planowania terenów i przekonania do wartości środowiskowych,

- problemy w dostarczaniu usług,

- nierówności społeczne w metropolii,

- efekt wymywania ${ }^{30}$.

Instytucjonalny podział między gminami, który zakłada wysoki stopień rozbieżności w funkcjach centralności między miastami centralnymi i innymi gminami tworzącymi obszar zurbanizowany, umożliwia owym mniejszym gminom uzewnętrznienie kosztów do ośrodków centralnych. To

${ }^{30}$ Efekt wymywania - odpływ z peryferii do rdzenia młodych i wykształconych ludzi, kapitału oraz innych zasobów., zob.: Myrdal 1957. 
doprowadziło do niezrekompensowanych obciążeń z tytułu centralności (centralisty-charges) dla miast rdzeniowych i znaczących korzyści dla „gapowiczów" - gmin podmiejskich. Do najbardziej kontrowersyjnych kwestii w zarządzaniu obszarami metropolitalnymi należą: wewnętrzna redystrybucja podatków, finansowanie wspólnych placówek (teatry, muzea) i świadczenie usług publicznych (gospodarka odpadami, zaopatrzenie w wodę) [Hall 1998, s. 56].

Większość europejskich ośrodków miejskich doświadcza zjawiska kurczenia się miast centralnych [Cieśla 2009] otoczonych rosnącym kręgiem bogatych przedmieść. Obserwuje się upadek centrów miast, które z czasem wymagają rewitalizacji. We wszystkich metropoliach rośnie zapotrzebowanie na przestrzeń, co powoduje wzrost kosztów ich funkcjonowania i zwiększa koszty życia w nich [Hausner 1998, s. 36].

W kontekście rozdrobnienia politycznego metropolizacja doprowadziła do nowych podziałów politycznych. Segregacja społeczna na obszarach miejskich wywołała istotne różnice pomiędzy strukturą populacji różnych gmin. Podczas gdy liczba gospodarstw domowych znajdujących się w niekorzystnej sytuacji ekonomicznej w miastach centralnych przekracza średnią, to otaczające je gminy odnotowują ponadprzeciętne proporcje zamożnych rodzin. Następstwem tego są olbrzymie różnice w strukturze preferencji. Elektorat i elity polityczne miast rdzeniowych w Stanach Zjednoczonych i Europie Zachodniej wykazują większą wrażliwość na kwestie społeczne polityki, jak również pewne upodobanie do interwencji państwa, sprzyjającej grupom o niskich dochodach. Spektrum partii, które zdobyły większość we władzach, potwierdza te preferencje: w miastach rdzeniowych zazwyczaj dominuje lewica, podczas gdy w gminach podmiejskich zwykle rządzi partia prawicowa [Le Gales 2002; Preteceille 2000]. Zatem obszary zurbanizowane charakteryzuje dodatkowo polityczne rozszczepienie, które pogłębia konflikty na polu polityki między miastem centralnym i otaczającymi je gminami ${ }^{31}$.

Konsekwencją globalizacji jest wzrost nierówności społecznych oraz zwiększenie się kontrastów społecznych. Jak zauważa Castells (1996) metropolie działają jak silne magnesy przyciągające ludność kraju i regionu. Społeczność miejską tworzą zarówno ci, którzy odnieśli sukces, jak i osoby,

${ }^{31}$ W Polsce takie badania prowadził P. Swianiewicz [2003; 2005], ale nie udało mu się wychwycić jakiejś prawidłowości. Podziały polityczne nie są jasno określone, nie ma czytelnej granicy między partiami prawicowymi i lewicowymi. Wiele partii przypisuje sobie, w zależności od okoliczności, w jakich działają, rożne cechy. Rola partii politycznych w wyborach lokalnych w mniejszych gminach jest na ogół niemal niezauważalna. $\mathrm{W}$ większości gmin podmiejskich trudno byłoby określić polityczne pochodzenie burmistrza czy większości radnych. 
którym się nie powiodło [Jałowiecki 2000]. Kapitał finansowy wielu mieszkańców metropolii, a także ich kapitał kulturowy oraz specyficzny charakter pracy w zawodach charakterystycznych dla społeczeństwa informacyjnego powoduje, że zaczynają oni tworzyć nową grupę społeczną zwaną klasą metropolitalną. Sektor usług wyższego rzędu, charakterystyczny dla metropolii, przynosi znacznie większe zyski niż inne działy gospodarki. Efektem tego jest zjawisko „nadwaloryzacji” pracy wykonywanej w „segmencie wysokim” gospodarki, przy jednoczesnej „dewaloryzacji” pracy w dziedzinach, które stanowią jego zaplecze [Maik 2005, s. 3]. To z kolei prowadzi do gentryfikacji dzielnic.

Skostniałość struktur instytucjonalnych tworzy trwałe nierówności między społecznościami o wysokich i niskich dochodach, z nikłą nadzieją na zmianę tej sytuacji, tworząc pętle sprzężeń zwrotnych między usługami i efektami zewnętrznymi. Wiele niezależnych badań, przeprowadzonych głównie w Stanach Zjednoczonych, wskazuje na zależność między fragmentacją jednostek terytorialnych a segregacją ze względu na rasę i klasę [zob.: Miller 2002; Rusk 1993; Weiher 1991], co nie wyklucza segregacji wewnątrz poszczególnych gmin.

Segregacji dochodowej i społecznej towarzyszy segregacja przestrzenna. Oznacza ona, że pewne jednostki terytorialne czerpią korzyści z trendów spowodowanych globalizacją oraz z konkurencji regionalnej, podczas gdy inne muszą zmagać się z negatywnymi skutkami specjalizacji i zróżnicowania przestrzennego [Hall 1998, s. 55]. Członkowie klasy metropolitalnej osiągają ponadprzeciętne dochody, żyją w realnej przestrzeni miast nie tylko Europy, ale całego świata, jednocześnie funkcjonując w cyberprzestrzeni. Dla nich tworzone są luksusowe przestrzenie (hotele, centra biznesowe, hale wystawowe itd.) [Jałowiecki 2000b, s. 77-80]. Centralne dzielnice mieszkaniowe przyciągają kapitał inwestowany w nieruchomości, rozwój i usługi telekomunikacyjne. Na drugim biegunie metropolitalnego społeczeństwa plasują się, pozostawieni samymi sobie, mieszkańcy o niskich dochodach. Procesy segregacji przestrzennej, będące skutkiem polaryzacji społecznej, powodują, że osobom z grup o niskich dochodach lub grup marginalizowanych coraz trudniej jest znaleźć przyzwoite mieszkanie za przystępną cenę. W większości obszarów metropolitalnych istnieją skupiska ekstremalnego bogactwa i skrajnego ubóstwa oraz cały szereg gmin pomiędzy nimi. Granice gmin nie tylko wyodrębniają skupiska ludzi o podobnych dochodach, ale również ograniczają możliwość restrukturyzacji, chroniąc korzyści osób zamożnych i ograniczając szanse tych, którzy 
żyją w biedniejszych gminach ${ }^{32}$. Kryzys gospodarczy dodatkowo zintensyfikował skutki globalizacji i stopniowe wycofywanie się z funkcji państwa opiekuńczego w większości państw Europy. [Smętkowski, Jałowiecki, Gorzelak 2009, s. 19].

Polaryzacja widoczna jest również na rynku nieruchomości. Ceny gruntów i budynków w pewnych lokalizacjach wykazują tendencje do gwałtownego wzrostu. Dotyczy to niektórych dzielnic miast centralnych, uprzywilejowanych pod kątem społecznym i estetycznym, oraz wybranych przedmieść zamieszkiwanych przez klasę wyższą. Jednocześnie w innych częściach obszaru metropolitalnego, w których zanieczyszczenie środowiska i erozja społeczna „odstrasza” gospodarstwa domowe średniej i wyższej klasy od inwestowania i osiedlania się, obserwuje się stagnację cen nieruchomości. To z kolei pogłębia segregację społeczną w obszarach metropolitalnych, gdzie całe dzielnice miast stają się wydzielonymi enklawami społecznymi i etnicznymi [Hall 1998, s. 55]. Zjawisko polaryzacji nie jest związane wyłącznie z zamożnością i ubóstwem, ale również ze zróżnicowaniem kulturowym, społecznym i etnicznym. Globalizacja doprowadziła do przyspieszenia przepływów ludzi, towarów, kapitału, tożsamości i wizerunków oraz do zwiększenia mobilności ideologii, zasad gospodarczych, strategii politycznych i stylów życia. Powszechne użycie takich wirtualnych serwisów społecznościowych jak Facebook nadało nowe znaczenie pojęciom przestrzeni i miejsca. Społeczeństwo nowoczesne, oparte na klasach, zmieniło się w niejednolite, postnowoczesne społeczeństwo miejskie, w którym wiele grup żyje obok siebie, czasem nie wchodząc ze sobą w żadne interakcje. Dostępność usług, w tym komunikacji publicznej i dóbr kultury, pozostaje również często na niższym poziomie w mniej atrakcyjnych częściach miast, co dodatkowo zwiększa wykluczenie i izolację osób najuboższych. Do wzrostu tych trudności przyczynia się rosnący poziom imigracji w połączeniu ze zjawiskiem utraty pracy, których wynikiem są problemy związane z integracją i coraz częstszym pojawianiem się postaw rasistowskich i ksenofobicznych [European Commission 2011, s. 4]. Jedną z przyczyn powstawania „osiedli za bramą" (gated communities) jest wzrost poczucia zagrożenia, szczególnie wśród zamożniejszych warstw społecznych. Percepcję potencjalnego ryzyka powoduje obecność w metropolii nie tylko ludzi określanych jako „społeczny margines”, ale także mniejszości etnicznych i w ogóle ludzi „obcych”.

Rozdrobnione władze wykazują tendencje do podtrzymywania poczucia odpowiedzialności indywidualnych mieszkańców, osłabiając zarazem po-

${ }^{32}$ Szerokie badania odnośnie nierówności na terenach zurbanizowanych były prowadzone przez socjologów. Zob.: Aaronson 1998; Cutler, Glaeser 1997; Jencks, Mayer 1990; Massey, Gross, Shibuya 1994; Vartanian, Gleason 1999. 
czucie, że problemy takie, jak skoncentrowane ubóstwo powinny obchodzić również podmioty spoza miejsca, w którym się pojawia. Także w największych polskich miastach od ponad 20 lat narasta segregacja społeczna. W coraz większym stopniu (choć nie na taką skalę jak w wielu metropoliach światowych) można wyróżnić enklawy bogactwa i obszary zaniedbane, w których mieszka najbiedniejsza część społeczeństwa [Swianiewicz, Krukowska, Nowicka 2011, s. 9]. Te dwa światy mają ze sobą coraz mniejszy kontakt, co z czasem prowadzi do zjawiska wykluczenia społecznego. Wiele miast doświadcza znacznego spadku zdolności angażowania ludzi oraz spójności, a także nasilenia wykluczenia społecznego, segregacji i polaryzacji. Zjawisko wykluczenia społecznego przejawia się w takich formach, jak warunki mieszkaniowe, rynek pracy, system edukacji, miejsce zamieszkania w przestrzeni miasta. Członkom biednej części społeczeństwa, którzy zamieszkują gorsze (pod względem bezpieczeństwa, warunków środowiskowych, wyposażenia w infrastrukturę, dostępności usług itp.) dzielnice, trudno przezwyciężyć swoje wykluczenie i podjąć działania zmierzające do pełniejszego uczestnictwa w życiu społecznym. Wynika to z ograniczonych kontaktów międzyludzkich, co powoduje, iż przepływ informacji związanych z pracą, działalnością polityczną i różnymi wydarzeniami jest utrudniony [Maik 2005, s. 32]. Wzrastająca liczba „wyrzutków społecznych" może prowadzić $\mathrm{w}$ wielu miastach do powstawania zamkniętych subkultur o fundamentalnie wrogim nastawieniu do głównego nurtu społeczeństwa, rządzących się różnymi ideologiami i kodami społecznymi, od religijnych po przestępcze [European Commission 2011]. Brak pracy i niskie dochody mają negatywny wpływ na rodzinę. Prowadzi to do rozwoju patologii, przestępczości, w tym także wśród nieletnich. Kwestie te są szczególnie złożone i powiązane w obszarach metropolitalnych, gdzie rozprzestrzenianie się miast i brak dostępu do tanich mieszkań bezpośrednio przyczyniają się do społecznego wykluczenia.

Wykluczenie dotyczy też drugiego bieguna społeczeństwa. Polega wówczas na tym, że jednostki zajmujące najwyższe pozycje w społeczeństwie rezygnują z uczestnictwa w podstawowych instytucjach społecznych. Zamykają się w swego rodzaju twierdzach - zamkniętych osiedlach - uciekając od obowiązków społecznych i finansowych [Maik 2005, s. 35].

Badania empiryczne potwierdzają związek między fragmentacją a rozlewającym się wzorcem rozwoju (urban sprawl). Termin urban sprawl oznacza nie tylko rozszerzanie się obszarów zurbanizowanych, ale również sposób tego rozszerzania, pozbawiony logiki i widocznego planu, a więc proces żywiołowy [Lisowski 2005, s. 96]. Jest on szczególną formą przejmowania gruntów, wynikającą z rozrastania się osiedli o niskiej gęstości zaludnienia. Obecnie obserwujemy natężenie tego procesu spowodowane rozwojem międzynarodowej kultury konsumpcji i pojawieniem się oraz 
rozszerzaniem podmiejskiego stylu życia preferowanym przez klasę średnią i wyższą w obszarach zurbanizowanych krajów rozwiniętych i rozwijających się. Sprzyja temu rozwój prywatnego rynku nieruchomości oraz dostępność kredytów hipotecznych [Solecki, Leichenko 2006].

Rozprzestrzenianie się miast związane jest również z działalnością ekonomiczną, która obecnie jest bardziej związana z koncentracją kapitału i zdolności ludzi niż z naturalnymi surowcami, a co za tym idzie wzrost nie musi koncentrować się w ośrodku centralnym. Zamiast tego stał się multimodalny z ośrodkami ekonomicznej aktywności wyrastającymi w całym obszarze metropolitalnym. W rezultacie granice między obszarami miejskimi, podmiejskimi i rolniczymi zaczęły zanikać i całe regiony metropolitalne stają się bardziej jednolite pod względem gospodarczym.

Intensywny rozwój w zewnętrznych obszarach przynosi wiele związanych z tym kosztów, które często są ponoszone przez inne społeczności w tym samym obszarze metropolitalnym [Downs 1994; Nelson, Duncan 1995; Rusk 1993; Squires 2002; Transportation Research Board 1998]. Niekontrolowany rozwój wpływa na atrakcyjność miast, efektywne użytkowanie ich zasobów, infrastrukturę drogową oraz rozmieszczenie usług publicznych i prywatnych. Co więcej, bardzo trudno jest nad nim panować, ponieważ tereny zajmowane w wyniku tego rozwoju leżą często poza obszarami administracyjnymi miast. Siły, które kierują rozlewaniem się obszarów metropolitalnych, stanowią naturalne odzwierciedlenie popytu ze strony gospodarki, natomiast nowe problemy może generować reakcja władz lokalnych na zachodzące zjawiska. W związku z tym, że rozwój przeniósł się z terenów centralnych, poszczególne miasta przyjmują polityki, które chronią ich interesy, ale tworzą patchwork przepisów, które w efekcie zagrażają perspektywom rozwoju całego regionu. Niedoskonałość regulacji w sferze planowania lub też niewystarczające ich egzekwowanie jest powszechnym zjawiskiem w wielu państwach Europy pozostawiając miejsce dla wpływania na rozwój przez interesy prywatne, związane z zasadą krótkoterminowego zysku, w której dobra publiczne nie stanowią wartości [European Commission 2011, s. 27]. Zjawisko prywatyzacji w państwach Europy Środkowej i Wschodniej doprowadziło do sytuacji, w której prywatni deweloperzy osiedli prowadzą szeroko zakrojone prace budowlane na obszarach podmiejskich, charakteryzujących się małymi ograniczeniami w zakresie jakości architektury, użytkowania gruntów bądź brakiem planów zagospodarowania przestrzennego. Powyższe czynniki mogą wyjaśniać, dlaczego zjawisko niekontrolowanego rozwoju występuje zarówno wokół miast rozrastających się, jak i kurczących się [Bauer et al. 2011]. Może je również spowodować nieskoordynowane, komercyjne dzielenie terenów podmiejskich na strefy, co wynika z fragmentaryczności administracji lokalnej i systemów planowania oraz pragnienia maksymalizacji 
zysków przez poszczególne gminy [Tosics 2011]. Początkowo miasta często dążą do osiągnięcia rozwoju praktycznie za wszelką cenę, wykorzystując jako narzędzia ulgi podatkowe i upusty cenowe na zakup gruntów. Niewiele uwagi poświęcają przy tym rosnącym przeciążeniom i zanieczyszczeniom, mogącym rozszerzać się na sąsiednie społeczności, które mogą nie posiadać infrastruktury, będącej w stanie przejąć te nowe obciążenia. Ponieważ korzyści związane z podatkiem od nieruchomości przedsięwzięć komercyjnych są ograniczone do miast, w których przedsięwzięcia te się pojawiają, przyległe jednostki terytorialne często zmuszone są do przyjęcia efektów owych przedsięwzięć bez większych korzyści budżetowych. Gdy zaś mieszkańcy uznają, że kolejne przedsięwzięcia gospodarcze nie są pożądane, miasta mogą przejść do następnego etapu tego procesu, a mianowicie wprowadzenia polityk zarządzania rozwojem, aby wymusić rozwój gdzie indziej lub regulować dokładnie rodzaj działalności, która może pojawić się na ich terenie. Tymczasem większość badań nad wpływem zmian w formach użytkowania terenu na finanse lokalne wykazuje, że rozwój mieszkalnictwa przynosi budżetowi gminy wzrost obciążeń, wynikający ze zwiększenia kosztów usług świadczonych nowym mieszkańcom [Sagan 2000, s. 81].

Obszary metropolitalne o większym stopniu fragmentacji „cierpią" z powodu dużo bardziej intensywnego rozlewania się zabudowy miejskiej, nawet wtedy gdy kontrolują szereg innych czynników [Carruthers 2003; Carruthers, Ulfarsson 2002; Fulton et al. 2001; Rusk 1993]. Niekontrolowany rozwój miast powoduje zwiększenie ruchu na istniejących drogach, które często nie mają wystarczającej przepustowości, aby poradzić sobie ze zwiększonym zapotrzebowaniem. To prowadzi do kongestii transportowej. Zwiększone zatory zwiększają czas, jaki trzeba poświęcić na dojazd oraz poziom zanieczyszczenia środowiska. Wykorzystanie samochodów prywatnych zwiększa się w miejscach, do których - z powodu niekontrolowanego rozwoju miast - doprowadzanie komunikacji publicznej jest zbyt trudne i kosztowne ze względu na małą gęstość zaludnienia. Rozwój infrastruktury drogowej jest wówczas jedynym sposobem skrócenia czasu podróży i poprawienia dostępności, co z kolei przyczynia się do dalszego niekontrolowanego rozwoju miast i w efekcie powoduje powstanie błędnego koła.

Rozwój peryferii obszaru metropolitalnego powoduje międzygminne subsydiowanie infrastruktury (efekt zewnętrzny). Rozwój zabudowy mieszkaniowej pociąga za sobą zapotrzebowanie na nową infrastrukturę (drogi, wodociągi, kanalizacja, szkoły itp.). Koszt nowej infrastruktury (w przypadku istnienia np. międzygminnych związków, porozumień czy innych podmiotów świadczących tego typu usługi) często jest ponoszony przez użytkowników z innych gmin, tym samym powodując krossubsydiowanie rozwoju nowych terenów [Carruthers, Ulfarsson 2002; Nelson, Duncan 1995]. Jedną z najbardziej kontrowersyjnych kwestii w zarządzaniu 
rozwojem obszarów metropolitalnych jest wewnętrzna redystrybucja podatków oraz finansowanie wspólnych obiektów (np. teatry, muzea) i usług publicznych (np. gospodarka odpadami, zaopatrzenie w wodę) [Kunzmann 1989, s. 56].

Rozlewanie się miast i rozprzestrzenianie się osiedli o niskiej gęstości zaludnienia stanowi jedno z głównych zagrożeń zrównoważonego rozwoju terytorialnego [zob.: Cieslewicz 2002; Ewing, Pendall, Chen 2002].

Problemy rozwojowe wielkich miast i otaczających je obszarów również w Polsce stają się coraz bardziej widoczne. Zachodzące na tych obszarach zjawiska prowadzą do kształtowania się specyficznych społeczności, nowej sieci infrastrukturalnej związanej z obsługą mieszkańców oraz nie zawsze w pełni kontrolowanych zmian formalnie obowiązującego modelu gospodarki przestrzennej [Lutrzykowski 2010, s. 6]. Pojawia się zatem potrzeba stworzenia nowych rozwiązań prawnych i organizacyjnych dla zarządzania rozwojem tych specyficznych struktur terytorialnych. W celu efektywnego rozwiązania problemów wywołanych przez metropolizację miasta centralne, otaczające je gminy i władze regionu muszą ze sobą współpracować [Kübler et al. 2003].

Zdolność do rozwiązania problemów będzie zależała głównie od instytucjonalnej zdolności do zmobilizowania publicznych, prywatnych i społecznych zasobów w długookresowej perspektywie. Dlatego też sukces we wdrożeniu polityk i strategii jest ściśle uzależniony od sposobu zarządzania. Good governance powinien być celem lokalnych władz ze względu na fakt, iż takie współdziałanie może stłumić wstrząs spowodowany globalizacją i otwarciem się rynków oraz rozwiązać poważne problemy, takie jak bieda i nierówności, jednocześnie czyniąc miasta bardziej atrakcyjnymi dla inwestycji.

\section{Polskie metropolie na tle metropolii światowych}

W literaturze często opisywana konkretna metropolia jest już sklasyfikowana według jakiegoś kryterium. Klasyfikacja tych ośrodków jest zasadna, ponieważ cała organizacja systemu osadniczego ma charakter hierarchiczny, od miast globalnych po ośrodki lokalne [Chakravorty 2003]. Ponadto różnią się one między sobą cechami ilościowymi i jakościowymi (stopniem wykształcenia układu osadniczego, charakterem, rangą oraz zasięgiem oddziaływania funkcji metropolitalnych). Najczęściej spotykaną w literaturze klasyfikacją jest podział ośrodków ze względu na znaczenie odgrywanej roli oraz siłę oddziaływania przestrzennego. W ramach różnych podziałów wyróżnia się metropolie:

- globalne (światowe),

- kontynentalne,

- międzynarodowe, 
- krajowe (regionalne) [Markowski, Marszał 2006a, s. 19]. Jałowiecki dodaje zaś jeszcze metropolie europejskie (tab. 6).

Tabela 6

Klasyfikacja metropolii europejskich

\begin{tabular}{|c|c|c|c|c|c|}
\hline \multirow{2}{*}{ Pozycja hierarchiczna } & \multicolumn{5}{|c|}{ Cechy strukturalne } \\
\hline & A & B & $\mathrm{C}$ & $\mathrm{D}$ & $\mathrm{E}$ \\
\hline Metropolie światowe & \begin{tabular}{|l|} 
Londyn \\
Paryż
\end{tabular} & & & & \\
\hline $\begin{array}{c}\text { Metropolie } \\
\text { europejskie }\end{array}$ & & \begin{tabular}{|l|} 
Bruksela \\
Genewa \\
Frankfurt \\
Amsterdam \\
Mediolan \\
Hamburg \\
Dusseldorf \\
Monachium \\
Strasburg \\
Zurich \\
Wiedeń \\
\end{tabular} & & & \\
\hline $\begin{array}{l}\text { Metropolie } \\
\text { międzynarodowe }\end{array}$ & & \begin{tabular}{|l|} 
Bazylea \\
Hanower \\
Kolonia-Bonn \\
Luksemburg \\
Lyon \\
Rotterdam \\
Stuttgart \\
Antwerpia
\end{tabular} & \begin{tabular}{|l|} 
Berlin \\
Madryt \\
Barcelona \\
Kopenhaga \\
Haga \\
Rzym \\
Bolonia \\
Florencja \\
Neapol \\
Sztokholm \\
\end{tabular} & & \\
\hline $\begin{array}{l}\text { Metropolie } \\
\text { regionalne } \\
\text { o przewadze } \\
\text { funkcji krajowych }\end{array}$ & & & $\begin{array}{l}\text { Edynburg } \\
\text { Marsylia }\end{array}$ & \begin{tabular}{|l} 
Ateny \\
Helsinki \\
Lizbona \\
Praga \\
Budapeszt \\
Genua \\
Glasgow \\
Lille \\
Turyn \\
Wenecja
\end{tabular} & \begin{tabular}{|l} 
Warszawa \\
Belfast \\
Oslo \\
Montpelier \\
Nancy-Metz \\
Grenoble \\
Tuluza \\
Bristol \\
Manchester \\
Salzburg \\
Nicea \\
Saloniki \\
Walencja \\
Sewilla \\
\end{tabular} \\
\hline
\end{tabular}

A - bardzo silna koncentracja decyzji i funkcji międzynarodowych o zasięgu światowym

B - Zróżnicowana struktura działalności. Silna koncentracja przedsiębiorstw i instytucji międzynarodowych o zasięgu europejskim. Bardzo dobra dostępność.

C - lekko zaznaczona specjalizacja. Funkcje międzynarodowe wyspecjalizowane lub niekompletne

D - średnio rozwinięte usługi metropolitalne i funkcje międzynarodowe. Średnia dostępność.

E - słabo rozwinięte usługi metropolitalne i funkcje międzynarodowe. Mierna dostępność.

Źródło: [Jałowiecki 1999]. 
Biorąc pod uwagę przytoczone wcześniej definicje metropolii oraz obszaru metropolitalnego, jednostki te powinny odznaczać się obecnością najwyższej rangi funkcji oraz usług, instytucji i wyposażenia, wysokim potencjałem innowacyjnym $\mathrm{z}$ rozbudowanym zapleczem naukowobadawczym oraz wyjątkowością i specyfiką miejsca, a jednocześnie być zamieszkiwane przez co najmniej pół miliona mieszkańców. W określaniu hierarchii metropolii globalnych najważniejszym czynnikiem branym pod uwagę jest liczba głównych siedzib korporacji transnarodowych [Kukliński 2000, s. 14].

Polskie miasta w większości przypadków mają słabo rozwinięte funkcje metropolitalne. Badania porównawcze miast Europy prowadzone między innymi przez ESPON pokazują, że tylko Warszawa, zakwalifikowana w opracowaniach ESPON jako potencjalna metropolia europejska - MEGA 2 (rys. 1), może być uznana za metropolię [Izdebski 2010a], natomiast inne miasta mają rozwinięte tylko niektóre funkcje [MRR 2012a, s. 190]. Głównie w Warszawie oraz częściowo na Śląsku i w Poznaniu obecne są znaczące funkcje decyzyjne. W przypadku funkcji kontrolnych zarządzania gospodarczego można wyróżnić dwa poziomy hierarchiczne: Warszawa i „reszta” kraju [MRR 2012a, s. 24]. Zmienia się też postrzeganie Warszawy na arenie międzynarodowej. Z raportu European Cities Monitor, międzynarodowej firmy doradczej Cushman \& Wakefield, analizującego miasta najbardziej atrakcyjne dla przedsiębiorców w Europie, wynika iż z roku na rok rośnie pozycja Warszawy w tym zakresie. W roku 2010 zajęła 21. pozycję pod względem dogodności lokalizacji biznesu, wyprzedzając tym samym inne ważne metropolie Europy Środkowowschodniej, takie jak Praga (25. miejsce) oraz Budapeszt (29. miejsce). O wysokiej atrakcyjności Warszawy decydują niskie koszty prowadzenia działalności, tj. ceny powierzchni biurowych (pierwsze miejsce) i koszty pracy (drugie miejsce). Działalność utrudnia jednak niska dostępność i jakość infrastruktury oraz jakość życia [Cushman \& Wakefield 2011].

Do głównych czynników decydujących o atrakcyjności miast należą:

- łatwy dostęp do rynków i klientów,

- wykwalifikowany personel,

- jakość połączeń telekomunikacyjnych,

- połączenia transportowe z innymi miastami i międzynarodowe,

- koszt i jakość powierzchni biurowych,

- koszt siły roboczej,

- dostępność powierzchni biurowych [Cushman \& Wakefield 2011, s. 7].

W badaniach prowadzonych przez Taylora Warszawa była na 31. miejscu. Kolejne miasto polskie - Kraków - na miejscu 239., pomiędzy Abidżanem, stolicą Wybrzeża Kości Słoniowej a Gorgetown, stolicą Gujany. Wśród 
35 miast europejskich Warszawa zajmuje pozycję 16., za Wiedniem, a przed Lizboną [Taylor 2002].

Opierając się na doświadczeniach grupy badaczy skupionych wokół GAWC badania metropolitalności polskich miast w roku 2008 przeprowadził Instytut Konkurencyjnej Ekonomii Regionów (IKER) (tab. 7).

Tabela 7

Ranking metropolitalności polskich miast

\begin{tabular}{|l|c|}
\hline \multicolumn{1}{|c|}{ Pozycja w rankingu } & $\begin{array}{c}\text { Stopień usieciowienia } \\
\text { (w stosunku do Warszawy) w \% }\end{array}$ \\
\hline Warszawa & 100,000 \\
\hline Kraków & 21,233 \\
\hline Poznań & 17,054 \\
\hline Wrocław & 15,400 \\
\hline Silesia & 13,161 \\
\hline Trójmiasto & 12,603 \\
\hline Łódź & 8,521 \\
\hline Szczecin & 5,926 \\
\hline Rzeszów & 4,638 \\
\hline Olsztyn & 3,988 \\
\hline Lublin & 3,985 \\
\hline Toruń & 3,838 \\
\hline Bydgoszcz & 3,743 \\
\hline Białystok & 3,454 \\
\hline Kielce & 3,397 \\
\hline Opole & 3,170 \\
\hline Zielona Góra & 2,815 \\
\hline Gorzów Wielkopolski & 2,058 \\
\hline
\end{tabular}

Źródło: [Bańczyk, Achrem, Mróz 2008].

W ich wyniku bezapelacyjnie na pierwszym miejscu znalazła się Warszawa. Kolejną, bardzo podobną pod względem usieciowienia grupę metropolii tworzą Kraków, Poznań, Wrocław, Aglomeracja Górnośląska i Trójmiasto, przy czym Kraków wyprzedza pozostałe pod względem jakości życia, dostępności dóbr i usług kultury, rozrywki, wypoczynku i rekreacji. $\mathrm{Na}$ kolejnych miejscach znalazły się Łódź i Szczecin. Liderem wśród metropolii określonych w KPZK jako „potencjalne” jest Rzeszów, który wyprzedził Lublin i Białystok. W międzynarodowych rankingach metropolii spośród metropolii polskich pojawia się z reguły tylko Warszawa. Warszawa jako jedyna jest wymieniona $\mathrm{w}$ rankingu WORLD CITIES i klasyfikowana $\mathrm{w}$ nim jako miasto pierwszorzędne (alpha city) w światowej hierarchii, na tym samym poziomie co np. Zurych, Wiedeń czy Bangkok [http://www. pocketinfo.net/2011/12/world-cities-2012.html].

Wszystko to nie oznacza, że innych miast Polski nie należy traktować jako metropolii. Wprawdzie nie można ich uznać za metropolie światowe, 
kontynentalne czy nawet regionalne, ale występują w nich liczne funkcje metropolitalne i z punktu widzenia krajowej hierarchii miast z pewnością są one ośrodkami metropolitalnymi. Ponieważ jednak powiedziano, iż za metropolie może być uznane miasto, które ma liczne powiązania międzynarodowe, to należy dążyć do wzmacniania metropolitalności tych ośrodków poprzez odpowiednie polityki państwa. Zespół ekspertów współpracujących z Ministerstwem Rozwoju Regionalnego (Markowski, Korcelli i in.) przy tworzeniu Koncepcji Przestrzennego Zagospodarowania Kraju próbował lansować ideę metropolii sieciowej, obejmującej główne ośrodki miejskie w Polsce. Ostatecznie jednak, ze względu na populistyczne naciski największych miast, zrezygnowano $\mathrm{z}$ tego pomysłu na rzecz traktowania wszystkich ośrodków wojewódzkich jednakowo i wprowadzono pojęcie miejskich obszarów funkcjonalnych [MRR 2012a]. 



\section{WSPÓŁCZESNE KONCEPCJE I KIERUNKI METROPOLITALNEGO ZARZĄDZANIA}

Zarządzanie obszarami metropolitalnymi rozumiane jest w ujęciu autorki w duchu metropolitan governace. Termin governance nie jest jednoznacznie przetłumaczony na język polski [Izdebski 2010b, s. 12]. Najczęściej spotykane $\mathrm{w}$ literaturze polskiej określenia to rządzenie, zarządzanie, współrządzenie, współzarządzanie, współdziałanie czy współwładanie. Autorka najczęściej posługuje się terminem metropolitalne zarządzanie, ale używa też innych sformułowań. W tej części pracy, ukazującej genezę koncepcji metropolitalnego zarządzania, wykorzystywana jest głównie terminologia angielska, gdyż sama idea governance wywodzi się z krajów anglosaskich. Różne konfiguracje użycia słowa governance: good governance, public governance, local/regional governance, metropolitan governance są traktowane wymiennie. Należy także $\mathrm{w}$ tym kontekście wymienić termin corporate governance, który można traktować jako inspirację dla rozwijania idei public governance. Każda z tych koncepcji prezentuje podobne podejście do kwestii zarządzania rozwojem i zakłada współpracę niezależnych podmiotów, cieszących się szeroką autonomią, które muszą podzielić się władzą, aby osiągnąć cele istotne dla całego obszaru metropolitalnego.

\section{Rola władz publicznych w świetle koncepcji zarządzania}

W ciągu ostatnich dziesięcioleci tradycyjne ujęcie sektora publicznego uległo zmianie. Coraz więcej wątpliwości budzi pogląd, że rządy narodowe są głównymi aktorami w polityce publicznej i że są w stanie skutecznie oddziaływać na gospodarkę i społeczeństwo. Wątpliwości te są przynajmniej częściowo rezultatem rosnącego znaczenia otoczenia międzynarodowego i malejącej zdolności państw do izolowania swoich gospodarek i społeczeństw od presji konkurencyjnej gospodarki światowej. Ta presja, wywierana na rządy w wyniku oddziaływania procesów globalizacji, pojawiła się m.in. za sprawą międzynarodowych rynków kapitałowych oraz ponadnarodowych organizacji takich, jak np. Unia Europejska ${ }^{33}$. Obserwacja wielu działań podejmowanych na poziomie wspólnoty i wcielanych w życie

33 Zob.: Strange 1996; Hirst, Thompson 1996; Peters 1998; Scharpf 1997. 
przez formalne organizacje polityków i władz pokazuje, iż organizacje te zostały uwikłane w pułapkę autonomicznej egzystencji, odseparowanej od rzeczywistego świata gospodarczego i społecznego. Skutkiem takiej sytuacji jest upośledzenie powiązań pomiędzy działaniami podmiotów władzy i podmiotów życia społeczno-gospodarczego.

Zatem w kontekście europejskim zarówno sfera gospodarcza, jak i społeczna podejmują intensywne działania, które mają na celu zreformowanie powiązań między politykami i administracją publiczną a życiem gospodarczym i społecznym. Konsekwencją tych działań ma być odejście od sformalizowanych sposobów sprawowania władzy i podążanie w kierunku partnerskiego współrządzenia. Należy jednak stwierdzić, że dążenia te, zgodne w swojej intencji, wyrażane są w różny, nierzadko konfliktogenny sposób. Biznesowi zależy bowiem na bardziej wydajnej infrastrukturze, odpowiednim otoczeniu biznesowym czy też klimacie sprzyjającym przedsiębiorczości. Natomiast sektorowi społecznemu zależy na działaniach mających doprowadzić do większej sprawiedliwości społecznej, wzrostu świadomości zróżnicowania podstawowych potrzeb i tożsamości kulturowych, a także silniejszej świadomości na temat zarządzania zasobami środowiska i długoterminowych ograniczeń środowiskowych [Coaffee, Healer 2003, s. 1979-1980]. Przy podejmowaniu próby zmiany charakteru powiązań między formalnym światem polityków a sferą społeczną i gospodarczą trzeba więc liczyć się z tym, że nastąpią spory o to, czyje praktyki mają dominować w reformowaniu form współrządzenia i o to, czyje strategie i interesy będą promowane przez utworzone systemy governance.

Adresatami zmian podejścia do rządzenia są nie tylko władze szczebla centralnego (rządy narodowe), ale także podmioty władzy publicznej innych szczebli. Z punktu widzenia niniejszej pracy szczególnego znaczenia nabierają zmiany zachodzące $\mathrm{w}$ procesach zarządzania miastami. W ostatnich latach doprowadziły one do sytuacji, w której władze miast nie są dłużej w stanie, a przynajmniej nie w tym stopniu, w jakim robiły to wcześniej, kierować wydarzeniami. Najbardziej doniosłe spośród nich to przesunięcie w kierunku globalizacji gospodarki włączające ruch kapitału inwestycyjnego, pojawienie się sektorów gospodarczych o zasięgu ogólnoświatowym, instytucji międzynarodowych i utworzenie globalnej areny wymiany informacji. Dla władz miejskich oznaczało to utratę kontroli nad gospodarkami miast i konieczność podjęcia nowych działań oraz nowe zakresy odpowiedzialności. W zmienionych warunkach polityczno-ekonomicznych rozwinęła się koncepcja współrządzenia miastem. Można wyróżnić kilka wyraźnych przesłanek charakterystycznych dla tej koncepcji:

1. Bardziej zawzięta jest konkurencja wewnątrz miast, które usilnie starały się "sprzedać" za pewną pulę inwestycji, co zostało określone jako „wojna o miejsce” [Haider 1992]. W coraz bardziej konkurencyjnym świecie 
samorządy miast - zarówno ich wybierani członkowie, jak i urzędnicy musiały stać się bardziej przedsiębiorcze.

2. W ramach tej rosnącej konkurencji, jednolitej kulturze globalnej jednocześnie towarzyszą próby stworzenia miejskich, lokalnych, unikalnych kultur w celu przyciągnięcia inwestycji biznesowych. Środowiska kulturowe same $\mathrm{w}$ sobie są $\mathrm{w}$ coraz większym stopniu modyfikowane w związku $\mathrm{z}$ próbami przyciągnięcia turystyki i inwestycji wewnętrznych [Kearns, Paddison 2000, s. 845].

3. Miasta zaczęły postrzegać, iż rządy narodowe są w stanie mniej im pomóc i są mniej związane $\mathrm{z}$ ich losem. W związku z tym podjęły próbę odłączenia się od gospodarek krajowych i wzięły odpowiedzialność za rozwój w swoje ręce.

4. W świetle zachodzących zmian miasta same „zorientowały się” w kierunku areny międzynarodowej poprzez nawiązywanie współpracy transgranicznej i tworzenie transgranicznych sieci.

Koncepcja lokalnego współrządzenia, która włącza w ten proces obywateli, odnosi się do takich sposobów rozwiązywania problemów miast jak współpraca i partycypacja na bazie relacji między instytucjami administracji, przedsiębiorstwami i grupami obywateli. Charakterystyczne dla lokalnego współrządzenia jest odzwierciedlanie, ustalanie i integrowanie celów strategicznych i interesów lokalnych za pośrednictwem nieformalnych powiązań w instytucjach administracji, przedsiębiorstwach, grupach obywatelskich zamiast systematycznych i formalnych związków, koncentrujących się na działaniach władz lokalnych czy regionalnych [Park 2003, s. 5].

Szeroki udział różnych aktorów w podejmowaniu decyzji i większa partycypacja społeczna są mocno lansowanym hasłem współczesnego zarządzania miastem, ale są to zarazem działania często ograniczone w praktyce. Faktyczne uczestnictwo wymaga politycznego procesu, który włączyłby ludzi, zmobilizował ich zasoby (kapitał społeczny), wzmocnił ich zdolność do partycypacji, budował wzajemne zaufanie oraz gwarantował przejrzystości polityk miejskich [Kampen, Naerssen 2008, s. 943].

Samorząd terytorialny ma wyraźny charakter polityczny. Wynika to po pierwsze ze sposobu wyboru władzy, a po drugie z mechanizmu jej sprawowania. Radni wybierani są w wyborach bezpośrednich. Organy stanowiące oraz ich organy zarządzająco-wykonawcze są ciałami politycznymi, a ich członkowie politykami. Zarówno w trakcie wyborów, jak i trwania kadencji samorząd staje się areną walki politycznej. Jest on zazwyczaj zdominowany przez jedną opcję polityczną bądź też koalicję, która proces rządzenia jednostką terytorialną postrzega nie tyle przez pryzmat jej potrzeb, ile przez pryzmat interesów danego ugrupowania politycznego.

Pojawia się więc problem dzielenia się władzą miedzy jednostkami politycznymi (partiami), który jest szczególnie widoczny w obszarach metropo- 
litalnych, gdzie oprócz kilku partii występujących w jednej jednostce administracyjnej, mamy do czynienia z ich zwielokrotnieniem we wszystkich jednostkach wchodzących w skład danego obszaru. Proces ten powinien mieć na celu takie delegowanie uprawnień, w wyniku którego nastąpi optymalne zaspokojenie potrzeb społeczności zamieszkującej dane terytorium, a nie interesów poszczególnych ugrupowań. Aby takie zjawisko zachodziło konieczny jest wzrost świadomości polityków. Muszą oni zrozumieć, iż dzielenie się władzą z innymi ugrupowaniami politycznymi, ale również z organizacjami (instytucjami), które są lepiej przygotowane do realizacji pewnych zadań, może doprowadzić do rozwoju jednostki terytorialnej, a poprzez to do poprawy wizerunku ugrupowań politycznych, które sprawują władzę.

W spojrzeniu na zarządzanie obszarami metropolitalnymi można wyodrębnić dwa podejścia - monocentryczne (scentralizowane) i policentryczne. Pierwsze z nich opowiada się za utworzeniem pojedynczego rządu, w którego kompetencjach byłoby zarządzanie całym obszarem metropolitalnym. Drugie zaś jest podejściem policentrycznym i głosi, że najbardziej odpowiedni jest system metropolitan governance, który dopuszcza współistnienie wielu konkurujących władz niższego szczebla [Boettke, Coyne, Leeson 2011].

Zwolennicy pierwszego podejścia ${ }^{34}$ uważają różnorodność zazębiających się jurysdykcji dostarczających usługi i dobra publiczne do różnych części obszaru metropolitalnego za chaotyczną i generującą straty. Według nich zdecentralizowany system świadczeń prowadzi do duplikowania kompetencji, nie jest w stanie właściwie radzić sobie $\mathrm{z}$ efektami zewnętrznymi a także wyklucza czerpanie korzyści z efektów skali, które są osiągane w scentralizowanym systemie dostarczania dóbr publicznych. Twierdzą oni, że nieskonsolidowane obszary metropolitalne cierpią z powodu „zbyt wielu władz i braku zarządzania" [Boettke, Coyne, Leeson 2011].

Prekursorzy podejścia policentrycznego ${ }^{35}$, które rozwinęło się w Stanach Zjednoczonych na przełomie lat 50. i 60. wieku XX, po pierwsze podkreślali, że to co zdawało się być zbyt skomplikowanym, chaotycznym układem wielu zazębiających się jurysdykcji w obszarze metropolitalnym, w istocie ma sens i wprowadza porządek. Podczas gdy przedstawiciele podejścia scentralizowanego wykazywali tendencje do zakładania, iż mieszkańcy metropolii stają przed jednakowymi problemami dającymi się rozwiązać przez jeden rząd, zwolennicy policentryzmu przyjmowali, że mieszkańcy ci mają do czynienia z licznymi, zróżnicowanymi problemami wymagającymi wielu, odpowiednio dostosowanych działań władz. Według „policentry-

34 Zob.: Ostrom 1972.

35 Zob.: Ostrom 1983; Oates 1972; Stigler 1962. 
stów" chaos i nakładanie się jurysdykcji stanowią odzwierciedlenie tych zróżnicowań [Boettke, Coyne, Leeson 2011, s. 210].

Jedną z funkcji władz publicznych jest dostarczanie obywatelom dóbr publicznych, co często jest nieefektywne. Samuelson [1954] stwierdził, że powszechna natura dóbr publicznych uniemożliwia władzom różnicowanie ich ilości w zależności od możliwości lub skłonności konsumentów do zapłaty za ich wykorzystanie. To prowadzi do nieefektywnej alokacji dóbr publicznych, ponieważ wszystkim członkom społeczeństwa dostarczany jest taki sam zasób owych dóbr bez względu na ich zróżnicowane preferencje. Przedstawiciele policentryzmu argumentowali, że wielość jednostek terytorialnych w obszarach metropolitalnych umożliwia konkurencję między nimi, co przynosi dwa, ważne i ściśle ze sobą powiązane, rezultaty. Po pierwsze pozwala na zaoferowanie mieszkańcom różnych pakietów podatków i dóbr publicznych, które są lepiej dopasowane do ich szczególnych potrzeb. Po drugie, konkurencja miedzy jednostkami powoduje, iż lokalne władze publiczne podlegają presji konkurencyjnej i są zmuszone do takiego zaspokojenia potrzeb swoich obywateli, aby nie utracić mieszkańców i wpływów z podatków, które ci mieszkańcy płacą - na rzecz sąsiednich jednostek [Boettke, Coyne, Leeson 2011]. Z punktu widzenia zadowalającej teorii finansów publicznych pożądane byłoby zmuszenie wyborców do ujawnienia swoich preferencji, zaspokojenie ich potrzeb, tak jak się to dzieje na rynkach dóbr prywatnych i odpowiednie ich za to opodatkowanie [Tiebout 1956, s. 418].

Próbą rozwiązania tego problemu miał być model zaproponowany przez Charlesa Tiebouta, który zauważył, że obszary metropolitalne składają się z wielu lokalnych jednostek, z których każda dostarcza unikalny zestaw usług publicznych, zatem konsumenci mogą ujawniać (i ujawniają) swoje preferencje odnośnie do dóbr publicznych poprzez wybór gminy, w której mieszkają. Założył on, że wiele konkurujących ze sobą jednostek dostarcza lepiej dostosowane do preferencji obywateli usługi wyższej jakości za niższą cenę, aniżeli jedna instytucja obejmująca całe terytorium (np. obszar metropolitalny). Konkurencja między samorządami zapewnia efektywność produkcji lokalnych dóbr publicznych, podobnie jak konkurencja między przedsiębiorstwami zapewnia efektywność produkcji dóbr prywatnych. W ten sposób wytwarza się quasi-rynek będący odpowiednikiem rynku produktów i usług prywatnych i problem efektywnego dostarczania dóbr publicznych przez gminy jest przynajmniej częściowo rozwiązany. Gdyby władze publiczne wszędzie zachowywały się jednakowo, to nikt nie byłby zadowolony. Aby model ten mógł funkcjonować, muszą być spełnione dwa warunki: 
- mobilności obywateli, mogących z łatwością przenosić się z jednej jednostki terytorialnej do innej; sprawiłoby to, że lokalne dobra publiczne stałyby się odpowiednikiem produktów kupowanych na klasycznym rynku,

- doskonałej znajomości pakietów podatkowo-usługowych oferowanych przez różne samorządy; gdyby konsumenci poszukiwali preferowanych pakietów podatkowo-usługowych i kupowali je, siły konkurencyjne zmusiłyby producentów (organy samorządowe i państwowe) do reakcji na preferencje obywateli.

Model ten nazywany jest niekiedy modelem „niewidzialnej stopy”, ponieważ zakłada, iż ludzie „głosują nogami”, czyli gromadzą się tam, gdzie samorząd lokalny gwarantuje im taki pakiet usług i podatków, którego oczekują (czyli po prostu przenoszą się do innej gminy) [Tiebout 1956, s. 416-424].

Naukowcy wskazują na liczne mocne i słabe strony tego modelu. Po pierwsze wprowadzenie konkurencji zawsze sprzyja poprawie alokacji posiadanych zasobów, pod warunkiem, że żaden z konkurentów nie osiągnie dominującej (monopolistycznej) pozycji. W takim bowiem przypadku może się okazać, iż silniejszy samorząd, np. miasta metropolitalnego, może uzyskać tak dużą przewagę nad pozostałymi jednostkami, iż pomimo niezadowolenia z poziomu podatków lokalnych mieszkańcy nie będą mieli możliwości przeniesienia się do innych gmin ze względu na oddziaływanie czynników pozafiskalnych (liczba miejsc pracy, wysokość płac, jakość infrastruktury transportu, wielość i jakość dostępnych dóbr publicznych, itp.). Po drugie, jeżeli stopień decentralizacji finansów publicznych jest za mały i zbyt duża część dochodów samorządu pochodzi z budżetu centralnego, to wielkość wydatków nie wynika wprost z wysokości podatków. Po trzecie model ten zakłada, iż ludzie korzystają głównie z dóbr dostarczanych przez ich własne władze lokalne, a nie przez władze sąsiednich gmin, co nie jest prawdą w przypadku obszarów metropolitalnych. Mieszkańcy miejscowości podmiejskich $\mathrm{w}$ dużym stopniu korzystają z usług i infrastruktury dostarczanej przez miasto centralne.

Wskazane słabe strony modelu Tiebauta wynikają z niesprawności rynku. Niesprawność ta definiowana jest jako niezdolność rynków do osiągnięcia optymalnej alokacji zasobów [OECD 2005b, s. 178]. Do głównych przyczyn niesprawności rynku zalicza się:

- Występowanie monopoli naturalnych, które powodują, że konkurencja jest nieefektywna. Może być to spowodowane korzyściami skali, dzięki czemu większe przedsiębiorstwo ma przewagę nad mniejszym i zawsze będzie wytwarzać dobra i usługi taniej niż konkurenci. Przyczyną ograniczenia konkurencji może być też działanie państwa, które przyznaje innowacyjnym przedsiębiorstwom patenty lub udziela koncesji na szczególne typy działalności [Stiglitz 2004, s. 92-93]. Wyjątkową skłonność do tworze- 
nia monopoli naturalnych wykazuje sektor publiczny, wykorzystujący brak konkurencji i swoją dominującą pozycję. W monopolach naturalnych nie występują bodźce stymulujące wzrost wydajności i jakości świadczonych usług. Usługi te często nie są rzetelnie wykonane, charakteryzują się niską jakością i wysokimi kosztami operacyjnymi, co w rezultacie powoduje brak możliwości wygospodarowania wystarczających środków na finansowanie kolejnych inwestycji w tej sferze [Erhardt, Burdon 1999, s. 6].

- Występowanie efektów zewnętrznych w produkcji i/lub konsumpcji niektórych dóbr. Tiebout zakładał, że nie pojawiają się efekty zewnętrzne między gminami. Tymczasem decyzje danej społeczności samorządowej mają wpływ na inne społeczności. Pojawiają się efekty zewnętrzne, które powodują problemy z efektywnością i równością. Jeżeli ludzie nie płacą faktycznych kosztów związanych z konkretnym układem instytucjonalnym pojawia się problem zniekształcenia ceny, znany jako nieskompensowany efekt zewnętrzny [Howell-Moroney 2008, s. 100]. Rynki nie są w stanie wytwarzać efektywnych rozwiązań tam, gdzie występują dodatkowe czynniki zewnętrzne (efekty zewnętrzne, skutki uboczne (spillover), które prowadzą do rozbieżności między kosztami i korzyściami społecznymi oraz prywatnymi, ze względu na fakt, iż ceny rynkowe nie odzwierciedlają prawdziwych kosztów i korzyści społecznych.

- Dobra publiczne i dobra szczególnie korzystne (książki, szczepienia) i szczególnie niekorzystne społecznie (narkotyki, alkohol, papierosy) [Zalewski 2005, s. 19]. Pewne dobra, jak np. obrona narodowa, nie byłyby w ogóle dostarczane przez rynek lub dostarczane w niewystarczającym zakresie. Są to tzw. czyste dobra publiczne, które charakteryzują się tym, iż korzystający z nich nie ponoszą żadnych kosztów, ich konsumpcja nie powoduje rywalizacji oraz niemożliwe (lub bardzo trudne) jest wykluczenie kogokolwiek z korzystania z tych dóbr. Ograniczenia w wytwarzaniu dóbr publicznych przez sektor prywatny spowodowane są z jednej strony za małą konsumpcją, a z drugiej zbyt niską podażą [Stiglitz 2004, s. 151-152]. Dobra publiczne mają cechy efektów zewnętrznych, gdyż są uzyskiwane $w$ transakcjach pozarynkowych. Są wytworem rynku lub innego podmiotu, najczęściej władzy publicznej, który ponosi koszty, natomiast dla odbiorców tych dóbr są one korzyścią zewnętrzną, gdyż nie pociągają za sobą konieczności bezpośredniej rekompensaty kosztów ich wytworzenia u nadawcy.

- Monopol władzy - w modelu nie ma barier do ustanawiania nowych jednostek terytorialnych. Niesprawności rynku pojawiają się na rynku monopolistycznym lub oligopolistycznym, a nie konkurencyjnym. W rzeczywistości istnieją bariery prawne do tworzenia nowych jednostek administracyjnych, zatem ich liczba jest ograniczona. Występują również ograniczenia co do rodzaju lokalnych pakietów dóbr i usług publicznych, jakie władze mogą zaoferować swoim mieszkańcom. Bariery te tłumią konkuren- 
cyjność, która umożliwiłaby pogrupowanie władz lokalnych według podatków/pakietów dóbr publicznych. Kolejnym czynnikiem ograniczającym konkurencyjność jest wprowadzenie przez władze lokalne rygorystycznych przepisów użytkowania gruntów (np. ustanawianie stref zieleni). Regulacje te zniechęcają mieszkańców bardziej liberalnej jednostki do opuszczenia jej i zamieszkania na terenie podlegającym sztywnym regulacjom.

- Niedoskonałości w informacji. Liczba konsumentów dysponujących informacjami o podatkach i pakietach dóbr publicznych oferowanych przez sąsiednie gminy jest zbyt mała, aby zapewnić funkcjonowanie konkurencyjnego rynku usług publicznych. Mieszkańcy nie wiedzą również, które podmioty zasługują na zaufanie lub które trzeba winić za działania, jakie nie podobają się obywatelom, szczególnie tam gdzie kompetencje różnych szczebli władzy, związane z dostarczaniem usług i dóbr publicznych, nakładają się. Gdy dostęp do informacji jest niepełny lub asymetryczny, dojść może do załamania się rynku.

- Rynki niepełne mogą powodować niesprawności, ponieważ nie są w stanie zapewnić potrzebnych dóbr i usług - popyt jest mniejszy niż koszty ich wytworzenia [Dollery, Wallis 2009, s. 84].

- Niezamierzone konsekwencje działań władzy. W rzeczywistości oczekiwania obywateli poszczególnych jednostek nie ograniczają się tylko do wyboru najlepszych podatków i pakietu dóbr publicznych. To dyskredytuje cele polityk nastawione na segregację mieszkańców na bazie podatków i oferowanych pakietów dóbr i powoduje niepożądane konsekwencje. Quasi-rynki dają obywatelom możliwość zastępowania ich własnych preferencji preferencjami stworzonymi przez twórców polityki publicznej. Na przykład władze mogą podjąć decyzję o decentralizacji systemu edukacji, mając nadzieję na pogrupowanie mieszkańców według ich potrzeb edukacyjnych. Jednakże obywatele mogą wykorzystać ten zdecentralizowany system do zaspokojenia swoich preferencji w zakresie segregacji rasowej, a nie potrzeb edukacyjnych. W takim przypadku możliwość wyboru szkoły nie podnosi jakości kształcenia, o co chodziło władzom, lecz tę jakość obniża [Boettke, Coyne, Leeson 2011].

Ponadto Bartik do niedoskonałości rynku zalicza:

- Niedoinwestowanie w dziedzinie badań i rozwoju, co ogranicza możliwość tworzenia nowych miejsc pracy.

- Niedobór kapitału przedsiębiorstw ze względu na fakt, że wiele regulacji sektora bankowego ogranicza możliwość udzielania kredytów na przedsięwzięcia biznesowe o spodziewanej wysokiej stopie zwrotu, lecz przy jednoczesnym wysokim ryzyku,

- Brak inwestycji w edukację i szkolenia pracowników, wynikający $\mathrm{z}$ obaw przedsiębiorstw o to, że przeszkoleni pracownicy przejdą do konku- 
rencji, natomiast w przypadku małych firm - spowodowany brakiem funduszy na szkolenia.

- Sztywne regulacje działalności gospodarczej i system podatkowy [Bartik 2003, s. 12-13].

Oates [1972] wykazał, iż sprawne dostarczanie dóbr publicznych następuje na najniższych szczeblach władzy, która internalizuje odpowiednie efekty zewnętrzne. Kiedy jednak mamy do czynienia z silnymi efektami skali, bardziej sensowne jest dostarczanie dóbr publicznych przez wyższe szczeble administracji. W niektórych przypadkach władze lokalne mogą czerpać korzyści z ekonomii skali lub zinternalizować efekty zewnętrzne poprzez zawieranie ze sobą umów na skoordynowane dostarczanie dóbr publicznych [Boettke, Coyne, Leeson 2011].

Przedstawiciele podejścia policentrycznego proponują model metropolitan governance podobny do modelu rynkowego. Model quasi-rynków zawiera cechy i procesy analogiczne do cech i procesów, jakie występują na prawdziwych rynkach, włączając $w$ to ich efektywność. I to podejście w ciągu ostatnich dziesięcioleci znalazło szerokie zastosowanie w obszarach metropolitalnych, gdzie świadczenie dóbr i usług publicznych zostało zdecentralizowane i stało się przedmiotem quasi-rynkowej konkurencji. W zależności od rodzaju usługi/dobra władza lokalna może je produkować i dostarczać lub też może zlecić to zadanie ponadlokalnemu producentowi i dostawcy. Ta elastyczność skali, w jakiej są świadczone usługi, jest kluczowa dla podejścia policentrycznego. W najprostszej postaci system policentryczny pozwala urzędnikom publicznym lub agencjom dokonywać wyboru formy świadczenia dóbr publicznych i produkcji ich na mniejszą lub większą skalę, w zależności od tego, który poziom produkcji jest bardziej efektywny dla danego dobra. Termin "policentryczny” trafnie oddaje wizję nakładających się skali produkcji i wielu obszarów politycznych interakcji [McGinnis 1999, s. 5].

W sytuacji występowania niesprawności rynku część ekonomistów (szkoła keynesistowska) postuluje interwencjonizm rządowy. Włączenie rządu w gospodarkę ma zapewnić dystrybucję dóbr na zasadach równości i sprawiedliwości. Przy czym należy pamiętać, że gdy władze publiczne rozdzielają dobra nie myślą o wydajności, lecz o tym, kto otrzyma korzyści i kto poniesie ich koszt. Kolejny argument za interwencją rządu opiera się na założeniu, że obywatele nie zawsze robią to co jest dla nich najlepsze (np. mogą nie posyłać dzieci do szkoły). Włączenie polityki publicznej w mechanizm ekonomiczny ma doprowadzić do równych szans ekonomicznych (interwencja na rynkach pracy) dla wszystkich członków danego społeczeństwa [Dollery, Wallis 2009, s. 85].

Zazwyczaj mówiąc o interwencji państwa rozumie się przez to interwencję rządu centralnego. Istotnym problemem jest rozstrzygnięcie, czy i w jakim 
zakresie samorząd jest częścią systemu organizacji państwa i w jakim stopniu może interweniować $w$ sferze publicznej. Często samorząd lokalny stawiany jest w opozycji do rządu centralnego. Mówi się wówczas o interesach publicznych, lokalnych. Pojawia się pytanie, czy interes publiczny i interes lokalny są tożsame? Jeśli przyjmiemy, że władze samorządowe w państwie jednolitym ustrojowo są częścią państwa i realizują ochronę interesu publicznego w sposób pośredni lub bezpośredni, na zasadzie subsydiarności, to można mówić o interwencji władz lokalnych. Rząd tworzy pewne ramy, regulacje, a władze lokalne, pełniąc funkcje poruczone przez rząd, chronią interes ogólnopaństwowy, a także interesy swoich mieszkańców. Przeciwdziałanie niesprawnościom rynku staje się zatem usprawiedliwieniem dla interwencji władzy w mechanizmy rynkowe [OECD 2005b, s. 78].

Spojrzenie na gospodarkę poprzez pryzmat niesprawności rynku zdominowało polityki publiczne w wielu krajach świata. Jednocześnie okazało się, że silny interwencjonizm władz publicznych nie poprawił efektywności gospodarki, natomiast wpłynął na rozwój szeregu instytucji, które ograniczają funkcjonowanie rynku. W tym kontekście niesprawności rynku stają się jednym z elementów ułomności instytucjonalnej, na którą składa się również między innymi niesprawność władzy publicznej czy przepisy prawa.

D. North definiuje instytucje jako stworzone przez człowieka ograniczenia, tworzące polityczne, ekonomiczne i społeczne relacje. Składają się one zarówno z nieformalnych ograniczeń, takich jak sankcje, tabu, zwyczaje, tradycja i kodeksy postępowania, a także formalnych, jak konstytucje, prawo i prawa własności. Najbardziej podstawową cechą instytucji jest to, że obejmują one egzekwowalne normy, reguły i zachowania, które służą zbiorowym celom oraz tworzą i ograniczają interakcje społeczne. Mimo że instytucje muszą zapewnić pewien stopień stabilności i przewidywalności, instytucjonalne zmiany i dostosowanie się do zmiennych warunków otoczenia są również konieczne. Zdolności przystosowawcze, wspomagane przez odpowiedni system bodźców, pomagają elastycznie reagować na zmiany w preferencjach społecznych, technologii czy strukturach politycznych i społeczno-gospodarczych [North 1991, s. 97]. Instytucjonalna macierz, w której indywidualni aktorzy, firmy, grupy społeczne, organizacje obywatelskie i politycy oddziałują na siebie nawzajem, tworzy istniejącą w państwie strukturę zarządzania w procesie realizowania polityki publicznej. Trwałe podstawy rozwoju mogą zostać osiągnięte tylko wtedy, gdy ta struktura zarządzania ułatwia wdrożenie i wykonanie polityk publicznych. A zatem nieodpowiednia struktura zarządzania (ułomność instytucjonalna) może być uznana za główną przyczynę opóźnienia w rozwoju [Arens, Rudolph 2006, s. 209].

Również E. J. Blakely [1994] podkreśla znaczenie instytucji dla rozwoju lokalnego i regionalnego. Coraz częściej sprawne instytucje lokalne, w tym 
władze samorządowe, stają się jednym z filarów rozwoju. Władze lokalne mogą przejąć kontrolę nad swoją przyszłością, gdy będą dysponowały zarówno pomysłami, jak i pełną wiedzą o swoich gminach i wykorzystają to w procesie planowania rozwoju [Blakely 1994, s. 59-62].

Jednym z elementów ułomności instytucjonalnej jest niesprawność rządu. Wynika ona przede wszystkim z niezdolności władzy do osiągnięcia założonych celów w efektywny sposób. Główne przyczyny niesprawności rządu są analogiczne do przyczyn niesprawności rynku. Są to:

- Monopol polityczny - konkurencja polityczna jest ograniczona poprzez zasadę większości w wyborach. Władze mają swoje własne cele, które rzadko są zbieżne z celami rozwoju społeczności, którą rządzą. Posłowie działają na korzyść pewnych grup interesu, co ma im zapewnić poparcie w wyborach i fundusze na kampanie wyborcze.

- Nadmierna biurokracja np. przy obsadzaniu dobrze opłacanych stanowisk.

- Krótki horyzont czasowy podejmowanych decyzji, obejmujący jedną kadencję. Brak wiedzy wśród obywateli, co powoduje, że nie dyscyplinują wybranych przez siebie polityków.

- Braki w wiedzy urzędników, negatywna selekcja kadry urzędniczej.

- Pułapki społeczne (,jazda na gapę") i polityczne związane z mechanizmami wyborczymi (populizm).

- Ograniczona kontrola nad funkcjonowaniem prywatnych rynków.

- Niedostatek informacji i niedoskonałości w ich przepływie.

- Nierealność kompetencji na poszczególnych poziomach władzy (często spowodowana niedoborem środków finansowych).

- Monopol w produkcji oraz dostawie dóbr i usług, wynikający z ustawowo przypisanej roli dystrybutora i reglamentatora tych dóbr [Markowski 2011, s. 28; Kożuch 2004, s. 45; Stiglitz 2004, s. 11].

Niesprawność rządu przyjmuje trzy podstawowe formy:

1. Niewydajności alokacyjnej wynikającej z niewłaściwego wykorzystania publicznych dóbr, ponieważ politycy stosują takie strategie, które zwiększą ich szanse na reelekcję, a rozwój wspólnych dóbr schodzi na dalszy plan. Jeżeli nie interesują się otoczeniem biznesowym i podejmują decyzje niezgodne z celami rozwoju, to obniżają konkurencyjność jednostek terytorialnych i w efekcie prowadzą do upadku gospodarczego.

2. Niesprawności administracji, która powoduje, że polityka związana z korzyściami społecznymi nie zostanie właściwie wdrożona. Przyczyną tego stanu rzeczy jest $\mathrm{z}$ jednej strony brak motywacji wśród urzędników publicznych, aby założenia te w odpowiedni sposób wprowadzać, z drugiej zaś - są oni bezkarni i nie ponoszą konsekwencji z tytułu utrudniania bądź zaniechania tych działań. 
3. Czerpania korzyści bez ponoszenia nakładów na wytwarzanie dóbr publicznych. Interwencja rządu przyczynia się do transferu bogactwa pomiędzy jednostkami i grupami społecznymi [Dollery, Wallis 2009, s. 86].

Ułomność władzy ujawnia się szczególnie silnie na szczeblu lokalnym. Samorządy gmin często walczą o przyciągnięcie nowych inwestycji, najczęściej dużych międzynarodowych przedsiębiorstw. Z uwagi na swą mobilność kapitał przemieszcza się między korzystniejszymi lokalizacjami, czerpiąc korzyści z niższych podatków i tańszej siły roboczej. W rezultacie pojawia się mechanizm fiskalnych oszczędności (fiscal austerity), który powoduje, że sektorowi publicznemu stawiane są coraz większe żądania, natomiast możliwości finansowe, $\mathrm{z}$ uwagi na globalizację i konkurencję o kapitał między miejscami, są coraz mniejsze. Korporacje zaczynają same kontrolować otoczenie, czyli w praktyce odbierają kompetencje władzom publicznym. Teoretycznie ciała polityczne powinny te ułomności rynku ograniczać, ale ponieważ same są ułomne, to mają ograniczone możliwości przeciwstawiania się temu zjawisku. Przede wszystkim władze publiczne nie mają wystarczających środków finansowych, które pozwoliłyby im prowadzić efektywną politykę zabezpieczającą pewne elementy otoczenia przed presją korporacji. Tym samym elementy korzystne dla działalności biznesu są sterowane przez sektor prywatny, który ma dużą siłę przebicia i narzuca swoje koncepcje w programach rozwoju jednostek terytorialnych. W rezultacie pojawiają się negatywne zjawiska, jak zanieczyszczenie środowiska, rozlewanie się miast, przeciążenia infrastruktury itd.

Niesprawność instytucjonalna przejawia się również w wymaganiach, jakie władze nakładają na przedsiębiorców. Nieskuteczność rządowych agencji, brak koordynacji działań, kapryśne mnożenie przepisów i niejasność jurysdykcji nakłada ogromne wymagania na przedsiębiorstwa, które chcą przestrzegać przepisów istotnych dla obszaru ich działalności lub które chcą robić interesy z rządem jako dostawcy towarów bądź usług. Taka sytuacja wymaga ogromnych inwestycji w przetwarzanie informacji w celu osiągnięcia minimalnego poziomu przewidywalności warunków funkcjonowania firm. Aby zapewnić przestrzeganie przepisów rządowych lub zdawać sobie sprawę z możliwości współpracy biznesowej z rządem, firmy muszą dysponować wysokiej klasy ekspertami z dziedziny prawa i szczegółową znajomością funkcjonowania biurokracji [Rogers 2004, s. 134]. W przypadku małych przedsiębiorstw jest to bardzo trudne i może stanowić poważną barierę w ich funkcjonowaniu.

Podczas gdy niesprawności rynku tworzą podstawę do interwencjonizmu rządowego, to niesprawności władzy dostarczają argumentów przeciwko temu interwencjonizmowi. Dlatego też zanim podejmie się decyzje o interwencji na rynku, należy zestawić oczekiwane korzyści z kosztami spowodowanymi przez niesprawność rządu. 
Ułomność rządu szczególnie ostro zarysowała się podczas kryzysu lat 2008-2009, który początkowo dotknął świat finansów, a następnie stopniowo rozprzestrzenił się na inne sektory i doprowadził do załamania gospodarek wielu krajów. Jego przyczyną była interwencja polityków na rynku nieruchomości, kredytów hipotecznych i stóp procentowych [Salsman 2012].

Obserwowane niesprawności władzy oraz zmienność otoczenia, w jakim przyszło działać organizacjom publicznym pod koniec XX w., spowodowały, że zaczęto inaczej podchodzić do problematyki sprawnej działalności organizacji publicznych. Zaobserwowano konieczność zmiany dotychczasowych sposobów rządzenia, opartych przede wszystkim na tradycyjnym modelu administracji [Weber 2002], a także wskazano nowe koncepcje zarządzania w sektorze publicznym polegające na przechodzeniu od administrowania do zarządzania [Kettl 2000; Osborne, Gaebler 1994]. Stwierdzono, że procesy zarządzania i zachowania typu biznesowego powinny być wykorzystywane $\mathrm{w}$ organizacjach publicznych, bo również w tego typu organizacjach można wyróżnić produkty i rynek docelowy. Było to podstawą całej fali reform sektora publicznego przeprowadzonych w ciągu ostatnich kilku lat w krajach wysoko rozwiniętych. Polegały one na stosowaniu w sektorze publicznym, zwłaszcza w krajach OECD, na coraz szerszą skalę bardziej „menadżerskiego" i biznesowego podejścia do zarządzania. Określa się je wspólnym mianem: nowe zarządzanie publiczne (z ang. New Public Management) ${ }^{36}$. Nowe zarządzanie publiczne polega na wprowadzeniu technik zarządzania biznesowego, większej orientacji na świadczoną usługę i klienta, wprowadzeniu mechanizmów rynkowych i konkurencji do sektora usług publicznych. Podstawą NPM jest twierdzenie, że efektywność organizacji publicznych powinna być mierzona, monitorowana i podawana do publicznej wiadomości, aby ulepszać świadczone usługi i zapobiegać poważnym katastrofom [Andrews 2008, s. 350] ${ }^{37}$.

O ile w sektorze prywatnym jest stosunkowo łatwo mierzyć efektywność organizacji stosując kryteria finansowe, o tyle w sektorze publicznym jest to problem o wiele bardziej złożony. Wynika to z faktu, iż efektywność jest

${ }^{36}$ Istnieje bogata literatura światowa i polska opisująca genezę, modele i cechy New Public Management, zob.: Hughes 1994; Kickert 1997; Kickert, Koppenjan 1997; Kicker, Klijn, Koppenjan 1997; Perry 1996; Naschold, von Otter 1996; Pollit, 1990; Osborne, Gaebler 1994; Kożuch 2004a; b; Zawicki 2011; Kieżun 2002; Hausner 2008.

37 Model NPM opisywany jest również za pomocą innych sformułowań, takich jak menedżeryzm (managerialism), menedżeryzm publiczny (public managerialism), rynkowa administracja publiczna (market-based public administration), przedsiębiorcza władza (entrepreneurial government), zarządzanie na zasadach biznesowych (business-like management), które stosowane są w literaturze wymiennie. 
oceniana przez wielu klientów (konsumentów, płatników podatków, polityków, pracowników itp.) [Boyne 2003, s. 368]. W związku z tym miarą porażki/ułomności w sektorze publicznym są subiektywne kryteria przyjęte przez kluczowych aktorów [Andrews 2008, s. 353].

- Bardzo ważne znaczenie w nurcie nowego zarządzania publicznego ma kategoria responsywności (ang. responsiveness), która opisuje zdolność władzy do szybkiego identyfikowania pojawiających się problemów lub dylematów zarządzania publicznego i reagowania na nie. Jak wskazuje Dahl [1971, s. 1], główną cechą demokracji jest ciągłe reagowanie władzy na preferencje swoich obywateli, którzy są traktowani jak równi politycznie partnerzy. Związek między tym, czego chcą obywatele, a tym co robi władza jest głównym czynnikiem, który jest brany pod uwagę przy ocenie jakości governance [Gilens 2005, s. 779]. Responsywność, jak zauważa Herbst, pozwala zwiększyć zdolność administracji do skutecznego odpowiadania na zmieniającą się sytuację, przyspieszyć reakcje na sygnały ze strony społeczeństwa, podnosi sprawność instytucji i polityk publicznych poprzez koncentrację na społecznie ważnych celach oraz legitymizując je w oczach elektoratu [Herbst 2008, s. 93].

R. Hambleton dokonał klasyfikacji typów przemian, jakim od końca lat 70. XX w. podlegał model zarządzania jednostkami lokalnymi [Hambleton 2001]. Obejmują one trzy etapy:

1. Zmniejszenie biurokracji i zastosowanie na szeroką skalę mechanizmów rynkowych w świadczeniu usług oraz traktowanie ich odbiorców nie jak petentów, lecz jako konsumentów. Najważniejszym punktem odniesienia stał się sektor prywatny.

2. Wprowadzenie modelu New Public Management, czyli koncentracja na menedżerskim podejściu do zarządzania jednostką terytorialną i przejmowaniu przez sektor publiczny metod zarządzania stosowanych dotychczas w sektorze prywatnym (zarządzanie strategiczne, zarządzanie przez cele, certyfikaty jakości, benchmarking, outsourcing itp.).

3. Rozwój mechanizmów demokratycznych podejmowania decyzji i społecznej kontroli nad realizacją zadań przez władze lokalne. Partycypacja społeczeństwa w zarządzaniu jednostką terytorialną [Swianiewicz 2005].

Ostatni z tych etapów zyskał nazwę public governance. W ujęciu Hambletona jest on postrzegany jako kolejny krok w ewolucji podejścia do zarządzania sektorem publicznym. Koncepcja public governance powstała na gruncie krytyki wobec nowego zarządzania publicznego uznawanego za zbyt rynkowe $\mathrm{w}$ odpowiedzi na anglosaskie nowe zarządzanie publiczne [Zawicki 2002, s. 230]. Kwestie publicznego współrządzenia zyskały na znaczeniu z uwagi na naciski spowodowane ekonomiczną globalizacją i zmianami technologicznymi. Presja ta jest również wywołana rosnącą liczbą ludności w krajach rozwijających się, koncentracją w miastach, wzra- 
stającą liczbą i rozmiarem regionów metropolitalnych, problemami środowiskowymi, starzejącą się ludnością i przekształceniami w kierunku gospodarki opartej na wiedzy i społeczeństwa informacyjnego.

W tym kontekście termin „rządzici” nie jest właściwy dla określenia sposobu, w jaki społeczności i terytoria są zorganizowane i administrowane. W świecie, w którym uczestnictwo społeczeństwa obywatelskiego i biznesu staje się w coraz większym stopniu normą, termin „współrządzenie” (governance) lepiej definiuje „proces”, poprzez który obywatele wspólnie rozwiązują swoje problemy i zaspokajają potrzeby społeczeństwa, wykorzystując rząd jako instrument do tego.

Decentralizacja, dekoncentracja i prywatyzacja wzmacniają proces rewidowania ról władzy na szczeblu krajowym, regionalnym i lokalnym. Reformy, które miały na celu zwiększenie zdolności do publicznego współrządzenia, zostały wprowadzone w zgodzie z nowym przestrzennym porozumieniem i partnerstwem między rządem centralnym, terytorialną administracją publiczną, sektorem prywatnym i społeczeństwem obywatelskim [OECD 2000]. Publiczne współrządzenie odnosi się do takich wartości, jak legalność, prawomocność, sprawiedliwość i inne, a więc nie tylko do zasad ściśle biznesowych. Również J. Hausner pisze o dwóch kierunkach w zarządzaniu publicznym - menedżerskim zarządzaniu publicznym, co jest polskim określeniem NPM oraz o partycypacyjnym zarządzaniu publicznym/zarządzaniu interaktywnym odpowiadającym public governance [Hausner 2008, s. 24-29]. Także Kickert [2002] uważa, iż nowy trend w zarządzaniu publicznym powinien być rozumiany w szerszym kontekście jako publiczne współrządzenie. Z kolei inni badacze [Kieżun 2002; Osborn, Gaebler 1992] uznają governance za odmianę NPM, a nawet traktują oba terminy wymiennie [Hood 1991]. Rhodes [1996] znalazł co najmniej sześć różnych zastosowań tej koncepcji, które zdają się pasować do dwóch grup definicji. W jednym przypadku governance odnosi się do ograniczenia roli państwa i służy odróżnieniu governance od government. Rola rządu powinna ulec ograniczeniu lub więcej powinno być robione przy zaangażowaniu mniejszych środków [Osborne, Gaebler 1992] dzięki zastosowaniu technik nowego zarządzania publicznego. $\mathrm{W}$ drugim przypadku termin governance odnosi się do sytuacji, które biorą pod uwagę współzależności podmiotów publicznych, prywatnych i półprywatnych. W tej definicji governance odnosi się do samoorganizujących się sieci. Te dwie koncepcje governance mają zupełnie różne podejście do zarządzania publicznego i roli władzy w społeczeństwie, inne jest także ich podłoże teoretyczne. Podczas gdy nowe zarządzanie publiczne jest próbą przełożenia idei kierowniczych, takich jak kontrakty zewnętrzne, orientacja na klienta czy wprowadzenie mechanizmów rynkowych z sektora prywatnego do publicznego [Pollitt 1990; Kickert 1997], to „zarządzanie siecią” skupia się bardziej na mediacji i koordy- 
nowaniu polityki realizowanej przez różne organizacje. Teoretyczne podstawy do tego alternatywnego spojrzenia znaleźć można w sieciowym podejściu do formułowania polityki, które zyskało znaczącą pozycję $\mathrm{w}$ naukach politycznych i administracji publicznej, o czym świadczy liczba publikacji na temat sieci politycznych i zarządzania sieciowego w Europie [Wilks, Wright 1987; Rhodes 1988; Marin, Mayentz 1991; Marsh, Rhodes 1992; Glasbergen 1995; Kickert i in. 1997] i w Stanach Zjednoczonych [Milward, Wamsley 1985; O’Toole 1997].

Autorka uważa, że bardziej zasadne jest podejście Hambletona i Hausnera ze względu na fakt, iż koncepcje NPM zakładają, że podmiotem zarządzania publicznego mogą być tylko te organizacje, których misją jest realizacja interesu publicznego, a zatem nie można przyjąć założenia, że organizacje wszystkich sektorów są podmiotami współrządzenia publicznego [Kożuch 2004a, s. 36], gdyż jest to sprzeczne z koncepcją governance. Ponadto NPM zajmuje się głównie doskonaleniem procesów zarządzania w instytucjach administracji publicznej, bazując na wdrażaniu zasad funkcjonujących w przedsiębiorstwach prywatnych, a także przechodzeniu od bezpośredniego sposobu zaspokajania potrzeb społeczności do sposobów pośrednich. Dzieje się to poprzez urynkowienie sfery usług. Realizacja usług publicznych przekazywana jest podmiotom prywatnym, które w sposób profesjonalny, menedżerski, rynkowy obsługują całą społeczność. Przy czym należy pamiętać, że nie zwalnia to władz publicznych z odpowiedzialności za świadczenie tych usług. W nurcie NPM stosowano do rozwiązywania problemów przede wszystkim analizy ekonomiczne. Kryteria marketyzacji ${ }^{38}$ usług publicznych uwzględniają efektywność, skuteczność i sprawiedliwość w ich dostarczaniu [Kożuch 2004a, s. 69].

Natomiast w koncepcji governance dołożono do tego konieczność uwzględniania otoczenia społeczno-politycznego i zwrócono uwagę na złożoność i kompleksowość relacji administracyjnych. Zaczęto patrzeć na obywateli nie jak na klientów, lecz interesariuszy (stakeholders) obiektywnie zainteresowanych efektami działań publicznych. Podmioty te powinny więc mieć, przynajmniej przez swoich przedstawicieli, możliwość udziału w procesie podejmowania decyzji. Wskazuje się tu na kluczową rolę społeczeństwa obywatelskiego [Izdebski 2010b, s. 23]. Sektor publiczny ma wiele cech typu politycznego, co powoduje, że wszechstronne stosowanie w nim metod ekonomicznych, będących podstawą modelu NPM, jest nie do końca poprawne i nie zawsze pozwala na rozwiązanie problemów publicznych [Zawicki 2002, s. 212]. Ze względu na złożoność i specyficzny charakter powiązań, jakie występują w sektorach polityk społecznych, konieczna jest

${ }^{38}$ Bardziej szczegółowo o sposobach urynkowienia usług publicznych pisze: Kożuch 2004a; OECD 2005a. 
szczególna forma współrządzenia publicznego, jaką jest współrządzenie w złożonych międzyorganizacyjnych sieciach politycznych, która uwzględniałaby interesy różnych aktorów funkcjonujących w obszarze metropolitalnym. Twórcy governance wprowadzili pojęcie zarządzania sieciami powiązań (network governance), które oznacza zarządzanie złożonymi relacjami, jakie są udziałem wielu różnorodnych podmiotów polityki publicznej [Wilks, Wright 1987; Rhodes 1988; Marin, Mayentz 1991; Marsh, Rhodes 1992; Glasbergen 1995; Kickert i in. 1997]. Istotę współczesnego rozwoju stanowi tworzenie terytorialnych sieci powiązań między jednostkami gospodarczymi, instytucjami obsługi biznesu, placówkami badawczymi, ośrodkami akademickimi, edukacyjnymi, NGOs oraz administracją publiczną. Istotną rolę $w$ tym procesie mogą odgrywać władze lokalne, ponieważ samorząd terytorialny jest zdolny prowadzić promocję terenu, wspierać zaplecze biznesowe, organizować szkolenia i pomoc w tym zakresie [Wojciechowski 2003, s. 100].

W koncepcji public governance instytucje administracji uznawane są za element społeczeństwa obywatelskiego, w którym występują inne segmenty tego społeczeństwa (grupy interesów, organizacje pozarządowe, przedstawiciele biznesu, pojedyncze jednostki), połączone ze sobą gęstymi sieciami współzależności i ciągłych interakcji. Każdy z tych aktorów reprezentuje odmienne, często konfliktowe wobec innych aktorów, interesy. W tej sytuacji administracja publiczna nie może jawić się jako jedyny uczestnik procesu zarządzania rozwojem, który nie musi zważać na opinie innych. Administracja publiczna została stworzona dla obywateli i dlatego też powinna zwracać baczniejszą uwagę na takie dążenie do osiągnięcia celów, które oznaczałoby wypracowanie kompromisu pomiędzy wszystkimi podmiotami funkcjonującymi na podległym jej terytorium. Funkcjonowanie tych sieci umożliwiają stosowane na szeroką skalę instrumenty konsultacyjne i mechanizmy partycypacji społecznej, które mają włączyć w proces ustalania i wdrażania polityk wszystkich interesariuszy [Herbst 2008, s. 97].

Network governance polega na:

- restrukturyzacji istniejących sieci relacji pomiędzy podmiotami życia publicznego,

- stwarzaniu warunków do współpracy miedzy podmiotami,

- wspólnym rozwiązywaniu problemów [Kickert 1997, s. 181-185].

Obecnie polityka publiczna jest wypracowywana i wdrażana w sieciach tworzonych przez współzależne od siebie publiczne i prywatne podmioty. Zarządzanie w układach sieciowych stanowi próbę kontroli efektów zewnętrznych.

Organizacje administracji publicznej mogą odnieść się do istniejących sieci politycznych na kilka sposobów:

1. Powstrzymać się od angażowania w procesy tworzenia sieci. 
2. Uczestniczyć w nich jako jedna ze stron.

3. Uczestniczyć w nich jako „specjalny podmiot” nakładający rozwiązania na innych uczestników sieci.

4. Przyjmować na siebie rolę menedżera sieci [Kickert, Koppenjan 1997, s. 59].

W przypadku governance pierwsze podejście jest niedopuszczalne, governance odrzuca bowiem skostniałą strukturę hierarchiczną na rzecz dialogu i negocjacji ze społeczeństwem. Jest to szczególnie istotne w obszarach metropolitalnych, które - jeśli mają się sprawnie rozwijać - wymagają współpracy poszczególnych jednostek wchodzących w ich skład. Osiągnięcie takiej współpracy jest często bardzo trudne i sposobem dojścia do niej jest wdrożenie koncepcji metropolitan governance. Natomiast znacznie łatwiej jest wyłączyć pewne funkcje (pod względem operacyjnym, podczas gdy w dalszym ciągu odpowiedzialność za ich świadczenie pozostaje w rękach samorządu) i je urynkowić, czyli przekazać ich faktyczną realizację podmiotowi rynkowemu. Wówczas dziedzina, która często była źródłem konfliktów między poszczególnymi samorządami, głównie ze względu na sposób finansowania, przestaje być źródłem sporów ${ }^{39}$. Zaprezentowany mechanizm (partnerstwo publiczno-prywatne) jest próbą znalezienia rozwiązań w zakresie świadczenia usług w momencie, gdy zawodzi zarówno model świadczenia tych usług przez państwo, jak i przez rynek [Plawgo, Zaremba 2005, s. 112], co jest konsekwencją niesprawności rynku i niesprawności władzy.

Pomimo znaczących różnic między NPM a public governance (PG) obie teorie w wielu aspektach są ze sobą zgodne. Governance nie odrzuca dorobku NPM. Wiele praktycznych elementów NPM stało się częścią składową governance [Izdebski 2010b, s. 24]. Krytycy NPM wskazują na jego czysto ekonomiczną mierzalność wyników. Natomiast PG kładzie nacisk na partycypację oraz poszukiwanie równowagi między uprawnieniami interesariuszy w społeczeństwie sieciowym [Bovaird 2005].

Odpowiedzialność, zaangażowanie, przewidywalność i przejrzystość są identyfikowane jako główne cechy struktury zarządzania, które sprzyjają

${ }^{39}$ Przykładem tego typu usług jest transport publiczny na terenie obszaru metropolitalnego, którego kosztów część gmin nie chce pokrywać w wystarczającym stopniu i w efekcie likwidowane są połączenia kluczowe dla społeczności obszaru. Przekazanie obsługi komunikacyjnej firmie prywatnej może przyczynić się do reorganizacji usług komunikacyjnych w oparciu o kryterium efektywności ekonomicznej. W sytuacjach gdy samorządy nie potrafią porozumieć się w zakresie transportu publicznego, samorząd wojewódzki może wprowadzić dotację dla obszaru metropolitalnego na transport, która będzie trafiać do firmy prywatnej, odpowiadającej za jego zorganizowanie, a nie do poszczególnych gmin, kłócących się między sobą. W Polsce taki sam mechanizm mógłby zadziałać w przypadku Przewozów Regionalnych. 
zintegrowanemu rozwojowi i są w stanie przełamać nieefektywności władzy [Ahrens, Rudolph 2006, s. 207].

\section{Corporate governance jako źródło koncepcji metropolitan governance}

Koncepcja współrządzenia wywodzi się z koncepcji corporate governanance. Narodziła się ona w Stanach Zjednoczonych i Wielkiej Brytanii, by następnie rozpowszechnić się we wszystkich państwach świata. Angielskie słowo governance wywodzi się od łacińskiego gubernare, które oznacza sterowanie, trzymanie kursu w trakcie żeglugi [Wawrzyniak, 2000, s. 17]. Angielski rzeczownik governance pochodzi od czasownika to govern, co oznacza rządzić, kierować, zarządzać, wpływać na kogoś, administrować [Stanisławski 1990, s. 357]. W znaczeniu wąskim termin corporate governance odnosi się do rad dyrektorów, rad nadzorczych, ich kompetencji, struktury i relacji (głównie) z zarządem i jest tłumaczony jako nadzór właścicielski [Wawrzyniak 2000, s. 17-18]. Najogólniej corporate governance to system, przez który korporacje są kierowane i kontrolowane [Cadbury 1995]. W podejściu amerykańskim corporate governance jest definiowany jako „zbiór metod mających na celu zapewnienie inwestorom uzyskania przychodu ze swoich pieniędzy" [Lis, Sterniczuk 2005, s. 26]. W szerszym ujęciu oznacza „maksymalizację tworzenia bogactwa w sposób nieobarczający innych lub całego społeczeństwa niewłaściwymi kosztami" [Monks, Minow 2003, s. 162]. OECD traktuje corporate governance jako system zarządzania i kontroli organizacji gospodarczych, który zapewnia podział praw i odpowiedzialności między różne grupy interesów zaangażowane w działalność przedsiębiorstwa, a także określa reguły ustalające jego cele, środki ich osiągania oraz monitorowania wyników działania firmy. Jest to sieć relacji między kadrą zarządzającą spółki, jej organami, udziałowcami i innymi grupami zainteresowanymi działaniem spółki [OECD 2004, s. 13]. W szerszym ujęciu corporate governance tłumaczone jest jako nadzór korporacyjny, ponieważ dotyczy relacji faktycznej władzy między organami spółki a jej interesariuszami [Wawrzyniak 2000, s. 18]. W praktyce jednak bardzo często funkcjonuje termin angielski, dla którego nie ma trafnego odpowiednika w języku polskim, ze względu na jego specyfikę. Samo governance można traktować jako proces godzenia ambicji indywidualnych z potrzebą utrzymania i rozwoju wspólnego dobra, które wiąże jednostki przez wspólne interesy [Davies 1999, s. VII].

Na szersze rozumienie corporate governance wpływ miały m.in. procesy globalizacji w obszarach finansów, rynków i strategii, technologii, kultury, polityki oraz regulacji prawnych, które wpływają na zmiany we wszystkich elementach otoczenia przedsiębiorstw. Globalizacja i nasilająca się konkurencja, będąca dla firm głównym bodźcem do poszukiwania nowych, bar- 
dziej efektywnych sposobów na pełne wykorzystanie posiadanych zasobów oraz stworzonych przez otoczenie możliwości, wpływają na przewartościowanie dotychczasowych założeń i mechanizmów rządzących systemami corporate governance [Zalega 2003, s. 17].

Spowodowało to, iż władza i kontrola nad spółkami zaczęły wykraczać poza granice określone przepisami prawa spółek, ponieważ w sprawowaniu corporate governance coraz intensywniej uczestniczą, inni niż menedżerowie i akcjonariusze, interesariusze (stakeholders). Wraz ze wzrostem znaczenia ingerencji państwa $w$ procesy gospodarcze oraz rosnącą rolą pracowników (za sprawą związków zawodowych), problem władzy we współczesnych korporacjach przestał dotyczyć tylko nadzoru sprawowanego w imieniu właścicieli. W sprawowaniu władzy i kontroli korporacyjnej uczestniczą zatem inne niż udziałowcy podmioty, mające interes w funkcjonowaniu organizacji [Zalega 2003, s. 20]. Do takich zaliczają się również: państwo, rynek kapitałowy, związki zawodowe, pracownicy, dostawcy, odbiorcy, kooperanci i inni. Każda z tych stron jest zainteresowana działalnością przedsiębiorstwa, wpływa na osiągane przez nie cele, wysuwa wobec niego pewne żądania i ma faktyczną lub hipotetyczną możliwość ich wyegzekwowania. Obecność tych interesariuszy wymusiła stosowanie innych niż rada nadzorcza instytucji kontrolnych [Zalega 2003, s. 17]. Corporate governance jest systemem, który obejmuje reguły i procedury gwarantujące, że firma jest właściwie zarządzana, zatrudnieni są odpowiedni dyrektorzy $\mathrm{z}$ należycie określonymi prawami i obowiązkami, działający $\mathrm{w}$ zgodzie z prawem i z interesem wszystkich stakeholders [Crainer, Dearlove 2004, s. 583]. Źródłem zainteresowania koncepcją governance wśród inwestorów spółek była chęć podniesienia efektywności firm, których byli udziałowcami [Davies 1999, s. VII]. A. Davies udowodnił, że kierowanie i kontrola dotyczą każdego typu organizacji. Problemy, które pojawiają się $\mathrm{w}$ zarządzaniu organizacjami pozarządowymi, sektorem publicznym i organizacjami zawodowymi, są ogólnie rzecz biorąc podobne do tych, z którymi borykają się przedsiębiorstwa. Struktury governance mają nawet większe znaczenie poza sektorem przedsiębiorstw. W przedsiębiorstwach jasne określenie celu, stworzenie planu jego osiągnięcia i realizacja koncepcji jest prostsza niż w przypadku jakiejkolwiek innej organizacji, np. sektora publicznego, która zazwyczaj musi zachować równowagę między kilkoma celami i nie ma jednego nadrzędnego celu. Co więcej, zasady governance są co najmniej tak samo istotne dla organizacji non profit jak dla publicznie notowanych spółek, w których kluczowa jest kwestia zysku. Istotą koncepcji governance jest to, iż good governance ma być pomocne w podniesieniu efektywności [Davies 1999, s. VII]. Efektywnego zarządzania według koncepcji governance wymaga cała hierarchia organizacji, począwszy od organizacji ponadnarodowych (np. Unia Europejska), przez władze krajowe, regionalne i lokal- 
ne, służby publiczne i obronne, organizacje biznesu, po Kościoły, grupy interesu, kluby itp. Koncepcja governance jest złożona i budzi kontrowersje. Zanim wyjaśni się znaczenie pojęcia good governance należy jasno doprecyzować, co jest rozumiane przez samo to słowo. Organizacja Narodów Zjednoczonych zdefiniowała governance jako sprawowanie gospodarczej, politycznej i administracyjnej władzy w celu zarządzania sprawami państwa na wszystkich szczeblach. Obejmuje to mechanizmy, procesy i instytucje, poprzez które obywatele i grupy określają swoje interesy, realizują swoje prawa, wywiązują się z nałożonych na nie obowiązków i osiągają porozumienie pomimo różnic, które ich dzielą [UNDP 1997, s. 2]. Governance nie oznacza więc tego samego co government. Governance ma szersze znaczenie. Podczas gdy government dotyczy takich zasad, jak konstytucja, system prawny, władza wykonawcza i sądownicza, governance odnosi się raczej do interakcji między tymi formalnymi instytucjami oraz organizacjami stworzonymi przez społeczeństwo obywatelskie [Ambruosi, Baldinelli, Cappuccini, Migliardi 2010, s. 322]. Według koncepcji governance władza istnieje zarówno wewnątrz, jak i na zewnątrz formalnych organów władzy i instytucji rządowych. J. Kooiman [2008, s. 146] definiuje „współrządzanie” jako „wykorzystywanie zorganizowanych form interakcji dla celów zarządzania. [...] aktorzy koordynują, kooperują, komunikują się bez centralnego czy dominującego aktora". U podstaw współrządzenia leży zdolność do funkcjonowania w strukturze rządzenia. Oznacza ono również zdolność społeczeństwa jako całości do współpracy, na każdym poziomie, od lokalnego po międzynarodowy [Kooiman 2008, s. 151]. P. John definiuje governance jako elastyczny model podejmowania decyzji, oparty na luźnych relacjach między różnymi aktorami zarówno publicznymi, jak i prywatnymi [John 2001, s. 9]. W wielu definicjach governance obejmuje government, sektor prywatny i społeczeństwo obywatelskie. Ponadto governance kładzie nacisk na proces i uznaje, że decyzje podejmowane są na podstawie złożonych relacji między wieloma podmiotami mającymi różne priorytety. G. Stoker, analizując liczne definicje governance, doszedł do wniosku, że odnoszą się one do rozwoju stylów zarządzania, w których granice między (i wewnątrz niego) sektorem publicznym i prywatnym zacierają się [Stoker 1998, s. 17]. B. Jessop traktuje governance jako heterarchię (samoorganizację), której formy obejmują: samoorganizujące się interpersonalne sieci, negocjowaną międzyorganizacyjną koordynację oraz zdecentralizowane, osiągające porozumienie w zależności od sprawy, międzysystemowe sterowanie [Jessop 1998, s. 29].

Wspólną cechą wszystkich powyższych definicji jest współpraca w procesie zarządzania wielu podmiotów, które zainteresowane są funkcjonowaniem przedsiębiorstwa i które wspólnie negocjują cele i strategie ich osiągania. 


\section{Definicja zarządzania metropolitalnego (metropolitan governance)}

Dynamicznie zmieniające się pod wpływem globalizacji miasta i obszary metropolitalne wymagają nowych sposobów zarządzania. Spowodowało to rozwój koncepcji metropolitan (regional, local, urban) governance, która obejmuje szereg zmian w sposobach działania państw i sektora publicznego, będących reakcją na procesy globalizacji, gospodarczej i politycznej restrukturyzacji (np. powstanie Unii Europejskiej) oraz zmian technologicznych $^{40}$. Jest to złożony proces obejmujący zmiany w wielu sferach społecznych i na różną skalę ${ }^{41}$. J. Pierre definiuje governance jako proces i mechanizmy, dzięki którym znaczące i dysponujące zasobami podmioty koordynują swoje działania i środki, aby osiągnąć wspólnie zdefiniowane cele [Pierre 2005, s. 452]. J. M. Fontan i współpracownicy [2009] twierdzą, iż urban governance zakłada przejście od hierarchii do horyzontalności, która opiera się na wzajemnej zależności sektora publicznego, prywatnego i NGOs. Ponadto, osiągnięcie celów polityki zależy od współpracy między wieloma podmiotami, których interesy i zakresy odpowiedzialności krzyżują się w sposób płynny i uwarunkowany wieloma czynnikami. Ten ostatni aspekt jest ważny, ponieważ sugeruje, że governance może być rozumiane jako będące w ruchu relacje, które nie podlegają stagnacji i nie muszą opierać się wyłącznie na stałych, zdefiniowanych zewnętrznie strukturach [Fontan et al. 2009, s. 834]. Diana Mitlin twierdzi, że termin governance odnosi się do instytucji i procesów zarówno formalnych, jak i nieformalnych, prowadzących do interakcji państwa z szeregiem innych podmiotów, których dotyczą działania rządu [Mitlin 2004, s. 3]. R. J. Oakerson definiuje governance jako proces, poprzez który ludzie regulują swoje współzależności w kontekście wspólnych, dzielonych z innymi środowisk. Każde środowisko jest źródłem wartości dzielonych przez członków danej społeczności. Jedne z tych społeczności są małe, a inne bardzo duże [Oakerson 2004, s. 19]. Pełen zestaw wartości dzielonych przez daną społeczność jest tym, co klasyczni republikanie określają mianem sfery publicznej/wspólnego dobra (res publica/public realm). Governance koncentruje się na ochronie i zmocnieniu tej sfery publicznej. Obejmuje ona zestaw wartości materialnych i niematerialnych: ulice i chodniki, zasoby wody i dziką przyrodę, rynki i rozliczenia, strukturę osadniczą, pokój i dobrobyt. Dzielenie wspólnych zasobów jest często problematyczne i to właśnie problem podziału leży u podstaw governance. Wspólne otoczenie jest źródłem wielu wartości, które powodują jedno główne ograniczenie, a mianowicie nie ma możliwości maksymalizowania wszystkich tych wartości jednocześnie. Dlatego konieczne są kompromisy, co do których członkowie społeczności często

\footnotetext{
40 Zob.: Harvey 1989; Jessop 1994; Harding, Le Gale 1997.

41 Zob.: Swyngedouw 1996; 1997; Brenner 1998; 1999; 2000.
} 
nie mogą się zgodzić i co wymaga wspólnych obrad. Governance, jako proces, przede wszystkim zajmuje się osiąganiem tych kompromisów. Aby to ułatwić ludzie tworzą struktury governance oparte na zgodzie chętnych do wspólnego decydowania. Struktury te dostarczają ustalonych środków pozwalających na identyfikację i zdiagnozowanie problemów, wyjaśnienie informacji, uszeregowanie i ocenę alternatywnych rozwiązań oraz wdrożenie, opartych na ustalonych wcześniej regułach, rozwiązań a także monitoring ich realizacji i wprowadzanie zmian, jeśli zajdzie taka potrzeba [Oakerson 2004, s. 20].

Dobrowolna współpraca między lokalnymi podmiotami ma decydujące znaczenie dla wypracowania nowoczesnych metod zarządzania na poziomie lokalnym. Oznacza ona potrzebę odejścia od tradycyjnie rozumianego modelu władzy lokalnej, który opiera się na hierarchizowanych, formalnych procedurach i instytucjach na rzecz tworzenia przywództwa potrzebnego do rozwoju społeczności lokalnej [Swianiewicz, Mielczarek, Klimska 2004, s. 25]. Istotą działania samorządu staje się tworzenie klimatu dla współpracy różnych aktorów funkcjonujących w danej jednostce terytorialnej, która ma doprowadzić do osiągnięcia celów rozwoju. W zakresie lokalnego zarządzania kluczowa jest teoria reżimów miejskich Clarence'a Stone’a, która zakłada rezygnację samorządu z modelu "władzy nad" innymi w sensie możliwości wydawania poleceń, narzucania swojej woli innym poprzez hierarchiczne zależności (power over) na rzecz modelu „władzy ku”, czyli umiejętności gromadzenia zasobów pozwalających na osiągnięcie założonych celów. Rozróżnienie między „władzą nad” i „władzą ku” oznacza nawiązanie do klasycznego rozróżnienia Burnsa pomiędzy władzą hierarchiczną i przywództwem [Burns 1995]. Gdy dany samorząd opanuje model „władzy ku”, to jednocześnie zyskuje zdolność do osiągania formułowanych celów publicznych. W oczywisty sposób zakłada ona łączenie zasobów różnych aktorów, co musi odbywać się na podstawie dobrowolnych i zazwyczaj nieformalnych porozumień [Swianiewicz, Mielczarek, Klimska 2004 , s. 25]. W tym drugim rozumieniu nowoczesny polityk lokalny ma być nie tyle władcą, ile przywódcą.

Również koncepcja „nowej kultury politycznej” Clarka akcentuje aktywną rolę społeczności lokalnej w procesie zarządzania. Dla Clarka jednym z wyróżników tej „nowej kultury” jest bezpośrednie odwoływanie się liderów politycznych do wyborców, z pominięciem struktur partyjnych i innych tradycyjnych pośrednich kanałów komunikacji [Clark, Hoffmann-Martinot 1998]. Częste staje się odwoływanie do mechanizmów demokracji bezpośredniej (zwłaszcza referendów lokalnych) i poszukiwanie sposobów wzmacniania partycypacji społecznej w zarządzaniu.

W teorii Stone’a najważniejszym partnerem władz lokalnych są zazwyczaj wpływowi przedsiębiorcy działający na terenie miasta. Typowy miejski 
reżim ma zatem charakter do pewnego stopnia elitystyczny [Stone 1989]. Teoria ta powstała na gruncie obserwacji prowadzonych w miastach amerykańskich, ale może znaleźć zastosowanie również w Europie, ponieważ dopuszcza różne formy reżimów. Według Mossberger i Stokera w miastach europejskich sektor prywatny nie odgrywa tak dużej roli jak w USA. Większe znaczenie w lokalnych koalicjach mają aktorzy z sektora publicznego, na przykład pracownicy administracji, grupy sąsiedzkie czy organizacje pozarządowe [Mossberger, Stoker 2001, s. 819].

Do rządzenia poprzez partnerstwa nawiązuje także koncepcja, która podkreśla, że w praktyce działania samorządów nastąpiło przejście od tradycyjnego samorządu terytorialnego do nowoczesnego zarządzania lokalnego (from local government to local governance). Peter John definiuje zarządzanie lokalne (local governance) jako elastyczny model podejmowania decyzji publicznych oparty na luźnych powiązaniach poziomych pomiędzy różnymi aktorami [John 2001, s. 9]. Z kolei według Stokera jest to system zarządzania, w którym granice między publicznym i prywatnym sektorem zacierają się. Jego istotą są mechanizmy zarządzania, które nie opierają się na wykorzystaniu władzy i sankcji nakładanych przez rząd, lecz na interaktywnych relacjach między instytucjami rządowymi i pozarządowymi (w tym prywatnymi) [Stoker 1998, s. 1]. Jak już wspomniano, termin governance jest często łączony ze słowem sieć, z czego zrodziło się pojęcie „sieci zarządzania" (governance networks). Przyczyną takiej idei jest fakt, iż governance często odbywa się w/i poprzez sieci społecznych i politycznych podmiotów. E. Sørensen i J. Torfing definiują owe „sieci zarządzania” jako: 1) stosunkowo stabilną, poziomą współpracę współzależnych od siebie, ale organizacyjnie autonomicznych aktorów; którzy 2) kontaktują się ze sobą poprzez negocjacje; 3) które to negocjacje odbywają się w ramach wspólnych ram normatywnych, poznawczych i regulacyjnych; 4) która to współpraca do pewnego stopnia ma charakter samoregulujący; 5) i przyczynia się do osiagnięcia celów o charakterze publicznym [Sørensen, Torfing 2004, s. 7]. L. Bruszt sądzi, iż współzarządzanie sieciowe (multilevel governance) może być postrzegane jako sposób zorganizowania różnorodności, włączający w programy rozwojowe interesy, wartości i oczekiwania reprezentowane przez różnych aktorów publicznych i niepublicznych, uczestniczących w tworzeniu i wdrażaniu programów rozwojowych [Bruszt 2008, s. 12].

Termin governance $\mathrm{w}$ szerszym znaczeniu odnosi się do sposobów i praktyk mobilizacji i organizacji wspólnych działań [Cars, Healer, Madanipour, Magalhaes 2002]. Governance oznacza również połączenie w zrównoważony sposób dwóch różnych działań: przewodzenia i zarządzania. Rolą zarządzania jest utrzymanie i administrowanie już istniejącym systemem, przy dbaniu o szczegóły operacyjne. Poprawne zarządzanie (good management) oznacza: 
- dostępność do informacji, procesów i instytucji, dla tych, których bezpośrednio dotyczą podejmowane decyzje;

- przejrzystość wobec obywateli, którym ułatwia się zdobywanie wiedzy o działalności decydentów;

- chęć współpracy/elastyczność wymaganą przez zainteresowane podmioty, które, dzięki możliwości zbierania informacji i monitorowania wyborów menedżerów, oczekują od decydentów by ci działali w ich interesie.

Te trzy elementy są kluczowe dla uzyskania skutecznego i efektywnego działania w zakresie zarządzania, uznanego za uczciwe i odpowiedzialne [Ambruosi et al. 2010, s. 322].

Efektywny metropolitan governance wymaga również kompleksowego i zintegrowanego zarządzania strategicznego, w tym planowania. Wizja rozwoju dla całego obszaru, wykraczająca poza granice pojedynczych jurysdykcji, ma zasadnicze znaczenie nie tylko w kontekście osiągnięcia spójności polityki rozwoju obszaru metropolitalnego, ale także efektywnego osiągania krótko-, średnio-i długookresowych celów tej polityki. I to jest to, co robią liderzy. Ich zadaniem jest zmiana i przekształcenie istniejącego systemu lub stworzenie nowego. $\mathrm{Z}$ tego punktu widzenia dobry governance polega $\mathrm{w}$ praktyce na inspirowaniu politycznego przywództwa, które $\mathrm{z}$ jednej strony daje społeczeństwu możliwość pokojowego rozwiązywania sporów i konfliktów, a z drugiej integruje je w procesie realizowania wspólnie wypracowanych zamierzeń. Aktywne zaangażowanie społeczeństwa, poprzez swoje jak największe uczestnictwo, uprawomocnia przywództwo. Liderzy natomiast muszą działać we współpracy z menedżerami, ponieważ ich funkcje wzajemnie się uzupełniają. Good governance w rzeczywistości potrzebuje jednocześnie osób, które „robią właściwe rzeczy” i ludzi, którzy "robią rzeczy we właściwy sposób” [Ambruosi et al. 2010, s. 322].

Aby doprecyzować, o co dokładnie chodzi, gdy mówimy o dobrym współdziałaniu (good governance), określono siedem głównych elementów, które powinien uwzględniać system good governance (tab. 8).

Urban governance jest sumą wielu sposobów w jakie osoby i instytucje, sektor publiczny i prywatny, planują i zarządzają wspólnymi sprawami miasta. Jest to ciągły proces, w którym sprzeczne i różnorodne interesy mogą zostać uwzględnione a wspólne działania mogą zostać podjęte. Obejmuje on zarówno formalne instytucje, jak i nieformalne układy oraz kapitał społeczny obywateli.

Urban governance jest nierozerwalnie związany z dążeniem do dobrobytu obywateli. Dobry urban governance musi umożliwić kobietom i mężczyznom dostęp do korzyści z obywatelstwa miejskiego. Dobry urban governance, oparty na zasadzie miejskiego obywatelstwa, zakłada, że żaden człowiek nie może być pozbawiony dostępu do produktów i usług zaspokajających podstawowe potrzeby życia w mieście, w tym odpowiedniego schronienia, 
bezpieczeństwa własności, czystej wody, kanalizacji, czystego środowiska, zdrowia, edukacji i wyżywienia, zatrudnienia oraz bezpieczeństwa publicznego i mobilności. Poprzez dobry urban governance zapewnia się obywatelom platformę, która pozwoli im na pełne wykorzystanie ich talentów do poprawy warunków społecznych i ekonomicznych [Good... 2000]. Governance wykracza poza poprawę usług publicznych, by skoncentrować się na podniesieniu jakości życia ludzi [Governance... 2006].

Tabela 8

Elementy governance

\begin{tabular}{|l|l|}
\hline Elementy governance & Kwestie \\
\hline Instytucje i prawo & $\begin{array}{c}\text { Kto stanowi i wprowadza w życie przepisy? Jakie to są przepisy } \\
\text { i jakie są kary za ich łamanie? Kto rozwiązuje spory? }\end{array}$ \\
\hline $\begin{array}{c}\text { Prawo uczestnictwa } \\
\text { i reprezentacji }\end{array}$ & $\begin{array}{c}\text { Jak społeczeństwo może wpływać lub określać stanowione przepi- } \\
\text { sy? Kto reprezentuje obywateli, którzy są zainteresowani lub } \\
\text { których dotyczą decyzje odnośnie do spraw publicznych? }\end{array}$ \\
\hline $\begin{array}{l}\text { Poziom władzy } \\
\text { Na jakim poziomie powinna być sprawowana władza dotycząca } \\
\text { kwestii lokalnych/regionalnych? }\end{array}$ \\
\hline $\begin{array}{l}\text { Odpowiedzialność } \\
\text { i jawność }\end{array}$ & $\begin{array}{l}\text { W jaki sposób osoby podejmujące decyzje są za nie odpowiedzial- } \\
\text { ne? }\end{array}$ \\
\hline $\begin{array}{l}\text { Prawa własności } \\
\text { Kto jest właścicielem zasobów naturalnych lub ma prawo je kontro- } \\
\text { lować? }\end{array}$ \\
\hline $\begin{array}{l}\text { Rynki i przepływy } \\
\text { finansowe }\end{array}$ & $\begin{array}{l}\text { W jaki sposób praktyki finansowe, polityki gospodarcze i rynki } \\
\text { wpływają na władzę publiczną? }\end{array}$ \\
\hline $\begin{array}{l}\text { Nauka i ryzyko } \\
\text { Jak nauki ekologiczne i społeczne są włączone w proces podejmo- } \\
\text { wania decyzji w celu ograniczania ryzyka dla ludzi } \\
\text { i ekosystemów? }\end{array}$ \\
\hline
\end{tabular}

Źródło: [World resources... 2003, s. 7].

W powyższych rozważaniach pojawiają się pojęcia urban governance, multilevel governance i metropolitan governance. Można uznać, że na metropolitan governance składa się urban/local governance oraz multilevel governance. Urban governance dotyczy współdziałania różnych interesariuszy w ramach jednej jednostki terytorialnej, natomiast multilevel governance dodatkowo włącza współpracę z podmiotami z innych poziomów władzy. Obszary metropolitalne składają się $\mathrm{z}$ wielu jednostek terytorialnych, z których każda powinna funkcjonować na podstawie swojego systemu local governance, ale oprócz tego istotną rolę odgrywają w nich władze regionalne oraz rząd centralny, które tworzą z władzami lokalnymi system współrządzenia wielopoziomowego (multilevel governance).

S. Davoudi i współpracownicy definiują governance przez pryzmat terytorium. Traktowane jest ono dwojako. Po pierwsze, jako struktura polityczna i społeczna, po drugie, jako kapitał terytorialny. Jako struktura społeczno-polityczna jest wynikiem wspólnych działań zorganizowanych grup interesów i instytucji terytorialnych, podjętych po to, aby rozwiązać wspól- 
ne problemy, będących pod wpływem interakcji zachodzących między poszczególnymi aktorami. W tym kontekście governance oznacza zdolność interesariuszy do osiągania konsensusu w ustalaniu celów dotyczących przyszłości terytorium i współpracy w celu ich osiągnięcia.

W podejściu do terytorium jako kapitału terytorialnego zróżnicowanie terytorialne wpływa na zdolność do promowania i przyciągania inwestycji. Governance rozumiany jest wówczas jako terytorialna organizacja wynikająca z relacji charakteryzujących interakcje miedzy aktorami. Ta wizja, zbudowana dzięki uznaniu i wzbogaceniu kapitału terytorialnego, promuje zrównoważoną spójność terytorialną $\mathrm{w}$ ramach podejścia wieloskalowego, przy jednoczesnym poszanowaniu zasady pomocniczości [Davoudi et al. 2008].

Na jakość governance w kategoriach efektywnego administrowania oraz otwartych i odpowiedzialnych polityków kładzie się w ostatnich latach coraz większy nacisk. To sprawia, że pojawiają się dwa dalsze cele. Po pierwsze, wytworzenie efektywnego i responsywnego procesu podejmowania decyzji wobec gwałtownie zmieniających się okoliczności. Po drugie, podniesienie jakości lokalnych demokracji. Jest to kolejny sposób na osiągnięcie przez miasta przewagi nad innymi oraz na wygenerowanie wartości dodanej do swoich działań.

Wreszcie governance szuka nowych sposobów bycia kreatywnym, budowania silnych stron oraz pozyskiwania i wykorzystywania zasobów. W skali lokalnej możemy znaleźć próby zidentyfikowania i wykorzystania lokalnej wiedzy, budowania instytucjonalnych kompetencji, rozwoju kapitału społecznego, a wszystko po to, aby wykorzystać to jako narzędzia, za pomocą których można rozwiązać lokalne problemy, zaspokoić lokalne potrzeby i osiągnąć społeczne włączenie wykluczonych jednostek poprzez kreatywne zatrudnienie, przy minimalnej interwencji państwa.

Na konieczność wdrożenia koncepcji współrządzenia w obszarach metropolitalnych wskazują również dokumenty przyjęte przez Unię Europejską:

1. Agenda Terytorialna Unii Europejskiej (Territorial Agenda of the European Union - TAEU).

2. Karta Lipska n.t. Zrównoważonych Miast Europejskich.

Agenda Terytorialna nie ma charakteru obligatoryjnego, ale stanowi strategiczne i zorientowane na działanie ramy dla terytorialnego rozwoju Europy, w tym dla krajowych polityk rozwoju przestrzennego. Dokument przyczynić się ma do trwałego wzrostu gospodarczego oraz tworzenia miejsc pracy, jak również do społecznie i ekologicznie zrównoważonego rozwoju poprzez wzmocnienie spójności terytorialnej Europy. Celem Agen$d y$ jest wzmocnienie globalnej konkurencyjności i zrównoważenie wszystkich regionów Europy poprzez zidentyfikowanie i zmobilizowanie ich terytorialnych potencjałów. W dokumencie zostały wyznaczone następujące priorytety: 
1. Wzmacnianie rozwoju policentrycznego oraz innowacji poprzez tworzenie sieci współpracy regionów miejskich i miast.

2. Nowe formy partnerstwa i zarządzania terytorialnego pomiędzy obszarami wiejskimi i miejskimi.

3. Wspieranie regionalnych klastrów (gron) konkurencyjności i innowacji w Europie.

4. Wzmacnianie i rozbudowa sieci transeuropejskich.

5. Wspieranie transeuropejskiego zarządzania ryzykiem, z uwzględnieniem efektów zmian klimatycznych.

6. Wzmacnianie struktur ekologicznych i zasobów kulturowych jako wartości dodanej dla rozwoju.

Z priorytetów tych wynika, że jednym z bardziej istotnych elementów, które mają się przyczynić do rozwoju spójności terytorialnej, jest współpraca regionów miejskich, w co niewątpliwie wpisują się obszary metropolitalne. Zwraca się też uwagę na konieczność znajdowania nowych form partnerstwa i zarządzania w obszarach metropolitalnych.

Osiągnięcie spójności terytorialnej możliwe jest wyłącznie poprzez intensywny i stały dialog pomiędzy wszystkimi interesariuszami rozwoju terytorialnego. Tego rodzaju proces współpracy nazywamy zarządzaniem terytorialnym. Sektor prywatny (a zwłaszcza przedsiębiorstwa działające w danym regionie lub miejscowości), środowisko naukowe, sektor publiczny (w szczególności władze lokalne i regionalne), organizacje pozarządowe, a także poszczególne sektory muszą działać wspólnie na rzecz lepszego wykorzystania najważniejszych inwestycji w europejskich regionach i rozwiązywania problemów związanych ze zmianami klimatycznymi [Agenda... 2007].

Agenda zaleca, by miasta centralne danego obszaru współpracowały jako elementy składowe systemu policentrycznego, aby umożliwić korzystanie z generowanej przez nie wartości dodanej innym ośrodkom położonym w sąsiedztwie. W celu ułatwienia tego procesu konieczne jest rozszerzenie i stałe aktualizowanie sieci infrastruktury.

Zgodnie z zasadą partnerstwa, odpowiednie władze, jako wzajemnie zależni od siebie partnerzy, winny rozpoznać wspólne aktywa, opracować wspólne strategie rozwoju na szczeblu regionalnym i lokalnym by $\mathrm{w}$ ten sposób wspólnie stworzyć podstawy zwiększania atrakcyjności obszaru metropolitalnego oraz warunki zachęcające do podejmowania decyzji inwestorskich zarówno ze strony sektora prywatnego, jak i publicznego [Agenda... 2007]. Decyzje o ulokowaniu inwestycji powinny być podejmowane wspólnie przez aktorów z sektora prywatnego i publicznego. W tym kontekście konieczne jest tworzenie, na przykład przez lokalne władze, wspólnych stowarzyszeń, mających na celu wspólną promocję oraz opracowanie strategii rozwiązywania wspólnych problemów. Ze względu na zmiany demogra- 
ficzne (starzenie się społeczeństw), jak również migracje pomiędzy rynkami pracy i wewnątrz nich, władze muszą ściśle ze sobą współpracować, aby być w stanie utrzymać na atrakcyjnym poziomie usługi użyteczności publicznej i infrastrukturę, co może przyciągnąć młodych obywateli. Tego rodzaju współpraca jest nowym zjawiskiem w upolitycznionych strukturach władzy i dla jej wzmocnienia niezbędne staje się zastosowanie nowych form zarządzania publicznego (governance) w obszarach metropolitalnych.

Karta Lipska stanowi uzupełnienie Agendy i podejmuje temat polityki zintegrowanego rozwoju obszarów miejskich jako zadania o wymiarze europejskim. Zintegrowane podejście do rozwoju miasta, tworzenie i zapewnianie wysokiej jakości przestrzeni publicznych, aktywna polityka innowacyjna i edukacyjna, promocja skutecznego i korzystnego cenowo transportu, to część z wielu zaleceń zawartych w tym dokumencie [Karta... 2007].

Współdziałanie różnych podmiotów może przyjmować różne formy, co przekłada się na konkretne korzyści dla organizacji (tab. 9). Z tabeli wynika, iż korzyści, jakie przynosi każda z form współdziałania są różne, ale zarazem, że są osiągane niezależnie od jej zakresu i pojawiają się zarówno w przypadku nieformalnych sieci, jak i ścisłych powiązań w ramach partnerskiej współpracy.

Nawiązywanie współpracy o charakterze dobrowolnym między lokalnymi podmiotami ma decydujące znaczenie dla osiągnięcia odpowiedniej jakości w nowoczesnym zarządzaniu lokalnym. Oznacza to fundamentalną zmianę w stosunku do tego, czym był tradycyjny samorząd lokalny, który opierał się na zhierarchizowanych, formalnych procedurach i instytucjach. Chodzi tu jednak o to, że samorząd stracił bezpośrednie uprawnienia władcze do decydowania. Jednocześnie powstał klimat do współpracy różnych aktorów, służący osiąganiu wspólnych celów.

Lokalni aktorzy formułujący i realizujący polityki lokalne tworzą sieci, które mają charakter otwarty (dla innych uczestników), ale jednocześnie często niestabilny. W ich ramach wielokrotnie brak formalnej hierarchii, co skłania do stwierdzenia, że proces budowy zaufania między aktorami ma kluczowe znaczenie dla efektywności funkcjonowania układów lokalnych. Współpraca aktorów oparta na wzajemnym zaufaniu jest niezbędna, ponieważ żadna z organizacji ani nikt $\mathrm{z}$ indywidualnych aktorów nie ma wystarczających zasobów do samodzielnego osiagnięcia swoich celów. A zatem w samym sercu koncepcji lokalnego zarządzania (local governance) leży potrzeba partnerstwa władzy lokalnej i aktorów wywodzących się ze społeczności lokalnej. 
Tabela 9

Rodzaje strategicznych zachowań organizacji nastawionych na współdziałanie

\begin{tabular}{|c|c|c|c|c|c|c|}
\hline Organizacja & 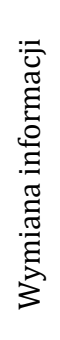 & 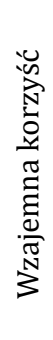 & 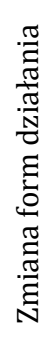 & 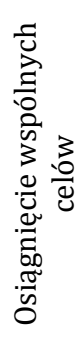 & 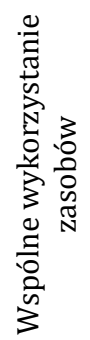 & 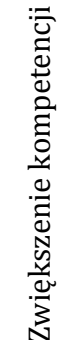 \\
\hline Sieć (networking) & + & + & & & & \\
\hline Koordynacja (co-ordination) & + & + & + & + & & \\
\hline Kooperacja (co-operation) & + & + & + & + & + & \\
\hline Partnerska współpraca (collaboration) & + & + & + & + & + & + \\
\hline
\end{tabular}

Źródło: [Kożuch 2005, s. 13].

Wszystkie wymienione tu pokrótce koncepcje teoretyczne mają jedną ważną, z naszego punktu widzenia, cechę wspólną - zakładają, że współczesne, skuteczne zarządzanie sprawami publicznymi nie może być pozostawione wyłącznie władzom publicznym. Samorządy mają więc ważną rolę do odegrania, ale nie będą w stanie się z niej wywiązać, o ile nie będą umiały współpracować $\mathrm{z}$ innymi aktorami, w tym przede wszystkim tymi wywodzącymi się ze społeczności lokalnej. Z punktu widzenia administracji publicznej, do szczególnych zalet local governance należy:

- zdolność do elastycznego reagowania na zmieniające się uwarunkowania lokalne [Giguere 2003, s. 22],

- osiągnięcie niższych kosztów poprzez stymulowanie wspólnych działań [Ostrom 1998],

- zmniejszenie kosztów transakcji związanych z rozdrobnionym świadczeniem usług [Sullivan, Skelcher 2002, s. 20],

- wzrost legitymizacji poprzez zwiększenie udziału w podejmowaniu decyzji [Rhodes 1990].

Z kolei metropolitan governance charakteryzuje się następującymi cechami:

- uczestnictwem społeczeństwa,

- bardziej kompromisowym niż antagonistycznym stylem polityki,

- silną reprezentacją,

- dominującym wzorcem publicznej przedsiębiorczości,

- zróżnicowaniem społeczności i samouporządkowaniem mieszkańców,

- wzorcami odpowiedzialności, które znacznie wzmacniają zdolność indywidualnych osób do samorządności (self-governance). 
W literaturze przedmiotu badacze stwierdzają, że metropolitan governance może istnieć, i istnieje, bez jednolitej metropolitalnej administracji publicznej i może być efektywny nawet wówczas, gdy obszar metropolitalny cechuje się wysokim rozdrobnieniem między dużą liczbę gmin ${ }^{42}$. Obszary metropolitalne są w stanie tworzyć struktury zarządzania nie uwikłane $\mathrm{w}$ formę pojedynczego dominującego metropolitalnego rządu [Oakerson 2004, s. 17].

\section{Interesariusze metropolitan governance}

W najbardziej ogólnym znaczeniu interesariusz ${ }^{43}$ to każda grupa lub osoba, która wpływa lub podlega wpływowi osiąganych przez organizację celów [Freeman, McVea 2001, s. 4]. Są to podmioty, które spełniają następujące kryteria:

- wysuwają żądania wobec organizacji,

- dysponują faktyczną lub hipotetyczną możliwością ich wyegzekwowania,

- mają chęć wykorzystania swojej siły wpływu na proces decyzyjny organizacji w celu realizacji swych żądań [Mendel 2000].

R. Mitchell, B. Agle i D. Wood [1997] do głównych charakterystyk interesariuszy determinujących ich wpływ na organizację zaliczają:

- siłę - rozumianą jako możliwość oddziaływania na organizację,

- legalność relacji między podmiotem a organizacją, wynikającą z prawa,

- pilność roszczeń.

Każdy interesariusz ma określoną pozycję i siłę oddziaływania w stosunku do organizacji, przy czym mogą one ulegać różnym transpozycjom. Podkreślenia wymaga także fakt, że katalog interesariuszy może być zmienny. Przez interesariuszy w koncepcji corporate governance rozumiemy akcjonariuszy, kadrę zarządzającą, banki, pracowników, kredytodawców, związki zawodowe, klientów, dostawców, konkurentów, administrację rządową, konsumentów, media, społeczności lokalne, organizacje społeczne. Każdy z tych podmiotów ma swoje partykularne, często sprzeczne interesy.

Analogicznie do koncepcji corporate governance można określić interesariuszy w metropolitan governance. Wyróżniamy wśród nich:

- Władze lokalne i regionalne - dokonują określonych inwestycji (np. w infrastrukturę) po to, by przyciągnąć firmy i osiągnąć korzyści z ich działalności na tym terenie. Władze lokalne podlegają najsilniejszej presji ze strony lokalnej społeczności.

42 Zob.: Oakerson 1999; Parks, Oakerson 2000.

${ }^{43} \mathrm{~W}$ literaturze funkcjonują różne określenia, które pochodzą od ang. stakeholders, co tłumaczone jest jako interesariusze, podmioty, oddziaływacze, grupy interesu, aktorzy. Autorka używa tych określeń wymiennie. 
- Przedsiębiorstwa - oddziałują pozytywnie (tworząc miejsca pracy, a co za tym idzie generując dochody), jak i negatywnie (zanieczyszczenia środowiska).

- Państwo i administrację rządową - w interesie państwa leży funkcjonowanie atrakcyjnych i zrównoważonych finansowo jednostek terytorialnych zapewniających właściwe warunki życia mieszkańców.

- Uczelnie i ośrodki badawcze, które odnoszą korzyści z pewnych aspektów rozwoju miasta i rozrastających się funkcji metropolitalnych oraz poprawiają dostępność do rynku usług edukacyjnych w obszarze. Odpowiednie zaplecze naukowo-badawcze dla przemysłu powoduje, że miasto postrzegane jest jako bardziej atrakcyjne dla przedsiębiorczości.

- Kluby sportowe - rozwijające się miasto stanowi źródło klientów klubów sportowych, mieszkańcy chodzą na mecze, z drugiej strony istnienie klubów sportowych na obszarze metropolitalnym przyciąga zainteresowanych ich działalnością obywateli. Drużyny sportowe zazwyczaj noszą lokalne nazwy, a co za tym idzie budują ducha wspólnoty i budzą potrzebę wspierania własnego środowiska w konkurencyjnej walce z innymi.

- Deweloperów - Logan i Molotch [1987] uważają, że lokalni właściciele nieruchomości są głównymi aktorami w obszarach metropolitalnych, ponieważ to oni mogą stracić lub zyskać najwięcej w zależności od lokalnego prosperity. Decyzja o lokalizacji zakładu produkcyjnego, przebiegu autostrady czy o utworzeniu specjalnej strefy ekonomicznej wpływa na zmianę wartości określonego terenu.

- Właściciele firm budowlanych - zainteresowani otrzymywaniem od władz lokalnych intratnych kontraktów - starają się wpływać na politykę władz tak, aby zwiększać liczbę sprzyjających im projektów.

- Organizacje pozarządowe - będąc reprezentacjami obywateli działającymi na rzecz interesu publicznego - tworzą tzw. trzeci sektor, obok sektora publicznego i rynkowego, który często wspomaga władze publiczne w realizowaniu przypisanych im zadań (kultura, edukacja, opieka społeczna itp.).

- Agencje rozwoju - często stanowią kluczowe ogniwo w sieci powiązań metropolitalnych, odpowiadając za przyciągnięcie inwestorów, pozyskiwanie środków finansowych i wdrażanie programów pomocowych.

- Instytucje szkoleniowe - mogą pomagać budować kapitał intelektualny i społeczny w regionie.

- Instytucje kultury - są zainteresowane rozwojem miasta, przyciągnięciem nowych obywateli, a z drugiej strony mogą stanowić o atrakcyjności danego ośrodka.

- Organizacje pracodawców - często stanowią silną grupę interesów, która wpływa na decyzje podejmowane przez samorządy.

- Drobnych kupców i ich zrzeszenia - starają się powstrzymać ekspansję wielkich sieci handlowych. 
- Lokalne media - z samego ich charakteru wynika zainteresowanie rozwojem obszaru metropolitalnego, gdyż jedynym sposobem na zwiększenie ich zysków jest zwiększenie liczby odbiorców.

- Organizacje ponadnarodowe, np. UE - w dobie globalizacji reguły tworzone przez organizacje ponadnarodowe stanowią ramy funkcjonowania większości podmiotów na niższych poziomach zarządzania. Na poziomie metropolitalnym najistotniejsze znaczenie ma możliwość finansowania zadań o znaczeniu metropolitalnym przez środki unijne. Często jest to główny bodziec do podjęcia współpracy przez innych interesariuszy.

- Indywidualnych obywateli, którzy będąc mieszkańcami danej jednostki terytorialnej korzystają z dóbr i usług świadczonych przez jej władze, mają konkretne oczekiwania, a poprzez system wyborów decydują o charakterze tej władzy.

Różnorodność aktorów będących partnerami w metropolitalnym zarządzaniu powoduje, że trudno jest zaspokoić tak zróżnicowane interesy, sukces governance $\mathrm{w}$ znacznym stopniu zależy więc od typu interesariuszy. $\mathrm{Z}$ jednej strony mamy olbrzymią liczbę organizacji publicznych (należą do nich samorządy wszystkich gmin wchodzących w skład obszaru metropolitalnego oraz samorząd wojewódzki), z drugiej zaś strony rzeszę użytkowników tego obszaru, wśród których znajdują się przedsiębiorstwa, organizacje społeczne, NGOs, mieszkańcy itp. Nieuchronnie prowadzi to do powstawania ogromnej liczby wspólnot interesu, a co za tym idzie - konfliktów. W zarządzaniu, obok odmiennych interesów podmiotów, występują różnice interesów pomiędzy nimi a interesem obszaru jako całości. Działalność instytucji odpowiedzialnych za rozwój metropolii powinna zmierzać do godzenia tych interesów między sobą, a równocześnie do zapewnienia ich zbieżności z naczelnym interesem metropolii [Wojciechowski 2003, s. 98].

Obecnie źródłem przewag konkurencyjnych przedsiębiorstw przestały być czynniki zależne od kadry menedżerskiej, wynikające np. ze sprawnych procesów zarządczych czy też rzetelnych analiz otoczenia, gdyż usprawnienia te daje się szybko skopiować i wykorzystać w innych przedsiębiorstwach w innych częściach świata. Źródłem przewag jest obecnie otoczenie w jakim przedsiębiorstwa funkcjonują. Na to otoczenie składają się takie elementy, jak kapitał ludzki, relacje sieciowe, powiązania, w których firmy funkcjonują. W tej sytuacji coraz większą rolę w organizowaniu środowiska biznesowego zaczynają odgrywać władze publiczne. Władze mogą działać dwojako, a mianowicie sprzyjać pozytywnym procesom lub je blokować.

W teorii reżimu miejskiego Stone’a najważniejszym partnerem władz lokalnych są wpływowi przedsiębiorcy działający na terenie miasta. Oba podmioty mają zasoby, które są konieczne do sprawowania władzy. W przypadku samorządów lokalnych jest to prawomocność (legitimacy) umożliwiająca realizowanie polityk. W przypadku przedsiębiorstw jest to 
kapitał, który generuje miejsca pracy, dochody z podatków i jest źródłem dodatkowych finansów dla samorządu. Według pierwotnego modelu miasta przedsiębiorcze władze i lokalny biznes są włączone w bliską współpracę spowodowaną obopólnym zainteresowaniem promowaniem lokalnego rozwoju gospodarczego. Dochody władz miasta zależą od rozwoju i wzrostu, a ich źródłem są m.in. podatki lokalne od osób prawnych. Jednocześnie istnieją wpływowi lokalni corporate aktorzy (właściciele gruntów, deweloperzy), których zainteresowanie handlowe (commercial interest) może być pogłębione tylko za sprawą lokalnego wzrostu gospodarczego. W takich warunkach społeczno-ekonomicznych istnieją silne obustronne zależności między prywatnymi i publicznymi aktorami, którzy wyraźnie preferują współpracę jako instrument do osiągnięcia wspólnych celów [Stone 1989, s. 7]. Iwona Sagan [2000, s. 175] zwraca szczególną uwagę na rolę kapitału zagranicznego, który jest pożądany przez większość jednostek terytorialnych, a co za tym idzie, międzynarodowe firmy bez trudu zdobywają dominującą pozycję w reżimie miejskim.

Mossberger i Stoker twierdzą, że w krajach europejskich obok przedsiębiorców większą niż w USA rolę odgrywają inni aktorzy: pracownicy administracji, grupy sąsiedzkie czy organizacje pozarządowe [Mossberger, Stoker 2001, s. 820].

Wśród badaczy trzeciego sektora można zauważyć dychotomiczne spojrzenie na jego rolę w funkcjonowaniu państwa. Jedni postrzegają jego istnienie jako opozycyjne wobec państwa, uznając je za oddzielną społeczną siłę [Norton 1991, s. 50-54], inni zaś dowodzą, iż dla krajów rozwiniętych charakterystyczne jest partnerstwo i współzależność między sektorami [Salamon, Anheier 1997, s. 60-65]. To drugie podejście jest ewidentnie podstawą relacji, jakie występują w obszarach metropolitalnych, w których wdrażana jest koncepcja governance. Powszechne jest wchodzenie organizacji pozarządowych $\mathrm{w}$ różne formy partnerstwa $\mathrm{z}$ sektorem publicznym. Polega ono nie tylko na wspólnym organizowaniu przez instytucje administracji publicznej i organizacje pozarządowe jednorazowych przedsięwzięć (koncerty charytatywne, akcje sprzątania świata itp.), lecz na przekazywaniu NGOs części zadań publicznych. Organizacje pozarządowe, występujące w roli partnera i kooperanta instytucji publicznych, biorą udział w podejmowaniu decyzji dotyczących usług publicznych oraz w kształtowaniu polityki publicznej [Bogacz-Wojtanowska 2005, s. 99].

Wśród aktorów współpracujących na poziomie lokalnym często znajduje się rząd centralny. Taka sytuacja obserwowana jest np. we Francji ze względu na udział władz centralnych w planowaniu lokalnym [Levine 1994], w Wielkiej Brytanii, gdzie rząd sponsoruje partnerstwo publiczno-prywatne w postaci korporacji rozwoju obszarów miejskich czy rad przedsiębiorców i szkoleń [Stewart 1996; Ward 1996]. 
Modelem relacji między władzami (government) a governance, który najlepiej pasuje do wysoce sfragmentaryzowanych obszarów metropolitalnych, jest model policentryczny ${ }^{44}$. Policentryzm oznacza proces podejmowania decyzji, $\mathrm{w}$ którym wiele niezależnych pomiotów współdziała, aby uzyskać rezultat, który jest powszechnie ceniony. Jest to przeciwstawne do modelu monocentrycznego, w którym pojedynczy podmiot dostarcza wytycznych innym. Policentryzm opisuje więc model governance, który wyłania się z wzajemnych relacji między wieloma niezależnymi ośrodkami władzy, podczas gdy monocentryzm stanowi model zarządzania przez pojedynczy ośrodek władzy [Ostrom 1989]. Model policentryczny dopuszcza do udziału również aktorów spoza władz, którzy mogą produktywnie włączyć się w proces governance. Policentryczny governance uzależniony jest od dwóch instytucjonalnych warunków związanych z projektowaniem. Pierwszym z nich jest istnienie wielu niezależnych ośrodków władzy, drugi zakłada, że ich niezależność nie jest absolutna. Każda władza musi podlegać pewnym ograniczeniom i musi być możliwe wprowadzanie nowych ograniczeń. Takie ograniczenia istnieją w rozpoznawaniu współzależności wśród gmin tworzących obszar metropolitalny i służą do zastrzeżenia niezależności różnych ośrodków władzy. Zatem policentryzm oznacza system umiarkowanej niezależności wśród współzależnych ośrodków władzy [Oakerson 2004, s. 22]. Utrzymanie tych ograniczeń i przyjętego stopnia niezależności stanowi istotną podstawę do formowania struktur metropolitan governance. Dla gmin takie granice ustalają przede wszystkim przepisy prawa, które normują ich funkcjonowanie tworząc ramy instytucjonalne i regulują współzależności między różnymi jednostkami terytorialnymi, koegzystującymi w obszarze metropolitalnym. Regulacje prawne $\mathrm{z}$ jednej strony ograniczają niezależność gmin, ale jednocześnie chronią je przed arbitralnym nadzorem i kontrolą administracji rządowej, tym samym podtrzymując ich autonomię [Oakerson 2004, s. 26].

Partycypacyjny model metropolitan governance jest konieczny, aby stworzyć zintegrowany obszar metropolitalny. Model partycypacyjny opiera się na zasadach dobrego współrządzenia (sustensywności, subsydiarności, równości, sprawności, przejrzystości i odpowiedzialności, zaangażowania obywatelskiego). Aby model ten dobrze funkcjonował, należy zastosować instrumenty, które zwiększą zaangażowanie społeczeństwa (partycypacyjne budżetowanie, walka z korupcją itd.) [UN-HABITAT 2002, s. 33].

44 Zob.: Ostrom, Tiebaut, Warren 1961; Ostrom 1972. 


\section{Zasady zarządzania $w$ obszarach metropolitalnych (metropolitan governance)}

Nie ma jednoznacznej odpowiedzi na pytanie, w jaki sposób wdrożyć taki model governance, który byłby uniwersalnym rozwiązaniem wszystkich problemów zarówno w przedsiębiorstwach, jak i w innych organizacjach. Można jednak określić kilka ogólnych zasad, które powinny znaleźć się u podstaw tworzenia takiego modelu.

Wiele źródeł proponuje kryteria oceny tego, co można nazwać good governance. Biała Księga na temat Good Governance, przyjęta przez Komisję Europejską w roku 2001, przewiduje pięć zasad przewodnich:

1. Otwartość - instytucje powinny działać w bardziej otwarty sposób.

2. Uczestnictwo - jakość, trafność i efektywność realizowanych polityk zależy od zapewnienia szerokiej partycypacji $\mathrm{w}$ procesie formułowania polityk, od koncepcji do wdrożenia.

3. Odpowiedzialność - role w procesach ustawodawczych i wykonawczych muszą być jaśniej określone. Każda instytucja musi wyjaśniać i odpowiadać za to, co robi.

4. Efektywność - polityki muszą być efektywne i trzymać się ustalonych ram czasowych, zaspokajanie potrzeb opierając na jasnych celach, ocenie oddziaływania w przyszłości i, jeśli to możliwe, wcześniejszych doświadczeniach.

5. Spójność - polityki i działania muszą być spójne i łatwo zrozumiałe [Commission... 2001, s. 10].

Program Rozwoju Narodów Zjednoczonych (UNDP) ogłosił zestaw zasad, które pojawiają się najczęściej w literaturze i wydają się dostarczać pewnych uniwersalnych wartości (tab. 10).

Oprócz wymienionych powyżej zasad, na których powinien bazować każdy demokratyczny rząd, różne instytucje międzynarodowe sformułowały zasady governance dotyczące miast i obszarów metropolitalnych.

Globalna kampania na rzecz urban governance, prowadzona przez UN Habitat, proponuje następujący zestaw wytycznych:

1. Trwałość we wszystkich obszarach rozwoju miasta;

2. Subsydiarność władz i zasobów na najniższym, odpowiednim poziomie;

3. Równość dostępu do procesu podejmowania decyzji dotyczących życia w mieście;

4. Efektywność w dostarczaniu usług publicznych i w promowaniu lokalnego rozwoju gospodarczego;

5. Jawność i odpowiedzialność osób podejmujących decyzje i wszystkich pozostałych podmiotów;

6. Zaangażowanie obywateli - ludzie są podstawowym bogactwem miast. Są oni zarówno podmiotem, jak i przedmiotem osiągnięcia zrównoważonego rozwoju; 
7. Bezpieczeństwo jednostek i środowiska, w którym one żyją [http:// www.unhabitat.org/content.asp?typeid=19\&catid=25\&cid=2097].

Tabela 10

Pięć zasad good governance

\begin{tabular}{|c|c|}
\hline Zasada & $\begin{array}{l}\text { Zasady UNDP i odpowiadające im definicje, } \\
\text { na których zostały one oparte }\end{array}$ \\
\hline $\begin{array}{l}\text { Prawomocności/ } \\
\text { legalności i głosu } \\
\text { (Legitimacy and } \\
\text { voice })\end{array}$ & $\begin{array}{l}\text { Partycypacja - wszyscy ludzie powinni mieć prawo do zabrania głosu } \\
\text { w procesie podejmowania decyzji bezpośrednio lub poprzez upra- } \\
\text { womocnione instytucje, które reprezentują ich poglądy. Tak szeroka } \\
\text { partycypacja jest zbudowana zarówno w oparciu na wolności mowy } \\
\text { i stowarzyszeń, jak i zdolności do konstruktywnego uczestnictwa. } \\
\text { Orientacja na porozumienie (consensus orientation) - good governance } \\
\text { łączy różne interesy w celu osiągnięcia szerokiego konsensusu na } \\
\text { bazie tego, co jest najlepsze dla danej społeczności i, gdzie to tylko } \\
\text { możliwe, na bazie polityk i procedur. }\end{array}$ \\
\hline $\begin{array}{l}\text { Ukierunkowania } \\
\text { (Direction) }\end{array}$ & $\begin{array}{l}\text { Wizja strategiczna - liderzy i społeczność mają szerokie i długofalowe } \\
\text { spojrzenie na good governance i rozwój człowieka, przy jednocze- } \\
\text { snym zrozumieniu tego, co jest potrzebne do takiego rozwoju. Jed- } \\
\text { nocześnie jest on oparty na zrozumieniu kompleksowości czynni- } \\
\text { ków historycznych, kulturowych i społecznych, na których ta wizja } \\
\text { jest tworzona. }\end{array}$ \\
\hline $\begin{array}{l}\text { Skuteczn } \\
\text { (Perform }\end{array}$ & $\begin{array}{l}\text { Responsywność - instytucje i procedury postępowania mają służyć } \\
\text { wszystkim aktorom. } \\
\text { Efektywność i sprawność - rezultatem podjętych działań ma być } \\
\text { zaspokojenie potrzeb społeczności przy jednoczesnym jak najlep- } \\
\text { szym wykorzystaniu zasobów. }\end{array}$ \\
\hline $\begin{array}{l}\text { Odpowie } \\
\text { (Account }\end{array}$ & $\begin{array}{l}\text { Odpowiedzialność - osoby podejmujące decyzje we władzach, sekto- } \\
\text { rze prywatnym czy organizacjach społeczeństwa odpowiadają za- } \\
\text { równo przed społeczeństwem, jak i instytucjami. Odpowiedzialność } \\
\text { ta może być różna w zależności od rodzaju organizacji } \\
\text { i tego, czy decyzja dotyczy wewnętrznego jej funkcjonowania, czy } \\
\text { też oddziałuje na otoczenie. } \\
\text { Przejrzystość/jawność - przejrzystość budowana jest w oparciu } \\
\text { na swobodnym przepływie informacji. Procedury, instytucje } \\
\text { i informacje są bezpośrednio dostępne dla wszystkich, których do- } \\
\text { tyczą, w formie zrozumiałej i umożliwiającej ich monitorowanie. }\end{array}$ \\
\hline $\begin{array}{l}\text { Sprawiedliwości } \\
\text { (Fairness) }\end{array}$ & $\begin{array}{l}\text { Równość - wszyscy mężczyźni i kobiety mają takie same możliwości } \\
\text { ulepszania lub podtrzymywania swojego dobrobytu. } \\
\text { Zasady prawa - przepisy prawa powinny być rozsądne i przestrzega- } \\
\text { ne bez wyjątku, szczególnie przepisy praw człowieka. }\end{array}$ \\
\hline
\end{tabular}

Źródło: opracowanie własne na podstawie [Graham, Amos, Plumptre 2003].

Również OECD ogłosiło zasady, które powinny być stosowane do zarządzania obszarami metropolitalnymi (OM) w wieku XXI:

- Miasta dla mieszkańców - miasta powinny się rozwijać nie tylko ze względów ekonomicznych, ale także po to, aby spełnić aspiracje ludności do 
lepszej jakości życia, poprzez środki, które mogą również utrzymać i wzmocnić atrakcyjność oraz żywotność miast.

- Spójność polityki - cele i ramy instytucjonalne metropolitan governance powinny być dostosowane do, i koncentrować się na, najważniejszych problemach lokalnych (rozwój gospodarczy, dostępność mieszkań, zatłoczenie, rozprzestrzenianie się miast, bezpieczeństwo, jakość środowiska, regeneracja terenów zdegradowanych), które powinny być poruszane jednocześnie, z uwzględnieniem zachodzących między nimi powiązań i kompromisów.

- Zasada rozwoju endogenicznego - rola regionów miejskich jako głównych jednostek w światowej gospodarce umacnia się. Wraz z likwidacją barier handlowych i wzrostem mobilności czynników produkcji, na poziomie metropolitalnym należy położyć nacisk na inwestowanie $\mathrm{w}$ rozwój społeczny oraz ludzki i odpowiednio: w twardą i miękką infrastrukturę zamiast ograniczania podatków jako instrumentu mającego przyciągnąć inwestorów. Te lokalne zasoby mają być źródłem konkurencyjności w stosunku do innych regionów.

- Zasada koordynacji - ze względu na fakt, iż administracja w obszarach metropolitalnych jest rozdrobniona, priorytetem powinna stać się koordynacja działań wszystkich organów władzy i innych rad czy agencji działających w regionie, uwzględniająca zarówno funkcjonalny, jak i sektorowy zakres odpowiedzialności.

- Zasada równości - rozwiązania organizacyjne i finansowe w regionach metropolitalnych muszą być zaprojektowane w sposób, który zapewni możliwie jak największą sprawiedliwość i jednakowe możliwości dla wszystkich jednostek terytorialnych wchodzących w skład OM oraz wszystkich grup społecznych składających się na populację regionu. Należy unikać segregacji przestrzennej i ułatwiać integrację terenów problemowych.

- Zasada fiskalnej uczciwości - każdy system podatkowy musi być tworzony z pełną świadomością, iż koszty rządzenia w OM muszą znaleźć swoje odzwierciedlenie w korzyściach. Należy również zagwarantować, że wszystkie części obszaru metropolitalnego będą uwzględniane w ocenie odpowiedniego poziomu kosztów i korzyści świadczenia usług publicznych.

- Zasada elastyczności - instytucje muszą być otwarte na zmiany spowodowane np. technologicznymi innowacjami, rozwojem przestrzennym, globalizacją i dostosowywać się do nich. Perspektywiczne podejście jest również niezbędne do zapewnienia elastyczności oraz właściwego planowania strategicznego.

- Zasada holizmu - system zarządzania musi odzwierciedlać potencjał i potrzeby całego obszaru metropolitalnego, który stanowi obszar definiujący gospodarcze i środowiskowe wyzwania. 
- Zasada szczególności - polityki i instytucje władzy muszą być dopasowane do szczególnych okoliczności występujących w różnych częściach kraju. Ma to również zwiększyć ich skuteczność.

- Zasada partycypacji - biorąc pod uwagę rosnące zróżnicowanie oraz rozmiar obszarów metropolitalnych, współrządzenie musi pozwolić na uczestnictwo reprezentacji różnych grup społecznych (kobiet, ludzi starszych, młodzieży, sektora biznesu, partnerów społecznych i wszystkich szczebli władzy).

- Zasada społecznego nastawienia w organizowaniu struktur zarządzania - cele i ramy instytucjonalne współrządzenia metropolią powinny odpowiadać potrzebom ludzi, którzy wymagają międzysektorowego podejścia, w przeciwieństwie do podziału sektorowego, który sprzyja tworzeniu biurokracji.

- Zasada subsydiarności - polega ona na decentralizacji działań i przenoszeniu decyzji na szczebel regionalny, lokalny w celu lepszego wydatkowania środków i uzyskiwania lepszych efektów.

- Zasada trwałości (sustensywności) - cele ekonomiczne, społeczne i środowiskowe muszą być w pełni zintegrowane i pogodzone w polityce rozwoju obszarów metropolitalnych. To wymaga większej współpracy obszarów miejskich z wiejskimi [OECD 2000; 2001b, s. 160-161].

Niektóre z tych zasad są zbieżne z Zasadami Nadzoru Korporacyjnego OECD, które zostały przyjęte w roku 1999 przez kraje członkowskie i stały się międzynarodowym punktem odniesienia dla decydentów, inwestorów, korporacji oraz innych interesariuszy na całym świecie [OECD 2004, s. 7].

Jak widać, wiele $\mathrm{z}$ powyższych zasad governance, zaproponowanych przez różne instytucje międzynarodowe, pokrywa się lub jest bardzo podobna do zasad metropolitan governance, których jest więcej i które są bardziej szczegółowe, gdyż dotyczą specyficznych obszarów funkcjonalnych, jakimi są obszary metropolitalne. Nie istnieje jeden idealny model współrządzenia metropolitalnego. Struktura współrządzenia każdego wielkiego miasta musi być dopasowana do jego specyficznej sytuacji i kontekstu krajowego. Wyzwaniem jest stworzenie właściwych form współwładania, które zoptymalizują potencjał danego obszaru metropolitalnego. Muszą one być na tyle elastyczne, aby dostosowywać się do gwałtownych zmian ekonomicznych i społecznych.

Podstawą różnych zbiorów przepisów dotyczących good governance, funkcjonujących na arenie międzynarodowej, jest otwartość (przejrzystość, jawność). Przejrzystość jest kluczowa dla governance w każdej organizacji. Otwartość odnośnie do sposobu, w jaki organizacje funkcjonują, pozwala wszystkim zainteresowanym ich działaniem, na pozytywne i konstruktywne wpływanie na kierunek tych działań. Otwartość jest też podstawą publicznego zaufania do danej instytucji. Zasada przejrzystości jest 
konieczna, aby zapewnić odpowiedzialność polityków za ich działania. Oznacza m.in. publikowanie wiarygodnych informacji dostępnych dla innych podmiotów w odpowiednim czasie, zmniejsza możliwości zachowań korupcyjnych, usprawnia prowadzenie analiz i formułowanie kierunków polityki publicznej i zwiększa ich akceptację [Ahrens, Rudolph 2006, s. 214]. Lepsza informacja może również działać jako czynnik motywujący ludzi do uczestnictwa w zbiorowych działaniach, co z kolei ułatwia rozprzestrzenianie się innowacji i zmian technicznych. Ponadto, przejrzystość odgrywa fundamentalną rolę w zapobieganiu korupcji. Korupcja często jest skutkiem braku odpowiedzialności i partycypacji [Ahrens, Rudolph 2006, s. 216]. $\mathrm{W}$ procesie metropolitan governance szczególnie istotne znaczenie ma otwartość samorządu, ponieważ dzięki niej mieszkańcy będą wiedzieć o zamierzeniach władz, stanie realizacji przyjętych programów, systemie monitoringu, kryteriach oceny i zasadach informowania [Potoczek 2005, s. 19]. Przejrzystość zarządzania publicznego wynika z samej istoty samorządu terytorialnego i jego funkcjonowania.

Zasada odpowiedzialności zapewnia, że politycy mogą być pociągnięci do odpowiedzialności za swoje czyny a wzmocniona jest przez partycypację, tzn. formalne i nieformalne sposoby oddziaływania obywateli na polityków [Ahrens, Rudolph 2006, s. 214]. Odpowiedzialność jest wysoka, jeżeli proces podejmowania decyzji jest przejrzysty i wyborcy są w stanie określić, kto odpowiada za efekty polityki, a tym samym są w stanie wspierać lub przeciwstawiać się tym podmiotom w procesie podejmowania decyzji. Uzupełnieniem tej zasady jest zasada przewidywalności, która dotyczy jasnego definiowania przepisów prawa i polityk regulujących funkcjonowanie gospodarki i społeczeństwa oraz ich spójności, jak również ich bezstronnego stosowania i egzekwowania. Stanowi ona uzupełnienie zasady odpowiedzialności w zakresie stabilizacji oczekiwań, co jest wymagane, jeżeli chcemy, aby zostały zrealizowane prywatne inwestycje. Inwestorzy uciekają z niepewnych systemów gospodarczych w poszukiwaniu bardziej stabilnego środowiska polityczno-ekonomicznego. Przewidywalność wymaga istnienia opartego na regułach systemu, wiążącego zarówno urzędników publicznych jak i podmioty prywatne. Istotne jest, aby ustabilizować oczekiwania przedsiębiorców - zarówno krajowych, jak i zagranicznych - i ich decyzje inwestycyjne [Ahrens, Rudolph 2006, s. 216]. Podstawa zwiększenia efektywności polityk miejskich polega na tym, aby wszyscy decydenci liderzy i menedżerowie, podmioty publiczne i prywatne - byli odpowiedzialni przed społeczeństwem będącym ostatecznym beneficjentem całego systemu urban governance.

W celu prowadzenia skutecznej polityki publicznej w obszarach metropolitalnych, kluczowe jest najbardziej efektywne rozdzielenie kompetencji między różnymi szczeblami władz, a służyć ma temu zasada pomocniczo- 
ści (subsydiarności), która może być użyteczna w zapobieganiu dublowaniu się kompetencji i niesprawnościom, poprzez upewnienie się, że usługi są świadczone przez szczebel władzy znajdujący się najbliżej użytkownika. Subsydiarność, która jest również naczelną zasadą Unii Europejskiej, może zaistnieć w praktyce tylko wtedy, gdy na szczeblu metropolitalnym będzie funkcjonowało efektywne współdziałanie. Bez niego ludność obszarów metropolitalnych nie jest w stanie wpływać na kluczowe kwestie związane z jej przyszłością i zrównoważonym rozwojem.

Zgodnie z zasadą pomocniczości procesy decyzyjne są usytuowane na tym poziomie reprezentacji terytorialnej, gdzie występują żywotne interesy danej grupy mieszkańców, którzy w sposób demokratyczny chcą mieć wpływ na przebieg zarządzania i sprawować odpowiednią kontrolę. Pomocniczość może odnosić się do dwóch różnych wymiarów: pomocniczości poziomej i pionowej. Pomocniczość pozioma zakłada szeroką współpracę między różnymi aktorami funkcjonującymi w tej samej przestrzeni miejskiej. Typową formą tego rodzaju interakcji jest współpraca między sektorem publicznym i prywatnym (partnerstwo publiczno-prywatne). Niemniej jednak wskazane jest rozszerzenie tej współpracy o partnerstwo lokalne poprzez włączenie jak największej liczby podmiotów.

Zasada pomocniczości pionowej mówi, że władze z wyższych szczebli nie mogą ingerować w sprawy, z którymi poszczególne jednostki są w stanie poradzić sobie same, a powinny robić to jedynie tam, gdzie pomoc jest niezbędna. W ramach pomocniczości należy również chronić słabsze finansowo jednostki poprzez system pionowego lub poziomego równoważenia finansów, uzgodniony na drodze konsultacji ze wszystkimi podmiotami w obszarze metropolitalnym.

Zasada ta jest stosowana w większości państw OECD i przyniosła bardzo pozytywne rezultaty w odniesieniu do efektów skali, ograniczenia powielania dostawców usług na różnych szczeblach władzy i odpowiedniego zaopatrzenia przedsiębiorstw i obywateli [Kamal-Chaoui, Leman, Rufei 2009, s. 64]. W przypadku zarządzania rozwojem obszarów metropolitalnych T. Markowski [2011, s. 35] proponuje, ze względu na dynamikę tych obszarów, stosowanie tzw. dynamicznej zasady subsydiarności, która pozwoliłaby ułatwić eliminowanie niesprawności władzy. Zakłada ona interwencjonizm wyższych szczebli władzy (regionalnej i centralnej) w sytuacji, gdy konflikty między samorządami nie pozwalają na współpracę $\mathrm{w}$ zakresie zarządzania szerszym układem terytorialno-funkcjonalnym. Z drugiej zaś strony interwencja ulega ograniczeniu lub zaprzestaniu, jeśli nie znajduje już uzasadnienia. W zależności od okoliczności można poszerzać zakres kompetencyjny poszczególnych jednostek terytorialnych bądź go ograniczać. W obszarach metropolitalnych, jeżeli podstawowa jednostka terytorialna nie chce lub nie może jakiegoś zadania (które należy do jej kompe- 
tencji) wykonać, to wówczas, zgodnie z dynamiczną zasada subsydiarności, przekazuje to zadanie na wyższy poziom (powiatu lub województwa).

Zasada partycypacji wynika z samej definicji metropolitan governance. Udział osób, grup i organizacji w procesie kształtowania polityki umożliwia im zabranie głosu i gwarantuje, że opracowane polityki, a także świadczone usługi, są politycznie konieczne, a także społecznie akceptowane. Udział beneficjentów w projektowaniu i realizacji projektów oraz polityk zwiększy ich zaangażowanie i współpracę w większym stopniu niż narzucone odgórnie nakazy. Ponadto sprawia, że polityki i projekty są lepiej dostosowane do rzeczywistych potrzeb [Ahrens, Rudolph 2006, s. 214]. Najprostszą formą partycypacji jest udział $\mathrm{w}$ wyborach, natomiast $\mathrm{w}$ governance chodzi o większą aktywność społeczności, która wykracza poza sam akt głosowania. Partycypacja w zarządzaniu oznacza, że obywatele biorą udział w formułowaniu, podejmowaniu decyzji i realizacji polityk publicznych. Związane jest to z aktywnością osób, które starają się wpływać na ostateczne decyzje poprzez osoby mające demokratyczną legitymizację (np. radnych) i często biorą też udział w realizowaniu tych decyzji [Parry, Moyser, Day 1992, s. 40].

Partycypacja społeczności lokalnej oznacza udział dwóch typów uczestników:

- mieszkańców i ich organizacji, a wiec obejmuje partycypację zarówno obywateli, jak i organizacji społeczeństwa obywatelskiego,

- wpływowych podmiotów życia społecznego, jak przedsiębiorcy i ich organizacje [Swianiewicz, Mielczarek, Klimska 2004, s. 35].

Bardzo ważne staje się lokalne uczestnictwo obywatelskie, które jest związane $\mathrm{z}$ aktywnością mieszkańców danego terytorium i ma na celu oddziaływanie na decyzje władz publicznych i wiąże się z ingerowaniem w różne obszary aktywności władz lokalnych [Potoczek 2005a, s. 19].

Wspólna praca może wzmocnić społeczności, ponieważ umacnia lokalną organizację i buduje zaufanie, umiejętności i zdolność do współpracy oraz świadomość. W związku z tym zwiększa się potencjał społeczności do ograniczenia ich słabych stron i bardziej ogólnie, pozycja ludzi wzmacnia się w miarę jak są oni włączani w podejmowanie innych wyzwań zarówno indywidualnie, jak i zbiorowo. Aby partycypacja była skuteczna konieczne jest dokładne zaprojektowanie polityczno-administracyjnej struktury, która będzie odpowiednia do kierowania skutecznym wdrożeniem strategii. Szczególne znaczenie ma doprecyzowanie kto powinien ponosić odpowiedzialność za różne decyzje, na jakim szczeblu władzy, i jaka powinna być kolejność w procesie podejmowania decyzji. Ponadto osoby i grupy powinny mieć prawo odwołania się do sądu, jeżeli zasady są łamane i należy wprowadzić różne formy bezpośredniej demokracji (prawo do referendum i inicjatywy), w celu dostarczenia głosującym elastycznych instrumentów bezpośredniego oddziaływania na polityczne wyniki [Ahrens, Rudolph 2006, s. 216]. 
Należy podkreślić znaczenie zintegrowanego podejścia do zarządzania metropoliami (spójność). Cele i ramy instytucjonalne powinny odpowiadać potrzebom ludzi. Wymaga to międzysektorowego podejścia, zamiast podejścia opartego na podziale sektorowym i udziału wielu zainteresowanych stron (nie tylko władz publicznych, ale także sektora prywatnego i społeczeństwa obywatelskiego) w definiowaniu, realizacji i monitorowaniu polityki miejskiej. To z kolei wymaga odpowiedniej koordynacji. Upraszczając można stwierdzić, iż koordynacja to uzgodnienie wspólnego działania.

W zarządzaniu jednostką terytorialną jej władze muszą kształtować warunki sprzyjające harmonizowaniu działań różnych jej użytkowników, organizacji i administracji publicznej wokół wspólnych wartości, jaką są rozwój jednostki i korzyści dla jej mieszkańców. W przypadku obszaru metropolitalnego jest to szczególnie trudne ze względu na olbrzymią liczbę aktorów, którzy reprezentują różne interesy. Aby ten cel osiągnąć konieczna jest koordynacja wszelkich działań.

Działalność koordynacyjna $\mathrm{w}$ zarządzaniu obszarem metropolitalnym przejawia się także w kształtowaniu proporcji między funkcjami występującymi na tym obszarze a zagospodarowaniem. Wyodrębnienie tych elementów ma zasadnicze znaczenie dla harmonizacji w obszarze planowania przestrzennego [Wojciechowski 2003, s. 99]. Wynika to z faktu, iż wiele obszarów o wyraźnie zdefiniowanych funkcjach, np. miasta przemysłowe, w wyniku restrukturyzacji, dysponuje zbędnymi obiektami i urządzeniami nieadekwatnymi do nowych funkcji. I odwrotnie, burzliwy rozwój handlu i usług napotyka barierę odpowiedniego zagospodarowania. Władze obszarów powinny przywracać właściwe relacje, a podstawę do takich działań stanowi przemyślany plan zagospodarowania przestrzennego.

Mówiąc o koordynacji w zarządzaniu obszarem metropolitalnym trzeba wspomnieć o odchodzeniu od zależności hierarchicznych w kierunku więzi poziomych, opartych na wspólnocie interesów. Doświadczenia z krajów Europy Zachodniej pokazują, że powiązania luźne mają przewagę nad związkami ścisłymi i są gwarancją nieodradzania się centralistycznych form zarządzania, a co za tym idzie prowadzą do większej efektywności zarządzania. Jak zauważa Czornik, zadaniem koordynacji jest tworzenie trwałych koalicji podmiotów dla rozwiązania określonych problemów, efektywna realizacja przedsięwzięć możliwa jest bowiem jedynie w trybie kooperacji i współdziałania wszystkich aktorów [Czornik 2003, s. 54].

\section{Cele metropolitan governance}

Governance obejmuje instytucje zarówno formalne, jak i niesformalizowane. Każdy z tych podmiotów ma swoje partykularne, często sprzeczne 
interesy. Cel organizacji krystalizuje się jako wypadkowa tych interesów na drodze kompromisów. Celem corporate governance jest:

- zapewnienie właścicielom i interesariuszom efektywnych procedur i instytucji monitoringu zarządu oraz korygowania jego błędów,

- harmonizowanie interesów zaangażowanych w firmę podmiotów,

- zapewnienie atrakcyjności inwestycyjnej i dopływu środków finansowych pozwalających na rozwój firmy,

- maksymalizacja wartości firmy z punktu widzenia właścicieli i innych zainteresowanych stron [Zalega 2003, s. 25].

Do głównych celów metropolitan governance należą:

- sprawne i efektywne wykorzystanie zasobów,

- podniesienie jakości lokalnych demokracji,

- wspieranie integracji społecznej,

- wytworzenie efektywnego i responsywnego procesu podejmowania decyzji,

- osiągnięcie równowagi między przebudową (redevelopment) miasta a jego ekspansją,

- stworzenie zintegrowanego systemu komunikacji, infrastruktury i zagospodarowania terenów,

- utrzymanie żywotności centrów ośrodka centralnego i otaczających go miast,

- umożliwienie gospodarczej konkurencyjności,

- ocena wpływu rozwoju na środowisko,

- ochrona dziedzictwa i zasobów naturalnych,

- ograniczenie emisji $\mathrm{CO}^{2}$.

Dla governance samego w sobie procesy polityczne i administracyjne (jak są podejmowane i wcielane w życie decyzje) są prawie tak samo ważne, jak to co jest robione. Jest kilka powodów takiego podejścia. Sprawność i efektywność w wykorzystaniu zasobów w dalszym ciągu ma ogromne znaczenie. Początkowe znaczenie słowa zarządzać (manage) obejmujące troskliwe wykorzystanie zasobów w dalszym ciągu jest aktualne. Uprawnienia samorządów miejskich w ogromnym stopniu dotyczą rozsądnego i sprawnego wykorzystania zasobów podatników. Bez tych kompetencji samorządy by nie przetrwały. W ostatnich latach kładzie się coraz większy nacisk na jakość urban governance w kategoriach efektywnego administrowania oraz otwartości i odpowiedzialności polityków.

Drugim powodem, dla którego procesy współrządzenia miastem zyskują na znaczeniu, jest fakt, że władze lokalne coraz częściej w proces decyzyjny włączają społeczeństwo. Wytworzenie efektywnego i responsywnego procesu podejmowania decyzji wobec gwałtownie zmieniających się okoliczności oraz podniesienie jakości lokalnych demokracji jest jeszcze jednym sposobem, dzięki któremu miasta mogą osiągnąć przewagę nad innymi i uzyskać wartość dodaną do swoich działań. 
Wreszcie, urban governance szuka nowych sposobów bycia kreatywnym, budowania silnych stron oraz pozyskiwania i wykorzystywania zasobów. W skali lokalnej możemy znaleźć próby zidentyfikowania i wykorzystania lokalnej wiedzy, budowania lokalnego potencjału instytucjonalnego, rozwoju kapitału społecznego, a wszystko po to, aby wykorzystać to jako narzędzia, za pomocą których można rozwiązać lokalne problemy, zaspokoić lokalne potrzeby i osiągnąć integrację społeczną poprzez kreatywne zatrudnienie przy minimalnej interwencji państwa.

Bez względu na formę governance, jego nadrzędnym celem jest maksymalizacja elastyczności w zarządzaniu programami rozwoju, utrzymanie efektywności w dostarczaniu usług i zapewnienie odpowiedzialności za wykorzystanie zainwestowanych środków [Giguère 2005, s. 11]. Cele te mogą być efektywnie osiągnięte tylko na szczeblu zintegrowanych obszarów funkcjonalnych, do których należą obszary metropolitalne.

Zintegrowany obszar metropolitalny oznacza:

- integrację społeczną - zintegrowany społecznie obszar metropolitalny zapewnia wszystkim mieszkańcom, niezależnie od rasy, pochodzenia etnicznego, płci lub statusu społeczno-ekonomicznego, odpowiednie warunki mieszkaniowe, przyzwoite podstawowe usługi oraz równy dostęp do socjalnych udogodnień, możliwości i innych dóbr publicznych istotnych dla ogólnego i środowiskowego dobrobytu wszystkich,

- integrację gospodarczą - ekonomicznie zintegrowany obszar metropolitalny zapewnia mieszkańcom równe szanse dla rozwoju biznesu i w dostępie do zatrudnienia oraz wspiera zapobiegające ubóstwu polityki gospodarcze,

- integrację polityczną - politycznie zintegrowany obszar metropolitalny przestrzega praw obywatelskich i wolności, zachęca do udziału w życiu politycznym i społecznym, aby władze miasta mogły podejmować bardziej świadome decyzje w sposób demokratyczny,

- integrację kulturową - zintegrowany kulturowo obszar metropolitalny sprzyja integracji społecznej i szanuje różnorodność. Docenia kulturowe prawa wszystkich grup społecznych i zachęca do zachowania sztuki i dziedzictwa [UN-HABITAT 2010].

\section{Instrumenty metropolitan governance}

Efektywny metropolitan governance, konkurencyjność gospodarcza i rozwój zrównoważony są wzajemnie od siebie zależne.

Efektywny metropolitan governance wymaga spełnienia trzech kluczowych funkcji:

- kompetencji, oznaczających posiadanie władzy do przyjęcia, wdrożenia i zabezpieczenia zintegrowanej strategii metropolitalnej, 
- możliwości, oznaczających posiadanie wiedzy i zrozumienia pozwalających na podejmowanie świadomych decyzji,

- posiadania środków do regularnego monitorowania, korygowania i uaktualniania strategii.

Wszystkie powyżej opisane funkcje wzajemnie się zazębiają. Rozwój metropolitalnej strategicznej wizji (przywództwo) wymaga, aby decyzje były podejmowane w odpowiedniej skali geograficznej (pomocniczość pionowa). W tym kontekście, umocnienie pozycji mieszkańców miast i okolic (pomocniczość pozioma) jest najlepszym sposobem na zagwarantowanie, że skala geograficzna/przestrzenna nie będzie oddalona od lokalnych problemów obywateli.

Praktyczną metodą zastosowania zasad metropolitan governance jest proces zintegrowanego podejmowania decyzji. Zazwyczaj na poziomie lokalnym uniwersalne zasady good governance zderzają się z bałaganem konkurujących ze sobą interesów i priorytetów. Środki i metody wykorzystywane do osiągnięcia równowagi, pojednania i uzyskania kompromisu miedzy konkurującymi interesami muszą być zintegrowane w celu zapewnienia większego prawdopodobieństwa zrównoważonego rozwoju [UNHABITAT 2002, s. 15].

Działania, jakie należy podjąć w celu wdrożenia zarządzania zgodnego z filozofią metropolitan governance, obejmują:

- decentralizację zadań i środków dla władz lokalnych opartą na zasadach subsydiarności i odpowiedzialności,

- wspieranie udziału społeczeństwa obywatelskiego w zakresie projektowania, wdrażania i monitorowania lokalnych priorytetów,

- korzystanie z szerokiej gamy form partnerstwa, w tym z sektorem prywatnym, aby osiągnąć wspólne cele,

- budowanie potencjału wszystkich podmiotów do pełnego uczestnictwa w procesach podejmowania decyzji oraz rozwoju miejskiego,

- ułatwianie tworzenia sieci na wszystkich poziomach.

Ponadto, trzeba w pełni wykorzystać zalety nowoczesnych technologii informacyjnych i telekomunikacyjnych w celu wspierania good governance i zrównoważonego rozwoju.

Do głównych instrumentów i sposobów zarządzania metropolitalnego należą:

- planowanie strategiczne,

- plany zagospodarowania przestrzennego,

- wspólne programy rozwoju transportu, infrastruktury, gospodarki odpadami itp.,

- zintegrowane działania promocyjne,

- agencje rozwoju,

- cywilne przywództwo, 
- partnerstwo publiczno-prywatne i inżynieria finansowa,

- kontrakty terytorialne ${ }^{45}$,

- komunikacja i reprezentacja (advocacy),

- sprawny i efektywny system pobierania podatków i opłat lokalnych,

- właściwe otoczenie instytucjonalne.

\section{Planowanie strategiczne}

Dla każdego obszaru metropolitalnego powinna zostać opracowana zintegrowana strategia rozwoju tego obszaru. Wdrażając metropolitan governance należy skoncentrować się na kilku najważniejszych dla całego terytorium zadaniach, dziedzinach i przestrzeniach, które powinny zostać ujęte w tej strategii.

Strategiczne planowanie metropolitalne powinno:

- odnosić się do wyjątkowych wartości i tożsamości obszaru metropolitalnego,

- bazować na uczciwej i solidnej analizie SWOT,

- ustalać wizję i określać priorytety,

- zidentyfikować wyzwania, którym należy sprostać,

- cele przełożyć na konkretne zadania,

- określać wspólne cele dla wszystkich interesariuszy,

- wykorzystywać efekt dźwigni i mobilizować zasoby,

- określać punkt odniesienia do oceny postępów (benchmark progress) [Clark 2011].

Sukces strategii rozwoju obszaru metropolitalnego zależny jest od zaangażowania wszystkich partnerów społecznych i gospodarczych. W tworzeniu strategii udział muszą wziąć wszystkie podmioty i osiągnąć consensus w zakresie misji i długoterminowej wizji rozwoju całego obszaru [Potoczek, Jachowicz 2005, s. 136]. Strategia ta powinna:

- kształtować sposób zarządzania rozwojem obszaru w przyszłości,

- stanowić jasne ramy dla rozwoju gospodarczego i inwestycji publicznych,

- opierać się na konkretnych danych i prognozach,

- sprzyjać zewnętrznym inwestycjomu, przezwyciężać widoczne napięcia,

- ustalać standardy i mierzalne cele; być przewodnią w stosunku do innych strategii i programów,

- integrować działania, wykorzystywać szeroki zestaw narzędzi i podchodzić do zagadnień przekrojowo,

- prowadzić do porozumień między różnymi poziomami władzy, które pozwolą na podejmowanie decyzji i osiągnięcie zgodności co do zakresu i sposobu ich realizacji,

- określać rodzaje inwestycji i sposób ich realizacji,

${ }^{45}$ Dokładniej opisane w rozdziale IV. 
- prowadzić do wzmocnienia roli poszczególnych podmiotów [Clark $2011]^{46}$.

\section{Plan zagospodarowania przestrzennego}

Wolny rynek jest ułomnym instrumentem koordynacji rozwoju złożonych układów funkcjonalnych, jakimi są obszary metropolitalne. Na skutek globalizacji i będącej jej następstwem metropolizacji jednostki terytorialne zmuszone są do konkurowania między sobą o mieszkańców i kapitał. Jednym ze sposobów tej konkurencji jest przygotowywanie przez gminy korzystnych ofert lokalizacyjnych pod kątem przedsiębiorstw i gospodarstw domowych oraz dostosowywanie do tego celu zagospodarowania terenu, często kosztem terenów otwartych. To z kolei prowadzi do nasilenia się zjawiska suburbanizacji i intensyfikacji wszystkich jej negatywnych skutków. Dlatego też konieczna jest koordynacja sposobów zagospodarowania przestrzeni a służyć temu powinno planowanie przestrzenne. Plan zagospodarowania przestrzennego umożliwia alokację w przestrzeni określonych dóbr publicznych (infrastruktury technicznej i społecznej, przestrzeni publicznych, obszarów chronionych itd.) na podstawie wcześniej prognozowaną wielkości popytu [Stawasz, Drzazga, Szydłowski 2011, s. 207]. Sporządzenie planu dla obszaru metropolitalnego pozwala m.in. na uniknięcie sytuacji, z jaką mamy do czynienia obecnie w Polsce, a mianowicie przeznaczenia nadmiernej powierzchni gruntów na daną funkcję ${ }^{47}$.

Podczas zagospodarowywania przestrzeni przez jej użytkowników powstają negatywne technologiczne efekty zewnętrzne, będące przyczyną powstawania konfliktów społecznych w „grze o przestrzeń" [Stawasz, Drzazga, Szydłowski 2011, s. 208]. Planowanie przestrzenne, będąc płaszczyzną ujawniania odmiennych interesów, a także negocjacji, porozumień i rozwiązywania konfliktów, jest szczególnym czynnikiem faktycznego upodmiotowienia zbiorowości terytorialnych i jej członków [Potoczek 2005b, s. 122]. Wielość interesariuszy, których dotyczą ustalenia planów zagospodarowania przestrzennego powoduje, że często jest on podstawowym instrumen-

${ }^{46}$ Istnieje bogata literatura zarówno krajowa, jak i światowa, na temat planowania strategicznego i procesu tworzenia strategii dla jednostek samorządu terytorialnego, zob.: Gawroński 2010; Hausner 2008; Lisiński 2004; Markowski 1999; Noworól 1998; 2007; Prusek 1995; Wojciechowski 2003; Bryson 2011; Denhardt, Denhardt 2008; Allison, Kaye 2003; Klasik, Kuźnik 2001.

47 Wiele gmin położonych $\mathrm{w}$ bezpośrednim sąsiedztwie metropolii przekwalifikowało grunty z rolnych na budowlane, co doprowadziło do nadmiernej podaży działek budowlanych i stało się źródłem problemów finansowych dla samorządów, które zobowiązane są wyposażyć te działki w odpowiednią infrastrukturę. 
tem metropolitan governance, najczęściej w proces opracowywania planu włączane są bowiem inne podmioty. Wynika, to w dużej mierze z obowiązku konsultacji ustaleń planu narzuconego przepisami prawa. Plan jest koncepcją, która rodzi się na podstawie negocjacji i kompromisów, z uwzględnieniem zasady partnerstwa [Potoczek 2005, s. 122]. Partycypacyjne opracowanie planu pozwala na jego skuteczniejszą realizację w przyszłości, natomiast porozumienia osiągnięte podczas tego procesu mogą zaowocować również innymi formami współpracy (w tym PPP), w innych dziedzinach.

Planowanie, jako narzędzie korygujące ułomności rynku, służyć powinno podnoszeniu sprawności zarządzania w obszarach metropolitalnych [Stawasz, Drzazga, Szydłowski 2011, s. 199].

\section{Wspólne programy rozwoju}

Zintegrowane programy dotyczące realizacji poszczególnych zadań będących w gestii gmin, jak np. rozwój transportu, infrastruktury, gospodarki odpadami, ochrony środowiska opracowane wspólnie przez wszystkie j.s.t. tworzące obszar metropolitalny pozwalają na bardziej skuteczną realizację zadań oraz umożliwiają obniżenie kosztów świadczenia poszczególnych usług publicznych. Pozwalają również na koordynację tych zadań na poziomie metropolitalnym. Skutki podejmowanych działań są wówczas rozpatrywane $\mathrm{w}$ powiązaniu z korzyściami i kosztami dla wszystkich gmin. Podstawą ich oceny jest analiza korzyści i kosztów sporządzana ex ante i ex post.

\section{Promocja}

Obszary metropolitalne, jeśli chcą być konkurencyjne na arenie międzynarodowej, powinny stworzyć metropolitalną markę 48 , która będzie je wyróżniać. Kiedyś miasta potrzebowały marki, aby przyciągnąć turystów. Po zwiększeniu mobilności spowodowanej globalizacją, marka jest potrzebna, aby przyciągnąć przedsiębiorstwa, inwestorów, innowatorów, studentów, nowych mieszkańców, imprezy międzynarodowe i wszystkie rodzaje instytucji. Inwestycja w jedną metropolitalną markę, która będzie wyróżniać uczelnie, przedsiębiorstwa, instytucje kultury, zdrowia itd., z jednego obszaru metropolitalnego przynosi więcej korzyści niż inwestycja w kilkadziesiąt marek przez każdy z podmiotów funkcjonujących w obszarze metropolitalnym. Jeśli każdy z nich będzie używać jednej metropolitalnej marki, to zwrot z inwestycji będzie znacznie większy. Silna marka jest instrumentem, który jest w stanie wypozycjonować metropolię i sprzedać potencjał, który ona posiada na rozwijających się rynkach [Clark 2011].

${ }^{48}$ W Polsce przykładem takiej marki jest Metropolia Poznań. 


\section{Agencje rozwoju}

Kolejnym instrumentem metropolitan governance są agencje rozwoju. Są to organizacje, które realizują część zadań rozwoju metropolitalnego $\mathrm{w}$ interesie publicznym, wykorzystując struktury korporacyjne, a nie komunalne czy rządowe. Działają one bardziej jak przedsiębiorstwo prywatne niż jako usługodawcy rządu. Zapewniają upodmiotowienie zarządzania w obszarze metropolitalnym. Agencje rozwoju działają głównie w takich dziedzinach, jak:

- tworzenie marki i promocja na arenie międzynarodowej,

- przyciąganie i utrzymanie inwestycji oraz nowych miejsc pracy,

- uruchamianie działalności gospodarczej i wzrost zatrudnienia,

- nieruchomości, rozwój infrastruktury,

- zielona ekonomia i problemy społeczne,

- tworzenie wizji, strategii, ułatwianie współpracy,

- rozwój kapitału ludzkiego,

- świadczenie usług bądź zarządzanie dzielnicą.

Utworzenie takiej agencji może przyśpieszyć działania prowadzone w obszarze metropolitalnym, może być pomocne przy rozwiązaniu sytuacji kryzysowej. Dzięki agencji rozwoju można podjąć działania na odpowiednia skalę, co nie zawsze jest możliwe w ramach istniejących struktur zarządzania, a co za tym idzie, można działać bardziej skutecznie i trwale. Pozwala to również na zaangażowanie szerokiej gamy partnerów oraz zastosowanie innowacyjnych rozwiązań. Agencje rozwoju stanowią swego rodzaju wartość dodaną do programów rozwoju lokalnego i dostosowują działania na rzecz rozwoju do zmian jakie zachodzą w otoczeniu społeczno-ekonomicznym i politycznym [Clark 2011].

\section{Przywództwo}

Ponieważ władze publiczne nie posiadają pełnej kontroli nad procesami rozwoju, które są ściśle powiązane z mechanizmem rynkowym, mogą szukać sposobów oddziaływania na te procesy za pośrednictwem odpowiednich polityk i programów. Można to określić jako przewodzenie. Najważniejsze funkcje przywódcze przedstawia rys. 6. 


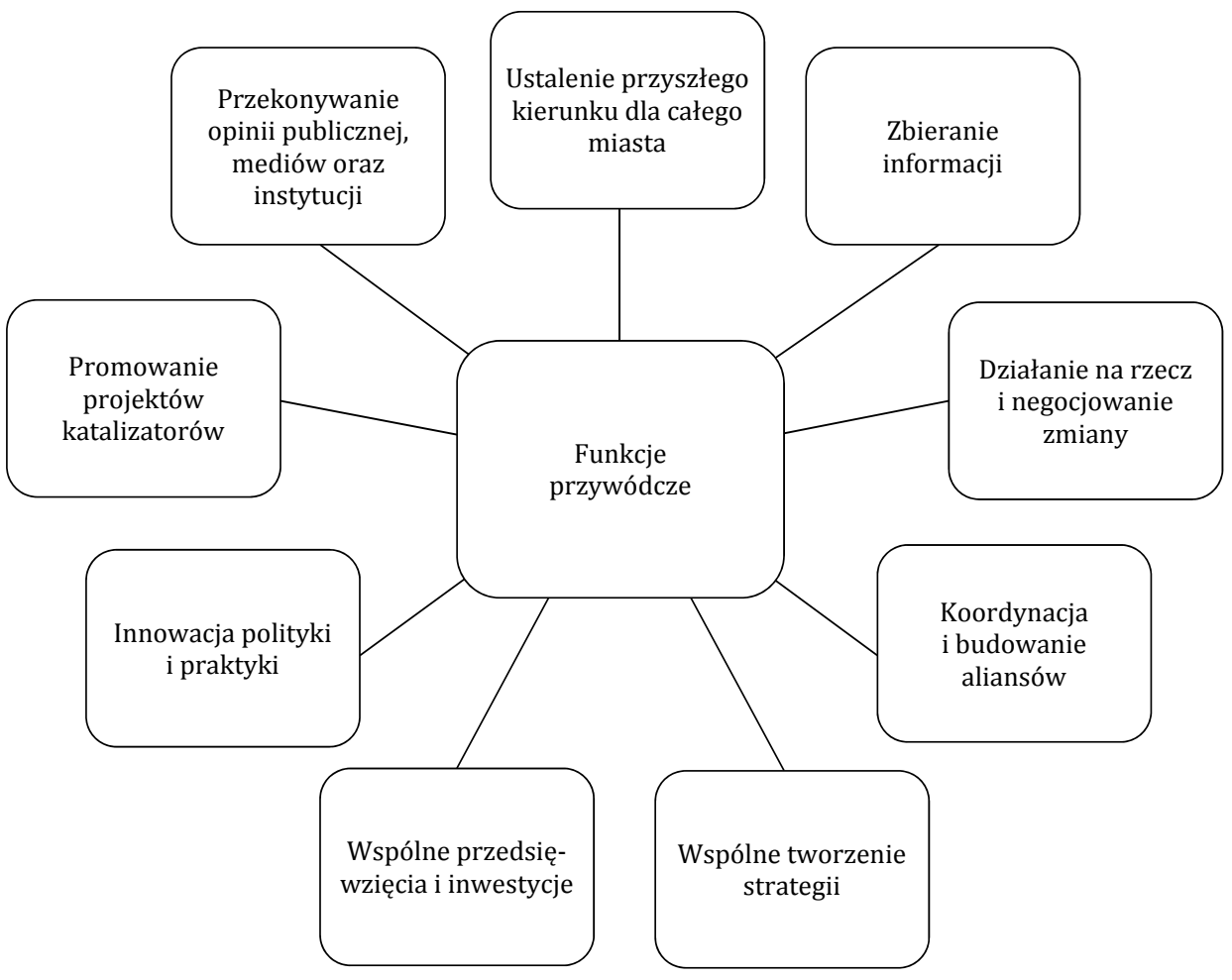

Rys. 6. Funkcje przywódcze w obszarach metropolitalnych

Źródło: [oprac. własne na podstawie Clark 2010, s. 12]

$\mathrm{Z}$ badań nad efektywnym przywództwem w miastach wynika, że na dobre przywództwo składają się:

- liderzy polityczni (często jest to kilku dobrych polityków, którzy pozostają na swoim stanowisku dłużej niż trwa jedna kadencja wyborcza),

- urzędnicy,

- przywództwo biznesu, polityków i obywateli jako części zespołu liderów,

- efektywne przywództwo ze strony wyższych poziomów władzy (np. urząd marszałkowski),

- efektywne współdziałanie i koordynacja pomiędzy wieloma podmiotami,

- silna, jasna i pewna obecność mediów, które oddziałują na opinię publiczną [Clark 2010, s. 12].

Ważnym instrumentem, który może wzmocnić metropolitan governance, są liderzy biznesowi. Najczęściej są to organizacje (np. organizacje pracodawców), powstałe po to, aby służyć swoim członkom, ale często angażują się też w działania na rzecz terytorium, w którym funkcjonują. Ich rola wynika z następujących czynników: 
- mogą skuteczniej lobbować u władz wyższych szczebli niż władze lokalne ponieważ reprezentują bardziej klientów niż podwładnych rządów narodowych i regionalnych oraz osiągają lepsze efekty,

- mogą przyciągać i zatrzymywać inwestycje dzięki oferowaniu wchodzącym liderom biznesowym gotowych „klubów” i ukazywaniu obszaru metropolitalnego jako atrakcyjnego miejsca z punktu widzenia wiarygodnego użytkownika,

- mogą zachęcać do współpracy metropolitalnej, ponieważ często działają jednocześnie $\mathrm{w}$ wielu gminach ościennych i łatwo mogą wykazać bezsensowność konkurencji między nimi,

- mogą zachęcać do ponadpartyjnej zgody i współpracy, gdyż są bezstronne,

- mogą ponosić koszty pewnych działań, których bezpośrednie sfinansowanie przez władze może być trudne (np. honorarium za udział gwiazdy w jakimś wydarzeniu),

- mogą pośredniczyć we włączeniu w proces promowania i rozwoju metropolii innych wiodących organizacji jak: uczelnie, lotniska, instytucje kultury i sportu i wiele innych,

- mogą poprawić jakość i innowacyjność programów i strategii rozwoju metropolitalnego poprzez zastosowanie know-how przedsiębiorstw,

- mogą zapewnić lepszą komunikację z mediami dla potrzeb miasta, gdyż postrzegane są przez nie jako mniej egoistyczne niż władze,

- mogą na szerszą skalę organizować i promować społeczną odpowiedzialność biznesu niż jest to możliwe, gdy firmy działają w pojedynkę,

- dzięki uczestnictwu w międzynarodowych sieciach biznesowych mogą włączać w programy rozwoju metropolitalnego najlepsze międzynarodowe praktyki.

$\mathrm{Z}$ tych powodów organizacje biznesowe zaczęły być postrzegane jako kluczowe elementy architektury instytucjonalnej dla miasta i rozwoju metropolii. Brak aktywnego przywództwa w biznesie w ramach programu rozwoju może prowadzić do luki, którą samorządom trudno będzie wypełnić we własnym zakresie [Clark 2011].

\section{Partnerstwo publiczno-prywatne}

Najistotniejsze dla rozwoju metropolitan governance jest szeroko rozumiane partnerstwo. Partnerstwo służy budowaniu sieci. Jest ono jednocześnie instrumentem polityki publicznej oraz formą organizacji sektora prywatnego, publicznego i obywatelskiego, która wzmacnia local/regional governance [Considine 2005, s. 105]. Wykorzystanie sieci prowadzi do mieszania się środków publicznych i prywatnych. Może ono przyjmować różne formy, ale najczęstszą stanowi tworzenie mniej lub bardziej formalnych partnerstw między władzami publicznymi a podmiotami z sektora 
prywatnego. Partnerstwa te pozwalają każdej ze stron korzystać z zasobów, które byłyby nieosiągalne, gdyby zostały w ich dyspozycji [Peters, Pierre 1998, s. 227]. Głównym powodem współpracy tych sektorów są ograniczone środki (finansowe i techniczne) władz publicznych, które nie są w stanie zaspokoić rosnących wymagań społeczeństwa w zakresie ilości i jakości dóbr i usług publicznych. Z drugiej strony, sektor prywatny nie jest w stanie przełamać monopolu sektora publicznego na dostarczanie tych dóbr i usług bez częściowego ustąpienia pola przez ten sektor, wymuszonego względami społecznymi, politycznymi i finansowymi [Gawroński 2010, s. 124]. W warunkach ograniczeń fiskalnych (fiscal austerity) konkurencja globalna powoduje osłabienie pozycji samorządów terytorialnych. Sektor publiczny, który na skutek globalizacji, ma coraz mniejsze wpływy z podatków, relatywnie ubożeje, natomiast sektor prywatny się bogaci. Samorządy permanentnie znajdują się $w$ sytuacji niedoborów, a potrzeby obu sektorów w zakresie infrastruktury są zbliżone. W tej sytuacji sektor prywatny jest gotów uczestniczyć w finansowaniu przedsięwzięć infrastrukturalnych, wiedząc, że w długim okresie odniesie dzięki temu korzyści.

Podstawowym założeniem dla przedsięwzięć PPP jest stworzenie związku między podmiotami prywatnym i publicznym, w którym ryzyko ponosić będzie ta strona, która potrafi nim najefektywniej zarządzać pod względem kosztów oraz w którym każda ze stron będzie mogła jak najlepiej realizować swoje zadania [Pieprzny i in. 2005, s. 508-509].

Partnerstwo publiczno-prywatne rozumiane jest jako oparte na umowie porozumienie między jednostką publiczną i podmiotem prywatnym o charakterze komercyjnym, dzięki któremu umiejętności i zasoby każdego z sektorów wykorzystywane są przy dostarczaniu usług odbiorcom i udostępnianiu obiektów użytkownikom [Rutkowski 2010, s. 31]. We wszystkich formach PPP mamy do czynienia z relacjami zachodzącymi między władzami publicznymi, organizacjami pozarządowymi, przedsiębiorstwami oraz instytucjami otoczenia biznesowego. Celem PPP jest zapewnienie społeczeństwu wysokiej jakości usług, za co odpowiedzialność ponosi sektor prywatny i publiczny [Brzozowska 2006, s. 21-22] ${ }^{49}$.

Sposobem na ograniczenie ułomności władzy, która zazwyczaj zainteresowana jest maksymalizacją budżetu i rozrostem administracji, może być prywatyzacja części zadań realizowanych przez sektor publiczny. Ma to prowadzić do zwiększenia konkurencji między podmiotami świadczącymi usługi, co w efekcie powinno spowodować obniżenie kosztów i zwiększenie efektywności realizacji zadań publicznych [Zalewski 2005, s. 13-15].

${ }^{49}$ Na temat uwarunkowań prawnych, form i korzyści PPP istnieje bogata literatura, zob.: Rutkowski 2010; Moszoro 2005. 
Na znaczenie PPP dla realizacji projektów inwestycyjnych w obszarze infrastruktury, świadczenia usług publicznych oraz wprowadzania szerzej zakrojonych innowacji wskazuje również Unia Europejska [Komunikat... 2009 , s. 2]. W celu stymulowania współpracy różnych sektorów wprowadza liczne programy i instrumenty. Jednym z nich jest JESSICA Uoint European Suport for Sustainable Investment in City Areas), co oznacza wspólne europejskie wsparcie na rzecz trwałych inwestycji w obszarach miejskich. Inicjatywa ta jest instrumentem inżynierii finansowej wpierającym inwestycje na obszarach miejskich. Zakres wsparcia w ramach inicjatywy obejmuje zróżnicowany krąg tematyczny - rozpoczynając od rewitalizacji, poprzez edukację, kulturę, turystykę, transport, kończąc na odnawialnych źródłach energii. JESSICA pozwala na wykorzystanie funduszy strukturalnych UE w systemie zwrotnym, czyli oferuje odnawialne instrumenty finansowe (pożyczki, gwarancje), dając możliwość lepszego wykorzystania środków funduszy strukturalnych i pozyskania udziału instytucji finansowych, banków i przedsiębiorców, m.in. dzięki partnerstwu publiczno-prywatnemu. Istotnym zastrzeżeniem jest fakt, że projekty realizowane przy wsparciu inicjatywy JESSICA powinny generować dochód. Współwystępowanie w tych projektach elementów komercyjnych z niekomercyjnymi ma umożliwić wypełnienie luki na rynku pomiędzy dotacjami a kredytami i innymi instrumentami bankowymi [http://www.funduszeeuropejskie.gov.pl/RPO/Aktualnosci/ Strony/Jessica_240310.aspx].

Możliwość autentycznej partycypacji partnera prywatnego w przedsięwzięciu i zachowanie kontroli przez partnera publicznego pozwala na efektywną współpracę, która jest główną ideą governance. Również mechanizm negocjacji, wykorzystywany przy zawieraniu umów, jest kluczowy dla governance. PPP mogą jednocześnie prowadzić do wzmocnienia współpracy $\mathrm{z}$ innym partnerami. Podmioty, które $\mathrm{z}$ sukcesem zrealizowały projekt w ramach PPP, powinny wykazywać większe zaufanie względem innych podmiotów i zwiększoną gotowość do podejmowania kolejnej współpracy.

Dzielenie władzy między publiczne, prywatne i obywatelskie podmioty przyjmuje różnorodne formy i jest szeroko propagowane przez różne organizacje międzynarodowe (UNDP, Bank Światowy, OECD), ale niewątpliwie najwięcej w tym zakresie zrobiła Unia Europejska. Wdrożyła liczne programy wspierające procesy rozwojowe wymagające współpracy różnych partnerów (np. LEADER), które były pionierskie, jeśli chodzi o nowe narzędzia finansowania i dostarczania usług, co prowadziło do wzmacniania local governance. $\mathrm{Z}$ punktu widzenia rozwoju metropolitan governance takim programem współpracy jest program URBAN ${ }^{50}$. Również Fundusze Strukturalne są instrumentem, który stymuluje współpracę różnych aktorów.

${ }^{50}$ Więcej na temat programu URBAN w rozdz. IV. 
Związki partnerskie między różnymi podmiotami stanowią wstępny warunek w procedurze ubiegania się o środki z funduszy strukturalnych. W efekcie tych uwarunkowań, rządzenie na poziomie lokalnym przestało być domeną wybranych polityków, a stało się procesem permanentnych negocjacji między kluczowymi podmiotami działającymi na obszarze gminy (regionu). Zatem efektywne rządzenie na szczeblu miasta, regionu, kraju czy też na arenie międzynarodowej możliwe jest jedynie poprzez pozyskanie i mobilizację zasobów oraz podmiotów spoza formalnych kręgów władzy [Painter 1997, s. 128].

Socjologowie, ekonomiści i planiści zwracają uwagę na fakt, że współpraca nie tylko poprawia elastyczność i efektywność władz, lecz przynosi również korzyści wynikające $\mathrm{z}$ tworzonych międzysektorowych sieci dla podnoszenia efektywności gospodarczej miast i regionów. W literaturze dotyczącej kapitału społecznego wskazuje się, że powiązane z nim zasoby mogą zostać uwolnione poprzez poprawę komunikacji i zaufania, które może być wzmocnione dzięki współpracy między uczestnikami sieci51.

\section{Komunikacja i reprezentacja (advocacy)}

W zarządzaniu obszarem metropolitalnym bardzo istotna jest kwestia komunikacji między poszczególnymi interesariuszami, w tym społeczeństwem. Wszelkie strategie i programy działania muszą być tworzone metodami partycypacyjnymi. Właściwa komunikacja pozwala na pełniejsze zrozumienie planowanych działań, a co za tym idzie zmniejsza obawę i opór przed wprowadzaniem zmian. Ważne jest, aby zwykli mieszkańcy, którzy są zaangażowani $\mathrm{w}$ proces $\mathrm{np}$. tworzenia strategii rozwoju mogli korzystać z pomocy eksperta („advocate”), który będzie im służył radą na temat omawianych problemów i możliwych rozwiązań oraz reprezentował społeczność przed oficjalnymi organami władzy publicznej. Osoba taka jest szczególnie potrzebna:

- grupom, które są w trudnej sytuacji społecznej, mają problem z wypowiadaniem się,

- aby zapewnić, że interesy wszystkich grup ludności, których dotyczy opracowywany plan są sprawiedliwie brane pod uwagę,

- do mediacji między poglądami zwykłych mieszkańców a spojrzeniem ekspertów [http://www.partizipation.at/advocacy-planning.html].

\section{Sprawny i efektywny system pobierania podatków i opłat lokalnych}

Podatki i opłaty lokalne stanowią znaczące źródło dochodów gmin. Prawo do ich ustalania mogą mieć również obszary metropolitalne (jeśli są

51 Więcej na temat roli kapitału społecznego w local governance zob.: Putnam 1993; Lin 2001; Stewart 2003. 
wyodrębnionym poziomem administracji). Od wielkości tych dochodów zależą możliwości finansowania usług publicznych o znaczeniu metropolitalnym. System podatkowy w obszarach metropolitalnych musi być sprawiedliwy i bazować na zasadzie, że użytkownik płaci za korzystanie z komunalnych usług i infrastruktury (wyeliminowanie zjawiska "jazdy na gapę"). Ważne jest podnoszenie świadomości społeczeństwa i pokazanie związków przyczynowo-skutkowych między pobieraniem podatków a płynącymi z opodatkowania korzyściami (finansowanie usług publicznych). Konieczna jest również profesjonalizacja struktur administracyjnych zajmujących się poborem podatku, doskonalenie procedur pobierania podatków (w celu realizacji powszechnie uznawanych zasad podatkowych, jak m.in. zasada wydajności, taniości, powszechności) [zob.: Owsiak 2005].

\section{Właściwe otoczenie instytucjonalne}

W zarządzaniu układem funkcjonalnym, jakim jest obszar metropolitalny, bardzo ważne jest budowanie sprawnych instytucji. Zgodnie z zasadą szczególności instytucje muszą być dopasowane do sytuacji, problemów, okoliczności występujących w obszarze metropolitalnym. Zatem kluczowy jest należyty podział odpowiedzialności między odpowiednie poziomy władzy oraz wyposażenie ich w kompetencje i środki umożliwiające realizację przypisanych im zadań52.

\section{Mierniki efektywności metropolitan governance}

Mierzenie efektywności metropolitan governance jest trudne. Problem ten występuje również w przypadku corporate governance. Jego przyczyną jest przede wszystkim brak uniwersalnych mierników, co wynika głównie z odmienności narodowych systemów, stosowanych mechanizmów oraz celów samej korporacji.

Jeśli chodzi o ocenę funkcjonowania organizacji publicznych, to coraz bardziej liczą się efekty uzyskiwane z poniesionych nakładów i to one stają się głównymi miernikami oceny działalności tych organizacji [Zalewski 2005, s. 17]. W analizie korzyści i kosztów (cost-benefit analysis - CBA) są to np.:

- liczba/wartość zintegrowanych inwestycji metropolitalnych,

- sprawiedliwość rozłożenia korzyści i kosztów między poszczególnych interesariuszy,

- system rekompensat lub transferów finansowych $\mathrm{w}$ przypadku stwierdzenia występowania nierówności w ponoszonych kosztach i czerpanych korzyściach.

52 Więcej na temat funkcjonowania instytucji zob.: Staniek 2005; North 1990, 1991; Acemoglu, Johnson, Robinson 2004; Matthews 1986. 
Skuteczność zarządzania metropolitalnego da się również oceniać przez pryzmat sprawności zarządzania. $W$ tej grupie można zaproponować następujące mierniki:

- liczbę zadań zleconych przez samorząd do realizacji innym, profesjonalnym podmiotom,

- czas, jaki upływa od pomysłu na zrealizowanie jakiegoś projektu do podjęcia uchwały o realizacji,

- liczbę pracowników w instytucjach publicznych przypadającą na mieszkańca w zestawieniu z liczbą realizowanych zadań.

Należy przy tym zaznaczyć, iż w pewnych przypadkach kryterium efektywności ekonomicznej nie może mieć nadrzędnego znaczenia, np. nie powinno tak być przy wyborze systemu organizacji zaspokajania potrzeb społecznych, ponieważ pozbawiałoby dostępu do różnego rodzaju usług publicznych mieszkańców mniejszych jednostek osadniczych. W takich przypadkach ważniejsze jest kryterium sprawiedliwości społecznej i równości w dostępie do podstawowych usług społecznych. Podobnie sytuacja wygląda w przypadku monopoli naturalnych, takich jak wodociągi czy kanalizacja [Zalewski 2005, s. 21].

W przypadku metropolitan governance zasadniczą trudność sprawia brak danych statystycznych na poziomie gmin. Do mierzenia efektywności powinno się podchodzić przez pryzmat celów. Podstawową metodą jest analiza korzyści i kosztów wynikających z działania systemów pozwalających na osiągnięcie wspólnie ustalonych celów. Stopień rozwoju metropolitan governance można mierzyć przez pryzmat jego zasad i procesów, za pomocą których będą projektowane i wdrażane w życie odpowiednie polityki publiczne. Elementami, które należy wziąć pod uwagę, są:

- stopień demokratyzacji podejmowania decyzji,

- zaangażowanie obywateli,

- przejrzystość,

- odpowiedzialność,

- integracja społeczna i równość (możliwości, wykorzystania, dostępu, kosztów, wyników) dla grup poszkodowanych,

- sprawiedliwe i uczciwe traktowanie mieszkańców,

- zdolność do konkurowania w globalnym otoczeniu,

- chęć i zdolność do pracy w partnerstwie,

- intensywność relacji między poszczególnymi interesariuszami,

- poszanowanie przepisów prawa,

- poszanowanie praw innych,

- poszanowanie różnorodności,

- sustensywność polityk.

Efektywność zarządzania metropolitalnego można też mierzyć poprawą jakości życia mieszkańców i innych podmiotów, będącą efektem działań 
podjętych wspólnie przez interesariuszy [Bovaird, Loeffler 2004]. Można też zastosować ocenę oddziaływania wdrażanych polityk. Umożliwia ona pomiar nakładów i wyników realizowanych przedsięwzięć wpływających na sferę środowiskową, społeczną i gospodarczą [Drobniak 2005, s. 283]. Od lat dużą popularnością cieszy się ocena oddziaływania projektów środowiskowych (Environmental Impact Assesssment), która legła u podstaw oceny oddziaływania społecznego (Social Impact Assessment). Jest ona wykorzystywana do oceny znaczących oddziaływań potencjalnych polityk, programów czy projektów na osoby, grupy, organizacje, sąsiedztwo, społeczności, instytucje i inne jednostki społeczne [Finsterbusch 1985, s. 194].

$\mathrm{Z}$ uwagi na silne powiązanie zarządzania metropolitalnego z konkretnym terytorium, do mierzenia efektów metropolitan governance można wykorzystać lansowane w Unii Europejskiej metody Oceny Oddziaływania Terytorialnego (Territorial Impast Assessment - TIA). Zostały one opracowane, aby mierzyć wpływ polityk unijnych na spójność terytorialną [Schindegger, Tatzberger 2004], ale mogą być również stosowane na niższych poziomach zarządzania. Ocena Oddziaływania Terytorialnego pozwala na podniesienie wiedzy (ex ante i ex post) na temat terytorialnych konsekwencji, efektów synergii lub kosztów spowodowanych brakiem koordynacji polityk unijnych, jak również do poprawy współpracy (zarówno poziomej, jak i pionowej) [ARL 2008; Finka 2007]. Aby to uzyskać TIA obserwuje i opisuje skutki polityk $w$ poszczególnych układach terytorialnych, jak również zwraca szczególną uwagę na poziom celów będących punktem odniesienia przy ocenie tych skutków. Jedną z metod TIA jest zaproponowany przez R. Camagniego model TEQUILA - syntetycznej oceny skutków poszczególnych polityk UE dla regionów UE (na poziomie NUTS 2 lub 3). Metoda ta ma charakter tzw. oceny punktowej i opiera się na wyliczeniu dość prostego wskaźnika wpływu danej polityki na konkretny region na podstawie ocen jego podatności na interwencję dokonanej przez ekspertów, przy udziale innych podmiotów [Camagni 2006; Camagni, Lenzi 2010]. Model można zastosować również do oceny efektywności współzarządzania na poziomie metropolitalnym. Trzeba tylko dobrać odpowiedni zestaw kryteriów.

Territorial Impast Assessment nie może być traktowana jako uniwersalne narzędzie oceny wpływu polityki, programu, planu czy projektu na rzeczywistość, zwłaszcza w wymiarze terytorialnym. Zawsze jest to narzędzie specyficzne, które powinno być stosowane wtedy, gdy terytorialne aspekty interwencji publicznej są istotne, a tak jest niewątpliwie w przypadku układów funkcjonalnych, jakimi są obszary metropolitalne.

Wybór modelu współrządzenia powinien zawsze być poprzedzony analizami nakładów i efektów, które dostarczą obiektywnych informacji o możliwych korzyściach, a co za tym idzie pozwolą, przynajmniej częściowo, wyeliminować wpływy polityczne. 


\section{Bariery metropolitan governance}

Problemy związane z zarządzaniem obszarami metropolitalnymi wynikają przede wszystkim $\mathrm{z}$ tego, że regiony metropolitalne pod względem prawnym nie istnieją. $\mathrm{W}$ większości państw brak jest przepisów, które przewidywałyby dodatkowy szczebel władzy na poziomie metropolitalnym. W krajach, w których prace nad takimi przepisami zostały rozpoczęte (np. w Polsce) współpraca w obszarach metropolitalnych nie jest podejmowana, lub jest realizowana w ograniczonym zakresie, gdyż wszyscy czekają na wejście w życie nowych przepisów. Społeczność lokalna w regionach metropolitalnych nie ma instrumentarium, w jakie wyposażone są władze, aby radzić sobie z pełnym zakresem problemów, które są wspólne dla całego obszaru. Istnieje wiele agencji rządowych, władz regionalnych i lokalnych, które rządzą w obszarze metropolitalnym. Funkcjonują więc liczne centra decyzyjne, natomiast brakuje jednego ośrodka zarządzającego całym obszarem metropolitalnym. Taka sytuacja powoduje dublowanie funkcji i nakładanie się kompetencji. Autonomiczne władze jednostek terytorialnych, działające w swoim imieniu, nie są w stanie rozwiązać różnorodnych problemów szerszej metropolitalnej społeczności. Polityczny układ metropolii jest często określany jako patchwork, a jego organizacja jako zorganizowany chaos ${ }^{53}$. Receptą na uzdrowienie tej sytuacji jest reorganizacja mniejszych jednostek administracyjnych (np. gmin) w większe układy w celu stworzenia ogólnych ram metropolitalnych, które umożliwiłyby zgromadzenie w jednym miejscu różnych funkcji władz. System polityczny z jednym dominującym ośrodkiem decyzyjnym jest uznawany za idealny model dla organizacji obszarów metropolitalnych [Ostrom, Tiebaut, Warren 1961].

$\mathrm{Z}$ analiz przeprowadzonych w krajach OECD wynika, że struktury współrządzenia istniejące $w$ obszarach metropolitalnych są przestarzałe i niedostosowane do zadań, które przed nimi stoją. Często utrwalają one niezadowalający klimat polityczny, jaki nie sprzyja rozwiązywaniu najważniejszych problemów obszarów metropolitalnych, wpływających na jakość życia i gospodarcze szanse rozwoju całego regionu.

Wśród przeszkód na drodze do lepszego współrządzania (governance) znajdują się również:

- rozdrobnienie administracyjnych kompetencji, czego skutkiem jest brak powiązań między obszarami administracyjnymi a funkcjonalnymi,

- fragmentacja polityczna,

- system finansowania/ograniczenia finansowej i fiskalnej zdolności władz lokalnych w obszarach metropolitalnych. Obszary metropolitalne muszą dostosować się do decentralizacji i fiskalnego federalizmu, zwiększyć

${ }^{53}$ Zob. Ostrom, Tiebaut, Warren 1961. 
lokalną autonomię, przy jednoczesnym ograniczaniu podatkowych zróżnicowań w ramach obszaru metropolitalnego, poprawić dostęp do kapitału inwestycyjnego oraz włączyć sektor prywatny jako partnera w inwestycjach i dostawcę usług. Instrumenty finansowe nie pasują do potrzeb obszarów metropolitalnych. System finansowy często nie zwraca wydatków na poziomie lokalnym. System podatków na poziomie lokalnym jest nieefektywny i prowadzi do powstania negatywnej spirali obciążenia podatkowego,

- bak przejrzystych, zrozumiałych procesów podejmowania decyzji (Kto co robi i na jakim szczeblu?),

- brak jasnego przywództwa na poziomie lokalnym [OECD 2001c, s. 241],

- niski poziom kapitału społecznego,

- nieujawnione konflikty,

- obawa gmin wchodzących w skład obszaru metropolitalnego przed utratą autonomii,

- brak elastyczności polityk realizowanych przez poszczególne organizacje działające w obszarze metropolitalnym. Często spotykaną praktyką na poziomie lokalnym i regionalnym jest wdrażanie kilku niezależnych strategii sporządzonych przez różne organizacje publiczne. Brak elastyczności odnośnie do celów poszczególnych organizacji oznacza, że część organizacji za nadrzędne uważa swoje własne cele, a nie te, które zostały wypracowane wspólnie z innymi podmiotami,

- silne upartyjnienie administracji rządowej i samorządowej. Wyraża się ono w politycznym doborze kadr według struktury koalicji partyjnej odnoszącej się zarówno do stanowisk kierowniczych, jak i wykonawczych,

- tradycyjna kultura administracyjna nastawiona na hierarchiczne zależności i sztywnie przestrzegająca przepisów prawa, przy jednoczesnym zachowaniu opory w przypadku wprowadzania jakichkolwiek innowacji,

- ograniczenia współpracy,

- kadencyjność władz - większość problemów metropolitalnych można rozwiązać w perspektywie 10-, 15-, 20-letniej lub dłuższej,

- brak polityki przestrzennej dotyczącej obszarów metropolitalnych na poziomie krajowym,

- brak identyfikacji z obszarem [OECD 2001c; Kieżun 2004, s. 20; Kamal-Chaoui 2003].

Nawiązanie dobrowolnej współpracy między różnymi podmiotami działającymi w obszarze metropolitalnym ma decydujące znaczenie dla osiągnięcia jakości w metropolitan governance [Swianiewicz 2008]. Jednak samo partnerstwo, czyli horyzontalne, przekraczające sektorowe granice porozumienie podmiotów, którym przyznaje się równorzędny status nie gwarantuje sukcesu. Sprawność jego funkcjonowania mogą ograniczać takie czynniki, jak niewystarczające zaangażowanie partnerów, niedostatek umiejętności, zasobów itp., ale również czynniki zewnętrzne, które są po- 
chodną siły instytucji i tradycji demokratycznych, ukształtowanych relacji między władzą a społeczeństwem. Szczególnym czynnikiem ograniczającym sprawne funkcjonowanie governance jest niski poziom kapitału społecznego ${ }^{54}$. W Polsce takimi czynnikami są słabe społeczeństwo obywatelskie i niski poziom zaufania [Kaźmierczak 2008, s. 37-38]. Utrudnia to zaangażowanie partnerów wywodzących się $\mathrm{z}$ organizacji pozarządowych, czy organizacji sąsiedzkich [Swianiewicz, Mielczarek, Klimska 2004, s. 196]. W Polsce lokalni przedsiębiorcy są zazwyczaj dość słabym partnerem dla władz lokalnych, a ich udział $\mathrm{w}$ partnerstwie (zwłaszcza potencjalnych dużych inwestorów) powoduje problemy natury politycznej (podejrzenia o lobbing, korupcję, itp.).

Teoria Stone’a, zakładająca łączenie zasobów różnych podmiotów, była też testowana w warunkach polskich. Iwona Sagan zwraca uwagę na to, że w systemach zarządzania polskimi miastami znaczącą rolę odgrywają często duzi inwestorzy międzynarodowi [Sagan 2000, s. 176]. Z kolei badania projektów zakładających partnerstwo różnych podmiotów lokalnych, przeprowadzone w Poznaniu i Ostrowie Wielkopolskim wykazały, że tworzenie rzeczywistych partnerstw lokalnych napotyka liczne przeszkody, które wynikają głównie z nierównowagi posiadanych zasobów. Największe zasoby skupiają władze miast, natomiast zasoby innych podmiotów są bardzo ograniczone, co powoduje, że ich pozycja w relacjach z samorządem jest nierównorzędna [Swianiewicz, Mielczarek, Klimska 2004, s. 195].

Z badań Olivera [2001], przeprowadzonych w obszarach metropolitalnych w Stanach Zjednoczonych, wynika, że stopień partycypacji społecznej jest funkcją przestrzeni obywatelskiej tworzonej przez małe jurysdykcje. Im mniejsze te jurysdykcje, tym większe zaangażowanie społeczeństwa. Badania wspomnianego autora dotyczyły standardowych dziedzin partycypacji:

- kontaktów z lokalnymi urzędnikami,

- uczęszczania na sesje rady gmin,

- uczęszczania na spotkania różnych organizacji,

- zaangażowania w nieformalną działalność obywatelską,

- udziału w lokalnych wyborach.

Badania wykazały, że pierwsze trzy typy aktywności spadają wraz ze wzrostem rozmiarów miasta [Oliver 2001, s. 42]. W małych gminach łatwiej jest zaangażować obywateli, gdyż mieszkańcy czują się bardziej uprawnieni i zainteresowani sprawami dotyczącymi ich społeczności i sąsiedzi jednoczą się ze sobą [Oliver 2001, s. 65]. Kolejnym wnioskiem było stwierdzenie, że partycypacja społeczna na poziomie lokalnym jest negatywnie skorelowana z jednorodnością gmin pod względem ekonomicznym [Oliver 2001, s. 87].

${ }^{54}$ Więcej na ten temat: Putnam 1993. 
Niemniej jednak negatywny wpływ tej jednorodności na partycypację nie przewyższa pozytywnego wpływu na nią małych gmin.

Fragmentacja władzy jest jedną z głównych przyczyn problemów w obszarach metropolitalnych, dlatego więc pewne formy regionalnego współrządzenia są pierwszym krokiem do ich rozwiązania [Mitchell-Weaver, Miller, Deal 2000]. Międzysamorządowe strategie są kluczowe, aby promować metropolitalny podział dochodów, zrównoważony rozwój, układ miast zgodny z zasadami nowej urbanistyki (new urbanism) i aby tak ukierunkować rozwój budownictwa mieszkaniowego i transportu, by dopasować je do zmieniających się lokalizacji, ekspansji zatrudnienia i potrzeb rynku pracy [Katz, Allen 1999].

Tradycyjny model funkcjonowania samorządów lokalnych, oparty na administrowaniu poszczególnymi jednostkami terytorialnymi, stawia pod znakiem zapytania zdolność przetrwania, zwłaszcza najmniejszych społeczności, w warunkach pogłębiających się procesów globalizacji, których skutkiem jest konieczność konkurowania regionów nie tylko w skali kraju, ale także Europy i świata. Z tego też względu tak ważna jest koordynacja działań w ramach polityki zrównoważonego rozwoju obszarów metropolitalnych oraz szeroko rozumiana współpraca w procesie osiągania jej celów.

Uzyskanie właściwych proporcji między politykami, które preferują podniesienie konkurencyjności, i politykami, wspierającymi spójność społeczną i tworzenie miejsc, w których ludzie chcą żyć i pracować, stanowi główny dylemat liderów w obszarach metropolitalnych. Wybrani urzędnicy muszą osiągnąć równowagę między rozwojem i redystrybucją oraz między międzynarodowymi celami a lokalnymi aspiracjami.

Ponieważ sam mechanizm rynkowy nie może zapewnić integracji kwestii środowiskowych, społecznych i gospodarczych w miastach, zdolność obszarów metropolitalnych do osiągnięcia konsensusu w sprawie współrządzenia jest niezmiernie ważna. Metropolitan governance nie polega tylko na reformie instytucji i systemu finansów, lecz wiąże się również ze zmianą podejścia do zarządzania i kultury organizacyjnej. Tradycyjne systemy zarządzania „z góry na dół” zastępowane są przez bardziej partycypacyjne formy governance. Doprowadzenie do zmiany w kulturze zarządzania wymaga otwarcia na nowe podmioty, które mają uzasadnione obawy o swe miejsce w obszarze metropolitalnym.

Wyniki prowadzonych badań dotyczących przebiegu procesów transformacji w krajach Europy Środkowowschodniej (z gospodarki centralnie planowanej w gospodarkę rynkową) wskazują, iż każdy z nich opracował własny sposób wdrożenia nowych rozwiązań instytucjonalnych i że różnią się one znacznie od rozwiązań stosowanych w Europie Zachodniej. Oddzia- 
ływanie zagranicy na narodowe przemiany jest faktem, a uwarunkowane jest krajowymi rozwiązaniami rządowymi. Pomimo ustalania przez UE pewnych wzorców, w poszczególnych krajach obserwowane są znaczne różnice. Wspólnym wyzwaniem dla krajów członkowskich jest znalezienie takiego sposobu aplikacji tych wzorców i wartości, aby problemy „wyłaniające się z Unii" mogły być skutecznie rozwiązane przez krajowe formy współrządzenia (governance) [Eriksen 2007]. 



\section{METROPOLITALNE ZARZĄDZANIE W WYBRANYCH KRAJACH EUROPY}

Problem rozbieżności podziałów administracyjnych obszarów metropolitalnych i regionów silnie zurbanizowanych z procesami i faktycznym zasięgiem obszarów metropolitalnych stał się przedmiotem rozważań i analiz wielu organizacji międzynarodowych, takich jak OECD, Unia Europejska, NAFTA.

OECD stworzyło listę 78 obszarów metropolitalnych w krajach będących jej członkami (zał. 1). W większości tych krajów zaczęto realizować reformy zmierzające do wprowadzenia zarządzania metropolitalnego (metropolitan governance).

Ze względu na fakt, iż nie ma jednolitej definicji obszarów metropolitalnych, trudno jest prowadzić badania porównawcze dotyczące zarządzania w poszczególnych obszarach. Brak jednoznacznej definicji powoduje problemy z utworzeniem właściwych instrumentów, które pozwoliłyby na określenie $\mathrm{w}$ sposób mierzalny stopnia zaawansowania wprowadzania procesów współrządzenia w obszarach metropolitalnych. Sposób, w jaki współrządzenie ewoluuje $\mathrm{w}$ danym obszarze metropolitalnym wygląda różnie $\mathrm{w}$ różnych regionach i $\mathrm{w}$ dużym stopniu zależy od politycznego, społecznego, kulturowego i historycznego kontekstu danego obszaru.

Miasta wykazują znaczące podobieństwa pod względem instytucjonalnym i są podobnie osadzone $\mathrm{w}$ gospodarce regionalnej i lokalnej, a co za tym idzie, w taki sam sposób podlegają wpływom procesów globalizacyjnych. Dlatego też możliwe jest porównanie zachodzących w nich procesów i czerpanie wzorów do wdrażania systemu współrządzenia w innych obszarach metropolitalnych. Badanie zarządzania metropolitalnego $\mathrm{w}$ różnych metropoliach ma też kluczowe znaczenie dla naukowych wyjaśnień procesów, które zachodzą w ich strukturze, oraz kierunków zmian.

W niniejszym rozdziale przedstawiono różne podejścia do zarządzania obszarami metropolitalnymi $w$ wybranych krajach Europy należących do OECD. W wielu przypadkach $w$ raportach OECD dokonano oceny efektów prowadzonych działań i stworzono bazę dobrych praktyk. Analizie poddano:

1. Obszary metropolitalne wyznaczone $w$ dokumentach planistycznych (w ramach systemu planowania przestrzennego) bądź stanowiące obszar 
odniesienia/zainteresowań innych polityk w dokumentach tworzonych na szczeblu centralnym.

2. Obszary mono-, jak i policentryczne.

3. Obszary, w których udało się wdrożyć elementy zarządzania metropolitalnego oraz przypadki, w których próby te zakończyły się porażką.

4. Różne podejścia do wdrażania zarządzania metropolitalnego - dobrowolne i odgórne, narzucone przez rząd centralny.

Opis doświadczeń poszczególnych obszarów metropolitalnych w zakresie metropolitan governance, został poprzedzony krótką charakterystyką ustroju administracyjnego danego kraju oraz systemu planowania przestrzennego. Uznano bowiem, że planowanie przestrzenne jest jednym z podstawowych instrumentów współrządzenia - powszechnie proponowanym w krajach OECD.

\section{Współpraca na poziomie metropolitalnym we Francji}

We Francji, poniżej rządu centralnego, istnieją trzy poziomy władzy: samorządy gmin (36 600), władze departamentów (96) i władze regionalne (22). Blisko 98\% gmin liczy mniej niż 10000 mieszkańców, 89\% - mniej niż 2000, co powoduje problemy z efektywnym świadczeniem usług publicznych.

Na czele regionu i departamentów stoją prefekci (mianowani przez prezydenta), reprezentujący państwo na poziomie regionu/departamentu, odpowiedzialni za koordynację i spójność działań departamentów w regionie, ale również za koordynację działań władz lokalnych z polityką rządu centralnego. Ich głównym zadaniem jest formułowanie średniookresowej strategii gospodarczej, która jednak wdrażana jest przez inne szczeble władzy [Herrschel, Newman 2002, s. 83]. Odpowiedzialne są one również za kształcenie zawodowe. Dysponują także mniejszymi środkami finansowymi niż departamenty.

Do głównych zadań departamentów należy polityka społeczna. Odpowiadają też za drogi, świadczenia społeczne (służba zdrowia, opieka nad osobami starszymi), główne projekty infrastrukturalne (czasami zadania te są przypisywane regionom).

Z kolei kompetencje gmin koncentrują się przede wszystkim na sprawach lokalnych, takich jak ruch miejski czy szkoły podstawowe [OECD 2006b, s. 155]. Gminy i departamenty odpowiadają więc głównie za zarządzanie usługami publicznymi, podczas gdy regiony są ukierunkowane bardziej na formułowanie strategii [OECD 2006b, s. 20-21].

Zadania z dziedziny edukacji i kultury podzielone są między różne poziomy administracji. Generalnie nie ma jasnego rozdzielenia zadań w poszczególnych obszarach między oddzielne poziomy administracji. Najlepiej widać to w przypadku edukacji. Rząd centralny odpowiada za nauczanie, 
rekrutację i wynagrodzenia personelu szkół i uniwersytetów. Na gminy nałożono obowiązek utrzymania szkół podstawowych. Departamenty odpowiadają za kolegia, regiony - za szkoły średnie, w obu przypadkach obsadzają też personel techniczny. Ten podział kompetencji w innych dziedzinach nie jest już tak przejrzysty [OECD 2006b, s. 134]. Burmistrzowie są jednocześnie szefami gminy i agentami rządu centralnego $w$ takich kwestiach, jak np. organizacja wyborów czy prowadzenie ewidencji ludności. Rząd centralny jest obecny na poziome regionalnym, międzydepartamentalnym i subdepartamentalnym również w postaci silnie rozwiniętej sieci zdekoncentrowanych biur terytorialnych różnych ministerstw, które podlegają prefektowi. Władza prefekta ogranicza się do świadczenia w sposób zdecentralizowany usług administracji rządowej, z wyłączeniem kształcenia, wymiaru sprawiedliwości i poboru podatków.

W związku z tak dużym rozdrobnieniem gmin i potrzebą współpracy między nimi funkcjonuje ponad 20000 związków międzygminnych [Stoker 2006, s. 3]. Między tymi szczeblami nie ma określonej hierarchii, mogą one działać samodzielnie i są od siebie niezależne. Taka decentralizacja nie została dostosowana do istniejącego podziału kompetencji, co spowodowało sytuację, w której trzy poziomy władzy zamiast ze sobą współpracować, konkurują. Regiony są silnie kontrolowane przez państwo, które do tego celu wykorzystuje kontrakty planistyczne (Contract de Plan Etat Région CPER), w które wpisuje głównie priorytety narodowe, zamiast pozwolić na inicjatywę ze strony regionów. Pierwsze kontrakty (od roku 1984) były zawierane na cztery lata, obecnie realizowane są kontrakty sześcioletnie. Perspektywa czasowa dostosowana jest do procesu programowania UE. Kontrakty są ściśle powiązane z planami/programami rozwoju regionalnego. Programy te są sporządzane na zasadzie partnerstwa i każdy z głównych partnerów zobowiązuje się do współfinansowania zadań. Ponadto CPER łączą narodową politykę zagospodarowania przestrzennego z europejską polityką $w$ dziedzinie funduszy strukturalnych. Obecnie UE finansuje ok. $40 \%$ całości programu, władze regionalne ok. $20 \%$, departamenty między 10 a $15 \%$, a rząd centralny ok. $10 \%$.

Podpisywanie przez regiony z państwem kontraktów dotyczących współfinansowania projektów zapewnia ich spójność z założeniami planu narodowego. Z drugiej strony współpraca dwóch publicznych jednostek finansujących projekt umożliwia efekt dźwigni w przypadku większych inwestycji. Formuła kontraktu pozwala zaadaptować cele polityki państwa do lokalnej specyfiki i zastąpić tradycyjne relacje oparte na podporządkowaniu stosunkami bazującymi na negocjacji i dyskusji. Charakterystyczną cechą CPER jest włączanie do nich różnych poziomów władzy czy też różnych aktorów publicznych z tego samego poziomu. Kontrakty planistyczne zawierane są między dwoma głównymi grupami podmiotów: 
1. Wybieralnymi władzami lokalnymi i regionalnymi oraz podmiotami związanymi $\mathrm{z}$ rozwojem $\mathrm{w}$ regionie (firmy, izby przemysłowe, związki biznesowe itp.), koordynowanymi przez władzę regionalną.

2. Prefektem regionu, który nie jest wybierany, lecz mianowany przez rząd centralny i pełni funkcję pośrednika.

Kontrakty mogą być również podpisane z władzami aglomeracji, obszarów miejskich, parków regionalnych czy innych wyznaczonych obszarów (rys. 7) [OECDb, 2006, s. 67].
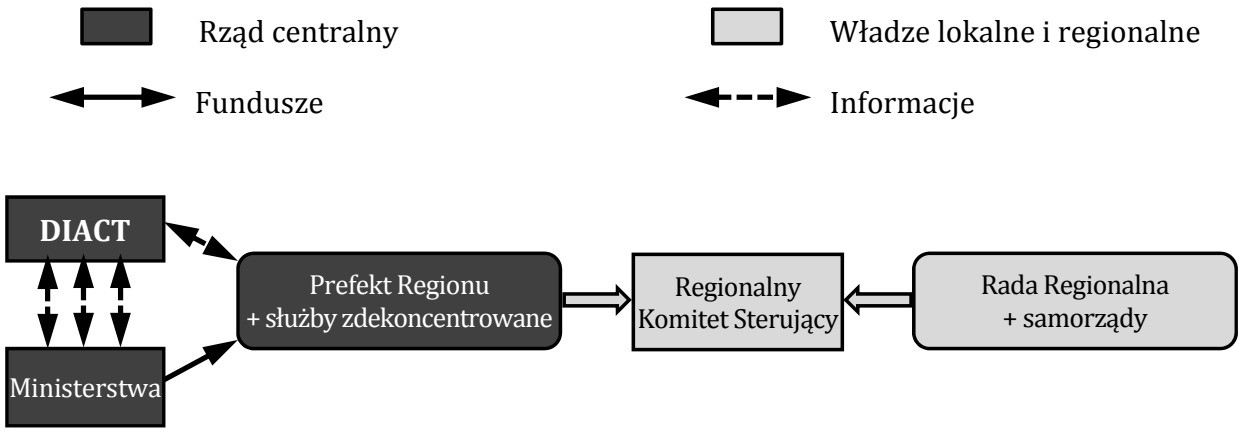

Rys. 7. Struktura organizacyjna kontraktów planistycznych (CPER)

Źródło: oprac. własne na podstawie [OECD 2006b, s. 154].

Wszystkie CPER koordynowane są przez narodową agencję planistyczną - DIACT (wcześniej: Delegację ds. Zarządzania Terytorialnego i Działań Regionalnych - DATAR [Délégation à l'aménagement du territoire et à l'action régionale]). Przedstawiciele różnych ministerstw tworzą Komitet Sterujący, który koordynuje działania podejmowane przez władze centralne i regionalne w poszczególnych sektorach $\mathrm{w}$ regionie.

Pierwsze kontrakty były poświęcone projektom infrastrukturalnym i modernizacji przemysłu, ostatnio podpisywane CPER dotyczą szerszego zestawu zagadnień i obejmują m.in. dotacje na innowacje i rozwój gospodarczy w regionie, planowanie miast oraz instrumenty stymulujące inicjatywy terytorialne. CPER są najważniejszym instrumentem wspierającym niższe poziomy władzy w wykonywaniu ich zadań w zakresie wielkoskalowych inwestycji.

Z punktu widzenia rozwoju wielopoziomowego współrządzenia kontrakty stosowane we Francji mają szereg zalet:

- łączą polityki lokalne i regionalne z priorytetami krajowymi. Będąc krokiem w kierunku decentralizacji utrzymują zarazem spójność w formułowaniu i wdrażaniu polityk publicznych;

- uczestniczą w budowaniu lokalnego potencjału. Niższe poziomy administracji czynnie biorą udział w procesie ustalania zapisów kontraktów. 
Rozwiązanie to wymaga więc wysokiego stopnia partycypacji, wiedzy i umiejętności ze strony lokalnych podmiotów;

- pełnią funkcję legitymizacyjną. W sytuacji gdy zarządzanie nakazowe nie jest już praktykowane przez rząd centralny, może on dzięki kontraktom przedłożyć swoje polityki jako przedmiot porozumień zawieranych z innymi organami, które będą musiały przestrzegać ich wykonania;

- pomagają $\mathrm{w}$ radzeniu sobie $\mathrm{z}$ instytucjonalną fragmentacją; CPER są użytecznym narzędziem poprawiającym koordynację działań między różnymi ministerstwami działającymi na poziomie lokalnym;

- stabilizują relacje. Ze względu na fakt, że kontrakty określają długoterminowe zobowiązania, każda ze stron jest w stanie $\mathrm{z}$ większym prawdopodobieństwem przewidzieć decyzje partnerów;

- pozwalają na rozłożenie obciążeń związanych z realizacją wielkich projektów i kompleksowych programów, dzięki czemu możliwe jest przeprowadzenie przedsięwzięć, które były poza zasięgiem pojedynczych podmiotów;

- umożliwiają zaangażowanie różnych partnerów; dzielenie obciążeń wiąże się również z dzieleniem ryzyka, nie tylko finansowego, ale także politycznego. $\mathrm{W}$ przypadku trudności $\mathrm{z}$ realizacją zobowiązań, krytyka polityczna nie będzie możliwa ze strony wszystkich tych aktorów, którzy są zaangażowani w CPER. Dlatego też kontrakty działają jako rodzaj zabezpieczenia, ale jedynie przy umowach wdrożeniowych, gdyż podejmowanie decyzji w dalszym ciągu należy do szczebla centralnego.

Niemniej jednak kontrakty te nie są pozbawione wad:

- wiążą się z wysokimi kosztami transakcji, ze względu na czasochłonne negocjacje i wykonanie; pojawia się ryzyko, że opierają się na niedoskonałej informacji. Aby tego ryzyka uniknąć konieczne są długotrwałe konsultacje, przygotowania i negocjacje, które mogą trwać nawet dwa lata;

- kraje korzystające z kontraktów (również Włochy i Hiszpania), twierdzą, że mają one tendencje do rozprzestrzeniania się (np. we Francji poprzednia generacja kontraktów obejmowała 170 rodzajów działań, 200 rozdziałów budżetu i około 20 ministerstw);

- ministerstwa odpowiedzialne za realizację kontraktów nie chcą utracić swoich przywilejów;

- mimo że mechanizmy negocjacji mają umożliwić większą elastyczność niż dzieje się to przy hierarchicznym podziale obowiązków, może wystąpić brak reakcji na zmiany w przypadku, gdy strony są sztywno przywiązane do ustalonych długoterminowych programów [OECD 2005a, s. 83-84].

Rozwój współpracy międzygminnej we Francji sięga roku 1890, kiedy to ustawa wprowadziła możliwość tworzenia dobrowolnych związków międzygminnych (Etablissements publics de coopération intercommunale EPCI), w celu realizowania zadań z zakresu wspólnego dostarczania usług 
publicznych. Państwo, chcąc zachęcić gminy do zawierania związków, wprowadziło system zachęt obejmujących granty oraz harmonizację dochodów z lokalnych podatków od przedsiębiorstw. Związki te były związkami monofunkcyjnymi (syndicats à vocation unique - SIVU). Kolejny krok we współpracy gmin wiązał się z ustawą z roku 1959 o „wielofunkcyjnych związkach międzygminnych" (SIVOM), które były zarządzane przez radę zarządczą wybraną przez gminy członkowskie, finansujące zarazem funkcjonowanie związku. Funkcjonowanie tych związków było trudne do pogodzenia z władzą, jaką miały departamenty, szczególnie w obszarach metropolitalnych.

W roku 1966 arbitralnie ustanowiono pierwsze cztery „wspólnoty urbanistyczne" (Communauté urbaine) w obszarach metropolitalnych Bordeaux, Lille, Lyonu i Strasburga. Stopniowo dziesięć innych wielkich miast wraz z gminami z obszaru metropolitalnego utworzyło, już na zasadach dobrowolności, kolejne wspólnoty. Tym, co różniło wspólnoty od związków było nadanie im prawa do ustalania własnych podatków, poza tymi, które już obowiązywały w gminach będących członkami wspólnot [OECD 2006b, s. 177].

W roku 1971 Zgromadzenie Narodowe przyjęło ustawę (Loi Marcellin), która miała rozpocząć reformę terytorialną polegającą na łączeniu się gmin opartym na zasadzie dobrowolności. Reforma ta okazała się kompletnym fiaskiem, ponieważ nigdzie nie został spełniony wymóg uzyskania od burmistrzów zgody na połączenie gmin. Przyczyną tej sytuacji była możliwość kumulacji mandatów, co powodowało, iż burmistrzowie wielu gmin jednocześnie byli członkami Zgromadzenia Narodowego oraz Senatu i optowali za utrzymaniem istniejącego status quo $0^{55}$. Od tej pory we wszelkich reformach przestano dążyć do łączenia gmin i skupiono się na zmianie układu instytucjonalnego relacji między gminami. Na mocy ustawy z 31 grudnia 1982 r. dodatkowo rozszerzono obligatoryjne zadania wspólnot miejskich o zagospodarowanie przestrzenne, infrastrukturę i usługi publiczne o znaczeniu metropolitalnym [Pyka 2010, s. 134].

W roku 1992 pojawiły się dwie kolejne formy prawne współpracy międzygminnej: „wspólnota gmin” (Communauté de commune) oraz „wspólnota miast" (Communauté de villes), których zadaniem miało być sprzyjanie lokalnemu rozwojowi ekonomicznemu oraz racjonalnemu zagospodarowaniu przestrzennemu. Jednostki te dysponowały standardowymi kompetencjami o charakterze obligatoryjnym, ale ustawodawca przewidział również harmonizację systemu podatkowego w ich obrębie. W szczególności chodziło o ujednolicenie wysokości podatku od przedsiębiorstw, który jest głów-

55 We Francji w roku 1998 95\% członków Parlamentu było jednocześnie burmistrzami, a $68 \%$ wchodziło w skład rad gmin. W przypadku Senatu liczby te wynosiły odpowiednio 68 i $44 \%$. 
nym źródłem dochodów fiskalnych francuskich gmin. Harmonizacja ta miała być obowiązkowa dla Wspólnot Miejskich, opcjonalna zaś dla Wspólnot Gminnych [Pyka 2010, s. 135]. EPCI są zarządzane przez ciało utworzone z przedstawicieli rad gminnych gmin wchodzących w skład wspólnoty. W ich tworzenie obowiązkowo zaangażowane jest państwo za pośrednictwem prefekta, który musi podpisać dekret tworzący wspólnotę.

W roku 1999 ustawa Chevènement uprościła reguły funkcjonowania EPCI i uporządkowała ich struktury, zostawiając tylko trzy dopuszczalne formy związków. Oprócz wspólnot urbanistycznych (communauté urbaines - CU), w których liczba ludności wynosi co najmniej 500 tys., funkcjonują „wspólnoty aglomeracji” (communautés d'agglomération - CA) (liczące powyżej 50 tys. ludzi) oraz wspólnoty gmin, tworzone poza terenami zurbanizowanymi. Ustawa spowodowała odejście od luźnej, stowarzyszeniowej formy współpracy (SIVU) na rzecz form zaawansowanych (federacyjnych), w których realizacja obligatoryjnych zadań finansowana jest m.in. z własnego lokalnego opodatkowania. Gminy zobowiązane są przekazać EPCI zadania w zakresie promocji gospodarczej, zagospodarowania przestrzennego i transportu. Inne zadania również mogą zostać przekazane wspólnotom, ale na zasadach dobrowolności [Parrado Diez 2006, s. 5].

Wspólne dla wszystkich tych form współpracy jest władztwo podatkowe. Wprowadzony ustawą mieszany system podatkowy pozwolił wspólnotom terytorialnym przyjmować dodatkowe, uzupełniające stawki podatku od nieruchomości czy podatku mieszkaniowego, zwiększając dochody tych wspólnot. Ujednolicony podatek od działalności gospodarczej pozwolił uniknąć niezdrowej konkurencji między gminami, które rywalizowały między sobą poprzez obniżanie stawek podatkowych w celu przyciągnięcia na ich teren zewnętrznych inwestycji. W wyniku tej ustawy nastąpiła eksplozja występowania współpracy międzygminnej, do czego przyczyniła się w dużej mierze zachęta finansowa w formie globalnej subwencji na działalność związku (DGF - Dotation Générale de Fonctionnement). Francuski rząd centralny oferował zainteresowanym gminom dotację motywacyjną jako dodatek do istniejących już dotacji. Jednym z warunków uzyskania tych środków była zgoda gmin na wprowadzenie na ich terenie ujednoliconego systemu podatków od przedsiębiorstw. Ponadto, aby uzyskać tę dotację, wspólnoty miejskie i wspólnoty aglomeracji muszą przyjąć tak zwany projekt terytorialny (aglomeracyjny). Projekt ten to 5-10-letni plan dotyczący infrastruktury, rozwoju gospodarczego, mieszkalnictwa, kultury, środowiska, itd. na poziomie metropolitalnym. Projekt określa również kwotę środków finansowych oraz wszystkie działania, które należy podjąć, aby zrealizować założenia planu. Obecnie realizowane są kontrakty sześcioletnie, których perspektywa finansowa dostosowana jest do procesu programowania UE. Po zatwierdzeniu przez radę wspólnoty projekt jest omawiany 
z rządem centralnym. Po zatwierdzeniu przez ten rząd, zostaje podpisane porozumienie pomiędzy rządem a wspólnotą, zwane kontraktem aglomeracyjnym (contrat d'agglomeration) ${ }^{56}$. Porozumienie gwarantuje, że rząd centralny sfinansuje część działań określonych w projekcie terytorialnym (dochodzi więc do negocjacji pomiędzy rządem a wspólnotą w kwestii finansowania). Ponadto prawo przewiduje, iż contrat d'agglomeration musi zostać podpisany także przez radę regionalną. Oznacza to, że działania określone w kontrakcie są również finansowane przez region i w związku z tym stanowią część CPER. Oznacza to też, że do generalnego budżetu projektu terytorialnego napływają środki z unijnych funduszy strukturalnych [OECD 2008a, s. 195]. Ogólnie wszystko zmierza w kierunku ograniczenia roli państwa i włączenia jak największej liczby aktorów w proces decyzyjny.

Od roku 2007 funkcjonują także kontrakty metropolitalne (na podobnych zasadach co kontrakty aglomeracyjne), które były głównym krokiem na drodze do uznania gospodarczych obszarów funkcjonalnych, jakimi są obszary metropolitalne.

Główne działania w zakresie rozwoju gospodarczego zapisane w kontraktach obejmują:

- przyciąganie biznesu (planowanie i tworzenie specjalnych stref aktywności, przedsiębiorstw, izb przemysłowych, parków technologicznych itp.),

- szkolnictwo wyższe, badania, kształcenie i zatrudnienie, m.in. Bordeaux, Renes, Nancy,

- dywersyfikację lokalnej gospodarki (klastry, centra doskonałości, tworzenie firm, inkubatory) - np. Lyon,

- transport, infrastrukturę, sieci cyfrowe (Bordeaux, Renes) [OECD, 2006b, s. 176].

Na początku roku 2012 we Francji funkcjonowało 2599 EPCI posiadających władztwo podatkowe, z czego 15 stanowiły wspólnoty miejskie (CU) a 191 - wspólnoty aglomeracji (CA), 22 z nich wokół wielkich aglomeracji [http://fr.wikipedia.org/wiki/Communaut\%C3\%A9_d'agglom\%C3\%A9ration]. 95\% gmin stało się członkiem wspólnot. Wspólnoty miejskie tworzą gminy znajdujące się w obszarach metropolitalnych. Skupiają od pięciu (Commu-

${ }^{56}$ Contrat d'agglomeration w Bordeaux wynosi 1,2 miliarda EUR na okres siedmiu lat. Został podpisany przez communaute urbaine w Bordeaux (CUB), radę departamentu Gironde, miasto Bordeaux, radę regionalną Akwitanii oraz przedstawicieli rządu centralnego (prefekta regionalnego). Wkład rządu centralnego stanowi $17 \%$ wszystkich środków, CUB $36 \%$, a rady regionalnej $15 \%$. Poza tym środki przekazuje również UE, Departament Gironde, gminy oraz instytucje publiczne, jak np. Koleje Narodowe (SNCF) lub Narodowe Centrum Aeronautyki (CNES). 
nauté urbaine de Cherbourg) do 85 (Lille Métropole Communauté urbaine) gmin [http://fr.wikipedia.org/wiki/Communaut\%C3\%A9_urbaine].

Tym samym powstały władze metropolitalne. Na ich czele stoi Zgromadzenie Wspólnoty. Radni wchodzący w skład Zgromadzenia wyznaczani są przez rady miejskie spośród ich członków (Prezes Wspólnoty wyłaniany jest przez Zgromadzenie Wspólnoty).

Podział mandatów między poszczególne gminy określany jest w sposób dowolny w statucie, jednakże żadna z gmin sama nie może mieć większości (nawet jeżeli reprezentuje ponad 50\% całej ludności). Zgromadzenie Wspólnoty przyjmuje statut i określa kompetencje interesujące Wspólnotę. Gmina może być członkiem tylko jednej wspólnoty.

Wspólnoty aglomeracyjne są odpowiedzialne za rozwój gospodarczy, równowagę społeczną i mieszkalnictwo oraz politykę miasta, ponadto mogą przejąć na siebie obowiązki $\mathrm{z}$ zakresu drogownictwa, infrastruktury wodnościekowej, infrastruktury w dziedzinie kultury i sportu oraz polityki środowiskowej na ich obszarze [Lefevre 2003, s. 296]. Gminy będące członkami wspólnot zostają zwolnione z przekazanych kompetencji (zasada wyłączności).

Do obowiązkowych kompetencji wspólnot urbanistycznych (CU) należy:

- rozwój gospodarczy, społeczny i kulturalny,

- zagospodarowanie przestrzenne,

- równowaga społeczna i mieszkalnictwo,

- zarządzanie usługami pożytku zbiorowego,

- ochrona i poprawa środowiska oraz jakości życia [MRR 2008].

W roku 2004 została uchwalona ustawa usprawniająca funkcjonowanie EPCI, nakładając na nie obowiązek zdefiniowania interesu wspólnotowego oraz możliwość wykonywania niektórych kompetencji Regionu i Departamentu na własną prośbę i za zgodą tych ostatnich.

Zarządzanie aglomeracjami oparte jest w znacznym stopniu na dobrowolnej współpracy gmin. Obserwuje się trzy formy współpracy:

1. Poziome związki pomiędzy miastem centralnym i innymi gminami $\mathrm{w}$ regionie.

2. Przekrojowe powiązania poprzez partnerstwo publiczno-prywatne.

3. Związki pionowe pomiędzy różnymi poziomami władzy (departament, region, państwo i UE) [Herrschel, Newman 2002, s. 83].

W ciągu ostatnich trzech dekad siła regionów uległa umocnieniu, m.in. dzięki polityce Unii Europejskiej, dla której regiony są kluczowymi elementami w tworzeniu zjednoczonej Europy.

W roku 2009 opublikowano raport Balladura, który sugerował zmniejszenie liczby regionów z 22 do 15, a także liczby departamentów. Obecnie regiony francuskie muszą zmierzyć się z kompleksowymi zmianami, wprowadzanymi nową reformą terytorialną. Celem jej jest uproszczenie architektury organizacji terytorialnych i wzmocnienie każdego poziomu admini- 
stracji, ponieważ proces decentralizacji spowodował powstanie ogromnej liczby struktur, które na każdym szczeblu były bardzo słabe. Reforma nie ogranicza liczby gmin, ale dąży do ograniczenia liczby związków międzygminnych poprzez możliwość utworzenia przez gminy, które są w takich związkach, jednej gminy (jeśli obywatele wyrażą na to zgodę), zwanej „nowa gminą".

Ustawę wprowadzającą nową organizację terytorialną kraju uchwalono 16 grudnia 2010 r. Reforma pociąga za sobą konsekwencje terytorialne i funkcjonalne:

- ułatwia proces łączenia się regionów i/lub departamentów,

- wprowadza radnych terytorialnych, którzy mają być wybrani w marcu 2014 r. i mają tworzyć wspólne władze dla połączonych regionów i departamentów, które będą realizować bardziej spójne polityki dla obu szczebli. Radni terytorialni będą określać, jakie kompetencje zostaną przypisane regionom, a jakie departamentom zgodnie z Modelem kompetencji organizacji i wspólnych usług, które to schematy każdy region ma opracować do roku 2015. Ma to zapobiec dublowaniu się kompetencji. Radni będą wybierani w wyborach bezpośrednich przez gminy, których liczba ludności jest większa niż 3500 osób. W przypadku mniejszych gmin zostanie utrzymany wybór pośredni przez rady gmin,

- szczebel lokalny i regionalny w dalszym ciągu będą mieć oddzielne kompetencje, z wyjątkiem dziedzin, które będą wspólne: turystyka, sport i kultura,

- utworzenie nowych struktur w obszarach zurbanizowanych:

- metropolie (métropoles) - nowa odmiana EPCI, o dobrowolnym charakterze, mają być tworzone na obszarach o liczbie ludności powyżej 500 tys. mieszkańców w oparciu o zasadę spójności terytorialnej; mają przejąć niektóre kompetencje departamentu i regionu (rozwój gospodarczy, transport, edukacja) oraz państwa (zarządzanie głównymi urządzeniami i infrastrukturą, np. autobusami szkolnymi) z mocy prawa bądź też na drodze porozumień $\mathrm{z}$ departamentem, regionem lub państwem. Wybory radnych międzygminnych mają być bezpośrednie. Metropolie otrzymają środki finansowe (granty rządowe i transfery lokalne). Raport Balladura wskazuje 11 metropolii na terenie Francji, w praktyce tylko w ośmiu z nich liczba ludności przekracza 500 tysięcy, kryterium liczby ludności najprawdopodobniej zostanie więc zrewidowane.

- ośrodki metropolitalne (pôles métropolitains) - zgrupowanie EPCI, powyżej 300 tys. mieszkańców, z których przynajmniej jeden EPCI liczy powyżej 150 tys. mieszkańców (np. Lyon-Saint-Etienne) [GaunardAnderson 2011, s. 40].

Nowością, którą wprowadza reforma, jest ponoszenie przez państwo odpowiedzialności za współpracę międzykomunalną w ramach poszczegól- 
nych departamentów. Prefekt departamentu posiada prawo zobligowania związków międzygminnych do połączenia się z innymi i takie połączenia planowane były do końca roku 2011.

Ideą reformy jest wzmocnienie poziomu lokalnego poprzez nową organizację obszarów metropolitalnych, które będą mogły realizować funkcje o zasięgu metropolitalnym. Może się to również przyczynić do wzmocnienia regionów potrzebujących silnego kapitału regionalnego i zrównoważonej sieci miast $w$ ramach regionu. Ewidentnie jednak zostaje $w$ tym przypadku podważona rola regionu.

W celu integracji planowania przestrzennego Francja stosuje Programy Spójności Terytorialnej (schéma de cohérence territoriale - SCOT), które zostały wprowadzone mocą ustawy z 13 grudnia 2000 r. Są one opracowywane przez wspólnotę gmin zamiast do tej pory obowiązujących gminnych planów i master planów oraz innych dokumentów planowania sektorowego (plany strategiczne, transportu, ochrony środowiska, ochrony krajobrazu itd.) i stanowią ramy prawne dla wszystkich lokalnych nowych planów zagospodarowania terenu, planów miast, planów komunikacji miejskiej i planów dotyczących mieszkalnictwa. SCOT powinien wpisywać się w globalną politykę aglomeracji. To wyjątkowe narzędzie strategiczne nakreśla długofalową wizję rozwoju terytorium i jest punktem odniesienia dla PLU (Plans Local d'Urbanisme - Lokalnych Planów Urbanistycznych). PLU są tworzone na okres 10-15 lat i w przypadku wspólnot urbanistycznych dotyczą całego obejmowanego obszaru. SCOT opracowywane są przede wszystkim dla obszarów zurbanizowanych. Zawierają główne założenia wspólnoty na okres 10 lat. Decyzje o opracowaniu SCOT inicjuje gmina lub związek gmin. Decyzja podejmowana jest na drodze uchwały przez każdą radę gminy znajdującej się w obszarze funkcjonalnym. Główną rolę odgrywa w tym wspólnota, a rząd centralny, region czy departament mogą uczestniczyć w jego opracowaniu [OECD 2008a, s. 191]. Program ten ma na celu zachowanie równowagi pomiędzy procesem odbudowy miast a peryferiami wiejskimi, zachowanie zróżnicowanych funkcji urbanistycznych i społecznej różnorodności oraz dążenie do zrównoważonego rozwoju opartego na zasadzie konkurencyjności. Ma również na celu zapewnienie spójności pomiędzy poszczególnymi strategiami sektorowymi (mieszkalnictwo, infrastruktura, mobilność itd.) poza poziomem danej gminy.

Urban travel plans (Plans de Deplacements Urbains - PDU) są powszechnymi instrumentami polityki transportowej i dotyczą nie tylko transportu publicznego, ale również transportu drogowego, bezpieczeństwa, parkingów, środowiska itp. [Lefevre 2003, s. 294]. PLU, plany transportu miejskiego i plany mieszkaniowe muszą być zgodne ze SCOT, aby były ważne i można było egzekwować ich zapisy [OECD 2007a, s. 113]. Wspólnoty urbani- 
styczne odgrywają strategiczną rolę w procesie planowania i nego-cjowania polityk podczas sporządzania PDU, PLU i SCOT.

W roku 2005 DIACT wskazał 15 obszarów metropolitalnych, które mogły ubiegać się o fundusze od państwa na przygotowanie planów metropolitalnych ${ }^{57}$.

Francuski system władzy charakteryzuje się z jednej strony silną centralizacją, a z drugiej olbrzymią liczbą innych podmiotów. W wyniku podejmowanych od lat reform proces podejmowania decyzji na poziomie regionalnym stał się bardziej otwarty i silniej oparty na partnerstwie, jednakże państwo w dalszym ciągu ma decydujący głos w wielu znaczących dziedzinach. Rada regionu staje się coraz bardziej znaczącym aktorem, którego uprawnienia są wzmocnione poprzez fakt, iż terytorium regionu jest odpowiednim obszarem do podejmowania tak ważnych kwestii, jak planowanie strategiczne, rozwój gospodarczy i ochrona środowiska. Współpraca między państwem a władzami lokalnymi jest konieczna, aby zapewnić spójność podejmowanych działań. To wywołuje dialog między różnymi podmiotami i otwartość decydentów publicznych na kulturę wspólnego podejmowania decyzji i negocjacji.

W wyniku decentralizacji państwa przekazano szereg kompetencji na niższe szczeble władzy. Teoretycznie każdy szczebel powinien dysponować swoim własnym zakresem odpowiedzialności. W praktyce jednak, co wielokrotnie było krytykowane ${ }^{58}$, każdy taki szczebel jest odpowiedzialny za część zadań z danej dziedziny i w rzeczywistości gminy są pozbawione faktycznych kompetencji. Z tego też względu gminy zaczęły tworzyć EPCI.

\section{Ile-de-France}

Region Ile-de-France tworzy Paryż (Ville de Paris) wraz z siedmioma departamentami i 1281 gminami, które zamieszkuje ponad $12 \mathrm{mln}$ ludzi. Rola Paryża jako miasta stołecznego jest szczególna. Od początku swego istnienia był on miejscem sporu między rządem centralnym a władzami Paryża,

57 Obszary wskazane przez DIACT to: Sillon lorrain (aglomeracja Nancy, Metz, Épinal i Thionville); métropole normande (aglomeracja Caen, Rouen i Le Havre); métropole Loire-Bretagne (aglomeracja Nantes, Rennes, Saint-Nazaire, Angers i Brest); metropolia obejmująca Marsylię i Aix-en-Provence; Lazurowe Wybrzeże (aglomeracja Nicei, Antibes, Menton, Grasse i Cannes); aglomeracja na granicy francusko-niemieckiej utworzona przez Strasbourg i Ortenaukreis; obszar metropolitalny Tuluzy; obszar metropolitalny Lille; aglomeracja miast centralnych i Rhône-Alpes; region zurbanizowany Lyonu; metropolia French-Valais-Geneva; Clermont-Auvergne; Sarrebrück - Moselle Est; obszar metropolitalny Côte d'Opale - Flandria - Zachodnia Belgia; sieć metropolitalna Rhine-Rhone. Sześć z tych obszarów jest obszarami transgranicznymi.

58 Zob.: OECD 2006b. 
które traktowały miasto jak „domenę królewską”. Funkcje stołeczne z czasem zdominowały jego rolę jednostki komunalnej, co sprawiło, że przez wiele lat ustrój Paryża różnił się od ustroju pozostałych metropolii francuskich. Jego forma miała zapewnić jak najszerszy wpływ władzy centralnej na funkcjonowanie stolicy [Niziołek 2008, s. 163]. Różnice te zostały zniesione dopiero $\mathrm{w}$ roku 1975 na mocy ustawy o gminach z 1884 i ustawy o departamentach z $1871 \mathrm{r}$.

Obecny ustrój Paryża ukształtowała ustawa z 31 grudnia 1982 r. o organizacji administracyjnej Paryża, Lyonu i Marsylii oraz o związkach międzygminnych. Samo miasto Paryż jest jednocześnie gminą i departamentem, a wewnętrznie podzielone zostało na dzielnice. Od roku 1975 na czele Paryża stoi mer (jest on jednocześnie przewodniczącym Rady Regionu Ile-de-France) wybierany przez Radę Gminy. Organem wykonawczym Departamentu Paryskiego jest reprezentant władzy centralnej - Prefekt Paryża. Rada Paryża pełni jednocześnie funkcję rady gminy i rady departamentu. Zasiada w niej 163 radnych.

Na czele każdej z 20 dzielnic stoi wybierana w wyborach powszechnych rada oraz wybierany przez radę mer dzielnicy.

Do kompetencji dzielnic należą m.in. sprawy z zakresu:

- budowy infrastruktury przeznaczonej dla dzieci (żłobki, place zabaw),

- budowy obiektów społeczno-kulturalnych (domy kultury),

- inwestycji sportowo-rekreacyjnych,

- projektowania terenów zielonych o powierzchni nie przekraczającej 1 ha.

Realizacja projektów w powyższych dziedzinach uzależniona jest od zgody Rady Gminy Paryż. Od roku 2002 rady dzielnic mają obowiązek tworzenia nowych organów doradczych - rad osiedli, które wyrażają opinie we wszystkich sprawach dotyczących osiedli [Niziołek 2008, s. 168-169].

Region Ile-de-France ma podobną strukturę organizacyjną jak inne regiony we Francji. Na jego czele stoi Rada Regionu, do której należy 209 radnych regionalnych. Zgodnie z reformą z roku 2010, od roku 2014 radni regionalni i 460 radnych departamentów mają zostać zastąpieni przez 308 radnych terytorialnych, którzy będą jednocześnie członkami rady regionalnej i rad departamentów. Będą oni wybierani na kadencję sześcioletnią.

Region Paryża ma nieco inne kompetencje niż pozostałe regiony Francji. Wynika to z tego, że rząd centralny nie chciał przekazać stolicy Francji tak wielu uprawnień jak innym regionom [Lefevre 2003, s. 14]. Do jego kompetencji należy m.in.:

- budownictwo socjalne i rewitalizacja,

- opieka społeczna,

- określanie zasad polityki w zakresie terenów zielonych, obszarów leśnych i miejsc spacerowych, 
- określanie (wspólnie z państwem) zasad polityki w odniesieniu do ruchu drogowego i transportu publicznego $\mathrm{w}$ regionie,

- zapewnienie miejsc pracy,

- budowa i utrzymanie liceów,

- kształcenie zawodowe [http://www.iledefrance.fr/english/the-regional-council/the-regional-councils-fields-of-intervention/the-regional-coun-cilsfields-of-intervention].

W kompetencjach rządu centralnego pozostał transport i planowanie regionalne. W praktyce bardzo trudne jest opracowywanie planów zagospodarowania przestrzennego regionu ze względu na nieustanne konflikty $w$ tej dziedzinie między państwem i regionem.

Region Ile-de-France ma specyficzne źródła finansowania. Tak jak wszystkie regiony we Francji ma prawo poboru podatków od wydawania praw jazdy i może ustanawiać podatki od wydawania dowodów rejestracyjnych pojazdów oraz z tytułu przeniesienia praw własności nieruchomości. Może też zaciągać pożyczki i otrzymuje pewne środki od państwa. Ponadto czerpie dochody ze środków pozyskiwanych wcześniej przez dystrykt, takich jak podatki lokalne (od nieruchomości, zamieszkiwania, prowadzenia działalności gospodarczej i inne) czy należności z tytułu budowy budynków i lokali użytkowych [Niziołek 2008, s. 173].

Na obszarze całego regionu Ile-de-France działa Związek Transportu Paryża. Na jego czele stoi Rada Administracyjna, której członkami są w połowie przedstawiciele państwa, a w połowie reprezentanci jednostek samorządu terytorialnego. Państwo dysponuje głosem rozstrzygającym. Związek koordynuje funkcjonowanie poszczególnych przedsiębiorstw transportu publicznego. Państwo kontroluje dwóch największych operatorów publicznych: RATP - obsługujący metro, główne linie autobusowe i tramwajowe oraz część sieci RER (kolejka podmiejska), a także SNCF (koleje państwowe), które obsługują wszystkie pociągi podmiejskie i pozostałą część sieci RER [Lefevre 2003, s. 291]. Do roku 2002 w radzie nie było przedstawicieli regionu, który $\mathrm{w}$ olbrzymim stopniu uczestniczył $\mathrm{w}$ finansowaniu infrastruktury transportowej. Zostało to „naprawione” w 2002 r., kiedy w wyniku przyjętej w roku 2000 ustawy o Solidarności i Odnowie Obszarów Zurbanizowanych (SRU), utworzono nowy podmiot - Syndykat Transportowy Regionu Ile de France (STIF). Jednak państwo w dalszym ciągu miało w nim tyle głosów, ile pozostali członkowie razem wzięci [Lefevre 2003, s. 295].

W grudniu roku 2000 został też przyjęty pierwszy plan funkcjonowania transportu na terenie zurbanizowanym (PDU), w którym po raz pierwszy obszar regionu stał się przedmiotem kompleksowej polityki transportowej. Jego opracowanie rozpoczęło proces, w którym sektor prywatny (izby handlowe, związki zawodowe, przemysł samochodowy itd.), sektor publiczny i społeczeństwo byli w stanie dyskutować nad formułowanymi 
politykami o skali regionalnej. Szczególnie zaangażowane w ten proces były gminy, z racji stworzenia wówczas lokalnych planów transportowych [Lefevre 2003, s. 295]. Od roku 2007 trwają prace, pod przewodnictwem STIF, nad weryfikacją PDU i dostosowaniem polityki transportowej regionu do nowych potrzeb mobilnego społeczeństwa. Jednym z elementów tego procesu były szerokie konsultacje społeczne, które trwały od września 2009 do stycznia 2010. W lutym roku 2011 został przyjęty projekt nowego PDU, który określa politykę transportową w regionie do roku 2020 [http://pdu. stif.info].

Współpraca między licznymi gminami w regionie była bardzo trudna. Wynika to głównie z faktu, że sam region ma wiodącą pozycję we Francji, natomiast Paryż, będący największą gminą w kraju (ponad 2 mln ludności), dominuje nad innymi jednostkami regionu. W praktyce gminy z regionu Ilede-France bardzo rzadko korzystały z możliwości współpracy. Sam Paryż zawsze odmawiał wejścia $\mathrm{w}$ jakiekolwiek struktury współpracy z innymi gminami czy departamentami. Nie jest on też włączony $w$ żaden SCOT [OECD 2007a, s. 113]. Takie podejście odgrywało bardzo ważną rolę w silnej fragmentacji całego regionu. Sytuacja zaczęła się zmieniać po wejściu w życie ustawy Chevenment, kiedy to w regionie Paryża zaczęły tworzyć się pierwsze wspólnoty (aglomeracji i gmin). Do chwili obecnej powstało ich w Ile-de-France 112, z czego 38 stanowią wspólnoty aglomeracji. Paryż w dalszym ciągu nie jest członkiem żadnego EPCI [http://www.amf.asso.fr /annuaire/?refer=region\&erg_n_id=14].

Niewielkie zmiany $\mathrm{w}$ zakresie dominacji państwa w regionie zaczęły pojawiać się w roku 2000, kiedy został zatwierdzony CPER na lata 2000-2006. Wówczas po raz pierwszy (od roku 1986) Rada Regionalna (Conseil Regional d'Ile-de-France - CRIF) „przebiła się” z planem regionalnym, który zawierał priorytety CRIF w różnych sektorach polityki i szczegółowe działania, które Rada chciała zrealizować w ramach CPER. Ponieważ opracowanie planu regionalnego wymagało dyskusji między regionem i innymi władzami lokalnymi, CRIF występowała jako rzecznik ośmiu departamentów w rozmowach z państwem. Jej pozycja polityczna i przetargowa tym samym znacznie się wzmocniła. Państwo zdało sobie sprawę, że nie może dłużej odgrywać roli dominującej, głównie z tego względu, iż nie ma konkretnej polityki terytorialnej dotyczącej regionu Ile-de-France i przyjęło plan przedstawiony przez CRIF [Lefevre 2003, s. 294].

W roku 2001, gdy większość we władzach Paryża uzyskała partia lewicowa, zostało utworzone biuro do spraw współpracy terytorialnej. Nawiązano wtedy pierwsze kontakty $\mathrm{w}$ celu rozpoczęcia realizacji wspólnych projektów włączając $\mathrm{w}$ nie Paryż i gminy z pierwszego pierścienia wokół stolicy [Lefevre 2003, s. 292]. 
Do 2001 r. w regionie Ile-de-France nie było żadnego podmiotu odpowiedzialnego za opracowanie strategii rozwoju. Jedynym aktorem w regionie, który mógł to zrobić, było państwo, ale strategię, którą przygotowywało i częściowo wdrażało $\mathrm{w}$ ramach CPER, można $\mathrm{w}$ najlepszym razie ocenić jako fragmentaryczną, w zależności od tego, jakiego obszaru polityki dotyczyła [Lefevre 2003, s. 298]. Sytuację miało poprawić utworzenie w 2001 r. Agencji Rozwoju Regionalnego (PREDA) funkcjonującej na zasadzie partnerstwa między Radą Regionu i izbami handlowymi. Do uczestnictwa w jej pracach zostały również włączone departamenty i lokalne organizacje. Rada regionu zasila budżet w 95\%. PREDA ma być ciałem strategicznym odpowiedzialnym za rozwój gospodarczy i społeczny. Pojawiają się jednak liczne konflikty między departamentami i izbami handlowymi, które do tej pory były odpowiedzialne za te dziedziny działalności i nie chcą, aby PREDA stało się silną agencją.

Agencja doradza i pomaga francuskim i międzynarodowym przedsiębiorstwom, które zamierzają rozpocząć, rozszerzyć lub przenieść swoją działalność w region Paryża [http://www.paris-region.com/ard_uk/outils /nos_partenaires.asp].

Cele strategiczne agencji obejmują:

1. Stworzenie i ochronę miejsc pracy w regionie paryskim;

2. Zwiększenie atrakcyjności gospodarczej regionu;

3. Wsparcie obszarów $\mathrm{w}$ regionie dotkniętym przez zmiany gospodarcze [http://www.paris-region.com/ard/paris-region-economicdeveloppement-agency/the-economic-development-agency/our-remit].

W roku 2002 rozpoczęto prace nad weryfikacją planu zagospodarowania regionu (SDRIF) i po raz pierwszy nie robiło tego państwo, lecz Rada Regionu. Nie oznaczało to całkowitego wyeliminowania państwa, które brało udział w opracowywaniu nowego SDRIF poprzez swoje służby regionalne ulokowane w prefekturze. Nowy SDRIF został przyjęty we wrześniu 2008 r. przez Radę Regionalną, ale dotąd czeka na zatwierdzenie przez Radę Stanu. Zawiera on wizje zagospodarowania regionu $\mathrm{w}$ perspektywie sięgającej roku 2030 [http://www.iledefrance.fr/lactualite/conseil-regional/conseilregional/le-projet-de-sdrif-en-ligne/].

Paryż ma miejscowy plan zagospodarowania przestrzennego (PLU) na lata 2005-2020, który jest aktualizowany w zależności od zmieniających się uwarunkowań [OECD, 2007, s. 113]. Pierwsza aktualizacja nastąpiła w roku 2009, kolejna jest w toku [http://mairie20.paris.fr/mairie20/jsp/site/Portal. jsp?page_id=896].

Zarządzanie $\mathrm{w}$ obszarze metropolitalnym Paryża jest utrudnione ze względu na wielość podmiotów władzy (region, wspólnoty aglomeracji i gmin, departamenty, gminy i dzielnice Paryża), których kompetencje często się zazębiają, oraz silny wpływ państwa. Niemniej jednak wraz ze 
zwiększaniem uprawnień Rady Regionu powoli następują przesunięcia w kierunku decentralizacji zarządzania. Governance sprowadza się jednak głównie do partnerstwa publiczno-publicznego. Sektor prywatny nie jest zbyt chętnie dopuszczany do udziału w podejmowaniu decyzji [Lefevre 2003, s. 298].

Dodatkowym utrudnieniem w zarządzaniu może być fakt, iż region funkcjonalny Paryża staje się coraz szerszy i wykracza poza terytorium regionu Ile-de-France. Planiści mówią o większym obszarze, tzw. Grand Basin Parisien, obejmującym części przyległych regionów [Lefevre 2003, s. 297].

\section{Portugalia}

Portugalia jest państwem o długoletniej tradycji centralistycznej. W roku 1976, na mocy Konstytucji, został wprowadzony podział administracyjny kraju na gminy i sołectwa. Portugalia formalnie nie ma regionalnego poziomu władzy, propozycja utworzenia którego została odrzucona w narodowym referendum w roku 1998. Tym samym władze lokalne są głównymi podmiotami na poziomie subcentralnym [Silva, Syrett 2006, s. 102]. Kontynentalna Portugalia podzielona jest na 18 dystryktów (nie będących formalnym szczeblem władzy) i 278 gmin oraz około 4200 sołectw, z czego tylko gminy i sołectwa są legalnie uznawanymi jednostkami administracji lokalnej. Dystryktami zarządzają gubernatorowie mianowani przez premiera. Organy władzy w gminie obejmują: zgromadzenie gminne (assembleia municipal) i radę wykonawczą (Câmara municipal) z burmistrzem (presidente da Câmara municipal) na czele, wybieraną na cztery lata. Gminy odpowiadają za zbiorowe usługi i podstawową infrastrukturę. Sołectwami zarządza lokalna rada (junta da freguesia) z prezydentem na czele. Do ich zadań należy tylko bieżąca administracja lokalna oraz utrzymanie pewnych elementów podstawowej infrastruktury [OECDb 2008, s. 24].

Z punktu widzenia Unii Europejskiej Portugalia podzielona jest na pięć regionów NUTS-2, którymi administrują Komisje ds. Regionalnej Koordynacji i Współpracy (CCDR), będące zdecentralizowanymi (właściwie zdekoncentrowanymi) organami Ministerstwa Środowiska, Planowania Przestrzennego i Rozwoju. Szeroki zakres ich kompetencji obejmuje m.in. planowanie przestrzenne na poziomie regionalnym [OECDb 2008, s. 109]. Ich rola umocniła się $\mathrm{w}$ momencie pojawienia się środków z funduszy strukturalnych i Funduszu Spójności UE. Proces ubiegania się o fundusze unijne, administrowania nimi i ich rozdzielania doprowadził też do rozwoju współpracy międzygminnej i nowych rozwiązań instytucjonalnych. Obserwuje się gwałtowny rozwój PPP i rosnące zaangażowanie sektora prywatnego w realizację polityk publicznych, spowodowane koniecznością współfinansowania projektów zasilanych ze środków unijnych. Zaczęły pojawiać 
się nowe formy instytucjonalne, takie jak agencje rozwoju lokalnego i regionalnego, spółki sektora publicznego oraz organizacje międzygminne [Silva, Syrett 2006, s. 102].

W art. 238 Konstytucji zapisano, że w wielkich obszarach metropolitalnych można, na mocy ustawy, ustalić inny rodzaj organizacji terytorialnej [Cid 2009].

2 sierpnia $1991 \mathrm{r}$. utworzono obszary metropolitalne Lizbony i Porto $\mathrm{w}$ formie obowiązkowego związku gmin [Lei $n .0$ 44/91].

W celu zwiększenia współpracy między gminami, w roku 2003 zostały uchwalone przepisy, które wprowadzały możliwość zawierania związków międzygminnych na zasadach dobrowolności. Gminy leżące na obszarach zurbanizowanych mogły zrzeszać się w następujące formy:

- wielkie obszary metropolitalne - musiały one obejmować co najmniej dziewięć gmin z populacją przekraczającą 350000 . Wówczas powstały obszary metropolitalne Lizbony i Porto;

- wspólnoty miejskie, które musiały obejmować przynajmniej trzy gminy zamieszkane przez 150000 mieszkańców.

Jednak utworzono tylko kilka takich związków i w roku 2008 nowa propozycja zmian $\mathrm{w}$ prawie została przedłożona parlamentowi. 27 sierpnia 2008 r. przyjęto ustawę, która określiła ustrój obszarów metropolitalnych Lizbony i Porto przywracając obowiązkowy związek gmin z roku 1991 i ograniczając istnienie obszarów metropolitalnych do Lizbony i Porto.

System planowania przestrzennego obejmuje Narodowy Program Polityki Przestrzennej (Programa Nacional da Política de Ordenamento do Território - PNPOT) opracowywany przez rząd centralny (przyjęty w roku 2007), regionalne plany zagospodarowania przestrzennego (Plano Regional de Ordenamento do Território - PROT) obejmujące swym zasięgiem wszystkie regiony NUTS-2 oraz miejscowe plany zagospodarowania przestrzennego (PDM) opracowywane przez gminy, dla których ustalenia PROT są wiążące - por. tab. 11 [OECDb 2008, s. 72].

PROT jest instrumentem rozwoju przestrzennego, który określa regionalną strategię tego rozwoju integrującą wytyczne sformułowane na poziomie krajowym ze strategiami gmin i stanowi punkt odniesienia przy opracowywaniu gminnych planów zagospodarowania przestrzennego. Ostatnie zmiany $\mathrm{w}$ przepisach dotyczących planowania przestrzennego przewidują partycypację i włączenie od samego początku w proces konsultacji zainteresowanych aktorów i odpowiedzialnych władz [National...]. Podczas prac nad PROT Komisje ds. Regionalnej Koordynacji i Rozwoju (CCDR) zapraszają gminy do uczestnictwa w nich.

PDM obejmuje obszar całej gminy, wymaga sformułowania strategii społeczno-gospodarczej, do której powinny odnosić się zapisy planu. Proces jego przygotowania uwzględnia partycypację społeczeństwa. 
System gospodarki przestrzennej w Portugalii

\begin{tabular}{|l|l|}
\hline \multicolumn{1}{|c|}{ Poziom } & \multicolumn{1}{c|}{ Rodzaj planu } \\
\hline Krajowy & $\begin{array}{l}\text { Narodowy Program Polityki Przestrzennej - PNPOT (ramowy) } \\
\text { Plany Sektorowe z odniesieniami do przestrzeni - PS (ramowe) } \\
\text { Specjalne Plany Środowiskowe (regulacyjne i obowiązkowe) }\end{array}$ \\
\hline Regionalny & Regionalne Plany Zagospodarowania Przestrzennego - PROT (ramowe) \\
\hline Lokalny & $\begin{array}{l}\text { Miejscowe Plany Zagospodarowania Przestrzennego Gminy - PDM (regu- } \\
\text { lacyjne i obowiązkowe) } \\
\text { Plany Międzygminne - PIOT (ramowe) } \\
\text { Plany Terenów Zurbanizowanych (regulacyjne i obowiązkowe) } \\
\text { Plany szczegółowe (regulacyjne i obowiązkowe) }\end{array}$ \\
\hline
\end{tabular}

Źródło: [Florentino 2007, s. 13].

Ponadto, opcjonalnie opracowywane są międzygminne plany zagospodarowania przestrzennego, które koordynują plany regionalne z gminnymi, gdy zachodzi potrzeba zintegrowanej koordynacji obszarów współzależnych od siebie pod względem strukturalnym. Plany te tworzone są dla obszarów (całych lub ich części) co najmniej dwóch gmin. Problemem jest brak przekazania gminom odpowiednich środków na realizację planów, w ślad za oddelegowaniem uprawnień do ich tworzenia.

Największymi obszarami zurbanizowanymi Portugalii są obszar Wielkiej Lizbony (Grande Lisboa) i Wielkiego Porto (Grande Porto). Na liście 78 obszarów metropolitalnych OECD figuruje tylko Lizbona.

\section{Lizbona}

Obszar Metropolitalny Lizbony (OML) zamieszkuje około 2,9 mln ludności. Proces metropolizacji zachodzący w regionie Lizbony doprowadził do przekształcenia tego obszaru z monocentrycznego w policentryczny. Wraz $\mathrm{z}$ dynamicznym rozwojem sieci transportowych oraz zmianami w zagospodarowaniu gruntów, w sąsiedztwie Lizbony zaczęły powstawać nowe centra handlowe, skupiska małych i średnich przedsiębiorstw. Zwiększona mobilność doprowadziła do utworzenia nowych ośrodków pracy oraz nowych terenów mieszkaniowych. Również przekształcenia gospodarki przemysłowej w kierunku gospodarki opartej na wiedzy ujawniły pilną potrzebę interwencji w centralnych, zdegradowanych obszarach Lizbony, takich jak centrum historyczne, rejon portu i tereny poprzemysłowe, co stworzyło miastu nowe możliwości rozwoju, nigdy wcześniej nie brane pod uwagę [Mendes, Morgado 2008, s. 2]. Wszystko to prowadziło do konieczności współpracy między gminami, które utworzyły jeden system funkcjonalny.

Współpraca między gminami w obszarze metropolitalnym Lizbony została prawnie sformalizowana w roku 1991 wraz z utworzeniem Rządu 
Metropolitalnego, który stanął na czele obowiązkowego związku obejmującego 19 gmin. Rząd ten posiadał jednak dość ograniczoną władzę. Nie był wybierany $\mathrm{w}$ bezpośrednich wyborach i składał się z lokalnych radnych oddelegowanych przez poszczególne gminy [Herrschel, Newman 2002, s. 85]. Żadnych istotnych kompetencji nie przekazano nowej władzy metropolitalnej i planowanie przestrzenne oraz polityka metropolitalna pozostały w rękach rządu centralnego [Florentino 2007, s. 13].

Od roku 2003, wraz z nową ustawą określającą zasady tworzenia obszarów metropolitalnych, uczestnictwo gmin w związku nie było obowiązkowe, lecz dobrowolne [Lei n. $\stackrel{o}{10 / 2003] . ~} 5$ lipca 2004 r. został utworzony Wielki Obszar Metropolitalny Lizbony (Grande Área Metropolitana de Lisboa), który obejmuje 18 gmin oraz 207 sołectw i pokrywa się z regionem NUTS-2. Od roku 2008, wraz z wejściem w życie ustawy, która przywróciła model obowiązkowego zrzeszania się gmin w obszarach metropolitalnych Lizbony i Porto, związek jest zarządzany przez trzy organy:

- reprezentujący - Rada Metropolitalna (Junta Metropolitana), który tworzy 18 burmistrzów zrzeszonych gmin. Wybierają oni spośród siebie prezydenta i dwóch wiceprezydentów;

- uchwałodawczy - Zgromadzenie Metropolitalne (Assembleia Metropolitana), utworzony $\mathrm{z}$ przedstawicieli Zgromadzeń Gminnych. Ich liczba maksymalnie sięga 55 osób;

- Wykonawczy Komitet Metropolitalny, odpowiedzialny za realizację uchwał Zgromadzenia Metropolitalnego i wytycznych Rady Metropolitalnej. Tworzy go od trzech do pięciu członków powoływanych przez Radę [Lei $n^{.} \cdot \underline{ }$ $46 / 2008$, art. 5].

Na mocy nowej Ustawy z 27 sierpnia 2008 r. określajacej ustrój obszarów metropolitalnych Lizbony i Porto, kompetencje władz metropolitalnych obejmują część uprawnień przekazanych przez rząd centralny oraz przez gminy. Należy do nich:

- osiągnięcie następujących celów publicznych:

- udział w przygotowywaniu planów i programów inwestycji publicznych w obszarze metropolitalnym,

- wspieranie planowania i strategii rozwoju gospodarczego, społecznego i środowiskowego obszaru,

- koordynowanie inwestycji komunalnych o charakterze metropolitalnym,

- udział w zarządzaniu programami wspierania rozwoju regionalnego, w szczególności w ramach Narodowych Strategicznych Ram Odniesienia (NSRO),

- uczestnictwo w określaniu usług i urządzeń sieciowych na poziomie metropolitalnym, 
- udział w metropolitalnych podmiotach publicznych, zwłaszcza w dziedzinie poprawy funkcjonowania transportu, wodociągów, dostarczania energii i gospodarki odpadami,

- planowanie działań podmiotów publicznych o zasięgu metropolitalnym,

- zapewnienie koordynacji działań między gminami i departamentami rządowymi w następujących obszarach:

- sieci zaopatrzenia ludności w wodę, infrastruktury, urządzeń sanitarnych, oczyszczania ścieków i odpadów komunalnych,

- ochrony zdrowia,

- kształcenia i szkolenia zawodowego,

- zagospodarowania terenu, ochrony przyrody i zasobów naturalnych,

- bezpieczeństwa i ochrony ludności,

- mobilności i transportu,

- obiektów użyteczności publicznej,

- promowania rozwoju gospodarczego i społecznego,

- sieci imprez kulturalnych, sportowych i turystycznych.

- wyznaczanie przedstawicieli gmin do publicznych lub gospodarczych podmiotów o charakterze metropolitalnym [Lei n.․ 46/2008, art. 1].

Środki finansowe obszaru metropolitalnego pochodzą z następujących źródeł:

- składek gmin tworzących obszar metropolitalny,

- transferów z gmin w przypadku kompetencji przekazanych przez nie władzom metropolitalnym,

- transferów wynikających z umów z administracją centralną lub z podmiotami publicznymi czy prywatnymi,

- dofinansowania ze środków unijnych,

- dotacji, subwencji i opłat za faktyczne dostarczanie usług publicznych, gdy zadanie to jest przypisane obszarowi metropolitalnemu,

- przychodów od majątku, z jego sprzedaży,

- dotacji z budżetu państwa przekazanych na bieżące funkcjonowanie, w wysokości 1\% Wyrównawczego Funduszu Finansowego (Fundo de Equilíbrio Financeiro),

- inne przychody na zasadach określonych prawem [Lei n.ํㅜㄴ 2008 , art. 25].

Plan zagospodarowania przestrzennego OML (PROT) został uchwalony w roku 2002 w związku z politycznymi decyzjami o rozpoczęciu inwestycji mających doprowadzić do restrukturyzacji obszaru metropolitalnego, takimi jak budowa nowego portu lotniczego w Lizbonie, budowa trzeciego mostu na Tagu, budowa kolei dużych prędkości i nowych platform logistycznych [http://www.cedru.com/en/what-we-do/development-and-landuse-management/31-plano-regional-de-ordenamento-do-territorio-da-areametropolitana-de-lisboa]. Bazując na zasadzie sustensywności, plan ma za 
zadanie restrukturyzację obszaru metropolitalnego, walkę z rozlewaniem się miasta, promowanie policentryzmu w kilku skalach, dążenie do miejskofunkcjonalnej równowagi pomiędzy dwoma dużymi jednostkami terytorialnymi - Grande Lisboa i Półwyspem Setúbal [Pereira, Carranca 2009, s. 5].

PROT AML jest podstawowym dokumentem dla Obszaru Metropolitalnego Lizbony, obejmującym priorytety w ochronie środowiska, wykorzystaniu potencjału metropolii, spójności społecznej i terytorialnej oraz organizacji metropolitalnego transportu publicznego [http://www.ccdrlvt.pt/content/index.php?action=detailfo\&rec=54]. Zawiera on, oprócz strategii rozwoju przestrzennego, m.in. strategię rozwoju gospodarczego i strategię ochrony środowiska [PROT-AML 2002]. Głównymi tematami, jakie porusza są:

- metropolitalne ośrodki centralne,

- sustensywny rozwój,

- metropolitalna sieć ekologiczna,

- ocena ryzyka i środowiskowa,

- zapobieganie kurczeniu się OML poprzez wielofunkcyjne użytkowanie terenów i rozwój sieci multimodalnych.

Lizbona próbuje przyciągnąć z powrotem ludzi i firmy m.in. poprzez realizację następujących polityk:

1. Strategię odnowy tkanki miejskiej;

2. Promowanie mieszkań dopasowanych do możliwości ekonomicznych mieszkańców;

3. Interwencję w obszarach priorytetowych;

4. Regenerację sąsiadujących z Lizboną obszarów;

5. Pomoc przedsiębiorstwom [Morgado 2012].

Za przygotowanie planu zagospodarowania przestrzennego dla OML jest odpowiedzialna Komisja Koordynacji i Rozwoju Regionalnego Lizbony i Doliny Tagu (CCDR-LVT), ale nie ma ona faktycznej możliwości jego realizacji, która uzależniona jest od szeregu inwestycji na szczeblu centralnym i od decyzji dotyczących zmiany użytkowania gruntów pozostających w kompetencji władz lokalnych. Większość planów zagospodarowania gmin została przy tym uchwalona przed PROT i w praktyce nie ma rzeczywistej koordynacji między metropolitalną polityka przestrzenną i 18 planami gmin [Florentino 2007, s. 13]. Aby zapisy PROT mogły zostać zrealizowane, musi być dokonana aktualizacja planów zagospodarowania przestrzennego poszczególnych gmin [Morgado 2007, s. 3]. Władze OML wykazują brak zdolności do realizacji regionalnej strategii i zapewnienia koordynacji działań międzygminnych. Wynika to z faktu, że struktura OML nie uwzględnia dystryktów, które wprawdzie nie są formalnie uznawanym poziomem władzy, ale sprawują władzę administracyjną nad gminami. Dystrykt Lizbony i Dystrykt Setúbal rywalizują ze sobą i próbują wpływać na władze 
obszaru metropolitalnego. W rezultacie władze OML są pasywne, co tłumaczą brakiem politycznej legitymizacji do interwencji na skalę metropolitalną. Zatem instytucje metropolitalne nie odgrywają skutecznej roli w systemie współrządzenia OML [Pereira, Carranca 2009, s. 10].

Wraz ze wzrostem rozmiaru i złożoności obszaru metropolitalnego Lizbony brak strategicznej władzy dla całego obszaru okazuje się coraz większym problemem. W kluczowych dziedzinach, w których skoordynowana polityka miałaby olbrzymie efekty dla rozwoju całego obszaru (transport, planowanie, marketing, stan środowiska), brak właściwych struktur zarządzania ogranicza możliwości wprowadzania rozwiązań optymalnych dla regionu jako całości i zarazem zakres odpowiedzialności. Wobec braku strategicznego podmiotu, relacje między gminami w obszarze stanowią mieszankę współpracy i konkurencji, z Lizboną odgrywającą dominującą rolę, nie tylko ze względu na fakt, że jest ośrodkiem centralnym obszaru metropolitalnego, ale również z uwagi na jej status stolicy państwa. Poza CCDR-LTV, która opracowała PROT zawierający wytyczne planistyczne dla departamentów rządu centralnego i gmin, brak jest koordynacji między Biurami Regionalnymi głównych ministerstw. Sytuację pogarsza jeszcze złożoność i brak ujednolicenia granic geograficznych dla działań podejmowanych przez departamenty rządu centralnego, z których każdy ma inny zasięg przestrzenny. W świetle tych rozwiązań krytykowane są władze metropolitalne, jako organ, który nie jest wybierany w wyborach bezpośrednich. Rada Metropolitalna jest w dużym stopniu niewłaściwym forum do dyskutowania i koordynacji kwestii metropolitalnych mając bardzo słabą władzę w stosunku do rządu centralnego i będąc w olbrzymim stopniu uzależniona od funduszy centralnych [Silva, Syrett 2005, s. 255].

Aby zrealizować zapisy PROT, w roku 2008 rząd centralny powołał zespół roboczy, składający się m.in. z przedstawicieli siedmiu ministerstw, do opracowania Strategicznego Planu dla Projektu Południowego Wybrzeża Rzeki (South Riverside Arch), który ma na celu przekształcenie obszarów poprzemysłowych. Projekt ten ma prowadzić do utworzenia Metropolii Dwóch Wybrzeży zapisanej w PROT dla OML. Na czele zespołu stał prezes CCDR-LVT. Do grupy roboczej weszli również przedstawiciele gmin, w których ma być realizowany projekt oraz przedsiębiorstwa będące właścicielami gruntów na terenie objętym projektem. Strategia została przyjęta w lipcu roku 2009 [http://www.ccdr-lvt.pt/pt/arco-ribeirinho-sul-oficialmente-lancado/1519.htm]. Działania w niej zapisane dotyczą obszaru 900 ha położonego w trzech gminach i prowadzone będą przez spółkę publiczną. Zakres finansowy inwestycji sięga $500 \mathrm{mln}$ euro. Wśród projektów strukturalnych przewidzianych $w$ ramach rewitalizacji Południowego Wybrzeża znajduje się rozwój przemysłów kreatywnych, żegluga rekreacyjna, przeniesienie terminali rzecznych, budowa mostu i rozbudowa metra. Cały 
projekt będzie miał wpływ na sześć gmin położonych wzdłuż wschodniego brzegu Tagu i zakłada przyciągnięcie do roku 2021500 tysięcy nowych mieszkańców [http://www.ccdr-lvt.pt/pt/arco-ribeirinho-sul-oficialmentelancado/1519.htm]. Jest to jednak strategia sektorowa i Lizbona w dalszym ciągu nie ma zintegrowanej strategii rozwoju całego obszaru metropolitalnego. Od roku 2009 PROT poddawany jest procesowi weryfikacji, który najprawdopodobniej zakończy się w roku 2012. Weryfikacji poddawane są również PDM.

Oprócz władz metropolitalnych w OML funkcjonuje szereg związków międzygminnych oraz różnych form partnerstwa publiczno-prywatnego, które zostały utworzone w celu promocji wszelkiego rodzaju wspólnych interesów/działań lub efektywniejszego świadczenia usług publicznych [Silva, Syrett 2005, s. 253]. Gminy mogą być członkami więcej niż jednego związku międzygminnego. Związki takie najczęściej tworzone są w oparciu na granicach dystryktów, ale część ma charakter subregionalny i często wykracza poza granice OML. Również stowarzyszenia biznesowe mają bardzo zróżnicowany zasięg [Silva, Syrett 2006, s. 108].

W OML funkcjonują dwie prywatne agencje rozwoju, z których każda obejmuje $\mathrm{w}$ przybliżeniu połowę obszaru. Ten podział terytorialny nie wynika jednak z faktycznych interesów lokalnych, lecz ma podłoże polityczne. Jedna z agencji obejmuje dziewięć gmin z południowej części obszaru i pięć gmin z sąsiedniego subregionu Setubal (NUTS-3). Silna partia komunistyczna funkcjonująca na tym obszarze doprowadziła do odrębnego zgrupowania władz lokalnych.

Druga agencja, obejmująca północną część obszaru, w praktyce jest instrumentem marketingowym dla Wielkiej Lizbony (subregion) z naciskiem na partnerstwo publiczno-prywatne. Została utworzona na początku lat 90. wieku XX i zakłada stworzenie jednolitych władz miejskich. W związku z tym nie odzwierciedla powiązań gospodarczych $w$ regionie i interesów wychodzących poza obszar Wielkiej Lizbony. Agencje te wprawdzie słabo odnoszą się do kwestii regionalnych, ale stanowią bardziej rozwiniętą formę współrządzenia, włączając sektor prywatny i inne grupy interesu [Herrschel, Newman 2002, s. 85].

Na początku roku 2009 prezydent Lizbony zwrócił się do zespołu niezależnych ekspertów i urbanistów o opracowanie dla miasta Karty strategicznej. Dokument ten miałby stanowić podstawę wszystkich innych nowo formułowanych polityk, strategii i instrumentów, a także nowego podejścia do miasta i jego mieszkańców. W długim okresie miałoby to doprowadzić do znaczącej zmiany w zarządzaniu miastem, w polityce miejskiej i lokalnej administracji publicznej [Seixas 2011, s. 264]. Karta miała objąć okres 2010-2024 i dotyczyć następujących obszarów: 
1. Demografii i witalności;

2. Jakości życia i integracji społecznej;

3. Energii, mobilności i sustensywności;

4. Gospodarki, kreatywności i zatrudnienia;

5. Kultury, edukacji i tożsamości;

6. Instytucji, administracji i zarządzania [Seixas 2011, s. 277].

Proces tworzenia dokumentu obejmował szereg debat publicznych i warsztatów w każdym z powyższych obszarów oraz wykorzystywał takie instrumenty, jak audycje internetowe i platformę internetową, poprzez którą każdy mógł zgłosić swoje uwagi.

W lipcu roku 2009 propozycja Karty została przedstawiona władzom Lizbony i poddana procesowi publicznych konsultacji [http://cartaestrategica.cm-lisboa]. W ciągu trzech lat, które upłynęły od tego momentu, nie została ona jednak poddana żadnemu procesowi politycznemu i przyjęta, tym samym odsuwając zapisane $\mathrm{w}$ niej propozycje $\mathrm{w}$ bliżej nieokreśloną przyszłość.

Niemniej jednak wydaje się, że niektóre z zawartych tam koncepcji zainspirowały polityki miejskie $\mathrm{w}$ takich obszarach, jak mieszkania socjalne, mobilność i reforma instytucjonalna. Jednak zarazem impas ten wydaje się wskazywać, że miejska władza wykonawcza nie była w stanie skutecznie kierować publiczną dyskusją i wypracować politycznego kompromisu.

Impas, w jakim znalazły się prace nad wdrożeniem Karty strategicznej pozwala na sformułowanie wniosków, które mogą dotyczyć nie tylko Lizbony, lecz również polityków i zmian w konfiguracji władzy w innych miastach europejskich.

Niepowodzenia związane z przyjęciem wspólnej strategii dla całego obszaru metropolitalnego pokazują, że oczekiwania, napięcia i zazębiające się strategie tworzące ramy dla funkcjonowania miejskich podmiotów w obecnym systemie politycznym Lizbony, są nadal w znacznym stopniu zorganizowane według logiki i rytmu opartych na klasycznych paradygmatach administracyjnej reprezentacji i władzy. Jest oczywiste, że pomimo tych wszystkich różnych oczekiwań i postaw interesariuszy istnieje stałe tempo miejskiej ewolucji i zmian. Postrzeganie problemów i wynikające z tego logiki działania prezentowane przez główne lizbońskie podmioty - w szczególności te związane z partiami politycznymi i instytucjonalnymi strukturami władzy oraz administracji - wciąż nie odzwierciedlają jasnej świadomości zmian zachodzących w miejskich społeczno-kulturowych paradygmatach. Ci centralni aktorzy na scenie politycznej miasta koncentrują się na procedurach prawnych i administracyjnych związanych z pełnionymi przez nich funkcjami oraz na utrzymaniu pozycji jaką mają w istniejących sieciach wzajemnych powiązań. 
Proces ten potwierdza także, że wysiłki na rzecz zmniejszenia luki między funkcjonalnymi systemami miejskimi i systemami politycznymi stanowią wyraźne wyzwania, a wręcz zagrożenia dla klasycznej długoletniej politycznej i administracyjnej organizacji miasta [Seixas 2011, s. 280].

Problemów tych nie jest w stanie przezwyciężyć nawet ciągłość władzy. Prezydent Lizbony, który zainicjował prace nad Kartq został wybrany na to stanowisko w roku 2007, ponownie w 2009 i jego mandat wygasa dopiero z końcem roku 2013, a mimo to do tej pory nie udało się przyjąć zaproponowanego dokumentu.

Jedną z największych przeszkód na drodze do skutecznego współrządzenia w OML jest labirynt instytucji i nakładających się kompetencji $\mathrm{w}$ procesie planowania. Jedne z badań prowadzonych w związku z pracami nad strategią rozwoju regionalnego Lizbony, wykazały co najmniej 180 podmiotów publicznych działających w regionie Lizbony, w obszarach tak różnych, jak przykładowo administracja terytorialna, rozwój regionalny czy turystyka [Crespo, Cabral 2010, s. 650]. Problemem jest fakt, iż podmiot zarządzający obszarem metropolitalnym nie jest ciałem wybieralnym, lecz jego członkowie nominowani są przez poszczególne rady gmin. Od czasu rewolucji i przywrócenia demokracji, lokalne władze w Portugalii odzyskały znaczenie polityczne, ale do tej pory cierpią na brak kompetencji typowych dla większości europejskich struktur lokalnych i regionalnych. Ponadto Portugalia ma, podobne jak Polska, problemy z rozwojem demokracji lokalnej, społeczeństwa obywatelskiego i kapitału społecznego. Tradycja aktywności obywatelskiej i partycypacji jest w obu krajach bardzo skromna. Kwestie publiczne bardzo długo nie były pojmowane w kategoriach zbiorowej odpowiedzialności.

W Portugalii obserwuje się również brak wiedzy na temat problemów miast i wyzwań, jakie pojawiają się współcześnie przed nimi, co pozwala na utrzymanie struktur administracyjnych z ograniczoną zdolnością do rozwijania przekrojowego i multidyscyplinarnego podejścia do zarządzania rozwojem. W dalszym ciągu istnieje wyraźny brak otwartych kanałów współrządzenia, przestrzeni publicznej do dialogu i współpracy ustanowionej poza debatami w okresach wyborczych i konsultacjami publicznymi narzucanymi przez przepisy w ramach planowania. Słabą stroną w rozwoju governance jest również brak zainteresowania ze strony elit miejskich procesami demokratycznymi, a nawet konkretnym zawodowym i politycznym zaangażowaniem w system miejskiego współrządzenia [Seixas 2011, s. 273].

Badacze tej problematyki ${ }^{59}$ uważają, że najlepszym rozwiązaniem, które zapewniłoby brakującą strategiczną koordynację i przywództwo, wydaje się utworzenie rządu metropolitalnego $\mathrm{z}$ odpowiednimi uprawnieniami i zaso-

${ }^{59}$ Zob.: OECD 2008b; Silva, Syrett 2006. 
bami. Jednakże nawet najbardziej fundamentalne reformy instytucjonalne niewiele zmienią, jeśli nie będą im towarzyszyć zmiany w kulturze społeczno-politycznej otoczenia instytucjonalnego. Obecna kultura polityczna charakteryzuje się wysokim poziomem biurokracji, elitaryzmem i tendencjami populistycznymi gmin funkcjonującymi w ramach wysoce scentralizowanego procesu opracowywania programów i podejmowania decyzji. Podczas gdy rozwój silniejszej współpracy pomiędzy sektorem publicznym i prywatnym był jednym z najbardziej uderzających aspektów ostatnich zmian, to brak przejrzystości i odpowiedzialności wielu działań zwiększył poziom nieufności i cynizmu wśród obywateli. Niepokojący jest również fakt, iż pomimo pewnych dowodów na rosnącą rolę podmiotów reprezentujących lokalne społeczności, działających na zasadzie woluntarystycznej, i silniejszego głosu ugrupowań tworzonych dla osiągnięcia pojedynczych celów, wiele elementów społeczeństwa obywatelskiego jest systematycznie wykluczanych z trudno dostępnych sieci współrządzenia, które aktualnie sprawują władzę w Lizbonie.

\section{Holandia}

Z uwagi na fakt, że Holandia jest stosunkowo niewielkim krajem, wyodrębnia się w niej jeden tylko obszar metropolitalny noszący nazwę Randstad lub Deltametropolis.

Ustrój terytorialny Holandii obejmuje trzy szczeble władzy: krajowy, władze prowincji (12) i gmin (458). Ponadto istnieją zarządy wodne, które są szczeblem władzy całkowicie odrębnym od gmin oraz regiony miejskie [http://dmp.zinnebeeld.nl/v1/cms/pdf_upload/Deltametropolis\%20Associa tion.pdf]. Rola władz regionalnych jest relatywnie słaba, podczas gdy władz lokalnych stosunkowo silna. Prowincją zarządza rada, której członkowie są wybierani w wyborach bezpośrednich na okres czterech lat. Na jej czele stoi komisarz mianowany przez rząd centralny, zarekomendowany na to stanowisko przez radę. Kadencja komisarza trwa sześć lat. Rada jest ciałem uchwałodawczym, powołuje ona także zarząd (od trzech do dziewięciu osób), pod przewodnictwem komisarza. Prowincje koordynują niektóre polityki publiczne (społeczną, planowanie, transport, kulturę). Sprawują również prawną kontrolę nad gminami (w szczególności w dziedzinie planowania, gdzie zatwierdzają miejscowe plany zagospodarowania przestrzennego) oraz zarządami wodnymi. Prowincje odpowiadają przede wszystkim za zagospodarowanie przestrzenne i infrastrukturę fizyczną, obejmującą planowanie, budowę i obsługę dróg regionalnych.

Gminy, podobnie jak prowincje, zarządzane są przez radę wybieraną na okres czterech lat w wyborach bezpośrednich na zasadzie proporcjonalnej reprezentacji. Rada jest również ciałem uchwałodawczym. Na jej czele stoi 
burmistrz rekomendowany przez radę i mianowany na to stanowisko przez rząd centralny na sześć lat. Rada gminy powołuje spośród radnych zarząd, któremu przewodzi burmistrz. W zależności od wielkości gminy zarząd liczy od dwóch do dziewięciu członków (oprócz burmistrza). Kompetencje gmin są dużo szersze i obejmują problematykę dotyczącą dróg, transportu publicznego, mieszkalnictwa, planowania lokalnego, środowiska, spraw społecznych, rozwoju gospodarczego, edukacji, opieki zdrowotnej, kultury i rekreacji, planowania przestrzennego [OECDb 2007, s. 159]. Wiele kompetencji gminy dzielą z rządem centralnym, ale są relatywnie autonomiczne. Rząd centralny jest wszechobecny $w$ kształtowaniu polityki, ponieważ ustanawia ogólne ramy, zasady i normy, których władze lokalne muszą przestrzegać, monitoruje większość realizowanych polityk i kontroluje finansowanie większości polityk sektorowych. Niemniej jednak ponad połowa decyzji podejmowanych przez gminy jest $\mathrm{w}$ pełni autonomiczna [Fleurke, Willemse 2006, s. 85].

Źródłem dochodów gmin tylko w niewielkim stopniu są podatki lokalne (ok. 5\%). Większość wydatków pokrywana jest z budżetu centralnego, co gwarantuje świadczenie usług publicznych przez różne gminy na zbliżonym poziomie i jednocześnie ogranicza konkurencję między gminami w zakresie stawek podatków. Z uwagi na ograniczony udział podatków i opłat lokalnych w finansowaniu działalności gmin, szukają one innych źródeł dochodów, takich jak np. dzierżawa gruntów, co wpływa na zahamowanie współpracy między sąsiadującymi gminami, gdyż powoduje konkurowanie o inwestycje [Kantor 2006, s. 808].

Na podobnych zasadach jak władze gmin i prowincji wybierane są władze zarządów wodnych, które są niezależną władzą publiczną na poziomie lokalnym. Odpowiadają one za kontrolę przeciwpowodziową, ilość i jakość wody oraz oczyszczanie ścieków. Spośród 26 zarządów w Holandii, 11 znajduje się na terenie Randstad. Ich granice administracyjne zdeterminowane są układem cieków wodnych, co oznacza, że niekoniecznie pokrywają się $\mathrm{z}$ granicami administracyjnymi prowincji czy gminy, lecz $\mathrm{w}$ praktyce przecinają się z nimi. Zarządy wodne mogą nakładać dwa rodzaje podatków w celu sfinansowania swoich obowiązków - opłaty na utrzymanie zarządów i opłaty za zanieczyszczenia.

W niektórych dużych gminach został utworzony dodatkowy szczebel władzy zwany okręgiem miejskim. W zależności od gminy struktura zarządzania nimi jest różna. W przypadku Amsterdamu na czele okręgu stoi bezpośrednio wybierana rada z przewodniczącym mianowanym przez radę lub zarząd gminy. W okręgach Rotterdamu przewodniczący powoływany jest przez radnych okręgu. W Hadze i Utrechcie każdym okręgiem miejskim zarządza komitet miejski utworzony z radnych gminnych. Zadaniem komitetu jest identyfikacja istotnych dla dzielnicy problemów, np. barier w roz- 
woju i zwrócenie na nie uwagi rady gminy. Poszczególni radni zwracają uwagę na jeden lub dwa okręgi miejskie. Zadania i obowiązki okręgów miejskich są porównywalne z tymi w gminach o podobnej wielkości.

Okręgi miejskie w Amsterdamie odpowiedzialne są za budowę i utrzymanie mieszkań socjalnych, utrzymanie przestrzeni publicznej, świadczenie większości usług komunalnych na rzecz mieszkańców i niektóre zadania z dziedziny opieki społecznej, sportu, edukacji i kultury. Działalność okręgów finansowana jest $\mathrm{z}$ budżetów gminnych, ale mogą one również nakładać własne podatki, np. za wywóz odpadów.

Holandia podejmowała próby utworzenia regionów miejskich wokół największych miast, gdzie zachodziły procesy i powiązania funkcjonalne typowe dla obszarów metropolitalnych. Jednak w obawie przed utratą autonomii gmin, reforma ta nie została wdrożona. W związku z tym $\mathrm{w}$ roku 1985 uchwalono Ustawę o Wspólnych Porozumieniach, która pozwalała gminom na dobrowolne zawieranie porozumień o współpracy poprzez tworzenie wspólnych władz, które miały uprawnienia do realizacji wspólnych zadań. Te rozwiązania dla regionów miejskich były bardziej zaawansowane, gdyż prowincje mogły wymusić na gminach współpracę. Ciałem, które oficjalnie określa obszar regionu miejskiego, są władze prowincji i to one mogą zaprosić gminy do utworzenia takiego regionu. Jeżeli nawet gminy nie chcą tego, to prowincja może je zmusić do współpracy. W praktyce jednak władze prowincji bardzo rzadko korzystały z tej możliwości. Powstałe regiony miejskie bazują na zasadzie dobrowolności. W roku 2007 w Holandii istniało osiem regionów miejskich, z czego na terenie Ranstad okręgi takie miały Amsterdam, Rotterdam, Haga i Utrecht. Regiony te składają się z miasta centralnego oraz sąsiednich gmin, które razem tworzą tzw. dzienny system miejski. Kompetencje regionów miejskich dotyczą takich dziedzin, jak transport, mieszkalnictwo, ochrona środowiska i gospodarka regionu, ale szczególnie istotną rolę odgrywają w transporcie. Jednym z głównych obowiązków regionów jest rozstrzyganie przetargów na koncesje na system regionalnego transportu publicznego. Ich zasoby finansowe są znaczne, choć nieporównywalne z budżetami wielkich miast czy prowincji (tab. 12). Pochodzą z dotacji celowych z budżetu centralnego i, w niewielkim stopniu, od gmin, które są członkami porozumienia [OECD 2007b, s. 172].

Ludność regionu Randstad liczy około siedmiu mln mieszkańców. Jest to obszar policentryczny, gdyż na jego terenie znajdują się cztery największe miasta Holandii: Amsterdam, Rotterdam, Haga i Utrecht. Randstad był uważany za jednolity region gospodarczy już w latach 30. wieku XX, jednak do tej pory nie uzyskał statusu jednostki administracyjnej [Kantor 2006, s. 809]. Granice tego obszaru nie zostały oficjalnie wyznaczone, ale przyj- 
muje się, iż obejmuje on swym zasięgiem 147 gmin oraz częściowo cztery prowincje (rys. 8).

Tabela 12

Regiony miejskie w Randstad (2002 r.)

\begin{tabular}{|l|c|c|c|c|}
\hline \multicolumn{1}{|c|}{ Region } & $\begin{array}{c}\text { Budżet } \\
\text { (mln euro) }\end{array}$ & $\begin{array}{c}\text { Budżet jako \% } \\
\text { budżetu } \\
\text { największej gminy } \\
\text { w regionie }\end{array}$ & $\begin{array}{c}\text { Liczba } \\
\text { współpracujących } \\
\text { gmin }\end{array}$ & $\begin{array}{c}\text { Liczba ludności } \\
\text { (w mln) }\end{array}$ \\
\hline Amsterdam & 400 & $8 \%$ & 16 & 1,3 \\
\hline Rotterdam & 350 & $8 \%$ & 18 & 1,2 \\
\hline Haga & 350 & $16 \%$ & 9 & 1,0 \\
\hline Utrecht & 200 & $17 \%$ & 10 & 0,6 \\
\hline
\end{tabular}

Źródło: [OECD 2007b, s. 172].

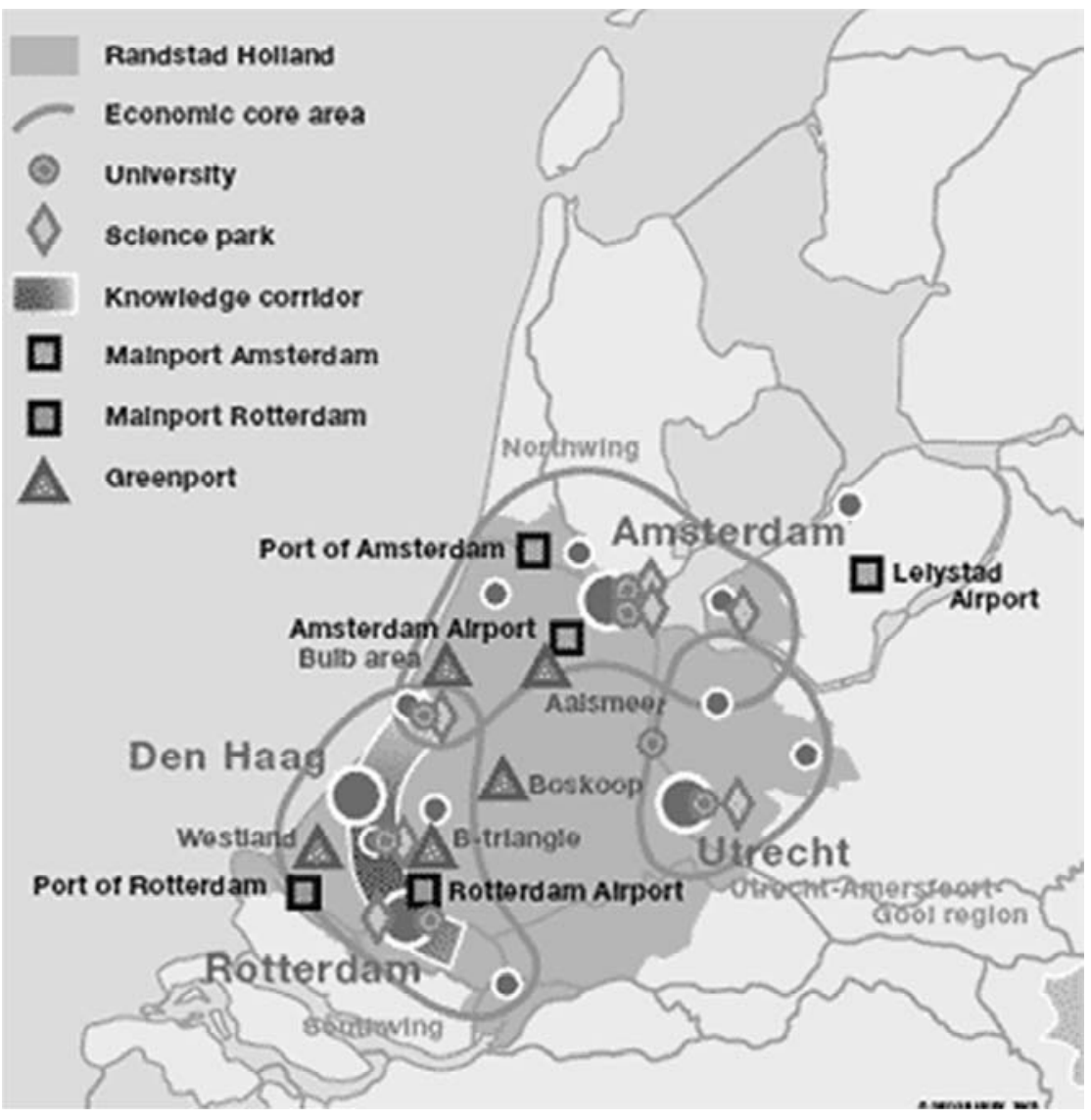

Rys. 8. Jednostki terytorialne w Randstad

Źródło: [http://haagse-lente.clubs.nl/foto/detail/2575987_randstad-groeit-dicht] 
Jednak należy zaznaczyć, że Randstad nie jest traktowany jak jednolity obszar funkcjonalny w kategoriach dziennych dojazdów do pracy.

Oprócz współpracy w ramach regionów miejskich, na obszarze Randstad zachodzi jeszcze współpraca obejmująca kilka regionów miejskich i gmin. Ten poziom współpracy jest określany jako „skrzydła” i nosi nazwy Skrzydła Północnego i Skrzydła Południowego. Oba skrzydła obejmują powierzchnię większą niż terytorium regionu miejskiego. Współpraca w ich ramach obejmuje współpracę zarówno poziomą (między gminami), jak i pionową (między gminami, regionami miejskimi i prowincjami). Przy czym trudno jest określić faktyczny obszar tej współpracy, ponieważ jednostki podejmujące ją ciągle się zmieniają.

Współpraca w ramach skrzydeł wynika m.in. z faktu, że Randstad pod względem gospodarczym jest obszarem bardzo podzielonym, który nie tworzy funkcjonalnej całości. Część północna zdominowana jest przez sektor usług, podczas gdy w części południowej koncentruje się przemysł przetwórczy i logistyka. Te dwa obszary funkcjonalnie są ze sobą słabo powiązane. Większość dojazdów do pracy odbywa się w ramach każdego $\mathrm{z}$ tych regionów tworząc raczej dwa różne systemy gospodarcze [Kantor 2006, s. 812].

Największym osiągnięciem Skrzydła Południowego było opracowanie po wielu latach sporów dwóch projektów strategicznych. Pierwszy dotyczył utworzenia Kolei Randstad. Jego realizacja została opóźniona ze względu na dążenie Rotterdamu do rozbudowania własnej sieci metra aż do Hagi oraz faktu, iż Haga, z rozwiniętym systemem tramwajów, miała swoje, inne, priorytety. Podobne opóźnienia związane były z projektem budowy autostrady A4, która jest korytarzem drogowym o strategicznym znaczeniu, ponieważ może usprawnić ruch długodystansowy, ale interesy gmin były sprzeczne z założeniami całego projektu. Ostatecznie po kilkudziesięciu latach udało się w obu przypadkach osiągnąć porozumienie. Jak widać, projekty te dotyczą infrastruktury technicznej, w ramach współpracy nie podjęto żadnych działań w innych obszarach, np. w kulturze, gospodarce, edukacji. Badania oceniające efektywność funkcjonowania tego porozumienia dowodzą, że mieszkańcy terenów nim objętych nie identyfikują się z tą platformą współpracy i nie widzą sensu w przynależności do niej [OECD 2007b, s. 174].

Z kolei współpraca w ramach Skrzydła Północnego jest uznawana za konstruktywną, ale w praktyce ogranicza się do regionu miejskiego Amsterdamu. Takie spojrzenie nie odzwierciedla jednak związków gospodarczych z innymi jednostkami, które leżą nawet poza obszarem Skrzydła Północnego. Współpraca koncentruje się na programach infrastrukturalnych i realizacji programów budownictwa, które są odpowiedzią na rekomendacje krajowych raportów dotyczących planowania przestrzennego 
i infrastruktury [Salet 2006]. Jedną z inicjatyw w ramach Skrzydła Północnego było podjęcie próby koordynacji rozwoju i zasobów powierzchni biurowych poprzez stworzenie porozumienia, które miałoby wpływać na planowanie w tej dziedzinie. Udało się stworzyć regionalny system monitoringu, który wskazał, w jakich gminach powinno przekształcić się odpowiednie obszary w powierzchnie biurowe.

Odpowiedzialność za nadzór nad działaniami w każdym skrzydle od roku 2002 przypisana jest różnym ministerstwom: Skrzydło Północne - Ministerstwu Transportu, Skrzydło Południowe - Ministerstwu Planowania Przestrzennego, Mieszkalnictwa i Środowiska, Zielone Serce - Ministerstwu Rolnictwa. Takie rozwiązanie zwiększyło koordynację nadzoru administracji centralnej nad realizacją poszczególnych polityk, natomiast nie stworzyło jasnych powiązań i mechanizmów koordynacji w kwestiach, które muszą być poruszane w skali całego Randstad.

Oprócz skrzydeł, istniało jeszcze stowarzyszenie zwane Administracyjną Platformą Zielone Serce. Zostało utworzone w roku 1996, aby uczestniczyć w tworzeniu i wdrażaniu polityk dla zielonych obszarów, stanowiących centrum Deltametropolis. Jego członkami są trzy prowincje oraz pięć porozumień międzygminnych. Również organizacje pozarządowe (izby handlowe, automobilklub i organizacje prośrodowiskowe) były reprezentowane $\mathrm{w}$ tej Platformie. Platforma miała na celu odnowienie współpracy, jednak nie osiągnęła szczególnych sukcesów. Nie udało się wypracować jednolitej koncepcji dla Zielonego Serca, ponieważ koncentrowano się głównie na rolnictwie i środowisku. Wspólnie opracowane plany dotyczące transportu, gospodarki i rozwoju miast nie zostały zbytnio rozwinięte, gdyż nie wdrożono odpowiednich przepisów i źródeł finansowania. Z uwagi na liczebność uczestników koordynacja działań była bardzo trudna. Ponieważ współpraca była dobrowolna, to członkowie nie byli w pełni zaangażowani $\mathrm{w}$ prace Platformy. Brakowało również koordynacji między ministerstwami. W końcu część członków wycofała się ze współpracy, aż w roku 2004 Platforma została rozwiązana. Ostatecznie gminy wchodzące w jej skład zjednoczyły się w roku 2005 w ramach tzw. Woerdense Beraad, a organizacje pozarządowe połączyły się w ramach Paktu Zielone Serce. Prowincje realizują swoje funkcje w ramach Grupy Sterującej Zielonym Sercem, w której są reprezentowane trzy z nich [http://www.woerdensberaad.nl/].

Współpraca między jednym z profesorów z Politechniki w Delft oraz czterema biurami planowania przestrzennego z Amsterdamu, Rotterdamu, Hagi i Utrechtu dotycząca przyszłości rozwoju miast w Holandii, rozpoczęła się w roku 1996 i doprowadziła do podpisania dwa lata później wspólnej deklaracji określającej strategię przekształcenia Randstad w region miejski o skali międzynarodowej, czyli w europejską metropolię, która może konkurować z innymi obszarami metropolitalnymi Europy i globalizującego się 
świata, i do utworzenia w roku 2000 Stowarzyszenia Deltametropolis. Stowarzyszenie pod względem terytorialnym obejmuje zachodnią część Holandii wyodrębnioną przez naturalne granice delty Renu i Mozy. Tereny zurbanizowane otaczają otwarte i zielone obszary stanowiące centrum regionu [http://www.acturban.org/biennial/ElectronicCatalogue/Delft/delft.htm]. Stowarzyszenie liczy 36 członków (dane za rok 2007). Są nimi gminy, prowincje, zarządy wodne, korporacje mieszkaniowe, izby handlowe, przedsiębiorstwa transportu publicznego i zorganizowane grupy interesu (rolnictwa, biznesu, ochrony przyrody i rekreacji). Stowarzyszenie funkcjonuje jako nieformalna platforma wymiany idei, która tworzy zintegrowane przestrzennie koncepcje i polityki mające na celu stworzenie Deltametropolis [http://dmp.zinnebeeld.nl/v1/cms/pdf_upload/Delta\%20Metropolis\%20 Association.pdf]. Za główny instrument mający doprowadzić do utworzenia metropolii uznaje planowanie przestrzenne.

W roku 1998 została utworzona przez Ministerstwo Planowania Przestrzennego, Mieszkalnictwa i Środowiska Komisja Administracyjna Randstad (Bestuurlijke Commissie Randstad - BCR), która stanowi polityczną platformę do koordynowania działań między rządem centralnym a władzami regionalnymi w Randstad. W jej skład weszli ministrowie z kluczowych departamentów i przedstawiciele władz w regionie. Komisja spotyka się trzy razy w roku. Nigdy jednak nie odegrała istotnej roli w tworzeniu regionalnych polityk dotyczących kwestii rozwoju, czy też relacji fiskalnych.

Działalność stowarzyszenia doprowadziła do zaaprobowania w piątym raporcie na temat polityki zagospodarowania terenu koncepcji Deltametropolis. To, oraz w zasadzie brak działań ze strony Komisji, pobudziło gminy do utworzenia nowej organizacji, która miała na celu zwrócenie większej uwagi na region - porozumienia o współpracy na poziomie metropolitalnym Regio Randstad [http://dmp.zinnebeeld.nl/v1/cms/pdf_upload/Deltametropolis,\%20connectivity,\%20competition,\%20cooperation.pdf]. Dobrowolne stowarzyszenie zostało zawarte w roku 2002 pomiędzy czterema głównymi miastami Holandii: Amsterdamem, Rotterdamem, Hagą i Utrechtem, czterema prowincjami i czterema regionami miejskimi, po czym zajęło się kwestiami przewidzianymi dla BCR. Porozumienie obejmuje tylko podmioty publiczne. BCR miała uczestniczyć również w negocjacjach między członkami Regio Randstad a przedstawicielami rządu. Biuro Regionu Randstad służy Komisji jako sekretariat. Celem partnerów w tej sieci jest wzmocnienie pozycji konkurencyjnej regionu na arenie międzynarodowej i poprawa jakości życia w regionie. Główne działania Regionu Randstad koncentrowały się do tej pory na przyciąganiu inwestycji sektora prywatnego.

Współpraca w Randstad odbywa się nie tylko na płaszczyźnie horyzontalnej (między gminami), ale również wertykalnej, gdyż włączają się do niej także władze prowincji. Randstad zarządzane jest przez radę regionu 
i zarząd [http://www.regio-randstad.nl/index_eng.php]. Władze te są wybierane przez rady wchodzących w ich skład gmin. Różnią się jednak od dobrowolnych związków gmin tym, że prawo przyznaje im większe uprawnienia decyzyjne dotyczące przede wszystkim planowania gospodarczego, planowania przestrzennego, infrastruktury technicznej, mieszkalnictwa i ochrony środowiska [Swianiewicz 2006]. Rada liczy 24 członków, mianowanych przez 12 samorządów członkowskich i spotyka się co najmniej dwa razy w roku. Do jej głównych obowiązków należy stymulowanie i opracowywanie strategicznych polityk oraz ustalanie budżetu. Rada powołuje spotykający się co miesiąc zarząd, który składa się z pięciu członków wybieranych spośród członków Rady. Do jego zadań należy monitorowanie integracji i spójności wewnątrz regionu oraz reprezentowanie go w konsultacjach z rządem [http://www.regiorandstad.com/eng_organisatie/dagelijksbestuur.php]. Władze Randstad wspomaga Biuro Regionu Randstad, które zatrudnia dziesięć osób. Biuro to reprezentuje również region w relacjach z Unią Europejską i rządem centralnym, jednak nie stanowi formalnej jednostki administracyjnej z oficjalnymi uprawnieniami.

W roku 2005 burmistrzowie czterech głównych miast i komisarze czterech zachodnich prowincji zaproponowali radykalną zmianę w strukturze Randstad, w wyniku czego rok później cztery wielkie miasta wystąpiły do rządu z propozycją utworzenia jednej lub dwóch prowincji Randstad. W odpowiedzi Ministerstwo Spraw Wewnętrznych opublikowało dokument konsultacyjny, celem zbadania tego wniosku i ustanowiło rządowy komitet, który miał zająć się ową sprawą [OECD 2007b, s. 169]. Ostatecznie propozycja została odrzucona, ponieważ rząd stwierdził, iż większość kwestii $\mathrm{w}$ niej przedstawionych nie pokrywa się z zasięgiem Randstad, lecz ma mniejszą skalę. Propozycja ta uwidoczniła jednak potrzebę lepszej koordynacji, zarazem uwypuklając polityczne trudności w przeprowadzeniu reform.

Po tym jak OECD opublikowało w 2007 r. Territorial Reviews: Randstad Holland ${ }^{60}$, rząd Holandii zdecydował się przyjąć Pilny Program dla Randstad (Randstad Urgency Program) określający działania, jakie zostaną podjęte w krótkim i długim czasie. Kluczowymi tematami w tym programie były dostępność, dynamizm gospodarczy, jakość życia i zrównoważony rozwój. Podkreślano przy tym wspólną odpowiedzialność za jego realizację. Celem programu było (zamiast zmiany struktury zarządzania poprzez utworzenie np. jednej prowincji Randstad) poszukiwanie partnerstw, które pozwolą osiągnąć oczekiwane rezultaty. Nowym sposobem na uzyskanie niezbędnego zaangażowania politycznego było wyznaczenie dwóch partnerów odpowiedzialnych za realizację każdego projektu. Odpowiedzialnymi za postępy projektu zostali jeden minister lub sekretarz stanu i jeden polityk regional-

${ }^{60}$ Zob.: OECD 2007b. 
ny. Fundusze dostępne $\mathrm{w}$ ramach programu pozwoliły na sfinansowanie 35 projektów. Mianowano również ministra ds. Randstad (obecny minister ds. transportu i wody), który sprawuje odpowiedzialność za postępy we wszystkich 35 konfiguracjach partnerskich [OECD 2009, s. 220]. Zespół wsparcia, złożony z przedstawicieli pięciu resortów i regionu, monitoruje projekty, wspomaga je i przygotowuje spotkania na wysokim szczeblu. Dodatkowym czynnikiem wsparcia są tak zwani ambasadorzy każdego projektu: szanowani przywódcy obywatelscy, którzy mogą doprowadzić do porozumienia przedstawicieli strony rządowej i osób spoza rządu. Jednym z takich projektów jest Randstad 2040. Jest to projekt, który ma stworzyć długookresową wizję jako podstawę do nowych projektów inwestycyjnych [van der Burg, Vink 2008, s. 3].

System planowania przestrzennego w Holandii obejmuje wizję zagospodarowania terenu tworzoną przez rząd centralny, która jest zapisana w Narodowej Strategii Zagospodarowania Przestrzennego „Przestrzeń dla rozwoju" [van der Burg, Vink 2006, s. 42]. Obecnie obowiązuje strategia do roku 2020, a w przypadku części problematyki - do roku 2030. Jest to zintegrowany dokument utworzony przez cztery różne ministerstwa. Strategia nie przewiduje planu dla regionu Randstad jako całości, natomiast pojawiają się w niej ciągłe odniesienia do niego. W praktyce brak współpracy w regionie Randstad stał się obecnie sprawą państwową. Już w Strategicznym Planie Zagospodarowania Przestrzennego z roku 1988 pojawił się apel do gmin położonych w Randstad o koordynację polityk mieszkaniowych oraz unikanie surowej konkurencji na polu rozwoju gospodarczego [Faludi, van der Valk 1994, s. 222]. Istotą krajowej strategii mieszkaniowej jest promowanie budownictwa mieszkaniowego o wysokiej gęstości, jak najbliżej istniejących terenów mieszkaniowych i innych elementów infrastruktury, a więc na obecnych terenach zurbanizowanych, takie też zapisy znajdują się w Narodowej Strategii Zagospodarowania Przestrzennego.

Polityka zapisana w Narodowej Strategii... jest doprecyzowana w innych dokumentach rządowych dotyczących zagospodarowania terenu, np.: w $R a-$ porcie Mobilności, Programie Rewitalizacji Obszarów Wiejskich.

Instrumentem służącym realizacji ustaleń Strategii... są kontrakty wdrożeniowe. Są to umowy podpisywane między rządem centralnym a czterema głównymi miastami Randstad, które dotyczą realizacji polityki w zakresie budownictwa mieszkaniowego, rozprzestrzeniania się miast, terenów zielonych i transportu publicznego. Oprócz tego funkcjonują również kontrakty wielostronne (Ruimtelijke Ordening en Milieu (ROM) - Planowanie Przestrzenne i Środowisko) poświęcone wrażliwym obszarom. Są one otwarte dla podmiotów prywatnych i podpisywane po osiągnięciu porozumienia przez wszystkie zainteresowane strony [OECD 2005a, s. 78]. 
Strategia wprowadza nowy instrument dla rozwoju regionalnego - plan regionalny. Plany regionalne tworzone są dla więcej niż jednej gminy i często łączą projekty budowlane z planami terenów zielonych. Są one opracowywane we współpracy z prywatnymi inwestorami i grupami interesu. W tak złożonych sytuacjach nie wystarczy prowincji lub platformie gmin jedynie wskazać na pożądane kierunki rozwoju. Niezbędne stały się kontrakty partnerskie, w których koszty i korzyści są dzielone między poszczególnymi zainteresowanymi stronami [van der Burg, Vink 2006, s. 44].

Ponadto każdy szczebel władzy odgrywa pewną rolę w systemie planowania przestrzennego. Na szczeblu prowincji opracowywane są plany strukturalne, które muszą uwzględniać zapisy Strategii.... Plany prowincji wskazują w jakich kierunkach mogą się rozrastać jednostki osadnicze (miasta i wsie) i które tereny powinny być przeznaczone na cele rolnictwa, rekreacji i ogólnie cele przyrodnicze. Z kolei bardziej szczegółowe plany tworzone przez gminy, muszą być rewidowane co 10 lat i mają uwzględniać wytyczne planów prowincjonalnych [OECD 2007b, s. 112].

Tym, co osłabia region Randstad, zwłaszcza w kontekście wypracowania spójnego planu dla całego obszaru metropolitalnego, jest brak uznania go w dokumentach rządowych. Polityka miejska formułowana na szczeblu centralnym nie jest adresowana do obszarów metropolitalnych, regionów miejskich czy dziennych systemów miejskich, lecz do miast.

Struktura zarządzania jednostkami terytorialnymi w Deltametropolis jest bardzo złożona. Oprócz trzech podstawowych poziomów władzy centralnego, prowincji i lokalnego - istnieje kilka innych struktur zarządczych działających w formie porozumień o współpracy. Istnieją one na poziomie regionów miejskich oraz ponad tymi regionami, w ramach Północnego i Południowego Skrzydła w Randstad, a także na poziomie Randstad jako całości. CZęść z tych kooperacji funkcjonuje względnie dobrze (np. Region Miejski Amsterdamu) i mogą się one pochwalić efektami swoich działań. Ponieważ w niektórych miastach funkcjonują również okręgi miejskie, to liczba szczebli władzy momentami sięga siedmiu: od poziomu okręgu, przez gminny, region miejski, prowincję, skrzydło, Randstad aż po rząd centralny. Ponadto istnieją jeszcze Zarządy Wodne i inne instytucje reprezentujące rząd $w$ regionach $w$ ramach dekoncentracji zadań oraz Unia Europejska. Problemy ze współpracą na poziomie metropolitalnym wynikają również ze scentralizowanego sytemu władzy. Teoretycznie poza rządem centralnym funkcjonują jeszcze trzy poziomy władzy i szereg innych form administracji, jednak $\mathrm{w}$ praktyce system finansów powoduje ścisłe uzależnienie gmin od rządu centralnego.

Ponadto, pomimo faktu, że w Holandii nie ma możliwości kumulacji mandatów, istnieje bardzo gęsta sieć powiązań między politykami, urzędnikami i ekspertami, w efekcie czego mamy do czynienia z powszechną za- 
mianą stanowisk we władzach lokalnych na stanowiska w rządzie i odwrotnie (np. większość burmistrzów Amsterdamu - mianowanych na to stanowisko przez rząd - była wcześniej ministrami w rządzie). Co za tym idzie, politycy nie są zainteresowani nawiązywaniem współpracy między różnymi jednostkami terytorialnymi [Kantor 2006, s. 819].

Niemniej jednak, pomimo niepowodzeń w zreformowaniu struktury terytorialnej, niektóre $\mathrm{z}$ form tej współpracy wykraczają poza nieformalne struktury i tworzą formy zinstytucjonalizowane, które prowadzą do ulepszenia governace $\mathrm{w}$ Randstad. Koordynacja między działaniami rządu centralnego a obszarem metropolitalnym poprawiła się odkąd za programy rozwoju w tym regionie odpowiada jedno ministerstwo.

\section{Szwecja}

Szwecja dzieli się na 21 okręgów (213ch) oraz 290 autonomicznych gmin [http://213ch.sweden.se/eng/Home/Society/Government-politics/213chmi/ Swedish-System-of-Government/]. Na poziomie okręgu funkcjonuje zarząd administracyjny, na czele którego stoi gubernator mianowany przez rząd na okres sześcioletni. Ponadto funkcjonują samorządowe wybieralne rady okręgów o funkcjach głównie uchwałodawczych. Organem uchwałodawczym w gminie jest wybierana na trzy lata rada gminy. Funkcje wykonawcze spełnia zarząd gminy [Sarnecki 2007, s. 381]. W Szwecji nie ma gmin wiejskich. Gmina to miasto i region je otaczający.

Najwięcej władzy mają szczebel centralny i lokalny, natomiast najbardziej ograniczone kompetencje ma poziom regionalny. Rząd centralny tworzy strategie, natomiast zarządy administracyjne odpowiadają za realizację i monitorowanie polityk na poziomie regionalnym i realizację kontraktów rozwojowych. Nie mają własnych dochodów, lecz administrują funduszami krajowymi na rozwój sektorowy i regionalny [Hudson 2005, s. 316]. Rady okręgów odpowiadają głównie za ochronę zdrowia $(80 \%$ wydatków) oraz transport regionalny ( $5 \%$ budżetu). Pełnią również funkcję doradczą przy tworzeniu strategii regionalnych. Środki finansowe rad okręgów pochodzą głównie (65\%) z podatków (własne prawo do nakładania podatków), składek pacjentów i dotacji rządowych [http://213ch.skane.se/sv/Webbplatser/skanese/English/Regional-self-government/SwedishAdministrative-System/].

Gminy odpowiadają m.in. za planowanie zagospodarowania terenów gminnych. W praktyce różne szczeble władzy starają się pilnować spójności poszczególnych planów poprzez proces wzajemnej komunikacji i osiągania porozumień, ale plany gminne nie muszą być formalnie zatwierdzone przez poziom regionalny czy krajowy. Gminy opracowują plany kompleksowe (Översiktsplan) i szczegółowe (Detajlplan). Plany kompleksowe są strate- 
gicznymi długoterminowymi planami, przy czym tylko plany szczegółowe mają moc prawa miejscowego i powiązane są z projektami budowlanymi [METREX 2010, s. 84]. W Szwecji nie ma krajowej strategii zagospodarowania przestrzennego, ale plany gminne muszą być spójne z narodowymi planami sektorowymi oraz przepisami dotyczącymi ochrony środowiska, dziedzictwa kulturowego i innych kwestii dotyczących zagospodarowania terenu na poziomie krajowym. Przepisy przewidują również plany regionalne tworzone dla kilku gmin. Gminy, które są zainteresowane opracowaniem takiego planu mogą wystąpić do rządu centralnego o powołanie regionalnego podmiotu planistycznego. $W$ przypadku przyjęcia planu regionalnego plany wszystkich gmin objętych planem musza być z nim zgodne. Planowanie regionalne funkcjonuje m.in. w regionie Sztokholmu [BSR].

Ponadto istnieją zinstytucjonalizowane oraz zawierane ad hoc porozumienia i formy współpracy międzygminnej w zakresie takich spraw, jak jakość powietrza, zarządzanie działami wodnymi oraz dostarczanie niektórych usług publicznych [Harsman, Olsson 2003, s. 95].

Za świadczenie wszelkich usług transportowych w Szwecji odpowiedzialny jest system urzędów transportu publicznego (public transport authorities - PTA) funkcjonujących w każdym okręgu. Drogi i infrastrukturę transportową dzieli się na gminną i krajową. W planowanie i finansowanie infrastruktury transportowej zaangażowany jest szereg podmiotów:

- przedstawiciele rządu centralnego, którzy reprezentują rząd w negocjacjach dotyczących planowania regionalnego transportu i infrastruktury,

- zarządy administracyjne - odpowiedzialne za koordynację wszystkich działań rządu centralnego na poziomie regionalnym, w celu zapewnienia równowagi między poprawą mobilności a ochroną środowiska. (W okręgu Sztokholmu zarząd dysponuje skromnym budżetem rocznym na wspieranie projektów transportowych w okręgu),

- samorządy okręgów i gmin, które zgłaszają swoje oczekiwania odnoszące się do zapisów planu. (Mimo to rząd centralny ostatecznie decyduje, które inwestycje należy wspierać).

W praktyce władze sektorowe czy ministerstwa zazwyczaj prowadzą bezpośrednie negocjacje z okręgami i gminami odnośnie do wielkoskalowych inwestycji [Harsman, Olsson 2003, s. 97]. Jednak koordynacja planów regionalnych i sektorowych jest trudna, gdyż granice obszarów, do których odnoszą się krajowe polityki sektorowe, nie pokrywają się z granicami regionalnymi.

W Szwecji istnieją trzy obszary metropolitalne wskazane przez Szwedzki Urząd Statystyczny, usytuowane wokół trzech największych miast: Sztokholmu, Malmoe i Geteborga. Wszystkie trzy wchodzą w skład większych regionów miejskich. Regiony te nie są statystycznie wyodrębnione, lecz zostały uformowane $\mathrm{w}$ wyniku politycznych porozumień zawieranych 
między gminami i okręgami na rzecz współpracy metropolitalnej [http://en.wikipedia.org/215chm/ListofMetropolitanAreasinSweden]. Są to regiony funkcjonalne stworzone na podstawie analizy dojazdów do pracy, struktury osadniczej i rynku pracy i nie mają odpowiadającej im władzy publicznej.

\section{Sztokholm}

Obszar metropolitalny Sztokholm-Mälaren jest jednym z niewielu przykładów gdzie obszar funkcjonalny jest zbieżny z granicami administracyjnymi. Obejmuje on 65 gmin, skupionych w pięciu okręgach. W centrum tego obszaru wyróżnia się region Sztokholmu, który tworzy sam Sztokholm i jezioro Mälaren oraz 40 innych gmin, zlokalizowanych w czterech okręgach, a także cztery związki współpracy międzygminnej. Liczba ludności w całym regionie Sztokholm-Mälaren sięga 2,9 mln, co stanowi 30\% populacji kraju [Hede 2006, s. 3].

Problemem, który zainicjował współpracę miedzy gminami, było zapobieganie zanieczyszczeniu jeziora. W roku 1988 powstała grupa dyskusyjna, działająca jako nieformalne forum wymiany informacji między radami okręgów i gminami położonymi wokół Sztokholmu. Większość dyskusji koncentrowała się na sprawach związanych z utrzymaniem jakości wody jeziora Mälaren oraz z inwestycjami infrastrukturalnymi wokół akwenu. Grupa początkowo składała się z czterech rad okręgów położonych wokół jeziora i czterech głównych gmin w regionie, w tym Sztokholmu [OECD 2006b, s. 169].

W roku 1992 grupa dyskusyjna przekształciła się w stowarzyszenie Radę Regionu Sztokholm-Mälaren. Rada jest nieformalną organizacją nonprofit oferującą ramy do współpracy między różnymi podmiotami w regionie. Sam okręg Sztokholm obejmuje 26 gmin. To rozwiązanie nie ma sztywnego terytorium i obszar metropolitalny jest definiowany pod względem przestrzennym jako suma terytoriów uczestniczących w nim gmin. Koncepcja przestrzenna regionu jest więc z natury zmienna [215chmid, Engström 2002, s. 140]. Tylko połowa gmin z okręgu Sztokholmu przystąpiła przy tym do stowarzyszenia, które skupia przedstawicieli 56 gmin i pięciu okręgów [http://215ch.malardalsradet.se/id=2587].

Celem stowarzyszenia jest promowanie regionalnej integracji i koordynacji spraw związanych z rozwojem regionalnym. Działaniami rady kieruje zarząd wybierany na okres czterech lat, który składa się z 18 członków i 18 zastępców [http://215ch.malardalsradet.se...]. W roku 2003 rada wypracowała wizję regionu atrakcyjnego dla jednostek i firm, stworzonego dzięki zrównoważonemu środowisku do życia w kontekście rosnącej globalnej konkurencyjności. Wizja ta była dosyć przejrzysta, natomiast brakowało mechanizmów, które pozwoliłyby na jej realizację. Dysponując skromnym 
budżetem, pochodzącym ze składek członkowskich, rada pozostaje raczej zwykłą organizacją pozarządową, która nie odgrywa formalnej roli w planowaniu regionalnym czy rozwoju gospodarczym. Służy głównie jako forum wymiany pomysłów oraz podnoszeniu świadomości o głównych strategicznych kwestiach związanych z rozwojem regionalnym. Niemniej jednak, będąc organizacją skupiającą zarówno polityków, jak i pracowników $\mathrm{z}$ różnych gmin $\mathrm{w}$ kilku grupach roboczych (planowanie i transport, handel/przemysł/B+R, kultura i środowisko), przyczynia się do bezpośredniego i skutecznego podejmowania decyzji. Ponieważ areną jej działania jest cały region, gminy członkowskie są zmuszone do zajęcia stanowiska w kwestiach, które dotyczą spraw wychodzących poza ich własne kompetencje. Muszą patrzeć na interesy regionu jako całości i rozważyć, co jest dla niego najlepsze [216chmid, Engström 2002, s. 140].

Odpowiedzialność za planowanie regionalne od roku 1971 ponosi jako jedyna z rad okręgów) Rada Okręgu Sztokholm. Tworzy ona wspólny regionalny plan zagospodarowania przestrzennego i transportu. Plan ten zawiera zasady dotyczące zagospodarowania gruntów i obszarów wodnych oraz wytyczne do lokowania rozwoju i infrastruktury, ale nie ma mocy prawnej. Biuro Rady ds. Planowania Regionalnego i Transportu Miejskiego opracowuje, mniej więcej co 10 lat, plany regionalne i prowadzi badania na temat różnych aspektów rozwoju regionalnego. Pomimo że plany regionalne są planami fakultatywnymi, to proces ich tworzenia jest bardzo wyczerpujący i uwzględnia wpływ gmin, grup interesów i ogółu społeczeństwa. Jest on również kluczowy dla planowania usług i infrastruktury transportowej, będących pod kontrolą Rady. Nawet władze centralne, odpowiedzialne za drogi i koleje, wykorzystują prognozy zawarte w planie regionalnym Sztokholmu jako podstawę swoich planów rozwoju infrastruktury w tym regionie. Plan regionalny prezentuje consensus odnośnie do długoterminowych celów rozwoju osiągnięty między gminami regionu. Ostatnio tworzone plany regionalne poszerzyły, bez zaleceń ze strony rządu centralnego, swój zakres o sprawy dotyczące rozwoju gospodarczego i społecznego. Opracowany w roku 2010 i przyjęty plan rozwoju regionalnego został obejmuje perspektywę do roku 2030, a wizja rozwoju przestrzennego sięga nawet roku 2050. Jest on jednocześnie planem regionalnym, zgodnie z przepisami prawa dotyczącymi planowania, jak i programem rozwoju regionalnego uwzględniającym przepisy dotyczące tej kwestii. Plan ten zawiera wizję rozwoju przestrzennego regionu Sztokholm-Mälaren jako obszaru policentrycznego z ośmioma ośrodkami miejskimi [METREX 2010, s. 84]. Skupia się na powiązaniach między okręgiem Sztokholmu i innymi okręgami. Podczas prac nad planem doszło do szerokiego dialogu z szeregiem podmiotów [Olsson, Cars 2011, s. 164]. Rada Okręgu Sztokholmu jest jednocześnie 
urzędem transportu publicznego dla okręgu Sztokholmu i odpowiada za funkcjonowanie autobusów, kolei i metra w regionie.

Za planowanie rozwoju gospodarczego na poziomie regionalnym technicznie odpowiedzialny jest Zarząd Administracyjny Sztokholmu. W ramach jednej z ostatnich inicjatyw rządu centralnego szczegółowe strategie rozwoju regionalnego, uwzględniane w „kontraktach rozwojowych”, są sporządzane przez zarządy administracyjne i ministerstwo handlu, bazując na modelu stworzonym przez Unię Europejską, który ma na celu promowanie współpracy między różnymi szczeblami władzy oraz sektorem prywatnym. Chociaż rady okręgów i gminy są w tym procesie konsultowane, to nie mają bezpośredniej możliwości wpływania na zapisy tych planów. Strategie opracowywane przez gminy i rady okręgów nie są formalnie powiązane z „kontraktami rozwojowymi” [Harsman, Olsson 2003, s. 96-97]. Słabością planowania regionalnego $\mathrm{w}$ regionie Sztokholmu jest brak uczestnictwa sektora prywatnego, który bierze $\mathrm{w}$ tym procesie udział tylko za pośrednictwem lokalnych izb handlowych. W związku z brakiem jednej metropolitalnej władzy, policentryczna struktura regionu rozwijana jest na drodze nieformalnych mechanizmów planistycznych, m.in. poprzez współpracę między istniejącymi organizacjami regionalnymi [METREX 2010, s. 84].

Wśród podmiotów funkcjonujących $\mathrm{w}$ regionie istnieje zgoda co do głównych wyzwań przed jakimi staje region, chodzi mianowicie o nowe mieszkania i infrastrukturę transportową. Istnieje również zgoda co do tego, że obecnie występujące zróżnicowanie aktorów regionalnych (tab. 13) doprowadziło do fragmentacji i nieskoordynowanego systemu zarządzania na poziomie regionalnym (regional governance), czego dowodem jest chociażby swoisty dualizm w opracowywaniu strategii rozwoju regionu (strategię opracowuje zarówno Rada Okręgu, jak i Zarząd Administracyjny), który prowadzi do marnotrawstwa zasobów zaangażowanych w ich tworzenie i może powodować problemy z ich realizacją, zwłaszcza gdy zapisy w obu dokumentach są sprzeczne.

Rada Okręgu Sztokholmu i gminy w regionie wyraziły chęć utworzenia „stabilnej struktury na rzecz współpracy regionalnej”, nie były jednak w stanie osiągnąć consensusu co do nowej instytucji zarządzającej rozwojem metropolitalnym. 


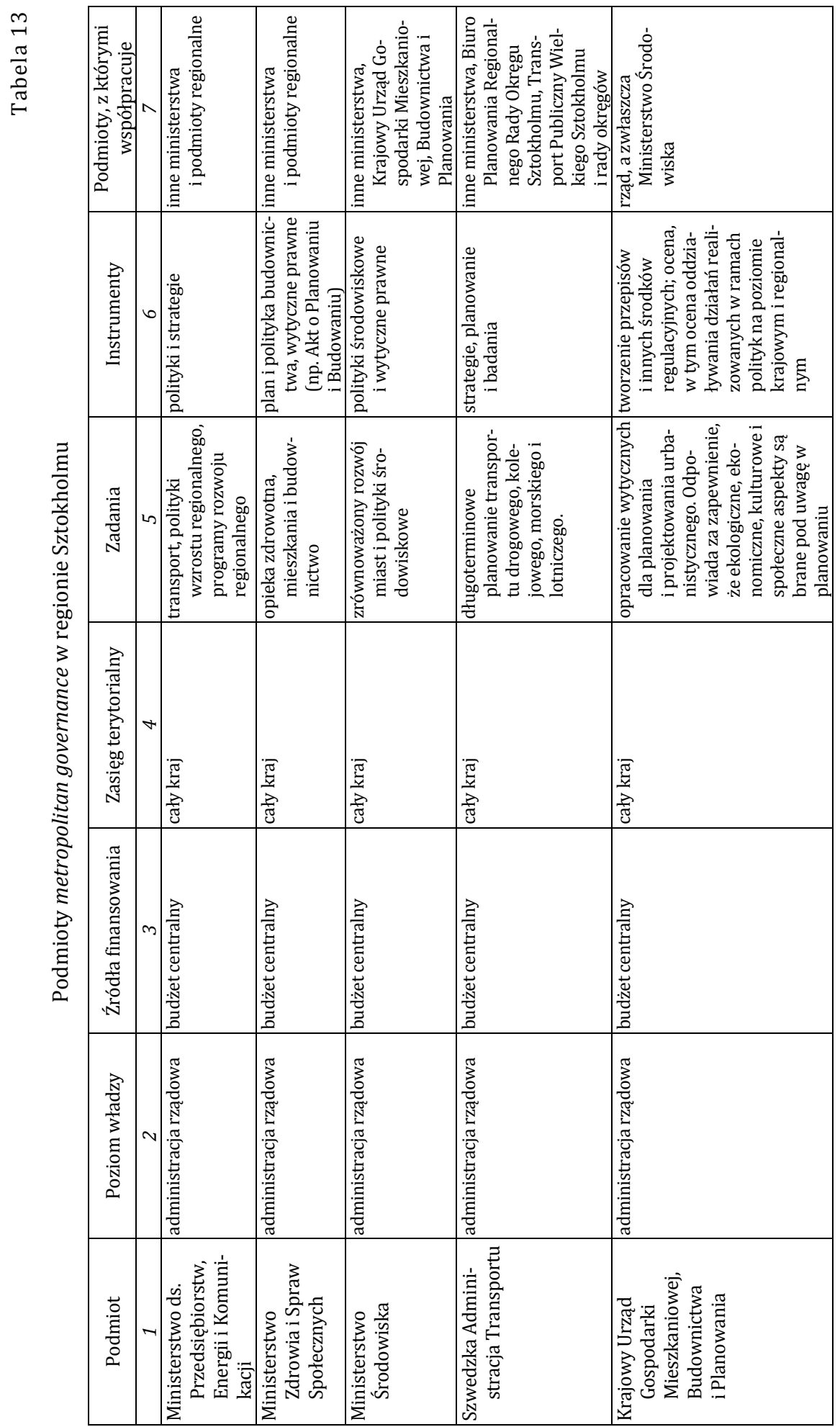




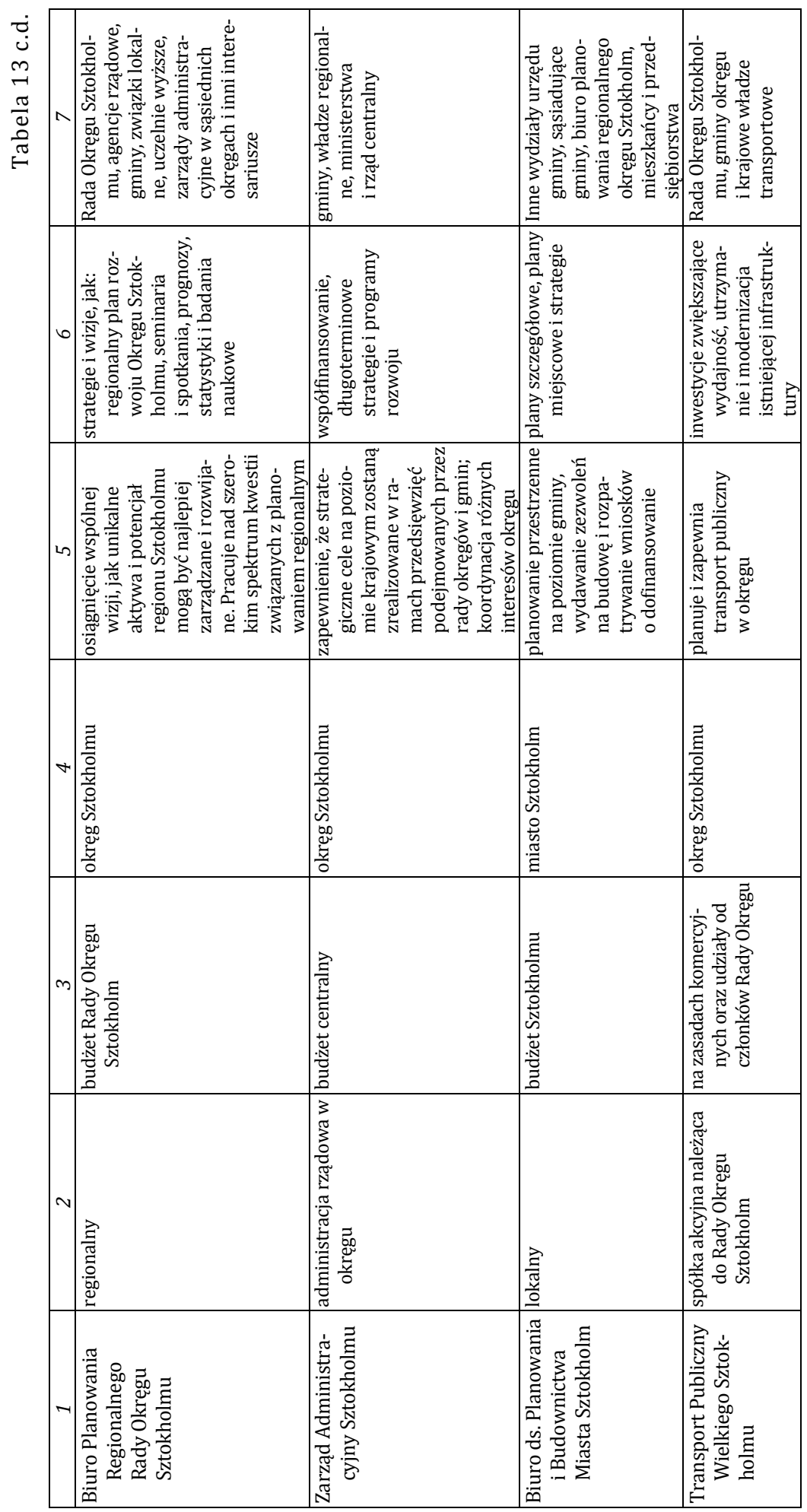




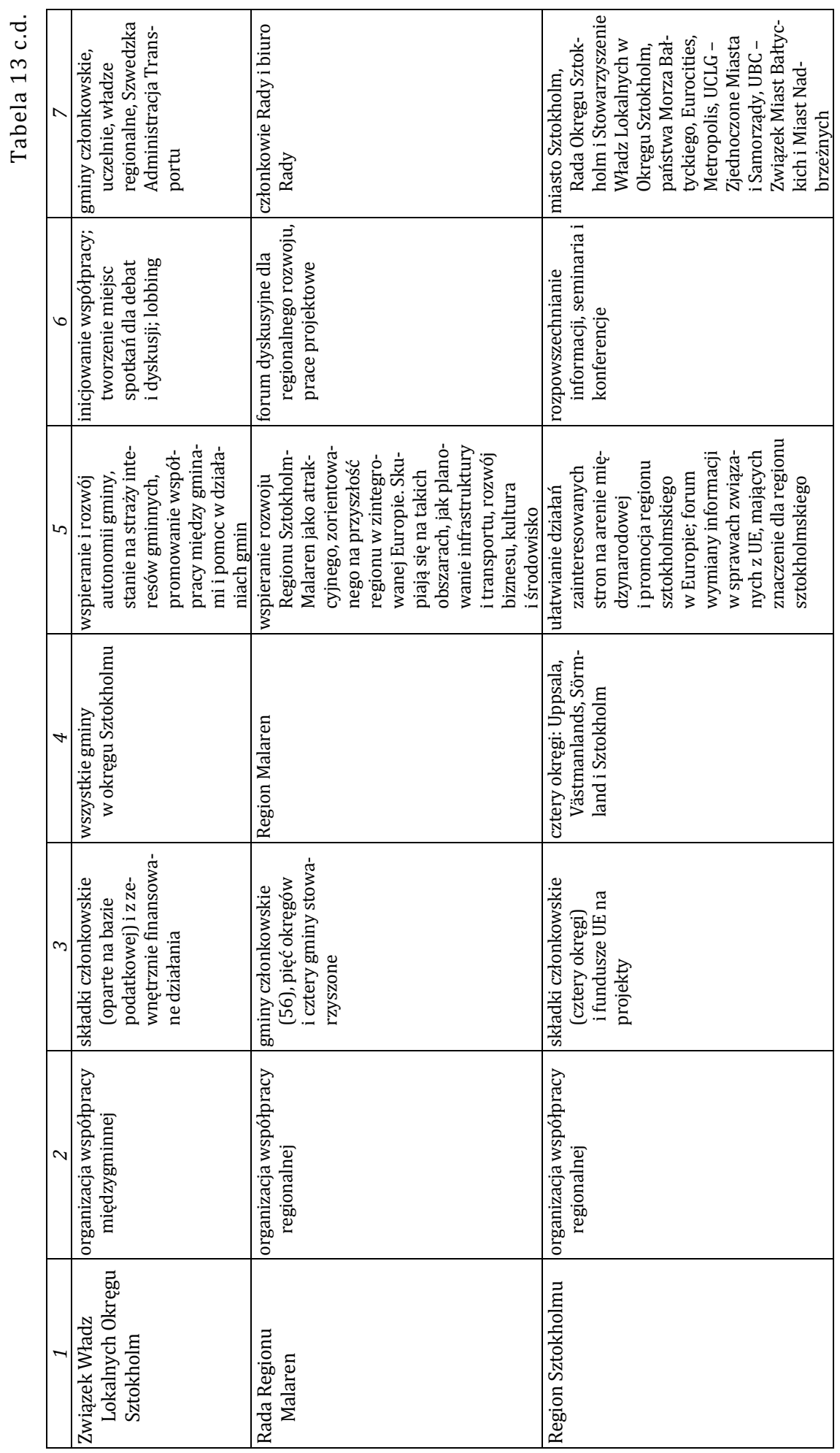




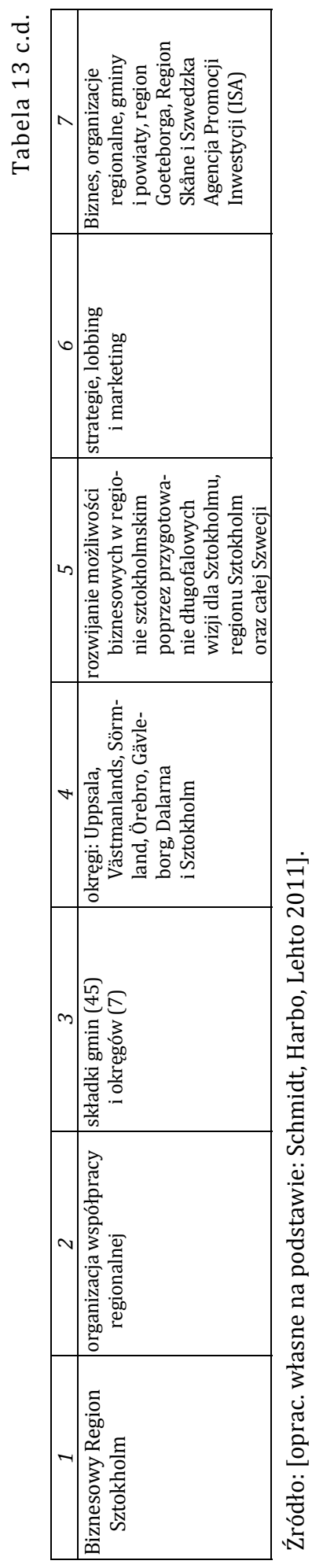


W całej Szwecji toczy się debata na temat współrządzenia na poziomie regionalnym. Jedni uważają, że obecne okręgi są zbyt małe, a instytucje rządzące zostały zdominowane przez planowanie i przepisy dotyczące ochrony zdrowia zamiast koncentrować się na kompleksowym planowaniu rozwoju regionalnego. Inni z kolei twierdzą, iż przykład regionu Sztokholmu udowadnia, że proces planowania regionalnego może z powodzeniem funkcjonować $w$ ramach struktur okręgowych zdominowanych przez sprawy związane $\mathrm{z}$ opieką zdrowotną. W toku tej debaty zostały wypracowane dwie alternatywy - utworzenie parlamentu regionalnego lub związku gmin. Parlament byłby wybierany w wyborach bezpośrednich, ale mogłoby mu brakować kompetencji planistycznych i doświadczenia gmin [Jansen, Leijon 1996, s. 24]. Związek gmin miałby członków z kompetencjami planistycznymi, ale mógłby z kolei skarżyć się na brak uprawnień do egzekwowania planów regionalnych. Obu tym rozwiązaniom przeciwny był rząd centralny, gdyż w praktyce oznaczały one ograniczenie roli zarządów administracyjnych w planowaniu rozwoju.

Obowiązująca struktura instytucjonalna na rzecz zarządzania regionalnego ograniczała zdolność regionów funkcjonalnych do pełnego wykorzystania tkwiącego w nich potencjału, zwłaszcza ze względu na niedopasowanie granic okręgów do granic regionu funkcjonalnego (z wyjątkiem Sztokholmu). Presja ze strony gmin i okręgów doprowadziła do tego, że w 1996 r. rząd zdecydował się pilotażowo przetestować zaproponowane rozwiązania w różnych regionach.

W obszarach metropolitalnych Skane i Vastra Gotaland powstały bezpośrednio wybierane samorządowe władze regionalne. Władze te przejęły kompetencje w zakresie rozwoju regionalnego od zarządów administracyjnych oraz od rad okręgów w dziedzinie opieki zdrowotnej. W związku $\mathrm{z}$ silnym poparciem ze strony regionu, te próbne rozwiązania w dalszym ciągu funkcjonują [OECD 2010, s. 195].

Od 1 stycznia 2003 r. gminy w Szwecji mogą tworzyć związki regionalne [Hudson 2005, s. 324]. W 14 regionach zostały utworzone podmioty koordynujące (Kommunala samverkansorgan) utworzone przez wszystkie gminy wchodzące w skład regionu, w 13 przypadkach członkiem związku została również rada okręgu. Podmioty te są wybierane w sposób pośredni, poprzez delegowanie członków przez poszczególnych uczestników związku i finansowane ze składek członkowskich. Częściowo są również finansowane przez rząd centralny. Środki te przeznacza się na zadania przejęte od zarządów administracyjnych. Związki odpowiadają za tworzenie planów rozwoju regionu i decydują o planowaniu infrastruktury takiej, jak drogi i sieć szerokopasmowa. Mogą również zdecydować o tym, aby skupić się na transporcie publicznym, instytucjach kultury, turystyce, rozwoju biznesu i współpracy międzynarodowej [OECD 2010, s. 196]. Jednocześnie rząd 
zaproponował rozszerzenie odpowiedzialności zarządów administracyjnych w kwestii nadzorowania interesów państwa na poziomie regionalnym.

Ponieważ bogate gminy i okręgi muszą uczestniczyć w finansowaniu jednostek biedniejszych, to może ten aspekt wyjaśnia, dlaczego rząd odnosił się negatywnie do silnych władz regionalnych w obszarach metropolitalnych. Mogą one bowiem zagrażać polityce państwa mającej na celu wspieranie wszystkich części Szwecji. W przypadku regionu Sztokholmu dodatkową barierą było przekazanie władzy ze szczebla centralnego, zdominowanego przez demokratów, na szczebel regionalny będący bastionem konserwatystów.

Podejście rządu do polityki regionalnej zmieniło się wraz z przejęciem władzy w roku 2006 przez rząd centroprawicowy oraz w związku z wpływami polityki regionalnej Unii Europejskiej. Przyjęta przez Szwecję w roku 2008 Regionalna Polityka Wzrostu odchodzi od równomiernego rozwoju wszystkich regionów na rzecz wykorzystania potencjału tkwiącego w poszczególnych obszarach funkcjonalnych. Rząd jeszcze w roku 2000 zaczął wprowadzać umowy z regionami w formie Regionalnych Porozumień Dotyczących Wzrostu, które później zostały zastąpione przez Regionalne Programy Wzrostu (RPW) i Regionalne Programy Rozwoju (RPR). Partnerami w tych kontraktach są: rząd centralny, władze regionalne, lokalne, podmioty biznesowe oraz reprezentujące społeczeństwo obywatelskie. Każdy region został zobowiązany do przygotowania RPR, który jest podstawą działań i programów związanych z regionalnym rozwojem: RPR, programy rozwoju infrastruktury, ochrony środowiska i inne [Hudson 2005; OECD 2010].

Pozytywna ocena dwóch regionów pilotażowych spowodowała, że rząd zaczął myśleć o rozszerzeniu tego modelu na inne regiony i utworzeniu, poprzez fuzje obecnych okręgów, sześciu do dziewięciu dużych regionów. Reforma nie została jednak wprowadzona odgórnie, lecz zaczęto stymulować oddolne zapotrzebowanie okręgów na łączenie. Od roku 2008 kilka okręgów zgłosiło wniosek o połączenie i przekształcenie we władze regionalne. Wnioski te są rozpatrywane. Natomiast w roku 2009 rząd uznał dwa pilotażowe rządy regionalne za rozwiązanie stałe oraz wyraził poparcie dla rozszerzenia modelu pilotażowego na wszystkie regiony, które wyrażą taką wolę [OECD 2010, s. 197].

Stopniowy proces oddolnej regionalizacji, jaki występował w Szwecji pozwolił na przetestowanie różnych rozwiązań i wybór najodpowiedniejszego dla każdego regionu. W przypadku obszaru metropolitalnego Sztokholmu, okręg Sztokholmu nie wyraża chęci połączenia się z sąsiednimi jednostkami. Tymczasem trzy inne okręgi wchodzące w skład obszaru Sztokholm-Mälaren złożyły wniosek o utworzenie regionu [OECD 2010, s. 227]. Pozytywne w obszarze metropolitalnym Sztokholmu jest coraz częstsze korzystanie $\mathrm{z}$ form partnerstwa publiczno-prywatnego na poziomie regionalnym 
(budowa szpitala, szybki pociąg łączący lotnisko z centrum miasta) [OECD 2010, s. 234].

Sukces we wprowadzaniu reformy regionalnej w Szwecji był możliwy dzięki silnemu kapitałowi społecznemu i długoletniej tradycji udziału społeczeństwa w podejmowaniu decyzji oraz dużemu zaufaniu szwedzkiego społeczeństwa do rządu61. Włączenie różnych podmiotów w proces podejmowania decyzji ułatwiło również opracowanie aktualnie obowiązujących Narodowych Strategicznych Ram Odniesienia, które stanowią nie tylko instrument wykorzystania funduszy unijnych, ale były również podstawą dialogu i lepszej koordynacji kwestii regionalnych między różnymi sektorami, na różnych szczeblach władzy i między różnymi aktorami (publicznymi, prywatnymi) [OECD 2010, s. 201].

\section{Dania}

Dania jest demokracją reprezentatywną. Władza ustawodawcza realizowana jest przez parlament, władza wykonawcza przez rząd. Od stycznia roku 2007 Dania podzielona jest na pięć regionów, które zastąpiły podział na 13 województw, oraz 98 gmin (wcześniej 270) [http://www.nyidan-mark. $\mathrm{dk} / \mathrm{pl}]$.

$\mathrm{Na}$ czele regionu stoi rada wybierana $\mathrm{w}$ wyborach bezpośrednich, z burmistrzem regionu (wybranym spośród członków rady) na czele. Kadencja rady trwa cztery lata. Do kompetencji regionu należy koordynacja planowania w dziedzinie transportu, szpitali, szkolnictwa średniego, usług socjalnych (domy dziecka, zakłady opieki socjalnej), ochrona środowiska, promowanie biznesu. W przeciwieństwie do wcześniejszych województw, regiony nie mają prawa nakładania podatków.

Na czele gminy również stoi rada, której członkowie są wybierani w wyborach bezpośrednich na okres czterech lat. Rada wybiera spośród radnych burmistrza i jego zastępców. Gminy odpowiadają za planowanie lokalnych usług socjalnych (pomoc medyczna, opieka pielęgniarska), za szkoły podstawowe, instytucje kultury i sportu, utrzymanie sieci dróg lokalnych, sprawowanie nadzoru budowlanego, zapewnienie infrastruktury technicznej. Gminy mają dużą swobodę w poszerzaniu swych kompetencji. W większości same finansują swoją działalność [Popławski 2008, s. 265]. Budżet gmin jest prawie dwa razy większy od budżetu centralnego [OECD 2009, s. 208].

System planowania przestrzennego na poziomie krajowym obejmuje niewiążący raport planistyczny oraz krajowe wytyczne planowania, które wiążąco regulują pewne kwestie zagospodarowania przestrzennego, takie

${ }^{61}$ Szwecja zajmuje najwyższe pozycje w rankingu Światowego Forum Ekonomicznego dotyczącym zaufania do rządu, transparentności działań publicznych i budowania consensusu. Więcej zob. [Schwab 2010]. 
jak np. domki letniskowe czy rezerwacje terenów pod duże inwestycje publiczne, jak naturalne elektrownie gazowe i turbiny wiatrowe.

Wraz z reformą z roku 2005, która weszła w życie w styczniu roku 2007, zostały zniesione wiążące plany wojewódzkie i poziom gminny przejął większość zadań związanych z planowaniem, które wcześniej były realizowane przez województwa.

Obecnie istniejące regiony przygotowują regionalne plany rozwoju, które są strategiczną wizją rozwoju regionu w dziedzinach takich, jak przyroda i środowisko, rozwój biznesu i obszarów wiejskich. Ponadto, regiony działają jako mediatorzy w przypadku gmin, które nie zgadzają się co do wspólnych kwestii planowania. Według nowej Ustawy o planowaniu, do regionu stołecznego stosuje się szczególne przepisy, według których odpowiedzialność za planowanie przestrzenne $\mathrm{w}$ tym regionie ponosi teraz minister środowiska. Minister musi określić ogólne warunki użytkowania gruntów $\mathrm{w}$ regionie stołecznym w krajowych wytycznych planowania. Wcześniejszy obowiązek województwa został więc przejęty przez szczebel krajowy.

Każda gmina opracowuje kompleksowy plan gminny, który obejmuje gminną strategię planowania oraz regulacje dotyczące zagospodarowania obszarów miejskich i wiejskich. Ponadto plan zawiera ogólny zarys decyzji gminnych i ograniczeń narzuconych przez rządowe plany i decyzje. Z tego względu od gmin wymaga się składania sprawozdań dotyczących szczegółowych takich zagadnień, jak obszary chronione, przepisy budowlane na drogach krajowych, rozwój w strefie przybrzeżnej i powiązania z planami w sąsiednich gminach, a także pełnych strategicznych ocen oddziaływania na środowisko.

Do gmin należy przełożenie szerokich wytycznych formułowanych na poziomie krajowym na poziom planowania przestrzennego w gminie. Plany gminne swoim zasięgiem muszą obejmować cały obszar gminy. Nie mogą być sprzeczne z zapisami planów regionalnych oraz wytycznymi szczebla krajowego [Schmitt, Harbo, Lehto 2011, s. 18]. Rząd centralny ma prawo veta do planów niższego szczebla.

\section{Region Kopenhagi}

Region stołeczny, utworzony reformą z roku 2005, obejmuje 29 gmin (w tym wyspę Bornholm). W stosunku do sytuacji sprzed reformy, nie obejmuje dawnego województwa Roskilde, które obecnie wchodzi w skład regionu Zelandii. Kopenhaga i miasto Frederiksberg, położone wewnątrz Kopenhagi, wraz z wejściem w życie reformy straciły swój specjalny status miast będących jednocześnie województwami, a co za tym idzie, część kompetencji.

Obszar metropolitalny Kopenhagi ma w różnych dokumentach różny zasięg. Duński Akt Planistyczny definiuje Region Kopenhagi, zwany Stołecznym 
Regionem Kopenhagi, jako obszar, który nie pokrywa się z żadnym podziałem administracyjnym kraju i obejmuje 34 gminy zamieszkałe przez około 1,8 miliona osób. Należy jednak pamiętać, że obszar metropolitalny Kopenhagi, od czasu wybudowania mostu łączącego ją z Malmo, coraz częściej rozważany jest $\mathrm{w}$ połączeniu $\mathrm{z}$ regionem Öresund, obejmującym duńskie regiony Zelandię i Region Stołeczny oraz szwedzki region Skania o łącznej liczbie ludności 3,7 miliona [Schmitt, Harbo, Lehto 2011, s. 17]. Jednak pod względem funkcjonalnym obszar ten jeszcze nie został w pełni zintegrowany [OECD 2009, s. 42].

Według OECD region funkcjonalny obszaru metropolitalnego Kopenhagi bazuje na dziennych dojazdach do pracy i obejmuje 45 gmin [OECD 2009, s. 208]. Obszar ten wykracza poza granice nowego planu (finger plan 2007), który służył jako podstawa planowania dla obszaru metropolitalnego, i obejmuje 35 gmin, jeden region stołeczny i część regionu Zelandii. Bez względu na przyjętą delimitację, wymaga on koordynacji na szczeblu metropolitalnym.

Do końca lat 90. krajowa polityka miejska była niemal wyłącznie skierowana do wewnątrz, oddając pierwszeństwo polityce rozwoju regionalnego Danii, która zakładała równomierny rozwój wszystkich regionów. Diametralna zmiana zaszła w trakcie kilku miesięcy lat 1989-1990, a zainspirowana została przykładem Wielkiej Brytanii, gdzie Londyn był traktowany jako lokomotywa rozwoju, czego następstwem była debata w duńskim parlamencie na temat przyszłości stolicy. Globalizacja spowodowała odejście od tradycyjnego, reagującego zarządzania zasobami publicznymi na rzecz tworzenia proaktywnych przedsiębiorczych strategii obejmujących bliską współpracę z firmami i prywatnymi organizacjami. Od tego momentu zaczęto dążyć do tego, aby Kopenhaga stała się ośrodkiem napędowym całej Skandynawii, a globalizacja legitymizowała ten zwrot w polityce i stała się motywem przewodnim metropolitan governance [Hansen, Andersen, Clark 2001, s. 862].

Przejście do współrządzenia otworzyło ramy dla tworzenia zorientowanych na wyniki sieci angażujących silne publiczne i prywatne podmioty będące w stanie pozyskać zasoby i osiągnąć konkretne rezultaty. Zmianę tę charakteryzowała decentralizacja zadań i kompetencji. Jednym z obszarów o szczególnym znaczeniu jest lokalna polityka mieszkaniowa jako instrument wpływania na społeczno-gospodarczą strukturę ludności. Polityka mieszkaniowa stała się kluczowa dla strategii rozwoju lokalnego. Kolejnym głównym instrumentem rozwoju lokalnego w konkurencji z innymi gminami była polityka rozwoju biznesu. W obu dziedzinach nowe formy partnerstwa i współpracy związane z governance stały się dominującym schematem organizacji. Doprowadziło to do zwiększenia politycznej zdolności do 
podejmowania skutecznych działań i ułatwiło podejmowanie niepopularnych decyzji [Hansen, Andersen, Clark 2001, s. 863].

Główne cele zostały osiągnięte przez następujące działania, bazujące na partnerstwie:

- stymulowanie budowy nowych luksusowych mieszkań poprzez tworzenie spółek i partnerstwa między gminami i inwestorami (fundusze emerytalne, firmy ubezpieczeniowe, właściciele ziemscy, firmy budowlane),

- odnośnie do mieszkań komunalnych wprowadzono nowe, bardziej elastyczne zasady przyznawania lokali i prywatyzację mieszkań,

- odnowiono dzielnice zamieszkiwane przez klasę robotniczą i emigrantów.

W roku 2000 powstała Rada Wielkiej Kopenhagi (HUR), która była właśnie takim mechanizmem koordynującym, jako organizacja publiczna obejmująca swoim zasięgiem obszar Wielkiej Kopenhagi. Na jej czele stała rada składająca się z 11 członków, wybieranych spośród polityków z trzech województw (Kopenhagi, Frederiksborga i Roskilde) i dwóch miast (Kopenhagi i Frederiksborga). Zatrudniała 320 pracowników zorganizowanych w trzech wydziałach - transportu, planowania i usług oraz w Sekretariacie Zarządzającym. HUR współpracowała z szeregiem organizacji branżowych, takich jak Wonderful Copenhagen (oficjalna organizacja turystyczna działająca w regionie Wielkiej Kopenhagi), Copenhagen Capacity (instytucja odpowiedzialna za przyciąganie międzynarodowych inwestorów i firm) i Komitet Öresund (Öresundskomiteen). Głównym zadaniem HUR była koordynacja i rozwój transportu (w tym transportu publicznego), planowanie ruchu, transgraniczna koordynacja i rozwój w obszarze Öresund, prowadzenie polityki przemysłowej, zajmowanie się turystyką i kulturą. Wcześniej funkcjonujące niezależne władze transportowe zostały włączone do wydziału transportu HUR, który zarządzał wszystkimi autobusami i lokalnymi przewozami kolejowymi (prowadzonymi przez podmioty prywatne). Centralny system kolejowy i podmiejskie pociągi pozostały własnością kolei państwowych. Także linie metra były zarządzane przez spółkę będącą współwłasnością państwa, miasta Kopenhagi i Frederiksborga. W przeciwieństwie do większości innych przypadków HUR nie tylko miał kontrolę nad środkami transportu publicznego, ale także pewien wpływ na planowanie dróg.

To rozwiązanie często było podawane jako przykład dobrej praktyki w świadczeniu usług transportowych. Składa się na to kilka czynników:

- silna integracja publicznej sieci transportowej, zwłaszcza w węzłach przesiadkowych ( $\mathrm{z}$ dopasowanymi czasowo połączeniami pomiędzy autobusami i pociągami),

- wysokiej jakości transport autobusowy (dzięki konkurencyjnym przetargom i zachętom dla operatorów jako nagrody za wysoką jakość usług), 
- integracja planowania użytkowania gruntów i transportu,

- stosowanie skutecznych instrumentów do ograniczenia korzystania z samochodów (np. strefy piesze, polityka parkingowa i polityka rowerowa).

Taka efektywność została osiągnięta poprzez skuteczny consensus i dobrowolną współpracę pomiędzy pięcioma głównymi władzami lokalnymi $\mathrm{w}$ regionie, $\mathrm{w}$ połączeniu ze zdecydowanym sterowaniem ze strony rządu centralnego [OECD 2006b, s. 157].

Niezbędna była współpraca między władzami nie tylko pod względem instytucjonalnym, ale także finansowym. Na przykład, duży projekt inwestycyjny rozpoczęty w roku 1992, jakim była budowa nowej linii metra do Orestad (50000 społeczność zamieszkująca tereny rekultywowane na południowym wschodzie Kopenhagi) był finansowany z pożyczek rządu centralnego, przy założeniu, że kredyt będzie w większości spłacony przez spółkę operującą tą linią, będącą współwłasnością rządu centralnego i samorządów lokalnych. Zasadnicza strategia tego projektu opierała się na założeniu, że sprzedaż terenów publicznych sfinansuje budowę linii metra, inwestycje $\mathrm{w}$ nieruchomości stały się więc źródłem finansowania infrastruktury transportowej, wcześniej finansowanej przez państwo [Hansen, Andersen, Clark 2001, s. 858]. Wprowadzenie form partnerstwa publicznopublicznego i publiczno-prywatnego było punktem zwrotnym w kierunku planowania zorientowanego na rynek. Rozwój tego typu korporacji umożliwił prywatnemu kapitałowi większy udział w procesie podejmowania decyzji, przy jednoczesnym zwiększeniu transparentności dla zaangażowanych w nie firm (ale niekoniecznie dla społeczeństwa) [Hansen, Andersen, Clark 2001, s. 861]. Z czasem, tego typu formy współpracy stawały się coraz bardziej powszechne i zaczęły być traktowane jako norma przy realizacji wielkich przedsięwzięć.

Tymczasem reforma strukturalna rozwiązała HUR. Zadania rozwiązanej Rady, które przekazały jej władze gmin i województw, zostały przeniesione do innych podmiotów. Najważniejszym z tych zadań był transport. Obecnie gminy współpracują w zakresie autobusowej komunikacji miejskiej (w ramach spółki Movia) oraz metra (za pośrednictwem firmy Kopenhaskie Metro). Movia należy do dwóch regionów: Kopenhagi i Zelandii oraz gmin. Ci partnerzy wyznaczają dziewięciu członków rady, która zarządza spółką.

Kopenhaskie Metro jest własnością państwa, miast Kopenhaga i Frederiksberg. Za koleje krajowe i regionalne odpowiada państwo [OECD 2009, s. 219]. Zarządzanie transportem publicznym w obszarze metropolitalnym jest więc rozproszone. Mamy do czynienia z kilkoma podmiotami, między którymi nie ma koordynacji.

W miejsce HUR powstała Rada Regionu, która miała uzupełnić braki występujące w HUR. Nie była ona bezpośrednio wybieranym podmiotem i nie miała swoich zasobów finansowych. Rada regionalna Kopenhagi składa się 
wprawdzie z 41 wybieranych bezpośrednio członków, ale uprawnienia jej są mniejsze niż HUR, ponieważ nie może podejmować żadnych działań w imieniu gmin. W dodatku bazuje na środkach finansowych nie tylko od gmin, ale również od państwa. Ponadto, obejmuje mniejszy obszar niż HUR [OECD 2009, s. 216].

Reforma w każdym regionie utworzyła Regionalne Fora Wzrostu, odpowiedzialne za opracowywanie regionalnych polityk rozwoju biznesu. Forum Wzrost Regionu Stołecznego, w którym reprezentowany jest biznes, środowisko akademickie, władze regionalne i lokalne, opracowało w roku 2007 strategię, której towarzyszył plan działań. Fora działają jako stymulatory regionalnych innowacji poprzez doradzanie regionom w kwestii udzielania wsparcia i dotacji na projekty w dziedzinie rozwoju regionalnego biznesu i innowacji [OECD 2009, s. 119].

Ponadto, w roku 2008 Region Stołeczny przedstawił Strategię Rozwoju Regionalnego, w której tworzenie zaangażowani byli obywatele, władze i organizacje społeczeństwa obywatelskiego. Są to inicjatywy godne docenienia ze względu na przeprowadzone dogłębne analizy i silne zaangażowanie zainteresowanych stron, jednak nie koncentrują się na priorytetach [OECD 2009, s. 29]. Zaangażowanie innych podmiotów, a zwłaszcza gmin, $\mathrm{w}$ formułowanie planu regionalnego jest konieczne, ponieważ realizacja jego zapisów jest możliwa tylko przy ich udziale.

Dla koordynowania rozwoju w regionie Öresund powstał w roku 1993 Komitet Öresund. Jest to forum, na którym politycy z obu stron Cieśniny Öresund spotykają się co najmniej dwa razy w roku w celu omówienia kwestii rozwoju transgranicznego [Schmitt, Harbo, Lehto 2011, s. 20]. Komitet składa się z 36 polityków (po 18 z każdego kraju) reprezentujących 12 organizacji członkowskich: gminy i regiony Zelandii, Stołeczny i Skane (Szwecja). Regionalne i gminne organizacje reprezentowane w komitecie tworzą Komisję Öresund złożoną z urzędników cywilnych oraz czterech (dwóch z każdego kraju) urzędników Öresund mianowanych przez rządy Danii i Szwecji. Komisja jest organem wykonawczym komitetu i spotyka się cztery razy w roku. Na czele komitetu i komisji stoją prezydent i wiceprezydent (ci sami dla obu organów) wybierani na okres jednego roku.

Działalność Komitetu finansowana jest ze składek gmin i regionów, proporcjonalnie do liczby mieszkańców, oraz z funduszy Nordyckiego Zgromadzenia Ministerstw przyznawanych na konkretne projekty. W roku 2007 wzmocniona została struktura instytucjonalna Komitetu Öresund i zwiększono nacisk na formułowanie polityk.

W latach 2009-2010 komitet skoncentrował się na czterech szczegółowych kwestiach:

1. Usunięciu transgranicznych przeszkód, które hamują rozwój rynku pracy. 
2. Inwestowaniu w nową infrastrukturę $w$ regionie i na analizie wpływu opłat za przejazd mostem Öresund i kosztów transportu na integrację $\mathrm{w}$ regionie.

3. Wzmocnieniu dobrych relacji na poziomie najbliższym społeczeństwu i promowaniu kontaktów społecznych i stowarzyszeń oraz współpracy w Öresund, a tym samym stworzeniu metropolii bazującej na rozwoju kultury.

4. Nowej wizji i strategii dla regionu Öresund.

W efekcie, w roku 2010 została przyjęta wspólna strategia rozwoju do roku 2020 [http://www.oresundskomiteen.org/en/].

W Danii głównym mechanizmem koordynacji między rządem centralnym, regionami i gminami są coroczne negocjacje biznesowe między ministrem finansów, związkiem regionów i związkiem gmin. Procedura ta ogranicza niepewność gmin co do interwencji rządu centralnego w lokalne decyzje.

Planowanie przestrzenne w Regionie Kopenhagi opiera się na układzie przestrzennym „Otwartej Dłoni” (Fingerplan), który po raz pierwszy został przyjęty w roku 1947. Zakładał on, że obszary zurbanizowane będą kształtować się na planie otwartej dłoni z rdzeniem miejskim w środku i pięcioma węzłami urbanizacji położonymi jak palce ręki (rys. 9). Przestrzeń między „palcami” miała być zachowana jako obszary zielone [Hansen, Andersen, Clark 2001, s. 857].
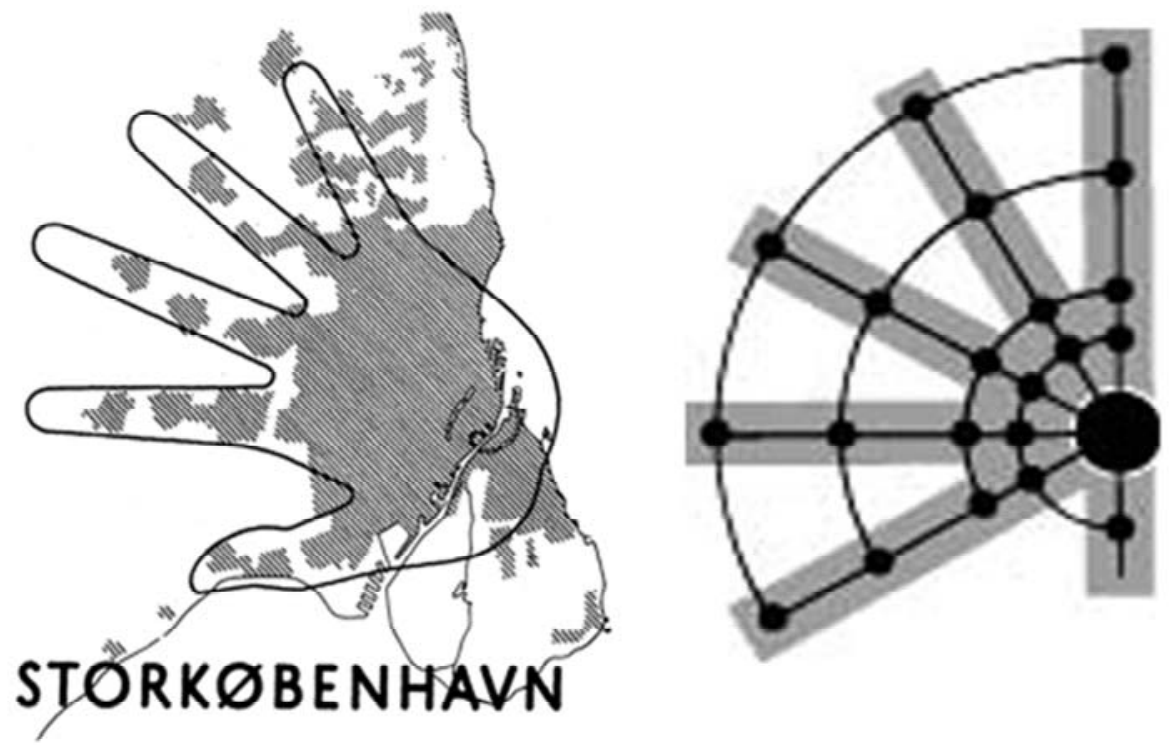

Rys. 9. Fingerplan z roku 1947

Źródło: [http://brandavenue.typepad.com/brand_avenue/2010/11/a-strong-greenbrand.html] 
W roku 2007 został przyjęty nowy Fingerplan, który za jedną z zasad, mających zapewnić zwartą strukturę miejską, przyjmuje zasadę dostępności. Mówi ona, że wielkie przestrzenie biurowe, silnie oddziałujące na natężenie ruchu, muszą być lokowane w odległości co najwyżej 600 metrów od najbliższej stacji [OECD 2009, s. 124]. Plan ten jest poszerzony o szósty "palec" uwzględniający most Öresund.

Nowe formy i praktyki współrządzenia, które zaczęły rozwijać się w obszarze metropolitalnym Kopenhagi po roku 1990 ograniczyły bariery dla globalizacji rynku nieruchomości komercyjnych i aktywnie zachęciły do napływu inwestycji zagranicznych do regionu.

Reforma w pewnym stopniu utrudnia ocenę współrządzenia w regionie Kopenhagi, ale można stwierdzić, że istnieją pewne bariery współrządzenia, wynikające z kilku czynników:

- fragmentacji na szczeblu metropolitalnym, istnienia 29 do 35 (w zależności od delimitacji) relatywnie silnych gmin i miasta centralnego, które jest stosunkowo małe w porównaniu z szerszym obszarem metropolitalnym,

- braku instrumentów koordynacji działań gmin,

- niedopasowania granic administracyjnych do funkcjonalnych,

- fragmentacji politycznej organów administracji,

- ze słabego szczebla regionalnego,

- ograniczonej autonomii finansowej gmin.

Dania ma jednak długoletnie tradycje jeśli chodzi o zaangażowanie mieszkańców w formułowanie polityk. Dotyczy to zarówno konkretnych projektów związanych z jakimś terytorium (np. regeneracja zdegradowanych obszarów w mieście - Port Północny), jak i tworzenia strategicznych wizji (Regionalny Plan Rozwoju Regionu Stołecznego i strategia Regionu Öresund) [OECD 2009, s. 237]. Również szereg prywatnych podmiotów jest włączony w formułowanie i realizację różnych polityk i projektów. Przedsiębiorcy są zaproszeni do think-tanków, czego przykładem jest Kreatywne Forum zajmujące się rozwojem rynku pracy oraz forum burmistrzów ds. biznesu. Biznes i związki zawodowe reprezentowane są w Regionalnym Forum Wzrostu. Ponadto tradycją w Danii jest zachęcanie prywatnych i półprywatnych podmiotów do bycia operatorami pewnych regionalnych i lokalnych polityk (np. biuro przyciągania inwestycji zagranicznych - Copenhagen Capacity, Wonderful Copenhagen) [OECD 2009, s. 238].

Istnieją mechanizmy, które mogą prowadzić do wdrożenia pewnych form metropolitan governance. Po pierwsze, procedura tworzenia Planu Rozwoju Regionalnego Regionu Stołecznego przewiduje włączenie gmin w jego tworzenie. Region Stołeczny ma również Radę do Kontaktów z Gminami, która ma zapewnić koordynację między poszczególnymi gminami oraz między gminami i regionem. 
Gminy oraz inne lokalne i regionalne podmioty są reprezentowane w Regionalnym Forum Wzrostu. Można więc uznać, że nowy Region Stołeczny staje się efektywnym narzędziem koordynacji na szczeblu metropolitalnym po zlikwidowaniu HUR. Problem polega jednak na tym, że wszelkie działania nie wykraczają poza granice regionu, podczas gdy funkcjonalny obszar metropolitalny ma szerszy zasięg, co jest uwzględnione w nowym planie zagospodarowania przestrzennego.

\section{Niemcy - różne modele zarządzania obszarami metropolitalnymi}

Niemcy są państwem federalnym składającym się z 16 krajów związkowych zwanych landami, w tym trzech miast federalnych na prawach kraju związkowego (Hamburg, Berlin i Brema). Każdy kraj związkowy ma swój własny rząd i parlament, które dysponują szerokimi kompetencjami w tworzeniu prawa i sprawowaniu władzy wykonawczej. Na niższych poziomach władzy znajdują się powiaty i gminy. Powiaty mają charakter jednostek jednocześnie samorządowych i rządowych. Na czele każdego stoi starosta, będący przedstawicielem władz rządowych, a zarazem organem samorządu terytorialnego. W gminach organem legislacyjnym są powszechnie wybierane rady. Na czele gminy stoi burmistrz (w zależności od gminy, może być też przewodniczącym rady) [Gdulewicz 2002, s. 107 i n.]. Wyznaczania obszarów metropolitalnych w Niemczech dokonuje rząd federalny wspólnie z krajami związkowymi.

Metropolie są określane $\mathrm{w}$ federalnej koncepcji zagospodarowania przestrzennego (Raumordnungsbericht), przyjmowanej przez rząd federalny, a wyznaczane w ustawach uchwalanych przez parlamenty landów. Zasadą jest, że obszary metropolitalne delimituje się jako grupy powiatów. Gdy leżą one w różnych landach - jak np. w przypadkach Hamburga, Berlina czy Regionu Rhein-Main - obszary metropolitalne są definiowane w umowach pomiędzy krajami związkowymi.

Najnowsza federalna koncepcja zagospodarowania przestrzennego z roku 2000 wyróżnia - biorąc za kryterium znaczenie w gospodarce światowej i rolę w integracji europejskiej - sześć metropolii: Berlin, Hamburg, Monachium, Stuttgart, Rhein-Main (Frankfurt n. M) i Rhein -Ruhr (KoloniaDüsseldorf-Essen). Do metropolii o drugorzędnym znaczeniu zalicza się m.in.: Hanower, Norymbergę, a także obszary metropolitalne Lipsk-Halle i Drezno-Chemnitz. Planowanie metropolitalne jest elementem centralnego planowania państwowego, wykonywanego podzielnie przez władze federalne i władze krajów związkowych. Parlamenty oraz rządy federacji i landów ustalają w drodze przepisów powszechnie obowiązujących:

- główne elementy sieci transportowej państwa, 
- główne elementy sieci osiedleńczej (ośrodki centralne o znaczeniu europejskim i krajowym),

- tereny chronione ze względów krajobrazowych i kulturowych.

Powyższe ustalenia stają się elementem planu metropolitalnego z mocy przepisów ustawowych.

Plany metropolitalne, pod względem formalnoprawnym, są częściami planów zagospodarowania przestrzennego krajów związkowych, uchwalanymi odrębnie na podstawie ustaleń planu państwowego. Planowanie metropolitalne do początku lat 90 . było wykonywane przez zrzeszenia gmin i powiatów obszarów metropolitalnych jako zadanie zlecone z zakresu administracji rządowej. Plany metropolitalne, poza ustaleniami przyjętymi w prawie landowym, określają:

- sieć transportową o znaczeniu regionalnym,

- sieć osiedleńczą o znaczeniu regionalnym (ośrodki centralne o znaczeniu regionalnym),

- sieć handlu detalicznego, w tym lokalizację hipermarketów,

- miejsca inwestycji o znaczeniu międzynarodowym (targi, kongresy, parki technologiczne) itp.

Plany lokalne są obowiązującym prawem, plany na poziomie landów mają charakter indykatywny. Ustalenia planów metropolitalnych są wiążące dla planowania na wszystkich szczeblach władzy, a zawarte w nich zalecenia powinny być uwzględnione w innych planach publicznych.

W celu pobudzenia współpracy między obszarami metropolitalnymi a ich wiejskim zapleczem rząd federalny w latach 2008-2010 zrealizował pilotażowy projekt z zakresu planowania przestrzennego o nazwie Supraregionalne partnerstwo - Innowacyjne projekty na rzecz miejsko-regionalnej współpracy, usieciowienia i wspólnej odpowiedzialności (MORO) [Knieling, Kuerschner 2011, s. 66]. Projekt zakładał przejście od tradycyjnej, utrwalonej przez wieki symbiozy, w kierunku tworzenia sieci opartych na szerokiej współpracy i zasadzie wzajemnych korzyści. Projekty miały być współfinansowane przez rząd centralny. W wyniku przetargu wyłoniono siedem regionów metropolitalnych do realizacji projektów pilotażowych. W efekcie partnerzy z terenów wiejskich i małych miast połączyli siły z partnerami metropolitalnymi, zrealizowali własne projekty i byli w stanie stać się partnerami w nowych sieciach i procesie podejmowania decyzji zmierzających do tworzenia rozszerzonego regionu, który łatwiej sprosta obecnym i przyszłym wyzwaniom. Mimo że takie procesy współpracy, prowadzonej przez przedstawicieli administracji, biznesu, nauki i społeczeństwa obywatelskiego, ze względu na istniejące granice administracyjne są dość powolne, prowadzą do lepszego wzajemnego zrozumienia i wzrostu zaufania [Kelling 2011, s. 7]. Od kilkunastu lat obszary metropolitalne RFN stają się jednostkami samorządu regionalnego [Zachariasz 2004]. 


\subsection{Region Stuttgart}

Region Stuttgart został utworzony w $1994 \mathrm{r}$. jako jednostka samorządu regionalnego. $\mathrm{W}$ jego skład wchodzi 179 miast i gmin zorganizowanych w pięć powiatów. Ludność regionu liczy około 2,7 mln mieszkańców, z czego ok. $17 \%$ stanowią obcokrajowcy.

Współpraca samorządowa w regionie Stuttgartu przyjęła formę sformalizowaną w roku 1994, kiedy został utworzony Związek Regionu Stuttgart (Verband Region Stuttgart - VRS) co było reakcją władz samorządowych na zmieniającą się sytuację polityczną i społeczno-gospodarczą w Niemczech (zjednoczenie) oraz postępującą integrację europejską, globalizację i wzrost konkurencyjności między metropoliami. Celem Związku jest wzmocnienie i poprawa konkurencyjności OM na arenie europejskiej i światowej poprzez wspólnie realizowane projekty na zasadach ścisłej współpracy międzygminnej. Zarządza nim Zgromadzenie Regionalne, którego członkowie (obecnie - 91) wybierani są co pięć lat w bezpośrednich wyborach [Heeg 2003, s. 168]. Jest ono ciałem decyzyjnym i do jego najważniejszych zadań należą planowanie (regionalne, transportu regionalnego, infrastruktury, krajobrazu), publiczny transport lokalny, gospodarka odpadami, promocja biznesu oraz marketing turystyczny. Ponadto związek może przyjmować na siebie obowiązek organizowania targów i wystaw o charakterze regionalnym oraz wydarzeń kulturalnych i sportowych [www.region-stuttgart. org/vrs/main. jsp?navid=67].

Na czele zgromadzenia stoi wybierany przez jego członków przewodniczący. Zgromadzenie powołuje na osiem lat dyrektora regionu odpowiedzialnego za zarządzanie nim. Kieruje on administracją regionu liczącą 50 osób, dysponuje prawem weta w stosunku do uchwał Zgromadzenia sprzecznych $\mathrm{z}$ interesem regionu i prawem. Prace $\mathrm{w}$ zakresie promocji, marketingu turystycznego oraz koordynacja lokalnego publicznego transportu pasażerskiego są obsługiwane we współpracy z innymi organizacjami regionalnymi i firmami przez pomocnicze spółki sektora prywatnego [Wójcicki 2009].

Źródłem dochodów budżetu regionu (rocznie ok. $260 \mathrm{mln}$ EURO) są prawie wyłącznie środki publiczne przekazywane przez władze gmin i powiatów oraz granty od rządów federalnego i związkowego. Największe wydatki (ok. $85 \%$ całości budżetu) ponoszone są na lokalny transport publiczny.

Związek realizuje swoje zadania na podstawie uchwalonego prawa związkowego. Do zadań obowiązkowych należą:

- planowanie regionalne,

- ramowe planowanie środowiskowe,

- planowanie komunikacji w regionie,

- wspieranie gospodarki regionu, 
- regionalny transport publiczny,

- gospodarka odpadami,

- regionalny marketing turystyczny.

Region Stuttgartu opracowuje i realizuje plan regionalny obowiązujący przez 10-15 lat. Plan ten zawiera cele, główne zasady i sugestie, na których muszą się opierać planiści w poszczególnych gminach. Obecnie obowiązuje Plan Regionalny 2020. Zawiera on cztery główne rozdziały:

1. Cele i założenia rozwoju Regionu Stuttgart.

2. Regionalna struktura osadnicza.

3. Regionalne struktury niezabudowane.

4. Infrastruktura regionalna.

Związek odpowiada za koordynację zintegrowanego systemu transportu: kolei podmiejskich (obsługiwanych przez państwowe Deutsche Bahn), autobusów i tramwajów (obsługiwanych przez spółkę akcyjną Stuttgarter Straßenbahnen oraz ok. 40 regionalnych przedsiębiorstw autobusowych) [OECD 2006b, s. 155].

W ramach promocji biznesu związek utworzył Korporację Rozwoju Regionalnego Regionu Stuttgart (Wirtschaftsförderung Region Stuttgart), która ma wspierać rozwój gospodarki regionu. Jest ona centralnym partnerem dla inwestorów, przedsiębiorców z OM. Zwiększa jakość i atrakcyjność obszarów inwestycyjnych, pełni funkcję doradczą, wspiera i wzmacnia innowacyjność i konkurencyjność gospodarki, rozwija strategie rozwoju kluczowych branż w regionie. W zakresie marketingu turystycznego Zgromadzenie realizuje swoje obowiązki poprzez udział w spółce Regio Stuttgart Marketing und Tourismus GmbH.

W regionie Stuttgartu współpraca metropolitalna wykracza poza działania Związku. W ramach rządowego projektu MORO w roku 2008 zaczął funkcjonować Europejski Region Metropolitalny Stuttgartu (EMS). Jest to dobrowolna współpraca między VRS a otaczającymi go regionami, oparta na szerokim porozumieniu i wspólnych interesach. Decyzje strategiczne dyskutowane są podczas regularnie odbywających się sesji komitetu sterującego, składającego się z 36 członków reprezentujących: VRS, gminy w regionie Stuttgartu oraz gminy i powiaty z czterech innych landów. Dla realizacji konkretnych zadań tworzone są grupy robocze. Do największych osiągnięć EMS należy wprowadzenie Metropoltiket - jednolitego biletu o zryczałtowanej opłacie na transport publiczny w całym regionie metropolitalnym. Ponadto, w ramach politycznego lobbingu została wypracowana wspólna strategia uzyskania wsparcia rządowego na poprawę infrastruktury wzdłuż Nekaru, który ma duży potencjał transportowy.

Dzięki wsparciu ze strony rządu federalnego, RSV, Agencja Rozwoju Regionalnego Stuttgartu oraz regionalne władze $\mathrm{z}$ czterech innych landów odpowiedzialne za planowanie regionalne zintensyfikowały swoją współ- 
pracę w kierunku rozwoju specyficznego potencjału regionu. Podstawą tej współpracy jest strategiczna koncepcja zagospodarowania przestrzennego EMS, która została przyjęta przez polityków ze wszystkich uczestniczących regionów [Kelling 2011, s. 18]. Aby osiągnąć cele koncepcji, przyjęto do realizacji sześć projektów dotyczących m.in. instrumentów koordynacji rozwoju przestrzennego, klastrów kompetencji czy usług logistycznych. Kolejne projekty, przewidywane do realizacji w następnych latach, dotyczą synchronizacji rozkładów jazdy kolei w EMS i rozwoju obszarów wiejskich [Kelling 2011, s. 19].

Obszar metropolitalny Stuttgartu, mający swoje własne zgromadzenie, jest przykładem zinstytucjonalizowanego obszaru metropolitalnego, choć o ograniczonych uprawnieniach. Jednak jako obszar zinstytucjonalizowany dysponuje zarówno władzą uchwałodawczą, jak i wykonawczą, co jest kluczowe dla procesu zarządzania. Ponadto różni metropolitalni aktorzy gminy, landy, eksperci i społeczeństwo obywatelskie - aktywnie uczestniczą w każdym etapie procesu planowania i realizowania rozwoju. Podmiot metropolitalny, który kieruje tym procesem, zapewnia wysoką odpowiedzialność przed obywatelami - bezpośrednimi wyborcami członków Zgromadzenia [Christmann 2011, s. 14].

\subsection{Zagłębie Ruhry}

Zagłębie Ruhry zamieszkuje prawie 5,2 milionów ludzi. Region ten zmienił się przez dziesięciolecia z obszaru przemysłowego wydobycia węgla kamiennego i produkcji stali $\mathrm{w}$ metropolię ukierunkowaną na usługi i kulturę. Metropolia Ruhry obejmuje 11 dużych miast i cztery powiaty z 53 gminami (rys. 10), które w roku 2004 połączyły się w Zrzeszenie Regionalne Ruhry (Regionalverband Ruhr - RVR).

Nadrzędnym celem zrzeszenia jest polepszenie jakości życia w Zagłębiu Ruhry. Zrzeszenie przejęło odpowiedzialność za największe atrakcje przyciągające turystów - trasę kultury przemysłowej i park krajobrazowy Emscher. Aby osiągnąć główny cel zrzeszenie założyło, wraz z gminami, holdingi i przedsiębiorstwa-córki: osiem parków rekreacyjnych, spółkę Kultur Ruhr GmbH, Wirtschaftsförderung Metropoleruhr GmbH, Ruhr Tourismus $\mathrm{GmbH}$, a także Spółkę Utylizacji Odpadów w Zagłębiu Ruhry (Abfallentsorgungs-Gesellschaft Ruhrgebiet). Własne spółki - Trasa Kultury Przemysłowej RVR i Zielona Ruhra RVR (Ruhr Grün) są odpowiedzialne za obie największe atrakcje regionu.

Na czele Zrzeszenia stoi Parlament Ruhry z siedzibą w Essen. Są w nim reprezentowane wszystkie miasta i powiaty metropolii Ruhry. W jego skład wchodzi około 70 członków uprawnionych do głosowania. Są to przedstawiciele poszczególnych jednostek, którzy zostali delegowani przez miasta i powiaty oraz 15 burmistrzów i starostów. Kadencja parlamentu trwa pięć 
lat. Jego członkowie wybierają przewodniczącego, jego zastępcę i reprezentantów do komisji. Wspólne działania dla metropolii Ruhry uchwalają komisje: planowania, gospodarki, środowiska naturalnego, związkowa, kontroli rachunkowości, jak również komisja kultury i sportu. Do parlamentu Ruhry należą również Route der Industriekultur (Trasa kultury przemysłowej) i RVR Ruhr Grün. Parlament Ruhry decyduje o budżecie Zrzeszenia Regionalnego Ruhry.

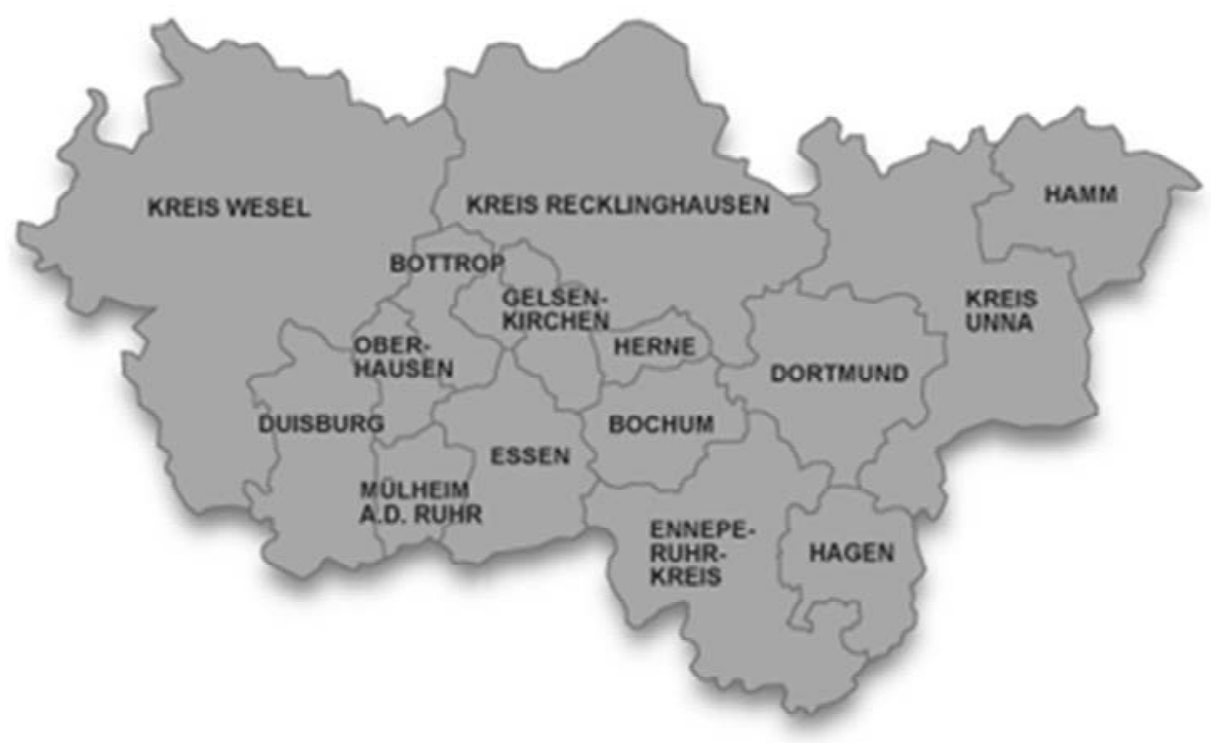

Rys. 10. Region Ruhry

Źródło: [http://www.metropoleruhr.de/pl/strona-glowna/metropoliaruhry/dane-i-fakty.html].

Od 2009 r. parlament, za pośrednictwem planu regionalnego, ustala przyszłościowe kierunki rozwoju metropolii Ruhry. Plan regionalny sporządzany jest na okres 10-15 lat i zawiera cele odnośnie do przyszłego rozwoju przestrzennego. $\mathrm{W}$ ramach planowania regionalnego prowadzona jest również obserwacja i analiza rozwoju przestrzennego w regionie. W tym celu dane są dokumentowane w systemie informacyjnym obejmującym całą powierzchnię Regionu Ruhry, z którego mogą korzystać wszystkie 53 gminy i wykorzystywać go jako podstawę informacyjną i decyzyjną dla lokalnego planowania [http://www.metropoleruhr.de]. Zrzeszenie prowadzi również intensywne działania marketingowe, które mają na celu wypromowanie Metropolii Ruhry jako obszaru gospodarczego, w którym warto mieszkać.

Zgodnie z mottem „Przemiana dzięki kulturze - kultura dzięki przemianie" miasto Essen zostało wybrane stolicą kultury 2010 r. jako przedstawiciel metropolii Ruhry. 


\subsection{Obszar Metropolitalny Monachium}

Obszar Metropolitalny Monachium (OMM) liczy 2,6 mln mieszkańców. W jego skład wchodzi 186 gmin, osiem powiatów i land Bawarii (rys. 11).

Brak struktur administracyjnych na poziomie OMM został, w pewnej mierze, zastąpiony organizacjami celowymi stworzonymi dla koordynowania działań podmiotów zaangażowanych w realizację przedsięwzięć ważnych dla rozwoju regionu. Jedną z pierwszych było Stowarzyszenie Planistyczne Wielkiego Monachium utworzone w roku 1950, do jego zadań należało przede wszystkim podniesienie poziomu profesjonalizmu w zakresie planowania przestrzennego (głównie użytkowania gruntów), osadnictwa i infrastruktury, a także koordynowania procesów rozwoju przestrzennego, szczególnie o charakterze ponadlokalnym.

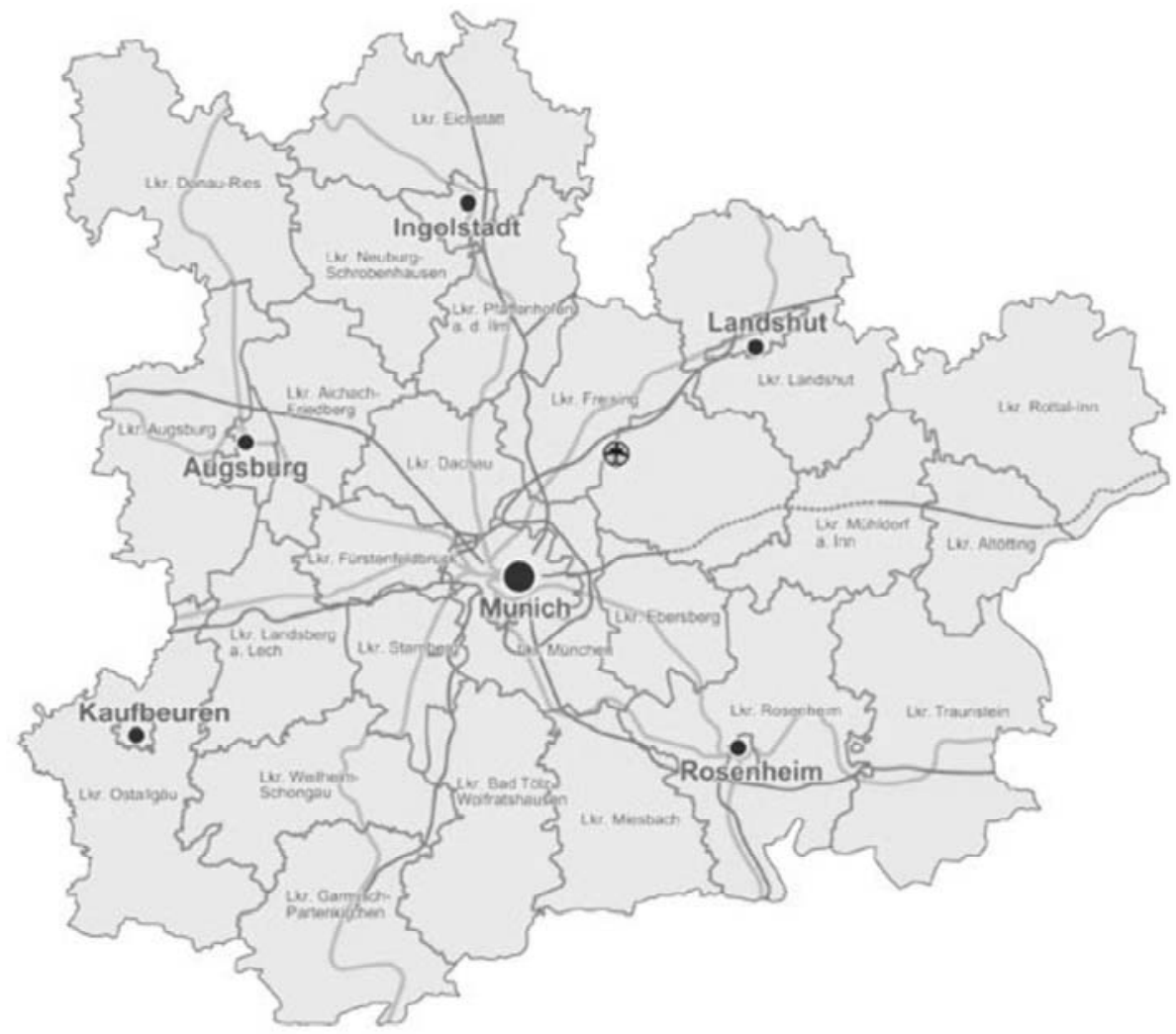

Rys. 11. Obszar Metropolitalny Monachium

Źródło: [http://www.metropolregion-muenchen.eu/en/about-the-region/map-and-siteinformation.html]

W roku 1973, wraz z wprowadzeniem w Bawarii obowiązku planowania regionalnego, utworzono Stowarzyszenie Planowania Regionalnego Monachium, w skład którego, obowiązkowo, weszli przedstawiciele wszystkich 
ośmiu powiatów i 186 gmin. Stowarzyszenie to jest oficjalną formą współpracy $\mathrm{w}$ Regionie Monachium. Do jego zadań należy przede wszystkim przygotowanie i zatwierdzenie planu regionalnego, jako podstawy prawnej dla tworzenia lokalnych planów użytkowania gruntów. Plan regionalny musi uwzględnić wytyczne zawarte w Programie Zagospodarowania Przestrzennego Bawarii [URBACT 2011, s. 22].

Na poziomie operacyjnym, początek współpracy pomiędzy jednostkami terytorialnymi wchodzącymi w skład OMM datuje się na rok 1965, kiedy powstało Stowarzyszenie na Rzecz Rozwoju Regionalnych Obszarów Rekreacyjnych (EFV). Koncentruje się ono na tworzeniu obszarów rekreacyjnych i ścieżek rowerowych, a finansowane jest przez 60 członków (Monachium, powiaty i gminy). W wyniku jego działalności utworzono 30 dużych obszarów rekreacyjnych o całkowitej powierzchni około 600 ha [URBACT 2011, s. 22]. Kolejnym stowarzyszeniem jest Obszar Wielkiego Monachium - OWM skupiający, na zasadzie dobrowolności, ponad 100 członków z sektora publicznego i prywatnego. OWM odpowiada za marketing regionalny oraz reprezentuje region podczas targów nieruchomości - ExpoReal.

W roku 1972 powołano do życia organizację, której działalność miała kluczowe znaczenie dla poprawy mobilności wewnątrz OWM - była to Współpraca na Rzecz Monachijskiego Transportu Publicznego. Organizacja ta koordynuje funkcjonowanie kolejowego i drogowego transportu publicznego, co daje możliwość ujednolicenia biletów i taryf wewnątrz OWM [Banachowicz, Danielewicz 2006, s. 46-47].

$\mathrm{Na}$ poziomie metropolitalnym w roku 2007 utworzono stowarzyszenie Region Metropolitalny Monachium (Europäischen Metropolregion München - EMM), które jest dobrowolną regionalną platformą współpracy powiatów i gmin ze wschodniej Bawarii. Jest to parasolowa organizacja skupiająca partnerów ze świata biznesu, polityki, edukacji i nauki, kultury i zarządzania, którzy chcą odegrać aktywna rolę w projektach z dziedzin: wiedzy, biznesu i marketingu, środowiska i zdrowia lub transportu oraz mobilności. Głównym celem jest stworzenie sieci współpracy w regionie metropolitalnym i uczynienie go wyraźnie widocznym na arenie międzynarodowej [http://www.metropolregion-muenchen.eu]. Na czele stowarzyszenia stoi rada składającą się z 16 przedstawicieli członków oraz komitet sterujący, w którego skład wchodzi 32 członków tworzących:

- Grupę Władz Regionalnych (16 przedstawicieli miast, powiatów i gmin),

- Grupę ds. Przemysłu i Społeczeństwa (sześciu przedstawicieli izb handlowych, sześciu przedstawicieli przedsiębiorstw oraz reprezentanci organizacji społecznych, nauki i władz związkowych),

- reprezentację grup roboczych (ds. nauki, gospodarki, mobilności, środowiska i kultury) [http://www.metropolregion-muenchen.eu]. 
Raz w roku organizowana jest Konferencja Metropolitalna, która ma na celu wykształcenie wspólnej tożsamości, zebranie kolejnych pomysłów na projekty i przyciągnięcie nowych uczestników oraz utrzymanie ich zaangażowania i wsparcia [URBACT 2011, s. 22].

Na początku roku 2010 EMM skupiało 30 powiatów (w tym sześć grodzkich), 28 gmin, sześć izb handlowych, 80 przedsiębiorstw i 40 innych przedstawicieli nauki i społeczeństwa [http://www.metropolregion-muenchen.eu/]. Obok wymienionych powyżej, w OWM funkcjonuje znaczna liczba organizacji, których działalność ma charakter sektorowy, np. w dziedzinie ochrony przyrody, rekreacji czy rozwoju gospodarczego, koncentrują one wysiłki na wybranych obszarach regionu [Reiss-Schmidt 2004, s. 5].

Taka różnorodność organizacji i inicjatyw w zakresie rozwoju regionalnego jest niezwykle użyteczna, głównie z uwagi na swą elastyczność i zintegrowany charakter, ale niestety jest też niewystarczająca dla działań związanych $\mathrm{z}$ rozwiązywaniem konfliktów, definiowaniem priorytetów czy przygotowaniem i podjęciem decyzji w sprawach budzących kontrowersje. Stąd też pojawiły się silne sugestie, głównie ze strony Stowarzyszenia Miast Niemieckich, aby ten dobrowolny model kooperacyjny przekształcić w strukturę znacznie bardziej sformalizowaną, z wybieralną (w bezpośrednich wyborach) Radą Regionalną, na której czele stałby Prezydent Regionu oraz silną administracją regionalną. Do kompetencji tej ostatniej należałoby: planowanie regionalne i w zakresie użytkowania gruntów, planowanie sieci transportowych i krajobrazu, szkolnictwo wyższe, usługi socjalne, mieszkalnictwo, sport i rekreacja oraz rozwój gospodarczy. Dużo uwagi należałoby poświęcić takim aspektom jak marketing regionalny i zarządzanie w regionie, a także wyrównywaniu dysproporcji pomiędzy budżetami obszarów silniejszych i słabszych gospodarczo. Ten sformalizowany model udało się, jak dotąd, wprowadzić tylko w dwóch regionach - Stuttgartu i Hanoweru. W pozostałych regionach liderzy polityczni odnoszą się bardzo sceptycznie, a niekiedy wręcz stają w opozycji, do proponowanego modelu. Podstawową przyczyną takich postaw jest obawa przed ograniczeniem kompetencji i uprawnień niższych szczebli władzy oraz zdominowaniem regionu przez interesy jednostki centralnej.

OWM jest niewątpliwie tworem specyficznym, gdyż nie istnieje z punktu widzenia podziału administracyjnego kraju, a co za tym idzie nie ma politycznej reprezentacji na żadnym szczeblu sprawowania władzy. Fakt ten traktowany jest zresztą przez wielu ważnych aktorów działających w ramach OWM jako korzyść, a nie niedogodność. Słabość administracji na poziomie regionalnym, której towarzyszy stosunkowo silna pozycja władz lokalnych, uważana jest nierzadko za jeden $\mathrm{z}$ warunków koniecznych w procesie tworzenia podstaw trwałego rozwoju regionu w długiej perspektywie. 
Niemniej coraz więcej argumentów przemawia za wprowadzeniem zintegrowanego i sformalizowanego modelu zarządzania obszarem metropolitalnym. Z punktu widzenia OWM istniejący system wydaje się wystarczający na potrzeby obecnych zdarzeń społecznych i gospodarczych, ale w dobie pogłębiających się procesów globalizacyjnych i wzrastającej konkurencji w ramach rynków europejskich może okazać się niewystarczająco efektywny w zakresie rozwiązywania przyszłych problemów i zaspokajania przyszłych potrzeb społeczności metropolitalnej.

Biorąc pod uwagę polityczne uwarunkowania, w jakich funkcjonuje OWM (konserwatywna większość w Bawarskim Parlamencie), należy stwierdzić, iż transformacja od woluntarystycznego modelu zarządzania w obszarach metropolitalnych do modelu sformalizowanego jest obecnie niemożliwa. Zatem OWM, na bazie dotychczasowych doświadczeń, musi znaleźć własną drogę do osiągnięcia większego stopnia integracji polityki i planowania na poziomie regionalnym i nie może w tym celu zaadaptować rozwiązań zastosowanych w innych regionach [Reiss-Schmidt 2004, s. 4-5].

\subsection{Region Metropolitalny Hamburga}

Region Metropolitalny Hamburga obejmuje miasto-kraj związkowy Hamburg i 800 gmin położonych w 14 powiatach w landzie SchleswigHolstein (sześć) i Dolna Saksonia (osiem). Cały obszar zamieszkuje około 4,3 miliona ludzi [Bureau of... 2006]. Współpraca w rejonie obszaru metropolitalnego Hamburga opiera się na zasadzie dobrowolności i zachodzi między trzema landami (Hamburg, Schleswig-Holstein i Dolna Saksonia) położonymi po obu stronach Elby.

Historia współpracy sięga roku 1928, kiedy Hamburg i Prusy rozpoczęły proces wspólnego planowania regionalnego. Na przełomie lat 50. i 60. XX w. ponownie wprowadzono wspólne planowanie regionalne, aby zmierzyć się z postępującym rozprzestrzenianiem się miast i sąsiedztwem granicy państwa. W tym celu utworzono dwustronne fundusze rozwojowe między Hamburgiem i Dolną Saksonią oraz Hamburgiem i krajem SchleswigHolstein. W roku 1980 nastąpiło przejście w kierunku bardziej politycznej współpracy i powołano „Metropolregion Hamburg” [Schulte 2006]. W roku 2005 nastąpiła strukturalna reorganizacja. Podpisano traktat między Hamburgiem i dwoma pozostałymi landami. Przyjęto nową strategię internacjonalizacji i terytorialnej ekspansji. Najwyższym organem decyzyjnym w Regionie Metropolitalnym Hamburga jest Rada Regionalna, która formułuje politykę i polityczne cele współpracy.

Komitet Sterujący koordynuje i kontroluje członków regionu, instytucje i sieci współpracy we wszystkich kwestiach dotyczących współpracy regionalnej. Decyduje jakiego rodzaju eksperckie grupy robocze należy utworzyć, rozwiązać bądź zastąpić innymi oraz decyduje o alokacji funduszy rozwo- 
jowych i tworzy wytyczne dla pracy biura http://english.metropolregion.hamburg.de/bodies/1072132/steering-committee.html]. Rodzaj grup roboczych zdeterminowany jest przez Programy Operacyjne dla Regionu Metropolitalnego.

W styczniu roku 2006, zgodnie z rozwiązaniem przyjętym w traktacie o współpracy podpisanym przez trzy landy, otwarto w Hamburgu Biuro Regionu Metropolitalnego. Ma ono za zadanie wspierać Komitet Sterujący, zarządzać wspólnymi projektami, odpowiada za public relations i koordynuje marketing regionalny $w$ regionie, reprezentując go $w$ regionalnych i krajowych organach. Biuro przygotowuje też plan gospodarczy, administruje funduszami na wypłaty i podpisuje umowy z zewnętrznymi dostawcami usług [http://english.metropolregion.hamburg.de/bodies/1072126/ secretariat.html].

Co roku odbywają się Konferencje Metropolitalne, w których uczestniczą wszyscy przedstawiciele zgromadzeń krajów związkowych tworzących Region Metropolitalny. Tematyka konferencji dotyczy głównych obszarów priorytetowych dla regionu, dostarcza bodźców do współpracy regionalnej i reprezentuje polityki gmin oraz krajów związkowych, instytucje oraz opinię publiczną w regionie [http://english.metropolregion.hamburg.de/ bodies/1072146/regional-conference.html].

Głównymi celami współpracy są:

- Zwiększenie międzynarodowej konkurencyjności, zwłaszcza w biznesie, nauce, transporcie, turystyce i kulturze.

- Zagwarantowanie podstawowych usług publicznych w dobie zachodzących przemian demograficznych i napiętych budżetów publicznych.

- Rozwijanie wspólnego podejścia do planowania regionalnego i spraw zagospodarowania przestrzennego.

Współpraca w regionie Metropolitalnym Hamburga skupia się na:

- polityce klastrowej o zasięgu regionalnym, która polega na tworzeniu transgranicznych sieci kompetencji i realizacji projektów regionalnych (np. Inicjatywa Rozwoju Gospodarczego w południowym rejonie Elby),

- zarządzaniu regionem w obszarze handlu i mieszkalnictwa,

- internacjonalizacji i marketingu regionalnym.

Wspólnie realizowane projekty obejmują m.in.:

- modernizację strony internetowej jako podstawy do marketingu regionalnego,

- wydawanie od roku 2005 nowego magazynu Regionu Metropolitalnego Hamburga,

- realizację od roku 2002 Targów Nieruchomości,

- rozszerzenie i ulepszenie regionalnej sieci transportu, 
- wprowadzenie regionalnej karty turystycznej, stworzenie nowych produktów turystycznych, połączenie ofert turystycznych na poziomie regionalnym [Schulte].

W ramach internacjonalizacji Region Hamburga współpracuje z innymi regionami w ramach sieci METREX.

We współpracę, oprócz odpowiedzialnych jednostek administracyjnych, bezpośrednio zaangażowane są stowarzyszenia, związki zawodowe, politycy, organizacje profesjonalistów, podmioty promujące turystykę i gospodarkę.

Działalność Regionu Metropolitalnego finansowana jest przez landy: Hamburg, Dolną Saksonię i Schleswig-Holstein.

Współpraca metropolitalna nie ogranicza się wyłącznie do Regionu Metropolitalnego i obejmuje dodatkowe jednostki, które są mniej lub bardziej intensywnie powiązane z regionem rdzeniowym. Celem tej współpracy jest zwiększenie partnerstwa miejsko-wiejskiego i promowanie sustensywnego wzrostu bez tworzenia nowej struktury biurokratycznej. W latach 2008-2010 intraregionalne partnerstwo rozpoczęło, w ramach rządowego projektu MORO, realizację 14 wspólnych projektów w różnych dziedzinach, m.in. w transporcie publicznym, tworzeniu klastrów, współpracy między uczelniami. Partnerami w tych projektach byli: Region Metropolitalny Hamburga, północna część landu Schleswig-Holstein i zachodnia część MeklemburgiiPomorza Zachodniego. MORO North finansowany był przez niemieckie Ministerstwo Transportu, Budownictwa i Zagospodarowania Miast, wchodzące w jego skład kraje związkowe, Region Metropolitalny Hamburga i izby handlowe. Nad koordynacją współpracy czuwał Komitet Sterujący, a kierownictwo projektu przyjął na siebie minister spraw wewnętrznych landu Schleswig-Holstein. Za ogólne zarządzanie odpowiedzialny był HafenCity Uniwersytet w Hamburgu. Każdy z poszczególnych projektów zarządzany był w sposób zdecentralizowany przez publiczne lub prywatne instytucje [Kelling 2011, s. 14]. Opierając się na tych początkowych pozytywnych doświadczeniach, partnerstwo podpisało w roku 2011 porozumienie i zostało sformalizowane jako Projekt Partnerstwa Północnego (PP Nord) [Knieling, Kuerschner 2011, s. 66]. PP Nord przez pierwsze dwa lata przewodniczy Hamburg, w celu kontynuowania rozpoczętych projektów i stworzenia nowych, których cele będą zbliżone do celów MORO North. Jednym z projektów jest np. projekt zatytułowany Zbliżenie - połq̨czenia transportowe między obszarami wiejskimi i miejskimi, w ramach którego stworzono studium Transport publiczny 2030, pokazujące możliwości rozwoju transportu publicznego w północnych Niemczech [Kelling 2011, s. 15].

W Niemczech występują różnorodne formy współpracy w obszarach metropolitalnych od bardzo nieformalnych konferencji metropolitalnych, poprzez stowarzyszenia, aż po władze metropolitalne. Każdy obszar metropolitalny ma swobodę w decydowaniu o sposobie zarządzania, przy czym 
nie można jednoznacznie stwierdzić, która z form zarządzania jest najlepsza, gdyż zależy to od specyfiki regionu funkcjonalnego.

\section{Włochy - trudna droga do współpracy}

Włochy były państwem instytucjonalnie scentralizowanym. Konstytucja z roku 1948 przewidywała wprowadzenie samorządu regionalnego, ale realizacja tego zapisu nastąpiła dopiero w latach 1975-1977. Dlatego też wszelkie polityki terytorialne były do tego momentu prowadzone na szczeblu centralnym [OECD 2001a, s. 71].

Chociaż nowe władze regionalne uzyskały uprawnienia legislacyjne w tak ważnych dziedzinach, jak rolnictwo, handel, rzemiosło, opieka zdrowotna i usługi socjalne, urbanistyka i zagospodarowanie przestrzenne, ochrona środowiska, transport, szkolenia techniczne itd., to ich autonomia finansowa była bardzo ograniczona. System finansów regionalnych cierpiał z powodu nadmiernego uzależnienia od transferów państwowych, które zazwyczaj nie miały związku ze zdolnością regionu do generowania dochodu. W dodatku władze regionu zazwyczaj przyjmowały ten sam, nieefektywny, mechanizm redystrybucji środków do niższych szczebli administracji [OECD 2001a, s. 72]. Władze lokalne są silnie uzależnione od dotacji z budżetu państwa, co w sposób naturalny ogranicza ich działalność i czyni zależnymi od władz centralnych.

Pod koniec lat 70. władze regionalne podjęły próby zmierzające $\mathrm{w}$ kierunku przeciwdziałania terytorialnej fragmentacji polityk sektorowych poprzez tworzenie ponadgminnych podmiotów (comprensori), które miały przejąć zadania związane z programowaniem od prowincji, podkreślając tym samym funkcje administracyjne, które miała pełnić prowincja. Jednakże comprensori nie tylko brakowało spójnej tożsamości terytorialnej, gdyż były w różnych regionach definiowane według różnych zasad, ale pozbawione były również politycznego poparcia i uprawnień koniecznych do tego, aby stać się instytucjonalną alternatywą dla prowincji [Gualini 2003, s. 269].

$\mathrm{Na}$ początku lat 90. przeprowadzono reformę terytorialną, która wzmocniła pozycję gmin i prowincji oraz ustanowiła region centrum nowej struktury instytucjonalnej [Gualini 2003, s. 252]. Gminy i prowincje po raz pierwszy zyskały prawo przyjmowania własnych statutów i określania swojej organizacji. Ustawa stworzyła ramy prawne do współpracy międzygminnej i wprowadziła instytucję samorządu metropolitalnego. Reforma umożliwiła zawieranie kontraktów na świadczenie usług publicznych oraz wprowadziła zasady i techniki Nowego Zarządzania Publicznego.

System samorządu lokalnego został wzmocniony w roku 1993, wraz z wprowadzeniem bezpośrednich wyborów burmistrzów i prezydentów prowincji. Reforma autonomii na poziomie lokalnym została zakończona 
w latach 1997-1999 po wzmocnieniu władzy i roli samorządów lokalnych. Prawo finansowe z 1996 r. i ustawa z 1997 r. stanowiły dwa znaczące kroki w kierunku określenia funkcji i zadań regionów i władz lokalnych, reformy administracji publicznej i uproszczenia procedur administracyjnych. W roku 2000 wprowadzono bezpośrednie wybory prezydentów regionalnych. Tym samym administracja w miastach stała się bardziej stabilna. Władza, przejrzystość jej sprawowania i odpowiedzialność burmistrzów uległy wzmocnieniu, prowadząc do większej sprawności i skuteczności samorządu, jednocześnie zmalał wpływ systemu partyjnego na poziom lokalny [OECD 2001a, s. 144]. Obecnie Włochy dzielą się na dwadzieścia regionów, spośród których pięć to tzw. regiony specjalne, 109 prowincji (z których dwie są autonomiczne) i 8100 gmin.

Regiony same uchwalają swoje statuty oraz mają szerokie kompetencje ustawodawcze i wykonawcze. Odpowiadają głównie za usługi zdrowotne, planowanie miast, kształcenie zawodowe, kulturę i turystykę, regionalny transport publiczny, ochronę środowiska, budownictwo mieszkaniowe. Urzędnikiem koordynującym działania regionów $\mathrm{z}$ administracją centralną jest przedstawiciel państwa do spraw autonomii regionalnej. Władzę ustawodawczą w regionach sprawują rady regionalne (consiglio regionale), a wykonawczą komitety regionalne (giunta regionale) [Sarnecki 2008, s. 160-161].

Prowincje są najsłabszym szczeblem władzy na poziomie subnarodowym. Są odpowiedzialne głównie za edukację i ochronę środowiska. Organem wykonawczym jest Komitet Wykonawczy wyznaczany przez prezydenta prowincji.

Do kompetencji gmin należy przede wszystkim świadczenie usług publicznych na poziomie lokalnym (budownictwo socjalne i usługi socjalne, lokalny transport publiczny, gminne drogi, budowa i utrzymanie szkół podstawowych, przedszkola). Organem wykonawczym jest Gminny Komitet Wykonawczy wyznaczany przez burmistrza [OECD 2001a, s. 131].

Potrzeba utworzenia specjalnych władz metropolitalnych we Włoszech została dostrzeżona przez szczebel krajowy w końcu lat 80. Ustawa z roku 1990 zinstytucjonalizowała obszary metropolitalne połączone z głównymi narodowymi biegunami miejskiej koncentracji (Turyn, Mediolan, Wenecja, Genua, Bolonia, Florencja, Rzym, Bari i Neapol). Ośrodki te uzyskały kompetencje w zakresie planowania terytorialnego, usług sieciowych i rozwoju gospodarczego. Pojawiła się możliwość przekształcenia prowincji we władze metropolitalne działające $w$ nowych granicach i wyposażone $w$ nowe uprawnienia. Okazało się jednak, że już ten etap wywołał tak dużo konfliktów, że nie udało się przystąpić do kolejnych kroków reformy [Swianiewicz 2006, s. 31]. Określenia tych granic i zakresu działań miały dokonać władze regionalne. W tym celu miały obowiązek konsultacji z gminami i prowincjami, których taka sytuacja mogła dotyczyć, ale zostały również uprawnione do 
modyfikowania granic gmin poprzez łączenie ich lub likwidację. Nowo utworzone obszary metropolitalne miały mieć dwuszczeblową strukturę zarządzania: jedno miasto metropolitalne (citta metropolitana) na wyższym poziomie i gminy na niższym. Od momentu nowelizacji konstytucji w roku 2001, jest w niej zapisane, że Republika składa się z gmin, prowincji, miast metropolitalnych, regionów i państwa [Costituzione... 2003, art. 114].

Miasto metropolitalne miało skupić obowiązki prowincji uznane za ponadgminne, takie jak planowanie przestrzenne, transport, ochrona i wzmocnienie dziedzictwa kulturowego i przyrodniczego, zasoby wody i energii, gospodarka odpadami, rozwój gospodarczy, opieka zdrowotna, edukacja i szkolenia. Na czele miasta metropolitalnego miała stanąć rada (wybierana bezpośrednio), komitet wykonawczy (wybrany przez radę) i burmistrz (wybierany przez radę i komitet). Metropolia miała czerpać środki finansowe $\mathrm{z}$ własnych podatków, transferów regionalnych i rządowych oraz opłat użytkowników. Przez ponad 10 lat od przyjęcia ustawy nie powstał ani jeden taki samorząd. Przyczyny tego mogą być następujące:

- możliwość taka opierała się na zasadzie dobrowolności,

- inicjatywa jego utworzenia została przekazana regionom, które były niechętne umocnieniu już i tak dużych i relatywnie silnych obszarów miejskich w ramach istniejącej jurysdykcji,

- brak było jakichkolwiek zachęt ze strony rządu centralnego [OECD 2006c, s. 135].

W roku 1999 przyjęto prawo, które złagodziło podejście odgórne do tworzenia miast metropolitalnych na rzecz większej możliwości podejmowania decyzji przez gminy, ale niczego to nie zmieniło.

W roku 2009 uchwalono ustawę wprowadzającą przepisy przejściowe dla miast metropolitalnych, które do tej pory nie zostały utworzone. Zgodnie z art. 23 ustawy każda forma miasta metropolitalnego, po zatwierdzeniu władz regionalnych, musi uzyskać aprobatę społeczeństwa z terenu, którego dotyczy zmiana, w drodze referendum [Legge 5 maggio 2009..., art. 23]. Okres przejściowy wynosił 36 miesięcy i do 21 maja 2012 r. powinny zostać utworzone miasta metropolitalne. Ponieważ i tym razem nie powstało żadne citta metroplitana, parlament, ustawą z dnia 7 sierpnia 2012 r., ustanowił - od dnia 1 stycznia 2014 r. - miasta metropolitalne Rzymu, Turynu, Mediolanu, Wenecji, Genui, Bolonii, Florencji, Neapolu, Bari i Kalabrii [Legge 7 agosto 2012, art. 18].

System planowania przestrzennego we Włoszech opiera się na ustawie z roku 1942, jest więc systemem hierarchicznym, pomimo faktu pojawienia się innowacji na poziomie regionów, prowincji i gmin [OECD 2001a, s. 103].

Regiony włoskie zostały utworzone dopiero w latach 70. pod wpływem decentralizacji i obdarzone mocą samozarządzania w kwestii programowania i planowania własnego terytorium. Przygotowują regionalne plany 
zagospodarowania przestrzennego (PTR), które powinny objąć całość bądź część ich terytorium i ustalić wytyczne odnoszące się do stref rezerwowanych na cele specjalne lub będące przedmiotem specjalnych ograniczeń oraz zidentyfikować obszary przeznaczone pod nowe zabudowy miejskie albo pod określone funkcje, w tym główny system komunikacji. Mogą one również przygotować plany krajobrazu (PTPR) zawierające wskazania, nakazy i ograniczenia odnoszące się do walorów środowiskowych terytorium. Projekt PTR jest przygotowywany z udziałem prowincji, gmin, podmiotów prywatnych itp. i zatwierdzany przez zgromadzenie regionalne [http://www.mlit.go.jp/kokudokeikaku/international/spw/general/italy/index _e.html].

Prowincje mają możliwość przygotowania planów wskazujących podział terenu na strefy, lokalizację infrastruktury, prace hydrogeologiczne oraz obszary przeznaczone na parki i rezerwaty przyrody, jeśli kwestie te nie są już uregulowane za pomocą planu regionalnego. Możliwe jest również tworzenie planów dla podregionów, np. dla obszarów metropolitalnych (città metropolitane) [Larsson 2006, s. 31].

Gminy - pojedynczo lub wspólnie - są zobowiązane do przygotowania ogólnego planu całego terytorium, wskazującego główne trasy komunikacyjne oraz podział obszaru na szczegółowe, prawnie określone strefy, a także ograniczenia, które muszą być przestrzegane. Plany te mają charakter indykatywny, a wdrażane są przez różne rodzaje planów szczegółowych, wykorzystywanych do różnych celów. Plan szczegółowy (Piano Particolareggiato) jest przede wszystkim używany na obszarach zabudowanych i rozwijających się. Programy rewitalizacji obszarów miejskich (programmi di recupero urbano) oraz zintegrowane programy interwencji (programmi integrati di intervento) używane są na potrzeby odnowy tkanki miejskiej. Jeżeli konieczna jest skomplikowana restrukturyzacja praw własności, plan może uzasadniać użycie narzędzia Compart. Jest to konsorcjum właścicieli, posiadających co najmniej $75 \%$ udziału w nieruchomości, które może później otrzymać zezwolenie na wywłaszczenie pozostałego terenu [Larsson 2006, s. 32].

Wraz z decentralizacją władzy pojawiła się potrzeba współpracy w ramach polityki planowana przestrzennego. Nowe instrumenty koordynacji włączają w ten proces gminy, prywatne firmy, stowarzyszenia prośrodowiskowe i obywateli. Obejmują one:

- porozumienia instytucjonalne - jest to rozwiązanie, w którym administracja centralna i każdy region negocjuje główne inwestycje publiczne w perspektywie wieloletniej. Dzięki porozumieniu, region może kierować fundusze krajowe na projekty priorytetowe dla niego [OECD 2001a, s. 157].

- kontrakty dzielnicowe, programy odnowy miast i zrównoważonego rozwoju (PRUSST) itp. 
Wysoka przejrzystość i odpowiedzialność w rozliczaniu funduszy unijnych skłoniły włoskie władze do stworzenia nowego, wiążącego zestawu zasad i procedur. Polityka ta opierała się na nowych, bazujących na partnerstwie i koordynacji, instrumentach, które były testowane od początku lat. 90. i miały na celu promocję poziomej i pionowej współpracy między organami władzy oraz publicznymi i prywatnymi podmiotami w takich dziedzinach, jak infrastruktura, planowanie miast i rozwój lokalny. W prawodawstwie włoskim partnerstwo publiczno-prywatne jest wdrażane poprzez:

- pakty terytorialne (patti territoriali),

- kontrakty obszarowe (contratti d'area),

- kontrakty programowe (contratti di programma) [OECD 2001a, s. 158].

Pakty terytorialne są publiczno-prywatnymi porozumieniami na poziomie lokalnym, stworzonymi w celu promowania współpracy i zaufania oraz stymulowania i koordynowania inwestycji przez przedsiębiorstwa prywatne i administrację lokalną. Jeśli chodzi o politykę przestrzenną, to $\mathrm{w}$ takich dziedzinach, jak odnowa obszarów miejskich, transport, handel, bezpieczeństwo czy marketing miejski, promowane były zintegrowane projekty miejskie. Kontrakty programowe zawierane są między władzami terytorialnymi różnych szczebli lub między władzami tego samego szczebla. Najczęściej stronami sa władze regionalne i lokalne, natomiast państwo jako partner wystepuje tylko w wyjątkowych przypadkach [Pietrzyk 2000, s. 328]. Stosowanie tych nowych instrumentów nie zawsze prowadziło do oczekiwanych efektów. Efektywność ich realizacji zależała od partnerów i ich zaangażowania, dyscypliny systemu oceny i selekcji, przejrzystości procesu podejmowania decyzji i skutecznej odpowiedzialności zaangażowanych aktorów [OECD 2001a, s. 21].

\section{Mediolan}

Obszar funkcjonalny Mediolanu jest większy niż samo miasto, lecz mniejszy niż region Lombardii. Najbliższy jest granicom administracyjnym prowincji (rys. 12), które nieznacznie przekracza. Nie został on jednak ostatecznie zdelimitowany. Zamieszkuje go ponad 3,2 mln osób [http:// www.tuttitalia.it/variazioni-amministrative/riordino-province-e-citta- metropolitane/per-regione/]. Prowincja Mediolan obejmuje 189 gmin.

Prowincja jest jednak najsłabszym poziomem władzy jeśli chodzi o kompetencje i zasoby. Dlatego też z jej strony pojawiła się propozycja utworzenia miasta metropolitalnego. Nie doszło to do skutku z powodu waśni między władzami lokalnymi i braku zachęt do utworzenia nowego poziomu władzy [OECD 2006c, s. 19].

Obszar metropolitalny charakteryzuje się ścisłymi zależnościami między jądrem obszaru skupiającym zaawansowane usługi i peryferiami „pokropkowanymi" funkcjami produkcyjnymi wzmacniającymi lokalny rozwój. 


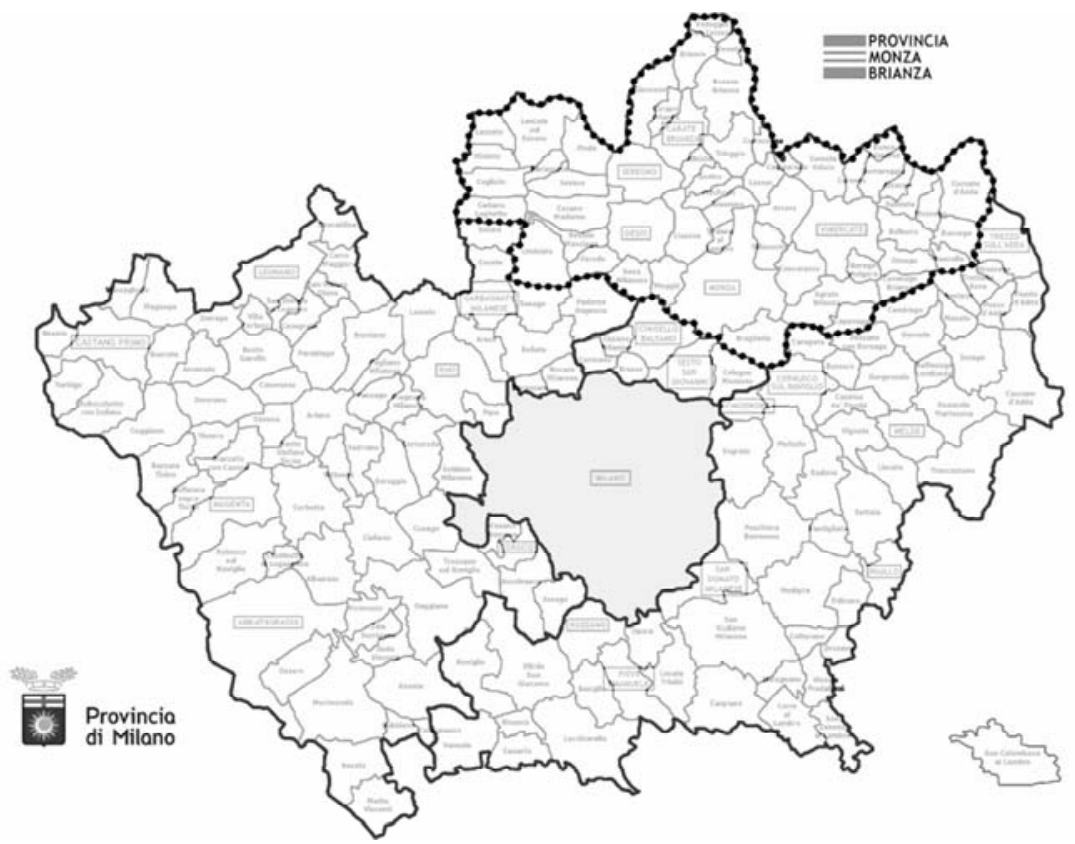

Rys. 12. Granice regionu metropolitalnego Mediolanu

Źródło: [http://www.provincia.milano.it/export/sites/default/affari_sociali/immagini/ sn_milano2400.gif]

Ponieważ władze regionalne są stosunkowo młodym tworem, a władze prowincji miały i mają bardzo ograniczone uprawnienia, to pierwsze próby planowania metropolitalnego polegały na współpracy gmin. W roku 1961 Mediolan i 34 gminy go otaczające utworzyły międzygminny podmiot planistyczny zwany Piano Intercomunale Milanese (PIM). Jest to dobrowolne konsorcjum, z organem stanowiącym w postaci zgromadzenia burmistrzów, które miało odpowiadać za planowanie strategiczne. PIM zwrócił się z prośbą do ekonomistów, architektów, socjologów i rozmaitych miejskich profesjonalistów, aby przygotowali projekt planu zagospodarowania przestrzennego dla Wielkiego Mediolanu. Mieli przy tym bazować na ekspertyzach przeprowadzonych rok wcześniej przez Mediolan, prowincję, Izbę Handlową, bank lokalny i instytut badawczy. PIM bardzo szybko przyciągnął nowych członków (do 1967 r. dołączyły do niego 94 gminy i prowincja Mediolan) i przedstawił wiele innowacyjnych i wysokiej jakości pomysłów. Jednak dwie kwestie osłabiły jego mandat. Po pierwsze, projekty te były często zbyt ambitne i trudne do realizacji. Po drugie, projektanci byli często $\mathrm{w}$ bliskich relacjach z członkami dwóch antagonistycznych partii politycznych, co prowadziło wielokrotnie do blokowania projektów podczas głosowania. Zasada jednomyślnego głosowania dodatkowo paraliżowała proces podejmowania decyzji. PIM stopniowo zaczął odgrywać rolę organu tech- 
nicznego wsparcia i ośrodka badawczego, a nie właściwego międzygminnego konsorcjum [OECD 2006c, s. 132]. Obecnie członkami PIM są dwie prowincje i 64 gminy. Każdy członek wnosi składki, których wysokość uzależniona jest od liczby mieszkańców. Na czele PIM stoi Zgromadzenie składające się z burmistrzów gmin i prezydentow prowincji, któremu przewodniczy wybierany przez nie, na okres pięciu lat, prezydent oraz Zarząd (Consiglio Direttivo). Obecny Zarząd składa się z 13 członków [http://www.pim.mi.it/].

Kolejne wspólne działania na poziomie metropolitalnym miały na celu wdrożenie jednolitego systemu opłat za transport publiczny. W roku 1999 zostały utworzone Władze Transportowe Mediolanu, które rok później przekształcono w komunalne przedsiębiorstwo - Mediolański Transport Miejski (ATM). Przedsiębiorstwo odpowiada za zarządzanie i rozwój wszystkich typów transportu publicznego w Mediolanie i jego najbliższym sąsiedztwie (85 gmin). Mediolan i kilka innych gmin wprowadziły Zintegrowany System Opłat w Obszarze Mediolanu (SITAM), ale obejmuje on tylko część regionu funkcjonalnego. Umowy między władzami, które mogłyby uzdrowić problemy $\mathrm{z}$ transportem za pośrednictwem wspólnego planowania i finansowania infrastruktury, rzadko dochodzą do skutku [OECD 2006c, s. 151].

Jednak inne kwestie spotkały się z obiecującą oddolną odpowiedzią na propozycje współpracy. W roku 1996 przez prowincje Mediolan i jedną gminę została założona agencja rozwoju lokalnego, nazwana Agenzia di Sviluppo Nord Milano (ASNM), która mała zmierzyć się z problemem deindustrializcji i upadku wielu tradycyjnych firm. Agencja promowała odnowę olbrzymich zdegradowanych terenów poprzez przekształcenie ich w inkubatory biznesu i miejsca powstawania małych firm. Umocniła również powiązania między uczelniami i biznesem poprzez finansowanie (ze środków EFS) innowacyjnych pomysłów biznesowych wychodzących od uniwersyteckich badaczy. Ponieważ ASNM odniosła sukces w swoich działaniach i zwiększyła liczbę członków, w roku 2005 została przekształcona w publiczno-prywatną agencję, Milano Metropoli, która uzyskała poszerzone uprawnienia [OECD 2006c, s. 19]. Partnerami zostały: prowincja Mediolan, Izba Handlowa Mediolanu, cztery gminy położone na północ od Mediolanu, które miały podobne problemy, dwie instytucje finansowe i duże firmy (Falk, ABB itd.). Milano Metropolii w dalszym ciągu specjalizuje się w odnowie zdegradowanych terenów (oferuje usługi konsultingowe władzom lokalnym) i innowacyjnej przedsiębiorczości (poprzez wspieranie nowych biznesów w kreatywnej gospodarce), ale przejęła również odpowiedzialność za marketing terytorialny. Ma to na celu przyciągnięcie BIZ i utalentowanych pracowników oraz stworzenie zintegrowanej oferty turystycznej [OECD 2006c, s. 164]. Działania agencji finansowane są z funduszy członków, opłat za świadczenie usług oraz źródeł zewnętrznych przeznaczonych 
na realizację konkretnych projektów. Metropoli Milano zarządzana jest przez Radę Dyrektorów złożoną z przedstawicieli partnerów [http://www. milanomet.it/en/cosa-facciamo/activities.html].

Agencja miała również swój udział w aktualizacji planu zagospodarowania przestrzennego prowincji (PTCP). Prace nad jego opracowaniem rozpoczęły się w związku z koniecznością dostosowania do przepisów nowej ustawy o zagospodarowaniu przestrzennym z roku 2005. Od początku założono szerokie uczestnictwo innych podmiotów w procesie przygotowania planu. Instrumentem partycypacji i konsultacji stało się, ustanowione przez prowincję, Forum dla Zarządzania Obszarem Metropolitalnym. Zostali do niego zaproszeni nie tylko aktorzy instytucjonalni i polityczni, ale również społeczno-gospodarczy, trzeci sektor i generalnie przedstawiciele społeczeństwa obywatelskiego. Agencja współpracowała z Wydziałem Przestrzeni prowincji w projektowaniu i realizowaniu działań $\mathrm{w}$ ramach Forum i od września roku 2006 do wiosny 2007 r. przeprowadzono szereg ogólnych spotkań i tematycznych warsztatów. Kolejny wkład agencji w opracowanie PTCP polegał na przygotowaniu diagnozy gospodarczej prowincji w perspektywie do roku 2020 [http://www.milanomet.it/it/valorizzazione-territoriale/piano-territoriale-di-coordinamento-provinciale-3.html].

Prace nad aktualizacją planu objęły również trzyetapowy proces konsultacji z gminami prowadzony przez władze prowincji, który trwal od roku 2009 do 2011. W październiku roku 2011 rada prowincji przyjęła projekt aktualizacji PTCP [http://www.provincia.mi.it/pianificazione_territoriale/ piano_territoriale/index.html].

Plan zakłada wzmacnianie policentrycznego obszaru metropolitalnego Mediolanu poprzez rozwój sieci transportowej oraz ochronę środowiska dzięki budowie sieci ekologicznej miedzy biegunami policentrycznego systemu. W styczniu 2012 r. plan został przedłożony Konferencji Gmin i władzom regionalnym do akceptacji. 7 czerwca 2012 r. został przyjęty przez radę prowincji [http://www.provincia.mi.it/pianificazione_territoriale/piano_territoriale].

Agencja zaangażowała się w również w zainicjowany w roku 2005 przez prowincję Mediolan projekt strategiczny dla Regionu Miejskiego Mediolan o nazwie „Città di città" (Miasto Miast). Projekt ma na celu poprawę jakości życia w prowincji, a tym samym umocnienie lokalnego współdziałania i powiększenie obszaru przewag konkurencyjnych [http://www.milanomet. it/en/valorizzazione-territoriale/the-citt-di-citt-strategic-project.html]. Partnerem w projekcie była również Katedra Architektury i Planowania Politechniki Mediolańskiej. Città di città podejmuje szereg takich kwestii, jak dostępność stałych i tymczasowych miejsc pobytu; dostęp do przestrzeni publicznych; promowanie nowego lokalnego dobrobytu; mobilność przy wykorzystaniu różnych środków transportu w różnych kierunkach; pro- 
mowanie kultury; zmniejszenie zagęszczenia ruchu i zanieczyszczenia; nowe, wspólne przestrzenie interakcji publicznych różnego rodzaju; tworzenie żywej atmosfery w innych miejscach; przestrzeń przeznaczona na niezaplanowane działania; ponowne wprowadzenie natury do miejsc, w których zanikła itp. [European Commission 2011, s. 70]. W wyniku tego projektu miasta i gminy postrzegają się jako komponenty obszaru o większym znaczeniu niż jedynie peryferia Mediolanu. Współpracują między sobą w celu rozwinięcia wspólnej komunikacji publicznej, otwartych przestrzeni i usług, jako elementów większego procesu rozwoju terytorialnego, który wykraczał poza ich możliwości w czasach, gdy były one jedynie odrębnymi satelitami metropolii.

Obszar metropolitalny Mediolanu jest, jednym z wielu we Włoszech, przykładem układu funkcjonalnego, w którym bardzo trudno osiągnąć współpracę na poziomie ponadlokalnym. Biorąc pod uwagę rozdrobnienie instytucjonalne, a zwłaszcza zmagania w osiągnięciu consensusu w regionie Mediolanu, rząd krajowy powinien odegrać aktywną rolę, pomagając umocnić odpowiednie mechanizmy i przeznaczając odpowiednie środki finansowe na współdziałanie w obszarach metropolitalnych.

Mediolan potrzebuje przede wszystkim wizji przyszłego rozwoju i dopiero potem powinien szukać sposobu na jego realizację. Liczne inicjatywy realizowane $\mathrm{w}$ mieście nie są skoordynowane, a to znacznie zmniejsza ich skuteczność.

Ostra debata w latach 1980-1990 dowiodła, że Mediolan ma wyjątkowo aktywny i innowacyjny zasób społeczno-gospodarczych podmiotów (przedsiębiorców, związki zawodowe, nauczycieli akademickich i naukowców, organizacje pozarządowe itd.). Podmioty te są zdolne, podobnie jak eksperci i obywatele, którzy zdecydowali o kierunkach rozwoju metropolii w roku 1950, do współpracy i debaty nad pomysłami dotyczącymi przyszłości obszaru metropolitalnego. Brakuje tu jednak publicznego forum wymiany poglądów, w ramach którego mogłyby one współdziałać z decydentami na rzecz rozwoju całego terytorium [OECD 2006c, s. 142].

W związku z trudnościami w nawiązywaniu współpracy na szczeblu metropolitalnym, za obiecujący instrument stymulowania partnerstwa należy uznać plan zagospodarowania przestrzennego prowincji (PTCP), tym bardziej że obszar metropolitalny Mediolanu właściwie pokrywa się z jej obszarem.

Sprzeciw w rozwiązywaniu problemów metropolitalnych wymagających zmian instytucjonalnych, pojawia się również ze strony urzędujących władz, które obawiają się utraty swoich uprawnień na rzecz innych organów. Niepowodzenia we wdrożeniu reformy wynikają głównie z konfliktów, które mogą pojawiać się na następujących płaszczyznach: 
- między regionem i państwem - obawa regionów przed silnymi władzami metropolitalnymi i ingerencją państwa w określanie ich granic,

- między prowincjami i nowymi władzami metropolitalnymi - będący wynikiem wcześniejszych zarzutów o znaczą utratę uprawnień na rzecz nowego podmiotu,

- między mniejszymi gminami i nowymi władzami metropolitalnymi ze względu na obawy przed centralizacja władzy [Gualini 2003, s. 277].

W ciągu ostatniego dwudziestolecia we Włoszech podejmowano liczne próby osiągnięcia ściślejszej integracji obszarów metropolitalnych i jej utrzymania. Proces ten trwa $\mathrm{w}$ dalszym ciągu. Wspomniane wysiłki angażowały takie środki, jak reforma instytucjonalna, porozumienia instytucjonalne dotyczące bardziej lub mniej kluczowych problemów, działania promujące efektywną integrację w kategoriach zarówno zintegrowanego planowania jak i zarządzania. Jednak do tej pory żadne ważne zmiany nie zostały w żadnym z tych obszarów wprowadzone. Nadal nie powstało żadne miasto metropolitalne. Należy mieć nadzieję, iż obowiązek utworzenia takich miast z początkiem roku 2014 zmusi wreszcie różnych interesariuszy do współpracy na rzecz całego obszaru. W obecnej sytuacji niezmiernie istotna jest rola planowania przestrzennego, którego zapisy mogą dać początek zintegrowanemu środowisku metropolitalnemu. Plany zazwyczaj obowiązują dłużej niż dobra wola władz [Toniolo, Pugliese 2003, s. 252-262].

\section{Hiszpania}

Od roku 1987, po przejściu od dyktatury generała Franco do demokracji i przyjęciem konstytucji, Hiszpania jest krajem podzielonym na gminy (8109), prowincje (50) i wspólnoty autonomiczne. Największe jednostki terytorialne to 17 wspólnot autonomicznych (las Comunidades Autónomas), które cieszą się dużą samodzielnością. Na czele wspólnot autonomicznych stoi zgromadzenie wybierane $\mathrm{w}$ wyborach bezpośrednich systemem proporcjonalnym, pełniące funkcje ustawodawcze. Zgromadzenie wybiera prezydenta, którego zatwierdza król Hiszpanii.

Organem wykonawczym w regionie jest rząd regionalny, któremu przewodniczy prezydent regionu. Wspólnoty autonomiczne mogą wpływać na określanie i realizację kompetencji gmin i prowincji w zakresie zagospodarowania przestrzennego, urbanistyki, dróg, kanałów, rolnictwa, rozwoju ekonomicznego, turystyki, higieny, opieki społecznej, oświaty i kultury [Niziołek 2008, s. 179-180]. W niektórych wspólnotach działają również powiaty. Jednak ze względu na brak wsparcia finansowego w praktyce nie odgrywają one istotnej roli. 
Na czele prowincji stoi gubernator, który pełni funkcję organu wykonawczego państwa. W czasach dyktatury gen Franco jego pozycja była bardzo silna, natomiast wraz z demokratyzacją państwa uległa stopniowym ograniczeniom.

Wspólnoty autonomiczne mają bardzo silną pozycję, która wynika głównie z systemu finansowania poszczególnych poziomów administracji przez państwo oraz z rosnącej roli regionów w Unii Europejskiej (hiszpańskie wspólnoty autonomiczne odpowiadają regionom NUTS 2). Administracja regionalna zarządza ok. 34\% funduszy strukturalnych, natomiast władze lokalne zaledwie 7\%. Pozostałymi 59\% zarządza rząd centralny.

Gminy w Hiszpanii są bardzo rozdrobnione. Około 86\% miast liczy mniej niż 5000 mieszkańców. Wraz z wprowadzeniem demokracji uzyskały one polityczną autonomię, ale ich zasoby finansowe, przekazywane głównie przez rząd centralny, były niewystarczające do zapewnienia obowiązkowych świadczeń wprowadzonych ustawą z roku 1985. Z tego też względu państwo wspiera współpracę między gminami w formie związków gmin (mancomunidad) oraz współpracę wertykalną między gminami a innymi poziomami władzy i podmiotami pozarządowymi (consortia) [Parrado-Diez 2006, s. 6-8]. Mancomunidades mogą być tworzone na zasadzie dobrowolności przez gminy znajdujące się w jednej wspólnocie autonomicznej. Są organizacjami wielocelowymi, które świadczą różne usługi, w zależności od ich charakteru, dla wszystkich lub części gmin członkowskich. Najczęściej jest to gospodarka odpadami, zaopatrzenie w wodę, działalność kulturalna, ochrona przeciwpożarowa, usługi socjalne oraz promocja turystyczna i gospodarcza. Nie mogą jednak przejąć od gmin świadczenia wszystkich usług, gdyż w praktyce oznaczałoby to likwidację gmin. Konsorcja zwykle są organizacjami jednocelowymi. Najczęściej świadczą usługi w zakresie promocji gospodarczej i kulturalnej, straży pożarnej i dostarczania wody [Font, Gutierrez-Suarez, Parrado Diez 1999, s. 11].

Z prawnego punktu widzenia, władze wspólnoty mogą (ale nie muszą) powoływać podmioty do zarządzania istniejącymi sieciami zintegrowanych powiązań gospodarczych i społecznych między gminami w dużych aglomeracjach miejskich. W praktyce jednak rzadko korzystają $\mathrm{z}$ tej możliwości [Navarro 2006, s. 1].

W Hiszpanii przenoszenie władzy ze szczebla państwowego na regionalny jest bardzo zaawansowane, także $\mathrm{w}$ dziedzinie planowania przestrzennego i związanej z tym legislacji Według konstytucji Hiszpanii z roku 1978 i Statutu Katalońskiej Autonomii z roku 1979 kompetencje w zakresie planowania przestrzennego leżą w gestii wspólnot autonomicznych.

Kompetencje dotyczące planowania lokalnego/miejskiego umocowane są zarówno na poziomie lokalnym, jak i regionalnym. Władze regionalne odpowiadają za transport i koordynację zagospodarowania gruntów. Do ich 
kompetencji należy ostateczne zatwierdzanie planów miejscowych. Gminy mają prawo tworzenia szczegółowych planów zagospodarowania [OECD 2007c, s. 168].

\subsection{Barcelona}

W Katalonii są cztery prowincje, 41 powiatów i 946 gmin [AMB 2003, s. 28]. Jeśli chodzi o finansowanie gmin przez budżet centralny, to o ile w przypadku budżetu Katalonii ok. 68\% stanowią transfery od państwa, o tyle budżet gmin w większości tworzą podatki lokalne. W roku 1999 transfery z innych szczebli administracji do budżetu Barcelony wyniosły zaledwie 34\% całości dochodów, z czego $91 \%$ pochodziło z budżetu centralnego. Usługi w zakresie edukacji, kultury, opieki zdrowotnej, pomoc społeczna i infrastruktura oświatowa zarządzane są przez gminy, ale finansowane bezpośrednio i w szerokim zakresie nadzorowane przez rząd Katalonii [Garcia 2003, s. 340].

Podstawowymi subjednostkami metropolitalnymi, osadzonymi w prawie katalońskim, jest obszar metropolitalny i region metropolitalny. Delimitacja tych jednostek jest uwarunkowana kryteriami funkcjonalnymi i terytorialnymi.

Obszar Metropolitalny Barcelony (OMB) obejmuje 36 gmin, w których mieszka ponad 3,6 mln mieszkańców (50\% ludności Katalonii). Jego powierzchnia wynosi $636 \mathrm{~km}^{2}$. Gminy zlokalizowane w OMB od 60 lat mają wspólną organizację instytucjonalną, zarządzanie usługami, planowanie miast i działania na rzecz stworzenia oraz promowania międzygminnej solidarności [AMB 2003, s. 149].

Najbardziej wpływowym podmiotem metropolitalnym była Metropolitalna Korporacja Barcelony (CMB), skupiająca 27 gmin, która działała w latach 1974-1987. Do jej kompetencji należały planowanie przestrzenne, transport publiczny i gospodarka wodno-ściekowa. Negatywny wpływ na działalność CMB miały konflikty polityczne między socjalistycznymi władzami Barcelony i otaczającymi je gminami, w których dominowała partia komunistyczna oraz przedstawicielami obu partii lewicowych a narodową partią mającą przewagę w parlamencie Katalonii [Kaczmarek, Mikuła 2007, s. 103]. Ustawa o ustroju administracyjnym przyjęta przez parlament Katalonii w 1987 r. rozwiązała, z przyczyn politycznych ${ }^{62}$, korporację i zastąpiła ją dwiema organizacjami: Metropolitalną Agencją Ochrony Środowiska (Entitat Metropolitana del Medi Ambient - EMMA), obejmująca swym zasięgiem 33 gminy i Metropolitalnym Zarządem Transportu (Entitat Metropolitana del Transport - EMT), skupiającym 18 gmin. Równolegle do tych podmiotów w roku 198823 gminy zdecydowały się utworzyć na zasadach dobrowolności Stowarzyszenie Gmin Obszaru Metropolitalnego Barcelony

62 Więcej na ten temat: Garcia 2003. 
(Mancomunitat de Municipis de l'Area Metropolitana de Barcelona $M M A M B$ ) (rys. 13). Stowarzyszenie przejęło na siebie kompetencje, które nie zostały przejęte przez dwie pierwsze organizacje. Jego działania nakierowane były głównie na zarządzanie przestrzenią publiczną, ochronę środowiska naturalnego, promowanie budownictwa komunalnego i planowanie [AMB 2003, s. 172].

W tym samym czasie został utrzymany w mocy Generalny Plan Metropolitalny opracowany $\mathrm{w}$ roku 1976, jeszcze $\mathrm{w}$ czasach panowania reżimu Franco, dla 27 gmin, wchodzących w skład CMB. Fragmentacja i różnice w obszarach przyjętych za punkt odniesienia przez każdą z powyższych organizacji doprowadziły do przyjęcia nazwy "Obszar Metropolitalny" odnoszącej się do terytorium obejmującego 36 gmin, które są członkami jednego lub kilku z powyższych podmiotów bądź objęte są planem. Ten punkt odniesienia został utrzymany w Strategicznym Planie Metropolitalnym z roku 2003 [AMB 2003, s. 151].

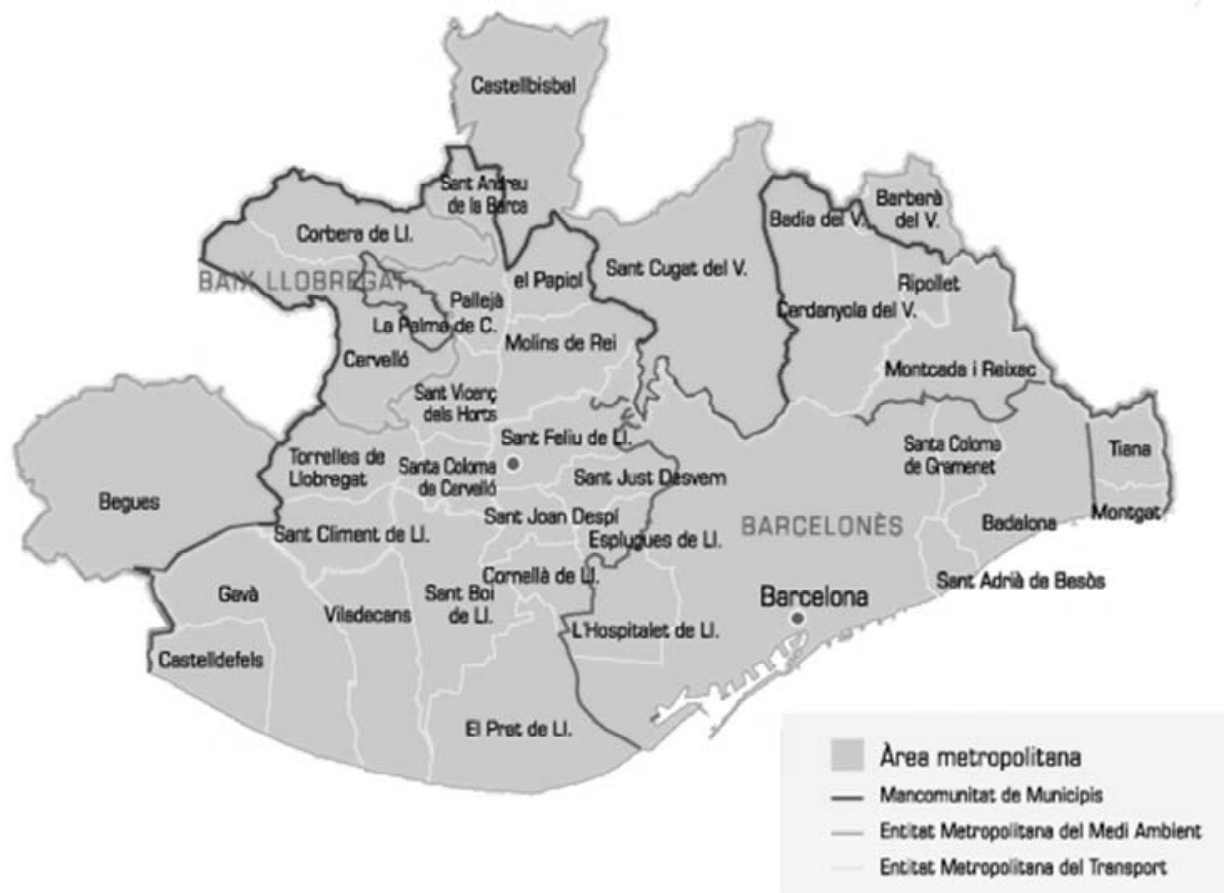

Rys. 13. Zasięg terytorialny organizacji metropolitalnych w Barcelonie Źródło:[http://www.xtec.cat/ jflorenz/comarca/rmb.htm]

Plan z roku 1976 był w pełni wdrażany od roku 1979, wraz z przywróceniem lokalnego szczebla zarządzania. Plan ten zakładał wprowadzenie nowego ładu przestrzennego poprzez stworzenie jasnych wytycznych dotyczących przestrzeni publicznych, a zwłaszcza systemów transportu 
i komunikacji. Zarezerwował również znaczące zasoby terenu pod obszary zielone i usługi zbiorowej konsumpcji. Plan przewidywał też, iż Barcelona będzie gościć międzynarodowe festiwale i wydarzenia, które będą generować bardzo potrzebne inwestycje w infrastrukturę, aby umożliwić wzrost gospodaczy. Wdrożenie planu ułatwiał fakt, że burmistrz Barcelony był jednocześnie prezydentem metropolitalnego rządu (CMB) [Garcia 2003, s. 345].

Proces planowania strategicznego $\mathrm{w}$ Barcelonie rozpoczął się $\mathrm{w}$ roku 1988, kiedy miasto otrzymało informację, że będzie gospodarzem Igrzysk Olimpijskich w roku. Powstało wówczas stowarzyszenie Strategiczny Metropolitalny Plan Barcelony (SMPB). Jest to prywatna organizacja non-profit, która obejmuje swoim zasięgiem 36 gmin. Została utworzona w celu tworzenia i promowania strategii mających wspierać rozwój gospodarczy i społeczny w OMB w oparty na inwestycjach zrealizowanych w związku z przygotowaniami do Igrzysk Olimpijskich. W jej skład wchodzi 300 reprezentantów sektora publicznego, biznesu i NGO, z burmistrzem Barcelony na czele. Wśród nich znajdują się:

- Rząd Katalonii,

- Rada Prowincji,

- Stowarzyszenie Gmin OMB,

- Izba Handlowa - inne instytucje otoczenia biznesu,

- Uniwersytet Barceloński i inne uczelnie,

- Targi międzynarodowe,

- Zarząd portu i lotniska,

- Metropolitalne agencje ds. transportu i środowiska [Pla... 2010, s. 14].

W pierwszym etapie (lata 1988-2001) prace stowarzyszenia koncentrowały się na obszarze Barcelony. Do jego głównych osiągnięć należy opracowanie trzech Planów Strategicznych dla Barcelony (1990, 1994 i 1999) oraz organizacja Igrzysk Olimpijskich w roku 1992. Około 1/3 inwestycji przeprowadzonych w związku z przygotowaniami do Olimpiady zrealizowały podmioty prywatne [Cahyadi, TenBrink 2004, s. 7]. Drugi etap prac, rozpoczęty w roku 2002, dotyczy już całego obszaru metropolitalnego. W roku 2003 przyjęto pierwszy strategiczny Plan Metropolitalny obejmujący swym zasięgiem 36 gmin. Plan ten zakladał ekonomiczne przekształcenie regionu w kierunku gospodarki opartej na przedsiębiorczości i nauce oraz zapewnienie zrównoważonego rozwoju. Nowy wizerunek Barcelony zakłada "bycie” miastem wiedzy w Europie. Strategia przewidywała przekształcenie obszaru metropolitalnego Barcelony w region, który byłby definiowany przez wysoki udziałał przemysłowych aktywności w sektorach wysokiej wiedzy, aby podtrzymać atrakcyjność Barcelony, w porównaniu z innymi obszarami metropolitalnymi w Europie, dla zagranicznych inwestorów [Cahyadi, TenBrink 2004, s. 15]. Plan został poddany weryfikacji w latach 2005-2007. W roku 2008 przyjęto nowy model rozwoju w Obszarze Metro- 
politalnym Barcelony, który zakłada, że główną ideą rozwoju ekonomicznego i społecznego OMB są:

- model koordynacyjno-partycypacyjny,

- zachowanie tożsamości i wspieranie różnorodności gmin,

- wspólna wizja rozwoju [http://www.pemb.cat/en/what-is-the-plan/ background-pemb/].

Aby sprostać wyzwaniom nowego tysiąclecia, Rada Miasta przyjęła w roku 1997 specjalne prawo - Komunalną Kartę Barcelony, która została też zatwierdzona przez Parlament Katalonii w 1999 r. i przez rząd Hiszpanii dopiero w 2006 r. Jednym z głównych celów Karty jest przezwyciężenie ograniczeń, jakie na zarządzanie dużymi miastami nałożyła Ustawa o samorzq̨dzie terytorialnym. Z jednej strony Karta domaga się takiej autonomii, aby zapewnić większą możliwość decydowania w kwestiach urbanistyki, infrastruktury, edukacji, usług socjalnych oraz kultury. Z drugiej strony, istotne jej postanowienia odnoszą się do systemu podatkowego (więcej dotacji państwowych, więcej podatków lokalnych). W odniesieniu do demokracji lokalnej Karta rozszerza instrumenty partycypacji społecznej, wzmacnia mechanizmy kontroli gospodarki komunalnej i umacnia podział funkcji między Radą Miejską i organami wykonawczymi [Tomas 2001, s. 23]. Nie porusza kwestii metropolitalnych, gdyż mogłoby to okazać się przeszkodą przy jej zatwierdzaniu przez wyższe szczeble, niemniej jednak stanowi dobrą podstawę do sformułowania w przyszłości Karty Metropolitalnej i instytucjonalizacji metropolitalnego współrządzenia.

W roku 2009 zostało utworzone Metropolitalne Konsorcjum Obszaru Metropolitalnego Barcelony (Consorci de l'Àrea Metropolitana de Barcelona) dobrowolne stowarzyszenie, które zastąpiło trzy podmioty metropolitalne i które miało przyczynić się do łatwiejszej realizacji Strategicznego Planu dla Barcelony poprzez stosowanie nowych instrumentów metropolitalnych [http://w3.bcn.es/V01/Serveis/Noticies/V01NoticiesLlistatNoticiesCtl/0,21 38,1653_35144087_3_1382332054,00.html?accio=detall\&home=HomeBCN\& nomtipusMCM=Noticia].

27 lipca 2010 r. Parlament Katalonii przyjął ustawę, na mocy której zinstytucjonalizowano władze metropolitalne, tworząc od 21 lipca $2011 \mathrm{r}$. Obszar Metropolitalny Barcelony (Àrea Metropolitana de Barcelona - AMB) [Llei de l'Àrea... 2010]. Tym samym zaakceptowana została nowa forma instytucjonalna obszaru, obejmująca swym zasięgiem 36 gmin. Konsorcjum zostało rozwiązane, a nowe organy władzy obejmują:

- organ uchwałodawczy - Radę Metropolitalną (Consell Metropolità), która liczy 89 radnych metropolitalnych. W jej skład wchodzą z urzędu 
wszyscy burmistrzowie gmin w obszarze metropolitalnym i radni wybierani przez gminy spośród swoich radnych ${ }^{63}$,

- prezydenta, powoływanego przez Radę Metropolitalną spośród jej członków, którzy są burmistrzami. Obecnie funkcję tę pełni burmistrz Barcelony,

- organ wykonawczy - Zarząd (Junta de Govern),

- Komisję Budżetową (Comissió Especial de Comptes) [Llei de l'Àrea... 2010, art. 4-12].

Ponadto funkcjonuje Càrrecs Directius - 17-osobowy zespół menedżerów, którzy są ekspertami w zakresie transportu i mobilności, środowiska, przestrzeni publicznej, planowania strategicznego, rozwoju miast itd. [http://www.amb.cat].

Nowy podmiot konsoliduje i upraszcza administrowanie obszarem metropolitalnym oraz zyskuje nowe kompetencje, zwłaszcza w zakresie planowania i urbanistyki. Ma opracować Generalny plan zagospodarowania metropolii (Pla director urbanístic metropolità) i plan szczegółowy (Pla d'ordenació urbanística metropolità), które mają zastąpić Generalny Plan Metropolitalny z roku 1976. Metropolitalny plan zagospodarowania miejskiego ma na celu:

- ustanowienie strukturalnych elementów urbanistycznych na terytorium metropolitalnym,

- przyjęcie ustaleń dotyczących zrównoważonego rozwoju obszarów miejskich, mobilności osób i towarów oraz transportu publicznego,

- określenie sposobów ochrony terenów niezurbanizowanych,

- wyznaczenie rezerwy gruntów dla systemów infrastruktury, sieci metropolitalnych, przestrzeni otwartych, itp.,

- określenie polityki metropolitalnej w zakresie gruntów i mieszkań, na które stać obywateli [Llei de l'Àrea... 2010, art. 13].

AMB ponosi również odpowiedzialność za promocję gospodarczą, spójność społeczną i infrastrukturę. Nowe kompetencje zostały dodane do kompetencji z zakresu spójności i równowagi terytorialnej, budownictwa, transportu i mobilności, gospodarki wodnej, gospodarki odpadami, ochrony środowiska, które podmioty metropolitalne miały już od roku 1987 [http://www.amb.cat].

Funkcjonowanie Obszaru Metropolitalnego Barcelony może być finansowane przede wszystkim ze składek gmin, opłat za świadczenie usług

${ }^{63}$ Barcelona ma dwudziestu pięciu członków Rady, gminy o liczbie ludności powyżej 100000 - czterech członków, gminy liczące 75 000-100 000 mieszkańców trzech członków, gminy liczące 20 000-75 000 mieszkańców - dwóch członków, miejscowości poniżej dwudziestu tysięcy mieszkańców - jednego czlonka. 
metropolitalnych, z dotacji państwa, własnych podatków i opłat oraz środków z Unii Europejskiej [Llei de l'Àrea... 2010, art. 40].

Planowanie przestrzenne w Barcelonie w latach 90. opierało się głównie na regeneracji terenów poprzemysłowych i włączało prywatnych deweloperów do programów budownictwa mieszkaniowego na takich samych zasadach, jakie obowiązywały przy budowie wioski olimpijskiej. Jednak realizacja planów pozostawała luźno powiązana z planami metropolitalnymi. To, raczej techniczne i architektoniczne, podejście stopniowo było zastępowane bardziej strategicznym trybem planowania. Ten nowy model, wypracowany w końcu XX w., można porównać do pewnego rodzaju korporacyjnego planowania urbanistycznego wokół jądra, utworzonego $\mathrm{w}$ celu ekonomicznego i konkurencyjnego rozwoju, któremu towarzyszą cele społeczne i środowiskowe. To przedsiębiorcze podejście było w dalszym ciągu rozwijane poprzez coraz częstsze korzystanie z doświadczeń sektora prywatnego i stosowanie form PPP, przy czerpaniu z doświadczeń w zakresie partnerstwa publiczno-prywatnego już funkcjonującego w trakcie olimpiady w roku 1992 [Clark, Huxley, Mountford 2010].

W listopadzie 2010 r. został przyjęty kolejny strategiczny Plan Metropolitalny - Wizja 2020 (PEMB 2020). Przyjęcie planu zbiegło się w czasie z uchwaleniem ustawy tworzącej Obszar Metropolitalny Barcelony, która do kompetencji OMB zaliczyła promowanie strategicznego metropolitalnego planu, który, z udziałem podmiotów ekonomicznych, społecznych i instytucjonalnych, będzie wspierać modernizację, badania i innowacje [http://www.pemb.cat/en/2020-vision/]. W pracach nad planem wzięło udział ponad 220 przedsiębiorców i ekspertów (menedżerów, naukowców, konsultantów, dziennikarzy i organizacji społecznych) pracujących w 17 różnych komisjach tematycznych. Nowa wizja planu zawiera następujące cele strategiczne:

- rozwój zrównoważony,

- umieszczenie Barcelony w globalnej sieci miast,

- stanie się liderem w branżach stymulujących rozwój (przemysły kreatywne, projektowanie i architektura, zdrowie, sport) oraz wzmocnienie marki i pozycji konkurencyjnej,

- uaktualnienie i wzmocnienie przemysłu i tradycyjnych sektorów,

- stanie się jednym z najbardziej atrakcyjnych regonów w Europie, przyciągającym innowacyjne talenty,

- bycie atrakcyjnym, społecznie zrównoważonym miejscem do życia [Pla ..., 2010, s. 30-44].

W poprzednich edycjach planu OMB zrealizowano projekty warte 22 mld euro. Oprócz obszaru metropolitalnego wyróżnia się jeszcze region metropolitalny Barcelony, który obejmuje 165 gmin, zamieszkiwanych przez ok. 4,5 mln ludzi. Obszar ten jest uznawany przez planistów, geografów i archi- 
tektów za obszar funkcjonalny od roku 1968 [CAEE 2010, s. 11]. Nie ma on instytucji nim zarządzającej, ale objęty jest Metropolitalnym Planem Zagospodarowania Przestrzennego, który 20 kwietnia 2010 r. został przyjęty przez rząd Katalonii.

System planowania regionalnego w Katalonii obejmuje generalny plan zagospodarowania przestrzennego całej wspólnoty, regionalne plany sektorowe i plany regionalne częściowe oraz (od roku 2002) kierunkowe plany miejskie [Redondo 2010].

Regionalne plany zagospodarowania przestrzennego muszą być zgodne z generalnym planem zagospodarowania i resztą planów regionalnych, z planami sektorowymi rządu (tworzonymi przez różne ministerstwa). Nie są obligatoryjne, lecz tylko wskazują przestrzenne warunki, które mają zapewnić, że przyszły rozwój będzie zachodził według oczekiwanego wzoru [Almirall 2009]. Obecnie takich planów jest siedem.

W roku 1995 został przyjęty Generalny Plan Zagospodarowania Przestrzennego Katalonii, który za odpowiedni poziom do planowania metropolitalnego uznał obszar 165 gmin, obejmujących obszar metropolitalny i siedem otaczających go powiatów. Tym samym rząd Katalonii przyjął, że region metropolitalny, który nie jest instytucjonalnie uprawomocniony, tworzy społeczno-gospodarczą i przestrzenną całość. Wdrożenie planu opiera się na częściowych planach terytorialnych tworzonych zgodnie z podziałem administracyjnym na powiaty [Garcia 2003, s. 349].

W roku 2008 został tymczasowo zatwierdzony Regionalny Plan Barcelony obejmujący terytorium 164 gmin, o łącznej powierzchni $3236 \mathrm{~km}^{2}$. W 2009 r. poddany został pod konsultacje społeczne, a następnie zatwierdzony w kwietniu roku 2010 http://territori.scot.cat/cat/notices/ 2010/12/ pla_territorial_parcial_de_la_regio_metropolitana_de_barcelona_2634.php].

Największym osiągnięciem rządu Katalonii w zakresie koordynacji zarządzania regionem metropolitalnym było utworzenie w roku 1997 Zarządu Transportu Metropolitalnego (MTA), który obejmuje 253 gminy w tzw. wielkim obszarze metropolitalnym [CAEE 2010, s. 7]. Jest to konsorcjum utworzone przez podmioty administracji publicznej, które są właścicielami usług transportu publicznego - Rada Miasta Barcelony, Rada OMB, rząd Katalonii, AMTU (Związek Gmin na rzecz Transportu) oraz rząd centralny. Za zadanie ma koordynację i integrację infrastruktury, usług i opłat za transport publiczny [http://www.atm.cat].

W przypadku Barcelony planowanie strategiczne w miarę upływu lat stopniowo poszerzało swój zasięg i rozprzestrzeniało się poza granice samego miasta. Przedsiębiorcze podejście zmusiło decydentów do tworzenia coraz bardziej kompleksowych planów. Strategiczne plany dla Barcelony są traktowane jako sukces ze względu na stworzenie kultury osiągania consensusu oraz z uwagi na fakt, że stanowiły one siłę napędową dla wdro- 
żenia szczegółowych projektów, a tym samym stały się wzorcem dla innych powiatów [OECD 2007a, s. 107]. Wprowadzona od roku 1988 strategia rozwoju połączyła publiczne i prywatne organizacje przy realizacji wspólnej wizji i działań na rzecz transformacji miasta. Jednym z ważniejszych bodźców była organizacja Igrzysk Olimpijskich w roku 1992. Organizacja tej imprezy pomogła Barcelonie zyskać wymiar globalny, podniosła prestiż miasta w oczach świata i wzbudziła mowy entuzjazm dla realizacji planu transformacji wśród jej mieszkańców [Maik 2005, s. 29]. W praktyce wszystkie siedem powiatów sąsiadujących z OMB, zaliczanych do Regionu Metropolitalnego, opracowało plany strategiczne, chociaż było to głównie inicjatywą głównych miast, a nie rady powiatu [Garcia 2003, s. 352].

$\mathrm{Z}$ drugiej strony zarządzanie obszarem metropolitalnym Barcelony utrudnia duża liczba poziomów zarządzania (gminy, związki międzygminne, konsorcja, powiaty, władze metropolitalne, prowincje, wspólnota autonomiczna i państwo), co często prowadzi do dysfunkcyjności i braku koordynacji oraz utrudnia podejmowanie decyzji.

\subsection{Madryt}

Obszar Metropolitalny Madrytu utożsamiany jest z obszarem Wspólnoty Madrytu (Autonomus Community of Madrid - CAM), chociaż pod względem powiązań funkcjonalnych, zwłaszcza komunikacyjnych, jest on bardziej rozległy. Z uwagi jednak na brak jednoznacznych delimitacji wiele analiz dotyczących metropolii Madrytu koncentruje się na terytorium wspólnoty [Tomas 2002]. Ludność obszaru metropolitalnego wynosi około 6,5 $\mathrm{mln}$, co powoduje, że jest on najgęściej zaludnionym regionem miejskim Hiszpanii) [OECD 2007c, s. 31]. Wspólnota Madrytu została utworzona w roku 1982 jako ostatnia ze wspólnot autonomicznych w Hiszpanii i objęła terytorium jednej prowincji, ponieważ inne prowincje, będące częścią historycznego regionu Kastylii, odmówiły wejścia w jej skład. Wspólnota Madrytu, oprócz Madrytu - miasta centralnego, obejmuje 178 gmin [http://www.madrid.org /iestadis/fijas/basicos/dguide.htm].

W przypadku Madrytu mamy do czynienia z jeszcze jednym poziomem zarządzania - dystryktami. W ramach dalszej decentralizacji terytorialnej Madryt został podzielony na 21 dystryktów. Pełnią one funkcje administracyjne przekazane przez burmistrza w dziedzinach: przemieszczania ludności i transportu, robót publicznych, miejskich parków, środowiska, licencji i zezwoleń, urbanistyki, ochrony zdrowia i konsumpcji, handlu, usług społecznych, kultury, edukacji, polityki młodzieżowej, bezpieczeństwa, sankcji administracyjnych i ślubów. Zarządzają około 15\% budżetu Madrytu. Na czele dystryktu stoi Rada Zarządzająca (Junta Municipal del Distrito) złożona z radnych - wyznaczonych proporcjonalnie do politycznej reprezentacji w Radzie Miasta - oraz przedstawicieli społeczeństwa mianowanych przez 
burmistrza na wniosek grup politycznych reprezentowanych w Radzie Miasta. Przewodniczący dystryktu nie jest wybierany przez ludność, lecz mianowany przez burmistrza spośród radnych Rady Miasta.

W praktyce rolę władz metropolitalnych pełni Wspólnota Madrytu. Organem władzy jest zgromadzenie, którego członkowie (120) są wybierani w wyborach bezpośrednich. Na czele wspólnoty stoi prezydent wybierany przez zgromadzenie. Oprócz tego funkcjonuje organ wykonawczy składający się $\mathrm{z}$ prezydenta, jego zastępcy oraz dziewięciu doradców [http:// www.madrid.org/cs/Satellite?pagename=ComunidadMadrid/Home]. Wspólnota zyskała szerokie uprawnienia. Tworzy swoje własne prawo dotyczące użytkowania gruntów oraz rozwoju regionalnego i sporządza strategiczny plan regionalny w celu koordynacji wszystkich planów miejscowych. Zapisy planu są wiążące dla wszelkich działań planistycznych. Stanowią punkt odniesienia dla pozostałych polityk sektorowych (mieszkalnictwo, ochrona środowiska, transport, działalność produkcyjna, itd.), ale jego działanie jest ograniczone do koordynacji i harmonizacji przedsięwzięć publicznych podmiotów [Franchini, Valverde 2004, s. 1].

Wzajemne oddziaływanie między szczeblem regionalnym i lokalnym w dużej mierze sprowadza się do zatwierdzania lub odrzucania propozycji zagospodarowania gruntów przedstawionych przez gminy. Brakuje natomiast wytycznych formułowanych na szczeblu regionalnym, które powinny zostać uwzględnione przez gminy podczas tworzenia planów zagospodarowania przestrzennego [OECD 2007c, s. 177].

Gminy opracowują dwa rodzaje planów: plany generalne (Plan General de Ordenación Urbana - PGOU), które zawierają ogólne wytyczne w zakresie planowania zagospodarowania gruntów oraz obowiązujące plany szczegółowe (plan parcial), które stanowią podstawę do kontrolowania rozwoju przestrzennego [Allmendinger, Ball 2006, s. 25]. PGOU jest najważniejszym instrumentem planistycznym, który określa, w jaki sposób miasto będzie się rozwijać w perspektywie dziesięcioletniej. Ostatecznego zatwierdzenia planu dokonują władze regionalne.

W celu przezwyciężenia problemów, jakie przez lata powodował z jednej strony brak planowania przestrzennego na szczeblu regionalnym, a z drugiej brak partycypacji aktorów lokalnych w procesie regionalnego planowania rozwoju, w czerwcu roku 1996 władze CAM przyjęły Regionalny Plan Strategii Przestrzennej (PRET), który zawiera wytyczne dla planowania przestrzennego na następne 20 lat. $\mathrm{W}$ planie tym zastosowano innowacyjne narzędzia zarządzania, które miały zapewnić włączenie wszystkich aktorów zarówno publicznych, jak i prywatnych, w celu osiągnięcia wypracowanego w planie modelu przestrzennego.

Regulacje dotyczące kompetencji trzech szczebli władzy w Hiszpanii zostawiają w gestii rad miejskich efektywne przełożenie propozycji zawartych 
w PRET na ich terytorium. Władze lokalne odgrywają tu kluczową rolę ze względu na fakt, iż są w pełni samodzielne w definiowaniu rozwoju swojej jednostki i plan miejscowy jest jedynym instrumentem umożliwiającym efektywną realizację działań mających wpływ na prawa własności poprzez specyficzne techniki i mechanizmy administracyjne (w szczególności klasyfikacje i kwalifikacje obszarów oraz przenoszenie korzyści miejskich).

Pierwsze cztery lata (1997-2000) zarządzania planem zostały poświęcone na osiągnięcie consensusu między trzema konkurencyjnymi poziomami władzy (krajowym, regionalnym i lokalnym), a w szczególności między radami gmin. Przeniesienie zapisów regionalnych na obszar gmin wymagało bowiem rewizji ówczesnych planów gminnych w celu ich uaktualnienia. Aby przyśpieszyć ten proces rozpoczęto specjalne negocjacje, które zakończyły się podpisaniem licznych protokołów między administracją regionalną i władzami lokalnymi.

W wyniku realizacji ustaleń zawartych w protokołach w ciągu czterech pierwszych lat istotna część planów miejscowych została zatwierdzona. Zapisy planów uwzględniły wytyczne zapisane w PRET, dotyczące głównie rezerwacji gruntów pod lokalizację urządzeń metropolitalnych [Gonzalez 2008, s. 452]. Niestety, od roku 2001 proces porozumień uległ pewnemu ograniczeniu ze względu na jednoczesne zmiany w obszarach podlegających planowaniu regionalnemu oraz $\mathrm{w}$ związku $\mathrm{z}$ nowym prawodawstwem dotyczącym zarządzania gruntami w CAM. Spowodowało to ograniczenie działań planistycznych z uwagi na czas, który był potrzebny do zapoznania się z nowymi uregulowaniami.

Do zaobserwowanych sukcesów podjętych działań należy jednak zaliczyć:

- wykorzystane metody pracy, które do tradycyjnego stylu administrowania dołączyły takie techniki, jak wykorzystanie nowego, bardziej zrozumiałego, języka w opracowaniach; stworzenie przez uznanych ekspertów opracowań monograficznych, które scaliły różne strategie; sposób dokumentacji graficznej i tekstowej; rozpowszechnienie idei PRET wśród całej społeczności CAM,

- efektywność administrowania - podpisanie protokołów okazało się efektywnym narzędziem ułatwiającym przeniesie wytycznych z PRET na konkretne obszary poprzez plany miejscowe,

- stworzenie rezerwy gruntów pod przyszły system transportowy, co w przyszłości pozwoli uniknąć straty czasu na uzyskanie takich obszarów,

- decentralizację planowania - promowanie małych i średnich miast miast [Banachowicz, Danielewicz 2006, s. 44-45].

PRET szczególne wsparcie przewidywał dla miejscowości leżących w odległości powyżej $30 \mathrm{~km}$ od Madrytu. Te małe miejscowości zostały zapisane jako miejsca absorbujące rozwój miejski generowany przez miasto centralne a zarazem leżące $\mathrm{w}$ jego bezpośrednim sąsiedztwie i silnie zintegrowane 
z Madrytem. Ich znaczenie dla całego obszaru ma wzrosnąć dzięki lokalizacji w nich mieszkań, na które będzie stać obywateli; terenów pod działalność produkcyjną oraz poprzez stworzenie szybkiego systemu komunikacji, a więc czynników, które wspomogą lokowanie nowych populacji i inwestycji w zewnętrznym kręgu obszaru [Franchini, Valverde 2004, s. 1-5].

Władze regionalne, $w$ ramach swoich kompetencji, kontynuowały działania konsolidujące cały region również z wykorzystaniem innych programów, jak np. budowa dróg, linii kolejowych i metra.

W większości obszarów metropolitalnych jedną z kluczowych kwestii, której rozwiązanie wymaga wdrożenia zasad metropolitalnego zarządzania, jest zintegrowany transport publiczny. Za transport w Obszarze Metropolitalnym Madrytu odpowiada Publiczne Konsorcjum Transportowe (Consorcio Regional de Transportes de Madrid - CRTM) utworzone w 1986 r. i podlegające władzy regionalnej [http://www.ctm-madrid.es/servlet/Cambiar Idioma?xh_TIPO=1]. Na jego czele stoi prezydent pochodzący z regionu, natomiast wiceprezydent wywodzi się z Madrytu. Zarząd CRTM składa się $\mathrm{z}$ pięciu przedstawicieli Madrytu, pięciu przedstawicieli regionu, trzech przedstawicieli innych gmin ze wspólnoty, dwóch reprezentantów rządu centralnego, dwóch osób reprezentujących stowarzyszenia prywatnych operatorów, dwóch przedstawicieli związków zawodowych i jednego reprezentanta stowarzyszenia użytkowników [OECD 2006b, s. 153]. Pozycja Madrytu w konsorcjum jest więc relatywnie silna. Do głównych zadań konsorcjum należy:

- planowanie i koordynacja infrastruktury transportu publicznego,

- integracja systemu opłat,

- kontrola jakości świadczonych usług oraz analiza trendów mobilności.

Dużym sukcesem było wprowadzenie zintegrowanego systemu opłat, który wpłynął na wzrost wykorzystania transportu publicznego w obszarze metropolitalnym [OECD 2007c, s. 170]. Za wzór we wdrażaniu metropolitan governance można postawić też wspólne działania konsorcjum z prywatnymi firmami, polegające na współfinansowaniu obiektów transportu publicznego (np. budowa nowej stacji metra w pobliżu dzielnicy przemysłowej) [OECD 2007c, s. 172].

Kluczowym czynnikiem sukcesu w przypadku Konsorcjum Transportu była jego silna autonomia, wynikająca za świadomości politycznych udziałowców, że bardzo ważne jest przekazanie opracowania i wdrożenia projektu podmiotowi technicznemu.

Za planowanie rozwoju na poziomie metropolitalnym odpowiedzialny jest Instytut ds. Rozwoju (IMADE), który jest częścią Wydziału ds. Rozwoju Gospodarczego i Innowacji Madrytu. IMADE przyjął korporacyjne podejście do polityki rozwoju w regionie Madrytu, próbując włączyć w prace nad planem związki zawodowe i główne organizacje biznesowe. Filarami korpo- 
racyjnego, skoncentrowanego na poziomie regionalnym systemu, są Izba Handlowa Madrytu, lokalny związek przemysłowy i dwa największe związki zawodowe. Organizacje te są formalnie reprezentowane w głównych agencjach i konsultują działania rządu regionalnego. Ta sieć relacji pomiędzy Madrytem, związkami zawodowymi oraz organizacjami pracodawców, stworzyła solidną podstawę do trwałych ram polityki metropolitalnej [OECD 2007c, s. 222].

Główne obszary działalności Instytutu to rozwój nauki i technologii, stworzenie platformy logistycznej dla obszaru metropolitalnego i zapewnienie gruntów oraz infrastruktury dla parków biznesowych. W ramach pierwszego obszaru Instytut koordynuje realizację parków naukowotechnologicznych, które mają stymulować rozwój sektora średnich i wysokich technologii. Możliwe to będzie dzięki poprawieniu powiązań między zainteresowanymi podmiotami w regionalnym systemie innowacji, a zwłaszcza wśród różnych poziomów władzy (krajowego, regionalnego i lokalnego), między uniwersytetami i sektorem prywatnym czy wreszcie między systemem innowacji w Madrycie a niektórymi międzynarodowymi podmiotami (międzynarodowe firmy, międzynarodowi naukowcy itp.). W obszarze logistyki IMADE, wspólnie z Madrid Emprende (agencja rozwoju - organ samorządu Madrytu), w partnerstwie z konfederacją pracodawców, porta$\mathrm{mi}$, gminą Coslada, firmami logistycznymi, realizuje projekt pod nazwą Madrid Plataforma Logística, który obejmuje serie przedsięwzięć typu suchy port - łączący Madryt z głównymi portami Hiszpanii czy Zintegrowane Centrum Transportu [OECD 2007c, s. 179].

Możliwości nawiązywania współpracy z innymi poziomami władzy dają Madrytowi dwie ustawy: Prawo dla Dużych Miast oraz Ustawa o Statusie Stolicy i Specjalnym Ustroju Madrytu. Pierwsza z nich wprowadza nowy wewnętrzny układ, w ramach którego kompetencje i siła organów wykonawczych zostają wzmocnione. Druga ustawa poszerza istniejące kompetencje i przewiduje decentralizację kilku funkcji z poziomu centralnego i regionalnego na szczebel miasta, takich jak mobilność obywateli, bezpieczeństwo publiczne i infrastruktura. Ustawa reguluje również ważne aspekty dotyczące stosunków między jednostkami administracji państwowej, regionalnej i Madrytu, a także politycznej i administracyjnej organizacji miasta [OECD 2007c, s. 220]. W szczególności dotyczy współpracy pionowej i wspólnego podejmowania decyzji w przypadku wielkich inwestycji infrastrukturalnych. Dla osiągnięcia tych celów została utworzona międzyrządowa komisja (Comisión Interadministrativa de Capitalidad), zrzeszająca przedstawicieli państwa, Wspólnoty Madrytu i miasta Madryt. Odpowiada ona za kwestie związane ze statusem Madrytu jako stolicy, a zwłaszcza za kwestie bezpieczeństwa. Ustawa przewiduje także udział władz lokalnych w zarządzaniu infrastrukturą państwową, taką jak lotnisko czy przewozy 
kolejowe. Jednak za przekazaniem kompetencji nie podąża przekazanie odpowiednich środków finansowych [OECD 2007c, s. 221].

Ponieważ rząd regionalny stanowi w przypadku Madrytu właściwie rząd metropolitalny, mamy do czynienia z jasnym zdefiniowaniem kompetencji, łatwymi do zidentyfikowania instytucjami, władzami wybranymi w bezpośrednich wyborach, reprezentującymi społeczeństwo, pracownikami samorządowymi, którzy odpowiadają za wdrożenie nowych polityk, i odpowiednim budżetem. Wszystkie te elementy tworzą solidne podstawy systemu, który ma istotny potencjał w zarządzaniu obszarem metropolitalnym [Navarro 2011, s. 8]. Należy również wziąć pod uwagę fakt, że gminy hiszpańskie formalnie cieszą się szeroką autonomią, w praktyce jednak nie dysponują wystarczającymi zasobami finansowymi, aby zarządzać lokalnymi potrzebami 64 .

Fakt, że obszar metropolitalny Madrytu pokrywa się z jurysdykcją szczebla regionalnego ma szczególnie istotne znaczenie ze względu na pozycję Madrytu. Gmina miejska Madryt jest silnym podmiotem, z wystarczającymi zasobami i kompetencjami do zarządzania swoim regionem miejskim [Maldonado 2003, s. 360]. Mocnymi stronami posiadania rządu regionalnego, który funkcjonuje jak rząd metropolitalny, są jego jasne kompetencje, możliwe do zidentyfikowania instytucje odpowiadające za sprawy metropolitalne, odpowiedzialni, bezpośrednio wybierani politycy i odpowiedni budżet [Navarro 2006, s. 10]. Nie bez znaczenia jest też fakt, że na czele Wspólnoty Madrytu, rządu centralnego oraz większości gmin stoi ta sama partia polityczna [Tomas 2002, s. 8]. Władze wspólnoty, nie będąc rządem metropolitalnym, przyjęły na siebie rolę lidera w stymulowaniu rozwoju całego obszaru metropolitalnego, wprowadzając typowe dla governance elementy, takie jak partnerstwo publiczno-prywatne. Dzięki PPP sfinansowano główne projekty infrastrukturalne $\mathrm{w}$ regionie. Poza tym udało się osiągnąć consensus między wszystkimi aktorami - zarówno gospodarczymi (przedsiębiorstwa, związki zawodowe, organizacje pracodawców), społecznymi (wszelkiego rodzaju stowarzyszenia), finansowymi (banki), jak i politycznymi (partie polityczne i władze wszystkich gmin). Wszystkie te podmioty udało się zjednoczyć wokół funkcjonalnych polityk. Rząd regionalny odegrał rolę ułatwiającego działania lidera, ponieważ wspierał wspólne interesy wszystkich podmiotów i wybrał model rozwoju, który umożliwia osiągnięcie równowagi terytorialnej. Regionalne i lokalne władze wykazały wysoki poziom strategicznego przywództwa, kluczowy dla zapewnienia dobrego współrządzenia. Wspólnie z innymi aktorami promowały ważne dla obszaru projekty i rozwinęły marketing miejski. Przykładem takiego

64 Ta sytuacja nie dotyczy Madrytu, którego funkcjonowanie reguluje oddzielna ustawa. 
strategicznego projektu była kandydatura Madrytu do organizowania Olimpiady w roku 2012 [Tomas 2002, s. 8].

Do głównych efektów istnienia zinstytucjonalizowanej władzy w obszarze metropolitalnym należy:

- funkcjonowanie efektywnego systemu transportu publicznego,

- utworzenie równomiernej sieci placówek opieki zdrowotnej oraz usług edukacyjnych w całym obszarze metropolitalnym,

- wspólne planowanie przestrzenne i miejskie w całym obszarze,

- wspólne świadczenie usług z zakresu dostaw i uzdatniania wody [Navarro 2006, s. 10].

Sam proces planowania i ponadgminnego rozwoju zadziałał jako mechanizm metropolitalnego współrządzenia, gdyż służy do dyskusji, uczestnictwa i konsultacji między różnymi organami administracji, ale także między publicznymi i prywatnymi przedsiębiorstwami, partnerami społecznymi, społeczeństwem obywatelskim, itd., pozwalając na wspólne myślenie i podejmowanie decyzji w kwestii gruntów.

Natomiast największym problemem w zarządzaniu obszarem metropolitalnym Madrytu jest jego silna pozycja jako stolicy, co prowadzi do napięć między władzami miasta i wspólnoty. Sytuacji tej nie łagodzi nawet fakt, że od lat władze obu podmiotów pochodzą z tej samej partii politycznej [Walliser, Callejo 2004, s. 280].

Słabością zarządzania na poziomie metropolitalnym Madrytu jest również bardzo ograniczone uczestnictwo $w$ tym procesie innych interesariuszy zarówno publicznych (gminy w obszarze metropolitalnym), jak i społecznych (organizacje społeczeństwa obywatelskiego, grupy interesu, NGOs) [Navarro 2011, s. 9].

Mimo że Hiszpania jest krajem, w którym przeprowadzono reformy prowadzące do zwiększenia autonomii na niższych szczeblach władzy, to system administracji publicznej $\mathrm{w}$ dalszym ciągu charakteryzuje się silną centralizacją będącą dziedzictwem po reżimie generała Franco. Wprowadzenie zasady autonomii w roku 1978 nie zwiększyło samodzielności gmin, lecz jedynie spowodowało zmianę podmiotu sprawującego nad nimi kontrolę z władzy państwowej na władze regionalne.

Warunkiem sukcesu w zarządzaniu obszarem metropolitalnym jest odpolitycznienie i profesjonalizm struktur zarządzających. Przykładem potwierdzającym skuteczność takich rozwiązań jest przekazanie odpowiedzialności za organizację transportu konsorcjum, które utworzyło efektywny system transportu publicznego $\mathrm{w}$ całym obszarze metropolitalnym Madrytu. 


\section{Wielka Brytania}

W Wielkiej Brytanii funkcjonuje model samorządu składający się z:

- hrabstw (counties),

- dystryktów (okręgów),

- parafii/gmin (parish).

Ponadto funkcjonują unithary authorities - jednostki samorządowe wykonujące jednocześnie zadania dystryktów i jednostek wyższego szczebla hrabstw.

Odrębna jest organizacja samorządowa Londynu. Dzieli się on na City of London oraz 32 dzielnice londyńskie (London boroughs). Władzę wykonawczą sprawowała Rada Hrabstwa Londynu, która była wspomagana przez rady dzielnicowe [Lasocka 2005, s. 42-43]. W strukturze administracyjnej Londynu nie występują gminy.

Samorządy terytorialne w Anglii nie stosują jednolitej struktury podziału. Różne regiony dzielą się w odmienny sposób. Londyn podzielony jest na dzielnice, inne regiony zaś na hrabstwa lub jednostki administracyjne (władze jednolite).

Od roku 1965 w Wielkiej Brytanii funkcjonowała władza metropolitalna w postaci powiatów metropolitalnych (metropolitan county councils - MCC), które zostały utworzone w siedmiu obszarach metropolitalnych przez rząd centralny $w$ ramach szerokiej reformy władz lokalnych [Norris 2001b, s. 536]. Powiaty metropolitalne rozwiązano w roku 1986 przez rząd konserwatystów [Saltzstein et al. 2008, s. 177]. Powodem tej decyzji były przede wszystkim napięcia polityczne między władzami Wielkiego Londynu i innych wielkich miast, w których przewagę miała Partia Pracy, a nowym rządem centralnym zdominowanym przez konserwatystów. Ich ofiarą padły wszystkie powiaty metropolitalne. Podczas stosunkowo krótkiego czasu swego istnienia realizowały szereg funkcji i świadczyły usługi publiczne w zakresie działań policji, ochrony przeciwpożarowej, transportu publicznego i ochrony konsumentów. Odpowiadały również, wspólnie z okręgami, za budowę dróg, utrzymanie i kontrolę ruchu. Dzieliły z okręgami kompetencje $w$ zakresie planowania przestrzennego. Po rozwiązaniu powiatów, ich funkcje przejęły istniejące na dawnym terytorium powiatu rady dystryktów lub utworzone ad-hoc struktury dla ograniczonej liczby usług. MCC nigdy nie zostały w pełni zaakceptowane przez Rady Dystryktów Metropolitalnych (Metropolitan District Council - MDC), ze względu na konieczność dzielenia się kompetencjami.

W roku 1994 rząd centralny utworzył Biura Rządowe dla Regionów, które miały polepszyć koordynację polityki regionalnej między różnymi ministerstwami, które mogły być włączone w sprawy regionalne. W każdym z dziewięciu biur byli przedstawiciele odpowiednich ministerstw. W $1997 \mathrm{r}$. 
powstały również Agencje Rozwoju Regionalnego. Miały one złagodzić problem fragmentacji instytucjonalnej na poziomie regionalnym oraz uczynić regiony bardziej konkurencyjnymi na arenie globalnej. Były nadzorowane przez zgromadzenia regionalne złożone $\mathrm{z}$ przedstawicieli władz lokalnych, biznesu i organizacji społecznych z regionu. Posiadały również regionalne rady planowania [Thornley 2003, s. 46].

Rząd centralny odgrywał rolę dominującą w planowaniu regionalnym, gdyż sporządzał krajowe i regionalne (w związku z brakiem władz regionalnych) wytyczne planistyczne (planning policy guidance notes), które były wiążące dla niższych szczebli władzy przy tworzeniu własnych planów i strategii. Doprecyzowują one zasady tworzenia i zawartość lokalnych dokumentów planistycznych oraz regionalnych strategii przestrzennych, ale też określają politykę rządu w wielu dziedzinach, np. w sprawie mieszkalnictwa, planowania centrów miejskich, tzw. Green Belts, oraz zabezpieczenia przed powodzią [Zajączkowska 2011, s. 28].

Wytyczne te, wydawane na podstawie ustawy Town and Country Planning Act z roku 1990, są zastępowane deklaracjami polityki planistycznej (planning policy statements - PPS), wydawanymi na podstawie ustawy z roku 200465.

\subsection{Władze Wielkiego Londynu}

Region Londynu, definiowany powiązaniami funkcjonalnymi mierzonymi dojazdami do pracy, obejmuje obszar o promieniu $60 \mathrm{~km}$ od centrum miasta zamieszkiwany przez ok. 19 mln ludzi. Dla tak zdefiniowanego obszaru nie istnieje instytucja zarządzająca jego zintegrowanym rozwojem. Natomiast rdzeń regionu, położony wewnątrz pasa zieleni, zwany Wielkim

65 Obecny system planowania przestrzennego w Wielkiej Brytanii bazuje na ustawie z roku 2004 (Planning and Compulsory Purchase Act - PCPA), która wprowadziła również regionalne strategie przestrzenne oraz lokalne ramy zagospodarowania przestrzennego (Local Development Framework - LDF). Strategie regionalne sporządzane są przez regionalne ciała planistyczne (nie będące władzą publiczną), a następnie zatwierdzane przez rząd centralny. Na poziomie lokalnym funkcjonują lokalne władze planistyczne, które sporządzają plany zagospodarowania dla całej jednostki administracyjnej. Plan obejmuje ogólną strategię i polityki rozwoju przestrzennego oraz konkretne propozycje rozwoju przestrzennego dla wyróżnionych aspektów zagospodarowania całości obszaru (np. centra handlowe) lub dla wyróżnionych terenów przewidywanego rozwoju przestrzennego, a także ustalenie obszarów chronionych przyrodniczo i urbanistycznie. LDF są zestawem polityk, propozycji i innych dokumentów dotyczących zagospodarowania terenu i planowania przestrzennego, przygotowywanych przy udziale lokalnej społeczności, które odzwierciedlają jej faktyczne poglądy i oczekiwania. Więcej zob.: Planning... 2004; Zajączkowska 2011; Izdebski, Nelicki, Zachariasz 2007; http://www.planninghelp.org.uk/planning-system/local-development-frameworks. 
Londynem, o populacji sięgającej ośmiu mln mieszkańców (2009 r.) taką instytucją dysponuje.

Współpraca metropolitalna w obszarze wielkiego Londynu przyjęła formę zinstytucjonalizowaną $\mathrm{w}$ roku 1888, gdy została utworzona nowa forma władzy: Rada Hrabstwa Londynu (London County Council - LCC) obejmująca cały ówczesny obszar zurbanizowany (z wyłączeniem dzielnicy finansowej City). W związku z rozrastaniem się Londynu i niedopasowaniem struktur zarządzania do struktury funkcjonalnej metropolii w roku 1965, utworzono Radę Wielkiego Londynu (Greater London Council - GLC). Stworzyło to dwuszczeblowy system władzy, gdyż GLC dzieliła swoje uprawnienia z Korporacją City of London, zarządzającą City oraz 32 radami dzielnic londyńskich [Rhodes 1970]. Zgromadzenie Wielkiego Londynu składało się ze 100 przedstawicieli wybieranych w wyborach bezpośrednich. Rada wykonywała zadania $\mathrm{w}$ zakresie planowania przestrzennego oraz infrastruktury metropolitalnej, policji, straży pożarnej i gospodarki odpadami [Gawłowski 2010, s. 112]. Po zniesieniu w roku 1986 Rady Wielkiego Londynu jej funkcje przejęły: korporacja i rady dzielnic oraz wspólne zarządy (policja, zaopatrzenie w wodę, transport publiczny), a także rząd centralny (administrowanie szpitalami, dostawa gazu i elektryczności). Londyn był bezpośrednio administrowany przez ministra do spraw Londynu. Został też utworzony komitet, który miał za zadanie opracowanie wytycznych do planowania strategicznego, ale jego rola była raczej symboliczna. Nowe rozwiązania wykazywały brak koordynacji na poziomie metropolitalnym. W praktyce strategiczne planowanie zostało wznowione w roku 1997 wraz ze zmianą władzy (wybór Toniego Blaira na premiera).

Rząd Partii Pracy zaproponował w roku 1999 utworzenie nowych władz lokalnych Wielkiego Londynu: Greater London Authority (GLA), o podobnym zakresie działań jak wcześniejsza Rada Wielkiego Londynu (Greater London Council - GLC). GLA powstały 3 lipca 2000 r. i od tego momentu Wielki Londyn jest zinstytucjonalizowanym obszarem metropolitalnym [Thornley 2003, s. 55]. Ma silną strukturę opartą na czterech głównych elementach: bezpośrednio wybieranym burmistrzu, oddzielnie wybieranym Zgromadzeniu (London Assembly), pełnoetatowych urzędnikach funkcjonujących pod nadzorem dyrektora naczelnego oraz administracyjnych i funkcjonalnych agencjach (odpowiedzialnych za transport, odnowę gospodarczą, planowanie strategiczne i usługi nadzwyczajne [emergency]). W skład zgromadzenia, które jest ciałem kontrolnym i uchwałodawczym, wchodzi 25 członków. Czternastu radnych wybieranych jest w jenomandatowych okregach wyborczych, a pozostałych jedenastu w całym Londynie. [Gawłowski 2010, s. 114]. Do głównych obszarów odpowiedzialność GLA należą:

- rozwój gospodarczy i tworzenie dobrobytu,

- rozwój społeczny, 
- poprawa stanu środowiska [http://www.london.gov.uk].

- Mają one odzwierciedlenie w sześciu statutowych kwestiach:

- równość szans,

- zrównoważony rozwój,

- zdrowie,

- nierówności w zakresie zdrowia,

- zmiany klimatyczne,

- bezpieczeństwo społeczności.

Ustawa z roku 2007 o GLA poszerzyła i wzmocniła kompetencje burmistrza i zgromadzenia w takich dziedzinach, jak mieszkalnictwo, planowanie, zmiana klimatu, gospodarka odpadami, ochrona zdrowia i kultura. Ważnym uprawnieniem GLA jest uchwalanie budżetu, którego projekt przygotowuje burmistrz Londynu.

Nowy podmiot przejął istniejące "Quangos"66, jednocześnie przejmując część uprawnień od rządu centralnego. Kompetencje GLA obejmują szereg istniejących programów rządowych dotyczących policji, straży pożarnej, transportu i rozwoju gospodarczego. Pozostałe funkcje to m.in. metropolitalne planowanie przestrzenne, ochrona środowiska, kultura, media i sport, służba zdrowia i inwestycje zagraniczne. Władze Wielkiego Londynu nie mają władztwa podatkowego [OECD 2011, s. 75]. Głównym źródłem ich dochodów są dotacje celowe od rządu centralnego, gdyż większość realizowanych zadań jest bezpośrednio zlecana przez rząd [Thornley 2003, s. 50].

Burmistrz Londynu przygotował kompleksową Strategię Rozwoju Przestrzennego, która obejmowała również kwestie rozwoju gospodarczego, rewitalizacji, mieszkalnictwa, środowiska, gospodarki odpadami itp. Zastąpiła ona wytyczne planistyczne tworzone przez rząd centralny. Strategia została poparta przez subregionalne ramy rozwoju ustanowione w partnerstwie między GLA, gminami i innymi zainteresowanymi podmiotami.

Istotną kwestią było uczynienie Londynu „bardziej odpowiedzialnym” przed obywatelami. Zakładano, że odpowiednie polityki mogą osiągnąć consensus i nawet wzmocnić przedsiębiorcze podejście, dlatego też włączono w proces ich formułowania liczne podmioty, mające innowacyjne podejście do formułowania celów rozwoju. Sektor biznesowy jest siłą napędową w tym partnerstwie i poprzez Londyńską Radę Biznesu jest w stanie znacząco wpływać na program konkurencyjności [OECD 2007a, s. 102].

W lutym roku 2011 rząd zaakceptował Lokalne Partnerstwo Przedsiębiorstw (Local Enterprise Partnership - LEP) dla Londynu, które ma być

${ }^{66}$ QUANGO - quasi-autonomous non-governmental organisation, organizacje publiczne w Wielkiej Brytanii, którym władze przekazały część kompetencji, głównie w zakresie świadczenia usług (ochrona zdrowia, edukacja, itp.) 
wspierane przez GLA. LEP koncentruje się na utrzymaniu i wzmacnianiu globalnej konkurencyjności Londynu [Pemberton 2011, s. 85].

Jeśli chodzi o zasięg przestrzenny GLA, to jej granice są zbieżne z obszarem administracyjnym Wielkiego Londynu. Natomiast zasięg przestrzenny LEP jest mniejszy. Może to spowodować istotny opór ze strony samorządów i firm, włączonych w innego rodzaju LEP poza Londynem, w stosunku do jakiejkolwiek strategii mającej za główne zadanie wzmocnienie pozycji Londynu na światowej arenie. Z drugiej strony może prowadzić do rozwoju nowych politycznych sojuszy tworzących szersze programy gospodarczej i społecznej współpracy [Pemberton 2011, s. 85].

Od 22 lipca 2011 r. realizowana jest nowa strategia pod nazwą Plan dla Londynu (London Plan).

W realizacji wizji rozwoju przyjętej przez burmistrza GLA wspierają, utworzone w roku 2000, cztery agencje funkcjonalne:

- Transport for London (TfL),

- London Development Agency (LDA),

- London Fire and Emergency Planning Authority (LFEPA),

- Mayor's Office for Policing and Crime (MOPAC), które zastąpiło Metropolitan Police Authority (MPA).

Transport for London (TfL) utworzono w celu zarządzania usługami transportowymi w obszarze Wielkiego Londynu oraz wdrożenia Strategii Transportowej Burmistrza Londynu. Na czele agencji stoi Rada Zarządcza, której członkowie są mianowani przez burmistrza, przewodniczącego radzie. Agencja zarządza wszystkimi środkami transportu w obszarze Wielkiego Londynu, kieruje sygnalizacją świetlną, zarządza dworcem autobusowym Victoria i Muzeum Transportu oraz reguluje funkcjonowanie taksówek [OECD 2006b, s. 155].

W celu opracowania strategii rozwoju gospodarczego oraz realizowania rozwoju i rewitalizacji została utworzona Agencja Rozwoju Lokalnego (LDA), którą rozwiązano 31 marca 2012 r. w związku z reorganizacją GLA. Przez 12 lat swego istnienia wywarła znaczący wpływ na Londyn i jego mieszkańców poprzez szereg inwestycji i programów, które zrealizowała [http://www.london.gov.uk/who-runs-london/greater-london-authority/glafunctional-bodies/london-development-agency].

Londyńską Strażą Pożarną kieruje LFEPA. Straż i LFEPA wspólnie odpowiadają za zarządzanie kryzysowe zarówno na obszarze całej metropolii, jak i poszczególnych dystryktów. Burmistrz powołuje 17 członków Władz Zarządzania Kryzysowego [http://www.london.gov.uk/who-runs-londrnance/ greater-london-authority/gla-functional-bodies ].

Obecnie funkcjonujące władze metropolitalne Wielkiego Londynu mają zagwarantować realizację jednej z podstawowych zasad governance, jaką jest odpowiedzialność przed społeczeństwem za podejmowane działa- 
nia. Ponieważ burmistrz jest wybierany bezpośrednio przez obywateli Londynu, może być pociągnięty do odpowiedzialności przez wyborców. Odpowiedzialność władz wzmocniona jest przez Radę, która stanowi forum do dyskusji i publicznych przesłuchań. Oprócz tego jej członkowie też są wybierani przez mieszkańców Londynu, którzy mogą ich odwołać. Za planowanie strategiczne w Londynie wspólnie odpowiadają burmistrz Londynu, 32 dzielnice oraz Korporacja City of London. Plan dla Londynu jest ogólnym planem strategicznym i określa w pełni zintegrowane ramy dla gospodarczego, środowiskowego, transportowego i społecznego rozwoju stolicy do roku 2031. Plany dzielnic muszą być zgodne z planem ogólnym [Government... 2008].

\subsection{Manchester}

Obszar metropolitalny Manchesteru obejmuje dziesięć okręgów (rys. 14), zamieszkiwanych przez ok. 2,6 mln ludności. Manchester miał rząd metropolitalny (Greater Manchester County Council) w latach 1974-1986 [Norris 2001b, s. 534]. Był on odpowiedzialny za transport publiczny, policję, ochronę przeciwpożarową, planowanie strategiczne i zarządzanie lotniskiem [CAEE 2010, s. 26].

Po zlikwidowaniu powiatów metropolitalnych w dalszym ciągu funkcjonowało Stowarzyszenie Władz Wielkiego Manchesteru - AGMA (Association of Greater Manchester Authorities). Skupia ono rady dziesięciu dystryktów, które na zasadzie dobrowolności współpracują z sektorem prywatnym w celu przyciągnięcia nowych inwestycji, koordynowania planowania i w „imię wyższego dobra”. AGMA przejęło funkcje pełnione przez powiat, w tym również uboczne w stosunku do obowiązków z zakresu dostarczania usług, jak np. badania, usługi archeologiczne, zarządzanie funduszem emerytalnym, co do których władze okręgów zgodziły się, że powinny one być koordynowane na szczeblu metropolitalnym. W dniu 31 lipca 2009 r. zarząd AGMA zatwierdził strategię dla Wielkiego Manchesteru (GMS), która określa cele strategiczne obszaru metropolitalnego do roku 2020 [http://www. agma.gov.uk]. 


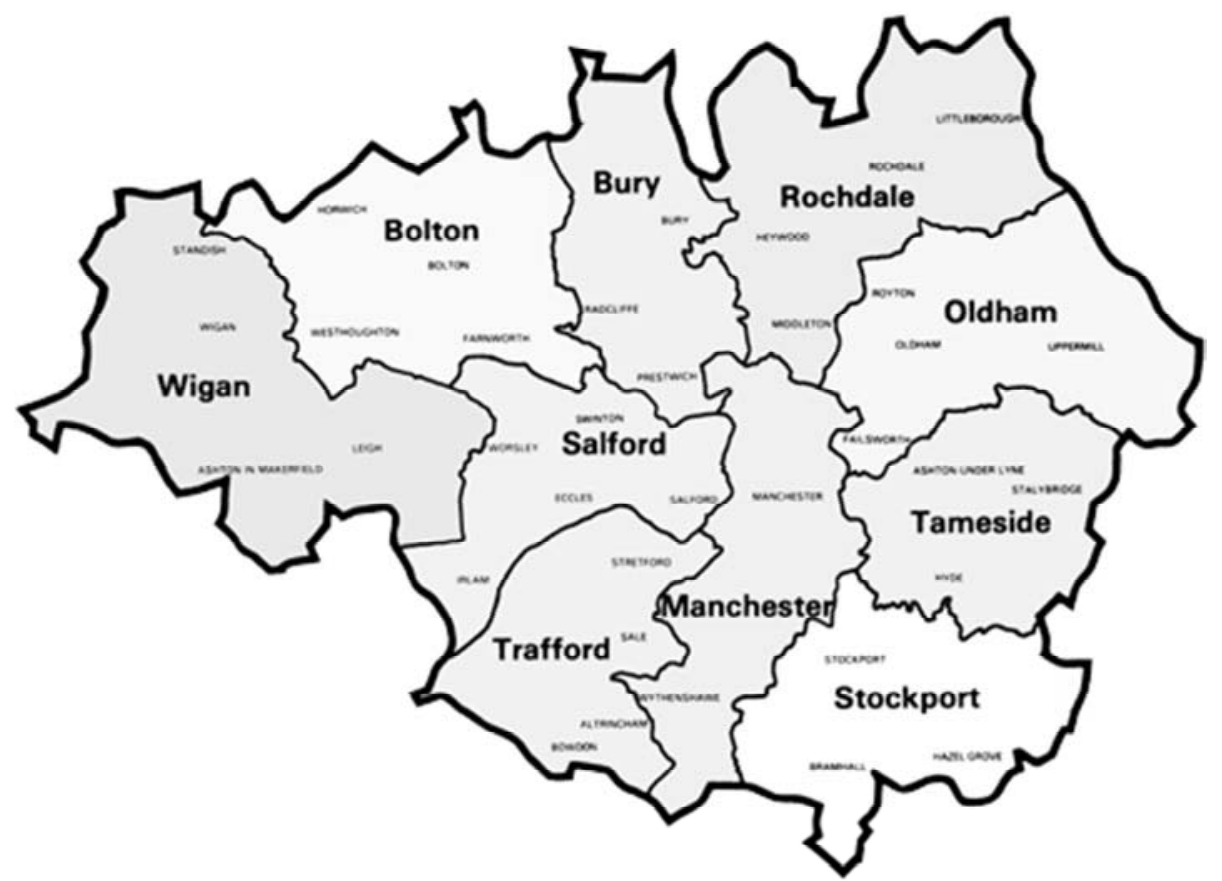

Rys. 14. Obszar Metropolitalny Manchesteru Źródło: [http://www.gmts.co.uk/explore/history/district.html]

W obszarze Wielkiego Manchesteru funkcjonują również inne instytucje o zasiegu metropolitalnym, skupiające dziesieć dystryktów i podmioty z sektora prywatnego:

- MIDAS - agencja utworzona w 1997 r. w celu przyciągania inwestycji zagranicznych [www.investinmanchester.com],

- Marketing Manchester - podmiot utworzony w $1996 \mathrm{r}$. mający na celu promocję regionu na szczeblu krajowym i międzynarodowym [http://www. marketingmanchester.com/].

1 kwietnia 2011 r. dziesięć jednostek lokalnych utworzyło, w drodze ustawowej, wspólny rząd (Greater Manchester Combined Authority GMCA), którego celem jest poprawienie, w obszarze Wielkiego Manchesteru, efektywności i sprawności usług transportowych, rozwój gospodarczy i rewitalizacja. Pozwoli to bardziej efektywnie pracować nad sprawami o zasięgu regionalnym, które wymagają podjęcia pewnych trudnych decyzji, co jest niemożliwe przy dobrowolnej tylko współpracy. Wielki Manchester włącza w proces podejmowania decyzji sektor prywatny i stworzył mechanizmy zachęcające sektor prywatny do odgrywania kluczowej roli w określaniu strategicznych kierunków rozwoju [http://www.agma.gov.uk]. Wszyscy członkowie Rady Biznesu (Business Leadership Council) pochodzą 
z sektora prywatnego i odpowiadają za doradztwo we wszystkich głównych obszarach formułowania polityk.

Cele GMCA są uzupełniane przez pracę AGMA, w którym okręgi nadal współpracują w obszarze:

- zdrowia,

- bezpieczeństwa publicznego,

- budownictwa mieszkaniowego,

- planowania strategicznego,

- środowiska,

- pozyskiwania dotacji.

AGMA jest partnerem w GMCA. Nowy Komitet ds. Transportu Wielkiego Manchesteru (TfGM Committee) pomaga GMCA w wykonywaniu swoich funkcji transportowych poprzez doradzanie w zakresie polityki transportowej. TfGM (Transport for Great Manchester) realizuje decyzje GMCA i TfGMC [http://www.transportforgreatermanchestercommittee. gov.uk/]. Rysunek 15 przedstawia schemat nowej struktury współrządzenia w obszarze metropolitalnym Manchesteru.

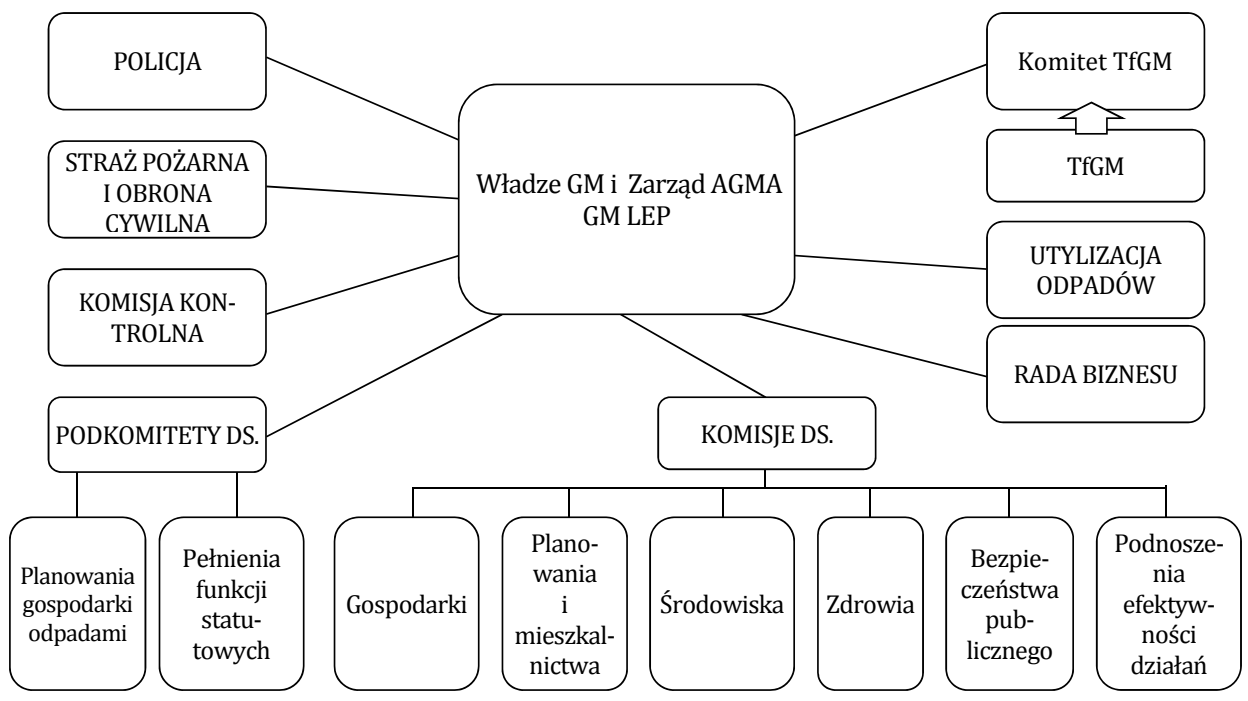

Rys. 15. Struktura zarządzania w Wielkim Manchesterze Źródło: oprac. własne na podstawie [http://www.agma.gov.uk]

Na czele AGMA stoi Zarząd, który jest organem wykonawczym. W jego skład wchodzi dziesięciu przedstawicieli władz lokalnych, a także przedstawiciele Straży Pożarnej Wielkiego Manchesteru, obrony cywilnej, policji, TfGM i instytucji odpowiadającej za utylizację odpadów. Zarząd powołał sześć komisji strategicznych, które przejęły jego funkcje w takich obszarach, jak gospodarka, planowanie i mieszkalnictwo, bezpieczeństwo publiczne, 
ochrona środowiska, zdrowie, oraz podnoszenie efektywności działania [http://www.agma.gov.uk/agma/how_agma_works/index.html].

Wielki Manchester utworzył partnerstwo z biznesem ${ }^{67}$ (Great Manchester Local Enterprise Partnership - GM LEP). GM LEP ma trzynastu członków, dziewięciu spoza władz lokalnych i czterech reprezentujących GMCA. Partnerstwo ma odgrywać kluczową rolę w kształtowaniu strategii i nadzorować wywiązywanie się z przyjętych ustaleń w następujących dziedzinach:

- zatrudnienie i umiejętności,

- wsparcie biznesowe dla nowych firm oraz dla wzrostu gospodarczego,

- inwestycje zagraniczne i handel międzynarodowy,

- marketing i turystyka,

- fundusze europejskie,

- rozwijanie gospodarki niskoemisyjnej,

- planowanie, mieszkalnictwo i transport,

- badania i rozwój strategii [http://www.agma.gov.uk/local-enterprise-partnership/index.html].

W celu osiągnięcia większej odpowiedzialności publicznej za podejmowane decyzje i usługi dostarczane dla całego Wielkiego Manchesteru utworzono Komisje Kontrolną (Scrutiny pool). Jej kluczową rolą jest ciągły monitoring realizowanych strategii i polityk [http://www.agma. gov.uk/scrutiny/ about_agma_scrutiny/index.html].

\subsection{Birmingham}

Obszar metropolitalny Birmingham tworzy siedem okręgów, będących częścią regionu West Midlands. Jego populacja wynosi prawie 3,7 mln [ESPON 2007, s. 120]. Od roku 1974, podobnie jak w obszarze Manchesteru, funkcjonowała tam rada powiatu metropolitalnego, która została rozwiązana w 1986 r. Po rozwiązaniu rady utworzono Wspólny Komitet West Midlands (West Midlands Joint Committee - WMJC), w którego skład weszło siedem rad okręgów metropolitalnych. Ogólnym celem WMJC jest koordynacja działań w sprawach ważnych dla lokalnych władz w West Midlands, takich jak drogi i planowanie [http://birmingham.gov.uk/cs/Satellite ?c=Page\&childpagename=SystemAdmin\%2FPageLayout $\&$ cid=12230927459

67 LEP - Local enterprise partnership są związkami partnerskimi między władzami lokalnymi i przedsiębiorstwami, które powstały w roku 2011. Mają one pomagać w określeniu lokalnych priorytetów gospodarczych i prowadzić do wzrostu gospodarczego oraz tworzenia miejsc pracy w swojej okolicy. Wykonują niektóre funkcje poprzednio realizowane przez regionalne agencje rozwoju (RDA), które zostały zniesione w marcu 2012 r. decyzją rządu centralnego. Więcej: http:// webarchive.nationalarchives.gov.uk/+/http://www.communities.gov.uk/localgovernment/local/localenterprisepartnerships/ 
07\&packedargs=currentType \%3DDate\%26eventSearchType $\% 3 D d a t e \% 26 \mathrm{w}$ ebsite\%3D]1\&pagename=BCC\%2FCommon\%2FWrapper\%2FWrapper\&rendermode=live].

Pomimo zniesienia rady metropolitalnej niektóre usługi lokalne nadal świadczone są na poziomie metropolitalnym i zarządzane przez połączone rady siedmiu okręgów. Najważniejszym aktorem w procesie planowania transportu jest publiczna agencja Centro utworzona w celu koordynacji transportu w powiecie metropolitalnym. W cały proces planowania została zaangażowana duża liczba podmiotów społeczeństwa obywatelskiego i władz lokalnych dzięki zorganizowaniu lokalnych imprez publicznych, forów użytkowników i konsultacji. Proces zakończył się stworzeniem wspólnego Planu Transportu Lokalnego, który został przyjęty przez rady lokalne i rząd centralny [http://www.westmidlandsltp.gov.uk/default. php? id=249]. Obecnie obowiązujący plan obejmuje lata 2011-2026 i składa się z części strategicznej (opracowanej w perspektywie 15-letniej) oraz operacyjnej (okres pięciu lat) [http://www.centro.org.uk/LTP/LTP.aspx].

Na poziomie metropolitalnym świadczone są również usługi w zakresie: działań policji (West Midlands Police), ochrony przeciwpożarowej oraz doraźnej pomocy medycznej (Fire and Rescue Authority). Te wspólne rady składają się z radnych mianowanych przez rady każdego z siedmiu okręgów. Wspólną własnością gmin, po rozwiązaniu rady powiatu, stało się lotnisko.

Formalnym rozwiązaniem przyjętym w regionie West Midlands, które miało wpływ na funkcjonowanie całego regionu, było utworzenie w 1999 r. Agencji Rozwoju Regionalnego - Advantage West Midlands oraz Izby Regionalnej, która miała nią kierować [Murie, Beazley, Carter 2003, s. 62]. Był to efekt realizacji programu przyjętego przez utworzony w 1997 roku rząd Partii Pracy, który zakładał utworzenie dziewięciu takich agencji w całym kraju.

Od roku 1999 na poziomie regionalnym funkcjonowało Zgromadzenie Regionalne (West Midlands Regional Assembly - WMRA), które było regionalnym organem planistycznym i odpowiadało za przygotowanie regionalnych strategii, $w$ tym regionalnej strategii zagospodarowania przestrzennego. WMRA miało również wpływ na politykę krajową i planowanie wydatków na szczeblu państwowym. Składało się ono ze 100 członków, w tym 68 członków reprezentujących władze lokalne, 16 - sektor przedsiębiorstw oraz 16 reprezentujących innych partnerów ekonomicznych i społecznych [http://www.wmra.gov.uk]. Jednak 31 marca 2010 r., decyzją nowego rządu, zgromadzenie zostało rozwiązane, a jego funkcje przejęła rada liderów (West Midlands Leaders Board), przekształcona w lipcu 2010 r. w Radę West Midland (West Midland Councils - WMC) [http://www.wmra.gov.uk]. Rada skupia przedstawicieli 33 rad okręgów regionu West Midland [http://www.wmcouncils.gov.uk]. Finansowana jest ze składek członkow- 
skich oraz przychodów ze szkoleń, doradztwa, usług korporacyjnych i wynajmu lokali. Jej celem jest zapewnienie:

- Zasobów dla umożliwienia, ułatwienia i koordynacji regionalnych, subregionalnych i lokalnych działań, w przypadku których współpraca będzie tworzyć wartość dodaną,

- usług o wartości dodanej dla organizacji członkowskich, na rzecz rozwoju organizacyjnego i doskonalenia działań,

- ukierunkowania działalności i zaangażowania władz lokalnych na rzecz realizacji priorytetów ustalonych przez West Midlands Councils.

Rada West Midlands tworzy też demokratyczne ramy, dzięki którym radni z różnych samorządów i różnych obszarów interesów mogą tworzyć sieć, debatować, uczyć się od siebie nawzajem i kiedy czują taką potrzebę, podjąć wspólne decyzje w ich wspólnych interesach [http://www.wmcouncils.gov.uk/what-we-do]. Nie jest ona podmiotem planistycznym ani nie odgrywa żadnej roli w systemie planowania. Wraz z likwidacją WMRA została unieważniona regionalna strategia.

Podobnie jak w przypadku Zgromadzenia Regionalnego, potoczyły się losy Agencji Rozwoju Regionalnego. W czerwcu roku 2010 rząd nakazał likwidację wszystkich agencji do końca marca 2012 r. Sprawy związane z rozwojem ekonomicznym i rewitalizacją przejęły departamenty rządu centralnego oraz nowo tworzone LEP funkcjonujące na poziomie subregionalnym [http://webarchive.nationalarchives.gov.uk/+/http://www.advantagewm.co.uk/about-awm/default.aspx]. W regionie West Midlands utworzono sześć LEP. Jednym z nich jest Wielkie Birmingham. Ponieważ LEP nie obejmują całego regionu, może to prowadzić do konkurencji na poziomie subregionalnym.

Birmingham jest przykładem obszaru metropolitalnego, w którym mamy do czynienia z metropolitan governance pomimo braku metropolitalnej władzy. Jest to obszar metropolitalny zarządzany na zasadzie sieciowego współrządzenia. Zmiany wprowadzone w ostatnich latach przez rząd centralny nie zlikwidowały współpracy na poziomie metropolitalnym, gdyż większość agencji funkcjonalnych kontynuuje swoje działania. Wynika to z faktu, iż długoletnia współpraca przekonała poszczególnych uczestników o korzyściach, jakie każdy czerpie z dystryktów.

Wielka Brytania jest państwem silnie scentralizowanym, czemu sprzyja relatywnie niewielka liczba jednostek terytorialnych. Dobrze rozwinięty system nadzoru nad samorządem terytorialnym obejmuje nie tylko kontrolę legalności działań, ale również sprawność, skuteczność i gospodarność jednostek terytorialnych [Niziołek 2008, s. 223]. Problemem we wszystkich obszarach metropolitalnych Wielkiej Brytanii, które dysponują instytucją zarządzającą na poziomie metropolitalnym, jest przekazanie im przez rząd centralny tylko części kompetencji. W gestii rządu centralnego w dalszym 
ciągu pozostaje kontrola nad tworzeniem prawa, ustanawianiem przepisów oraz alokacja większości środków finansowych [Thornley 2003, s. 53]. Takie rozwiązanie będzie wywoływać problemy, zwłaszcza w sytuacji, gdy władze metropolitalne będą z innej opcji politycznej niż rząd centralny, co siłą rzeczy musi rodzić więcej konfliktów.

\section{Szwajcaria}

Szwajcaria jest krajem federalnym, składającym się z 26 kantonów i 2890 gmin, które mają bardzo szeroką autonomię. Każdy kanton ma swoją własną konstytucję, parlament (organ legislacyjny) i rząd (organ wykonawczy). Szwajcaria jest krajem o długich tradycjach samorządowych i z uwagi na zasadę subsydiarności rząd centralny ma tu słabą pozycję. Demokracja bezpośrednia szczególnie dobrze funkcjonuje na poziomie lokalnym. W większych gminach wprowadza się demokrację przedstawicielską. Na jej czele stoi parlament gminny z przewodniczącym na czele, który może tę funkcję pełnić jednokrotnie.

Współpraca ponadlokalna sięga lat 70. wieku XX i wiązała się głównie z zaopatrzeniem $\mathrm{w}$ wodę. Większość aglomeracji, w reakcji na rosnący wzrost populacji miejskiej, zdecydowała się na przekazanie kwestii zarządzania wodą na poziom ponadlokalny, w celu lepszego wykorzystania ograniczonych zasobów. We współpracę były włączone ośrodki centralne oraz otaczające je gminy.

Szwajcarski federalizm nie zapewnia właściwych form instytucjonalnych dla zarządzania obszarami zurbanizowanymi, pomimo faktu, iż około $70 \%$ ludności kraju żyje na takich obszarach.

W roku 1999 w konstytucji Szwajcarii po raz pierwszy pojawiły się odniesienia do miast i aglomeracji. To skłoniło rząd federalny do opracowania celów i strategii dla terenów zurbanizowanych. W zakresie polityki transportowej rząd szwajcarski zobowiązał się do finansowego uczestnictwa w tworzeniu transportu aglomeracyjnego jako kluczowego elementu polityki miejskiej. To dało początek całej serii programów i narzędzi opracowywanych przez państwo i kantony, które miały na celu poprawę społecznej i technicznej infrastruktury, co stopniowo doprowadziło do włączenia ich $\mathrm{w}$ proces formułowania polityki federalnej. Uruchomienie tych programów zmierzało w kierunku poszukiwania nowego rozumienia miejskiej polityki, pociągającego za sobą poprawę międzyrządowej współpracy zarówno w wymiarze poziomym, jak i pionowym. Utworzenie współpracy międzygminnej i budowanie sieci (władze publiczne, planiści, deweloperzy, inwestorzy) było warunkiem koniecznym przy ubieganiu się o dofinansowanie ze strony państwa [Kübler, Schenkel, Leresche 2003, s. 275]. 
Prawo veta samorządów lokalnych jest w Szwajcarii silniejsze niż w pozostałych krajach europejskich, co czyni potrzebę koordynacji w obszarach zurbanizowanych jeszcze większą [Sager 2005, s. 238].

Ustawa o planowaniu przestrzennym z roku 1980 wprowadziła trójszczeblowy system planowania. System ten nie jest zhierarchizowany, lecz opiera się na dialogu i współpracy między konfederacją a kantonami. $\mathrm{Na}$ poziomie państwa formułowane są koncepcja i plany sektorowe. W celu koordynacji polityki przestrzennej rząd federalny opracowuje Wytyczne dla Rozwoju Przestrzennego Szwajcarii. Główna odpowiedzialność w zakresie planowania przestrzennego spoczywa na kantonach, które opracowują plany strukturalne (przewodnie). Plany te muszą być zatwierdzone przez szczebel centralny. Po ich zatwierdzeniu obowiązują na każdym poziomie administracji. Plany te odgrywają podwójną rolę, z jednej strony zawierają pożądane zasady zagospodarowania przestrzennego, a z drugiej są planem działania, gdyż zawierają najważniejsze decyzje dotyczące działań i projektów o znacznym wpływie na przestrzeń. Plany muszą być aktualizowane co dziesięć lat [Ringli 1997, s. 116].

Kantony odpowiadają również za organizację planowania przestrzennego na całym obszarze. Często przekazują ten obowiązek gminom. Na poziomie gminy tworzone są plany zagospodarowania przestrzennego, które muszą być zatwierdzone przez kanton. Cały obszar gminy musi być objęty planem [VLP-ASPAN 2004, s. 2]. Plany kantonalne i gminne poddawane są publicznym konsultacjom, w których aktywnie uczestniczą organizacje pozarządowe, przedstawiciele mieszkańców, stowarzyszenia zmotoryzowanych, grupy nacisku pieszych i rowerzystów itd. Kantony nadzorują gminy w zakresie planowania przestrzennego.

\section{Zurych}

Według Szwajcarskiego Urzędu Statystycznego Obszar Metropolitalny Zurychu obejmuje 171 gmin, leżących w kantonie Zurych. Liczba ludności sięga tu prawie 1,5 miliona [Kübler, Schenkel, Leresche 2003, s. 267]. Natomiast uwzględniając powiązania funkcjonalne, obszar ten obejmuje 236 gmin położonych w ośmiu kantonach. Zatem rozmiar tych gmin jest bardzo mały. Koordynacja pojawia się w odniesieniu do spraw dotyczących całego obszaru.

Zaopatrzenie $\mathrm{w}$ wodę na poziomie metropolitalnym zostało powierzone publicznemu przedsiębiorstwu w Zurychu, od którego 63 gminy podmiejskie kupują wodę na podstawie długoterminowych umów i na zasadach efektywności kosztowej.

Planowanie i zarządzanie na poziomie metropolitalnym dotyczy również transportu publicznego. Ponadlokalny zakres tego zagadnienia został uznany już w latach 80 . W roku 1987, podążając za zmianą przepisów kantonów 
odnośnie do transportu publicznego, wypracowano schematy koordynacji obejmujące cały obszar zurbanizowany. Podmiot koordynujący Zürcher Verkehrsverbund (ZVV) - przedsiębiorstwo publiczne - jest organem dwuszczeblowym, a w jego skład wchodzą kanton oraz gminy (186), przy czym kanton ma silniejszą pozycję, co wynika również z faktu, że jego granice i granice obszaru metropolitalnego są bardzo zbliżone. Większość decyzji zapada po przegłosowaniu przez większość członków Zarządu Transportu Kantonu. Dwuszczeblowa forma organizacyjna przewiduje też konsultacje z odpowiednimi grupami interesów (np. organizacje środowiskowe). Co roku, w okresie poprzedzającym zmianę rozkładów jazdy, do mieszkańców i użytkowników komunikacji publicznej kierowane są publiczne zapytania, z prośbą o opinie odnoszące się do świadczonych usług. Ponadto przeprowadzane są pogłębione badania użytkowników, podczas których na stronie internetowej funkcjonują wyrafinowane narzędzia umożliwiające interaktywna komunikację. W wyniku wprowadzenia nowego systemu zarządzania, została ulepszona infrastruktura oraz wprowadzono jeden bilet funkcjonujący na całym obszarze metropolitalnym [Kübler, Schwab 2007, s. 481].

Kolejny obszar współpracy dotyczy usług społecznych dla narkomanów. W roku 1992 został ustanowiony mechanizm zarządzania tymi usługami i dzielenia kosztów w skali całego obszaru. Głównymi aktorami są tutaj gminy, ponieważ do ich kompetencji należy świadczenie tego typu usług, jednak również kanton, opierając się na zasadzie subsydiarności, włącza się do tej współpracy. Równorzędnymi partnerami w tej współpracy są również organizacje pozarządowe [Kübler, Schwab 2007, s. 482].

W latach 90. w Szwajcarii zaczęto sobie zdawać sprawę z faktu, że usługi kulturalne mają coraz większe znaczenie w kontekście międzynarodowej konkurencyjności miast. W związku z tym, że na gminach spoczywa główny ciężar finansowania tych usług (48\%), doszło do porozumienia w kwestii partycypacji gmin podmiejskich $w$ finansowaniu usług kulturalnych zlokalizowanych w mieście centralnym, gdyż tego typu usługi są korzystne dla rozwoju całego obszaru metropolitalnego. W obszarze metropolitalnym Zurychu został, na mocy prawodawstwa kantonu, wprowadzony system finansowej kompensacji, w którym 169 gmin podmiejskich uczestniczy w wydatkach na kulture, jakie ponosi miasto centralne, natomiast odpowiedzialność finansowa za Operę w Zurychu została przejęta przez kanton. Gminy z obszaru metropolitalnego finansują $71 \%$ wydatków na kulturę ponoszonych przez miasto. Prywatni sponsorzy mogą przedstawiać swój punkt widzenia za pośrednictwem rad poszczególnych instytucji kultury [Kübler, Schwab 2007, s. 483].

Większość obszarów współpracy na poziomie metropolitalnym nie przewiduje bezpośredniej partycypacji przedstawicieli społeczeństwa obywatelskiego. Z punktu widzenia zasad współrządzenia najlepiej rozwi- 
nięta jest współpraca w obszarze usług społecznych dla narkomanów. Racjonalnym uzasadnieniem włączenia NGOs jako równorzędnego partnera jest ich doświadczenie w pomocy narkomanom. Decyzje są podejmowane jednomyślnie w wyniku consensusu osiąganego w trakcie dyskusji. Górę nad lokalnymi interesami biorą racjonalne argumenty, co jest możliwe dzięki podobnym ideologicznym i zawodowym korzeniom partnerów.

Bliższa współpraca metropolitalna rozpoczęła się w roku 2007, kiedy to z inicjatywy kantonu Zurych, miast Zurych i Winterthur oraz stowarzyszenia burmistrzów gmin kantonu Zurych odbyła się pierwsza Konferencja Metropolitalna. W czerwcu roku 2009, podczas piątej konferencji, zostało utworzone Stowarzyszenie Obszaru Metropolitalnego Zurychu. Członkami założycielami było osiem kantonów oraz 65 gmin w tych kantonach [http://www.stadt-zuerich.ch/...]. Jego organami są:

1. Konferencja Metropolitalna, w skład której wchodzą wszyscy członkowie reprezentujący organ wykonawczy kantonu lub gminy (obecnie członkami jest 110 gmin). Prawo głosu jest proporcjonalne do liczby populacji w danej jednostce terytorialnej. Konferencja składa się z dwóch izb Izby Kantonów i Izby Miast/Gmin.

2. Rada Metropolitalna (Metropolitanrat) składająca się z ośmiu przedstawicieli kantonów (będących członkami zarządu kantonu) oraz ośmiu przedstawicieli gmin. Prezydenta i wiceprezydenta Rady oraz jej członków wybiera Konferencja Metropolitalna. Rada reprezentuje stowarzyszenie na zewnątrz [http://www.currentconcerns.ch/index.php?id=837]. Niepokojący jest fakt, że mamy tu do czynienia z kumulowaniem funkcji. Na przykład wiceprezydent Rady jest jednocześnie prezydentem Konferencji.

3. Komitet Operacyjny składający się z czterech przedstawicieli kantonów i czterech przedstawicieli gmin wybieranych przez Radę.

4. Komisja Rewizyjna wybierana przez Konferencję.

5. Biuro rady pełniące funkcje administracyjne.

Działalność Stowarzyszenia finansowana jest ze składek członkowskich w wysokości proporcjonalnej do liczby mieszkańców poszczególnych jurysdykcji.

Stowarzyszenie przyjęło wizję rozwoju obszaru do roku 2030. Zgodnie z nią celem jest poprawa jakości życia i międzynarodowej konkurencyjności obszaru metropolitalnego Zurychu. Stowarzyszenie przewiduje cztery obszary działań. Są to gospodarka, społeczeństwo, transport i jakość życia [http://www.metropolitanraum-zuerich.ch].

Współpraca w obszarze metropolitalnym Zurychu zachodzi również w zakresie promocji i marketingu. W roku 1998 została utworzona spółka akcyjna Greater Zurich Area (GZA), która jest organizacją non-profit. Do jej zadań należy m.in.:

- dostarczanie informacji o regionie biznesowym Wielkiego Zurychu, 
- zachęcanie i pomaganie międzynarodowym firmom chcącym ulokować się w regionie Zurychu,

- przyciąganie wykwalifikowanych pracowników i know-how.

Wszystkie usługi świadczone są bezpłatnie. Działalność GZA finansowana jest przez fundację "Greater Zurich Area Standortmarketing”, właściciela GZA. Fundacja została utworzona w roku 1998 jako partnerstwo publicznoprywatne. Członkowie jej to siedem kantonów, miasta Winterthur i Zurych oraz największe przedsiębiorstwa. Na czele fundacji stoi rada, której prezydentem jest minister gospodarki Parlamentu Kantonu Zurych [http:// www.greaterzuricharea.ch].

Ustawa Prawo budowlane i planowanie z roku 1975 nakłada na gminy obowiązek tworzenia grup planistycznych. W kantonie Zurych jest 11 takich grup. $\mathrm{W}$ bezpośrednim regionie Zurychu grupy te skupione są $\mathrm{w}$ organizacji Regional Planning for Zürich and the Surrounding Area (RZU), będącej planistyczną organizacją parasolową miasta Zurych, sześciu sąsiadujących regionów planistycznych i kantonu Zurych. Jest więc organizacją wieloszczeblową. Na jej czele stoi Rada Delegatów i Zarząd. Terytorium RZU obejmuje 70 gmin. Stanowi ona „centrum doskonałości” w zakresie zagospodarowania przestrzennego i jest zobowiązana do utrzymania jakości życia i konkurencyjności aglomeracji Zurychu [Keller 2009]. Celem RZU jest zaprojektowanie koncepcji aglomeracji Zurychu, a także prace nad realizacją zadań planistycznych, które mają znaczenie dla całego regionu. RZU promuje także i koordynuje współpracę między jej członkami i reprezentuje ich życzenia w kwestii planowania [http://www.stadt-zuerich.ch/prd/en/ index/stadtentwicklung/aussenbeziehungen/zuerich_regional/rzu.html].

Celem planowania przestrzennego w Kantonie Zurych jest zagwarantowanie sustensywnego rozwoju przestrzeni do życia przez promowanie osadnictwa i infrastruktury transportowej. Jednocześnie obszary o centralnym znaczeniu dla całego kantonu, które są połączone przez system kolei metropolitalnej, mają zapewnić rozwój wewnętrznych obszarów miejskich i taką samą jakość życia w całym kantonie [Cantonal... 2002]. Plan strukturalny wskazuje miejsca lokalizacji wielkich inwestycji, zgodnie z własną wizją rozwoju.

Ważnym aktorem w procesie planowania stał się biznes. W roku 199330 firm utworzyło Grupę Interesu Przedsiębiorstw Zurychu, aby uczestniczyć $\mathrm{w}$ procesie planowania przestrzennego. $\mathrm{W}$ jej skład weszły banki, firmy ubezpieczeniowe, agencje nieruchomości itp. Aby dostarczyć władzom skutecznych argumentów, zleciły opracowanie odpowiednich studiów planistycznych uniwersytetom i firmom prywatnym [Ringli 1997, s. 121]. Tym samym planowanie przestrzenne zostało wykorzystane do stawienia czoła wyzwaniom globalnego rynku. 


\section{Podsumowanie sposobów zarządzania obszarami metropolitalnymi}

Podsumowując rozważania w niniejszym rozdziale należy stwierdzić, iż przedstawione obszary metropolitalne różnią się między sobą pod wieloma względami (tab. 13).

Przede wszystkim różny jest ich rozmiar i struktura. Ich powierzchnia wynosi od zaledwie $636 \mathrm{~km}^{2}$ w przypadku Barcelony, aż do $26000 \mathrm{~km}^{2}$ dla Regionu Metropolitalnego Hamburga. Również liczba jednostek administracyjnych tworzących obszar metropolitalny waha się między zaledwie 22 jednostkami administracyjnymi a aż 1281 - w przypadku Ile-de-France. Wszystkie te różnice nie mają jednak istotnego znaczenia dla wprowadzania metropolitalnego zarządzania, ponieważ problemy, jakie się tam pojawiają, a których rozwiązanie wymaga interwencji na poziomie metropolitalnym, są wszedzie takie same.

Opierając się na zaprezentowanych przykładach rozwiązań przyjętych w zakresie zarządzania obszarami metropolitalnymi, zasadniczo można wyróżnić dwa rodzaje modeli - władzy metropolitalnej i kooperacyjny które mogą wykorzystywać różne struktury zarządzania, począwszy od relatywnie silnych aż do relatywnie słabych. Relatywnie najsilniej zinstytucjonalizowane struktury zarządzania, dostosowane do obszarów funkcjonalnych miasta centralnego, obejmują fuzję gmin oraz rząd metropolitalny.

Koncepcja fuzji gmin bazuje na przekonaniu, iż silniejsze władze metropolitalne poprawią konkurencyjność obszarów metropolitalnych. Utworzone w wyniku fuzji struktury administracyjne próbują przezwyciężyć złożone trudności spowodowane rozdrobnieniem podatkowym w ramach metropolii (w niektórych przypadkach ograniczając zakres odpowiedzialności) i ograniczoną władzą na poziomie lokalnym. Dalszym celem jest wyrównanie wzrostu populacji i struktury społeczeństwa w ramach obszarów metropolitalnych. Zwolennicy tej koncepcji argumentują, że taka forma może ograniczyć powielanie tych samych działań, stworzyć efekty ekonomii skali i warunki bardziej efektywnego dostarczania usług, polepszyć odpowiedzialność/jawność, umożliwić bardziej sprawiedliwy podział wpływów z podatków i poprawić wydajność planowania przestrzennego [KamalChaoui 2003, s. 3]. Krajem, który ma największe doświadczenia we wdrażaniu fuzji gmin w obszarach metropolitalnych jest Kanada. W wyniku fuzji powstały tam m.in.: Metro-Toronto, Miasto Ottawa i Nowe Miasto Montreal ${ }^{68}$. W Europie fuzja gmin nastąpiła w obszarze metropolitalnym Madrytu,

68 Więcej na temat fuzji gmin w obszarach metropolitalnych Kanady zob.: http://www.cmm.qc.ca, Fontan, Hamel, Morin, Shragge 2007; Klein, Tremblay 2010; Skogstad 2003; Rosso 2004; Collin, Leveillee, Poitras 2002; Reese 2004. 
kiedy to na przełomie lat 40. i 50. XX w. w granice administracyjne Madrytu włączonych zostało 13 otaczających go gmin [Navarro 2006, s. 6].

Tabela 13

Podstawowe charakterystyki obszarów metropolitalnych

\begin{tabular}{|l|c|c|c|c|}
\hline $\begin{array}{c}\text { Obszar } \\
\text { metropolitalny }\end{array}$ & Liczba gmin & $\begin{array}{c}\text { Liczba ludności } \\
\text { miasta } \\
\text { rdzeniowego } \\
\text { (w tys.) }\end{array}$ & $\begin{array}{c}\text { Liczba ludności } \\
\text { całego obszaru } \\
\text { metropolitalnego } \\
\text { (w mln) } \\
\text { wg EUROSTATU } \\
2011\end{array}$ & $\begin{array}{c}\text { Powierzchnia } \\
\left(\mathrm{km}^{2}\right)\end{array}$ \\
\hline Barcelona & 36 & 1620 & 3,6 & 636 \\
\hline Madryt & 179 & 3300 & 6,5 & 2704 \\
\hline Lizbona & 19 & 548 & 2,9 & 2934 \\
\hline Londyn & $33^{\mathrm{a}}$ & 7800 & 15 & $1607 \mathrm{c}$ \\
\hline Manchester & $10^{\mathrm{b}}$ & 484 & 2,6 & 1276 \\
\hline Kopenhaga & $29-45$ & 520 & 1,9 & 2561 \\
\hline Sztokholm & 65 & 872 & 2,1 & 6519 \\
\hline Mediolan & 189 & 1242 & 3,2 & 1578 \\
\hline Zurich & 171 & 390 & 2 & 2103 \\
\hline Stuttgart & 179 & 613 & 2,7 & 3654 \\
\hline Monachium & 186 & 1330 & 2,8 & 1114 \\
\hline Zagłębie Ruhry & 53 & & 7,8 & 4435 \\
\hline Hamburg & 800 & 1800 & 5 & 26000 \\
\hline Randstad & 147 & & 6,5 & 4500 \\
\hline Ile-de-France & 1281 & 2200 & 11,8 & 12000 \\
\hline
\end{tabular}

a boroughs; b dystryktów; c (GLA).

Źródło: [oprac. własne].

Model władzy metropolitalnej najczęściej polega na utworzeniu specjalnie na potrzeby zarządzania obszarem metropolitalnym, jedno lub dwuszczeblowej struktury władz. Rządy metropolitalne najczęściej są wybierane w wyborach bezpośrednich i dysponują szerokim zakresem uprawnień w ramach spraw społecznych, gospodarczych, infrastrukturalnych, środowiskowych i planowania przestrzennego, które pozwalają na realizację efektywnych i zintegrowanych strategii. Model dwuszczeblowy jest bardziej popularny. Występuje on m.in. w obszarach metropolitalnych Sztokholmu, Barcelony, Kopenhagi, Lizbony, Stuttgartu, Londynu. Madryt jest szczególnym przypadkiem obszaru metropolitalnego, który ma władze zintegrowane, usytuowane na poziomie regionalnym. Zintegrowany model władzy metropolitalnej wydaje się najbardziej efektywny z punktu widzenia skali problemów i możliwości, jakie stoją przed obszarami metropolitalnymi.

W środku tego rankingu znajduje się szereg porozumień o współpracy, które przyjmują formę różnego rodzaju władz międzygminnych tworzonych zazwyczaj z wykorzystaniem zasady dobrowolności. Są to najczęściej jednolub wielofunkcyjne agencje, których głównym zadaniem jest transport, 
planowanie przestrzenne czy rozwój gospodarczy. Takimi wielofunkcyjnymi podmiotami współpracy międzygminnej są przede wszystkim wspólnoty aglomeracji i wspólnoty miejskie we Francji.

Najczęstszą formą współpracy kooperacyjnej są związki współpracy międzygminnej, które mogą pełnić dwojakiego rodzaju funkcję:

- organu doradczego,

- podmiotu przejmującego od gmin członkowskich powierzone mu kompetencje (Holandia, Włochy, Szwajcaria, Niemcy).

Szczególnymi przypadkami są obszary metropolitalne Mediolanu i Zurychu, gdzie związki te są stowarzyszeniami prawa prywatnego [Niziołek 2008, s. 200].

Związki międzygminne mogą dotyczyć jednej dziedziny funkcjonowania współpracujących jednostek terytorialnych bądź obejmują większość spraw o znaczeniu metropolitalnym. Częstą praktyką jest tworzenie w jednym obszarze metropolitalnym wielu związków celowych, często o niejednakowym zasięgu terytorialnym (Barcelona, Manchester). W niektórych przypadkach kooperacja ta nie opiera się na dobrowolności, lecz zostaje wymuszona przez państwo, które, na drodze ustawy, określa jednostki terytorialne, mające $\mathrm{w}$ niej uczestniczyć oraz zakres kompetencji utworzonej w ten sposób władzy metropolitalnej (Lizbona).

Natomiast na drugim końcu tego rankingu lokują się nieformalne formy współpracy, przyjmujące formy konferencji, platform, forów, stowarzyszeń czy partnerstw tworzonych np. dla celów planowania strategicznego. Bazują one często na istniejących w regionie sieciach powiązań między aktorami, niekoniecznie mających związek z granicami terytorialnymi. Do grupy tej należą Stowarzyszenie Władz Lokalnych Zagłębia Ruhry i Region Metropolitalny Monachium.

Modele kooperacyjne pozwalają na zachowanie specyfiki, różnorodności i odrębności jednostek terytorialnych, które ze sobą współdziałają, reprezentując często odmienne interesy, przy jednoczesnym uwzględnieniu potrzeb zarządzania całym obszarem.

Obszary metropolitalne, w zależności od kraju, mogą być tworzone dobrowolnie lub mocą ustawy. Doświadczenia pokazują jednak, iż dobrowolność $\mathrm{w}$ łączeniu gmin $\mathrm{w}$ większe jednostki administracyjne nigdzie nie zdała rezultatu (Francja, Włochy).

Fragmentacja władz lokalnych i, w wielu przypadkach, mały rozmiar gmin w krajach europejskich (np. we Francji, w Szwajcarii), powoduje problem z dystrybucją funkcji i kompetencji między poszczególne szczeble władzy. Wiele władz lokalnych, znajdujących się najbliżej obywateli, które, zgodnie z zasadą subsydiarności, powinny świadczyć usługi powszechne, często nie ma odpowiedniego potencjału (organizacyjnego, finansowego, ludzkiego, technicznego), aby sprostać tym wymogom, gdyż są zbyt małe. 
Gospodarka gruntami, zanieczyszczenia, przeciążenia komunikacyjne, zdrowie publiczne, mieszkalnictwo oraz sprawy gospodarcze składają się na problemy pozornie nie do pokonania. Niektórzy przypisują tę nierozwiązywalność niedopasowaniom między skalą problemów, które występują na szczeblu metropolitalnym, a możliwościami prywatnych i publicznych instytucji, które są odpowiedzialne za ich rozwiązywanie. Małe samorządy nie są $\mathrm{w}$ stanie poradzić sobie z zadaniami metropolitalnymi ze względu na występowanie zbyt wielu sprzężeń zwrotnych z innymi jednostkami terytorialnymi, dlatego muszą ze sobą współpracować.

Współpraca międzygminna ma przewagę nad fuzjami, ponieważ pozwala na zróżnicowanie łączonych zasobów i partnerów, biorąc pod uwagę różnorodność wyłaniających się problemów. Zgodnie z zasadą subsydiarności oferuje większą elastyczność jeśli chodzi o określenie najbardziej odpowiedniej skali terytorialnej. Jej oczywistą zaletą jest to, że lokalni decydenci podnoszą swoje umiejętności w wyniku dzielenia się wiedzą i mając do czynienia z większymi problemami niż te, które musi rozwiązywać pojedyncza gmina.

Dobrowolna współpraca często jest bardzo trudna. Niemniej jednak bariery współpracy istnieją również w przypadku jej instytucjonalizacji. Do głównych czynników dezintegrujących należą:

- silne upolitycznienie i fragmentacja władzy,

- system finansowania działalności jednostek administracyjnych,

- nieujawnione konflikty,

- brak zaufania ze strony gmin ościennych do miasta centralnego,

- niechęć do współpracy dużych jednostek administracyjnych z małymi,

- niepełne zaangażowanie w pracę członków podmiotów metropolitalnych,

- brak uznania obszaru metropolitalnego w dokumentach rządowych,

- brak na szczeblu metropolitalnym kompetencji do realizacji zadań,

- centralizacja władzy i finansów,

- brak koordynacji między szczeblem metropolitalnym i gminnym oraz między działaniami różnych instytucji,

- wielość instytucji i zazębianie się kompetencji,

- brak identyfikacji mieszkańców z obszarem metropolitalnym,

- rozproszenie odpowiedzialności za kwestie metropolitalne na poziomie centralnym, brak koordynacji polityk sektorowych między ministerstwami,

- pośrednie wybory organów władzy,

- słaby udział sektora prywatnego,

- niedopasowanie granic administracyjnych do funkcjonalnych,

- obawa przed utratą kompetencji szczebla regionalnego i gminnego w przypadku stołecznych obszarów metropolitalnych.

Współpraca dotyczy bardzo różnych sytuacji w zależności od okoliczności, w jakich jest podejmowana oraz stawianych celów. Ogólnie rzecz biorąc, 
przybiera formę kumulowania zasobów (budżetowych, ludzkich, infrastrukturalnych) w celu poprawy lokalnych usług publicznych objętych jurysdykcją gmin członkowskich. Wszystkie sektory działalności komunalnej mogą być przedmiotem umów o współpracy. Należy jednak zauważyć, że lista kompetencji gmin różni się znacznie w poszczególnych krajach. Do najczęstszych kompetencji, jakie gminy przekazują instytucji metropolitalnej należą:

- tworzenie i utrzymywanie wspólnych instytucji zwiększających ich przewagę konkurencyjną, jak lotniska, parki technologiczne, placówki kultury, atrakcje turystyczne itp.,

- zagospodarowanie przestrzenne,

- infrastruktura i usługi publiczne o znaczeniu metropolitalnym (transport, gospodarka odpadami, bezpieczeństwo publiczne),

- promocja gospodarcza, przyciąganie inwestycji,

- podniesienie jakości życia mieszkańców,

- marketing terytorialny,

- planowanie strategiczne,

- rozwój mieszkalnictwa,

- ochrona środowiska,

- rozwój społeczny,

- podniesienie jakości życia,

- opieka zdrowotna,

- kultura i sport.

Ponieważ granice administracyjne niekoniecznie pokrywają się z obszarami, które tworzą gospodarczą całość, gminy mogą współpracować z zamiarem odgrywania bardziej skutecznej roli w lokalnym rozwoju gospodarczym dzięki wymianie informacji i dzieleniu się odpowiedzialnością za niektóre inwestycje, wspólnej produkcji wiedzy, etykietowaniu terytorialnemu (territorial labelling) oraz programom marketingowym, które mają pomóc odróżnić dany obszar od innych.

Formy współpracy najczęściej rozwijane są w krajach o rozwiniętej demokracji lokalnej i wysokim poziomie społeczeństwa obywatelskiego, które ma możliwość wyrażania swoich oczekiwań i partycypacji w procesach zarządzania rozwojem (Dania, Szwecja). W krajach na niższym poziomie rozwoju kapitału społecznego (Hiszpania, Portugalia, Włochy) droga do współpracy jest znacznie dłuższa i trudniejsza.

Najciężej jest nawiązać współpracę między poszczególnymi podmiotami w obszarach metropolitalnych w państwach, które dopiero zaczynają tworzyć społeczeństwo obywatelskie i silny kapitał społeczny. Do tej grupy krajów należą wszystkie kraje Europy Środkowowschodniej (z Polską na czele), w których demokracja jest bardzo młoda i rozwija się po długim okresie panowania reżimu komunistycznego. 
Dla Polski dobrym przykładem są przypadki Hiszpanii i Portugalii, w których przez lata reżimu funkcjonował model jednolitej władzy państwowej, oddziałujący na stosunki miejskie. Gminy były pozbawione autonomii. Sytuacja zmieniła się wraz z wprowadzeniem demokracji i przekazaniem odpowiedzialności za większość spraw publicznych gminom. Ten stan rzeczy powodował konieczność wprowadzania wielu zmian w ich kompetencjach, aby doprowadzić do dopasowania ich do potrzeb zarządzania podległym samorządom terytorium.

Różnie wygląda kwestia identyfikacji obszarów metropolitalnych na szczeblu centralnym. W niektórych krajach (Holandia) obszary metropolitalne stanowią punkt odniesienia $\mathrm{w}$ formułowaniu różnego typu polityk, ale nie mają politycznej legitymacji, która umożliwiłaby realizację tych polityk i sprostanie wyzwaniom, jakie przed nimi się pojawiają. Z kolei w innych są powołane ustawami wydawanymi przez rząd (Portugalia, Hiszpania) bądź wyznaczone w odpowiednich aktach prawnych (Francja). Francja to jeden z tych krajów OECD, które zajęły najbardziej jednolite stanowisko w kwestii tworzenia konkretnych układów instytucjonalnych w obszarach metropolitalnych. Z kolei w Szwecji i Szwajcarii są one wyznaczane przez Główne Urzędy Statystyczne. W Niemczech i Danii podchodzi się zaś do obszarów metropolitalnych od strony planistycznej i wyznacza się je w planach zagospodarowania przestrzennego.

Nowe systemy zarządzania, angażujące szerokie spektrum partnerów, którzy działają jako sieć, mogą w przyszłości zastąpić obecnie działające hierarchiczne struktury wykorzystując związki kontraktowe, takie jak partnerstwo między rządem centralnym a władzami lokalnymi (włączając również szczebel regionalny). Jednym z głównych problemów w zarządzaniu rozwojem obszarów metropolitalnych jest finansowanie różnego rodzaju działań. Funkcjonowanie władz metropolitalnych w większości wypadków realizowane jest ze składek gmin tworzących taki podmiot (Zurych, Lizbona, Sztokholm, Stuttgart, Mediolan), dotacji z rządu centralnego (Niemcy, Francja, Wielka Brytania) oraz ze środków unijnych (Dania). Tylko wybieralna władza metropolitalna może pozyskiwać środki z lokalnych podatków lub opłat i ma prawo dowolnie je wydawać, zgodnie z własnymi priorytetami (Francja).

Efektywnym mechanizmem finansowym stymulującym współpracę metropolitalną jest system kontraktów programowych. Kontrakty określają cele, charakter przekazywanych środków, warunki, jakie należy spełnić w związku z ich przekazaniem i zobowiązania poszczególnych stron. Jednocześnie kontrakty są w stanie wykorzystać rolę odgrywaną przez lokalnych decydentów, ich znajomość problemów oraz zasobów regionu co zapewnia zdolność lepszego ukierunkowania działań i wykorzystania niewydobytego dotychczas potencjału rozwojowego. Pociąga to za sobą otwarcie procesu 
negocjacji dla lokalnych podmiotów spoza sektora publicznego: przedstawicieli biznesu, obywateli, grup interesu itp. Kontrakty mogą pomóc wykorzystać różnorodność i rozwijać szczególne cechy każdego regionu w ramach pożądanej spójności na poziomie krajowym. Fakt, iż są one wynikiem negocjacji oznacza, że mają więcej wspólnego z planowaniem realizowanym razem przez różne poziomy władzy niż z ujednoliceniem regionalnych i lokalnych rozwiązań. Kontrakty praktykowane są we wszystkich krajach demokratycznych, najlepiej jednak funkcjonują we Francji. Najczęściej skierowane są na działania mające na celu:

- przyciąganie biznesu,

- dywersyfikację gospodarki,

- realizację inwestycji infrastrukturalnych (transport, sieci cyfrowe),

- rozwój szkolnictwa wyższego, badań, kształcenia i zatrudnienia.

Przypadki zarządzania w obszarach metropolitalnych Europy wyraźnie wskazują, że oprócz bliższej współpracy między władzami centralnymi i lokalnymi, między lokalnymi i regionalnymi oraz między samymi gminami coraz powszechniejsza jest zgoda co do tego, że czysto publiczna interwencja ma swoje granice. To zaś otwiera drogę dla lepszej współpracy pomiędzy sektorem publicznym i prywatnym. Główną zaletą partnerstwa publiczno-prywatnego jest dzielenie kosztów i ryzyka realizowanych projektów między oba te sektory. Jednak najważniejszą kwestią jest wspólna wola różnych podmiotów odnosząca się do poprawy warunków życia i gospodarczego rozwoju terytorium. Gospodarcza dynamika regionów wymaga, aby wszyscy aktorzy na poziomie krajowym, regionalnym i lokalnym - zarówno z sektora publicznego, jak i prywatnego - byli zaangażowani w podejmowanie decyzji dotyczących ich przyszłości. Uczestnictwo prywatnych partnerów w podejmowaniu decyzji i w realizacji różnego rodzaju usług, wspólnie z władzami publicznymi, leży w ich bezpośrednim interesie jako dostawców lub dostarcza pośrednich korzyści jako użytkownikom.

Partnerstwo publiczno-prywatne (PPP) dąży do zwiększenia bądź zapewnienia ram instytucjonalnych dla zaangażowania firm, obywateli i szeregu stowarzyszeń w lokalny i regionalny rozwój gospodarczy. Kluczową kwestią staje się więc nie to jak poprawić efektywność wydatków publicznych, ale w jaki sposób zapewnić, żeby prywatne zarządzanie publicznymi działaniami mogło nadal funkcjonować w interesie społeczeństwa. Formy partnerstwa publiczno-prywatnego najlepiej rozwinęły się $w$ tych obszarach, których władze podjęły się realizacji olbrzymich imprez na skalę międzynarodową (Lizbona, Barcelona) i które na podstawie pozytywnych doświadczeń zaczęły korzystać z tej formy współpracy przy realizacji innych projektów. PPP również dobrze funkcjonuje we Włoszech, Danii, Niemczech, natomiast bardzo niewielkie osiągnięcia $w$ tym zakresie ma 
Holandia, w której mamy do czynienia z silną centralizacją finansów publicznych.

Rekomendacje wypracowane przez rządy OECD przypisują bardzo ważne znaczenie w zarządzaniu obszarem metropolitalnym kwestiom planowania strategicznego. Doświadczenia państw Europy Zachodniej pokazują, iż planowanie strategiczne na poziomie metropolitalnym występuje bardzo rzadko, a strategie rozwoju tworzone są najczęściej przez miasta centralne. Pozytywnym przykładem w tym zakresie jest obszar metropolitalny Sztokholmu, w którym strategia rozwoju wpisana jest w regionalny plan zagospodarowania przestrzennego. Podobnie sytuacja wygląda w obszarze metropolitalnym Lizbony, ale $\mathrm{w}$ tym przypadku brak jest efektywnych instrumentów jej realizacji. Strategie na poziomie metropolitalnym mają też Kopenhaga, Londyn i Manchester, natomiast np. w regionie Ile-de-France taki dokument nie istnieje. Za wzór w tej dziedzinie może uchodzić Barcelona, gdzie zostało powołane specjalne stowarzyszenie do realizacji planów strategicznych.

W sytuacji, gdy funkcje planistyczne i administracyjne podzielone są między różne władze terytorialne najważniejsze są interesy lokalne i samorządy coraz bardziej ze sobą konkurują. Przeszkody w tworzeniu sieci planistycznych zależą od problemów strukturalnych, z jakimi borykają się poszczególne jednostki administracyjne oraz od charakteru organizacji metropolitalnych.

Wdrażanie strategii dla regionu metropolitalnego wymaga politycznego poparcia. Choć pomysły i projekty mogą wychodzić z think tanków i społeczności gospodarczej, to wdrożenie ich w życie wymaga zaangażowania politycznego i przywództwa. Brana pod uwagę musi być także specyfika lokalnego systemu zarządzania.

Konflikty między lokalnymi interesariuszami dotyczące kwestii metropolitalnych pojawiają się zarówno w tych obszarach, w których próby planowania są podejmowane, jak i w tych, w których ono nie istnieje. Systemy koordynacji międzygminnej często cechują ostre konflikty między miastem centralnym i otaczającymi je jednostkami, które to konflikty nie pozwalają na utworzenie skutecznych i politycznie autonomicznych podmiotów poziomej współpracy (Mediolan, Paryż). W przypadku monocentrycznych obszarów metropolitalnych, w których główne miasto jest zdecydowanie największą jednostką administracyjną i automatycznie dominuje w całym obszarze (Madryt), kluczowe jest wzmocnienie zaangażowania mniejszych gmin. Gminy powinny podejmować tę współpracę dobrowolnie, często w sposób nieformalny, i postrzegać ją jako „bezpieczną” w obliczu dominującej siły ośrodka centralnego. Jeśli takie początkowe kontakty pozwolą na zbudowanie wzajemnego zaufania (tak było np. w Regionie Sztokholmu), to te początkowo luźne, nieformalne układy mogą przekształcić się w bardziej 
trwałe i sformalizowane, gdyż władze mniejszych gmin zdadzą sobie sprawę, iż ich autonomia nie jest zagrożona przez wielkiego partnera.

Podstawowymi warunkami osiągnięcia sukcesu w zarządzaniu obszarem metropolitalnym jest uzyskanie consensusu wszystkich aktorów dotyczącego celów rozwoju, uzyskanie korzyści przez wszystkich interesariuszy. Pomóc temu może stosowanie rachunku korzyści i kosztów, który pozwoli na przedstawienie w czytelny sposób efektów realizowanych działań. Aby uwzględnić $\mathrm{w}$ rachunku korzyści i kosztów na poziomie lokalnym skutki efektów zewnętrznych (środowiskowe, społeczne) trzeba wymusić to $\mathrm{w}$ tym rachunku poprzez centralny system regulacyjny. Rząd powinien więc wdrożyć odpowiednie mechanizmy lub zmienić system finansowania jednostek terytorialnych a wtedy same władze lokalne dojdą do porozumienia. Typowy dla obszarów metropolitalnych jest problem tzw. jeźdźca na gapę. Polega on na tym, iż ośrodki centralne zazwyczaj finansują różnego typu usługi świadczone dla mieszkańców całego obszaru metropolitalnego, natomiast gminy ościenne niechętnie partycypują w kosztach tych usług. Pozytywnym przykładem dzielenia się kosztami usług jest przypadek Zurychu. Gminy zazwyczaj też konkurują ze sobą o mieszkańców i inwestorów wysokością stawek podatkowych. Zapobiec tej konkurencji może harmonizacja systemów podatkowych w obszarach metropolitalnych, która bardzo dobrze sprawdziła się we Francji.

Chociaż różnice między krajami w miejskiej ekonomii politycznej niewątpliwie wpływają na różnice w sposobach zarządzania, to specyficzne wzorce zarządzania, które się pojawiają, faktycznie są efektem dużo bardziej skomplikowanego zestawu wpływów i procesów. Największy wpływ na niechęć do współpracy wydają się mieć czynniki polityczne i obawa przed utratą własnej autonomii. Dużo łatwiej współpracuje się gminom w tych regionach, w których władza w różnych jednostkach administracyjnych sprawowana jest przez przedstawicieli tych samych partii. Przykładem kraju, w którym podziały polityczne są ważną barierą współpracy na szczeblu metropolitalnym są Włochy. Pomimo przyjęcia ustawy wprowadzającej miasta metropolitalne, przez okres trzech lat od wejścia jej w życie nie powstało żadne citta metropolitana.

Ważne jest również, aby w przypadku współpracy na poziomie metropolitalnym podjęły ją wszystkie gminy będące w zasięgu powiązań funkcjonalnych. Priorytetową dziedziną współpracy, która pojawia się praktycznie w każdym obszarze metropolitalnym, jest zintegrowany system transportu publicznego. Różne sposoby organizacji planowania transportu wskazują, że w proces planowania włączone są wszystkie gminy, których problem dotyczy, jeżeli nowo tworzona instytucja od razu ma obejmować cały obszar metropolitalny (Sztuttgart, Londyn). Jeśli jest to inicjatywa kilku gmin, do których przyłączają się kolejne, rzadko udaje się stworzyć system trans- 
portowy dla całego obszaru funkcjonalnego. Często udana współpraca w zakresie komunikacji publicznej jest przyczynkiem do podejmowania wspólnej realizacji kolejnych przedsięwzięć. Na przykład Metropolitalna Komisja Transporu miała kluczowe znaczenie dla procesu podejmowania decyzji w Stuttgarcie.

Bez względu na to, jaki model metropolitan governance zostanie przyjęty przez dany obszar, konieczne jest utworzenie władzy lub agencji mającej możliwość planowania, monitorowania, rewidowania, gwarantowania i realizacji strategii metropolitalnej. Z uwagi na fakt, że planowanie strategiczne $\mathrm{z}$ założenia jest procesem długotrwałym, obejmującym zbieranie danych, analizy, sformułowanie strategii i towarzyszących jej polityk, programów i projektów, wymaga alokacji profesjonalnych zasobów na zasadzie ciągłości. Zatem stały zaangażowany zespół profesjonalistów zapewni konieczną ciągłość i zaangażowanie oraz rozwój wiedzy oparty na własnych doświadczeniach.

W celu uzyskania pewności, że planowana strategia identyfikuje i odnosi się do kluczowych strategicznych spraw w obszarze metropolitalnym i że przyjęty dokument spotka się z powszechnym zrozumieniem i poparciem, konieczne jest stworzenie warunków do publicznej partycypacji w jego opracowaniu. Proces planowania strategicznego zazwyczaj angażuje wiele formalnych podmiotów, natomiast powinien włączyć również szereg nieformalnych ugrupowań i ogólnie społeczeństwo. Pełna transparentność i otwartość dla ogółu społeczeństwa i kluczowych interesariuszy w całym procesie planowania oraz późniejszy monitoring i ocena zapewnią powszechne zrozumienie strategii i ciągłość poparcia dla jej realizacji.

Jeśli chodzi o kwestie planowania przestrzennego na poziomie metropolitalnym, to bardzo ważne jest, aby na poziomie krajowym został opracowany Krajowy Plan Zagospodarowania Przestrzennego, który zapewniłby warunki do strategicznego planowania w regionach. Zasada subsydiarności zależy od przestrzennych ram funkcjonujących na poziomie Unii Europejskiej, kraju, regionu i lokalnym.

Aby osiągnąć cele planowania na poziomie metropolitalnym, musi istnieć ciało planistyczne, wyposażone $\mathrm{w}$ formalne uprawnienia, jakie pozwolą efektywnie je realizować. Musi ono mieć również prawo rozstrzygania konfliktów wokół kwestii, które wiążą się z interesem obszaru metropolitalnego jako całości.

Analiza przedstawionych przypadków metropolitan governance nie pozwala jednoznacznie stwierdzić, które z zastosowanych rozwiązań jest najlepsze. Niemożliwe jest stworzenie jednolitego modelu, który dałoby się zastosować we wszystkich krajach, a nawet w jednym z nich dla wszystkich obszarów metropolitalnych. Do podobnych wniosków doszły rządy państw 
członkowskich OECD, które wypracowały następujące kierunkowe rekomendacje dla tworzenia struktur zarządzania obszarami metropolitalnymi:

1. Przyjęcia takich struktur miejskich finansów publicznych, które lepiej pasowałyby do nowych czy też zmodyfikowanych struktur instytucjonalnych i podziału odpowiedzialności między różne szczeble władzy.

2. Unowocześnienia struktur administracyjnych w celu ulepszenia poziomu i jakości usług $\mathrm{w}$ obszarze metropolitalnym oraz oceny wpływu podejmowanych działań poprzez wprowadzenie systemów oceny.

3. Zastąpienia struktur hierarchicznych poprzez nowe elastyczne formy poziomej i pionowej współpracy (partnerstwo włączające kilka szczebli władzy lub podobne jurysdykcje w obszarze metropolitalnym, czasami przy współpracy sektora prywatnego i/lub wolontariuszy).

4. Wdrożenia większej przejrzystości i odpowiedzialności w procesach podejmowania decyzji, poprawienia dostępu społeczności do informacji i usług publicznych, wzmocnienia lokalnej demokracji poprzez ulepszone procedury wyborów.

5. Stworzenia lepszych ram dla długookresowego planowania strategicznego, pozwolenia władzom lokalnym na przejęcie inicjatywy w dziedzinie strategii rozwoju gospodarczego i pracy w ramach partnerstwa ze społecznością biznesu i osób poszukujących pracy [Kamal-Chaoui 2003, s. 3].

Za stworzeniem jednej struktury zarządzania obszarem metropolitalnym przemawiają następujące przesłanki:

1. W praktyce obszar metropolitalny stanowi jedną społeczność połączoną wspólną gospodarką, która została sztucznie podzielona pomiędzy rozdrobnione struktury władzy.

2. Potrzeby mieszkańców i przedsiębiorstw o zasięgu metropolitalnym nie mogą być zaspokojone poprzez te rozdrobnione struktury.

3. Wyeliminowanie rozproszenia kompetencji zlikwiduje problem nakładania i zazębiania się kompetencji poszczególnych władz, a władza metropolitalna będzie mogła bardziej efektywnie dostarczać dobra publiczne i usługi, osiągając przy tym większe korzyści skali.

Zwolennicy jednolitej struktury zarządzającej wskazują następujące dziedziny, w których władza metropolitalna może być bardziej efektywna:

- zaopatrzenie w wodę i odprowadzanie ścieków,

- gospodarka odpadami,

- dostarczanie energii,

- transport publiczny,

- planowanie przestrzenne.

I na tych płaszczyznach podejmowana jest współpraca na szczeblu metropolitalnym przez większość gmin wchodzących w skład analizowanych obszarów metropolitalnych. Natomiast nieco gorzej rola władz metropolitalnych przedstawia się $\mathrm{w}$ dostarczaniu takich usług społecznych, jak edu- 
kacja czy ochrona zdrowia. W tym przypadku lokalne społeczności mogą same woleć zdecydować, na jakim szczeblu dostarczać te usługi [Bish, Nourse 1975, s. 201].

Utworzenie struktury, która miałaby na celu rozwiązywanie regionalnych problemów i tworzenie consensusu stało się bardziej istotne odkąd stwierdzono, że miasta i ich przedmieścia stają się współzależne $\mathrm{w}$ wielu dziedzinach. Liczne badania wskazują na związek między zdrowymi miastami centralnymi a rozwojem przedmieść. Wzrost populacji w mieście i na przedmieściach, dochód per capita i ceny nieruchomości są pozytywnie skorelowane i te zależności umacniają się co dekadę począwszy od roku 1960 [Mattoon 1995, s. 4].

Inni badacze wskazują na przewagę modeli kooperacyjnych nad administracyjnymi, w których władze metropolitalne stanowią element jednolitego, hierarchicznego systemu władzy państwowej lub oparte są na szczeblowej, również hierarchicznej, strukturze zarządzania obszarem funkcjonalnym.

Każdy obszar metropolitalny musi w ramach ogólnej „filozofii" wypracować własny model organizacyjno-instytucjonalny pasujący do jego specyficznej sytuacji i narodowego kontekstu. 


\section{METROPOLITALNE ZARZĄDZANIE W POLSCE}

\section{Obszary metropolitalne wobec procesów globalizacji}

Otwarcie gospodarki Polski na procesy globalizacji i modernizacja związana $\mathrm{z}$ transformacją ustrojową przyniosły szereg zmian, które wpływają zarówno na gospodarkę, społeczeństwo, jak i organizację przestrzenną kraju [Kukliński, Kołodziejski, Markowski, Dziemianowicz 2000]. Reformy polityczne i gospodarcze jakie zostały przeprowadzone w Polsce, zmieniły sposób funkcjonowania i rozwoju miast oraz regionów. Mechanizm nakazowo-rozdzielczy został zastąpiony mechanizmem rynkowym, który jednak nie działał tak samo we wszystkich jednostkach terytorialnych [Domański 2001, s. 19]. W globalną sieć powiązań zostały włączone również polskie miasta. Globalizacja i metropolizacja spowodowały zmiany $\mathrm{w}$ hierarchii głównych ośrodków miejskich, ale przede wszystkim w intensywności i kierunkach relacji między poszczególnymi jednostkami osadniczymi.

Integracja krajowych systemów miast i rozszerzający się globalny wymiar gospodarki prowadzą do zwiększenia dominacji miast stołecznych i innych dużych ośrodków metropolitalnych. Włączenie polskiej sieci osadniczej w światowy system przepływu informacji, kapitału i inwestycji spowodowało odejście od koncepcji równego rozwoju całego kraju na rzecz umocnienia pozycji obszarów metropolitalnych [Dutkowski 2000, s. 37].

Te właśnie ośrodki, wraz z otaczającymi je strefami, są magnesem przyciągającym szybko rozwijający się sektor wyspecjalizowanych usług finansowych, konsultingowych, mediów, przemysłu wysokich technologii, strumienie kapitału, migrantów i turystów. To w nich następuje koncentracja nowoczesnego kapitału, infrastruktury techniczno-instytucjonalnej najwyższego rzędu, która doprowadziła do uzyskania przez metropolie, w stosunkowo krótkim czasie, istotnej przewagi konkurencyjnej nad innymi ośrodkami kraju [Makieła 2009, s. 6]. Znajduje to wyraz w niskiej stopie bezrobocia, skupianiu inwestycji dużych firm polskich i zagranicznych w usługach, a także w przemyśle, jak również w wysokim nasyceniu małymi i średnimi przedsiębiorstwami [Domański 2008, s. 136]. Z drugiej strony z wielkich miast i obszarów metropolitalnych 
wypierane są działalności zaliczane do tradycyjnej lub „starej” gospodarki. Następuje restrukturyzacja i przebudowa tych obszarów, przy stabilizacji czy nieznacznym wzroście ludnościowym netto.

W starych okręgach przemysłowych Europy, w tym w Polsce, nastąpiło przesunięcie sektorowe w kierunku wzrostu sfery usług i polaryzacji rynku. „Dojrzałe” krajowe systemy miast podlegają jednoczesnym procesom deindustrializacji oraz koncentracji nowych funkcji usługowych wysokiego rzędu w dużych miastach i na obszarach metropolitalnych. Deindustrializacja zachodzi głównie w obszarach metropolitalnych, w których był rozwinięty przemysł tradycyjny. Istotną rolę w przekształceniu produkcji przemysłowej odgrywają wewnętrzne efekty skali. To one były powodem rozwoju masowej produkcji w wielkich przedsiębiorstwach. Jednakże w niektórych gałęziach przemysłu efekty kosztowe mogą mieć dla sukcesu przedsiębiorstwa mniejsze znaczenie. Podobnie na znaczeniu mogą stracić bliskość i powiązania lokalizacyjne między różnymi etapami systemu produkcyjnego (częściami zakładu). To z kolei może prowadzić do pionowej dezintegracji produkcji i lokowania się pojedynczych procesów produkcyjnych w różnych miejscach. Spadek znaczenia wewnętrznych efektów skali otworzył pole dla małych i średnich przedsiębiorstw, a zarazem do elastycznej produkcji lepiej dostosowanej do zmieniającego się popytu. Nowe przedsiębiorstwa, zazwyczaj z sektora MŚP, tworzone są poza tradycyjnymi aglomeracjami. Dla przedsiębiorstw wznawiających produkcję lub dla firm nowo zakładanych, atrakcyjne są miasta będące ośrodkami centralnymi dzięki ich dobrze rozwiniętemu sektorowi usług i dostępności transportowej. Nowo powstające firmy lokują się zazwyczaj w pobliżu ośrodka centralnego, wzdłuż głównych szlaków drogowych. W ten sposób zmienia się pozycja miast i powstaje nowa sieć powiązań między nimi [Domański 2001, s. 26-29]. Ta pionowa dezintegracja starych przedsiębiorstw oraz rozkwit małych i średnich firm stworzyły nowe - zarówno pionowe, jak i poziome - związki produkcyjne i usługowe, których efektem jest zmieniona koncentracja przestrzenna związana $\mathrm{z}$ jednej strony z korzyściami wielkich miast i ich otoczenia, a z drugiej z ekspansją sieci wymiany w skali międzynarodowej [Harańczyk 1998, s. 88].

Obserwujemy upadek obszarów uprzemysłowionych o tradycyjnej produkcji, które miały wiodącą pozycję w rozwoju gospodarczym, a także przejmowanie roli liderów rozwoju przez nowe tereny, często do tej pory nieuprzemysłowione. Powstają nowe obszary produkcyjne, skupiające dziedziny o wysoko zaawansowanych technologiach [Wysocka 1994]. Upadek przemysłu i rozwój usług spowodowały dekoncentrację miejsc pracy z wielkich dzielnic przemysłowych i wzrost nasycenia obszaru metropolii firmami usługowymi. Usługi wyższego rzędu rozwijają się głównie w wielkich miastach, których pozycja w sieciach regionalnych, krajowych i międzynarodowych wzrasta, podczas gdy usługi niższego rzędu, które nie potrzebują wyso- 
ko wykwalifikowanych pracowników, towarzyszą rozwojowi nowych osiedli mieszkaniowych i przedsiębiorstw w strefie zewnętrznej oraz w bardziej oddalonych od centrum metropolii małych i średnich miastach. Spowodowało to również zmianę w charakterze dzielnic miejskich - z monofunkcyjnych w obszary o funkcjach mieszanych.

Wstąpienie Polski do Organizacji Współpracy Gospodarczej i Rozwoju (Organization for Economic Cooperation and Development - OECD) oraz NATO, przynależność do WTO czy integracja z Unią Europejską, zwiększyły dostęp zagranicznych inwestorów do polskiego rynku, a zarazem ich zaufanie do trwałości transformacji i dobrych perspektyw działalności w Polsce [Zorska 2002, s. 47]. Zmiany własnościowe, będące wynikiem prywatyzacji majątku państwowego, spowodowały pojawienie się polskich miast na globalnym rynku nieruchomości i umożliwiły napływ kapitału zagranicznego. Polska stała się krajem otwartym, do którego przypływa kapitał zagraniczny, głównie z Holandii, Francji, Niemiec, USA [Korol, Szczuciński 2006, s. 310] ${ }^{69}$. Firmy z kapitałem zagranicznym lokują się przede wszystkim w największych aglomeracjach [Harańczyk 1998, s. 60]. Na ich korzyść przemawia dobra infrastruktura techniczna oraz zaplecze produkcyjne, badawcze, dostępność komunikacyjna, bankowa, ubezpieczeniowa, a także wykwalifikowana kadra pracownicza [Skwierczyński 2004, s. 97-101].

Wchodzące do Polski nowe firmy potrzebowały dla swoich pracowników - zarówno cudzoziemców, jak i Polaków - lokali biurowych, mieszkań i usług. Spowodowało to rozwój rynku nieruchomości, opanowanego w dużym stopniu przez zagranicznych deweloperów [Jałowiecki 2000b, s. 43]. Rosnące dochody klasy średniej wywołały wzrost popytu na dobra i usługi, a to z kolei doprowadziło do ekspansji centrów handlowych i rozrywkowych. Nastąpił rozwój wielkopowierzchniowych obiektów handlowych, które lokuje

${ }^{69}$ Nabycie nieruchomości (pozamieszkaniowych) wymaga zezwolenia ministra spraw wewnętrznych i administracji. Z danych opublikowanych przez MSWiA wynika, że w latach 1990-1999 nierezydenci kupili legalnie około 17 tys. ha gruntów, czyli około 0,054\% powierzchni Polski. W 1999 r. zagraniczni inwestorzy otrzymali 1491 zezwoleń na zakup około 4,7 tys. ha gruntów, z czego np. na budowę stacji benzynowych kupiono ponad 119 ha gruntów, a pod budowę supermarketów 81 ha. W roku poprzednim spółki z udziałem kapitału zagranicznego otrzymały 1471 zezwoleń na zakup łącznie około 4 tys. ha gruntów, a w 1997 r. 1326 zezwoleń na zakup łącznie 2,7 tys. ha gruntów. Nierezydenci stają się także właścicielami akcji i udziałów w spółkach, które są właścicielami nieruchomości. Jeśli nierezydent chce objąć kontrolę nad taką spółką, musi otrzymać zezwolenie z MSWiA. W 1999 r. wydano 452 zgody, w tym 384 dla nierezydentów będących podmiotami gospodarczymi. W ten sposób nierezydenci nabyli 8,3 tys. ha. 
się najczęściej na obrzeżach miast lub w strefie podmiejskiej, zmieniając organizację ruchu w aglomeracjach. Nastąpiła zmiana w sposobie podróżowania do miejsc zakupów, polegająca na intensywnym wykorzystaniu samochodów przy jednoczesnym zmniejszeniu udziału pieszych i transportu zbiorowego [Parteka 2000b, s. 161-162]. Konsekwencją tego zjawiska jest wzrost ruchu na, i tak już przeciążonych, pasmach komunikacyjnych i powstawanie korków ulicznych. Lokalizacja obiektów wielkopowierzchniowych wpływa często negatywnie na środowisko, zaburzając stosunki wodne, zwiększając emisję hałasu i zanieczyszczeń bądź zakłócając krajobraz. Pojawia się konflikt interesów i funkcji zlokalizowanych w przestrzeni.

Zglobalizowanie sektora finansów w bardzo znacznym stopniu decyduje o tym co się dzieje na rynkach budowlanych w Polsce. 0 rozwoju miast decydują deweloperzy i banki. To oni podejmują wysiłek inwestycyjny i ryzykują pieniądze. Decyzje lokalizacyjne firm międzynarodowych pozostają de facto poza kontrolą władz lokalnych. Sektor biznesu z uwagi na procesy globalizacji, informatyzacji, skrócenie się cyklów życia produktów jest bardzo ekspansywny względem przestrzeni, zwłaszcza otwartych, niezabudowanych (green fields) dążąc do ich zawłaszczenia [Drzazga 2010, s. 229]. Działalność inwestycyjna podmiotów zagranicznych, nabywających droższe tereny budowlane i podejmujących znaczne inwestycje według własnych projektów architektonicznych, nie zawsze odpowiednich dla danego otoczenia i lokalnych warunków (np. komunikacyjnych), powoduje specyficzne efekty przestrzenne. $\mathrm{Z}$ jednej strony dynamizują procesy rozwojowe miast, ale mogą powodować też trudności w realizacji wielkich przedsięwzięć, np. komunalnych, nie będących przedmiotem zainteresowania prywatnych inwestorów krajowych i zagranicznych [Harańczyk 1998, s. 19].

Jak pokazała praktyka, inwestorzy ci nie są skłonni do samodzielnego inwestowania np. w przestrzeń publiczną. Zainteresowani są głównie zyskiem. Nie należy mieć złudzeń i oczekiwać poszanowania przez podmioty prywatne - często „na dorobku”, prymatu interesu publicznego. Przy słabości systemu planowania oddziaływanie obcego kapitału na decyzje władz dotyczące zagospodarowania terenów modyfikuje w ukryty sposób systemy planowania i prowadzi do spekulacji gruntami, która z kolei przyczynia się do fragmentacji przestrzeni w jeszcze większym zakresie niż w gospodarkach wysoko rozwiniętych.

Samorządy są w stanie oddziaływać na rynek nieruchomości poprzez odpowiednie regulacje i system planów zagospodarowania przestrzennego [Gaczek 2000]. Jednak fakt, iż większość planów zagospodarowania przestrzennego straciła swoją ważność po roku 2003 ułatwia spekulację gruntami i powoduje, że władze lokalne pozostają pod silnym wpływem inwestorów. Brak planów jest też jednym z czynników, które mogą zniechęcać potencjalnych inwestorów, z uwagi na długotrwałe procedury związane z uzyskaniem 
pozwolenia na budowę. Słabość planowania urbanistycznego doprowadziła do chaosu przestrzennego [Dutkowski 2000, s. 44], co jednoznacznie wskazuje na potrzebę reformy systemu planowania tak, aby metropolie i obszary metropolitalne miały skuteczną władzę planistyczną.

Obecnie presja ze strony obcego kapitału została przyhamowana przez kryzys. Załamanie $\mathrm{w}$ świecie finansowym bardzo mocno oddziałuje na procesy spowolnienia, zahamowania, niedoinwestowania w sektorze usług. Procesy globalizacji gospodarki wraz z uniwersalnym działaniem renty budowlanej, kształtującej ceny terenów w obszarach metropolitalnych sprawiają, że mechanizm rynkowy racjonalizuje wykorzystywanie terenów [Markowski 2000, s. 134].

Na skutek nadziei związanych z napływem zagranicznych inwestycji w całym kraju zostały odrolnione tysiące hektarów, czemu sprzyjała ustawa o automatycznym odrolnieniu terenów w granicach miast. Gminy przeszacowują potrzeby odnośnie do nowych terenów pod zabudowę i ulegając populistycznym namowom właścicieli terenów rolnych przekwalifikowują grunty rolne na budowlane. Analiza bezpośrednich inwestycji zagranicznych w Polsce pokazuje, że kapitał zagraniczny zainteresowany jest lokowaniem się głównie w sektorach małego ryzyka, regionach inwestowania strukturalnego, specjalnych strefach ekonomicznych oraz gminach tworzących dogodne preferencje podatkowe [Broszkiewicz 2005, s. 44]. Dlatego też gminy konkurują między sobą wysokością stawek podatków od nieruchomości oraz przygotowując atrakcyjne, uzbrojone tereny inwestycyjne lub też podejmując korzystne dla zewnętrznych inwestorów decyzje lokalizacyjne. Gminy rywalizują również o mieszkańców przygotowując atrakcyjne tereny pod budownictwo mieszkaniowe, przy czym nie myślą o rozbudowie usług - tym samym koszty obsługi pozostawiając w ośrodku centralnym. Celem konkurencji jest wzrost dochodów. Sytuacja ta nie sprzyja koordynacji działań poszczególnych j.s.t. wchodzących w skład obszarów metropolitalnych, co prowadzi do atomizacji procesów zarządzania rozwojem na poziomie poszczególnych gmin.

Ujednolicenie stylu życia, przejawiające się m.in. dążeniem wyższych warstw społeczeństwa do mieszkania w przyjaznym środowisku, powoduje rozlewanie się miast. Dynamicznie postępujący proces suburbanizacji polega na odpływie ludności miejskiej z dzielnic centralnych oraz wielkich osiedli do stref zewnętrznych głównych ośrodków miejskich, przyczyniając się do zmiany charakteru funkcjonalnego obszarów wiejskich w otoczeniu dużych miast, w odległości około 20-30 km od ich granic administracyjnych. Rośnie liczba osób zatrudnionych poza rolnictwem, utrwala się miejski styl bycia, jednocześnie postępuje zanik funkcji rolniczych i upodobnienie do krajobrazu miejskiego w wyniku utraty charakterystycznych cech 
tych obszarów. Na obszarach podmiejskich osiedlają się przede wszystkim ludzie zamożni, często dobrze wykształceni.

Rozlewanie się miast w Polsce jest silnie powiązane $\mathrm{z}$ chaosem budowlanym i brakiem różnego typu usług. Na Zachodzie wprawdzie również przejmuje się otwarte tereny, żeby zaspokoić nowe potrzeby i oczekiwania mieszkańców, ale buduje się jednostki kompleksowe, łączące funkcje mieszkaniowe $\mathrm{z}$ usługami. Natomiast w Polsce, wskutek presji obcego kapitału, zainteresowanego szybkim zyskiem, który nie jest nastawiony na zyski z wynajmu tych zasobów w dłuższej perspektywie, lokalom tym nie towarzyszą odpowiednie usługi. Powszechna jest sytuacja, że na tym samym obszarze poszczególne apartamentowce budowane są przez różne spółki, które po sprzedaży lokali opuszczają teren i realizują w innym miejscu kolejne inwestycje, nie troszcząc się o towarzyszącą infrastrukturę, która w praktyce nigdy się nie pojawia.

Ze względu na słaby i powolny rozwój infrastruktury społecznej i usług, a także brak miejsc pracy na tych obszarach, nowi mieszkańcy przedmieść zmuszeni są pracować i zaspokajać część swoich potrzeb w centrach głównych ośrodków miejskich. Powoduje to konieczność wielokrotnego przemieszczania się między miejscem zamieszkania a ośrodkiem centralnym lub strefą podmiejską położoną po przeciwnej stronie obszaru funkcjonalnego. Ze względu na brak dostatecznie rozwiniętego transportu publicznego mieszkańcy strefy podmiejskiej uzależnieni są od transportu indywidualnego, co przyczynia się do niewydolności układów transportowych i powstania kongestii, a także obniżenia sprawności całego układu danego ośrodka miejskiego [MRR 2012a, s. 75-76]. Globalizacja konsumpcji, przemiany na rynkach pracy, rozwój technologii komunikacyjnych (Internet, masowa motoryzacja) powodują potęgowanie zjawiska suburbanizacji.

Wyrazem globalnej konkurencji jest likwidowanie w poszczególnych krajach ograniczeń w rozwoju miast, a także realizowanie inwestycji mających na celu przyciągnięcie instytucji międzynarodowych [Szlachta 1995]. Pojawia się zapotrzebowanie na innowacje, dąży się do rozwoju sektora B+R. Poprawia się infrastruktura usług dla biznesu i infrastruktura otoczenia. Powstają powierzchnie biurowe, centra logistyczne, będące jednym z warunków konkurencyjności. Lokalne zasoby dają miastom szanse na rozwój nowych sektorów działalności oraz na wypełnienie nisz rynkowych, które nie zostały jeszcze odkryte.

Globalizacja wpływa również na sytuację na rynku pracy. Od początku okresu transformacji z jednej strony obserwujemy wzrost popytu na wysoko wykwalifikowaną siłę roboczą ze strony firm świadczących usługi wyższego rzędu oraz lokowanie się przedsiębiorstw zagranicznych w związku z niskimi kosztami niewykwalifikowanych pracowników. Powoduje to konieczność dostosowania oferty edukacyjnej do wymogów inwestorów. Z drugiej strony 
obserwujemy również odpływ tych przedsiębiorstw do innych krajów, w których koszty produkcji są mniejsze [Domański 2010, s. 267]. To stwarza nowe wyzwania dla samorządów związane ze wzrostem bezrobocia w wyniku masowych zwolnień. Pojawienie się obiektów handlowych będących własnością kapitału zagranicznego doprowadziło do upadku dużej liczby rodzimych przedsiębiorstw handlowych, które nie mają szansy wygrać walki konkurencyjnej z zagranicznymi inwestorami, często korzystającymi z różnych ulg. Sytuacja ta również stanowi wyzwanie dla samorządów.

Problemy, jakie można zaobserwować w polskich miastach, to niedostateczne zaangażowanie władz publicznych w procesy rozwoju miast, niewystarczające sposoby włączania mieszkańców i użytkowników miast w procesy dotyczące ich planowania i funkcjonowania, zły stan gospodarki przestrzennej i słabość planowania przestrzennego, co prowadzi także do niekorzystnych zjawisk na rynku nieruchomości [Rezolucja Lubelska 2012]. Brak jest $w$ dalszym ciągu mechanizmów negocjacyjnego zaspokajania sprzecznych interesów narastającej liczby podmiotów rywalizujących o przestrzeń miast. Miasto jest bardziej sceną otwartych lub ukrytych konfliktów, nie zaś sceną współpracy [Sagan 2000]. Cele rozwoju miast w małym jeszcze zakresie są kształtowane przez ich mieszkańców. Osiągnięcie satysfakcjonującej partycypacji mieszkańców wymaga ciągle dłuższego czasu i prowadzenia świadomej polityki społecznej.

Wymienione nowe zjawiska zachodzące w kształtującej się obecnie przestrzeni obszarów metropolitalnych wymagają nowych, niekonwencjonalnych sposobów zarządzania, nowych instytucji (publicznych oraz publicznoprywatnych), a także nowych rozwiązań instrumentalnych. Należy pamiętać, iż

region globalny to taki obszar, który budowanie swojej przewagi konkurencyjnej opiera także na sprawnym zarządzaniu władz, umożliwiającym wykorzystanie istniejących i tworzenie nowych walorów zwiększających jego atrakcyjność dla potencjalnych inwestorów i podmiotów już w nim funkcjonujących [Markowski, Kot, Stawasz 2000, s. 215].

Polskie metropolie właściwie nie mają wyboru, muszą aktywnie i innowacyjnie stawić czoła presji globalizacyjnej. Muszą się stosunkowo szybko dostosować i wywalczyć miejsce w hierarchii miast Europy. Od tego procesu zależy w dużym stopniu pomyślność i poziom życia ich mieszkańców. Obszary metropolitalne muszą podjąć działania w kierunku podniesienia konkurencyjności, aby uniknąć marginalizacji na arenie światowej. Do tego konieczne jest właściwe zarządzanie całym terytorium funkcjonalnym.

\section{Podejście do obszarów metropolitalnych $\mathbf{w}$ dokumentach krajowych}

Globalizacja procesów rozwoju i konieczność przestrzegania zasad zrównoważonego rozwoju spowodowały zmiany w relacjach między mia- 
stem a jego bezpośrednim otoczeniem i regionem [Fuhrmann i in. 2005, s. 17]. Zasadniczą kwestią stało się zarządzanie jednostkami funkcjonalnymi, jakimi są obszary metropolitalne. Nieformalne spotkanie ministrów Unii Europejskiej ds. Rozwoju Miast i Regionów, do którego doszło w grudniu 2005 r. w Bristolu zakończyło się tzw. Porozumieniem z Bristolu, w którym jedną z zakładanych cech zrównoważonych wspólnot miejskich jest przyjęcie systemów współrządzenia, które łączą strategiczne przywództwo z rzeczywistą partycypacją mieszkańców i organizacji [UK Presidency 2005]. Odniesienia do instytucji unijnych na temat metropolitan governance odnotowano również w maju 2007 r., podczas konferencji w Lipsku, na której przyjęto Agendę Terytorialnq Unii Europejskiej oraz Kartę Lipskq na temat Zrównoważonych Miast Europejskich ${ }^{70}$. Wagę miast i obszarów metropolitalnych dla rozwoju gospodarek krajowych zaczęto dostrzegać w Unii Europejskiej i na szczeblu krajowym. Raport Komisji Europejskiej pt. Cities of tomorrow stwierdza, iż „miasta mają kluczowe znaczenie dla zrównoważonego rozwoju Unii Europejskiej" [European Commission 2011, s. 6] i zwraca uwagę na fakt, że granice administracyjne miast nie odzwierciedlają już fizycznych, społecznych, gospodarczych, kulturalnych ani środowiskowych warunków ich rozwoju i konieczne są nowe formy elastycznego zarządzania.

W warunkach rozwoju Europy w XXI w. podstawę rozwoju obszarów metropolitalnych muszą tworzyć dwa współzależne cele strategiczne:

- stały wzrost pozycji metropolii na arenie Europy i świata,

- równoważenie procesu rozwoju ekonomicznego ze społecznym i przestrzennym, jako niezbędny warunek długofalowego utrzymania i utrwalenia jej pozycji.

Na podstawie diagnoz procesów rozwoju w Europie pojawił się nowy model/paradygmat polityki pobudzania rozwoju. W polityce regionalnej UE na okres programowania 2014-2020 można zauważyć wyraźne odejście od modelu zarządzania sektorowego na rzecz podejścia zintegrowanego i terytorialnego. Charakteryzuje się ono ukierunkowaniem na wykorzystanie endogenicznych potencjałów terytoriów określonych funkcjonalnie, integracją działań publicznych $\mathrm{w}$ wymiarze przestrzennym oraz wielopoziomowym systemem zarządzania.

Planowanie zintegrowane w UE jest rozumiane dwojako:

- jako narzędzie integracji przestrzeni europejskiej,

- jako narządzie realizacji rozwoju zrównoważonego.

Wyrazem tego może być dostrzeżenie znaczenia obszarów miejskich dla rozwoju Europy i wzmocnienie wymiaru miejskiego przyszłej polityki spójności.

Takie podejście obserwuje się również $\mathrm{w}$ dokumentach tworzonych przez polski rząd, np. Koncepcji Przestrzennego Zagospodarowania Kraju

70 Zobacz: rozdz. 3. 
(KPZK) czy Krajowej Strategii Rozwoju Regionalnego (KSRR). Także horyzontalne dokumenty strategiczne: Długookresowa Strategia Rozwoju Kraju 2030 (DSRK) oraz Średniookresowa Strategia Rozwoju Kraju 2020 (ŚSRK) umiejscawiają wymiar terytorialny jako istotny element wszystkich polityk i działań publicznych o charakterze rozwojowym.

27 kwietnia 2009 r. rząd przyjął dokument pt. Założenia systemu zarzqdzania rozwojem Polski. Przedstawiono w nim propozycję modelu systemu zarządzania rozwojem, mającego na celu zwiększenie skuteczności programowania i wdrażania polityki rozwoju oraz podniesienie jakości funkcjonowania instytucji publicznych. Model ten ma stanowić podstawę dalszych działań reformujących sposób prowadzenia i realizacji polityki rozwoju [MRR 2009]. W pierwszej części dokumentu dokonano diagnozy mankamentów obecnego systemu zarządzania. Z punktu widzenia wdrażania współzarządzania na szczeblu metropolitalnym, zwrócić należy uwagę na następujące stwierdzenia:

brak jest w Polsce jasno określonej polityki rządu zorientowanej na miasta - polityki miejskiej, rozumianej jako część polityki rozwoju. Konieczność wprowadzenia polityki miejskiej do zarządzania rozwojem na wszelkich poziomach władzy publicznej uzasadniona jest wieloletnimi zaniedbaniami w modernizacji miast, nawarstwiającymi się problemami społecznymi, zagrożeniami dla miejskich systemów przyrodniczych, a przede wszystkim potrzebą stworzenia warunków dla rozwoju polskich miast.

W obecnej strukturze administracyjnej [...] nie ma wyodrębnionej, centralnej jednostki odpowiadającej za szeroko rozumiane, kompleksowe zarządzanie rozwojem, w gestii której leżałaby m.in. koordynacja prac nad wszystkimi dokumentami strategicznymi, zapewnienie ich efektywnej realizacji oraz ocena rezultatów ich wdrażania. [i dalej:] Dominuje jednocześnie myślenie sektorowe w procesie programowania, wyrażające się w programowaniu działań w odniesieniu do określonego sektora i niechęci do programowania działań wychodzących poza zakres odpowiedzialności danego resortu... [MRR 2009, s. 8].

Niewątpliwą słabością dotychczasowego systemu programowania i realizacji polityk rozwojowych w Polsce było niewykorzystywanie dla zapewnienia osiągania celów rozwojowych [...] współpracy pomiędzy partnerami reprezentującymi różne instytucje publiczne (w szczególności administracji rządowej i jednostek samorządu), podmioty prywatne czy organizacje trzeciego sektora [MRR 2009, s. 10].

Bardzo istotnym mankamentem jest również oderwanie planowania przestrzennego od planowania społeczno-gospodarczego [MRR 2009, s. 10].

Pozytywne jest, iż rząd centralny zauważa te niedoskonałości i zamierza je przezwyciężyć, co znajduje wyraz w przyjmowanych w ostatnich latach strategiach i politykach. 
Wśród wyzwań i kierunków zmian zostały wymienione:

- konieczność uwzględnienia w polityce regionalnej koncepcji podejścia do obszarów strategicznej interwencji (w tym obszarów metropolitalnych i obszarów zurbanizowanych) [MRR 2009, s. 13],

- aktywne zaangażowanie wszystkich szczebli administracji publicznej oraz partnerów społeczno-gospodarczych $\mathrm{w}$ formułowanie i realizację polityk [MRR 2009, s. 14],

- zmiana formuły kontraktów wojewódzkich.

Proponowany model rozwoju przewiduje m.in. integrację wymiaru społeczno-gospodarczego z wymiarem terytorialnym oraz poszerzenie uprawnień samorządów (na poziomie regionalnym) [MRR 2009, s. 23].

Zastanawia jednak fakt, że w proponowanym układzie dokumentów strategicznych [zob. MRR 2009, s. 31] nie występują plany zagospodarowania przestrzennego obszarów metropolitalnych, do których odniesienia pojawiają się $\mathrm{w}$ innych dokumentach strategicznych i aktach prawnych (ustawa o zagospodarowaniu przestrzennym). Prawdopodobnie wynika to z faktu, że zgodnie z zapisem ustawy o zagospodarowaniu przestrzennym stanowią one część planów zagospodarowania przestrzennego województw, jednak w sytuacji, gdy we wszystkich dokumentach rządowych zaczyna dostrzegać się znaczenie obszarów metropolitalnych dla rozwoju kraju, zasadne wydaje się ich wyraźne wyodrębnienie jako jednego z bardziej istotnych elementów systemu zarządzania rozwojem.

Ministerstwo Rozwoju Regionalnego zobowiązało się przygotować Założenia krajowej polityki miejskiej, w zakresie m.in. rewitalizacji miast, przeciwdziałania niekontrolowanej suburbanizacji, wzmacniania funkcji metropolitalnych ośrodków miejskich. Krajowa polityka miejska ma być zintegrowana z dokumentami strategicznymi na poziomie zarówno rządowym, jak i regionalnym, metropolitalnym oraz lokalnym.

Rada Ministrów przyjęła również (24 listopada 2009 r.) Plan uporządkowania strategii rozwoju. Jego celem jest:

- ograniczenie liczby strategii i polityk z 42 obecnie obowiązujących do 9 nowych (rys. 16)

- stworzenie efektywnego systemu zarządzania rozwojem kraju z uwzględnieniem:

- większej spójności i komplementarności pomiędzy dokumentami strategicznymi,

- odejścia od „sektorowości” w planowaniu strategicznym,

- bardziej efektywnego wydatkowania środków z budżetu;

- aspekt terytorialny [Tumielewicz 2011]. 


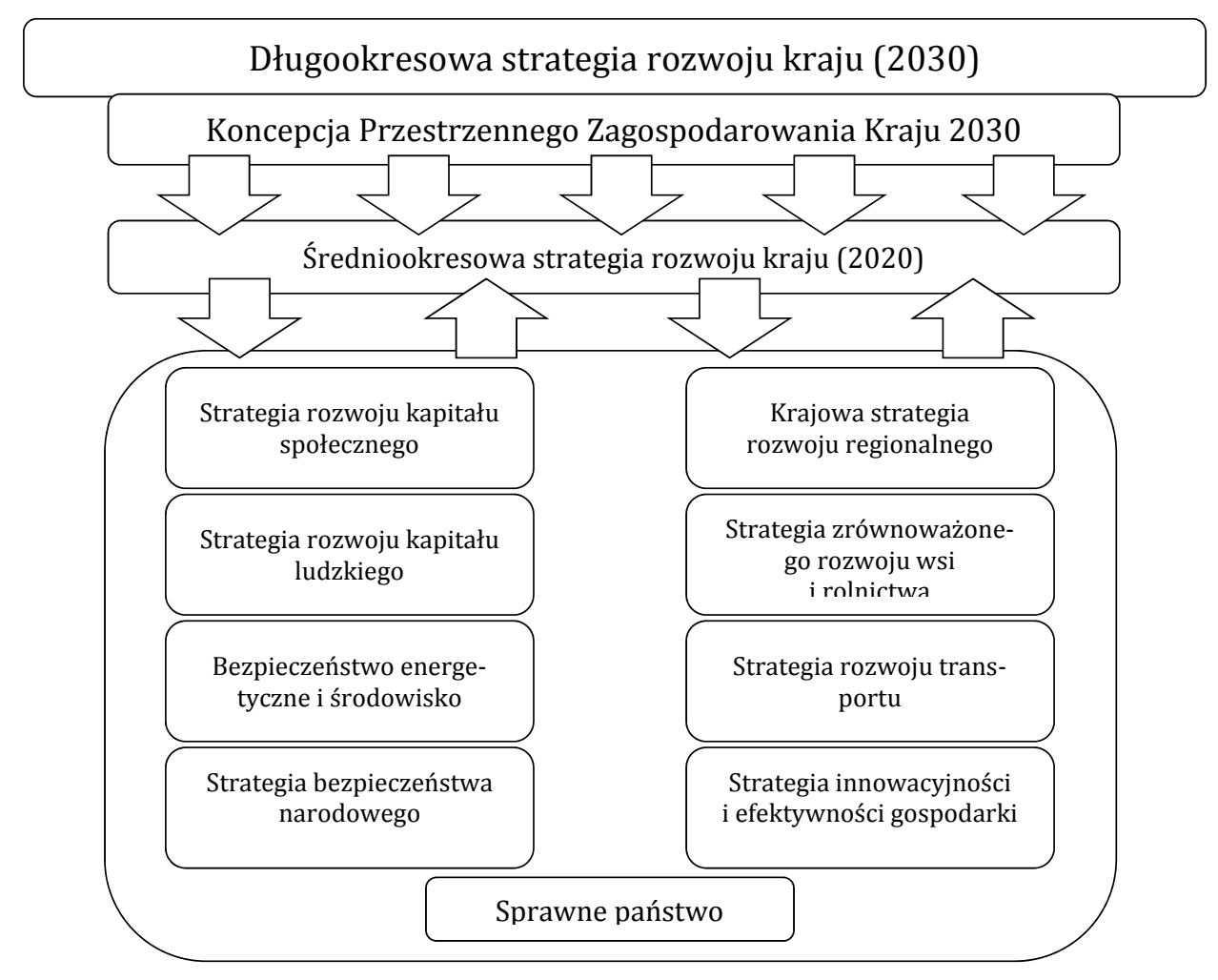

Rys. 16. Struktura nowych strategii

Źródło: oprac. własne na podstawie [Tumielewicz 2011]

Z Planu wynika, że za rozwój miast i obszarów metropolitalnych odpowiada Krajowa Strategia Rozwoju Regionalnego - Regiony - miasta - obszary wiejskie (KSRR), której koordynatorem jest Ministerstwo Rozwoju Regionalnego [MRRa 2010, s. 7]. KSRR została przyjęta przez Radę Ministrów 13 lipca 2010 r. Jednym ze strategicznych wyzwań w niej zapisanych jest lepsze wykorzystanie potencjałów najważniejszych obszarów miejskich do kreowania wzrostu i zatrudnienia oraz stymulowania rozwoju pozostałych obszarów [MRR 2010a, s. 24]. W KSRR nie używa się określenia obszary metropolitalne, lecz zalicza się je do grupy obszarów funkcjonalnych miast wojewódzkich. Uznaje się je za obszary nie tylko o największym znaczeniu społeczno-gospodarczym, naukowym i kulturowym, ale również za ośrodki przyciągające kapitał materialny i ludzki, za pośrednictwem których regiony konkurują w przestrzeni międzynarodowej. Obszary metropolitalne zostały zaliczone do obszarów strategicznej interwencji (OSI), na których będą koncentrować się ograniczone środki finansowe. Jednym z priorytetów rozwojowych jest tworzenie warunków, w ramach polityki regionalnej i innych koordynowanych przez nią polityk publicznych, do lepszego wyko- 
rzystania potencjału miast wojewódzkich jako „węzłów sieci miejskiej” w Polsce oraz włączenie ich w konkurowanie z najważniejszymi ośrodkami w Europie i na świecie. Konieczna jest do tego wymiana doświadczeń i wiedzy z zarządzania publicznego, współdziałanie instytucji naukowych i gospodarczych, które mogą przyczynić się do podniesienia rangi tych obszarów oraz zapewnienia stabilnego wzrostu gospodarczego całego kraju [MRR 2010a, s. 28]. Strategia wyraźnie wskazuje, że wykorzystanie terytorialnych potencjałów rozwojowych zależy także od sprawności i efektywności instytucji publicznych i jakości ich interakcji między sobą oraz od szerokiego spektrum innych podmiotów procesów rozwojowych [MRR 2010a, s. 70]. Warunkiem koniecznym do prowadzenia skutecznej polityki rozwoju obszarów metropolitalnych jest zintegrowanie procesu programowania strategicznego rozwoju społeczno-gospodarczego z planowaniem przestrzennym i planowaniem finansowym.

Według tego dokumentu kluczowe dla realizacji polityki regionalnej jest partnerstwo, które jest rozumiane jako współudział, współdecydowanie i współodpowiedzialność podmiotów publicznych $\mathrm{w}$ tworzeniu polityki i osiąganiu jej celów [MRR 2010a, s. 74]. Strategia wskazuje na znaczenie wzajemnego zaufania jako podstawy relacji między poszczególnymi podmiotami, głównie administracji rządowej i samorządowej, dla zwiększenia efektywności działań. To zaufanie partnerów ma być budowane z wykorzystaniem wzajemnej pewności i stałości celów rozwojowych, niezależnie od bieżących uwarunkowań politycznych [MRR 2010a, s. 75].

Strategia wprowadza bardzo ważną zasadę do sterowania rozwojem obszarów metropolitalnych. Jest nią warunkowość przekazywania środków finansowych. Podmioty najbardziej skuteczne w osiąganiu celów rozwojowych będą mogły liczyć na rodzaj premii, jaką będą dodatkowe środki lub instrumenty [MRR 2010a, s. 75]. Przewiduje się również umowy o charakterze cywilnoprawnym, tzw. kontrakty terytorialne, których celem będzie ukierunkowanie dotychczas rozproszonych działań rozwojowych na osiąganie wspólnych celów wyznaczonych $\mathrm{w}$ stosunku do terytorium [MRR 2010a, s. 145].

Koncepcja Przestrzennego Zagospodarowania Kraju 2030 (KPZK) za punkt odniesienia polityki przestrzennej uznaje miejskie obszary funkcjonalne, w ramach których wyróżnia obszary funkcjonalne ośrodków wojewódzkich, w tym metropolitalnych (obszary metropolitalne). Pierwszym z sześciu celów strategicznych KPZK 2030 jest „Podwyższenie konkurencyjności głównych ośrodków miejskich" [MRR 2012a, s. 6]. Cel ten ma zostać osiągnięty poprzez:

1. Wspieranie rozwoju funkcji metropolitalnych głównych ośrodków miejskich; 
2. Intensyfikację powiązań funkcjonalnych pomiędzy obszarami metropolitalnymi w układzie krajowym i międzynarodowym;

3. Integrację obszarów funkcjonalnych głównych ośrodków miejskich.

Kluczem do osiągnięcia tych celów ma być zintegrowane podejście do zarządzania oraz współpraca różnych podmiotów. Funkcjonowanie zintegrowanego systemu rozwoju opierać się ma na:

- zasadzie hierarchiczności celów zapewniającej koordynację działalności wszystkich podmiotów podejmujących decyzję z poszanowaniem subsydiarności organizacji władz samorządowych, co ma prowadzić do ograniczania szkodliwych zjawisk przestrzennych, m.in. konfliktów przestrzennych;

- zasadzie dynamicznego strefowania i wyznaczania obszarów planistycznych jako podstaw do planowania funkcjonalnego w celu wykorzystania lokalnych i regionalnych potencjałów oraz minimalizacji sytuacji konfliktowych. Zasada ta jest realizowana m.in. poprzez wyznaczenie obszarów metropolitalnych;

- zasadzie partycypacji społecznej. Aktywność społeczna jest niezbędna przy formułowaniu $\mathrm{w}$ pierwszej kolejności lokalnych strategii, polityk i prawa miejscowego. Efektywność realizowania polityki przestrzennej wymaga wzmacniania jakości kapitału ludzkiego i budowy społeczeństwa obywatelskiego, jak również przyjęcia zasady większej partycypacji społecznej, oznaczającej współudział oraz współodpowiedzialność podmiotów realizujących politykę rozwoju.

Podobnie jak KSRR, KPZK wskazuje na istotność zasad odnoszących się do wdrażania polityk publicznych, takich jak koncentracja geograficzna i tematyczna, partnerstwo i współpraca, warunkowość, gospodarka oparta na wiedzy, zintegrowane podejście terytorialne i koordynacja $\mathrm{z}$ innymi politykami, subsydiarność i wieloszczeblowość [KPZK 2012, s. 68]. Najważniejszym instrumentem planistycznym zapewniającym realizację polityk publicznych o oddziaływaniu terytorialnym, uwzględniającym specyficzne uwarunkowania geograficzne i społeczno-gospodarcze, będzie kontrakt terytorialny. Kontrakt wyznaczy cele w odniesieniu do różnych terytoriów, zidentyfikuje poszczególne podmioty zaangażowane w jego realizację, określi ich zadania oraz wskaże niezbędne środki finansowe [KPZK 2012, s. 171].

W maju 2012 r. Ministerstwo Rozwoju Regionalnego przedstawiło projekt założeń Krajowej Polityki Miejskiej. Przyczynkiem do jej tworzenia są prace nad nową perspektywą finansową Unii Europejskiej na lata 20142020. Już sama definicja polityki miejskiej podkreśla jej ukierunkowanie terytorialne [MRR 2012, s. 4], a zasady, którymi ma się kierować są zbieżne z zasadami przyjętymi w KSRR i KPZK. Najważniejsze z nich to: 
- zasada integralności: podporządkowanie krajowej polityki miejskiej polityce rozwoju, jest ona kierowana do miejskich obszarów funkcjonalnych w rozumieniu KPZK;

- zasada zintegrowanego podejścia terytorialnego;

- zasada wielopoziomowego zarządzania, która polega na ścisłej współpracy i koordynacji działań między rządem (i całą administracją rządową), samorządami województw i samorządami lokalnymi w układzie pionowym oraz poziomej współpracy jednostek samorządu terytorialnego (j.s.t.) i innych podmiotów dla osiągania wyznaczonych celów [MRR 2012b, s. 6].

Podobnie jak przedstawione wcześniej dokumenty również polityka miejska wskazuje na kluczową rolę miast i ich obszarów funkcjonalnych w rozwoju polskiej gospodarki [MRR 2012b, s. 6]. Cele w stosunku do obszarów metropolitalnych pokrywają się z zapisanymi w przyjętych już dokumentach i obejmują:

1. Poprawę ich konkurencyjności i zdolności do kreowania rozwoju, wzrostu i zatrudnienia.

2. Odbudowę zdolności do rozwoju poprzez rewitalizację zdegradowanych społecznie, ekonomicznie i fizycznie obszarów miejskich.

3. Wspieranie zrównoważonego rozwoju ośrodków miejskich, w tym przeciwdziałanie negatywnym zjawiskom niekontrolowanej suburbanizacji.

4. Stworzenie warunków do skutecznego, efektywnego i partnerskiego zarządzania rozwojem [MRR 2012b, s. 12].

We wszystkich dokumentach jednym z podstawowych zapisów jest rozwój miast i obszarów metropolitalnych jako ośrodków przemian i wzrostu. Pomimo pewnych niezgodności, jakie zachodzą między zaprezentowanymi dokumentami (np. różnice w zasięgu terytorialnym OSI oraz obszarów funkcjonalnych) bardzo pozytywnie należy ocenić fakt, iż wszystkie dokumenty kluczowe dla prowadzenia polityki regionalnej i zarządzania obszarami metropolitalnymi prezentują to samo podejście funkcjonalne do terytorium oraz zakładają konieczność zintegrowanego zarządzania rozwojem. Obiecująca jest również koncepcja wprowadzenia bardzo istotnego dla stymulowania rozwoju obszarów metropolitalnych instrumentu finansowego, jakim jest kontrakt metropolitalny. Doświadczenia wielu krajów Europy Zachodniej (Francja, Hiszpania, zob. rozdz. IV) pokazują, że instrument ten bardzo dobrze spełnia swoją funkcję.

\section{Projekty ustaw metropolitalnych}

W systemie organizacji terytorialnej państwa brak jest obszarów metropolitalnych jako wyodrębnionych struktur, które ze względu na wysoki poziom złożoności i specyfikę powinny być przedmiotem zarządzania strategicznego i koordynacji bieżących procesów rozwoju społeczno-gospodar- 
czego i zagospodarowania przestrzennego [Kołodziejski, Parteka 2000, s. 199]. W związku z toczoną od lat dyskusją na temat usprawnienia funkcjonowania obszarów metropolitalnych, podejmowane są różnego rodzaju inicjatywy zmierzające do zinstytucjonalizowania obszarów metropolitalnych. Bardzo wiele takich obszarów wstrzymuje się z podejmowaniem jakichkolwiek działań, czekając na ustawę metropolitalną. Mają one nadzieję, że nowe prawo sformalizuje dopuszczalne formy współpracy i określi sposób finansowania działań. Konieczność uchwalenia takiej ustawy silnie promowała m.in. Unia Metropolii Polskich (UMP), skupiająca przedstawicieli władz największych aglomeracji kraju.

\section{Projekt Unii Metropolii Polskich}

Unia Metropolii Polskich proponuje, aby w Polsce, w wyniku połączenia powiatów, powstało 12 subregionów metropolitalnych. Obszar metropolitalny miałby przejąć jak najmniej kompetencji gmin. Na czele metropolii stałaby rada regionu wybierana przez mieszkańców, dyrektor regionu i kolegium złożone m.in. z prezydenta największego miasta regionu, który byłby jego przewodniczącym, a także z przedstawicieli innych miast obszaru, gmin wiejskich, instytucji finansowych, dużych przedsiębiorstw, małych i średnich firm, uczelni, szkół średnich i instytucji badawczo-rozwojowych [Miasto... 2010].

28 czerwca 2007 r. na konferencji pt: Ustawa o zwiq̨zkach aglomeracyjnych. Wstęp do reformy samorzq̨du terytorialnego?, zorganizowanej we Wrocławiu przez Centrum Partnerstwa Publiczno-Prywatnego Lądka Zdroju, zostały zaprezentowane projekty ustaw aglomeracyjnych.

\section{Projekt ustawy metropolitalnej z 2007 r.}

3 stycznia 2007 r. minister spraw wewnętrznych i administracji powołał Zespół do Spraw Uregulowania Funkcjonowania Obszarów Metropolitalnych. Założenia do projektu ustawy metropolitalnej, przyjęte przez rząd PIS, przewidywały stworzenie instytucji obligatoryjnych komunalnych związków gmin zwanych Związkiem Metropolitalnym - z obwarowaną zastrzeżeniami możliwością opuszczenia ich przez samorządy. Część kompetencji związków miała być nadana mocą ustawy. Należą do nich opracowywanie wspólnego studium uwarunkowań i kierunków zagospodarowania przestrzennego, plan rozwoju komunikacji publicznej i zarządzanie drogami ważnymi dla związku [Mironowicz 2007, s. 31]. Pozostałe uprawnienia miałyby być stopniowo przejmowane z niższych szczebli. Projekt ustawy przewidywał wyznaczenie konkretnej liczby takich związków.

Organem stanowiącym związku, zgodnie z ustawą, miała być rada złożona $\mathrm{w}$ połowie $\mathrm{z}$ wójtów, burmistrzów i prezydentów a $\mathrm{w}$ połowie $\mathrm{z}$ przewodniczących rad gmin wchodzących w skład związku [Rząd... 2007]. 
Decyzje podejmowaliby tzw. podwójną większością głosów, drogą równoległych głosowań - w pierwszym każdy z członków dysponowałby jednym głosem, a w drugim o wadze głosu decydowałaby liczba mieszkańców gminy [MSWiA 2007].

Organ wykonawczy miał być jednoosobowy - funkcję tę sprawowałby menedżer wybierany w drodze konkursu na dwuletnią kadencję (bez ograniczenia ich liczby). To on dysponowałby finansami związku, a do jego odwołania potrzebna byłaby większość $2 / 3$ głosów w organie stanowiącym.

Trzecim organem metropolii byłaby instytucja arbitrażowa, powołana do rozwiązywania sporów między członkami związku [Borkowski 2007].

Na etapie prac projektowych przewidziano następujące sposoby finansowania związku:

- subwencję metropolitalną z budżetu, której wysokość miała być wprost proporcjonalna do dobrowolnych składek wniesionych przez członków;

- transfer dochodów z tych jednostek, które przekażą zadania obligatoryjnie lub dobrowolnie;

- dotacje celowe z budżetu państwa na realizację zadań zleconych przez administrację rządową;

- dobrowolne składki członków na finansowanie zadań nieobligatoryjnych;

- środki unijne [Stefaniuk 2007].

Akt ten nigdy nie został uchwalony, gdyż po opublikowaniu projektu do Ministerstwa Spraw Wewnętrznych i Administracji wpłynęło dużo interpelacji ze strony władz regionalnych z zastrzeżeniami co do prezentowanej treści. Fakt ten pokazuje, że problematyka obszarów metropolitalnych jest bardzo ważna dla przedstawicieli władz regionalnych, gdyż to one stanowią fundament rozwoju społeczno-gospodarczego, na który regiony chcą mieć wpływ. Potem zaniechano prac nad ustawą, ponieważ zaczęły powstawać propozycje nowych aktów prawnych.

Nieco inne rozwiązania proponował prezes Regionalnej Izby Obrachunkowej we Wrocławiu. Jego projekt ustawy metropolitalnej zakładał, że na czele związku gminnego stałby prezydent miasta. W zarządzie byliby wójtowie i burmistrzowie innych gmin, którzy będą się wymieniać. Przy zarządzie miałaby działać rada mająca - podobnie jak w przypadku sejmiku charakter uchwałodawczy. Nad całością nadzór miałby sprawować premier, uchwały rady mógłby zaś zaskarżać wojewoda.

Różnica między przedstawionymi koncepcjami jest zasadnicza: rząd chce, by przynależność do aglomeracji była obowiązkowa (być może zostałyby więc powołane „odgórnie”), autorzy projektu wrocławskiego proponują zaś, by aglomeracje powstawały dobrowolnie, oddolnie.

Jeszcze śmielsze rozwiązanie - opracowania dla każdej polskiej aglomeracji odrębnej ustawy metropolitalnej - zaproponował Jerzy Stępień, prezes Trybunału Konstytucyjnego [Stefaniuk 2007]. 


\section{Projekt ustawy o rozwoju miast, centrach rozwoju regionalnego i obsza- rach metropolitalnych}

Na posiedzenie Komisji Wspólnej Rządu i Samorządu Terytorialnego w dniu 28 maja 2008 r. przygotowany został projekt ustawy, który przewidywał obligatoryjne utworzenie 12 obszarów metropolitalnych wokół Warszawy, Katowic, Poznania, Krakowa, Wrocławia, Trójmiasta, Szczecina, Łodzi, Lublina, Rzeszowa, Białegostoku i Bydgoszczy z Toruniem. Obszary metropolitalne mogły być również tworzone na obszarach o łącznej liczbie mieszkańców powyżej 500 tys. mieszkańców, jeżeli gminy wykażą się zdolnością do podejmowania współpracy.

Zarządzanie obszarem metropolitalnym miało być powierzone powołanemu zespołowi metropolitalnemu. Do zakresu działania zespołu zaliczono:

- programowanie strategii rozwoju i zagospodarowania obszaru metropolitalnego;

- opracowywanie i uchwalanie programów lub planów metropolitalnych w dziedzinach:

- ładu przestrzennego, ochrony dziedzictwa kulturowego i ochrony środowiska,

- zaopatrzenia w energię elektryczną, cieplną oraz w gaz, wodociągów i zaopatrzenia w wodę, kanalizacji i oczyszczania ścieków komunalnych, wysypisk i unieszkodliwiania odpadów komunalnych,

- komunikacji i transportu zbiorowego,

- rynku pracy;

- przedsięwzięć, w tym o charakterze infrastrukturalnym;

- inicjowania i rozwijania współpracy jednostek samorządu terytorialnego w celu realizacji zadań mających znaczenie dla obszaru metropolitalnego;

- pozyskiwanie środków publicznych i prywatnych niezbędnych do realizacji zadań zespołu;

- promocji obszaru metropolitalnego [Projekt... 2008a].

Organem stanowiącym i kontrolnym zespołu miało być zgromadzenie zespołu (złożone z wójtów/burmistrzów/prezydentów i starostów wszystkich jednostek samorządu terytorialnego należących do zespołu), a organem wykonawczym - kolegium wykonawcze zespołu (złożone z prezydentów miast na prawach powiatu i przedstawicieli powiatów należących do zespołu).

Projekt przewidywał, iż dochodami zespołu metropolitalnego będą:

- składki jednostek samorządu terytorialnego,

- udział w podatku od towarów i usług, w wysokości określonej w ustawie z 13 listopada 2003 r. o dochodach jednostek samorządu terytorialnego,

- dochody z majątku zespołu,

- odsetki od środków finansowych gromadzonych na rachunkach bankowych zespołu, 
- dotacje i subwencje z budżetu państwa lub funduszy celowych,

- wpływy ze zbiórek publicznych a także spadki, zapisy i darowizny,

- inne dochody, w tym środki pochodzące z Unii Europejskiej i innych źródeł zagranicznych [Projekt... 2008a].

Projekt został oprotestowany z jednej strony przez mniejsze miasta, które zostały pominięte $\mathrm{w}$ ustawie, a $\mathrm{z}$ drugiej przez niektóre metropolie (np. Kraków), które nie chciały, aby rząd narzucał im zasad współpracy z innymi j.s.t. [Grochal 2008]. Kontrowersje wzbudziły też kwestie składu kolegium, w którym pominięte zostały gminy oraz fakt, iż na czele zespołu miał stanąć prezydent największego miasta, względnie funkcja przewodniczącego miała być sprawowana rotacyjnie przez prezydentów różnych miast [Rot 2009].

\section{Projekt ustawy o polityce miejskiej i współpracy jednostek samorządu terytorialnego w tym zakresie z 15.09.2008}

Kolejny projekt ustawy zakładał utworzenie mocą ustawy tylko warszawskiego i górnośląskiego obszaru metropolitalnego. 0 status metropolii miały ubiegać się też aglomeracje z liczbą ludności powyżej pół miliona mieszkańców, które będą chciały ze sobą współpracować. Mniejsze miasta miałyby więc udowodnić rządowi, że dogadały się z okolicznymi gminami. Za to aglomeracja, która nie chciałaby tworzyć metropolii, nie musiałaby tego robić. 0 przyznaniu statusu metropolii wnioskodawcom ostatecznie decydować miała Rada Ministrów na podstawie analiz i rekomendacji MSWiA. Granice obszarów metropolitalnych miał wyznaczać minister, po zaakceptowaniu ich przez zainteresowane gminy.

Do dochodów zespołu dodano wpłaty jednostek samorządu terytorialnego przeznaczone na realizację zadań, przyjętych przez zespół, ale usunięto udział w podatku VAT. Wysokość składek wnoszonych przez poszczególne j.s.t. ograniczono do wysokości $1 \%$ dochodów uzyskanych w poprzednim roku budżetowym. Organem wykonawczym, zamiast kolegium, miał być zarząd [Projekt... 2008b].

Projekt został oprotestowany przez marszałków wszystkich województw. Zastrzeżenia budził m.in. fakt, że narusza on istniejący system planowania przestrzennego i ogranicza samodzielność gmin. Grozi ponadto stworzeniem kolejnej, czwartej jednostki samorządu terytorialnego. Inna wątpliwość, to stworzenie w ustawie ram prawnych dla tworzenia dwóch kategorii obszarów metropolitalnych, wyznaczanych na podstawie różnych kryteriów potencjału demograficznego [Samorządy... 2008]. Nowy projekt ustawy nie gwarantował metropoliom dodatkowych pieniędzy [Metropolie... 2008]. Ograniczenie wysokości składek oznaczało, że w przypadku największych miast byłyby to kwoty rzędu kilkunastu, najwyżej kilkudziesięciu milionów złotych, natomiast w przypadku mniejszych gmin kwoty te 
byłyby symboliczne, podczas gdy inwestycje metropolitalne nierzadko warte są kilkaset milionów złotych [Rot 2009].

\section{Projekt z 8 maja 2009 r. ustawy o polityce miejskiej państwa i wspót- pracy jednostek samorządu terytorialnego $w$ tym zakresie}

Nowa propozycja ustawy przewidywała utworzenie z mocy prawa obszarów metropolitalnych z łączną liczbą mieszkańców co najmniej 2 mln i o gęstości zaludnienia 200 osób na $1 \mathrm{~km}^{2}$ oraz w przypadku, gdy co najmniej trzy miasta na prawach powiatu pozostają ze sobą w bezpośrednim związku funkcjonalno-przestrzennym [Projekt... 8.05.2009]. Biorąc pod uwagę te kryteria odpowiednie rozporządzenia Rady Ministrów utworzyłyby trzy obszary metropolitalne: warszawski, górnośląski i trójmiejski. Obszary metropolitalne mogły być również tworzone na obszarach o łącznej liczbie mieszkańców powyżej 500 tys. mieszkańców z inicjatywy Rady Ministrów lub gmin.

Na skutek protestu marszałków wobec poprzedniego projektu [Kuraś 2008], do składu zarządu zespołu metropolitalnego dodano marszałka województwa, na terenie którego znajduje się obszar metropolitalny, lub jego przedstawiciela [Projekt... 15.09.2009]. Pozostałe zapisy pozostały takie same jak w projekcie poprzednim.

Ponieważ kolejne projekty ustaw metropolitalnych spotykały się z brakiem akceptacji, żeby uciąć spory, szef MSWiA Jerzy Miller zaproponował w kwietniu 2010 r., by polskie metropolie same stworzyły ustawy regulujące kwestie ich aglomeracji, opierając się na własnych potrzebach i uwzględniając lokalne konteksty [http://m.wroclaw.gazeta.pl/wroclaw/1,106542,8645769.html]. Natomiast ministerstwo zaproponowało bardziej elastyczne pojęcie metropolii i zamiast „ustawy metropolitalnej" zaczęto prace nad ustawą o rozwoju lokalnym, współpracy samorządów terytorialnych i rozwoju obszarów wiejskich.

\section{Projekt ustawy o współdziałaniu w samorządzie terytorialnym na rzecz rozwoju lokalnego i regionalnego (zw. ustawa o współdziałaniu)}

Niezależnie od prac w MSWiA trwały prace w Kancelarii Prezydenta nad ustawą o wzmocnieniu udziału mieszkańców w samorządzie oraz o współdziałaniu gmin, powiatów i województw. Pierwotny projekt ustawy powstał wiosną 2011 r. i został stworzony przez społecznych doradców prezydenta RP ds. samorządu oraz przedstawicieli środowisk samorządowych. Projekt zawierał rozwiązania proponowane przez korporacje samorządowe podczas spotkań Forum Debaty Publicznej, czyli konsultacji społecznych prowadzonych przez Kancelarię Prezydenta RP. Korporacje samorządowe i organizacje pozarządowe wyraziły jednak negatywne stanowisko wobec niego. 
Najnowszy projekt tej ustawy pojawił się 21 grudnia 2012 r. pod nazwą Ustawa o współdziałaniu $w$ samorządzie terytorialnym na rzecz rozwoju lokalnego i regionalnego oraz o zmianie niektórych ustaw.

Ustawa o współdziałaniu wprowadza dodatkowe formy organizacji społeczności lokalnej w celu szerszej partycypacji społeczeństwa w życiu publicznym, ale przede wszystkim stwarza warunki prawne do dobrowolnej współpracy jednostek samorządu lokalnego. Formy współpracy przewidują powołanie:

- konwentu powiatowego,

- konwentu delegatów samorządu lokalnego w województwie - konwentu wojewódzkiego,

- zespołu współpracy terytorialnej.

Konwent powiatowy ma być instrumentem współdziałania gmin i powiatu o charakterze koordynacyjnym, w zakresie:

- polityki rozwoju lokalnego powiatu i gmin z terenu powiatu,

- planowania przestrzennego,

- zadań z zakresu ochrony zdrowia, pomocy społecznej, oświaty, transportu zbiorowego i dróg publicznych, bezpieczeństwa i porządku publicznego, usuwania odpadów i ochrony środowiska.

Konwent ma dysponować uprawnieniami opiniodawczymi w zakresie strategii rozwoju oraz studium kierunków i uwarunkowań zagospodarowania przestrzennego. $W$ jego skład wchodzą wójtowie gmin, burmistrzowie i prezydenci miast $\mathrm{z}$ terenu powiatu oraz starosta powiatu. Prace konwentu mają odbywać się w stałych zespołach roboczych, w obradach, których mają brać udział przedstawiciele podmiotów istotnych z punktu widzenia funkcjonowania danej dziedziny zarządzania publicznego, w szczególności przedstawiciele instytucji użyteczności publicznej, organizacji pozarządowych i przedsiębiorców.

Konwent wojewódzki ma stanowić formę współdziałania gmin i powiatów z samorządem województwa, o charakterze koordynacyjnym, z uprawnieniami opiniodawczymi w zakresie strategii rozwoju województwa, innych dokumentów planowania strategicznego, w tym regionalnego programu operacyjnego, a także projektu budżetu województwa.

Zespół współpracy terytorialnej ma być tworzony w celu współpracy sąsiadujących jednostek samorządu lokalnego w odniesieniu do zagospodarowania przestrzennego, polityki rozwoju oraz wspólnych przedsięwzięć i zadań mających znaczenie dla całego obszaru. Mogą go utworzyć gminy stanowiące ciągły przestrzennie układ osadniczy. W skład zespołu może wejść także powiat, który obejmuje przynajmniej niektóre gminy tworzące zespół. Powstanie zespołu wymaga przyjęcia jego statutu przez rady zainteresowanych jednostek samorządu lokalnego bezwzględną większością głosów ustawowego składu rady. Uproszczony - w stosunku do przypadku 
zespołów metropolitalnych proponowanych w ustawach metropolitalnych został tryb przyjmowania do zespołu nowych członków. Wymaga on uchwały organu stanowiącego zainteresowanej jednostki oraz zgody zgromadzenia zespołu (a nie uchwał organów stanowiących wszystkich członków).

Do zakresu działania zespołu należeć ma przede wszystkim opracowanie i uchwalenie ramowego studium uwarunkowań i kierunków zagospodarowania przestrzennego całego obszaru zespołu, zawierającego ustalenia wiążące przy sporządzaniu studium uwarunkowań i kierunków zagospodarowania przestrzennego gminy oraz miejscowego planu zagospodarowania przestrzennego. Inne zadania podejmowane przez zespół mają charakter dobrowolny. Ich realizacja zależy od wspólnej decyzji zainteresowanych samorządów lokalnych.

Organem stanowiącym i kontrolnym zespołu ma być zgromadzenie zespołu składające się z wójtów (burmistrzów, prezydentów miast) i starostów j.s.t. należących do zespołu. Organem wykonawczym ma być dyrektor wykonawczy wybierany przez zgromadzenie. Ustawa proponuje podobne dochody jak ustawy metropolitalne (bez udziału w podatkach).

Z uwagi na fakt, iż współdziałanie dotyczy nie tylko współpracy jednostek terytorialnych, lecz również innych podmiotów, bardzo istotny jest zapis, który proponuje ustawa, a mianowicie wprowadzenie przepisów umożliwiających tworzenie na szczeblu powiatów powiatowych konferencji rozwoju gospodarczego. Konferencja taka ma być płaszczyzną współpracy między samorządami a podmiotami gospodarczymi, mającą na celu wspieranie rozwoju gospodarczego. Ma ona opiniować projekty tych uchwał, zgłaszanych przez powiat lub gminę, które mają potencjalnie największy wpływ na rozwój powiatu. Warto w tym miejscu zauważyć rozwiązanie wprowadzające obligatoryjnie, nie rzadziej niż raz w roku, wspólne posiedzenie konferencji i konwentu powiatowego.

Z punktu widzenia realizacji zasad metropolitalnego zarządzania bardzo korzystne jest:

- wprowadzenie obowiązku podawania do publicznej wiadomości projektów uchwał, co znacznie zwiększy przejrzystość funkcjonowania samorządu;

- wprowadzenie, jako zasady, głosowania imiennego $\mathrm{w}$ organach stanowiących. Możliwość ustalenia sposobu głosowania przez poszczególnych radnych zwiększa przejrzystość funkcjonowania samorządu, a jednocześnie sprzyja kształtowaniu się poczucia odpowiedzialności radnych za podejmowane decyzje;

- przesądzenie o możliwości tworzenia przez organ wykonawczy j.s.t. ciał pomocniczych i doradczych. Zmiana ta ułatwi tworzenie instytucjonalnej płaszczyzny współpracy z grupami i środowiskami istotnymi dla rozwoju lokalnego i regionalnego; 
- umożliwienie tworzenia związków celowych gminno-powiatowych, jeżeli celem działania związku jest wykonywanie zadań publicznych w dziedzinie należącej zarówno do zakresu działania gminy, jak i powiatu [Projekt... grudzień 2012].

Przypuszczalnie zaproponowane rozwiązanie sprawdzi się w tych miejscach, gdzie jednostki samorządu terytorialnego są aktywne, a władze skłonne do współpracy. Ze względu na skalę działania proponowane rozwiązania mogą być natomiast niewystarczające dla dużych zespołów metropolitarnych.

\section{Projekty „na miarę” poszczególnych obszarów metropolitalnych}

W opozycji do propozycji rządowych, powstają projekty ustaw „skrojonych" na potrzeby konkretnych obszarów metropolitalnych. Przeciwnikiem ustawy metropolitalnej regulującej w jednolity sposób funkcjonowanie wszystkich obszarów metropolitalnych jest Konurbacja Górnośląska, której przedstawiciele stoją na stanowisku, że dla obszaru policentrycznego, jaki tworzy 14 miast aglomeracji katowickiej, powinna opracowana zostać oddzielna ustawa. Pierwszy pomysł śląskich samorządowców, dążących do formalnego ukonstytuowania największej w Polsce metropolii, złożonej z 17 miast, pojawił się już w grudniu roku 2006, jeszcze przed zarejestrowaniem Górnośląskiego Związku Metropolitalnego (GZM). Projekt ustawy metropolitalnej dla aglomeracji katowickiej, z inicjatywy śląskich posłów Platformy Obywatelskiej, opracowany został przez ekspertów z Uniwersytetu Śląskiego. Zgodnie z projektem 14 miast aglomeracji katowickiej miało z mocy ustawy wejść w skład powiatu metropolitalnego, by wspólnie realizować strategiczne zadania. Samorządowcy nie zaakceptowali jednak tego projektu. Projekt do chwili obecnej nie został złożony w sejmie [Zasada 2012]. Konkurencyjną ustawę tworzy w Gliwicach Stowarzyszenie „Ordynacka” oraz prezydent miasta [„Dziennik Zachodni” 2012]. Obecnie powstaje już czwarty projekt tzw. ustawy śląskiej.

Od dawna wiadomo, że niechętny tej ustawie jest rząd [Zasada 2012, s. 7], który zaniechał prac nad ustawami metropolitalnymi i rozpoczął prace nad Zieloną księgą obszarów metropolitalnych.

Urząd Marszałkowski województwa dolnośląskiego w listopadzie $2010 \mathrm{r}$. zainicjował dyskusję nad stworzeniem Ustawy o Wrocławskim Obszarze Metropolitalnym. Przeciwny temu pomysłowi jest prezydent Wrocławia będący zwolennikiem ustawy zaproponowanej przez UMP [Dyskusja... 2010].

\section{Biała księga obszarów metropolitalnych}

Z kolei Ministerstwo Administracji i Cyfryzacji przeprowadziło konsultacje dotyczące funkcjonowania obszarów metropolitalnych w ramach tzw. Zielonej księgi obszarów metropolitalnych. Księga zawierała 17 pytań odno- 
szących się do wydzielonych obszarów problemowych, odpowiedzi na te pytania $^{71}$ były podstawą do przygotowania na początku roku 2013 Białej księgi obszarów metropolitalnych, która proponuje szereg rozwiązań mających na celu usprawnienie funkcjonowania obszarów metropolitalnych. Do najważniejszych z nich należą:

- wprowadzenie możliwości powoływania związków gminno-powiatowych,

- zachęty finansowe dla gmin do podejmowania współpracy; gminy, które wspólnie zdecydują się realizować projekty o znaczeniu metropolitalnym, miałyby możliwość uzyskania dodatkowych funduszy;

- Zintegrowane Inwestycje Terytorialne (ZIT), przygotowane przez MRR, których finansowanie ma odbywać się ze środków UE w ramach nowo projektowanej polityki spójności na lata 2014-2020; Najważniejszym warunkiem realizacji ZIT jest udokumentowanie chęci jednostek samorządu terytorialnego do współpracy, które będzie wyrażać się zawiązaniem zinstytucjonalizowanej formy partnerstwa zwanej Związkiem ZIT72. Organem wykonawczym Związku ZIT miałby być Zarząd Związku ZIT, którego przewodniczącym jest prezydent miasta wojewódzkiego, realizującego konkretny ZIT, również zapewniający obsługę administracyjną Związku³. W przypadku obszarów metropolitalnych z dwoma miastami wojewódzkimi (Bydgoszcz i Toruń) przewodnictwo miałoby być pełnione rotacyjnie [MAC 2013]. Zapis ten już spotkał się z protestem prezydenta Bydgoszczy [zob.: Wątpliwości... 2013].

$$
* * * *
$$

Każdy z przedstawionych projektów ma swoich zwolenników i przeciwników. Szerokie grono samorządowców uważa też, że żadna nowa ustawa nie jest potrzebna. Ich zdaniem byłby to niepotrzebny rozrost biurokracji, zwłaszcza że Ustawa o samorządzie gminnym daje możliwość tworzenia związków gminnych jako podstawy prawnej powstawania aglomeracji [Stefaniuk 2007]. Śledząc różne propozycje aktów prawnych, które miałyby regulować funkcjonowanie obszarów metropolitalnych, z całą pewnością można stwierdzić, że panuje w tym zakresie wielki chaos. Proces metropoli-

71 MAC uzyskało 158 odpowiedzi na pytania zawarte w Zielonej księdze (78 od instytucji publicznych, 34 od NGOs oraz 46 od osób fizycznych i przedsiębiorstw.

72 Związek ZIT może być utworzony w formie związku międzygminnego lub powiatowego, stowarzyszenia jednostek samorządu terytorialnego, porozumienia międzygminnego lub spółki założonej wspólnie przez jednostki samorządu terytorialnego.

${ }^{73}$ Szczegółowe zasady realizacji instrumentu ZIT opisane są w dokumencie Zasady uwzględniania wymiaru miejskiego polityki spójności UE, $w$ tym realizacja Zintegrowanych Inwestycji Terytorialnych, przygotowanym przez Ministerstwo Rozwoju Regionalnego. 
zacji w Polsce jest w dużym stopniu upolityczniony. To, czy dane miasto zostanie metropolią czy też nie (według Ustawy), zależy od siły przebicia i zdolności politycznych jego włodarzy [Dziemianowicz, Łukomska 2009, s. 28]. Za przygotowanie ustaw biorą się ministerstwa, które oderwane są od polityki regionalnej. Żaden z projektów nie wyszedł z Ministerstwa Rozwoju Regionalnego, które z założenia powinno zajmować się tą problematyką. Żaden $\mathrm{z}$ analizowanych projektów nie jest też doskonały. Wykazują one braki, niejasności, są niedopracowane, brak w nich głębszego przemyślenia odnośnie do konsekwencji wprowadzonych ewentualnie rozwiązań. Cały czas rząd nie może zdecydować się nawet na ostateczną definicję obszaru metropolitalnego. Istotne jest zapewnienie odpowiednich środków finansowych, gwarantujących systemowe rozwiązywanie żywotnych dla obszarów metropolitalnych problemów; dokładne określenie, jakie sprawy winny być rozwiązywane na poziomie metropolitalnym, a jakie pozostałby w całość w gestii gmin, powiatów, województwa rządowego i samorządowego; przeprowadzenie oceny, w jakim zakresie j.s.t. byłyby skłonne przekazać część zadań na rzecz jednostki realizującej przedsięwzięcie zgodnie z potrzebami mieszkańców obszaru metropolitalnego, a także, co się z tym ściśle wiąże, jakie kwoty środków finansowych winny być przekazane przez j.s.t. na te cele oraz czy jest możliwe i uzasadnione przekazanie środków finansowych z budżetu państwa.

Równie ważne jest, że w ogóle pojawiła się w kręgach decyzyjnych dyskusja o przyszłości polskich miast i obszarów metropolitalnych. Wydaje się, że istotnym aspektem wpływającym na przyśpieszenie prac zmierzających do wprowadzenia odmiennych rozwiązań w zakresie zarządzania w obszarach metropolitalnych, które można nazwać innowacyjnymi w polskich warunkach, jest w pierwszym rzędzie zmiana sposobu myślenia wśród elit politycznych oraz rządowych, czyli tam, gdzie podejmowane są strategiczne decyzje. Jest to punkt wyjścia do pożądanych przekształceń. Zatem przyjęcie stosownych aktów prawnych jest warunkiem koniecznym do usprawnienia procesu zarządzania w obszarach metropolitalnych.

0 ile pojawiają się wątpliwości, czy koordynacja zadań j.s.t. w obszarze metropolitalnym powinna być efektem odgórnych zapisów prawnych, czy też wynikiem chęci współpracy [Dziemianowicz, Łukomska 2009, s. 24], o tyle nie podlega dyskusji, że powinno się wprowadzić instrumenty, które będą tę współpracę stymulowały.

\section{Doświadczenia obszarów metropolitalnych w zakresie współpracy}

Dynamika rozwoju i złożoność wewnętrznych powiązań w obszarach metropolitalnych powodują konieczność współdziałania funkcjonujących na tych terenach podmiotów. Dla sprawnego rozwoju tych obszarów ko- 
nieczna jest przede wszystkim współpraca tworzących je gmin. Wybór zakresu oraz formy współpracy międzygminnej ma wpływ nie tylko na stopień integracji zarządzania na szczeblu metropolitalnym, ale może również wpływać na tempo i charakter procesu metropolizacji w dłuższej perspektywie.

\subsection{Formy wspótpracy dopuszczalne przez prawo}

Obecnie prawo polskie dopuszcza możliwość współpracy jednostek samorządu terytorialnego $\mathrm{w}$ formie publicznoprawnej (związki i porozumienia międzygminne) oraz w formie cywilnoprawnej (tworzenie odrębnych podmiotów publicznego prawa gospodarczego, stowarzyszeń czy umów prawa cywilnego) [Konstytucja, art. 172; Ustawa... 1990].

Zgodnie z ustawą o samorządzie gminnym gminy mogą tworzyć związki międzygminne w celu wspólnego wykonywania zadań publicznych. Uchwały o utworzeniu związku podejmują rady zainteresowanych gmin. Związek przejmuje prawa i obowiązki gmin wchodzących w jego skład, związane z wykonywaniem zadań przekazanych związkowi. Wykonuje zadania publiczne w imieniu własnym i na własną odpowiedzialność oraz ma osobowość prawną. Związek otrzymuje stosowne środki finansowe konieczne do wykonania zadania. Organem stanowiącym i kontrolnym jest zgromadzenie związku, w skład którego wchodzą wójtowie poszczególnych gmin. Organem wykonawczym jest zarząd powoływany i odwoływany przez zgromadzenie spośród jego członków [Ustawa... 1990].

Związki międzygminne są nieskomplikowaną formą współpracy jednostek samorządu terytorialnego, pozwalającą tworzyć więzi partnerstwa o klarownych zasadach. Jasno zdefiniowany system odpowiedzialności, finansowania i podziału obowiązków pozwala na skuteczną realizację zadań określonych w statucie [Kogucik b.r.].

Inną formą współpracy dopuszczoną w ustawie o samorządzie gminnym jest porozumienie. Gminy mogą zawierać porozumienia międzygminne (art. 74) w sprawie powierzenia jednej z nich określonych przez nie zadań publicznych. Gmina realizująca zadanie publiczne objęte porozumieniem przyjmuje jednocześnie prawa i obowiązki pozostałych gmin, związane z powierzonymi jej zadaniami, a wszystkie gminy mają obowiązek partycypować w kosztach realizacji powierzonego zadania.

Kolejną możliwą formą współpracy gmin są stowarzyszenia, przy czym gminy mogą tworzyć stowarzyszenia także z powiatami i województwami. Stowarzyszenie jest dobrowolnym, samorządnym, trwałym zrzeszeniem o celach niezarobkowych. Organizację, zadania oraz tryb pracy stowarzyszenia określa jego statut [Ustawa... 1989]. Prawo o stowarzyszeniach obowiązuje $\mathrm{w}$ całej rozciągłości $\mathrm{w}$ stosunku do stowarzyszeń j.s.t., przy 
czym w przypadku tych stowarzyszeń, wystarczy do założenia stowarzyszenia trzech członków-założycieli [Klimek 2012, s. 16]

Ostatnio dużą popularnością cieszy się współpraca w ramach Lokalnych Grup Działania (LGD). Lokalne Grupy Działania są rodzajem partnerstwa terytorialnego tworzonego zazwyczaj na obszarach wiejskich, zrzeszającego przedstawicieli lokalnych organizacji (z sektora publicznego, prywatnego i pozarządowego) oraz mieszkańców danego obszaru wyznaczonego granicami gmin członkowskich. Tworzone są na podstawie przepisów o stowarzyszeniach. Członkiem lokalnej grupy działania mogą być osoby fizyczne i osoby prawne, w tym jednostki samorządu terytorialnego. Nadzór nad lokalnymi grupami działania sprawuje marszałek województwa [Ustawa... 2007, art. 15].

Najważniejszym gremium decyzyjnym LGD jest zgromadzenie członków. Obecnie w radach LGD przedstawiciele sektora publicznego nie mogą stanowić więcej niż 50\% składu. LGD przygotowuje Lokalną Strategię Rozwoju. Obszar nią objęty powinien być spójny i liczyć co najmniej 10 tys. i nie więcej niż 150 tys. mieszkańców. Po akceptacji LGD przez samorząd danego województwa, może ona korzystać ze środków finansowych w ramach Programu Rozwoju Obszarów Wiejskich [http://pl.wikipedia.org/wiki/Lokalna _Grupa_Dzia\%C5\%82ania].

Analogicznie wyglądają regulacje prawne dla powiatów.

\subsection{Analiza związków międzygminnych $w$ obszarach metropolitalnych}

W Polsce na dzień 30.09.2012 r. zarejestrowano 300 związków międzygminnych oraz trzy związki powiatów (w tym jeden zlikwidowany). Analizie poddano związki międzygminne utworzone przez gminy leżące na terenie dziecięciu obszarów metropolitalnych wskazanych w Koncepcji Przestrzennego Zagospodarowania Kraju 2030. W badaniach zostały uwzględnione związki utworzone przez gminy od momentu, kiedy przepisy prawa wprowadziły taką możliwość, czyli od roku 1990 i które cały czas funkcjonują. Zasięg przestrzenny analizowanych obszarów metropolitalnych bazuje na delimitacjach dokonanych przez urzędy marszałkowskie.

W skład Wrocławskiego Obszaru Metropolitalnego wchodzą 44 gminy. Są one członkami sześć związków międzygminnych (rys. 17 i 18).

Celem powołanych związków jest przede wszystkim rozbudowa infrastruktury, głównie wodociągowej, gospodarka odpadami i ochrona środowiska. Jeden związek w swoich celach przewiduje dodatkowo rozwój kultury. Wrocław jest członkiem jednego związku, do zadań którego należy m.in. ochrona wód w zlewni Ślęzy i Oławy, gospodarka wodno-ściekowa i budowa schroniska dla zwierząt. 


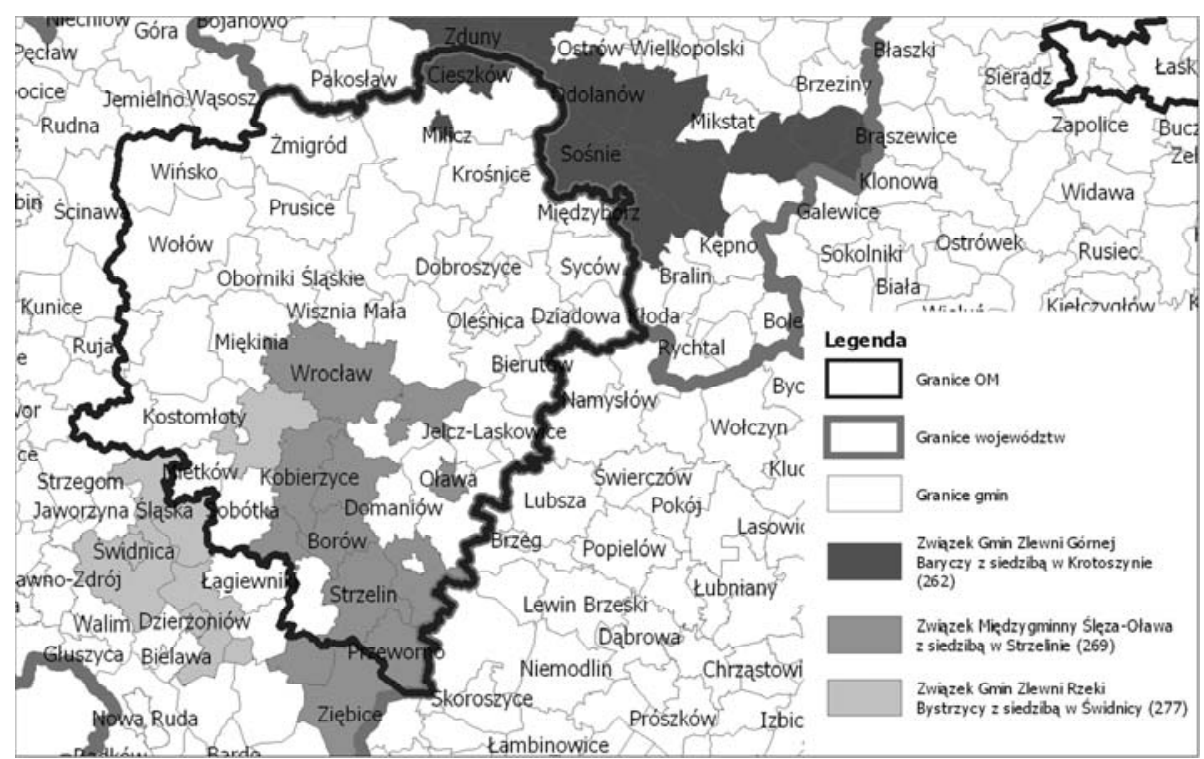

Rys. 17. Związki międzygminne na terenie Wrocławskiego Obszaru Metropolitalnego Źródło: oprac. własne

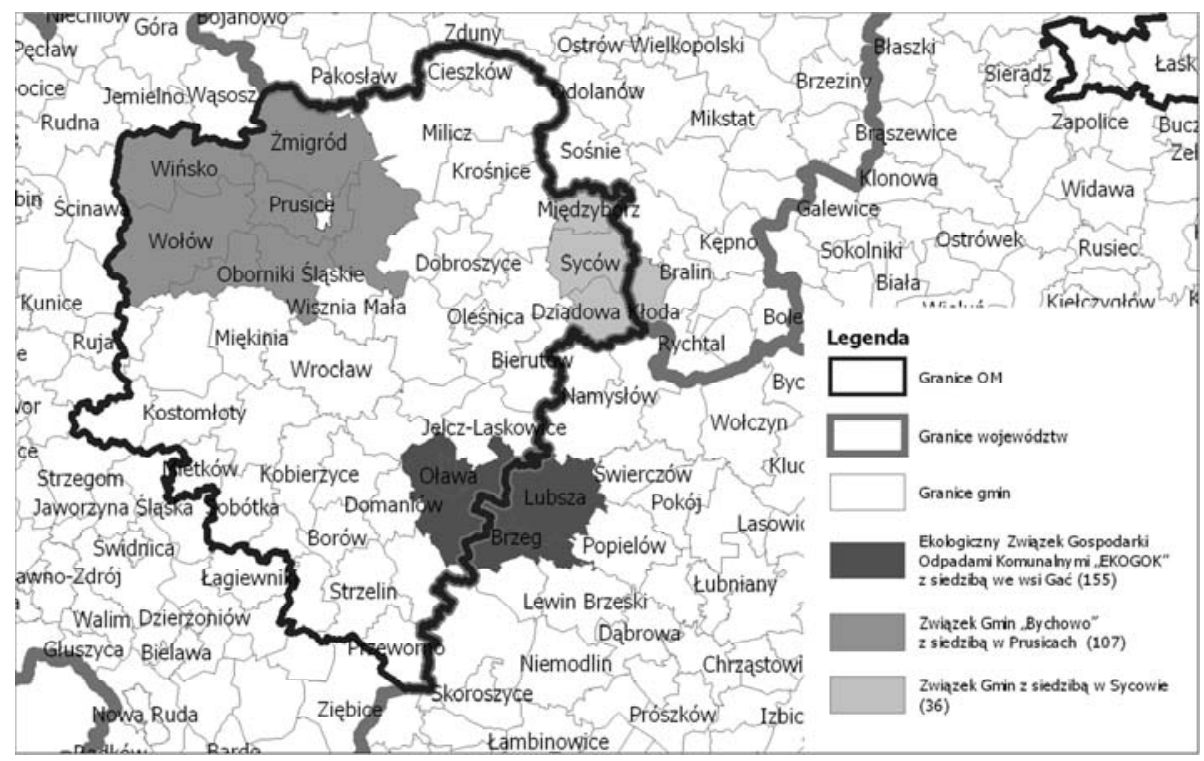

Rys. 18. Związki międzygminne na terenie Wrocławskiego Obszaru Metropolitalnego Źródło: oprac. własne

W skład Bydgosko-Toruńskiego Obszaru Metropolitalnego wchodzi 19 gmin i funkcjonuje w nim tylko Związek Gmin Dorzecza Brdy (rys. 19). 


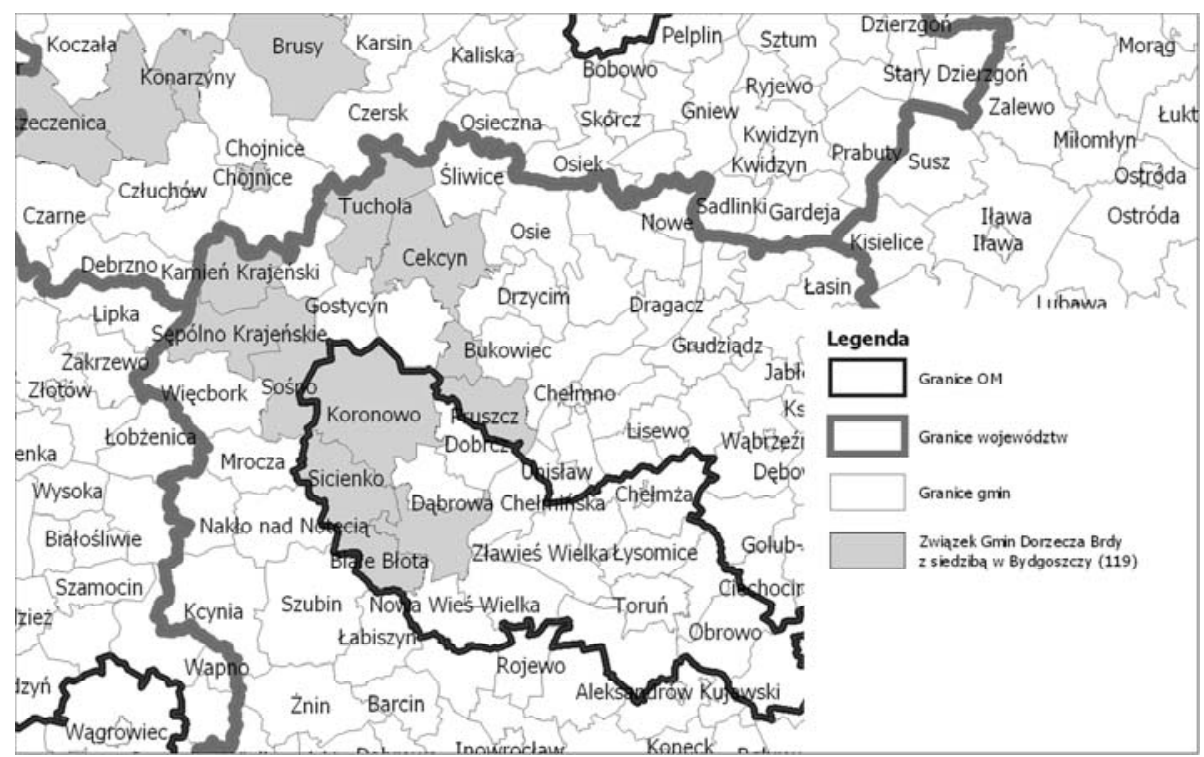

Rys. 19. Związki międzygminne na terenie Bydgosko-Toruńskiego Obszaru Metropolitalnego Źródło: oprac. własne

Jego celem jest ochrona środowiska i krajobrazu w dorzeczu rzeki. Toruń - jeden z dwóch głównych ośrodków tej bipolarnej aglomeracji - nie należy do żadnego związku.

Lubelski Obszar Metropolitalny obejmuje 41 gmin. Gminy utworzyły sześć związków (rys. 20 i 21) do realizacji zadań z zakresu ochrony środowiska i gospodarki odpadami. Lublin nie jest członkiem żadnego związku.

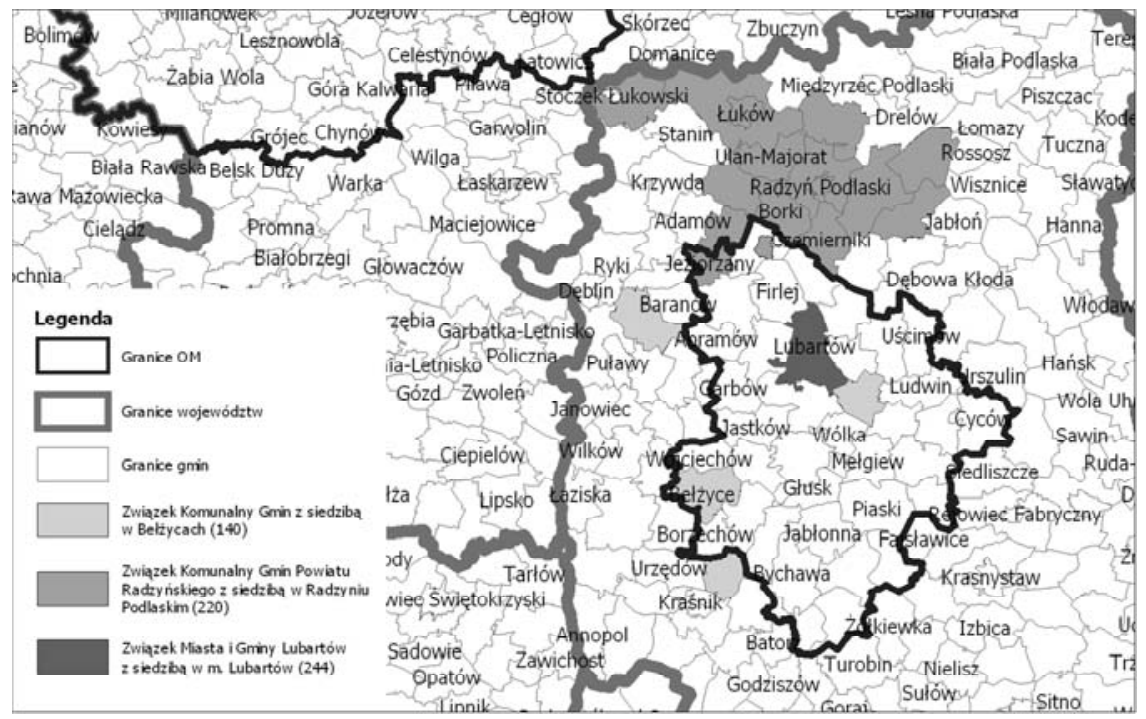

Rys. 20. Związki międzygminne na terenie Lubelskiego Obszaru Metropolitalnego 
Źródło: oprac. własne

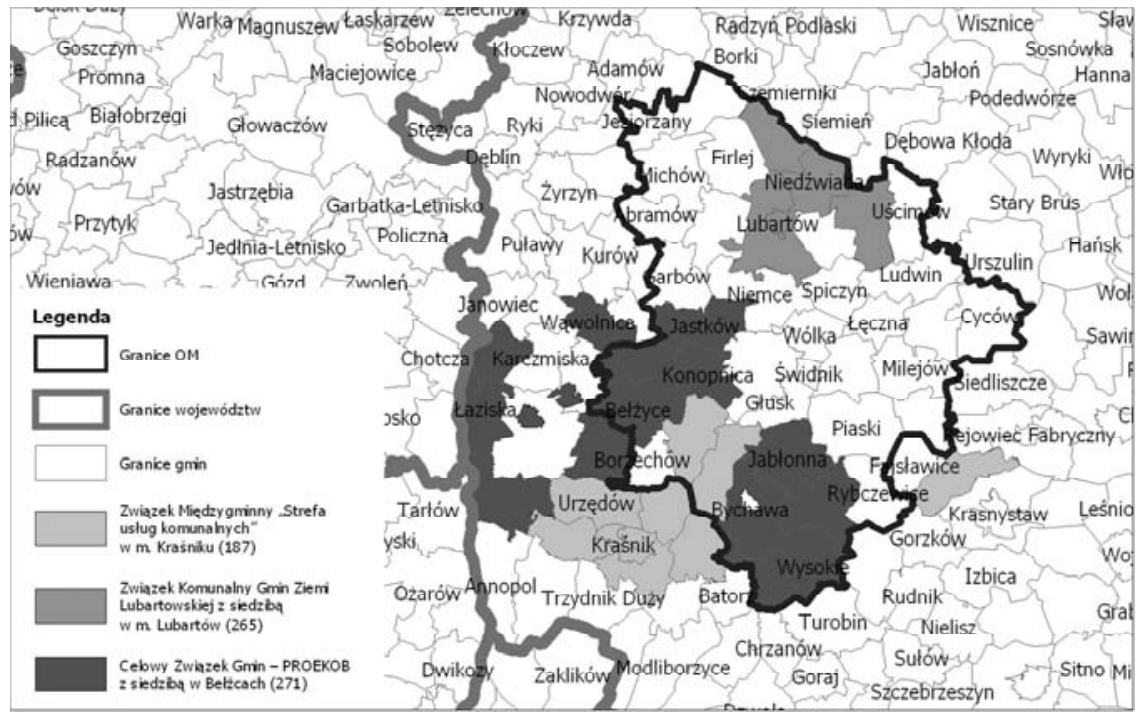

Rys. 21. Związki międzygminne na terenie Lubelskiego Obszaru Metropolitalnego Źródło: oprac. własne

W skład Łódzkiego Obszaru Metropolitalnego (tOM) wchodzą 32 gminy. Powołały one cztery związki (rys. 22 i 23)

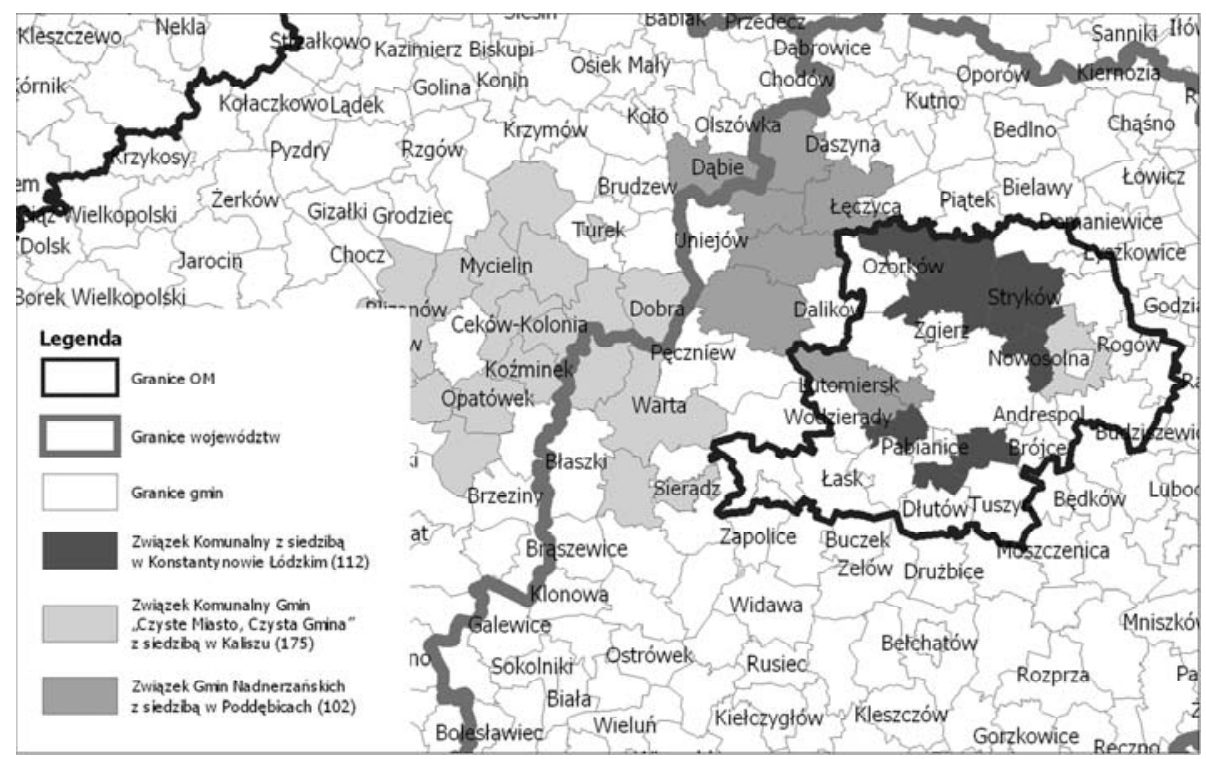

Rys. 22. Związki międzygminne na terenie Łódzkiego Obszaru Metropolitalnego Źródło: oprac. własne 


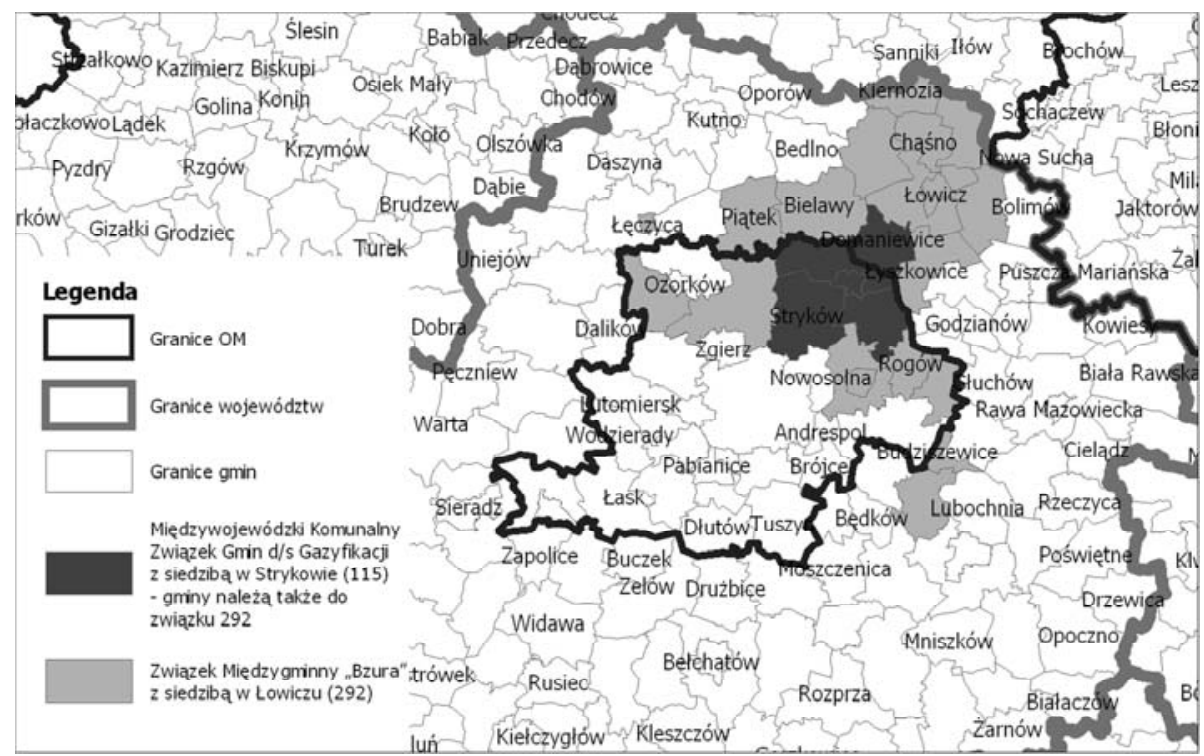

Rys. 23. Związki międzygminne na terenie Łódzkiego Obszaru Metropolitalnego Źródło: oprac. własne.

Większość związków utworzona jest z gminami spoza ŁOM, a nawet spoza województwa łódzkiego. Ich cele związane są z rozbudową i utrzymaniem infrastruktury (wodociągowej, gazowej), gospodarką odpadami oraz utrzymaniem ładu ekologicznego. Niektóre z nich utworzone są przez gminy, które nie tylko nie sąsiadują ze sobą, lecz są znacznie od siebie oddalone. Łódź, będąca centrum obszaru metropolitalnego, nie utworzyła żadnego związku z innymi gminami.

Krakowski Obszar Metropolitalny obejmuje 50 gmin. Powołały one pięć związków międzygminnych (rys. 24 i 25).

W Krakowskim Obszarze Metropolitalnym związki utworzyły głównie gminy leżące na jego obrzeżach wspólnie z gminami spoza obszaru. Za wspólny cel uznają one ochronę środowiska, a zwłaszcza czystości rzek, które przepływają przez ich teren oraz gospodarkę odpadami. Również Kraków należy do tego typu związku. Związki realizują też zadania z zakresu rozwoju infrastruktury technicznej. 


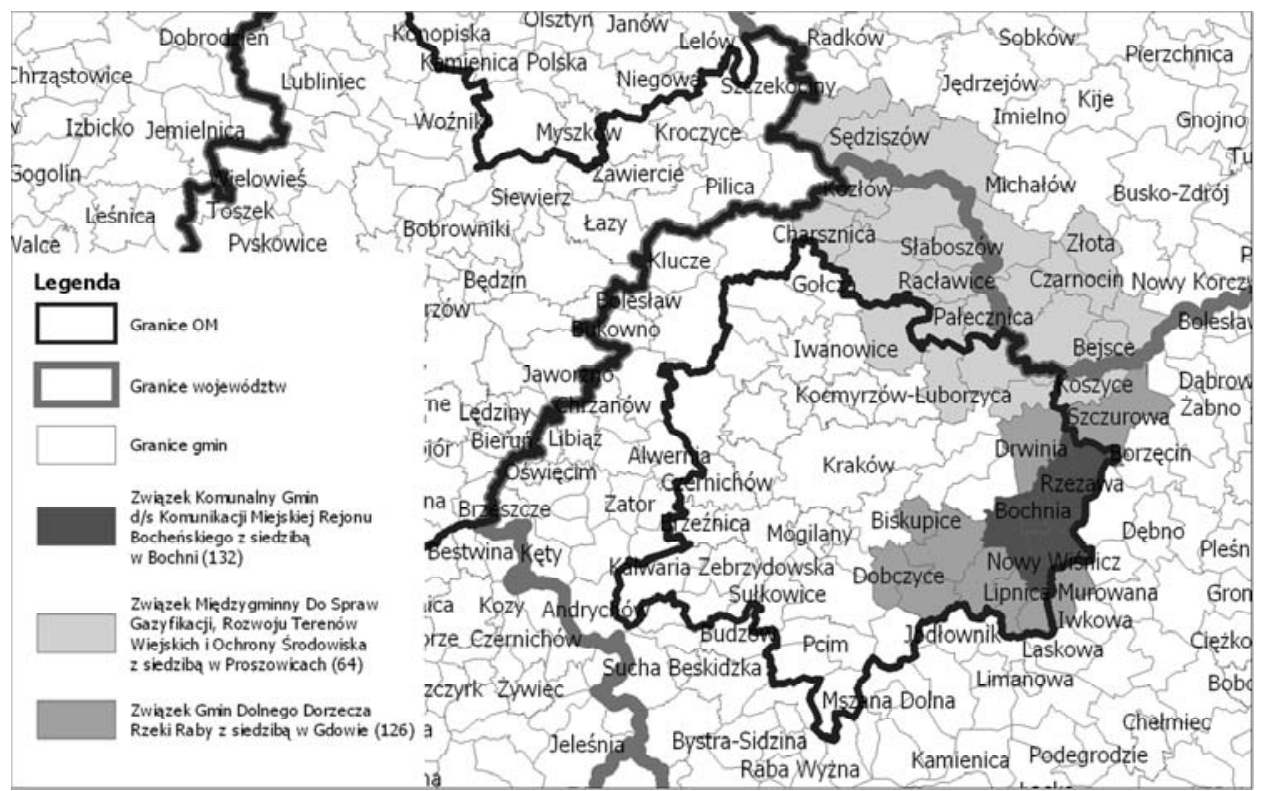

Rys. 24. Związki międzygminne na terenie Krakowskiego Obszaru Metropolitalnego Źródło: oprac. własne

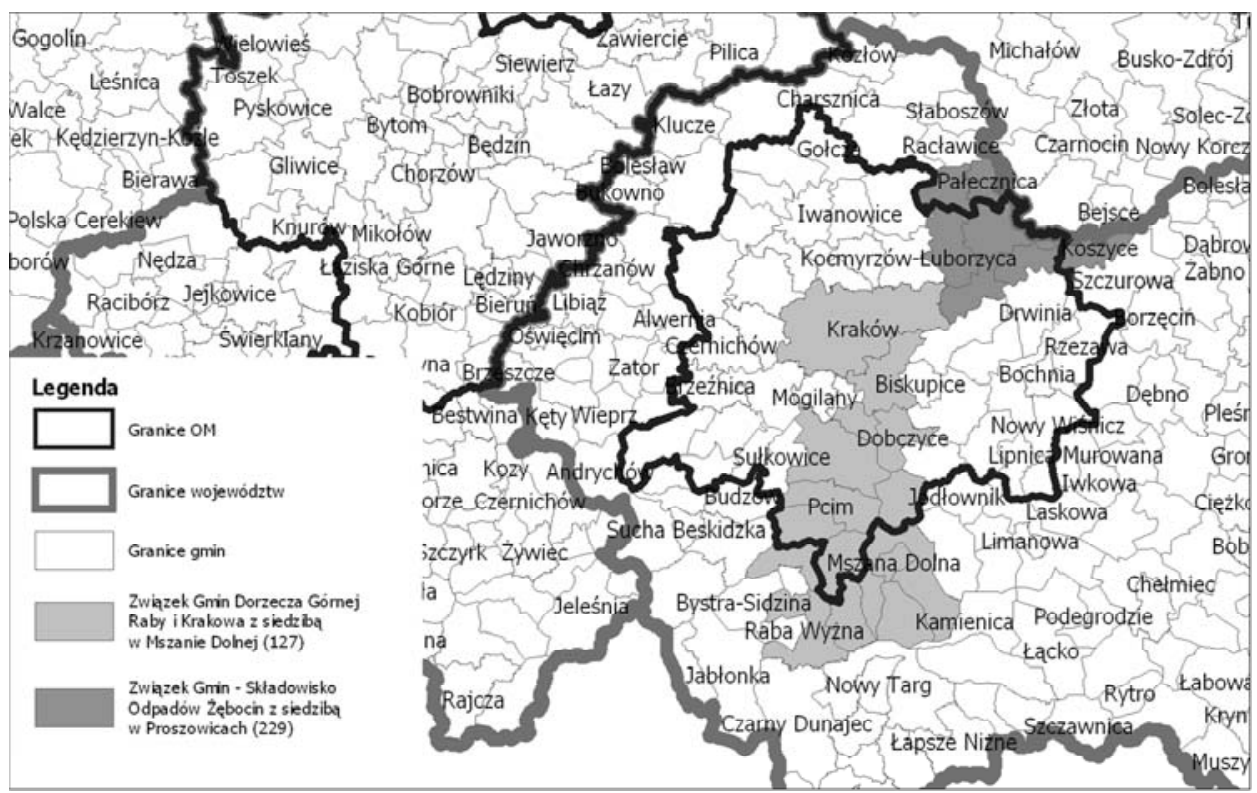

Rys. 25. Związki międzygminne na terenie Krakowskiego Obszaru Metropolitalnego Źródło: oprac. własne 
W skład Warszawskiego Obszaru Metropolitalnego wchodzi 81 gmin. $\mathrm{Na}$ jego terenie funkcjonuje dziewięć związków międzygminnych (rys. 26 i 27).

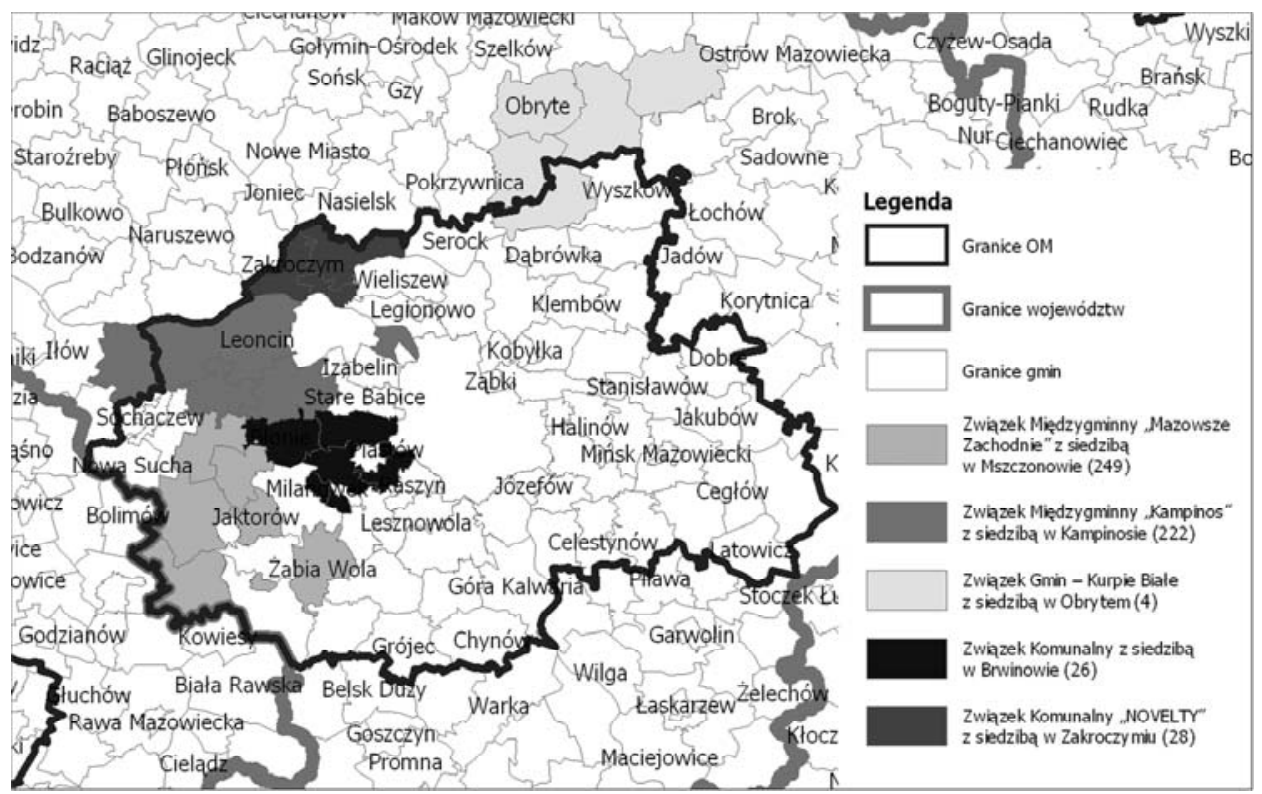

Rys. 26. Związki międzygminne na terenie Warszawskiego Obszaru Metropolitalnego Źródło: oprac. własne

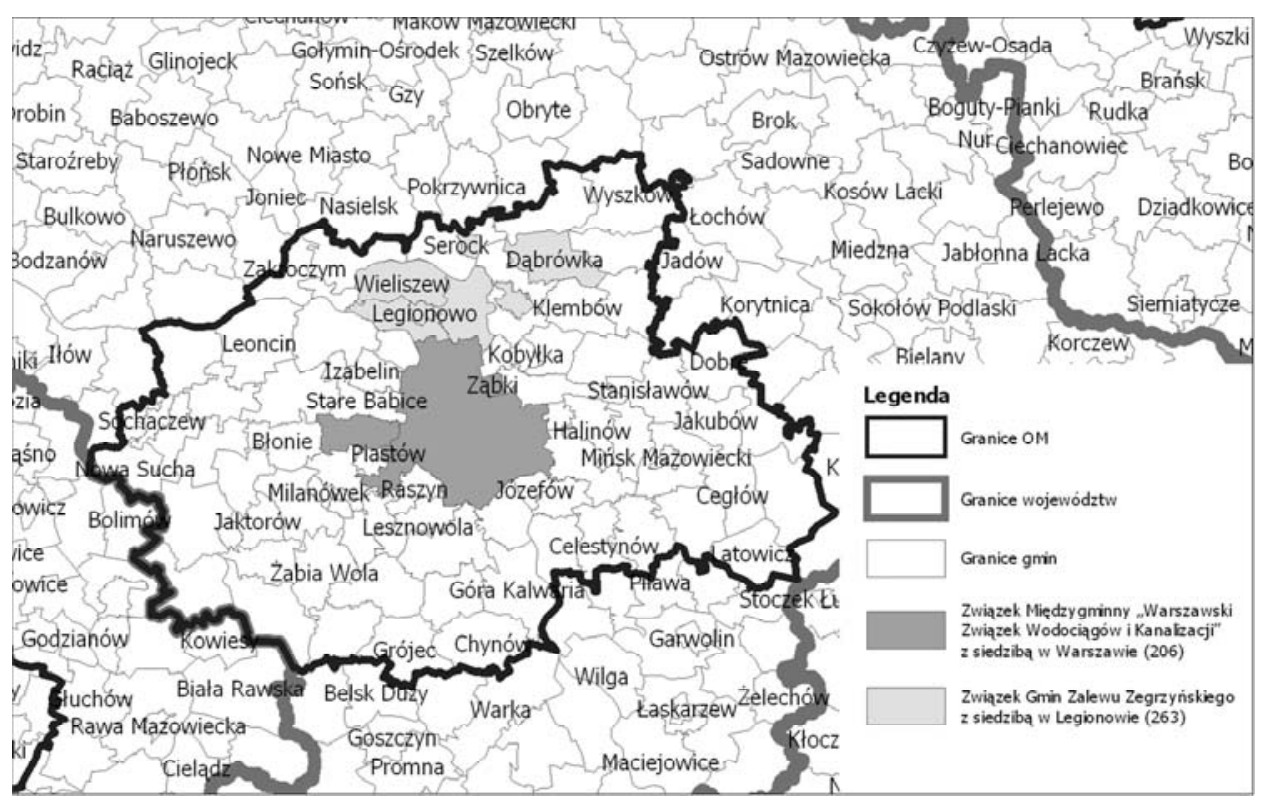

Rys. 27. Związki międzygminne na terenie Warszawskiego Obszaru Metropolitalnego Źródło: oprac. własne 
Warszawa jest członkiem tylko jednego związku, który został utworzony w roku 2000 przez wszystkie gminy, na które podzielone była stolica i kilka gmin ościennych w celu wspólnego organizowania gospodarki wodnościekowej. Pozostałe związki realizują zadania z zakresu ochrony środowiska, gospodarki odpadami, opieki nad bezdomnymi zwierzętami, transportu, sportu i rekreacji, rozwoju turystyki, ale również planowania przestrzennego i koordynacji przedsięwzięć gospodarczych.

Na terenie Górnośląskiego Obszaru Metropolitalnego znajdują się 73 gminy, w tym 14 miast na prawach powiatu. Miasta te utworzyły Górnośląski Związek Metropolitalny (rys. 24a), którego celem jest ustalanie wspólnej strategii rozwoju, zarządzanie drogami, aktywizacja rynku pracy, opracowywanie analiz i sprawozdań dotyczących rynku pracy oraz wspieranie edukacji publicznej [Statut Górnośląskiego... b.r.]. Ponadto funkcjonuje sześć innych związków (rys. 28 i 29), do zadań których należą organizacja i koordynacja transportu zbiorowego, gospodarka wodno-ściekowa oraz ochrona środowiska.

Obszar funkcjonowania dwóch związków wykracza poza granice województwa śląskiego, ze względu na fakt, że celem ich działania jest ochrona środowiska na terenach w dorzeczu rzek. Aż trzy związki powstały w celu stworzenia zintegrowanych systemów zarządzania transportem publicznym.

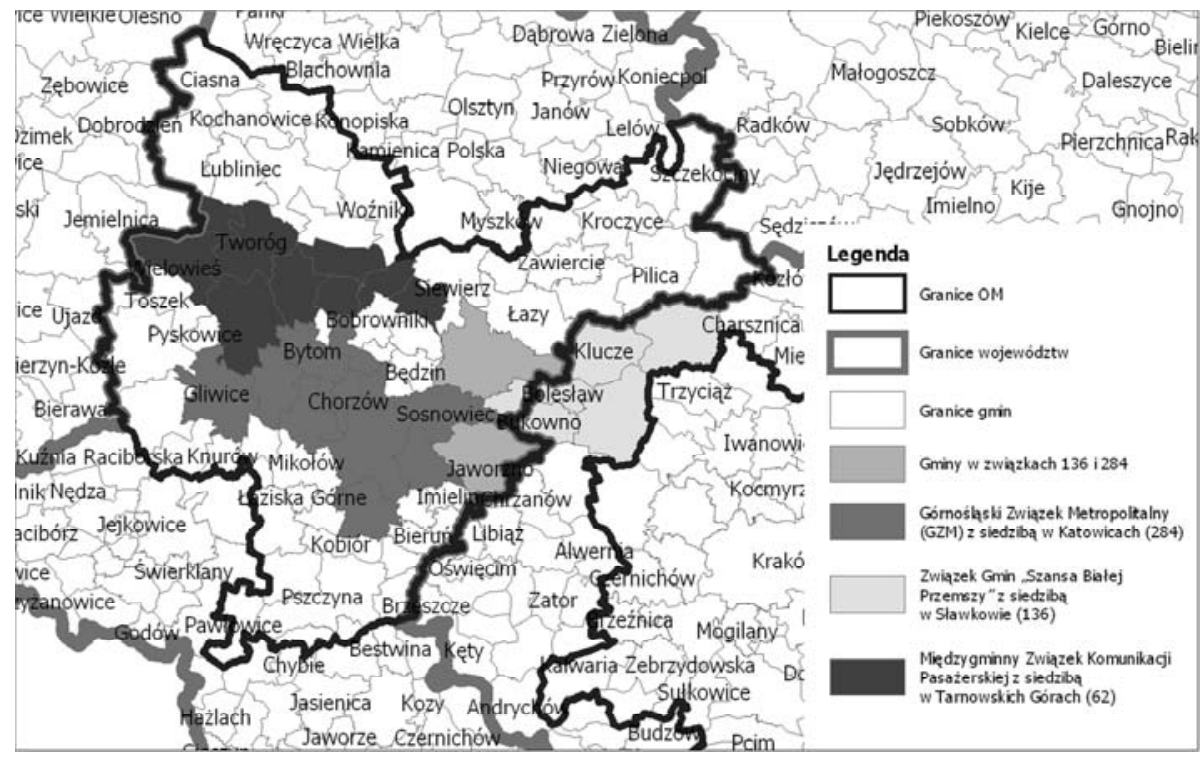

Rys. 28. Związki międzygminne na terenie Górnośląskiego Obszaru Metropolitalnego Źródło: oprac. własne 


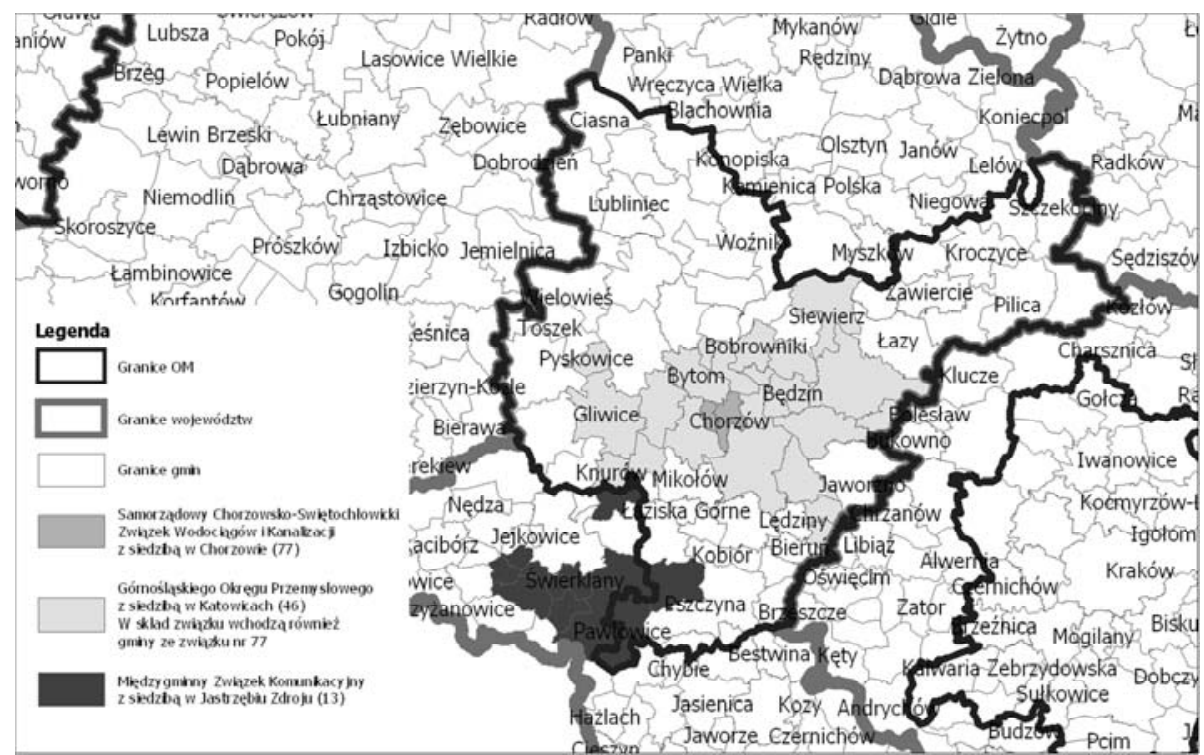

Rys. 29. Związki międzygminne na terenie Górnośląskiego Obszaru Metropolitalnego Źródło: oprac. własne

Na Poznański Obszar Metropolitalny składa się 45 gmin. Część z nich jest członkami siedmiu związków międzygminnych (rys. 30 i 31).

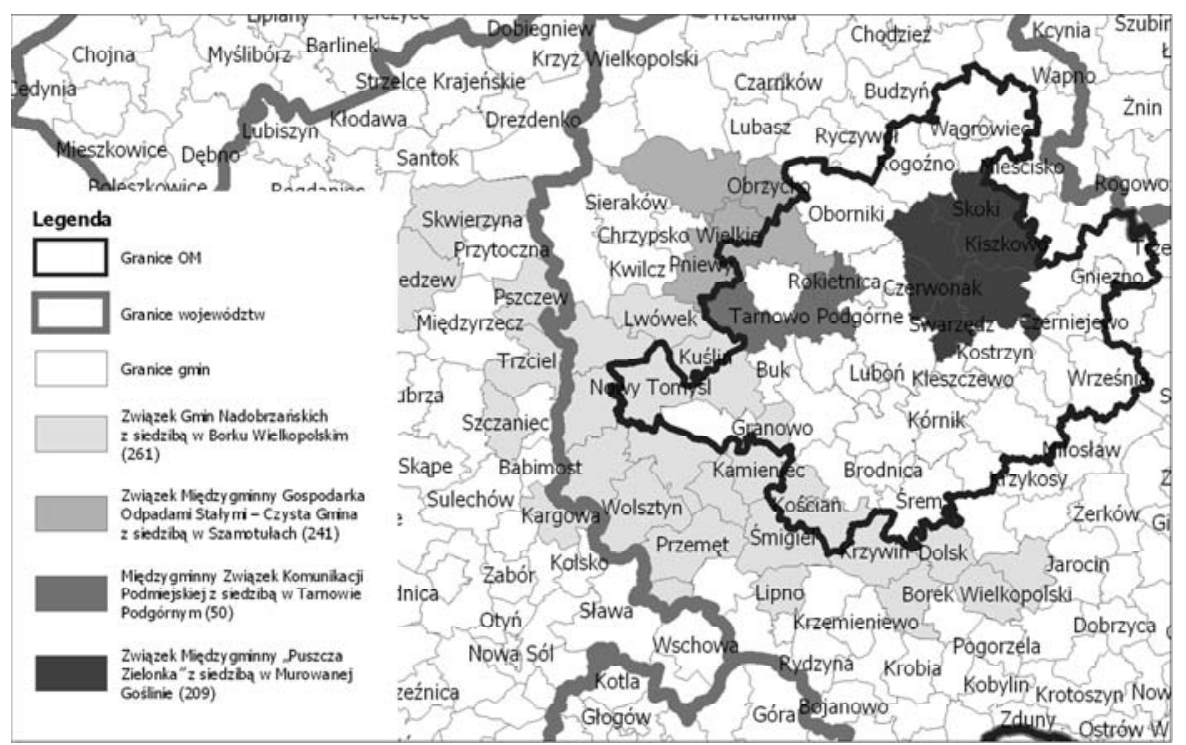

Rys. 30. Związki międzygminne na terenie Poznańskiego Obszaru Metropolitalnego Źródło: oprac. własne 


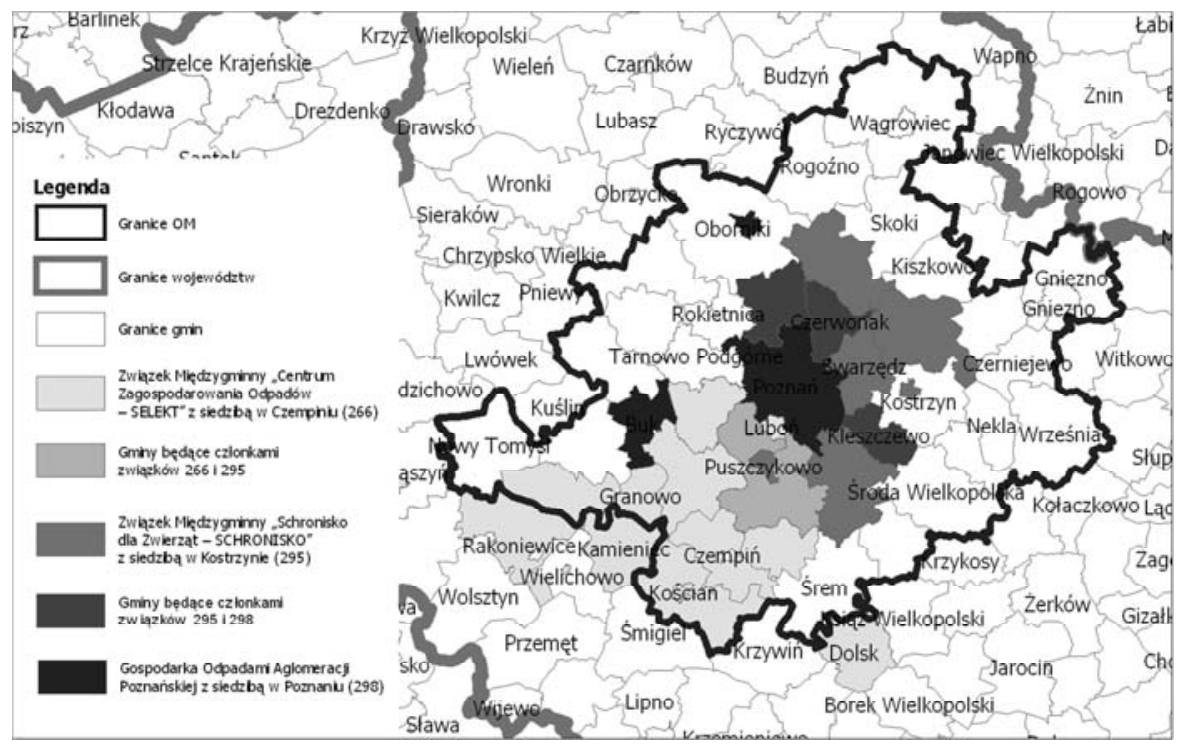

Rys. 31. Związki międzygminne na terenie Poznańskiego Obszaru Metropolitalnego Źródło: oprac. własne

Cele większości związków wiążą się z ochroną środowiska i gospodarką ściekową. Najmniejszy związek ma za zadanie organizowanie przejazdów pasażerskich na liniach podmiejskich. Poznań - centralne miasto Obszaru jest jedynie członkiem Związku Gospodarki Odpadami Aglomeracji Poznańskiej.

Szczeciński Obszar Metropolitalny tworzy 10 gmin. Funkcjonują one w trzech związkach międzygminnych (rys. 32 i 33), których członkami są również gminy spoza OM. Szczecin nie wchodzi w skład żadnego związku, choć jest siedziba związku „Pomerania”. 


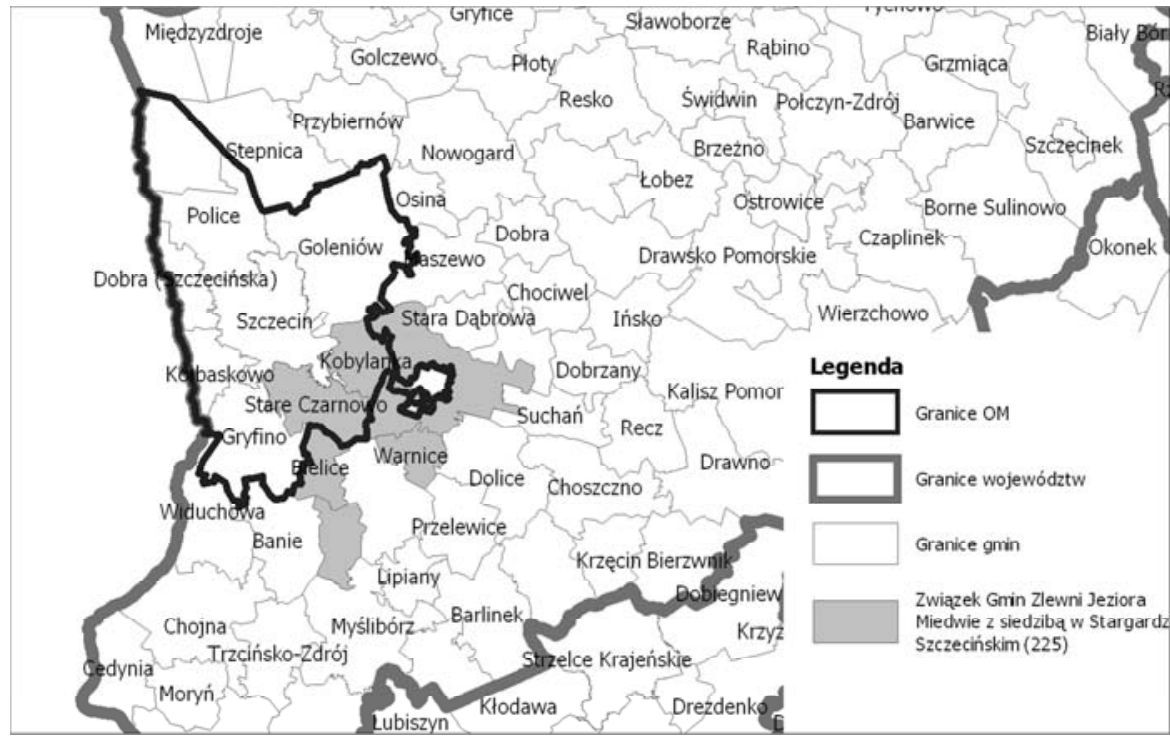

Rys. 32. Związki międzygminne na terenie Szczecińskiego Obszaru Metropolitalnego Źródło: oprac. własne

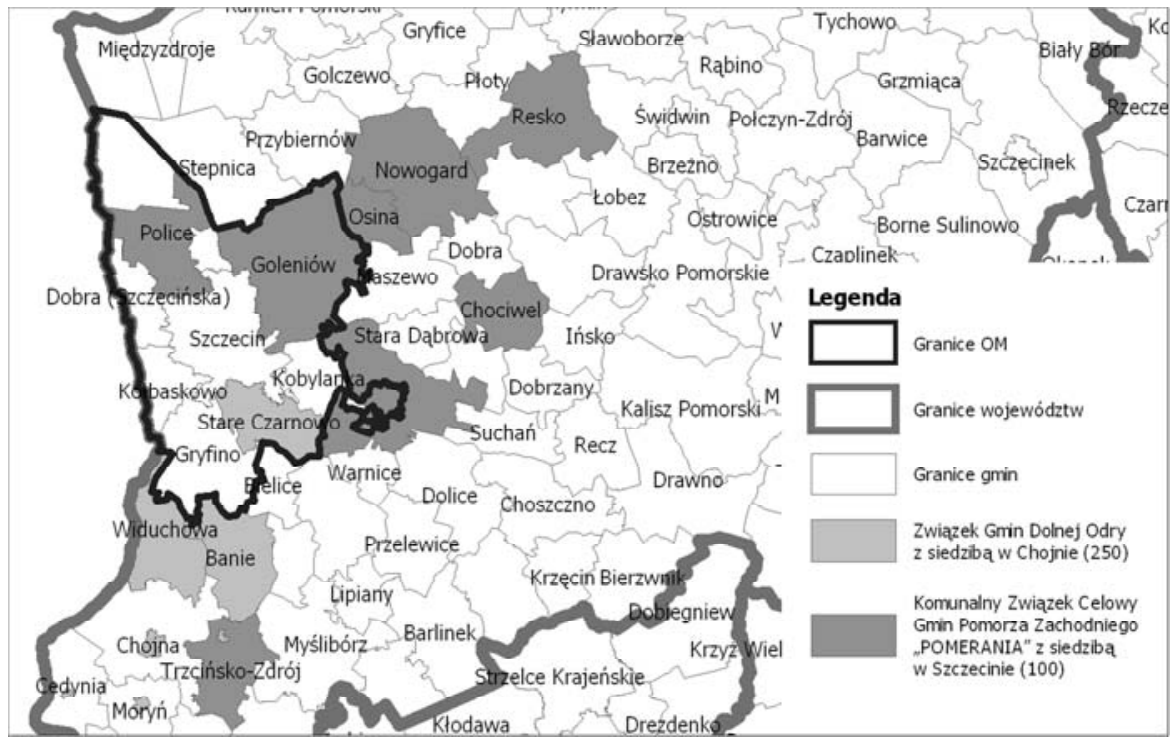

Rys. 33. Związki międzygminne na terenie Szczecińskiego Obszaru Metropolitalnego Źródło: oprac. własne

Do głównych zadań związków utworzonych przez gminy z terenu obszaru metropolitalnego należą ochrona środowiska i gospodarka odpadami, infrastruktura komunalna, komunikacja zbiorowa, turystyka, sport i rekreacja oraz kultura. 
W skład Trójmiejskiego Obszaru Metropolitalnego wchodzi 49 gmin. Część z nich współpracuje z innymi w ramach sześciu związków międzygminnych (rys. 34 i 35.).

Związek, który tworzy najwięcej (13) gmin, stanowiących centrum regionu, za cel stawia sobie zintegrowane zarządzanie transportem zbiorowym w aglomeracji. Do zadań pozostałych związków należy gospodarka wodno-ściekowa oraz ochrona środowiska.

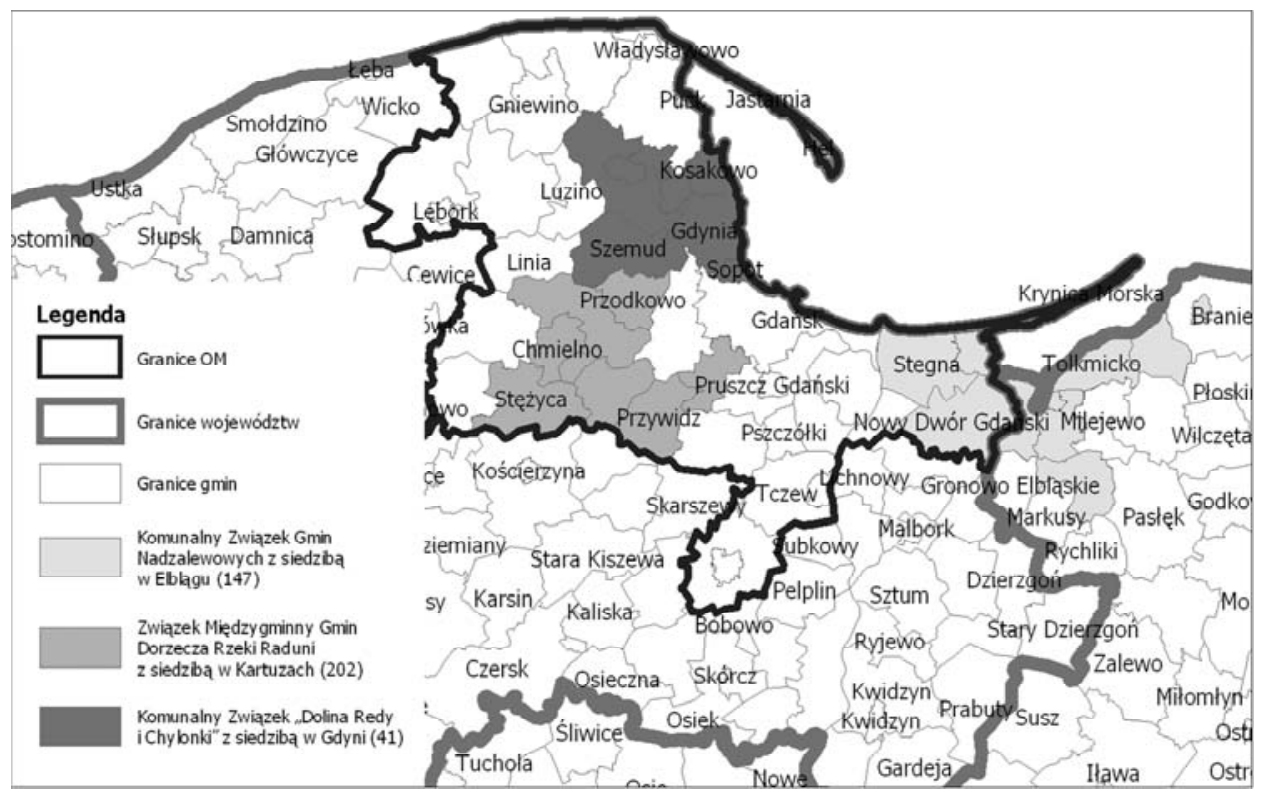

Rys. 34. Związki międzygminne na terenie Trójmiejskiego Obszaru Metropolitalnego Źródło: oprac. własne 


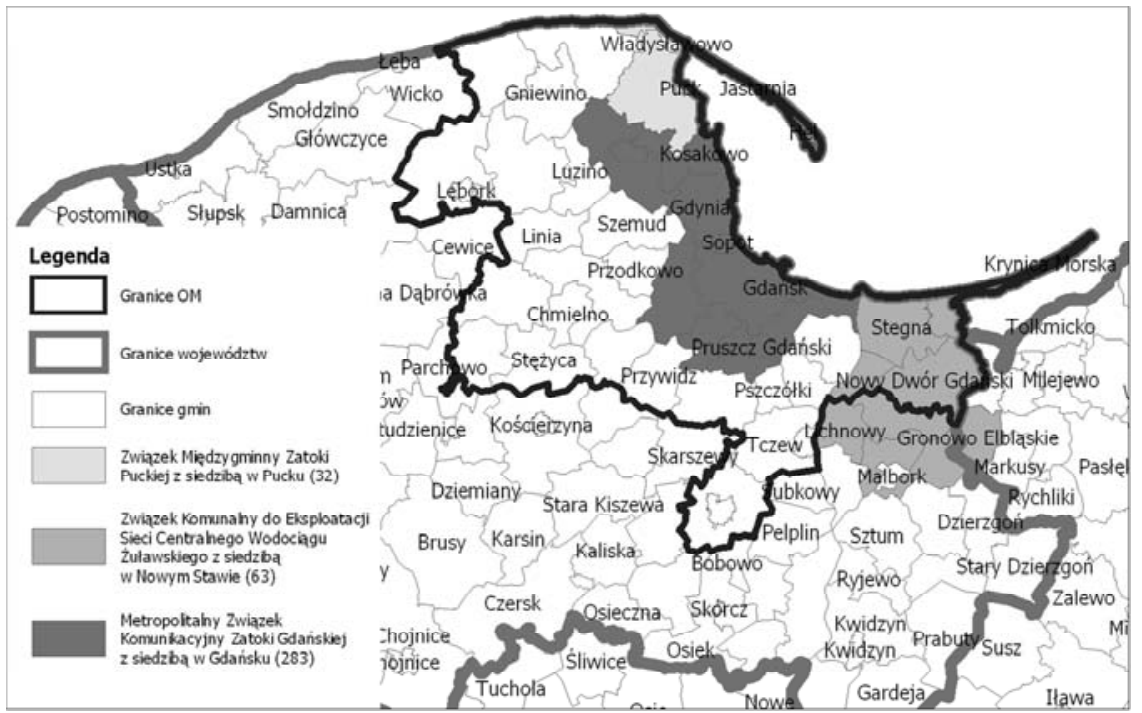

Rys. 35. Związki międzygminne na terenie Trójmiejskiego Obszaru Metropolitalnego Źródło: oprac. własne

Rzeszowski Obszar Metropolitalny obejmuje 11 gmin. Dziesięć z nich tworzy, z innymi gminami położonymi w zlewni rzeki Wisłok, związek międzygminny, którego celem jest ochrona środowiska i edukacja ekologiczna (rys. 36).

Sześć gmin współpracuje w zakresie organizacji transportu lokalnego i wspólnie zarządza transportem autobusowym (rys. 36).

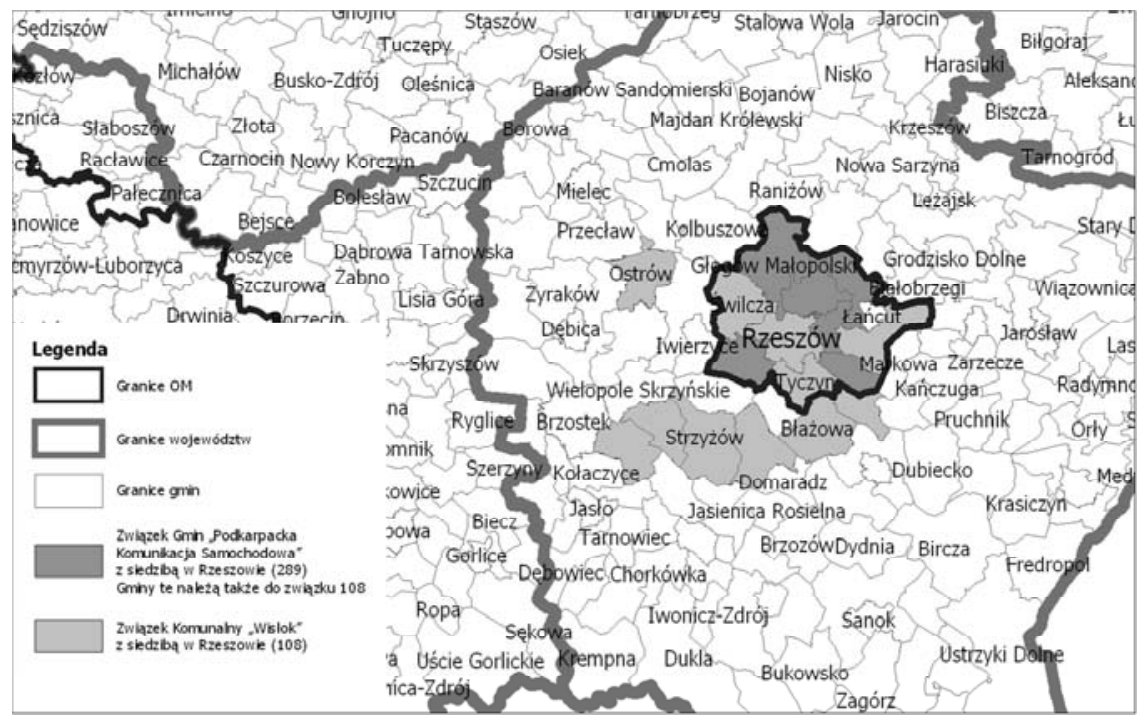

Rys. 36. Związki międzygminne na terenie Rzeszowskiego Obszaru Metropolitalnego Źródło: oprac. własne 
Białostocki Obszar Metropolitalny obejmuje 33 gminy, które współpracują w ramach sześciu związków komunalnych (rys. 37 i 38).

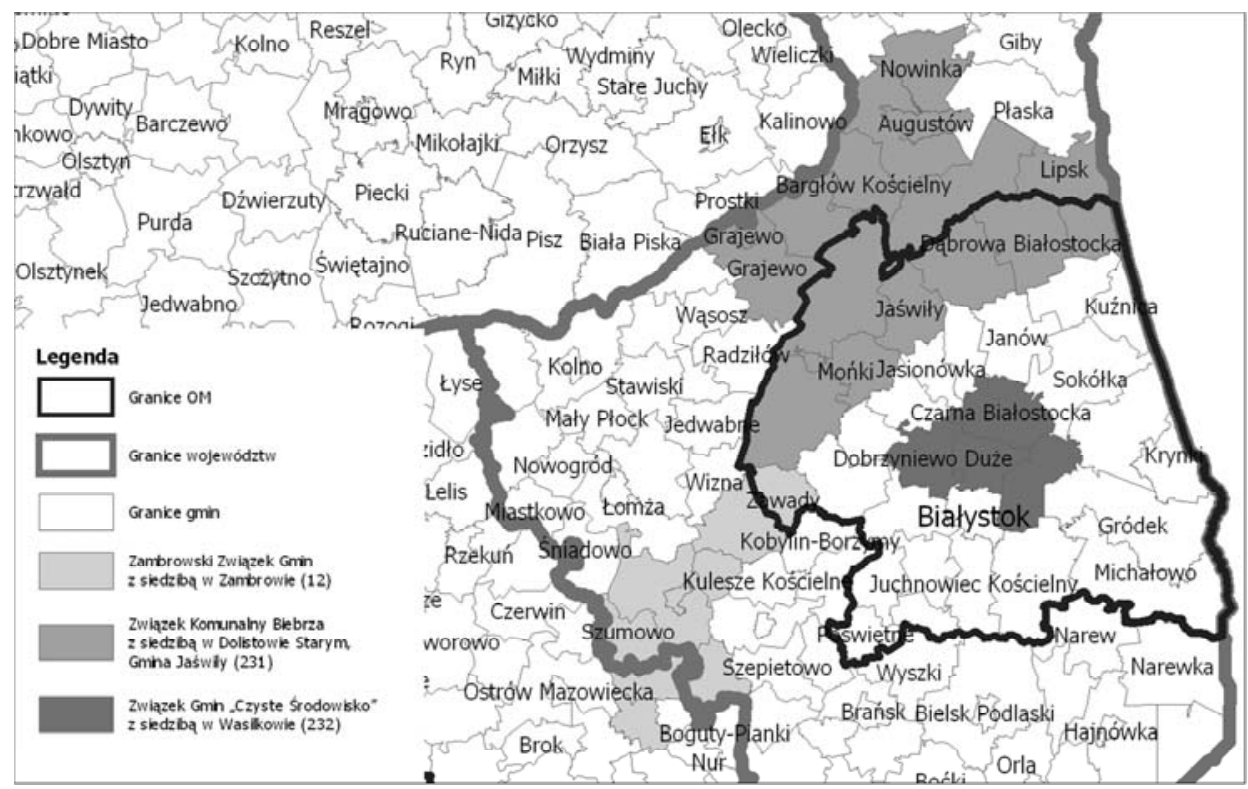

Rys. 37. Związki międzygminne na terenie Białostockiego Obszaru Metropolitalnego Źródło: oprac. własne

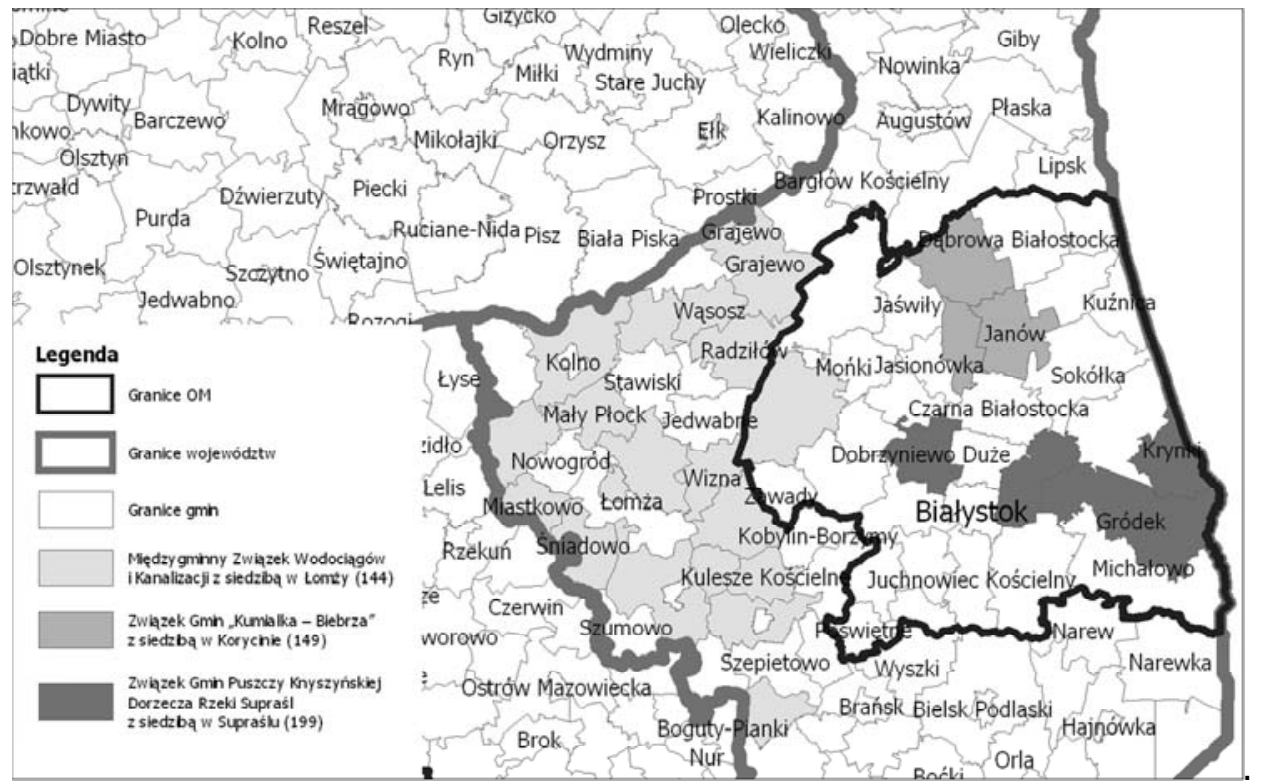

Rys. 38. Związki międzygminne na terenie Białostockiego Obszaru Metropolitalnego Źródło: oprac. własne 
Większość związków utworzyły gminy położone na obrzeżach obszaru metropolitalnego. Do ich głównych zadań należy gospodarka odpadami, ochrona środowiska, rozwój i utrzymanie infrastruktury oraz promocja. Białystok nie jest członkiem żadnego związku.

Przedstawiona analiza związków międzygminnych pozwala na stwierdzenie, że taka forma współpracy nie jest wykorzystywana do zarządzania rozwojem w obszarach metropolitalnych. Spośród zaprezentowanych związków żaden nie obejmował wszystkich gmin, które leżą na terenie obszaru metropolitalnego. Ponadto w większości przypadków takich związków nie tworzyły miasta centralne. Obecnie funkcjonujące związki międzygminne charakteryzuje duża różnorodność form współpracy, a także zasięg terytorialny odbiegający od teoretycznych delimitacji obszarów metropolitalnych. Zaobserwować można większą skłonność gmin położonych w obszarach zewnętrznych do nawiązywania współpracy, i zdecydowanie mniej przykładów tworzenia porozumień między miastem centralnym a otaczającymi je jednostkami terytorialnymi. W wielu przypadkach ta współpraca nawiązywana jest z jednostkami spoza obszaru metropolitalnego, a nawet spoza województwa. Korzyści ze współpracy mogą więc występować lokalnie i być związane z koniecznością wspólnego rozwiązywania pewnych problemów (np. ochrona środowiska, gospodarka odpadami), albo wynikać z ponadlokalnej infrastruktury komunikacyjnej, wodociągowej czy kanalizacyjnej. Może to również świadczyć o obawach gmin ościennych, które, nie chcąc by miasto centralne osiągało korzyści ich kosztem, unikają włączania ośrodka centralnego w związki gmin. Z drugiej strony wiele jednostek samorządu terytorialnego powstrzymuje się przed podejmowaniem formalnej współpracy na rzecz rozwiązywania problemów dotyczących całego obszaru metropolitalnego z uwagi na oczekiwanie na przyjęcie przez rząd przepisów, które mają regulować kwestie zarządzania w obszarach metropolitalnych. Obecnie jednak zaprzestano prac nad ustawą metropolitalną, a opracowana przez Ministerstwo Administracji i Cyfryzacji tzw. Biała księga, zawierającą propozycje rozwiązań prawnych mające usprawnić funkcjonowanie metropolii, nie uwzględnia obligatoryjnych wytycznych do współpracy w obszarach metropolitalnych.

Oceniając zaawansowanie w zakresie tworzenia instytucjonalnych form zarządzania obszarami metropolitalnymi w Polsce stwierdzić można, że procesy te znajdują się obecnie $\mathrm{w}$ stadium początkowym i dobrowolne związki międzygminne nie są skutecznym instrumentem, który mógłby ten proces przyspieszyć. 


\subsection{Nieformalne formy współpracy}

We współczesnej gospodarce czynnikiem rozwoju jest nie tylko konkurencyjność, ale także kooperacja między podmiotami, gdyż element, jakim jest współpraca nie neguje znaczenia konkurencji, lecz nadaje mu nowy wymiar [Ładysz 2009, s. 12]. Polskie obszary metropolitalne nie mają jednolitej struktury zarządzania. Niemniej jednak można zauważyć pewne formy współpracy, mające na celu zaangażowanie jak największej liczby aktorów funkcjonujących $\mathrm{w}$ danym obszarze. Współpraca ta najczęściej inicjowana jest przez proces opracowywania planów zagospodarowania przestrzennego województwa, gdyż zgodnie z art. 39 Ustawy o planowaniu i zagospodarowaniu przestrzennym, dla wyznaczonych w KPZK obszarów metropolitalnych należy przygotować i uchwalić plan zagospodarowania przestrzennego obszaru metropolitalnego jako część planu zagospodarowania przestrzennego województwa [Ustawa... 2003, art. 6]. W proces ten zostali włączeni, oprócz podmiotów bezpośrednio związanych z terenem, aktorzy zewnętrzni, czyli m.in. zespoły eksperckie i zespoły konsultantów.

Poza współpracą opartą na konieczności stworzenia planu metropolitalnego można również zauważyć inicjatywy, które miały na celu rozwiązanie problemów istotnych dla całego obszaru metropolitalnego. W związku z problemami związanymi z funkcjonowaniem i rozwojem obszarów metropolitalnych, spowodowanymi głównie niedopasowaniem kompetencji i granic administracyjnych do zasięgu realizowanych zadań, zaczęto podejmować różne inicjatywy współpracy, które najczęściej przyjmowały postać nieformalnych porozumień. Wśród nich możemy wyróżnić:

- Komitet Planu Strategicznego Aglomeracji Wrocławskiej składający się z wójtów, burmistrzów, starostów i prezydenta Wrocławia. Przystąpienie do niego było całkowicie dobrowolne. W drodze wspólnych konsultacji wypracowano wspólną strategię rozwoju, przyjętą przez Komitet 12 lipca 2001 r., a więc po dwóch latach konsultacji [Banachowicz, Danielewicz 2006, s. 196]. Następnie strategia została przyjęta w formie uchwały przez Wrocław, siedem powiatów i 24 gminy. Przyjęcie Strategii oraz powołanie Komitetu daje możliwość koordynacji rozwoju i integrowania planowania przestrzennego, a także decydowania o kierunkach i tempie realizacji wspólnych przedsięwzięć. W strategii zastosowano zasadę zarządzania poziomego, a nie sektorowego. Został wyznaczony koordynator, który monitoruje działalność wydziałów urzędu miasta zaangażowanych w realizację konkretnych przedsięwzięćc ${ }^{74}$. W rozwoju całego obszaru stosowane jest zarządzanie przez cele. Działania dotyczące realizacji konkretnego zadania koordynuje jedna gmina. Często jest to jednostka nie zainteresowana bezpo-

${ }^{74}$ Szeroko współpracę we Wrocławskim Obszarze Metropolitalnym opisała M. Lackowska [2009]. 
średnio skutkami danego przedsięwzięcia. Takie podejście pozwala na zwiększenie zaufania między poszczególnym stronami [Ossowicz 2005].

- Rada Krakowskiego Obszaru Metropolitalnego - ma na celu podjęcie działań zwiększających przyszłe możliwości współpracy i zapewnienia wzrostu konkurencyjności gmin i miast Małopolski w dłuższym horyzoncie czasowym [Deklaracja... 2007]; Forum Gmin Krakowskiego Obszaru Metropolitalnego - koncentrujące się głównie na problemach zagospodarowania przestrzennego.

- Porozumienie Partnerskie podpisane przez marszałka województwa, prezydentów Bydgoszczy i Torunia oraz starostów powiatów bydgoskiego i toruńskiego, w dniu 20 kwietnia 2005 r. w Toruniu. Zawarte porozumienie daje poczucie zacieśnienia współpracy między samorządami, kierunkuje wspólne działania samorządów na rzecz metropolii oraz powołuje Kolegium B-TOM. Często bodźcem do nawiązania współpracy były prace nad Regionalnymi Strategiami Innowacyjnymi lub strategiami rozwoju województwa. Opracowanie strategii rozwoju województwa kujawsko-pomorskiego było pierwszym, najważniejszym etapem, zmuszającym do ścisłej współpracy samorządy i społeczności Bydgoszczy i Torunia. Powołana przez marszałka województwa Rada Konsultacyjna pomogła znaleźć konsensus w określeniu kierunków rozwoju każdego z tych dwóch miast, czego wyrazem stało się opracowanie w 1999 r. Wizji rozwoju województwa kujawsko-pomorskiego. Zatem głównym podmiotem stymulującym tę współpracę był marszałek.

- Porozumienie partnerskie z 23 listopada 2005 r. w sprawie Białostockiego Obszaru Metropolitalnego powołało Kolegium na rzecz Białostockiego Obszaru Metropolitalnego, w skład którego wchodzą marszałek województwa podlaskiego, prezydent Białegostoku oraz starosta białostocki. Porozumienie zakładało, że członkowie Kolegium będą:

- dążyć do utworzenia i integracji Białostockiego Obszaru Metropolitalnego,

- proponować wspólne projekty metropolitalne Rządu Polskiego

i Komisji Europejskiej zmierzające do podniesienia konkurencyjności Polski w Europie,

- w szczególności działać na rzecz określenia granic Białostockiego Obszaru Metropolitalnego, wypracowania koncepcji organizacji zarządzania, sporządzenia strategii rozwoju, a w następnej kolejności wypracowania wspólnej koncepcji planu zagospodarowania przestrzennego Białostockiego Obszaru Metropolitalnego.

Kolegium nie podjęło jednak żadnych istotnych działań, natomiast w kwietniu 2009 r. 20 samorządów z powiatów białostockiego i sokólskiego oraz miasto Białystok podpisało deklarację współpracy w ramach Białostockiego Obszaru Metropolitalnego (BOM). Celem współpracy jest rozwijanie więzi społecznych, gospodarczych i komunikacyjnych, wspólne roz- 
wiązywanie problemów z różnych dziedzin, m.in. gospodarki, turystyki, zagospodarowania odpadów, komunikacji, transportu. Białostocki Obszar Metropolitalny chce się także przygotować na przyszłość, gdyby w nowej perspektywie finansowania UE po roku 2013 pojawiła się możliwość pozyskiwania środków dla takich właśnie obszarów [20 samorzq̨dów... 2009].

Porozumienie partnerskie dotyczące współdziałania na rzecz zarządzania rzeszowskim obszarem metropolitalnym, zostało zawarte w maju roku 2005 pomiędzy starostami powiatów wchodzących w skład OM [Danielewicz, Markowski 2008]. Jednak samorządy do tej pory nie podjęły wspólnych działań [Metropolia... 2007].

\subsection{Od wspótpracy nieformalnej do formalnej}

Wśród samorządów działających w jednym obszarze funkcjonalnym często pojawia się wyraźna potrzeba zinstytucjonalizowania współpracy. Zazwyczaj dochodzi do tego po wieloletnich doświadczeniach współpracy w ramach struktur nieformalnych. Poniżej zaprezentowano funkcjonujące obecnie w polskich obszarach metropolitalnych zinstytucjonalizowane formy współdziałania.

\subsubsection{Górnośląski Związek Metropolitalny}

Sztandarowym przykładem zinstytucjonalizowanej współpracy jest Górnośląski Związek Metropolitalny (GZM), jako jedyny w kraju, związek komunalny utworzony na potrzeby realizacji zadań o znaczeniu istotnym dla całego obszaru (Górny Śląsk). Idea metropolizacji konurbacji górnośląskiej, potrzeba efektywniejszego zarządzania, a tym samym wzmocnienia słabszych obszarów aglomeracji od dawna stanowiła temat rozważań samorządów miast górnośląskich. Temu zagadnieniu, począwszy od pierwszej połowy lat 90. poświęcano seminaria i spotkania prezydentów oraz burmistrzów. Decyzja o utworzeniu związku pod roboczą nazwą Związku Konurbacji Górnośląskiej została podjęta w grudniu 2005 r. Do górnośląskich jednostek samorządowych skierowano ankietę, której celem było zebranie opinii dotyczących planów utworzenia Związku Konurbacji. Spośród 21 gmin i powiatów, które odpowiedziały na ankietę, 20 wyraziło zdecydowane poparcie dla projektu utworzenia związku miast konurbacji górnośląskiej, który byłby docelowo powołany na mocy odrębnej ustawy. Wówczas rozpoczęto prace nad projektem Górnośląskiego Związku Metropolitalnego i nad jego statutem, które zostały zakończone w lutym 2007 r. złożeniem wniosku o rejestrację. Związek został zarejestrowany 8 czerwca 2007 r. W jego skład weszło 14 miast na prawach powiatu, leżących na obszarze konurbacji śląsko-dąbrowskiej. Za cele związku uznano ustalanie wspólnej strategii rozwoju dla miast wchodzących w skład Związku, zarządzanie drogami, aktywizację rynku pracy, opracowywanie analiz i sprawozdań 
dotyczących rynku pracy oraz wspieranie edukacji publicznej i pozyskiwanie środków finansowych.

Organami związku są Zgromadzenie Związku (organ stanowiący), liczące 29 członków oraz Zarząd Związku (organ wykonawczy), mający siedmiu członków. Ich kadencja pokrywa się $\mathrm{z}$ kadencją rad miast członkowskich związku. Miasta członkowskie mają po dwóch delegatów w Zgromadzeniu ( $w$ tym prezydenta miasta), $\mathrm{z}$ wyjątkiem Katowic, które mają tam trzech delegatów. Delegatów do Zgromadzenia powołują rady miast, natomiast Zarząd wybierany jest przez Zgromadzenie Związku. W skład Zarządu wchodzą przewodniczący Zarządu i sześciu członków.

GZM opracował i uchwalił następujące dokumenty:

- Strategię rozwoju systemu gospodarki odpadami (30 września 2008);

- Strategię promocyjnq Górnośląsko-Zagłębiowskiej Metropolii „Silesia” (28 kwietnia 2009);

- Strategię Rozwoju Górnośląsko-Zagłębiowskiej Metropolii „Silesia” do 2025 r. (30 marca 2010);

Nadrzędnym celem strategicznym jest umacnianie wizerunku Metropolii jako miejsca, które daje pełnię możliwości korzystania z życia (największy rynek pracy i możliwości spędzania czasu wolnego). Ma on zostać osiągnięty poprzez realizacje celów strategicznych w ramach pięciu priorytetów rozwoju:

Priorytet A: Zarządzanie i pozycja metropolii Silesia:

1. Silna konkurencyjna metropolia;

2. Promocja i nowy wizerunek metropolii.

Priorytet B: Gospodarka, nauka, kultura:

1. Wysoka atrakcyjność i konkurencyjność gospodarki;

2. Sprzyjające warunki do rozwoju gospodarczego.

Priorytet C - transport i komunikacja:

1. Dostępność i otwartość komunikacyjna;

2. Zwiększanie udziału transportu publicznego w przewozach pasażerskich.

Priorytet D - środowisko:

1. Wysoka jakość środowiska oraz racjonalne gospodarowanie jego zasobami;

2. Zintegrowana gospodarka odpadami komunalnymi.

Priorytet E - warunki zamieszkania i usługi społeczne:

1. Zrównoważona struktura funkcjonalno-przestrzenna metropolii;

2. Zabezpieczanie potrzeb społecznych.

Do głównych osiągnięć GZM należy zaliczyć stworzenie Metropolitalnego systemu naboru do szkół oraz budowę portalu internetowego „Pełnia Kultury". Portal ma stanowić bazę danych oferty kulturalnej Metropolii, aktywować mieszkańców do uczestniczenia w życiu kulturalnym i zachęcać do uczestnictwa we współtworzeniu treści platformy. Projekt uzyskał dofinansowanie ze środków Unii Europejskiej. 
Wspólna promocja odbywa się w ramach unijnego projektu Metropolia Silesia - atrakcyjne miejsce inwestycji, realizowanego przez Górnośląski Związek Metropolitalny (GZM). Głównym elementem projektu była przygotowana w kilku wersjach językowych multimedialna oferta inwestycyjna. Zawiera ona 73 oferty inwestycyjne z 12 miast metropolii. Każda oferta zawiera krótki opis miasta, typ inwestycji, powierzchnię nieruchomości, dostępną infrastrukturę techniczną i dostępność komunikacyjną. Oferta została przygotowana w siedmiu językach: angielskim, niemieckim, rosyjskim, francuskim, hiszpańskim, chińskim i arabskim. Na realizację tego projektu GZM dostał blisko 900 tys. zł unijnego dofinansowania.

Metropolia Silesia przygotowała ofertę inwestycyjną na odbywające się w Mediolanie targi nieruchomości Expo Italia Real Estate EIRE 2012. Wcześniej swoją ofertę przedstawiała podczas podobnych imprez w Wiedniu, Monachium, Cannes i Madrycie. Po zakończeniu tego projektu GZM przystąpiła do realizacji podobnego przedsięwzięcia pod nazwą Inwestuj w Metropolii Silesia. W jego ramach zaplanowano udział w targach inwestycyjnych Expo Real w Monachium w latach 2012-2013, stworzenie kolejnej multimedialnej oferty inwestycyjnej oraz produkcję materiałów promocyjnych. Wartość projektu to prawie 1 mln zł. Metropolia Silesia prezentuje na targach kompleksową ofertę inwestycyjną wszystkich swoich miast. W sumie 97 nieruchomości położonych na terenie 14 miast. Projekt również uzyskał dofinansowanie z UE. Metropolia „Silesia” jest niezwykle atrakcyjnym miejscem dla inwestorów. Miasta w coraz bardziej profesjonalny sposób pozyskują inwestorów, a potem się nimi opiekują.

W roku 2012 GZM dokonał grupowego zakupu energii dla śląskich i zagłębiowskich samorządów. W imieniu wszystkich podmiotów tworzących grupę zakupową, całą procedurę przetargową przeprowadzała gmina Świętochłowice. Inicjatorem całego przedsięwzięcia był jednak Górnośląski Związek Metropolitalny. To on wziął na siebie ciężar organizacji wszystkich spotkań, rozmów i zbierania potrzebnych danych. Pracę nad organizacją grupowego przetargu na zakup energii elektrycznej rozpoczęły się w czerwcu ubiegłego roku.

Od lat trwają prace nad Śląską Kartą Usług Publicznych, która ma zostać wprowadzona w roku 2013. Karta jest wspólnym projektem Komunikacyjnego Związku Komunalnego Górnośląskiego Okręgu Przemysłowego (KZK GOP) oraz 21 miast aglomeracji śląskiej. Jest to system informatyczny pozwalający na obsługę płatności za usługi dostarczane przez instytucje publiczne. Równolegle do funkcji pieniądza elektronicznego karta stanowić będzie identyfikator mieszkańca oraz nośnik certyfikatu podpisu elektronicznego. System pozwoli na korzystanie z różnych usług: komunikacyjnych, kulturalnych, sportowo-rekreacyjnych, bibliotecznych, płatnego parkowania [http://www.gzm.org.pl/]. 
Ogromną wartością jest to, że Górnośląski Związek Metropolitalny powstał z oddolnego zapotrzebowania, a nie został narzucony odgórnie. Dopóki w życie nie wejdzie ustawa metropolitalna, działanie GZM opierać się będzie ona na przepisach dotyczących związków komunalnych. Na tej podstawie związek może funkcjonować w ograniczonym zakresie, dlatego też samorządowcy ze Śląska opowiadają się za przyjęciem ustawy metropolitalnej, ale specjalnie dopasowanej na potrzeby konurbacji. Nowa ustawa ma mu dać m.in. prawną możliwość występowania jako samodzielny organ, o którego działaniu współdecydują tworzące go gminy.

\subsubsection{Metropolia Poznań}

Geneza współpracy w obszarze metropolitalnym Poznania sięga roku 1999, w którym podpisano porozumienie miasta Poznań i powiatu poznańskiego o wspólnej administracji w zakresie opieki społecznej i rynku pracy. W latach 2000-2007 powstały pierwsze celowe związki międzygminne oraz podpisano porozumienia administracyjne pojedynczych gmin z Poznaniem. Przełomowy był rok 2007, kiedy podpisano Porozumienie o współpracy pomiędzy samorządami aglomeracji poznańskiej i utworzono Radę Aglomeracji Poznańskiej jako forum wymiany informacji i uzgodnień. W skład Rady wchodzą wójtowie i burmistrzowie 20 gmin, prezydent Poznania i starosta powiatu poznańskiego. Współpraca dotyczy następujących obszarów:

- gospodarki komunalnej,

- polityki gospodarczej,

- transportu,

- edukacji,

- służby zdrowia,

- polityki przestrzennej.

Rada nie ma oddzielnej stałej obsługi administracyjnej - funkcjonuje opierając się na pracownikach urzędów miast, gmin i starostwa. W listopadzie 2008 r. Rada podjęła decyzję o rozpoczęciuprac nad wspólną strategią rozwoju. W roku 2008 zorganizowano I Forum Gospodarcze Aglomeracji Poznańskiej (organizowane odtąd corocznie) oraz konferencję samorządową Powiat poznański - jakość przestrzeni i jakość życia, podczas której przeprowadzono debatę nt. podstawowych problemów w skali aglomeracji. W ciągu pierwszych dwóch lat funkcjonowania Rady wydano publikację pn. Aglomeracja Poznańska, zawierającą zestawienie ofert inwestycyjnych, zorganizowano warsztaty planistyczne, dzięki którym zinwentaryzowano konflikty na stykach między gminami oraz finalizowano prace nad utworzeniem związku międzygminnego dotyczącego gospodarki odpadami.

W roku 2009 powstało Centrum Badań Metropolitalnych (CBM), które pełni funkcję koordynatora prac Konsorcjum Badań nad Aglomeracją Po- 
znańską utworzonego przez Uniwersytet im. Adama Mickiewicza, Uniwersytet Ekonomiczny, Politechnikę Poznańską i Uniwersytet Przyrodniczy. W tym samym czasie rozpoczęto realizację projektu Funkcjonowanie i kierunki rozwoju aglomeracji poznańskiej, współfinansowanego przez samorządy. Celem projektu było określenie głównych potencjałów oraz problemów rozwojowych aglomeracji poznańskiej i wypracowanie wspólnej dla Poznania i strefy podmiejskiej średnioterminowej strategii rozwoju - do 2020 r. Rozpoczęto również cykl 20 debat z udziałem przedstawicieli władz i administracji samorządowej, naukowców, ekspertów, organizacji gospodarczych i społecznych pod nazwą Akademia Aglomeracyjna.

W 2010 r. opracowano Zielonq Księgę Aglomeracji Poznańskiej, która miała charakter prestrategii. Dokument został poddany konsultacjom społecznym i samorządowym. III Forum Gospodarcze Aglomeracji Poznańskiej odbyło się pod hasłem: Silna Aglomeracja - Nowoczesna Metropolia. Odbył się też I Zjazd Samorządów Aglomeracji Poznańskiej w Auli UAM.

W roku 2011 powstało Stowarzyszenie Metropolia Poznań. Rada Aglomeracji przekształciła się w Radę Metropolii. Do stowarzyszenia nie weszła jedna z gmin powiatu poznańskiego - Czerwonak. Pozostałe gminy kontynuują swoje członkowstwo. Przyjęta została Strategia Rozwoju Aglomeracji Poznańskiej. Opierając się na niej zaczęto wdrażanie programów strategicznych Metropolia 2020. Strategia wdrażana jest na trzech poziomach: organizacyjnym (tworzenie instytucji na poziomie metropolitalnym), merytorycznym (aktualizacja istniejących dokumentów lokalnych) i społecznym (upowszechnianie zapisów strategii i celów integracji).

W roku 2012 Centrum Badań Metropolitalnych opracowało Studium Uwarunkowań Rozwoju Przestrzennego Aglomeracji Poznańskiej [http:// www.cbm.amu.edu.pl/]. Obecnie trwają prace nad utworzeniem Związku Transportowego Aglomeracji Poznańskiej, rozpoczęto wspólną promocję Metropolii. Składają się na nią:

- współpraca samorządów aglomeracji z WBPP w zakresie tworzenia polityki przestrzennej województwa (konstruktywne zaopiniowanie POM),

- V Forum Gospodarcze Aglomeracji Poznańskiej,

- Ogólnopolska konferencja samorządowo-naukowa Polskie Metropolie - dokonania i kierunki rozwoju (MTP),

- ujęcie POM w zaktualizowanej Strategii rozwoju województwa 2020,

- prace koncepcyjne nad Poznańską Koleją Metropolitalną,

- prace nad Planem zrównoważonego rozwoju transportu dla całej aglomeracji,

- utworzenie Metropolitalnego Forum Planowania Przestrzennego.

Do sukcesów współpracy należy zaliczyć:

- wypracowanie wspólnej strategii,

- realizację kolei metropolitalnej. 
W ramach zintegrowanego transportu publicznego udało się wprowadzić Poznańską Elektroniczną Kartę Aglomeracyjną „PEKA”, co było bardzo trudne z uwagi na ogromną liczbę operatorów. Prowadzona jest na szeroką skalę edukacja w zakresie rozwoju tożsamości metropolitalnej.

Uznano, że czynniki sukcesu to:

- struktura instytucjonalna - tylko jeden powiat,

- dobry klimat polityczny, liderzy integracji,

- różne formy współpracy,

- silna podbudowa merytoryczna - szereg diagnoz dotyczących całej aglomeracji.

Specyfiką poznańskiej ścieżki integracji jest ścisła współpraca ze środowiskiem naukowo-akademickim, której głównymi zaletami są:

- niezależność od jednej konkretnej jednostki samorządowej,

- ekspercki charakter, łagodzący lokalne spory polityczne,

- interdyscyplinarność,

- elastyczność.

Do wad należą zaś:

- niepewność finansowania,

- brak zaplecza administracyjnego i organizacyjnego,

- brak szerokiego zaplecza urbanistów - praktyków,

- problemy z koordynacją międzyuczelnianą.

Model na najbliższe lata przewiduje oparcie współpracy na dwóch filarach merytoryczno-organizacyjnych - CBM i Stowarzyszeniu Metropolia Poznań, ściśle współpracujących ze sobą oraz ze związkami i stowarzyszeniami samorządowymi, a także pracowniami planistycznymi (MPU, WBPP) [Kaczmarek 2012].

Ponadto dziewięć gmin aglomeracji utworzyło spółkę akcyjną Aquanet S.A, kolejne cztery gminy pobierają od niej wodę [Mikuła 2009].

\subsubsection{Gdański Obszar Metropolitalny}

Idea współpracy gmin w obszarze metropolitalnym Trójmiasta pojawiła się na początku lat 90. XX w. W 1992 r. samorządowcy z Gdańska, Sopotu, Gdyni, Pruszcza Gdańskiego, Rumi, Redy i Wejherowa powołali Konwent Wójtów, Burmistrzów i Prezydentów Gdańskiego Obszaru Metropolitalnego. Na czele Konwentu stanął ówczesny prezydent Sopotu. Konwent rozpoczął prace nad delimitacją obszaru i powołał kilka komisji problemowych, złożonych z urzędników poszczególnych urzędów, które identyfikowały obszary możliwej współpracy metropolitalnej. W $1993 \mathrm{r}$. wiceprezydent Wejherowa zaproponował utworzenie Gdańskiego Związku Metropolitalnego, który zajmowałby się koordynacją planów przestrzennych, działań ekologicznych, komunikacji, polityki rozwoju gospodarczego oraz powołaniem policji metropolitalnej. Na forum Gdańskiego Związku Metropolitalne- 
go miałyby więc być podejmowane decyzje, które nie powinny być rozstrzygane na szczeblu jednej gminy. 19 czerwca 1993 r. odbyła się gdańska konferencja metropolitalna, na której dyskutowano, jakie szanse i ewentualne zagrożenia dla miast pomorskich niesie za sobą powstanie Gdańskiego Zespołu Metropolitalnego.

W 1997 r. powstało Stowarzyszenie Lobbingu Pomorza Gdańskiego, skupiające menadżerów, naukowców, przedsiębiorców, urzędników samorządowych i rządowych oraz kilku posłów. Prezesem, aż do zakończenia działania Stowarzyszenia w roku 2005, był prezes zarządu firmy Polnord. Stowarzyszenie doprowadziło do kilku debat z udziałem prezydentów miast Trójmiasta. W roku 1999 podpisano porozumienie w sprawie współdziałania na rzecz aglomeracji, które było wymiernym efektem tych debat. Prezydenci rozpoczęli prace nad wspólnym biletem metropolitalnym [http://www.metropoliagdansk.pl/stowarzyszenie-gom/inicjatywy-metropolitalne-1990-2011].

Od 2003 r. działa, utworzona z inicjatywy marszałka województwa pomorskiego oraz prezydenta Gdańska, Rada Metropolitalna Zatoki Gdańskiej, której celem jest współdziałanie samorządów miast, gmin i powiatów oraz samorządu województwa na rzecz rozwiązywania takich wspólnych problemów metropolii Trójmiasta, jak:

- komunikacja i transport,

- marketing i promocja,

- koordynowanie przygotowania wspólnych inwestycji,

- pozyskiwanie funduszy unijnych,

- zagospodarowanie przestrzenne.

Rada podjęła pracę nad następującymi zagadnieniami:

- integracja systemu transportowego w aglomeracji,

- potencjał rozwojowy inwestycji zagranicznych na Pomorzu,

- utworzenie Bałtyckiego Metropolitalnego Forum Gospodarczego - rozumianego jako płaszczyzna współpracy i budowy wzajemnych relacji inwestorów z kraju i zagranicy oraz przedstawicieli władz oraz samorządów lokalnych. Główną ideą Forum jest długoterminowa aktywizacja inwestycyjna całego regionu Pomorza, mająca w konsekwencji przyczynić się do wzrostu jego znaczenia na mapie atrakcyjności gospodarczej Europy. Pierwsze Forum odbyło się we wrześniu 2006 r.,

- rozwój funkcji metropolitalnych - istniejące i potencjalne lokalizacje, jako przygotowanie do tworzenia ofert inwestycyjnych,

- problem suburbanizacji w trójmiejskim obszarze metropolitalnym,

- rozwój powiązań transportowych.

Do głównych osiągnięć w dziedzinie współpracy należy zaliczyć dojście do porozumienia w sprawie utworzenia Metropolitalnego Związku Komunikacyjnego. W czerwcu 2007 r. został zarejestrowany Metropolitalny 
Związek Komunikacyjny Zatoki Gdańskiej, w skład którego weszło 13 gmin. Związek doprowadził do powstania biletu metropolitalnego.

Ważnym i konkretnym efektem prac Rady Metropolitalnej były konsultacje i opiniowanie dokumentów strategicznych oraz planistycznych, np.:

- Strategii Rozwoju Województwa Pomorskiego do 2020 r.,

- Regionalnego Programu Operacyjnego Województwa Pomorskiego na lata 2007-2013,

- planu zagospodarowania przestrzennego obszaru metropolitalnego.

Żadna z inicjatyw nie doprowadziła jednak do sformalizowania współpracy na rzecz metropolii na szerszym polu, aż do utworzenia we wrześniu 2011 r. stowarzyszenia samorządowego Gdański Obszar Metropolitalny (GOM). Najwyższą władzą GOM jest Walne Zgromadzenie Członków, którzy są delegowani przez rady poszczególnych jednostek samorządowych. Każdy $\mathrm{z}$ nich ma jeden, tak samo znaczący, głos. Działalność stowarzyszenia polega na realizacji wspólnych projektów. Od stycznia roku 2012, w ramach współpracy ośmiu powiatowych urzędów pracy, realizowany jest projekt o nazwie Metropolitalny Rynek Pracy. W jego ramach w maju 2012 r. zorganizowano Metropolitalne Targi Pracy, Przedsiębiorczości i Edukacji. Realizowany jest projekt Wsparcie dla aktywnie poszukujących pracy. Dzięki niemu bezrobotni mieszkańcy miast GOM, którzy aktywnie poszukują pracy, mogą korzystać z bezpłatnych przejazdów środkami komunikacji miejskiej. Podpisano również wspólną deklarację o swobodzie wyboru miejsca prowadzenia działalności gospodarczej. Dzięki temu osoby bezrobotne, które będą skutecznie ubiegać się o przyznanie środków na otworzenie własnej działalności gospodarczej w PUP w jednym powiecie, będą mogły bez przeszkód otworzyć swoją firmę w innym [http://www.metropoliagdansk.pl/ stowarzyszenie-gom/projekty]. GOM przygotowało też wspólną ofertę inwestycyjną, która została zaprezentowana po raz pierwszy na największych na świecie Targach Nieruchomości w Cannes, w marcu 2012 r. Oferta przygotowana przez Gdańską Agencję Rozwoju Gospodarczego (InvestGDA), prezentuje potencjał gospodarczy całego obszaru metropolitalnego [http:// www.metropoliagdansk.pl/stowarzyszenie-gom/projekty].

Stowarzyszenie GOM jest bardziej przychylne koncepcji utworzenia zarządu metropolitalnego, natomiast Gdynia sprzyja formie zrzeszeniowej [Konferencja... 2012]. Za formą zinstytucjonalizowaną (powiatu metropolitalnego, na czele $\mathrm{z}$ prezydentem, wybranym w bezpośrednich wyborach) zdecydowanie opowiadają się prezydenci Sopotu i Gdańska, którzy twierdzą, iż na arenie międzynarodowej ważny jest wizerunek silnego lidera, a to może zagwarantować tylko prezydent metropolii [http://www.metropolia gdansk.pl/stowarzyszenie-gom/inicjatywy-metropolitalne-1990-2011]. 


\subsubsection{Szczeciński Obszar Metropolitalny}

15 kwietnia 2005 r. powstało Samorządowe Stowarzyszenie Współpracy Regionalnej, które 4 września 2009 r. zmieniło nazwę na Stowarzyszenie Szczecińskiego Obszaru Metropolitalnego - SOM. W skład stowarzyszenia wchodzi Urząd Marszałkowski Województwa Zachodniopomorskiego, powiat policki i 11 gmin. Celem SOM jest stworzenie silnego ośrodka metropolitalnego. Wspólne prace polegają m.in. na przygotowaniu koncepcji zarządzania Szczecińskim Obszarem Metropolitalnym, strategii rozwoju, wprowadzeniu uregulowań legislacyjnych, lobbingu i innych działaniach eksponujących atrakcyjność inwestycyjną, gospodarczą i kulturową obszaru. Stowarzyszenie osiąga swoje cele w gospodarce przestrzennej, transportowej, edukacji, ochronie środowiska i infrastrukturze za pośrednictwem komisji. Do tej pory na zlecenie SOM została stworzona spójna mapa planistyczna obszaru metropolitalnego i opracowana Koncepcja rozwoju transportu publicznego w SOM. W Szczecinie trwa budowa zakładu termicznego unieszkodliwiania odpadów, który ma służyć wszystkim gminom z obszaru metropolitalnego. Wydawany jest również „Kurier Metropolitalny” - bezpłatny dodatek do „Kuriera Szczecińskiego”, który promuje ideę metropolitalności [www.som.szczecin.pl].

\subsubsection{Agencja Rozwoju Aglomeracji Wrocławskiej (ARAW)}

Innym przykładem zinstytucjonalizowanej współpracy jest, utworzona w roku 2005, Agencja Rozwoju Aglomeracji Wrocławskiej, która działa w formie spółki akcyjnej non-profit. Jej akcjonariuszami są Wrocław i otaczające go gminy (30). Ponieważ ARAW jest spółką publiczno-publiczną, to może przyjmować zadania (i środki finansowe) gmin będących jej współudziałowcami bez procedury przetargowej. Głównym celem spółki jest tworzenie warunków aktywizacji gospodarczej. ARAW realizuje dla gmin zadania w zakresie:

1. Pozyskiwania inwestycji zagranicznych (Centrum Wspierania Biznesu). Przedstawiciele spółki uczestniczyli w negocjacjach z IBM. Agencja pomagała także $\mathrm{w}$ pozyskiwaniu innych inwestorów dla Wrocławia i okolic;

2. Doradztwa i świadczenia usług w zakresie zamówień publicznych (grupowe, zielone), partnerstwa publiczno-prywatnego, projektów unijnych, finansów publicznych, pozyskiwania zewnętrznego, procesów prawnych, legislacyjnych i prawodawczych, gospodarki odpadami, audytu energetycznego, cech endogenicznych samorządów, organizacji szkoleń i seminariów (Centrum Usług Samorządowych);

3. Projektów unijnych [http://www.araw.pl].

Agencja przygotowała tzw. produkt turystyczny aglomeracji wrocławskiej. Inicjatywa ta ma zachęcić wrocławian do spędzania wolnego czasu na terenie aglomeracji. Opracowano także plan modernizacji zarządzania 
w administracji samorządowej w partnerstwie dolnośląskich j.s.t. Ponadto zakończono projekt Nauczyciel przyszłości, który podnosić ma kwalifikacje zawodowe nauczycieli.

Spółka koordynuje również Program dla Wrocławia - autorski projekt antykryzysowy prezydenta Dutkiewicza, mający na celu stworzenie pakietu zadań wraz z narzędziami ich realizacji, które złagodzą skutki pogłębiającego się na świecie kryzysu [Program... 2009] oraz projekt Wracajcie, którego celem jest nakłonienie do powrotu z zagranicy młodych i zdolnych ludzi, na których praca czeka w Aglomeracji Wrocławskiej.

Dzięki zabiegom ARAW Wrocław otrzymał wiele nagród i wyróżnień, m.in. Europejską Nagrodę Sektora Publicznego EPSA 2009, Most Business Friendly Region 2008 (według British-Polish Chamber of Commerce). Ponadto aglomeracja wrocławska stała się regionem najmocniej przyciągającym inwestorów (według „Pulsu Biznesu” 2008), a sam Wrocław najbardziej przyjaznym dla biznesu miastem w Polsce (według „Forbesa” 2008) oraz najbardziej innowacyjnym (raport za rok 2008 firm KPMG) [Szumska 2009].

Agencje rozwoju są powszechnie wykorzystywane w zarządzaniu rozwojem obszarów metropolitalnych w Europie (zob. rozdz. IV). Model współpracy utworzony we Wrocławiu jest obecnie przenoszony na grunt innych polskich metropolii (Lublin, Trójmiasto) ${ }^{75}$.

\subsection{Szczególne problemy występujące w obszarach metropolitalnych}

\subsubsection{Konkurencja między jednostkami samorządu}

Powyżej zostały zaprezentowane inicjatywy współpracy między różnymi podmiotami, jakie występują w obszarach metropolitalnych naszego kraju. Tymczasem równolegle do tych pozytywnych przedsięwzięć panuje w nich także silna konkurencja, zwłaszcza między samorządami. Najbardziej spektakularny wyraz przybiera ona w Obszarze Metropolitalnym Trójmiasta, gdzie wyraźnie widać rywalizację miedzy dwoma ośrodkami rdzeniowymi Gdańskiem i Gdynią. Przejawia się ona w utworzeniu dwóch stowarzyszeń, które nie są w stanie ze sobą współpracować. Są to Gdański Obszar Metropolitalny (GOM) i NORDA.

GOM powstał 15 września 2011 r. z inicjatywy prezydenta Gdańska, który od razu zaprosił do współpracy członków stowarzyszenia NORDA. W skład

75 Formalnym podmiotem współpracy jest również Stowarzyszenie „Metropolia Warszawa" utworzone w 2000 r. przez gminy warszawskie i otaczające stolicę. Celem stowarzyszenia jest współpraca gmin oraz utworzenie metropolii stołecznej. Poza zleceniem przygotowywania opracowań, mających stanowić podstawę do wdrażania intensywnej współpracy metropolitalnej, nie podejmuje działań mających na celu rozwiązywanie problemów metropolitalnych. 
GOM weszło 29 przedstawicieli (obecnie 40) gmin i powiatów, przy czym część gmin jest jednocześnie członkiem obu stowarzyszeń (rys. 39).

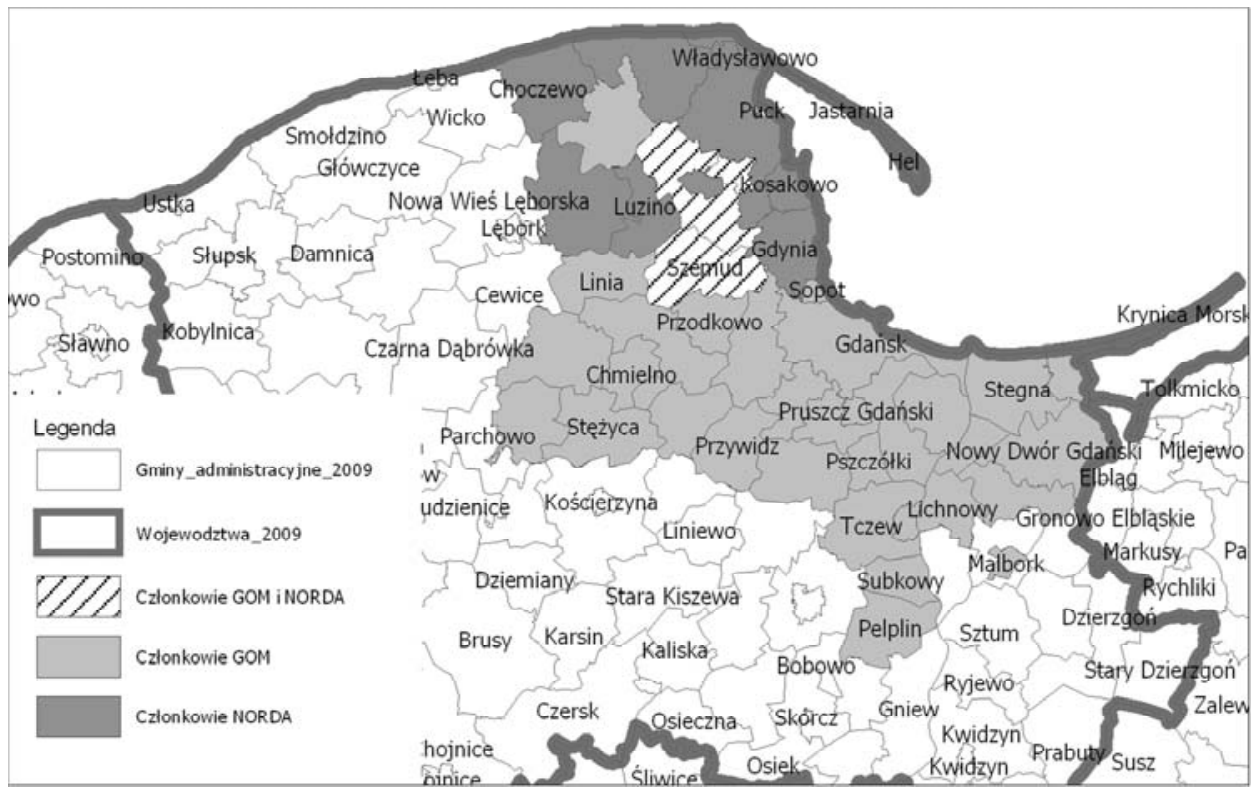

Rys. 39. Członkowie stowarzyszeń w Trójmiejskim Obszarze Metropolitalnym Źródło: oprac. własne

Na dwa dni przed spotkaniem założycielskim GOM, przedstawiciele 15 gmin z północnej części województwa pomorskiego podpisali się pod listem o współpracy w ramach mającego „charakter nieformalny" Forum Wójtów, Burmistrzów i Prezydentów NORDA. Większość tych gmin zadeklarowało wcześniej chęć przystąpienia do Stowarzyszenia GOM. Forum NORDA ma działać jedynie na rzecz północnej części Pomorza. Współpraca ma dotyczyć realizacji Obwodnicy Północnej Aglomeracji Trójmiejskiej, wspólnej gospodarki komunalnej, polityki turystycznej oraz edukacyjnej. NORDA powstała z inicjatywy prezydenta Gdyni, który w kwietniu, po otrzymaniu propozycji przystąpienia do GOM, odmówił przyjęcia zaproszenia, twierdząc, że byłoby ono tworem nic nie wnoszącym i nie dającym żadnych realnych instrumentów do działania na rzecz metropolii [Moritz 2011].

W Bydgosko-Toruńskim Obszarze Metropolitalnym, zaprzeczając porozumieniu o powołaniu Kolegium B-TOM, w Bydgoszczy powstało Stowarzyszenie Metropolia Bydgoska. Prezydenci obu głównych miast obszaru od lat nie są w stanie porozumieć się w sprawach istotnych dla całej metropolii. Prezydent Bydgoszczy uważa, że między oboma miastami nie ma związków funkcjonalnych, natomiast prezydent Torunia i sejmik województwa opowiadają się za utworzeniem duopolu. 


\subsubsection{Niski poziom kapitału społecznego}

Badania przeprowadzone w 25 krajach Unii Europejskiej pokazują, że społeczeństwo polskie prezentuje jeden z najniższych poziomów zaufania względem innych obywateli wśród krajów Wspólnoty. Polska znalazła się na przedostatnim miejscu spośród krajów objętych badaniem. Również inne mierzalne wskaźniki kapitału społecznego należą w Polsce do najniższych w całej Unii Europejskiej [European Comission 2005, s. 42]. Jeśli chodzi o zaufanie do władz lokalnych, to w roku 2002 kształtowało się na poziomie 43\%, a w roku 2008 już na poziomie 68\%, jednak w roku 2010 znów spadło do 55\% [CBOS 2010]. Kolejny czynnik określający poziom kapitału społecznego wskazuje, że w 2011 r., aż 49\% obywateli wykazywało obojętność wobec sześciu form naruszania dobra wspólnego ${ }^{76}$ i, co jest niezwykle niepokojące, odsetek osób obojętnych wzrósł aż o 14 punktów procentowych w stosunku do roku 2005 [Czapiński, Panek 2011]. Według badań CBOS tylko 21\% społeczeństwa ufa polskiemu parlamentowi, a $14 \%$ partiom politycznym. Te dwa ostatnie wskaźniki także plasują nas na jednych z ostatnich miejsc w Europie. Największym zaufaniem Polacy darzą organizacje charytatywne (powyżej 80\%). Sumaryczny wskaźnik zaufania w sferze publicznej wskazuje, że „połowicznie” ufają różnego rodzaju instytucjom i organizacjom funkcjonującym w społeczeństwie. Średnie zaufanie mierzone na skali od 0 do 23 dla ogółu Polaków wyniosło bowiem 12,08 [CBOS 2010, s. 13].

Poziom rozwoju kapitału społecznego mierzy się również udziałem obywateli w wyborach. Największą frekwencję $w$ wyborach do sejmu zanotowano w miastach (Warszawa 73\%, Poznań 69\%, Gdańsk 67\%) i gminach znajdujących się w obszarze funkcjonalnym największych miast, co może wskazywać na nieco wyższy poziom kapitału społecznego w najsilniejszych obszarach miejskich [MRR 2010a, s. 63].

Zaufanie do władz lokalnych jest niższe na byłych ziemiach zaboru rosyjskiego niż pruskiego i austriackiego. Poza tym Polacy na tych obszarach wolą podejmować działania indywidualne, ustalać rozwiązania w nieformalnych układach lub czekać na inicjatywy władz lokalnych, aniżeli podejmować zorganizowane działania zbiorowe [Klimczuk 2009, s. 7].

Najprostszą miarą stanu społeczeństwa obywatelskiego jest stopień zrzeszania się - odsetek obywateli, którzy należą do organizacji dobrowolnych. W Polsce w 2011 r. członkami jakichś organizacji, stowarzyszeń, partii, komitetów itp. było 14,8\% badanych. W porównaniu z rokiem 2003 wzrost wyniósł zaledwie 2,6 punktu procentowego. Równie rzadko ludzie

${ }^{76}$ Zaniżanie wysokości płaconych podatków, unikanie płacenia za korzystanie z transportu publicznego, unikanie płacenia za światło, czynszu za mieszkanie, ceł, pobieranie niesłusznie zasiłku dla bezrobotnych. 
w Polsce podejmują lub włączają się w działania na rzecz własnej społeczności (15,6\% badanych), chociaż w porównaniu z rokiem 2000 (8\%) nastąpił tu prawie dwukrotny wzrost [Czapiński, Panek 2011, s. 278].

Jak zauważył Fukuyama

[...] komunizm przyczynił się do powstania wielu nawyków społecznych takich jak: nadmierna zależność od państwa, prowadząca do zaniku inicjatyw społecznych, niezdolność do kompromisu oraz niechęć do zrzeszania się w dobrowolnych organizacjach [za: Frykowski 2005, s. 54].

Niski poziom zaufania między Polakami, według K. Skarżyńskiej, można tłumaczyć tradycyjnym wychowaniem, słabym wykształceniem, wysoką religijnością oraz pamięcią o życiu w autorytarnym systemie politycznym. Polacy nie starają się zrozumieć zachowań innych, wolą wybierać rozwiązania siłowe, bezpieczne i akceptowane przez autorytety, a nie innowacyjne. Do tego widząc, że inni łamią prawo sami postępują podobnie. Ponadto Polacy mają doświadczenia generujące nieufność (pamięć o II wojnie światowej, realnym socjalizmie, trudnościach z transformacją ustrojową i integracją europejską czy aferach wśród elit politycznych). W społeczeństwie polskim rywalizacji w dążeniu do zdobycia społecznie cenionych dóbr nie traktuje się w kategoriach mobilizacji, sposobu na maksymalizację wysiłków i osiąganie w jakimś zakresie doskonałości, lecz jako przejawy agresji, zawiści, łamania norm [Skarżyńska 2005, s. 84-87].

Badania kapitału społecznego w województwie mazowieckim zostały przeprowadzone w ramach projektu Trendy rozwojowe Mazowsza pod kierownictwem Z. Strzeleckiego. Celem projektu była ocena poziomu zaufania do instytucji lokalnych jako istotnego czynnika kapitału społecznego, mającego wpływ na jakość życia obywateli. Do instytucji tych zaliczono: władze lokalne, szkoły, policję, Kościół i organizacje społeczne. Największym zaufaniem respondentów cieszyła się szkoła (65\% ankietowanych), na kolejnych miejscach znalazły się: Kościół (57\%), policja (55\%), samorząd lokalny $(48 \%)$ oraz organizacje społeczne (43\%). Uderzający jest niski poziom zaufania do samorządu, który powinien być aktywnym podmiotem zachęcającym ludność do partycypacji w życiu publicznym. Podobnie sytuacja wygląda $\mathrm{z}$ organizacjami społecznymi. Z założenia są one tymi podmiotami, w których powinno kształtować się społeczeństwo obywatelskie, tymczasem ankietowani wykazywali wobec nich najniższy poziom zaufania.

Badania wskazują też na przestrzenne zróżnicowanie poziomu zaufania. Wynika z nich znacząco większe zaufanie do szkoły na terenach wiejskich niż w mieście. Z kolei wskaźnik poziomu zaufania do organizacji społecznych jest wyższy na terenach miejskich niż wiejskich, co wynika z większej liczby i różnorodności tych organizacji działających w miastach. Są one też lepiej rozpoznawane. Jeśli chodzi o zaufanie do samorządu, to badania 
wskazują na wyraźną korelację między poziomem zaufania a sposobem zarządzania gminą. Im lepszy był gospodarz, tym większy był poziom zaufania [Strzelecki 2011].

Podobne badania należałoby przeprowadzić w pozostałych obszarach metropolitalnych, lecz powinny być poszerzone o badanie zaufania różnych interesariuszy względem siebie, w tym zaufania samorządów i mieszkańców strefy podmiejskiej do władz regionalnych, które powinny stymulować rozwój obszarów metropolitalnych.

Niski poziom kapitału społecznego powoduje, iż szczególną uwagę poświęcić należy wzmacnianiu mechanizmów kooperacji i zaufania między ludźmi, gdyż ich jakość będzie wpływać na szanse rozwojowe poszczególnych regionów i całego kraju.

\subsection{Wnioski z przeglądu studiów przypadku}

Zaprezentowane formy współpracy j.s.t., dopuszczone przez stosowne ustawy, są oczywiście wykorzystywane w praktyce zarządzania w układach terytorialnych. Współpraca między różnymi jednostkami terytorialnymi najczęściej jest ograniczona do wąskich problemów i rzadko są tworzone organy, które kompleksowo koordynowałyby wszelkie działania podejmowane w obszarze metropolitalnym. Z punktu widzenia obszarów metropolitalnych, problemów występujących w tychże obszarach, zadań o charakterze użyteczności publicznej wydaje się, że najbardziej odpowiednią formą współpracy jest związek gmin. Pozostałe rozwiązania organizacyjne w zakresie współdziałania nie stwarzają, ze względu na swoją specyfikę, szans na efektywną i skuteczną współpracę gmin. W dzisiejszych uwarunkowaniach prawnych jedynie związek gmin daje szansę realizacji założonych zadań. Jednak analiza utworzonych dotychczas związków gminnych pokazuje, iż nie są one wykorzystywane do rozwiązywania problemów na poziomie metropolitalnym i stanowią zalążkową formę współpracy. Potwierdza się zatem hipoteza twierdząca, iż system związków gminnych nie może być podstawą do wdrożenia zarządzania metropolitalnego. $\mathrm{Z}$ punktu widzenia naszej gospodarki, wzmacniania konkurencyjności, nie można nawiązywania współpracy pozostawić siłom żywiołowym i czekać aż społeczeństwo i gminy poniosą na tyle duże koszty, żeby przejść z fazy konkurowania do fazy kooperowania. Dlatego trzeba przyspieszyć tę współpracę poprzez wdrożenie odpowiednich instrumentów.

Jednym z kluczowych problemów związanych z zarządzaniem obszarami metropolitalnymi jest kwestia finansowania. Większość jednostek terytorialnych zanim zdecyduje się przystąpić do struktur metropolitalnych, wymaga informacji, z jakimi dokładnie kosztami należy się liczyć (wysokość składek, współfinansowanie opracowywania planu zagospodarowania, 
dodatkowe obciążenia). Jasno określony sposób finansowania przyjął GZM. Na majątek związku składają się m.in.:

- wkłady członkowskie,

- roczne składki członków (1 zł od każdego mieszkańca miasta członkowskiego),

- składniki majątkowe przekazane przez poszczególne gminy, służące realizacji zadań przejętych przez związek,

- składniki nabyte przez związek,

- dochody z majątku i urządzeń związku,

- dochody z działalności gospodarczej związku,

- subwencje, dotacje, darowizny, zapisy,

- dotacje celowe na realizację zadań powiatowych przejętych przez związek [Statut Górnoślq̨skiego... b.d.].

Podobnie wygląda sytuacja w Metropolii Poznań. Działalność Stowarzyszenia finansowana jest m.in. ze składek członkowskich, których wysokość uzależniona jest od liczby mieszkańców jednostki terytorialnej. Poznań płaci składkę w podwójnej wysokości [Statut Stowarzyszenia... §51].

Jeśli chodzi o nieformalne formy współpracy, to często istnieją one tylko na papierze i nie przynoszą żadnych wymiernych efektów (rzeszowski OM, BOM). Oczywiście kwestią stosownych wyborów politycznych jest przesądzenie o obligatoryjności czy też dobrowolności uczestnictwa gmin w związku bądź innej formie współpracy. W każdym przypadku proponowane rozwiązania organizacyjno-finansowe winny być przedmiotem wieloaspektowych dyskusji, pokazujących władzom gmin korzyści z przystąpienia do związku oraz korzyści dla całego obszaru metropolitalnego w przypadku realizacji części zadań z zakresu użyteczności publicznej nie tylko przez wyalienowane gminy, ale także przez wykreowany podmiot. Realizacja części zadań związanych z tworzeniem jak najkorzystniejszych warunków dla mieszkańców i podmiotów gospodarczych w ramach związku, stwarza szanse, dzięki efektom synergicznym, na uzyskiwanie większych efektów przy angażowaniu tych samych środków finansowych.

\section{Współrządzenie w obszarach metropolitalnych $w$ świetle przepro- wadzonych badań}

Badania dotyczące funkcjonowania gmin i współpracy w obszarach metropolitalnych stanowiły część szerszego projektu, mającego ocenić sprawność procesów zarządzania w obszarach funkcjonalnych. Celem badań kwestionariuszowych była analiza współpracy w obszarach metropolitalnych oraz zapoznanie się z opiniami gmin odnośnie formy prawnej funkcjonowania obszarów metropolitalnych. Kwestionariusze skierowano do wszystkich polskich gmin. Spośród 486 gmin położonych w 12 obszarach 
metropolitalnych Polski ${ }^{77}$, ankiety odesłały 152 gminy (31,28\%), przy czym na pytania związane z kwestiami metropolitalnymi odpowiedzi udzieliło tylko 77 samorządów. Fakt ten świadczy o braku świadomości metropolitalnej i braku zrozumienia problemu wśród respondentów. Gminy, które nie wypełniły tej części ankiety, uważają, iż nie należą do obszaru metropolitalnego, co często wręcz pisały w kwestionariuszu. Wydaje się, że za część obszaru metropolitalnego uważać się będą tylko wtedy, gdy obszar ten zostanie zinstytucjonalizowany ${ }^{78}$.

Poniżej przedstawiono szczegółowe wyniki opracowane na podstawie ankiet otrzymanych od gmin, które odpowiedziały na pytania "metropolitalne". Rozkład odpowiedzi na pytanie o współpracę z innymi podmiotami przy tworzeniu dokumentów strategicznych przedstawia tabela 14.

Z tabeli wynika, że gminy przy tworzeniu dokumentów strategicznych najczęściej współpracowały ze społecznością lokalną, przedstawicielami lokalnego biznesu i organizacjami pozarządowymi. Natomiast jeśli chodzi o współpracę z j.s.t., to np. przy tworzeniu strategii zaledwie sześć gmin (ze 116) współpracowało z inna gminą, 16 - z powiatem, a 12 z samorządem województwa. W przypadku studium i planów miejscowych ta współpraca była znacznie częstsza, ale jest to zapewne efektem wypełnienia wymogów narzuconych przepisami prawa. Pozytywnym zjawiskiem jest współpraca przy tworzeniu strategii rozwiązywania problemów społecznych. Aż 40 gmin współpracuje z NGOs, które są naturalnym partnerem przy rozwiązywaniu problemów społecznych. Jeśli chodzi o formy współpracy, to najczęściej przebiegała ona w postaci spotkań z mieszkańcami i przedsiębiorcami oraz polegała na zbieraniu opinii za pośrednictwem ankiet. Gminy często korzystały również z ekspertyz przygotowywanych przez profesjonalistów.

77 Gminy na potrzeby niniejszego opracowania dobrano według delimitacji przeprowadzonych w każdym z obszarów metropolitalnych. Najczęściej były one efektem działań prowadzonych $w$ ramach opracowywania planu zagospodarowania przestrzennego województwa, którego częścią ma być plan zagospodarowania obszaru metropolitalnego. W przypadku, gdy nie było jednej, wiążącej delimitacji, do badań przyjęto najszerszy z zaproponowanych zasięgów obszaru metropolitalnego.

${ }_{78}$ Takie podejście do zagadnienia prezentowało nawet jedno z miast centralnych, którego władze odpowiedziały na pytania dotyczące części metropolitalnej dopiero po ponownej prośbie zespołu badawczego i wyjaśnieniu, że w badaniach nie chodzi o zinstytucjonalizowane obszary metropolitalne. 
Tabela 14

Współpraca gmin z interesariuszami przy tworzeniu dokumentów strategicznych

(\% współpracujących gmin)

\begin{tabular}{|c|c|c|c|c|c|c|c|c|c|c|c|}
\hline \multirow[b]{2}{*}{ Rodzaj dokumentu } & \multicolumn{11}{|c|}{ Z jakim podmiotem/podmiotami gmina współpracowała? } \\
\hline & 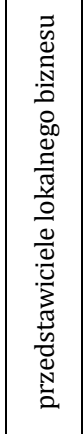 & 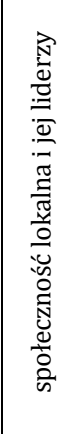 & 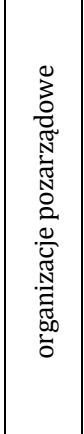 & 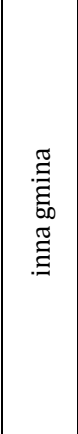 & 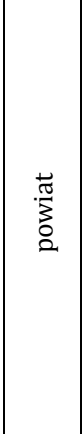 & 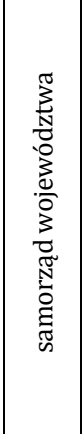 & 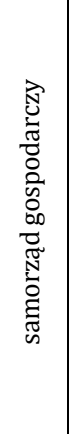 & 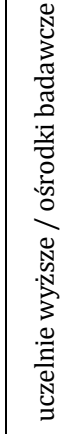 & 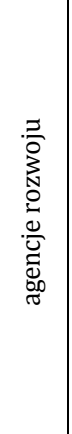 & 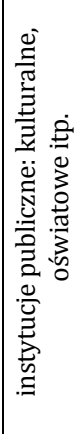 & 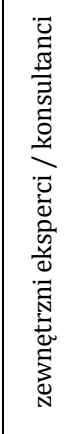 \\
\hline Strategia rozwoju gminy & 52,59 & 64,66 & 43,97 & 5,17 & 13,79 & 10,34 & 8,62 & 10,34 & 6,03 & 35,34 & 35,34 \\
\hline Plan rozwoju lokalnego & 24,14 & 38,79 & 28,45 & 1,72 & 3,45 & 3,45 & 0,86 & 1,72 & 0,86 & 14,66 & 13,79 \\
\hline Wieloletni plan inwestycyjny & 13,79 & 35,34 & 14,66 & 5,17 & 14,66 & 12,07 & 1,72 & 2,59 & 1,72 & 8,62 & 7,76 \\
\hline Wieloletni plan finansowy & 6,03 & 22,41 & 13,79 & 7,76 & 11,21 & 11,21 & 0,86 & 0,86 & 1,72 & 9,48 & 4,31 \\
\hline Studium u.k.z.p. & 35,34 & 77,59 & 22,41 & 53,45 & 50,86 & 50,00 & 6,03 & 4,31 & 4,31 & 16,38 & 27,59 \\
\hline $\begin{array}{c}\text { Miejscowe plany zagospoda- } \\
\text { rowania przestrzennego }\end{array}$ & 33,62 & 73,28 & 23,28 & 47,41 & 47,41 & 45,69 & 5,17 & 4,31 & 3,45 & 17,24 & 29,31 \\
\hline \begin{tabular}{|l|} 
Strategia rozwiązywania \\
problemów społecznych
\end{tabular} & 11,21 & 40,52 & 34,48 & 2,59 & 16,38 & 6,03 & 0,86 & 2,59 & 0,86 & 32,76 & 18,97 \\
\hline Plan gospodarki odpadami & 14,66 & 32,76 & 8,62 & 7,76 & 34,48 & 31,03 & 1,72 & 1,72 & 0,00 & 6,03 & 25,00 \\
\hline $\begin{array}{l}\text { Program współpracy z } \\
\text { organizacjami pozarządo- } \\
\text { wymi }\end{array}$ & 5,17 & 27,59 & 60,34 & 1,72 & 2,59 & 0,00 & 1,72 & 0,00 & 0,00 & 6,90 & 0,00 \\
\hline Program ochrony środowiska & 14,66 & 33,62 & 11,21 & 5,17 & 37,93 & 29,31 & 1,72 & 1,72 & 0,86 & 5,17 & 28,45 \\
\hline
\end{tabular}

Źródło: oprac. własne.

Za główne bariery współpracy gminy z przedsiębiorcami przy opracowywaniu dokumentów strategicznych i podejmowaniu innych działań rozwojowych ankietowane jednostki uznały bariery organizacyjne i proceduralne oraz prawne i formalne. W przypadku współpracy ze społecznością lokalną, jako główna została wskazana bariera psychologiczna. Może to być potwierdzeniem niskiego poziomu zaufania społeczeństwa. Najważniejsze bariery przy współpracy z organizacjami pozarządowymi oraz innymi jednostkami samorządu terytorialnego dotyczą kwestii finansowych i organizacyjno-proceduralnych. Brak środków jest również barierą dla współpracy z ekspertami i ośrodkami badawczymi.

Następnie gminy zostały zapytane o działania, jakie podejmują wspólnie $\mathrm{z}$ innymi partnerami i w jakiej dzieje się to formie. Najczęściej wskazywaną dziedziną współpracy był transport publiczny. Połowa gmin, które udzieliły odpowiedzi, współpracowało z inną gminą w zakresie transportu autobuso- 
wego, 10,5\% w przypadku transportu kolejowego. Najmniej gmin współpracowało w dziedzinie komunikacji tramwajowej i trolejbusowej $(7,24 \%)$, co jest naturalną konsekwencją braku tego typu usług w większości gmin. Najpopularniejszą formę współpracy stanowią porozumienie między jednostkami samorządu terytorialnego, porozumienie między j.s.t a innym podmiotem oraz związek międzygminny. Tylko jedno miasto organizuje transport kolejowy w formie partnerstwa publiczno-prywatnego (Zabrze) (tab. 15).

Tabela 15

Formy współpracy w zakresie transportu publicznego (\% współpracujących gmin)

\begin{tabular}{|l|c|c|r|}
\hline \multirow{2}{*}{ Forma współpracy } & \multicolumn{3}{|c|}{ Dziedzina } \\
\cline { 2 - 4 } & $\begin{array}{c}\text { Transport } \\
\text { autobusowy }\end{array}$ & $\begin{array}{c}\text { Transport } \\
\text { tramwajowy } \\
\text { trolejbusowy) }\end{array}$ & $\begin{array}{c}\text { Transport } \\
\text { kolejowy }\end{array}$ \\
\hline Związek gmin & 25,00 & 54,55 & 6,25 \\
\hline Porozumienie między j.s.t. & 56,58 & 18,18 & 56,25 \\
\hline $\begin{array}{l}\text { Porozumienie między j.s.t. } \\
\text { a innym podmiotem }\end{array}$ & 13,16 & 0,00 & 18,75 \\
\hline Stowarzyszenie/fundacja & 0,00 & 0,00 & 0,00 \\
\hline PPP & 0,00 & 0,00 & 6,25 \\
\hline Przedsiębiorstwo publiczne & 5,26 & 27,27 & 12,50 \\
\hline Inna forma & 0,00 & 0,00 & 0,00 \\
\hline
\end{tabular}

Źródło: oprac. własne.

W kwestii świadczenia usług publicznych gminy intensywnie współpracują również w zakresie gospodarki odpadami $(42,76 \%)$ i gospodarki wodno-ściekowej $(39,47 \%)$ (tab. 16).

Tabela 16

Formy współpracy w zakresie gospodarki odpadami i gospodarki wodno-ściekowej (\% współpracujących gmin)

\begin{tabular}{|l|c|c|c|c|}
\hline \multirow{2}{*}{ Forma współpracy } & \multicolumn{4}{|c|}{ Dziedzina } \\
\cline { 2 - 5 } & $\begin{array}{c}\text { Gospodarka } \\
\text { odpadami }\end{array}$ & $\begin{array}{c}\text { Gospodarka } \\
\text { wodno- } \\
\text {-ściekowa }\end{array}$ & $\begin{array}{c}\text { Opieka } \\
\text { społeczna }\end{array}$ & $\begin{array}{c}\text { Budownictwo } \\
\text { mieszkaniowe }\end{array}$ \\
\hline Związek gmin & 43,08 & 6,67 & 0,00 & 0,00 \\
\hline Porozumienie między j.s.t. & 26,15 & 36,67 & 40,00 & 0,00 \\
\hline $\begin{array}{c}\text { Porozumienie między j.s.t. } \\
\text { a innym podmiotem }\end{array}$ & 15,38 & 23,33 & 50,00 & 27,27 \\
\hline Stowarzyszenie/fundacja & 1,54 & 0,00 & 7,50 & 0,00 \\
\hline PPP & 0,00 & 0,00 & 0,00 & 9,09 \\
\hline Przedsiębiorstwo publiczne & 10,77 & 31,67 & 0,00 & 63,64 \\
\hline Inna forma & 3,08 & 1,67 & 2,50 & 0,00 \\
\hline
\end{tabular}

Źródło: oprac. własne. 
Podobnie jak w przypadku transportu, najczęstsze formy współpracy, to związek międzygminny, porozumienie między jednostkami samorządu terytorialnego, porozumienie między j.s.t a innym podmiotem oraz związek międzygminny. Nieco ponad dziesięć procent $(12,5 \%)$ gmin jako formę współpracy w zakresie zaopatrzenia w wodę wskazało przedsiębiorstwo publiczne. Najczęściej są to spółki z udziałem gminy.

Rzadziej gminy współpracują z innymi podmiotami w zakresie opieki społecznej. Występują tu tylko dwie formy współpracy: porozumienie między j.s.t., które najczęściej dotyczy współpracy z powiatem, oraz porozumienie między j.s.t. a innym podmiotem (13,56\%). W tym przypadku samorząd gminy przekazuje zazwyczaj zadania do realizacji organizacji pozarządowej. Na uwagę zasługuje fakt bardzo słabej współpracy $(7,24 \%)$ w zakresie budownictwa mieszkaniowego, co wynika z tego, że gminy najczęściej w ogóle nie podejmują inwestycji mieszkaniowych.

Kolejna dziedzina współpracy, o którą pytane były gminy, dotyczyła promocji oraz pozyskiwania inwestorów i środków finansowych. Odpowiedzi na te pytania przedstawia tabela 17 .

Tabela 17

Formy współpracy w zakresie promocji, pozyskiwania inwestorów i funduszy (\% współpracujących gmin)

\begin{tabular}{|l|c|c|c|}
\hline \multirow{2}{*}{ Forma współpracy } & \multicolumn{3}{|c|}{ Dziedzina } \\
\cline { 2 - 4 } & Promocja & $\begin{array}{c}\text { Pozyskiwanie } \\
\text { inwestorów }\end{array}$ & $\begin{array}{c}\text { Pozyskiwanie } \\
\text { środków } \\
\text { finansowych }\end{array}$ \\
\hline Związek gmin & 13,24 & 11,43 & 6,40 \\
\hline Porozumienie między j.s.t. & 19,12 & 37,14 & 41,56 \\
\hline $\begin{array}{c}\text { Porozumienie między j.s.t. a } \\
\text { innym podmiotem }\end{array}$ & 25,00 & 42,86 & 19,48 \\
\hline Stowarzyszenie/fundacja/LGD & 35,29 & 5,71 & 28,57 \\
\hline PPP & 0,00 & 0,00 & 1,30 \\
\hline Przedsiębiorstwo publiczne & 1,47 & 2,86 & 1,30 \\
\hline Inna forma & 5,88 & 0,00 & 1,30 \\
\hline
\end{tabular}

Źródło: oprac. własne.

Badane gminy najintensywniej współpracują w zakresie pozyskiwania środków finansowych $(50,66 \%)$. Przyczynia się do tego potrzeba mobilizacji wspólnych zasobów w celu ubiegania się o dofinansowanie ze środków Unii Europejskiej. Na uwagę zasługuje fakt, że współpraca ta bardzo często przyjmuje formę Lokalnej Grupy Działania. Jest to stowarzyszenie, które może funkcjonować na podstawie ustaw o wspieraniu rozwoju obszarów wiejskich oraz o stowarzyszeniach i po akceptacji przez samorząd województwa może korzystać ze środków finansowych w ramach Programu 
Rozwoju Obszarów Wiejskich. Obecnie w Polsce funkcjonuje 338 stowarzyszeń tego typu [Wykaz LGD].

Również promocja jest zadaniem, które gminy realizują najczęściej na drodze partnerstwa $\mathrm{z}$ innym podmiotem lub innym samorządem (również powiatowym) bądź za pośrednictwem LGD. Współpracę przy realizacji działań promocyjnych zadeklarowało $44,74 \%$ gmin, które udzieliły odpowiedzi. Nieco rzadziej pojawia się współpraca w celu przyciągnięcia inwestycji $(23,03 \%)$ i przyjmuje formę porozumienia między j.s.t. a innym podmiotem lub porozumienia między samorządami.

Kluczową kwestią w zarządzaniu obszarem metropolitalnym jest właściwa polityka przestrzenna. Gminy zapytano o udział w opracowaniu projektu planu zagospodarowania przestrzennego obszaru metropolitalnego. Ponad połowa (52\%) gmin położonych w obszarach metropolitalnych, które odpowiedziały na pytanie, stwierdziło, że nie uczestniczyło w pracach nad planem. Natomiast gminy, które współpracowały przy tworzeniu planu, w zdecydowanej większości przypadków $(87,18 \%)$ wyrażały swoje niezobowiązujące opinie. Zaledwie w $12,82 \%$ gmin były to uzgodnienia (wiążące stanowiska gmin). Współpraca dotyczyła głównie infrastruktury transportowej i komunalnej (tab. 18).

Tabela 18

Dziedziny współpracy podczas prac nad planem zagospodarowania przestrzennego obszaru metropolitalnego

\begin{tabular}{|l|c|}
\hline \multicolumn{1}{|c|}{ Dziedzina współpracy } & Odsetek współpracujących gmin \\
\hline Rozwój/rozbudowa infrastruktury drogowej & 39,47 \\
\hline Budowa linii kolei metropolitalnej & 27,63 \\
\hline Budowa linii tramwaju regionalnego & 14,47 \\
\hline Organizacja linii autobusowego transportu metropolitalnego & 22,37 \\
\hline Budowa ponadlokalnego systemu ścieżek rowerowych & 22,37 \\
\hline Kanalizacja & 26,32 \\
\hline Wodociągi & 21,05 \\
\hline Energetyka & 13,16 \\
\hline Składowiska odpadów & 23,68 \\
\hline Oczyszczalnie ścieków & 18,42 \\
\hline Działania w zakresie ochrony środowiska & 28,95 \\
\hline Działania w zakresie ochrony zasobów wodnych & 25,00 \\
\hline Promocja i rozwój turystki & 26,32 \\
\hline
\end{tabular}

Źródło: oprac. własne.

Najczęściej gminy wspólnie decydowały o rozwoju infrastruktury drogowej oraz kolei metropolitalnej. Jest to pozytywne zjawisko, gdyż odpowiednia sieć transportowa jest kluczowym czynnikiem dla efektywnego funkcjonowania obszarów metropolitalnych. Kolejną, często wskazywaną, 
dziedziną współpracy była ochrona środowiska oraz wspólna promocja i rozwój turystyki.

Gminy, które podjęły się wspólnych działań na rzecz transportu publicznego z reguły ujednoliciły lub zamierzają ujednolicić system opłat za przejazdy (tab. 19).

Tabela 19

Odpowiedzi na pytanie dotyczące ujednolicenia systemu opłat za przejazdy komunikacja publiczną

\begin{tabular}{|c|c|}
\hline \multicolumn{2}{|c|}{ Odsetek gmin, w których: } \\
\hline $\begin{array}{c}\text { Wprowadzono jednolity system taryf za } \\
\text { przejazd jednym środkiem transportu }\end{array}$ & 56,10 \\
\hline $\begin{array}{c}\text { Wprowadzono jednolity system taryf za } \\
\text { przejazd wszystkimi środkami transportu }\end{array}$ & 26,83 \\
\hline $\begin{array}{c}\text { Zamierza się wprowadzić jednolity system } \\
\text { taryf za przejazd jednym środkiem trans- } \\
\text { portu }\end{array}$ & 14,63 \\
\hline $\begin{array}{c}\text { Zamierza się wprowadzić jednolity system } \\
\text { taryf za przejazd wszystkimi środkami } \\
\text { transportu }\end{array}$ & 17,07 \\
\hline Nie planuje się ujednolicenia sytemu opłat & 12,20 \\
\hline
\end{tabular}

Źródło: oprac. własne.

W największej liczbie gmin $(56,10 \%)$ udało się doprowadzić do ujednolicenia opłat za jeden środek transportu, ale znacząca część samorządów dąży do wprowadzenia jednolitej taryfy na wszystkie środki transportu. Tylko pięć gmin, które współpracowały w zakresie transportu publicznego, nie zamierza ujednolicić opłat.

Kolejna grupa pytań dotyczyła kwestii zarządzania obszarem metropolitalnym. Spośród 77 samorządów, które odpowiedziały na pytanie o konieczność utworzenia instytucji zarządzającej obszarem metropolitalnym, aż 46 (65\%) nie widzi potrzeby utworzenia nowej instytucji (władzy) zarządzającej obszarem metropolitalnym. Natomiast gminy, które sądzą, że taka instytucja jest potrzebna, za właściwą jej formę uważają utworzenie ustawą nowego podmiotu (szczebla) „samorządowej administracji metropolitalnej" (55\% odpowiedzi) lub porozumienie gmin i powiatów koordynowane przez administrację samorządu województwa bez udziału administracji rządowej (25\%). Zwolennikami instytucjonalizacji są prawie wszystkie ośrodki centralne ( $\mathrm{z}$ wyjątkiem Gdyni). Podobne wyniki uzyskała M. Lackowska [zob.: Lackowska 2009]. Za dobrowolną formą współpracy opowiedziały się zaledwie dwie gminy. Wynika z tego, iż te gminy, które popierają instytucjonalizację, są zwolennikami „twardych rozwiązań" narzuconych prawnie. Natomiast nie ma wśród nich zwolennika związków gmin i/lub powiatów, co potwierdza tezę o małej przydatności tej formy do 
zarządzania obszarem metropolitalnym, tym bardziej że 14 z tych gmin ma doświadczenia w zakresie współpracy w postaci związku komunalnego.

Również z badań przeprowadzonych przez UMP wśród mieszkańców gmin obszarów metropolitalnych na temat modelu zarządzania metropolitalnego wynika, że najwięcej zwolenników ma model samorządu regionalnego, z odrębnymi władzami [Lackowska 2009, s. 146]. Do podobnych wniosków doszli naukowcy badający w roku 2008 organizację i funkcjonowanie Obszaru Metropolitalnego Warszawy. Prawie 43\% gmin zapytanych o szanse współpracy w obszarze metropolitalnym obawiało się braku dobrowolnej współpracy. Blisko 70\% gmin widziało konieczność wspólnego zarządu, natomiast jedynie $50 \%$ pytanych skłonnych było zaakceptować ograniczenie kompetencji gmin na rzecz wspólnego zarządu [Grochowski 2010, s. 28-29]. Gminy zapytane o najlepszą formę współpracy (w przyszłości) wskazały:

- dobrowolne stowarzyszenie metropolitalne z dodatkowymi kompetencjami i stworzenie przez rząd zachęt finansowych do dobrowolnej współpracy j.s.t.,

- stworzenie na obszarze metropolitalnym odpowiednich struktur zarządzających, które zajmą się sprawami np. rozwoju infrastruktury drogowej, transportu publicznego, gospodarki odpadami itp. (bez konieczności sztywnego wydzielenia obszaru metropolitalnego, a na zasadzie porozumienia zainteresowanych gmin) [Grochowski 2010, s. 34].

- w kontekście sposobu wyboru władz, w przypadku przyjęcia przez rząd ustawy tworzącej władze metropolitalne złożone $\mathrm{z}$ rady i zarządu, uznały, że rada powinna składać się z przedstawicieli gmin i powiatów, natomiast zarządem winien kierować wybierany przez radę $\mathrm{w}$ otwartym konkursie menedżer [Grochowski 2010, s. 35].

Większość gmin dostrzega konieczność i korzyści instytucjonalizacji OMW.

Wyniki te nieco różnią się od odpowiedzi otrzymanych w ramach konsultacji Zielonej księgi, gdzie najczęściej wskazywanym rozwiązaniem były metropolitalne związki celowe powoływane dla zarządzania jedną lub kilkoma usługami publicznymi. Dopiero na drugim miejscu za właściwą formę instytucjonalizacji obszaru metropolitalnego uznano tzw. powiat metropolitalny. W świetle tych danych oraz analizy obecnie funkcjonujących związków międzygminnych wątpliwości budzą propozycje MAC zapisane w Białej księdze, które jako formę współpracy proponują związki gminno-powiatowe. Rozstrzygnięcie tej kwestii niewątpliwie wymaga przeprowadzenia pogłębionych badań wśród władz lokalnych.

Jeśli chodzi o kwestie finansowania zadań na poziomie metropolitalnym, to ponad 57\% gmin byłoby skłonnych przekazać część swoich dochodów do wspólnego budżetu instytucji powołanej do zarządzania obszarem metropolitalnym. Samorządy mogły określić wysokość tych wpłat jako część 
dochodów gminy lub jako stawkę w przeliczeniu na jednego mieszkańca. Udzielone odpowiedzi wahają się w granicach od 0,005\% (Gdańsk) do 5\% (Nowosolna) dochodów oraz od 0,27 PLN (Gdańsk) aż do 121,5 PLN (Niepołomice) na jednego mieszkańca.

Do kompetencji, które należałoby przekazać instytucjom zarządzającym obszarami metropolitalnymi, gminy zaliczyły przede wszystkim transport publiczny i promocję, pozyskiwanie inwestorów i gospodarkę odpadami oraz gospodarkę wodno-kanalizacyjną. Większość z samorządów ma już doświadczenie w zakresie współpracy w tych dziedzinach (rys. 40).

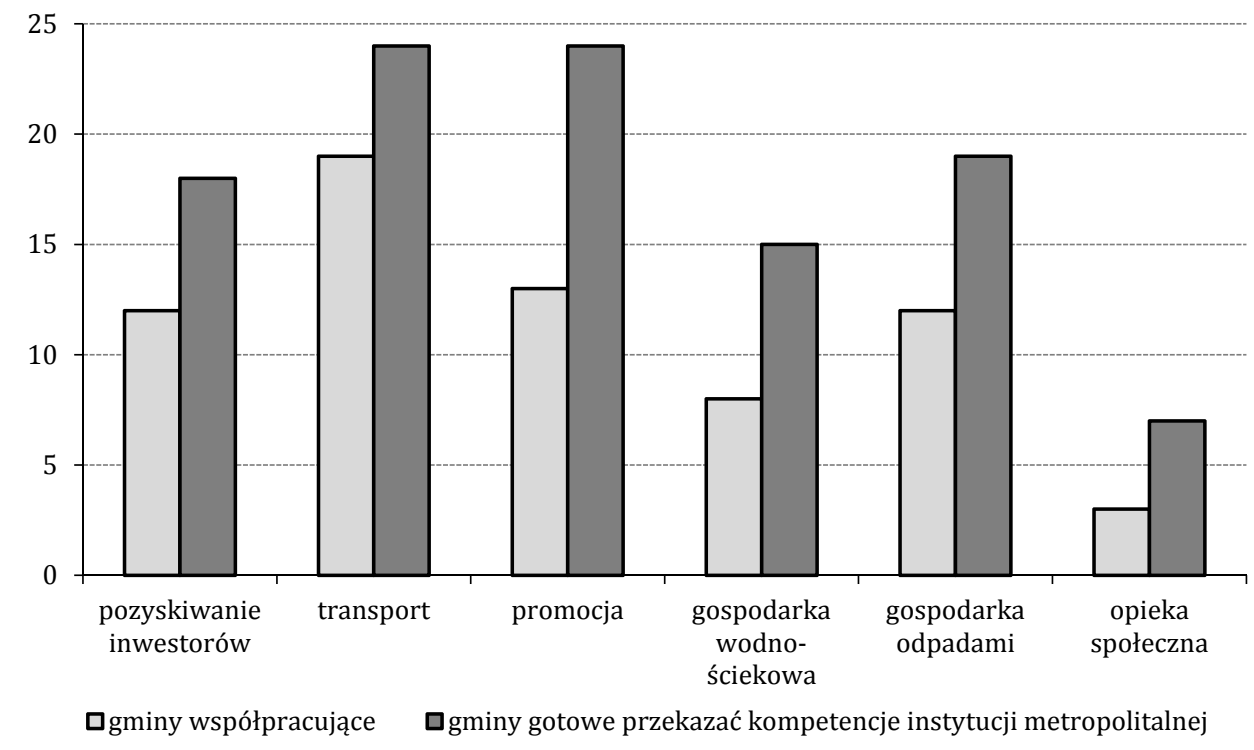

Rys. 40. Gotowość gmin do przekazania kompetencji instytucji metropolitalnej, a doświadczenia współpracy

Źródło: oprac. własne

Wyniki te są zbieżne z danymi uzyskanymi w ramach konsultacji Zielonej księgi, w których najczęściej wskazywaną odpowiedzią były zadania publiczne mające na celu zaspokajanie zbiorowych potrzeb mieszkańców w zakresie transportu publicznego, porządku i bezpieczeństwa publicznego, służby zdrowia, kultury i edukacji. Drugim, najczęściej wskazywanym, zadaniem było planowanie strategiczne realizowane za pomocą wspólnej strategii obszaru metropolitalnego, zarządzanie drogami publicznymi, planowanie przestrzenne oraz strategia promocji [MAC 2012]. W zakresie planowania 19 gmin gotowych jest przekazać na poziom metropolitalny planowanie strategiczne, a 13 planowanie przestrzenne.

Kolejne pytanie dotyczyło opinii na temat relacji i form współpracy między samorządami gminnymi a instytucją zarządzającą obszarem metropoli- 
talnym. W 75\% gmin stwierdzono, że instytucja zarządzająca obszarem powinna odgrywać rolę inicjatora i koordynatora działań samorządów lokalnych, przyjmować indykatywne strategie, plany i programy. Tylko $25 \%$ samorządów opowiedziało się za tym, by instytucja zarządzająca obszarem pełniła funkcję nadrzędną względem samorządów lokalnych, wydając decyzje i tworząc wiążące dla samorządów lokalnych przepisy, plany i programy.

Spośród 46 gmin, które nie widzą potrzeby utworzenia instytucji metropolitalnej, 11 nie nawiązało żadnej formy współpracy z inną j.s.t. Natomiast 16 gmin miało pozytywne doświadczenia w zakresie obniżenia kosztów świadczenia usług dzięki takiej współpracy.

Za główne bariery współpracy gmin z ośrodkiem centralnym obszaru metropolitalnego zostały uznane: obawa o drenowanie budżetu gminy przez centrum metropolii (59,65\% wskazań), brak przekonania co do możliwości uzyskania korzyści dla całego obszaru (54,39\%) oraz obawa przed utratą własnej autonomii i brak zaufania $(47,37 \%)$. Na kolejnych miejscach znalazły się: spory polityczne/fragmentacja, konkurencja w zakresie przyciągania inwestorów i mieszkańców oraz kadencyjność władz. Gminy wymieniały również brak zrozumienia i ignorowanie przez ośrodek centralny potrzeb i możliwości gmin ościennych czy dominującą pozycję dużego miasta wobec sąsiadujących z nim małych gmin. Podobne wyniki uzyskano $\mathrm{w}$ ramach innych badań prowadzonych w obszarach metropolitalnych.

Badania M. Fuhrmann i zespołu przeprowadzone w roku 2004 w gminach obszaru metropolitalnego Warszawy wskazują na słabą współpracę gmin z ośrodkiem centralnym i brak takiej potrzeby (65\% nie współpracowało, a tylko $41 \%$ uważa, że taka współpraca jest potrzebna), przy jednoczesnej potrzebie współpracy z innymi gminami [Fuhrmann i in. 2005, s. 29-30].

Za główne bariery współpracy w Poznańskim Obszarze Metropolitalnym uznano:

- fragmentację administracyjną - silna autonomia j.s.t.,

- odrębne polityki rozwoju (także polityki przestrzenne),

- różnice potencjałów demograficznych i gospodarczych partnerów,

- wykorzystywanie free-riding,

- lęk małych gmin przed „efektem wymywania” (backwash effect),

- obawy dużego miasta przed utratą części kompetencji,

- ambicje lokalne wobec dominującej pozycji miasta centralnego,

- konkurencję między szczeblami samorządu [Kaczmarek 2012].

Jako główny instrument, który spowodowałby zwiększenie współpracy między gminami w obszarze metropolitalnym, samorządy wskazały wprowadzenie zachęt finansowych, np. granty na wspólne projekty, kontrakty rozwojowe. Za takim rozwiązaniem opowiedziało się aż 92\% gmin, $24 \%$ samorządów uznało, że zwiększeniu współpracy mogłoby służyć ujednolicenie podatków we wszystkich gminach obszaru. Jedna z gmin wskazała też 
wybranie koordynatora działań. W badaniach ankietowych na temat organizacji i funkcjonowania Obszaru Metropolitalnego Warszawy, które zostały zrealizowane w 2008 r., za najważniejsze czynniki sprzyjające efektywnej współpracy gmin uznano jasny podział kompetencji i czytelny mechanizm planowania oraz zarządzania rozwojem, a także wspólne cele i interesy gmin i innych podmiotów [Grochowski 2010, s. 30]. Jako bardzo istotne kwestie potraktowano:

- równowagę sił między gminami o różnej wielkości i liczbie mieszkańców,

- polityczną wolę współpracy i umiejętność szukania porozumienia,

- specjalny mechanizm finansowania działań w obszarach metropolitalnych $(78,6 \%)$,

- zachęty prawne w postaci dodatkowych kompetencji dla sprawnie współpracujących gmin obszaru metropolitalnego [Grochowski 2010, s. 30].

Z kolei wśród propozycji zawartych w Zielonej księdze spośród instrumentów finansowych, które byłyby najlepszym wsparciem dla obszarów metropolitalnych, zdecydowanie największe poparcie zyskała opcja bezpośrednich udziałów w podatku dochodowym PIT i CIT bądź VAT. Na drugim miejscu znalazł się specjalny program operacyjny skierowany wyłącznie do obszarów metropolitalnych [MAC 2012].

W związku z tym, że przeprowadzona ankieta dotyczyła również sprawności zarządzania, podjęto próbę wychwycenia związków między potrzebą instytucjonalizacji zarządzania na poziomie metropolitalnym a sprawnością zarządzania w gminie. Niestety, nie udało się takich zależności stwierdzić. Nie ma związku między tym, czy gmina chce utworzenia instytucji na szczeblu metropolitalnym a tym, czy wypracowała strategię. Większość gmin ma taką strategię lub plan rozwoju lokalnego. Podobny brak zależności występuje w przypadku innych dokumentów o charakterze strategicznym, takich jak wieloletni plan inwestycyjny czy wieloletni plan finansowy. Prawie wszystkie gminy dysponują tymi instrumentami. Niemal wszystkie gminy mają też studium i miejscowe plany zagospodarowania przestrzennego (oczywiście w różnym stopniu pokrywające powierzchnie gminy).

Spośród 25 gmin, które chcą utworzenia instytucji na poziomie metropolitalnym, 15 współpracowało przy tworzeniu studium uwarunkowań i kierunków zagospodarowania przestrzennego z gminami ościennymi. Współpraca ta dotyczyła w równym stopniu (twierdzące odpowiedzi udzieliło od sześciu do dziewięciu gmin):

- rozwoju infrastruktury komunikacyjnej w zakresie transportu publicznego i transportu indywidualnego oraz lokalizacji ścieżek rowerowych,

- rozwoju infrastruktury komunalnej w zakresie kanalizacji, wodociągów, energetyki, utylizacji i składowania odpadów i oczyszczania ścieków,

- obszarów budownictwa mieszkaniowego,

- działań w zakresie ochrony środowiska. 
Interesująca jest odpowiedź gmin zapytanych o powody aktualizacji planów zagospodarowania. Trzynaście ze 152 gmin jako powód podało przeszacowanie potrzeb budownictwa mieszkaniowego, 15 - zmianę koncepcji rozwoju gminy. Pięć gmin jako przyczynę zmian wskazało wnioski mieszkańców i inwestorów o przekwalifikowanie gruntów. Odpowiedzi te wprawdzie nie obrazują skali zjawiska, ale potwierdzają wpływ presji inwestorów i mieszkańców na władze lokalne. Pogłębione badania w tym zakresie mogłoby prowadzić do ciekawych wniosków i stanowić podstawę do tworzenia instrumentów umożliwiających przeciwstawienie się tym naciskom.

Natomiast żadna z gmin jako powodu zmian planów nie wskazała zbyt wysokich kosztów wyposażenia terenów, przeznaczonych w planie pod funkcję mieszkaniową, w niezbędną infrastrukturę techniczną. Może to świadczyć o tym, że gminy cały czas kalkulują koszty podejmowanych decyzji w bardzo ograniczonym stopniu lub wcale.

Wszystkie gminy współpracują z częścią organizacji pozarządowych funkcjonujących na ich terenie. Nie ma żadnego związku między intensywnością współpracy z NGOs, a chęcią instytucjonalizacji obszaru metropolitalnego. Rozkład odpowiedzi w obu przypadkach jest porównywalny.

Trudno też mówić o związku między potrzebą instytucjonalizacji a odległością gminy od ośrodka centralnego. Zarówno odsetek gmin, które są zwolennikami utworzenia instytucji metropolitalnej, jak i tych, które są temu przeciwne, jest podobny we wszystkich pierścieniach otaczających metropolię. Wyjątek stanowią Poznański i Krakowski Obszar Metropolitalny. Tutaj wszystkie gminy bezpośrednio sąsiadujące z rdzeniem, które wypełniły ankietę, opowiedziały się za instytucjonalizacją. W Metropolii Poznań jest to zapewne efektem intensywnych działań Stowarzyszenia Metropolia Poznań, promującego ideę współpracy metropolitalnej.

Celem badań ankietowych było znalezienie racjonalnych podstaw do współpracy gmin. Tymczasem otrzymane wyniki pokazują, że trudno takie podstawy zidentyfikować. Czynniki, które decydują o współpracy są bardzo złożone. Rzadko brane pod uwagę bywają ekonomiczne efekty tego współdziałania. Mogą o nim decydować również lokalne sympatie bądź antypatie personalne, różne ukryte konflikty, które nie pozwalają na tym etapie badań odkryć wielu prawidłowości.

\section{Potencjalne instrumenty metropolitalnego zarządzania $w$ świetle zasad metropolitan governance}

Analizując przedstawione formy współpracy oraz problemy, jakie występują $\mathrm{w}$ obszarach metropolitalnych, a przede wszystkim opinie gmin w tej kwestii, należy stwierdzić, iż zasadne wydaje się wdrażanie zasad 
metropolitalnego zarządzania $\mathbf{w}$ warunkach polskich. Wymaga to jednak zastosowania odpowiednich instrumentów. Instrumenty zarządzania stosowane przez organy władzy i administracji publicznej traktujemy jak prawem dostępne formy oddziaływania na niezależne ekonomicznie jednostki w taki sposób, aby ich zachowania służyły realizacji wyznaczonych

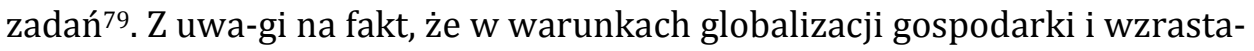
jącej konkurencji między regionami wzrasta rola strategicznego i antycypacyjnego kształtowania rozwoju, instrumenty należy tworzyć opierając się na doświadczeniach rozwiniętych gospodarek, które etap, w jakim znajduje się nasz kraj, mają już za sobą [Markowski 1999, s. 34].

Grupując instrumenty $\mathrm{z}$ uwagi na charakter wywoływanych zmian w otoczeniu, w którym działają użytkownicy przestrzeni metropolitalnej, możemy wyróżnić:

- instrumenty administracyjno-prawne, w tym planistyczne,

- ekonomiczne,

- fiskalne,

- informacyjne,

- organizacyjne i instytucjonalne,

- materialnego kształtowania przestrzeni (bezpośrednia realizacja projektów infrastrukturalnych) [Markowski 1999; 2001].

Podstawowymi instrumentami zintegrowanego zarządzania rozwojem są instrumenty planistyczne. Metropolie muszą mieć stosowną władzę planistyczną, żeby - dosłownie - wymuszać na użytkownikach przestrzeni odpowiednie zachowania. Plan zagospodarowania przestrzennego województwa nie stanowi dostatecznego narzędzia koordynacji procesów rozwoju przestrzennego w obszarze metropolitalnym, ponieważ nie określa wymogów i parametrów wiążących dla gmin w zakresie zagospodarowania terenu. Z kolei miejscowe plany zagospodarowania przestrzennego pokrywają tylko część obszaru i służą osiąganiu celów rozwojowych pojedynczych jednostek. Instrumentem, który koordynowałby rozwój obszaru metropolitalnego, powinno być studium uwarunkowań i kierunków zagospodarowania przestrzennego obszaru metropolitalnego. Instrument ten nie może jednak ograniczać się do kwestii zagospodarowania przestrzennego, lecz łączyć w sobie elementy planowania przestrzennego i strategicznego. Jego integralną częścią powinna być strategia rozwoju całego obszaru metropolitalnego. Przepisy prawa muszą nakładać obowiązek sporządzenia studium. Pytanie, kto miałby ten dokument opracowywać? W przypadku instytucjonalizacji obszarów metropolitalnych (co wydaje się bardzo odległe w czasie, jeżeli w ogóle możliwe) oczywiście studium winny sporządzać władze obszaru metropolitalnego. Natomiast

79 Zob.: Gajl 1979; Regulski, Kocoń, Ptaszyńska-Wołoczkowicz 1988. 
w sytuacji, gdy na obszarze metropolitalnym nie funkcjonuje żadna forma instytucji metropolitalnej, za opracowanie studium powinien odpowiadać marszałek, którego rola polegałaby na zachęceniu samorządów do współpracy. Problematyczną kwestią jest finansowanie prac nad studium. Gminy mogą nie być chętne do ich finansowania. W budżetach urzędów marszałkowskich powinny zostać wydzielone środki na profesjonalne przygotowanie tego dokumentu.

Ustalenia przyjęte w studium muszą być wiążące dla wszystkich gmin obszaru metropolitalnego. Studium obszaru metropolitalnego powinno być podstawowym instrumentem regulującym sposób zagospodarowania przestrzeni, zapobiegającym rozlewaniu się zabudowy i degradacji środowiska, przy jednoczesnym stymulowaniu procesów koncentracji działalności gospodarczej $\mathrm{w} z$ góry przeznaczonych do tego strefach. W studium powinny być wyznaczone tereny pod inwestycje o znaczeniu metropolitalnym, metropolitalny system komunikacyjny, metropolitalna infrastruktura. W przypadku wyznaczenia stref urbanizacji gminy powinny mieć ustawowy obowiązek sporządzania dla nich planów miejscowych. Miejscowe plany zagospodarowania przestrzennego gmin muszą uwzględniać zapisy studium, przy czym studium to powinno wskazywać, dla których terenów obligatoryjne jest opracowanie planów (dotyczy to obszarów kluczowych dla rozwoju funkcji metropolitalnych). Podobne rozstrzygnięcia powinny dotyczyć strategii poszczególnych gmin, które nie mogą być sprzeczne ze strategią metropolii. Natomiast obowiązek sporządzania studiów gminnych należy znieść.

Studium, będące jednocześnie strategią rozwoju przestrzennego, gospodarczego i społecznego dla obszarów metropolitalnych, powinno być tworzone przy silnym zaangażowaniu wszystkich zainteresowanych pomiotów. W trakcie tych prac możliwa jest diagnoza problemów i konfliktów, jakie pojawiają się między gminami oraz różnymi grupami interesów. Do procedur planistycznych, w przypadku konfliktów ponadlokalnych, trzeba wprowadzić obowiązek przeprowadzania analiz korzyści i kosztów, które jasno pokażą gminom, które są największymi beneficjentami, a które najwięcej tracą. W przypadku jednostek tracących należy wprowadzić system kompensacji kosztów.

Taka forma opracowania studium umożliwi realizację aż ośmiu zasad zarządzania metropolitalnego:

- spójności polityki - takie spojrzenie na studium pozwoli na jednoczesne poruszenie najważniejszych problemów, przy uwzględnieniu zachodzących między nimi powiązań i kompromisów;

- rozwoju endogenicznego - jednym z podstawowych celów studium powinno być takie określenie kierunków rozwoju, które pozwoli na 
wzmocnienie potencjału obszaru metropolitalnego, a co za tym idzie podniesienie jego konkurencyjności na arenie międzynarodowej;

- koordynacji i holizmu - realizacja tych zasad wynikać będzie z samej istoty studium, którego powstanie i wdrożenie będą wymagały koordynacji działań na całym obszarze funkcjonalnym;

- szczególności - planowanie na poziomie metropolitalnym będzie uwzględniać specyficzne cechy poszczególnych regionów, co pozwoli na zwiększenie skuteczności realizowanych polityk;

- partycypacji - warunkiem efektywnej realizacji studium jest udział wszystkich interesariuszy obszaru metropolitalnego w jego tworzeniu;

- subsydiarności - władze metropolitalne lub współpracujące samorządy lokalne i regionalne są najlepszym poziomem odniesienia przy rozwiązywaniu problemów metropolitalnych. W przypadku braku chęci współpracy między samorządami lokalnymi zasadę subsydiarności należy rozumieć dynamicznie i przekazać opracowanie studium marszałkowi;

- trwałości (sustensywności) - zaproponowane podejście do tworzenia studium pozwoli na integrację celów ekonomicznych, społecznych i środowiskowych.

Instrumentami, które zachęcają do współpracy władz lokalnych i regionalnych oraz innych aktorów w obszarach metropolitalnych, są fundusze strukturalne Unii Europejskiej. Rozwinięty system programowania na potrzeby funduszy strukturalnych zrodził potrzebę współpracy z różnymi grupami partnerów społecznych i gospodarczych [Potoczek 2005, s. 20]. Mając dobre doświadczenia w tej dziedzinie, Polska powinna wdrożyć, wzorem innych krajów, kontrakty terytorialne. Mogą one stanowić główny instrument motywujący władze publiczne, partnerów prywatnych i społecznych do współpracy.

Kolejnym instrumentem, w swej konstrukcji podobnym do kontraktów terytorialnych, są zintegrowane projekty inwestycyjne. Realizacja ich będzie możliwa dzięki nowemu instrumentowi UE, proponowanemu od roku $2014 \mathrm{w}$ ramach polityki spójności, jakim są Zintegrowane Inwestycje Terytorialne (ZIT). Dzięki temu obszary metropolitalne zostaną włączone w zarządzanie programami operacyjnymi i będą mogły realizować kompleksowe projekty o znaczeniu metropolitalnym. Projekty te będą mogły łączyć działania „twarde” z „miękkimi”, czyli np. inwestycje infrastrukturalne ze szkoleniami. Samorządy funkcjonujące na danym terenie, chcące uzyskać dofinansowanie takiego projektu, będą musiały się ze sobą porozumieć i, co więcej, zawiązać zinstytucjonalizowaną formę partnerstwa oraz przygotować program działań w ramach ZIT, który będzie podstawą do udzielenia wsparcia. Muszą także mieć odpowiednią zdolność instytucjonalną do realizacji projektu oraz podpisać porozumienie z zarządem województwa, który dysponuje środkami programów regionalnych. Powinien 
zostać zachowany wymóg utworzenia struktury zarządzającej takim projektem, przynajmniej na jednym z jego etapów (przygotowania, realizacji lub eksploatacji). Podstawą stworzenia takiego projektu musi być analiza korzyści i kosztów, aby każdy z interesariuszy wiedział, czego może oczekiwać. Dodatkowo pożądane będzie przygotowanie strategii rozwoju obszaru funkcjonalnego miasta. Funkcjonowanie zintegrowanych projektów inwestycyjnych $\mathrm{w}$ ramach realizacji polityki spójności zmusi samorządy do rzetelnego liczenia korzyści i kosztów, co doprowadzi do przejrzystości działań i pozwoli przełamać brak zaufania między partnerami.

Zarówno kontrakty terytorialne, jak i zintegrowane projekty pozwolą na realizację zasady spójności polityki, gdyż będą wymagały zintegrowanego podejścia do problemów metropolitalnych, tym samym powodując odejście od sektorowego planowania rozwoju. Umacnianie potencjału obszarów będzie następowało zgodnie z zasadą rozwoju endogenicznego, podnosząc tym samym ich konkurencyjność. Oba instrumenty pozwolą też na realizację pozostałych zasad metropolitalnego zarządzania, w tym partycypacji, koordynacji czy holizmu.

Z kolei spośród instrumentów fiskalnych należałoby zaproponować harmonizację podatków od nieruchomości w obszarach metropolitalnych oraz możliwość ustalania własnych podatków przez instytucję metropolitalną.

Konieczna jest również zmiana systemu finansowania obszarów metropolitalnych pozwalająca na wyeliminowanie zjawiska "gapowicza". Możliwe to jest dzięki wprowadzeniu systemu opłat i podatków zgodnego z zasadą sprawiedliwego dostępu do usług publicznych. Gminy ościenne muszą przejąć część kosztów ponoszonych przez ośrodek centralny, w wysokości odpowiadającej kosztom usług wykorzystywanych przez ich mieszkańców.

Problem metropolitalny nie jest problemem poszczególnych obszarów, lecz całego państwa. Dlatego też należy pamiętać, że możliwość wdrożenia tych instrumentów zależy od polityki państwa i odpowiednich rozwiązań instytucjonalno-prawnych, w tym m.in. zmian legislacyjnych dotyczących podziału kompetencji między administracją rządową i samorządową. 


\section{WNIOSKI I REKOMENDACJE}

W świetle przeprowadzonych rozważań teoretycznych, analizy doświadczeń w zakresie zarządzania rozwojem w obszarach metropolitalnych Europy Zachodniej oraz zrealizowanych badań nasuwają się następujące wnioski i rekomendacje.

W Polsce nie istnieje kompleksowy (holistyczny) system zarządzania obszarami metropolitalnymi. Procesy rozwoju społeczno-gospodarczego zachodzące w obszarach metropolitalnych, oraz ich przestrzenne skutki, są efektem zarówno swoistej gry podmiotów prywatnych i społeczności lokalnych o uzyskiwanie korzyści lokalizacyjnych, jak i, w znacznej mierze, przypadkowych i nieskoordynowanych decyzji planistycznych samorządów (lokalnych i regionalnych).

Nasz system sprawowania władzy jest nastawiony raczej na rządzenie hierarchiczne a nie partnerskie - sieciowe. Polska przestrzeń charakteryzuje się deficytem relacji sieciowych, który potęgowany jest słabością instytucjonalną i infrastrukturalną. Koniecznym działaniem jest promowanie i wzmacnianie liderów, którzy mogą stać się motorem nawiązywania relacji partnerstwa i współdziałania.

Nowego sposobu zarządzania musimy się dopiero nauczyć mimo jego ewidentnej potrzeby i teoretycznej przydatności. Instytucja zajmująca się rozwojem obszaru metropolitalnego, musi dysponować kompetencjami do sterowania siecią partnerskich powiązań wynikających z rozpoznanych właściwości tego systemu.

Istota zarządzania obszarem metropolitalnym polega na umożliwieniu użytkownikom tej przestrzeni realizacji inwestycji publicznych i prywatnych w długim okresie. W szczegółach oznacza to m.in. takie zarządzanie systemami infrastruktury, które zapewnia jednostkom gospodarującym i konsumentom maksymalne wykorzystywanie pozytywnych efektów zewnętrznych, unikanie efektów negatywnych oraz daje możliwości wykorzystywania zależnych od nich korzyści skali i zakresu, a także umożliwia dostęp do specyficznych dóbr „klubowych” wynikający z przynależności do metropolitalnej sieci.

Zintegrowane i odpowiedzialne zarządzanie obszarem metropolitalnym wymaga kompleksowych i racjonalnych zasad rządzenia, adekwatnego prawa, sprawnych instytucji publicznych, uspołecznienia decyzji o mieście, 
ale także zwiększenia odpowiedzialności wszystkich obywateli za miasto. Zarówno dorobek teoretyczny, jak i doświadczenia praktyczne pokazują, że jedną z najlepszych koncepcji zarządzania rozwojem obszarów metropolitalnych jest metropolitan governance. Efektywne wdrożenie tej metody wymaga jednak spełnienia szeregu uwarunkowań o charakterze instytucjonalno-prawnym.

Przede wszystkim na szczeblu centralnym musi być rozpoznane znaczenie obszarów metropolitalnych dla rozwoju gospodarczego kraju. W świetle polityki spójności Unii Europejskiej, nowego okresu programowania na lata 2014-2020 oraz dokumentów przyjętych (KPZK, KSRR) lub obecnie tworzonych przez polski rząd wydaje się, że ten warunek został spełniony. Rząd zaczął zdawać sobie sprawę z roli metropolii jako „lokomotyw rozwoju", przynajmniej od strony zapisu w strategicznych dokumentach.

Dużym wyzwaniem pozostaje przełamanie stereotypowego myślenia sektorowego na rzecz zintegrowanego podejścia do planowania rozwoju układów terytorialnych. Wymiar terytorialny podkreślany jest we wszystkich politykach Unii Europejskiej i został również zapisany w polskich dokumentach strategicznych. Problemem jednak z pewnością będzie implementacja zapisanych rozwiązań. Należy jak najszybciej wdrożyć mechanizmy regulacyjne, prawne i instytucjonalne, niezbędne do prawidłowego planowania i efektywnego zarządzania rozwojem obszarów zurbanizowanych. Rząd powinien niezwłocznie przyjąć założenia Krajowej Polityki Miejskiej oraz rozpocząć kompleksową reformę gospodarki przestrzennej zgodną z kierunkami określonymi w Koncepcji Przestrzennego Zagospodarowania Kraju 2030.

Konieczne jest stworzenie warunków do powoływania instytucji koordynujących zarządzanie całym obszarem metropolitalnym, które będą wyposażone $\mathrm{w}$ realne kompetencje umożliwiające osiąganie założonych celów rozwoju. Głównymi urządzeniami infrastruktury wymagającymi koordynacji na poziomie metropolitalnym są transport publiczny, gospodarka wodno-ściekowa, gospodarka odpadami, systemy ciepłownicze. $\mathrm{W}$ celach i zadaniach związanych z zarządzaniem obszarem metropolitalnym muszą znaleźć się też zagadnienia związane z ochroną środowiska, w tym kształtowaniem terenów otwartych, parków oraz metropolitalna polityka mieszkaniowa.

Jednym z kluczowych problemów zarządzania obszarami metropolitalnymi jest właściwa delimitacja obszaru. W większości przypadków mamy tendencję do sztywnego wyznaczania granic obszaru metropolitalnego i tworzenia, dla tak administracyjnie wyznaczonego obszaru, określonego instytucjonalnego systemu zarządzania. W praktyce, jak zauważają również inni badacze tej problematyki [Markowski 2005], jest to podejście błędne, gdyż obszary metropolitalne są układami funkcjonalnymi, które z czasem 
ewoluują i wykazują tendencje do poszerzania swoich granic. Dlatego też powinno się elastycznie traktować granice obszaru metropolitalnego. W przypadku przyjęcia ustawy metropolitalnej, zamiast sztywnej delimitacji obszarów metropolitalnych, zaleca się wskazanie ich minimalnego zasięgu, z możliwością łatwego rozszerzania granic poprzez włączanie do struktur zarządzania obszarem zainteresowanych gmin.

Brak sztywnej delimitacji może stanowić problem przy sporządzaniu planów zagospodarowania przestrzennego obszarów metropolitalnych. W tym przypadku o delimitacji powinny decydować władze regionalne wspólnie z samorządami lokalnymi i w przypadku rozważania kilku wersji zasięgu obszaru metropolitalnego, do ostatecznych prac nad planem przyjmować zasięg najszerszy.

Polityce metropolitalnej musi towarzyszyć właściwa polityka przestrzenna. Żywiołowe rozlewanie się miast można skutecznie ograniczać przez sprawny system planowania przestrzennego. Jednym $\mathrm{z}$ podstawowych instrumentów tego systemu jest plan zagospodarowania przestrzennego obszaru metropolitalnego. Niestety, w Polsce żaden obszar metropolitalny do tej pory takiego planu nie stworzył, a plany zagospodarowania przestrzennego tworzone przez gminy leżące w sąsiedztwie metropolii, które konkurują między sobą o mieszkańców i inwestycje, proces rozprzestrzeniania się nawet nasilają. Powinna tu zostać przyjęta zasada hierarchizacji, która w obecnie obowiązującym systemie została odrzucona. Plany obszarów metropolitalnych (lub studia) nie powinny być ściśle planami wskazującymi sposób zagospodarowania przestrzeni. Na poziomie metropolitalnym należy wprowadzić zintegrowany system planowania terytorialnego, który będzie uwzględniał aspekty gospodarcze, społeczne i przestrzenne. Plan bądź studium obszaru metropolitalnego powinien łączyć w sobie strategię rozwoju obszaru ze sposobem jego zagospodarowania. Należy odejść od planowania sektorowego.

W celu zahamowania procesu rozlewania się zabudowy rząd powinien wprowadzić rozwiązania zapobiegające masowemu przekwalifikowywaniu gruntów (zwłaszcza w bezpośrednim sąsiedztwie metropolii) na cele mieszkaniowe. Konieczne jest sporządzenie prognoz rozwojowych (demograficznych, gospodarczych), dzięki którym możliwe będzie określenie zapotrzebowania na grunty w skali kraju. Następnie, bazując na prognozach przeprowadzanych w województwach (które muszą się bilansować na poziomie kraju), każdy region uzyskałby zgodę na przeznaczenie określonej puli terenów na cele rozwojowe. Ponadto poszczególne regiony mogłyby korzystać z możliwości handlu prawem do zabudowy na podobieństwo handlu koncesjami na emisję $\mathrm{CO}_{2}$. Władze województwa powinny decydować o wielkości terenów przeznaczonych pod rozwój w obszarze metropolitalnym, a studium powinno określać strefy tej zabudowy. 
Z kolei, w celu stymulowania wykorzystania zdegradowanych terenów, położonych często $\mathrm{w}$ centrach ośrodków metropolitalnych, należy wprowadzić podatki powiązane z wartością gruntów i naniesień. Od terenów niezabudowanych, a przygotowanych do zabudowy ze środków publicznych, podatki powinny być wyższe niż na obszarach nie wyposażonych w infrastrukturę. Takie rozwiązanie z jednej strony byłoby bodźcem dla właścicieli gruntów do zagospodarowania wartościowych działek w centrach miast, a z drugiej ograniczyłoby rozlewanie się zabudowy. Środki uzyskane z takiego podatku mogłyby zasilać specjalny "fundusz metropolitalny", który mógłby być wykorzystany np. na tworzenie „banku ziemi”.

Przeprowadzone badania potwierdziły hipotezę, że polski samorząd nie jest jeszcze przygotowany do instytucjonalizacji obszarów metropolitalnych. Obecnie trwająca dyskusja nad formą zarządzania obszarami metropolitalnymi

w Polsce wydaje się problemem głównie natury politycznej, reprezentowanym przede wszystkim przez środowiska z poziomu wojewódzkiego oraz miasta centralne, podczas gdy gminy ościenne, w dużej mierze, w ogóle nie mają „świadomości metropolitalnej”. Nie wykluczone więc, że problem jest politycznie przerysowany, a nie istnieje $\mathrm{w}$ takim zakresie, $\mathrm{w}$ jakim jest postrzegany na szczeblu rządowym i regionalnym. Wniosek ten wskazuje na konieczność pogłębienia badań dotyczących problemów i motywów współpracy na poziomie metropolitalnym.

Z reformą systemu zarządzania obszarami metropolitalnymi trzeba postępować ostrożnie. W polskich samorządach obserwujemy dwukierunkowy proces. Z jednej strony władze lokalne ze sobą konkurują, a z drugiej chcą ze sobą współpracować. Postępuje proces uczenia się samorządów, „dojrzewania” do współpracy z innymi podmiotami. Podobne procesy zachodziły i zachodzą w Europie Zachodniej. Nie powinno się obligatoryjnie tworzyć, mocą ustawy, obszarów metropolitalnych, lepszy jest model dobrowolnej współpracy funkcjonalnej. Należy raczej powoli stymulować współpracę, stopniować jej formy i przestrzegać podstawowych zasad governance. Również w Europie Zachodniej zaszła ewolucja systemu społecznego i systemu wartości. Administracja publiczna, która nie zaspokajała potrzeb społeczności metropolitalnej powodowała konieczność tworzenia nowych struktur. Taka tendencja jest już obserwowana w polskich obszarach metropolitalnych, które dojrzały do systemu współwładztwa (Śląsk, Poznański OM). Z drugiej strony są obszary, w których współpraca nie występuje w ogóle lub pozostaje w fazie początkowej. Wiele samorządów wstrzymuje się z podjęciem jakichkolwiek wspólnych działań na poziomie metropolitalnym w oczekiwaniu na zapowiadane od lat regulacje prawne. Dlatego też należy przyjąć ustawę metropolitalną, która umożliwi tworzenie instytucji metropolitalnych w tych obszarach, które dążą do instytucjonali- 
zacji/upodmiotowienia. Proponowane przez rząd projekty ustaw metropolitalnych wskazują na skłonność do jednakowego traktowania wszystkich obszarów. Ze względu na brak akceptacji takiego rozwiązania przez przedstawicieli niektórych obszarów, głównie policentrycznych, należy zaproponować swobodę wyboru formy instytucji metropolitalnej. Pozwoliłoby to na realizację zasady szczególności, która mówi, że polityki i instytucje władzy muszą być dopasowane do szczególnych okoliczności występujących w różnych częściach kraju. Takie rozwiązania z powodzeniem funkcjonują w innych krajach.

Jednostki samorządu terytorialnego, które podejmą decyzję o instytucjonalizacji obszaru metropolitalnego, powinny obligatoryjnie zostać członkami podmiotu metropolitalnego. Kraje, które mają znacznie większe doświadczenia w zakresie demokracji niż Polska, wypracowały rozwiązania obligatoryjne.

Metropolitalny zarząd powinien składać się z bezpośrednio wybieranego organu decyzyjnego i powinien nie tyle przejmować zadania od gmin i powiatów, ile otrzymać kompetencje i środki do rozwiązywania problemów metropolitalnych, zgodnie z zasadą subsydiarności. Niewątpliwie będzie to wymagać zmian w aktualnie obowiązujących przepisach (przede wszystkim w ustawach samorządowych).

Ustawa metropolitalna powinna być przygotowana przez Ministerstwo Rozwoju Regionalnego, które w pełni odpowiada za politykę regionalną i miejską, po konsultacjach z przedstawicielami regionów i samorządów lokalnych. Dobrą praktyką, która może mieć zastosowanie w tym przypadku, były konsultacje prowadzone przez MRR podczas prac nad Koncepcją Przestrzennego Zagospodarowania Kraju.

Niezależnie od ustawy metropolitalnej powinno się przyjąć ustawę o współdziałaniu w samorządzie terytorialnym na rzecz rozwoju lokalnego i regionalnego. Pozwoli ona na łatwiejsze - niż obecnie - nawiązywanie współpracy między różnymi interesariuszami. Budowanie trwałych podstaw konkurencyjności wymaga przesunięcia akcentu na przedsięwzięcia partnerskie i wielopodmiotowe, oparte na współpracy i relacjach sieciowych. Dotychczasowe działania samorządów często cechuje duża indywidualizacja działania, postawa konkurencji i niechęć do współpracy, co w konsekwencji prowadzi do powstawania w jednym obszarze metropolitalnym konkurujących ze sobą obiektów, które nie są w pełni wykorzystywane (centra wystawiennicze, hale sportowe itp.).

Niwelowanie dystansu rozwojowego polskich metropolii wymaga rozwijania funkcji metropolitalnych. Część z owych funkcji zależy od biznesu. Aby ten biznes przyciągnąć, należy kreować innowacyjne środowisko, budować infrastrukturę techniczną, rozwijać funkcje metropolitalne o charakterze publicznym. Kontrakty terytorialne i zintegrowane projekty metropolitalne są szansą na przezwyciężenie wspomnianych ograniczeń. 
Konieczna jest większa aktywność władz publicznych w realizacji projektów w formule partnerstwa publiczno-prywatnego. Stosunkowo krótki okres rozwoju demokracji powoduje, że współpraca między różnymi podmiotami jest szczególnie trudna z uwagi na brak wcześniejszych doświadczeń. Niewątpliwą barierą jest powszechny brak wiedzy i zaufania do potencjalnych partnerów. Polskie samorządy stopniowo uczą się realizacji zadań, które na nie nałożono, ale również współpracy. Problemem jest też niewielka partycypacja społeczności w zarządzaniu rozwojem lokalnym. Wynika to ze słabo rozwiniętego społeczeństwa obywatelskiego oraz niskiego poziomu kapitału społecznego. Poprawa tej sytuacji, jak pokazują przykłady państw rozwiniętych, wymaga czasu i budowy zaufania między obywatelami, instytucjami i organizacjami, dlatego konieczna jest promocja tej formy współpracy oraz rozwijanie zaufania i kapitału pomostowego.

Wszystkie ministerstwa powinny zająć się rozwiązaniem omawianego problemu. Szczególna rola przypada tu Ministerstwu Kultury i Dziedzictwa Narodowego, które musi przyjąć i rozpocząć realizację Strategii Rozwoju Kapitału Społecznego. Niezależnie od strategii, należy wdrażać instrumenty zaproponowane przez Komisję Europejską, takie jak zintegrowane inwestycje terytorialne i Lokalne Grupy Działania. Gwałtowny rozwój LGD, obserwowany w Polsce, może być pierwszym etapem budowy zaufania między różnymi partnerami.

Trzeba wprowadzić instrumenty, które z jednej strony będą motywować samorządy do współpracy, a z drugiej wyposażą je w zasoby finansowe niezbędne do realizacji przedsięwzięć o zasięgu metropolitalnym. Konieczne jest wymuszanie partnerstwa poprzez uprzywilejowanie przedsięwzięć realizowanych w oparciu o sieci współpracy. Umożliwi to system kontraktów i zintegrowanych projektów. Zaprezentowane w pracy doświadczenia obszarów metropolitalnych wyraźnie wskazują na wysoką skuteczność tych instrumentów.

W Polsce, na poziomie szczebla rządowego, podjęto już pierwsze działania na rzecz stworzenia zintegrowanego systemu planowania. To, czy uda się go wdrożyć, zależeć będzie od decyzji samorządów terytorialnych, lokalnych społeczności i akceptacji nowych pomysłów. 


\section{LITERATURA}

20 samorzq̨dów deklaruje współpracę $w$ ramach Białostockiego Obszaru Metropolitalnego, 2009, Puls Biznesu, http://www.pb.pl/1745920,86351,20-samorzadowdeklaruje-wspolprace-w-ramach-bialostockiego-obszaru-metropolitalnego, 19.12.2012.

Aaronson D., 1998, Using Sibling Data to Estimate the Impact of Neighbourhoods on Children's Educational Outcomes, „Journal of Human Resources”, vol. 33, No 4, s. 915-46.

Acemoglu D., Johnson S., Robinson J, 2004, Institutions as the Fundamental Cause of Long-Run Growth, NBER Working Paper Series, Working Paper 10481, http://www. nber.org/papers/w10481.

Adshead M., 2002, Developing European Regions? Comparative Governance, Policy Networks and European Integration, Ashgate.

Agenda Terytorialna Unii Europejskiej. W kierunku bardziej konkurencyjnej i zrównoważonej Europy zróżnicowanych regionów, 2007.

Aguilar A. G., 1997, Metropolitan growth and labor markets in Mexico, „Geo Journal”, No 43, s. 371-383.

Ahrens J., Rudolph P. M., 2006, The Importance of Governance in Risk Reduction and Disaster Management, "Journal of Contingencies and Crisis Management", vol. 14 , no 4, s. 207-220.

Albrow M., 1997, The Global Age: State And Society Beyond Modernity, Stanford University Press, Stanford.

Allison M., Kaye J., 2003, Strategic Planning for Nonprofit Organizations: A Practical Guide and Workbook, John Wiley \& Sons Inc., Hoboken.

Allmendinger P., Ball M., 2006, New Horizons Research Programme. Rethinking the Planning Regulation of Land and Property Markets: Final Report, Office of the Deputy Prime Minister, London.

Almirall R. S., 2009, The Regional Spatial Plan of the Metropolitan Region of Barcelo$n a$, The Multigenerational Metropolis - METREX Meeting, Wrocław. 
AMB, 2003, The metropolitan territory of Barcelona. Basic data, recent developments, perspectives, Mancomunitat de Municipis de l'Area Metropolitana de Barcelona, Barcelona.

Ambruosi C. S., Baldinelli G. M., Cappuccini E., Migliardi F., 2010, Metropolitan Governance: Which Policies for Globalizing Cities?, „Transition Studies Review”, No 17, s. 320-331.

Amin A., Graham S., 1997, The ordinary city, "Transactions of the Institute of British Geographers", vol. 22, no 4, s. 411-429.

Amin A., Thrift N., 2002, Cities: Reimagining the Urban, Polity Press, Cambridge.

Amin S., 1997, Capitalism in the Age of Globalization: The Management of Contemporary Society, Zed Books, London.

Andersen H. T., van Kempen R., 2001, Governing European Cities. Social Fragmentation, Social Exclusion and Urban Governance, Ashgate, Aldershot.

Andersson H., Jorgensen G., Joye D., Ostendorf W., 2001, Change and Stability in Urban Europe. Form, Quality and Governance, Ashgate.

Andrews, R., 2008, An Institutionalist Approach to Spatial Variations in Public Service Failure: Evidence from England, „European Urban and Regional Studies”, vol. 15, No 4, s. 349-362.

Appadurai A., 2005, Nowoczesność bez granic. Kulturowe wymiary globalizacji, Wydawnictwo Universitas, Kraków.

Appiah K. A., 2007, Przedmowa, [w:] S. Sassen, Globalizacja. Eseje o nowej mobilności ludzi i pieniędzy, Wydawnictwo UJ, Kraków.

Arens J., 2002, Governance And Economic Development. A Comparative Institutional Approach, Edward Elgar Publishing, Northampton.

Arens J., Rudolph P. M., 2006, The Importance of Governance in Risk Reduction and Disaster Management, „Journal of Contingencies and Crisis Management”, Volume 14, Issue 4.

ARL, Academy for Spatial Research and Planning, 2008, The Territorial Cohesion Principles. Position Paper to the EU Green Paper on Territorial Cohesion. Position Paper from the ARL. No. 78, Hanover

Arytmiak R., 2000, Między przeszłościa a przyszłością. Społeczeństwo globalne przełomu tysiącleci, [w:] S. Bielański, T. Biernat (red.), Wokół problematyki integracji europejskiej, Wydawnictwo Adam Marszałek, Toruń.

Asheim B., Clark E., 2001, Creativity and Cost in Urban and Regional Development in the “New Economy”, „European Planning Studies”, vol. 9, No. 7.

Asheim B., Cooke P., 1998, Localised innovation networks in a global economy: a comparative analysis of endogenous and exogenous regional development approaches, “Comparative Social Research", vol. 17, JAI Press, Stamford, s. 199-240. 
Bakan J., 2006, Korporacja. Patologiczna pogoń za zyskiem i władzq, Wydawnictwo Lepszy Świat, Warszawa

Banachowicz B., Danielewicz J., 2006, Wspótrządzenie jako forma zarządzania publicznego w obszarach metropolitalnych, „Współczesne Zarządzanie”, nr 1.

Banachowicz B., Danielewicz J., 2006, Wspótrządzenie w zarządzaniu obszarami metropolitalnymi, [w:] S. Korenik, K. Wilk (red.), Gospodarka-przestrzeń-rozwój, „Prace Naukowe Akademii Ekonomicznej we Wrocławiu”, nr 1143, s. 186-198

Bańczyk M., Achrem A., Mróz J., 2008, NORDEA METROX.2008. Pierwszy ranking metropolitalności miast polskich, METROPOLIA POZNAŃ sp. z o.o., Poznań.

Bartik T. J., 2003, Local Economic Development Policies, Upjohn Institute Working Paper, Nr. 03-91.

Bartkowski J., 2007, Kapitał społeczny i jego oddziaływanie na rozwój w ujęciu socjologicznym, [w:] Herbst M. (red.), Kapitał ludzki i kapitał społeczny a rozwój regionalny, Scholar, Warszawa.

Bauer A., Röhl D., Haase D., Schwarz N., 2011, Leipzig - between growth and shrinkage, [w:] S. Pauleit, S. Bell, C. Aalbers (red.), Peri-Urban Futures: Land Use and Sustainability, Springer, Berlin.

Bauman Z., 1998, Globalization: The human consequences, Polity, Cambridge.

Bavkis H., Juillet L., 2004, The Horizontal Challenge: Line Departments, Central Agencies and Leadership, Canada School of Public Service, Ottawa.

Baylis J., Smith S. (red.), 2001, The Globalization of World Politics, Oxford University Press, Oxford.

Baylis J., Smith S., Owens P. (red.), 2009, The Globalization of World Politics. An Introduction to International Relations, Oxford University Press, Oxford.

Beauregard R. A., 1995, Theorizing the global-local connection, [w:] P. L. Knox, P. J. Taylor (red.), 1995, World Cities in a World-System, Cambridge University Press, s. 232-48.

Beauregard R. A., 2006, The radical break in late twentieth-century urbanization, „Area”, vol. 38, No 2, s. 218-220

Beck U, 2000, What is globalization?, Polity, Cambridge.

Beim M., 2009, Modelowanie procesu suburbanizacji w aglomeracji poznańskiej, Bogucki Wydawnictwo Naukowe, Poznań.

Bendyk E., 2010, Metropolia w sieci, „Samorząd Terytorialny”, nr 6.

Berry B. J. L., Conkling E. C., Ray M., 1997, The global economy in transition, Prentice Hall, Upper Saddle River.

Bis R., 1971, The political economy of metropolitan areas, Markham, Chicago. 
Bish R. L., Nourse H. O., 1975, Urban Economics and Policy Analysis, McGraw-Hill, New York.

Blakely E. J., 1994, Planning Local Economic Development. Theory and Practice, SAGE Publications, Thousand Oaks-London-New Delhi, s. 59-62.

Boettke P. J., Coyne C. J., Leeson P. T., 2011, Quasimarket failure, „Public Choice”, No 149, s. 209-224.

Bogacz-Wojtanowska E., 2005, Strategia działania organizacji pozarzqdowych $w$ budowaniu relacji z sektorem publicznym i komercyjnym, [w:] B. Plawgo, W. Zaremba (red.), Partnerskie współdziałanie $w$ sektorze publicznym i prywatnym, Fundacja Współczesne Zarządzanie, Białystok, s. 97-102.

Bogason P., 2001, Public Policy And Local Governance. Institutions in Postmodern Society, Edward Elgar Publishing London.

Borkowski, 2007, Koło zamachowe, „Gazeta Bankowa”, nr 25.

Bourdieu P., 1985, The Forms of Capital, [w:] J. G. Richardson (red.), Handbook of Theory and Research for the Sociology of Education, Greenwood, New York.

Bovaird T., 2005, Public governance: balancing stakeholder power in a network society, "International Review of Administrative Sciences", vol. 71, No 2, s. 217-228.

Bovaird T., Loeffler E. (red.), 2004, Public Management and Governance, Routledge, London-New York.

Bovens M. (red.), 2002, Success And Failure In Public Governance A Comparative Analysis, Edward Elgar Publishing, Cheltenham.

Boyne G. A., 2003, Sources of Public Service Improvement: a Critical Review and Research Agenda, "Journal of Public Administration Research and Theory", vol. 13, No 3, s. 367-94.

Bradford N., 2003, Public-private Partnership? Shifting Paradigms of Economic Governance in Ontario, „Canadian Journal of Political Science”, vol. 35, No 5, s. $1005-1033$.

Brenner N., 1998, Global cities, glocal states: global city formation and state territorial restructuring in contemporary Europe, „Review of International Political Economy", No 5, s. 1-37.

Brenner N., 1999, Globalisation as Reterritorialisation: The Re-scaling of Urban Governance in the European Union, „Urban Studies”, vol. 36, No 3, s. 431-451.

Brenner N., 2000, The urban question as a scale question: reflections on Henri Lefebvre, urban theory and the politics of scale, „International Journal of Urban and Regional Research", No 24, s.. 361-378.

Brenner N., 2003, Metropolitan Institutional Reform and the Rescaling of State Space in Contemporary Western Europe, "European Urban and Regional Studies", vol. 10, no 4, s. 297-324. 
Brenner N., 2004, New State Spaces. Urban Governance and the Rescaling of Statehood, Oxford University Press, Oxford-New York.

Broszkiewicz R., 2005, Kierunki i metody projektowania optymalnych struktur rozwoju regionalnego $w$ warunkach integracji Polski z Unia Europejska, [w:] F. Kuźnik (red.), Studia regionalne w Polsce. Teoria, polityka, projektowanie, Wydawnictwo Akademii Ekonomicznej w Katowicach, Katowice.

Brueckner J. K., 2000, Urban Sprawl: Diagnosis and Remedies, „International Regional Science Review", vol. 23, No 2, s. 160-171.

Brunn S. D., Hays-Mitchell M., Zeigle D. J. (red.), 2012, Cities of the World: World Regional Urban Development, Rowman \& Littlefield, Lanham.

Bruszt L., 2008, Wielopoziomowe zarzadzanie - warianty wschodnie. Wyłaniajace się wzorce zarzadzania rozwojem regionalnym $w$ nowych państwach członkowskich, „Zarządzanie publiczne”, nr 1 (3), s. 5-22.

Bryson J. M., 2011, Strategic Planning for Public and Nonprofit Organizations: A Guide to Strengthening and Sustaining Organizational Achievement, Jossey-Bass.

Brzozowska K., 2006, Partnerstwo publiczno-prywatne. Przesłanki, możliwości, bariery, Wydawnictwa Fachowe CeDeWu, Warszawa.

BSR INTERREG III B project. Promoting Spatial Development by Creating COMmon MINdscapes", Planning System of Sweden, http://commin.org /upload/Sweden /SE_Planning_System_in_English.pdf., 24.07.2012.

Buciak R., 2012, Szersze strefy miejskie programu Urban Audit jako przykład delimitacji zasięgu oddziaływania miast, GUS, Warszawa.

Bureau of Statistics Hamburg and Schleswig-Holstein, 2006, Hamburg Metropolitan Area, http://www.statistik-nord.de/fileadmin/download/faltblaetter/Metropolregion_englisch.pdf

Burns J., 1995, Władza przywódcza, [w:] J. Szczupaczyński, (red.), Władza i społeczeństwo: antologia tekstów z zakresu socjologii polityki, t. 1 Scholar, Warszawa, s. 261-272.

Byong-Man A., 2002, Reforming Public And Corporate Governance. Management and the Market in Australia, Britain and Korea, Edward Elgar Publishing.

Cadbury A., 1995, The Company Chairman (2nd Ed), Prentice Hall, Nowy Jork.

Cahyadi G., TenBrink S., 2004, Barcelona Metropolitan Economic Strategy, Global Urban Development, Praga.

Camagni R., 2006, Territorial Impact Assessment (TIA): a methodological proposal, "Scienze Regionali - Italian Journal of Regional Science", No 2, s. 135-146, http://www.grupposervizioambiente.it/aisre/pendrive2010/pendrive/Paper/Ca magni1.pdf. 
Camagni R., Lenzi C., 2010, Multi-criteria analysis in Territorial Impact Assessment: An application of the TEQUILA model to the European transport policies case,

Camiller J. A., Falk J., 1992, The End of Sovereignty? The Politics of a Shrinking of Fragmenting World, Edward Elgar, Aldershot.

Cantonal Office of Spatial Planning and Surveying, 2002, Settlement Development in the Canton of Zurich. A Review of 50 Years of Spatial Planning, Das kleine Forum, Zurych.

Car, J. B., Feiock R. C. (red.), 2003, Reshaping the local government landscape: citycounty consolidation and its alternatives, M. E. Sharpe, Armonk.

Carr J. B., Feiock R. C., 1999, Metropolitan government and economic development, „Urban Affairs Review”, vol. 34, No 3, s. 476-488.

Carruthers J. I., 2003, Growth at the Fringe: The Influence of Political Fragmentation in United States Metropolitan Areas, „Papers in Regional Science”, vol. 82, No 4, s. 475-499.

Carruthers J. I., Ulfarsson G. F., 2002, Fragmentation and Sprawl: Evidence from Interregional Analysis, „Growth and Change”, vol. 33, No 3, s. 312-340.

Cars G., Healer P., Madanipour A, Magalhaes C. (red.), 2002, Urban Governance, Institutional Capacity and Social Milieux, Ashgate, Aldershot.

Castells M., 1996, The Rise of Network Society, Blackwell, Oxford.

Castells M., 2000, End of Millennium, The Information Age: Economy, Society and Culture, Vol. III., Blackwell, Oxford.

Castells M., 2008, Społeczeństwo sieci, PWN, Warszawa.

CBOS, 2010, Zaufanie społeczne, Warszawa.

Chakravorty S., 2003, Urban development in the global periphery: The consequences of economic and ideological globalization, „The Annals of Regional Science”, vol. 37, No 3, s. 357-367.

Chądzyńska E., 2008, Miasta przyszłości - tendencje rozwojowe wybranych miast na świecie, [w:] J. Słodczyk, M. Śmigielska (red.), Współczesne kierunki i wymiary procesów urbanizacji, Wydawnictwo Uniwersytetu Opolskiego, Opole, s. 27-36.

Chmielewski J. (red.), 1995, Studium Obszaru Metropolitalnego Warszawy, Biuro Planowania Rozwoju Warszawy, Warszawa.

Christmann A., 2011, Legitimacy of Governance Structures. A comparative approach to measure in- and output legitimacy in metropolitan areas, EGPA Annual Conference, Bukareszt.

Chute Ch. F., 1956, Today's Urban Region, „National Municipal Review”, vol. 45, issue 6, s. 274-280.

Cid S. L., 2009, Metropolitan Area of Lisbon, Konferencja METREX, Wrocław. 
Cieslewicz D. J., 2002, The Environmental Impacts of Sprawl, [w:] Squires G. D. (red.), Urban Sprawl: Causes, Consequences and Policy Responses, Urban Institute Press, Washington, s. 23-38.

Cieśla A., 2009, Co to jest kurczące się miasto?, http://www.regioportal.pl/pl28/ teksty1060/co_to_jest_kurczace_sie_miasto.

Cini M. (red.), 2007, Unia Europejska. Organizacja i funkcjonowanie, Polskie Wydawnictwo Ekonomiczne, Warszawa.

Clark G., 2010, Leadership and Governance of OPENCities, British Council, Madryt.

Clark G., 2011, Narzędzia rozwoju metropolii, prezentacja na konferencji „Od miasta do metropolii - drogi rozwoju Europy", Katowice, listopad.

Clark G., Huxley J., Mountford D., 2010, Organising Local Economic Development: The Role of Development Agencies and Companies, Local Economic and Employment Development (LEED), OECD Publishing,doi: 10.1787/9789264083530-en.

Clark T. N., 2000, Old and new paradigms for urban research: Globalization and the fiscal austerity and urban innovation project, „Urban Affairs Review”, vol. 36, No 1, s. 3-45.

Clark T. N., Hoffmann-Martinot V. (red.), 1998, The New Political Culture, Boulder, Colorado Westview.

Clavel P., Pitt J., Yin J., 1997, The community option in urban policy, „Urban Affairs Review", vol. 32 No 4, s. 435-458.

Coaffee J., Healer P., 2003, "My Voice: My Place”: Tracking Transformations in Urban Governance, "Urban Studies”, vol. 40, No 10, s. 1979-1980.

Cole A., John P., 2001, Local Governance in England and France, Routledge.

Coleman J. S., 1990, Foundations of Social Theory, Harvard University Press, Cambridge.

Collin J.P., Léveillée J., Poitras C., 2002, New Challenges And Old Solutions: Metropolitan Reorganization in Canadian and U.S. City-Regions, "Journal of Urban Affairs", vol. 24, No 3, s. 317-332.

Commission of The European Communities, 2001, European Governance - a White Paper, Bruksela.

Considine M., 2005, Partnerships, Relationships and Networks: Understanding Local Collaboration Strategies in Different Countries, [w:] OECD, Local Governance and the Drivers of Growth, OECD, Paris.

Cooke P., Heidenreich M., Braczyk H. J., 2004, Regional Innovation Systems. The Role of Governances in a Globalized World, Routledge.

Coombes M., 2006, Defining Metropolitan Regions (MRs): coping with complexity, OECD, Paryż

Cornforth C., 2002, The Governance of Public and Non-Profit Organizations, Routledge 
Costituzione della Repubblica Italiana, 2003

Cote S., Healy T., 2001, The Well-being of Nations: The Role of Human and Social Capital, OECD, Paris.

Cox K. R. (red.), 1997, Spaces of Globalization: Reasserting the Power of the Local, The Guilford Press, New York-London.

Cox R. W., 1987, Production Power and World Order: Social Forces in the Making of History, Columbia University Press, New York.

Crainer S., Dearlove D. (red.), 2004, Financial Times Handbook of Management, Pearson Education Limited, Harlow.

Crespo J. L., Cabral J., 2010, The institutional dimension to urban governance and territorial management in the Lisbon metropolitan area, „Análise Social”, vol. XLV (197), s. 639-662.

Cushman \& Wakefield, 2011, European Cities Monitor, http://www.cushwake.

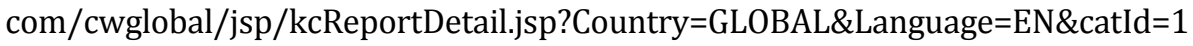
00003\&pId=c38200001p.

Cutler A. C., Haufler V., Porter T. (red.), 1999, Private Authority and International Affairs, State University of New York Press, Albany.

Cutler D. M., Glaeser E. L., 1997, Are Ghettos Good or Bad?, „Quarterly Journal of Economics", vol. 112, No 3, s. 827-72.

Czapiński J., Panek T., 2011, Diagnoza społeczna 2011. Warunki i jakość życia Polaków, Rada Monitoringu Społecznego, Warszawa.

Czaputowicz J., 2001, Globalizacja - wpływ na państwo narodowe, „Polska w Europie”, nr 4 (38).

Czornik M. (red.), 2003, Wdrażanie strategii rozwoju miasta, Wydawnictwo Akademii Ekonomicznej, Katowice.

Czornik M., 2004, Miasto. Ekonomiczne aspekty funkcjonowania, Wydawnictwo Akademii Ekonomicznej w Katowicach, Katowice.

Czyż T., 2009, Koncepcje aglomeracji miejskiej i obszaru metropolitalnego w Polsce, „Przegląd Geograficzny”, nr 4, s. 445-459.

Dahl R. A., 1971, Polyarchy. Participation and Opposition, Yale University Press, New Haven.

Dahl R., Tufte E. R., 1973, Size and Democracy, Stanford University Press, Berkeley.

Dalby S., 2009, Security and environmental change, Polity Press, Cambridge.

Danielewicz J., Markowski T., 2008, Zarzadzanie w obszarze metropolitalnym podejście instytucjonalne, [w:] T. Stryjakiewicz, T. Czyż (red.), O nowy kształt badań regionalnych w geografii i gospodarce przestrzennej, „Biuletyn KPZK”, z. 237, s. 73-103. 
Danson M., Halkier H., Cameron G., 2000, Governance, Institutional Change and Regional Development, Ashgate.

Davies A., 1999, A strategic approach to corporate governance, Gower.

Davoudi S., Evans N., Governa F., Santangelo M., 2008, Territorial governance in the making. Approaches, methodologies, practices, „Boletín de la A.G.E.”, No 46, s. 33-52.

Deklaracja o utworzeniu rady Krakowskiego Obszaru Metropolitalnego podpisana w Krakowie 22 listopada 2007 r.

Denhardt R. B., Denhardt J. V., 2008, Public Administration: An Action Orientation, Wadsworth Publishing Company.

DiGaetano A., Klemanski J. S., 1999, Urban regime capacity: A comparison of Birmingham, England and Detroit, Michigan, „Journal of Urban Affairs”, vol. 15, No 4, s. 367-84.

DiGaetano A., Strom E., 2003, Comparative Urban Governance An Integrated Approach, „Urban Affairs Review”, vol. 38, No 3, s. 356-395.

Doh J. P. (red.), 2005, Handbook On Responsible Leadership And Governance In Global Business, Edward Elgar Publishing.

Dollery B. F., Wallis J. W., 2009, Niesprawność rynku, niesprawność rzq̨du, przywództwo i polityka publiczna, „Zarządzanie Publiczne”, nr 2(8), s. 83-91.

Domański B., 2008, Rozwój polskich metropolii a regiony peryferyjne. Bezpowrotna separacja czy współzależność rozwoju?, „Studia KPZK PAN”, nr 120, s. 135-143.

Domański R., 2001, The innovative city, House of Poznań University of Economics, Poznań.

Domański R., 2004, Geografia ekonomiczna: ujęcie dynamiczne, Wydawnictwo Naukowe PWN, Warszawa.

Downs A., 1994, New Visions for Metropolitan America, Brookings Institution, Washington.

Drobniak A., 2005, Ocena projektów publicznych, Wydawnictwo Akademii Ekonomicznej w Katowicach, Katowice.

Drzazga D., 2010, Zarządzanie w obszarach metropolitalnych: procesy-struktury organizacyjne-instrumenty, [w:] Procesy metropolizacyjne $w$ teorii naukowej i praktyce, Główny Urząd Statystyczny, Warszawa.

Dubisz S. (red.), 2003, Uniwersalny słownik języka polskiego, Wydawnictwo Naukowe PWN, Warszawa.

Dunning J. H., Lundan S.M., 2008, Multinational Enterprises and The Global Economy, Edward Elgar, Northampton. 
Duranton G., 2000, Urbanisation, urban structure and growth, [w:] J. M. Huriot, J. F. Thisse (red.), Economics of Cities: Theoretical Perspectives, Cambridge University Press, Cambridge, s. 290-317.

Dutkowski M., 2000, Zmiany postsocjalistycznych metropolii w Polsce, [w:] R. Domański (red.), Nowe problemy rozwoju wielkich miast i regionów, „Biuletyn KPZK PAN", z. 192, s. 37-48.

Dyskusja o Wrocławskim Obszarze Metropolitalnym, 2010, http://www.umwd. dolnyslask.pl/urzad/aktualnosci/artykul/dyskusja-o-wroclawskim-obszarze-metro politalnym/, 26.01.2012.

Działek J., 2008, Geografia kapitału społecznego. Regionalne zróżnicowanie zasobów kapitału społecznego w Polsce, [w:] T. Nawrocki, K. Bierwiaczonek, M. S. Szczepański (red.), Kapitały ludzkie i społeczne a konkurencyjność regionów, Wydawnictwo Uniwersytetu Śląskiego, Katowice, s. 127-143.

Dzieciuchowicz J. (red.), 2009, Usługi dla producentów i biznesu w przestrzeni wielkomiejskiej. Przykład Łodzi, Wydawnictwo Uniwersytetu Łódzkiego, Łódź.

Dzieciuchowicz J., (red.), 2009, Usługi dla producentów i biznesu w przestrzeni wielkomiejskiej. Przykład Łodzi, Wyd. UŁ, Łódź.

Dziemianowicz W., Łukomska J., 2009, Bieguny wzrostu, ośrodki centralne i metropolie - gdzie jesteśmy i dokąd zmierzamy?, [w:] Z. Makieła (red.), Potencjalne metropolie ze szczególnym uwzględnieniem Polski Wschodniej, Studia KPZK PAN, t. CXXV, Warszawa, s. 18-29.

„Dziennik Zachodni”, 2012, http://www.dziennikzachodni.pl/artykul/545395,slaskw- sejmie-na-razie-jest-godka-a-co-z-metropolia,id,t.html, 1.12.2012.

Dziewoński K., 1967, Baza ekonomiczna i struktura funkcjonalna miast. Studium rozwoju pojęć, metod i ich zastosowań, „Prace Geograficzne IG PAN”, t. 63.

Eldredge H. W., 1967, Taming Megalopolis: How to manage an urbanized world, Doubleday \& Company, New York.

Erhardt D., Burdon R., 1999, Free Entry in Infrastructure, Discussion paper, nr 2093, World Bank, Washington.

Eriksen S., 2007, Promoting Good Governance in Eastern Europe - Domestic Responses to External Influences, [w:] D. Coombes, L. Vass (red.), Post-Communist Public Administration: Restoring Professionalism and Accountability, NISPAcee Press, Bratislava.

ESPON, 2006, Atlas ESPON Struktura terytorium Europy, Bundesamt für Bauwesen und Raumordnung, Bonn, http://www.espon.pl/files/11_2/2/ESPON\%20Atlas_ FIN_600_2.pdf.

European Comission, 2005, Social Capital, Special Eurobarometer 223 / Wave 62.2 TNS Opinion \& Social. 
European Commission, 2011, Cities of tomorrow - Challenges, visions, ways forward, Brussels.

Ewing R., Pendall R., Chen D., 2002, Measuring Sprawl and Its Impact, Smart Growth America, Washington.

Faliński S., 2008, Warszawa - jaka metropolia?, materiały z konferencji naukowej, Wyższa Szkoła Ekonomiczno-Informatyczna, Warszawa.

Faludi A., van der Valk A., 1994, Rule and order: Dutch planning doctrine in the twentieth century, Kluwer Academic, Dordrecht.

Farazmand A., 2004, Sound Governance. Policy and Administrative Innovations, Praeger.

Feiock C. R. (red.), 2004, Metropolitan Governance. Conflict, Competition and Cooperation, Georgetown University Press, Washington.

Ferri V., 2009, Le Città metropolitane in Italia. Una istituzione del federalismo, „Economia Italiana”, nr 2, s. 367-403.

Finka M., 2007, Territorial Cohesion - Between Expectation, Disparities and Contradictions, [w:] D. Scholich (red.), German Annual of Spatial Research and Policy, Springer Verlag, Leipzig, s. 23-40.

Finsterbusch K., 1985, State of the Art in Social Impact Assessment, „Environment and Behavior", vol. 17, No 2, s. 193-221.

Fisher R., Shragge E., 2000, Challenging community organizing: Facing the 21st Century, ,Journal of Community Practice”, nr 8(3), s. 1-19.

Fleurke F., Willemse R., 2006, Measuring Local Autonomy: A Decision-making Approach, "Local Government Studies", vol. 32, No 1, s. 71-87.

Florentino R., 2007, The Spatial Governance of the Lisbon's Metropolitan Region, THE VITAL CITY, European Urban Research Association (EURA) 10th Anniversary Conference, University of Glasgow, 12-14 September

Florida R., 2000, The Economic Geography of Talent, Heinz School of Public Policy and Management, Carnegie Mellon University, Pittsburgh

Florida R., 2002, The Rise of the Creative Class: And How It's Transforming Work, Leisure, Community, and Everyday Life, Basic Books, New York.

Florida R., 2004, The Flight of the Creative Class: The New Global Competition for Talent, Harper Business, New York, London.

Florida R., 2005, Cities and the Creative Class, Routledge, New York-London.

Font J., Gutierrez-Suarez R., Parrado-Diez S., 1999, Inter-governmental Partnerships at the Local Level in Spain: Mancomunidades and Consortia in a Comparative Perspective, OECD, Paris. 
Fontan J. M., Hamel P., Morin R., Shragge E., 2007, Community Organizations and Local Development in a Metropolitan Region: Does Place Matter?, [w:] J. E. Klausen, P. Swianiewicz, Cities in City Regions: Governing the Diversity, Wydawnictwo Uniwersytetu Warszawakiego, Warszawa, s. 175-191.

Fontan J. M., Hamel P., Morin R., Shragge E., 2009, Community Organizations and Local Governance in a Metropolitan Region, „Urban Affairs Review”, vol. 44, No 6, s. 832-857.

Franchini T., Valverde F., 2004, Madrid Strategic Plan, 40 th $I$ SoCaRP Congress, Genewa.

Freeman R. E., McVea J., 2001, A Stakeholder Approach to Strategic Management, Darden Business School Working Paper, No. 01-02, http://ssrn.com/abstract $=263511$ or doi: $10.2139 /$ ssrn. 263511

Friedmann J., 1986, The world city hypothesis, „Development and Change”, No 17, s. 69-83.

Friedmann J., 1995, Where we stand: a decade of world city research, [w:] P. L. Knox, P. J. Taylor (red.), 1995, World Cities in a World-System, Cambridge University Press, s. 48-62.

Friedmann J., 1998. The new political economy of planning: The rise of civil society, [w:] M. Douglass, J. Friedmann (red.), Cities for citizens, Planning and the rise of civil society in a global age, John Wiley and Son, Chichester, s. 19-35.

Friedmann J., Wolff G., 1982, World city formation: an agenda for research and action, „International Journal of Urban and Regional Research”, No 6, s. 309-344.

Frykowski M., 2005, Zaufanie społeczne mieszkańców Łodzi, Wydawnictwo Uniwersytetu Łódzkiego, Łódź.

Fuhrmann M., Grochowski M., Pieniążek M., Wilk W., Zegar T., 2005, Warszawa Obszar Metropolitalny - Mazowsze. Relacje międzygminne: współpraca czy obojętność?, „Samorząd Terytorialny”, nr 7-8, s. 17-37.

Fukuyama F., 1997, Zaufanie. Kapitał społeczny a droga do dobrobytu, PWN, Warszawa-Wrocław.

Fukuyama F., 2003, Kapitał społeczny, [w:] Harrison L. E., Huntington S. P. (red.), Kultura ma znaczenie, Zysk i S-ka, Kraków.

Fulton W., Pendall R., Nguyen M., Harrison A., 2001, Who Sprawls Most? How Growth Patterns Differ across the U., Brookings Institution Washington, http://www. brookings.edu/es/urban/publications/fulton.pdf

Furubotn E.G., Richter R., 2000, Institutions and Economic Theory. The Contribution of the New Institutional Economics, The University of Michigan Press, Ann Arbor.

Gaczek W., 2000, Urynkowienie gospodarki gruntami a przemiany struktury użytkowania terenów dużych miast, „Przegląd Geograficzny”, nr 4, s. 411-428. 
Gajl N., 1979, Instrumenty finansowe w zarzq̨dzaniu gospodarkq narodowq, PWE, Warszawa.

Garcia M., 2003, The case of Barcelona, [w:] W. Salet, A. Kreukels, A. Thornley (red.), Metropolitan Governance and Spatial Planning, Spon Press, London-New York, s. 337-358.

Gaunard-Anderson M. F., 2011, New challenges for a border region and its metropolitan area at the beginning of the new French territorial reform. The case of Lorraine and its metropolitan area Metz-Nancy in the Greater Region, [w:] Contested Regions: Territorial Politics and Policy, Regional Studies Association, Seaford.

Gaussier N., Lacour C., Puissant S., 2003, Metropolitanization and territorial scales, "Cities”, vol. 20, No 4, s. 253-263.

Gawłowski R., 2010, Reprezentacja polityczna obszarów metropolitalnych na przykładzie Londynu, [w:] Lutrzykowski A., Gawłowski R. (red.), Metropolie - wyzwanie polskiej polityki miejskiej, Wyd. Adam Marszałek, Toruń, s. 107-116.

Gawroński H., 2010, Zarządzanie strategiczne w samorządach lokalnych, Wolters Kluwer Polska sp. z o.o., Warszawa-Kraków.

Gawryszewski A., Korcelli P., Nowosielska E., 1998, Funkcje metropolitarne Warszawy, „Zeszyty IGiPZ PAN”, nr 53.

Gdulewicz E., 2002, Ustrój polityczny Niemiec. [w:] Skrzydło W. (red.), Ustroje państw współczesnych, Wydawnictwo Uniwersytetu Marii Curie-Skłodowskiej, Lublin.

Gereffi G., 1994, The organization of buyer-driven global commodity chains, [w:] G. Gereffi, M. Korzeniowicz (red.), In Commodity Chains and Global Capitalism, Greenwood, Westport, s. 95-120.

Giddens A., 1990, Consequences of Modernity, Polity Press, Cambridge.

Giddens A., 1991, Modernity and Self-Identity, Polity Press, Cambridge.

Gidlund J., 2000, Local And Regional Governance In Europe. Evidence from Nordic Regions, Edward Elgar Publishing, Cheltenham.

Giguère S., 2003, Managing Decentralisation and New forms of Governance, [w:] Managing Decentralisation: A New Role for Labour Market Policy, OECD, Paris, s. 11-26.

Giguère S., 2005, The Drivers of Growth: Why Governance Matters, [w:] Local Governance and the Drivers of Growth, OECD, Paris, s. 11-37.

Gilens M., 2005, Inequality and democratic responsiveness, „Public Opinion Quarterly", vol. 69, No 5, s. 778-796.

Gilpin R., 1987, The Political Economy of International Relations, Princeton University Press, Princeton.

Glasbergen P. (red)., 1995, Managing Environmental Disputes. Network Management as an Alternative, Kluwer Academic Publishers, Dordrecht. 
Glazer A., Konrad K. A. (red.), 2003, Conflict and Governance, Springer Verlag

Globalization: Threat or Opportunity?, http://www.imf.org/external/np/exr/ib/2000/ 041200to.htm\#II, 02.09.2010.

Gonzalez R. de Miguel, 2008, Spatial planning, metropolitan government and governance in the major cities in Spain, "Boletín de la A.G.E", No 48.

Good Urban Governance: A Normative Framework (HS/C/PC.1/CRP.6), 26 February 2000, http://www.un-habitat.org

Gorzelak G., 2008, Fakty i mity rozwoju regionalnego, „Zarządzanie Publiczne”, nr 4 (6), s.73-89.

Gorzelak G., 2009, Metropolizacja a globalizacja, [w:] B. Jałowiecki (red.), Czy metropolia jest miastem?, Wydawnictwo Naukowe Scholar, Warszawa.

Gorzelak G., Smętkowski M., 2005, Metropolia i jej region, Wydawnictwo Naukowe Scholar, Warszawa.

Gorzelak G., Smętkowski M., 2009, Dynamika rozwoju regionów w krajach Europy Środkowej i Wschodniej, [w:] G. Gorzelak, M. S. Szczepański, W. Ślęzak-Tazbir (red.), Człowiek - miasto - region: zwiq̨zki i interakcje, Wydawnictwo Naukowe Scholar, Warszawa.

Gottdiener M., 2002, Urban Analysis as Merchandising: The 'LA School' and the Understanding of Metropolitan Development, [w:] Eade J., Mele C. (red.), Understanding the City: Contemporary and Future Perspectives, Blackwell, Oxford, s. $159-180$.

Gough J., Eisenschitz A., McCulloch A., 2006, Spaces of social exclusion, Routledge, London.

Governance International, 2006, http://www.govint.org/english.html.

Government Office for London, 2008, „Circular”, 1.

Górka Z., 1994, Zmiany w strukturze funkcjonalnej centrum Krakowa $w$ dobie transformacji społeczno-ekonomicznej Polski, [w:] VII Konwersatorium Wiedzy o Mieście, Region miejski. Centrum a peryferia w okresie transformacji politycznej, gospodarczej i społecznej, Katedra Geografii Miast i Turyzmu UŁ, Komisja Geografii Osadnictwa i Ludności PTG, Łódź

Graham J., Amos B., Plumptre T., 2003, Principles for Good Governance in the 21 ${ }^{\text {st }}$ Century, „Policy Brief”, nr 15.

Graizbord B., Rowland A., Aguilar A. G., 2003, Mexico City as a peripheral global player: The two sides of the coin, „The Annals of Regional Science”, no 37, s. 501518. 
Graniszewski L., 2009, Wielocentryczność systemu prawa - implikacje dla państwa i obywateli, [w:] K. Kamińska, S. Mrozowska, G. Piwnicki, Państwa - regiony świat w kształtującej się rzeczywistości globalnej, Wydawnictwo Uniwersytetu Gdańskiego, Gdańsk.

Gras N. S. B., 1922, The Development of Metropolitan Economy in Europe and Ameri$c a$, „American Historical Review”, nr 27, s. 695-708.

Graves P. E., 2003, Non-Optimal Levels of Suburbanization, „Environment and Planning", No 35 (2), s. 191-98.

Greer J., 2001, Partnership Governance in Northern Ireland. Improving Performance, Ashgate.

Griffin K., 1996, Studies in Globalization and Economic Transitions, Macmillan, London.

Grochal R., 2008, Metropolie będq oddolne, http://wyborcza.pl/1,85996,5430243, Metropolie_beda_oddolne.html.

Grochowski M., 2010, Samorząd na obszarach metropolitalnych. Raport z badań, „Samorząd Terytorialny”, nr 6, s. 24-36.

Grootaert Ch., 1998, Social Capital: The Missing Link?, "Social Capital Initiative Working Paper", No. 3, The World Bank.

Gualini E., 2003, The region of Milan, [w:] W. Salet, A. Kreukels, A. Thornley (red.), Metropolitan Governance and Spatial Planning, Spon Press, London-New York.

Guillen M., 2001, Is Globalization Civilizing, Destructive or Feeble? A Critique of Five Key Debates in the Social Science Literature, „Annual Review of Sociology”, vol. 27.

Haider D., 1992, Place wars: new realities of the 1990s, „Economic Development Quarterly", No 6.

Hall P., 1966, The World Cities, World University Library, Weidenfeld \& Nicolson, London.

Hall P., 1989, London 2001, Unwin Hyman, London.

Hall P., 1998, Cities in Civilisation: Culture, Innovation and Urban Order, Weidenfeld \& Nicolson, London.

Hall P., 2001, Global city-regions in the twenty-first century. [w:] A. Scott, (red.), Global city-regions: trends, theory, policy, Oxford University Press, Oxford, s. 59-77.

Hall T., Hubbard P. (red.), 1998, The Entrepreneurial City: Geographies of Politics, Regime, and Representation, Wiley, Chichester; New York.

Hambleton R., 2001, The new city management, [w:] R. Hambleton, H. Savitch, M. Stewart, (red.), Globalism and Local Democracy, Palgrave London.

Hamel P., Lustager-Thaler H., Mayer M. (red.), 2000, Urban Movements in a Globalising World, London, New York, Routledge. 
Hamilton D. K., Miller D. Y., Paytas J., 2004, Exploring the Horizontal and Vertical Dimensions of the Governing of Metropolitan Regions, „Urban Affairs Review”, vol. 40, No. 2.

Hamnett C., 1994, Social polarisation in global cities: theory and evidence, "Urban Studies", No 29, s. 401-424.

Hampton K., Wellman B., 2002, The Not So Global Village of Netville, [w:] Wellman B., Haythornthwaite C. (red.), The Internet in Everyday Life, Blackwell, Oxford, s. 345-371.

Hanifan L. J., 1916, The Rural School Community Center, „Annals of the American Academy of Political and Social Science", no 67, s. 130-138.

Hansen A. L., Andersen H. T., Clark E., 2001, Creative Copenhagen: Globalization, Urban Governance and Social Change, „European Planning Studies”, vol. 9, No 7, s. 851-869.

Harańczyk A., 1998, Miasta Polski w procesie globalizacji gospodarki, Wydawnictwo Naukowe PWN, Warszawa.

Harding A., 1997, Urban regimes in a Europe of the cities? „European Urban and Regional Studies", No 4, s. 291-314.

Harding A., Le Gale` S. P., 1997, Globalization, urban change and urban policies in Britain and France, [w:] Scott A. (red.), The Limits of Globalization, Routledge, London, s. 181-201.

Harper T. L., Hibbard M., Gar-On Yeh A., Costa H. (red.), 2011, Dialogues in urban and regional planning, Routledge, New York, London

Harsman B., Olsson A. R., 2003, The Stockholm Region Metropolitan governance and spatial policy, [w:] Salet W., Kreukels A., Thornley A. (red.), Metropolitan Governance and Spatial Planning, Spon Press, London-New York.

Hartog R., 1999, Growth without Limits: Some case studies of $20^{\text {th }}$ century urbanization, „International Planning Studies”, vol. 4, No 1, s. 95-130.

Harvey D., 1989, From managerialism to entrepreneurialism: the transformation in urban governance in late capitalism, Geografiska Annaler, No 71B, s. 3-17.

Hausner J., 1998, Metropolie-luka koncepcyjna?, [w:] J. Purchla (red.), Metropolitalne funkcje Krakowa, MCK, Kraków, s. 33-38.

Hausner J., 2001, Modele polityki regionalnej w Polsce, „Studia Regionalne i Lokalne”, nr 1(5), s. 5-24.

Hausner J., 2008, Zarządzanie publiczne, Scholar, Warszawa.

Healey P., 2007, Urban Complexity and Spatial Strategies: Towards a Relational Planning for our Times, Routledge, London. 
Healey P., Cameron S., Davoudi i in., 1995, Introduction: the city-crisis, change and invention, [w:] P. Healey, S. Cameron, S. Davoudi at al. (red.), Managing Cities: The New Urban Context, John Wiley and Sons, Chichester, s. 1-20.

Healey P., Khakee A., Motte A. (red.), 1997, Making Strategic Spatial Plans: Innovation in Europe, UCL Press Limited.

Hede H., 2006, The Stockholm Region. Regional Planning and Development Overview, Office of Regional Planning and Urban Transportation, Stockholm County Council, Sztokholm.

Heeg S., 2003, Governance in the Stuttgart metropolitan region. [w:] W. Salet, A. Thornley, A. Kreukels, (red.), Metropolitan Governance in Europe. Comparative Case Studies of European City-Regions, Routledge, London-New York.

Heinelt H., Kübler D., 2004, Metropolitan Governance in the 21st Century Capacity, Democracy and the Dynamics of Place, Routledge, London.

Held D., McGrew A., Goldblatt D., Perraton J., 1999, Global Transformations: Politics, Economics, and Culture, Stanford University Press, Stanford.

Herbst J., 2008, O kategorii „responsywności” władzy i opewnym warunku responsywności władzy w Polsce, „Zarządzanie Publiczne”, nr 4 (6), s. 91-106.

Herbst M., 2003, Koniunktura gospodarcza metropolii, Scholar, Warszawa.

Herrschel T., Newman P., 2002, Governance of Europe's City Regions. Planning, Policy $\&$ Politics, Routledge, Londyn Nowy York.

Hill M., Hupe P. L., 2002, Implementing Public Policy. Governance in Theory and in Practice, Sage Publications Ltd.

Hirst P., Thompson G., 1996, Globalization in Question, Polity Press., Oxford.

Hnat P., 2009, Regional and global levels of economic governance: the case of trade liberalization efforts, [w:] W. Niemiec, I. Benczes, (red.), The economic dimensions of global and regional governance, Wydawnictwo Adam Marszałek, Toruń.

Hodgson G. M., (red.), 2003, Recent Developments in Institutional Economics, Elgar, Northampton.

Hoen H. W., 2003, Good Governance In Central And Eastern Europe. The Puzzle of Capitalism by Design, Edward Elgar Publishing.

Holland E. W., 1991, Deterritorializing „Deterritorialization”: From the „AntiOedipus” to „A Thousand Plateaus”, „Substance”, vol. 20, No. 3, issue 66, s. 55-65.

Hood C., 1991, A Public Management for All Seasons, „Public Administration”, vol. 69, No 3-19.

Howell-Moroney M., 2008, The Tiebout Hypothesis 50 Years Later: Lessons and Lingering Challenges for Metropolitan Governance in the 21 $1^{\text {st }}$ Century, „Public Administration Review", vol. 68, No 1, s. 97-109. 
Hudson C., 2005, Regional Development Partnerships in Sweden: Putting the Government Back in Governance?, "Regional and Federal Studies", vol. 15, No 3, s. 311-327.

Hughes 0., 2003, Public Management and Administration. An Introduction, Palgrave Macmillan, London.

Hugo G., Champion T. (red.), 2004, New Forms of Urbanization: Beyond the UrbanRural Dichotomy, Ashgate, Aldershot.

Hurrell A., 1995, Regionalism in Theoretical Perspective, [w:] L. Fawcett, A. Hurrell (red.), Regionalism in World Politics, Oxford University Press, Oxford, s. 36-73.

Ilcan S., Basok T., 2004, Community government: Voluntary agencies, social justice and the responsibilization of citizens, „Citizenship Studies”, No 8 (2), s. 129-44.

Ilnicki D., 2003, Miasta polskie jako potencjalne metropolie o znaczeniu kontynentalnym, [w:] I. Jażdżewska (red.), Funkcje metropolitalne $i$ ich rola $w$ organizacji przestrzeni, XVI Konwersatorium wiedzy o mieście, Łódzkie Towarzystwo Naukowe, Łódź, s. 61-72.

Irazabal C., 2005, City Making and Urban Governance in the Americas. Curitiba and Portland, Ashgate.

Izdebski H., 2010a, Dwadzieścia lat samorzq̨du terytorialnego - potrzeba rozwiqzania problemu metropolii, [w:] Lutrzykowski A., Gawłowski R. (red.), Metropolie wyzwanie polskiej polityki miejskiej, Wyd. Adam Marszałek, Toruń, s. 15-23.

Izdebski H., 2010b, Nowe kierunki zarzq̨dzania publicznego a współczesne kierunki myśli polityczno-prawnej, [w:] A. Bosiacki, H. Izdebski, A. Nelicki, I. Zachariasz (red.), Nowe zarządzanie publiczne i public governance $w$ Polsce i $w$ Europie, Liber, Warszawa

Izdebski H., Nelicki A., Zachariasz I., 2007, Zagospodarowanie przestrzenne. Polskie prawo na tle standardów demokratycznego państwa prawnego, Program Sprawne Państwo, Ernst \& Young, Warszawa, s. 18.

Jacobs J., 1969, The Economy of Cities, Vintage, New York.

Jacobs J., 1984, Cities and the Wealth of Nations: Principles of Economic Life, Vintage Books, New York.

Jakóbczyk-Gryszkiewicz J., 2005, Procesy urbanizacji we współczesnym świecie, [w:] I. Jażdżewska (red.), Współczesne procesy urbanizacji i ich skutki, XVIII Konwersatorium wiedzy o mieście, Łódzkie Towarzystwo Naukowe, Łódź, s. 8-24.

Jałowiecki B., 1999, Metropolie, Wydawnictwo Wyższej Szkoły Finansów i Zarządzania w Białymstoku, Białystok.

Jałowiecki B., 2000a, Społeczna przestrzeń metropolii, Wydawnictwo Naukowe Scholar, Warszawa. 
Jałowiecki B., 2000b, Warszawa jako metropolia europejska?, [w:] A. Kukliński, J. Kołodziejski, T. Markowski, W. Dziemianowicz (red.), Globalizacja polskich metropolii, EUROREG, Warszawa, s. 24-80.

Jałowiecki B., 2002, Zarządzanie rozwojem aglomeracji miejskich, Wydawnictwo Wyższej Szkoły Finansów i Zarządzania w Białymstoku, Białystok.

Jałowiecki B., 2007, Globalny świat metropolii, Wydawnictwo Naukowe Scholar, Warszawa.

Jałowiecki B., Szczepański M. S., 2006, Miasto i przestrzeń w perspektywie socjologicznej, Wydawnictwo Naukowe Scholar, Warszawa.

Jansen Ch., Leijon S., 1996, Theorizing and Conceptualising Regions, [w:] J. Alden, P. Boland (red.), Regional Development Strategies. A European Perspective, Regional Studies Association.

Jażdżewska I. (red.), 2003, Funkcje metropolitalne i ich rola $w$ organizacji przestrze$n i$, XVI Konwersatorium wiedzy o mieście, Łódzkie Towarzystwo Naukowe, Łódź.

Jażdżewska I. (red.), 2005, Współczesne procesy urbanizacji i ich skutki: XVIII Konwersatorium Wiedzy o Mieście, Wydawnictwo Uniwersytetu Łódzkiego, Łódź.

Jencks C., Mayer S. E., 1990, The Social Consequences of Growing Up in a Poor Neighborhood, [w:] L. E. Jr. Lynn, M. G. H. McGreary (red.), Inner-City Poverty in the United States, National Academy Press, Washington, s. 111-86.

Jessop B., 1994, Post-Fordism and the state, [w:] Amin A. (red., Post-Fordism: a Reader, Blackwell, Oxford, s. 251-279.

Jessop B., 1998, The rise of governance and the risks of failure: the case of economic development, „International Social Science Journal”, No 155, s. 29-45.

Jessop B., 1999, Narrating the Future of the National Economy and the National State? Remarks On Remapping Regulation and Reinventing Governance, [w:] G. Steinmetz (red.), State/culture: state-formation after the cultural turn, Cornell University Press. Ithaca, s. 378-406.

Jeżak J., 2010, Orientacja stakeholders jako podstawa zrównoważonego rozwoju dużego przedsiębiorstwa, [w:] Cisek M, Domańska-Szaruga B. (red.), Zrównoważony rozwój przedsiębiorstw, Wydawnictwo Studio Emka, Warszawa.

Jędralska K., Żabiński L., 2003, Gospodarka w obliczu globalizacji: przegląd wybranych zagadnień, PTE, Katowice.

John P., 2001, Local Governance in Western Europe, Sage, London.

Jóźwik B., 2007, Globalizacja i integracja europejska, Wydawnictwo KUL, Lublin.

Juchnicka M., Proniewski M., 2009, Procesy metropolizacyjne w Polsce - metropolizacja przestrzenie, [w:] W. Czarnecki, M. Proniewski (red.), Metropolie. Problemy rozwoju, Wyższa Szkoła Finansów i Zarządzania w Białymstoku, Białystok, s. 13-27. 
Jurgielaniec A., 2011, Partnerstwo Publiczno-Prywatne, CUS, ARAW, Wrocław.

Kaczmarek S., 2001, Rewitalizacja terenów poprzemysłowych: nowy wymiar w rozwoju miast, Wydawnictwo UŁ, Łódź.

Kaczmarek T., 2010, Proces integracji metropolitalnej - „od dołu” i „od góry”, [w:] A. Lutrzykowski, R. Gawłowski (red.), Metropolie - wyzwanie polskiej polityki miejskiej, Wyd. Adam Marszałek, Toruń, s. 45-61.

Kaczmarek T., 2012, Integracja zarządzania w Aglomeracji Poznańskiej, prezentacja na seminarium, Łódź.

Kaczmarek T., Mikuła Ł., 2007, Ustroje terytorialno-administracyjne obszarów metropolitalnych w Europie, Wydawnictwo Naukowe Bogucki, Poznań.

Kamal-Chaoui L., 2003, Metropolitan Governance in OECD Countries, OECD.

Kamal-Chaoui L., Leman E., Rufei Z., 2009, Urban trends and policy in China, „OECD Regional Development Working Papers", s. 64, http://www.oecd.org/dataoecd/ 28/21/42607972.pdf. 1.08.2011

Kamińska K., Mrozowska S., Piwnicki G., 2009, Państwa-regiony-świat w kształtującej się rzeczywistości globalnej, Wydawnictwo Uniwersytetu Gdańskiego, Gdańsk.

Kampen M. H. A. van, Naerssen A. L. van, 2008, Globalisation and Urban Governance in Two Asian Cities: Pune (India) and Cebu (The Philippines), „European Planning Studies", no 16(7), s. 941-954.

Kantor P., 2006, Regionalism and Reform; A Comparative Perspective on Dutch Urban Politics, „Urban Affairs Review”, vol. 41, No 6, s. 800-829.

Karta Lipska w sprawie Europejskich Miast Zrównoważonych, 2007, http://www. izbaarchitektow.pl/pliki/karta_lipska_16.02.2007_projekt.pdf.

Kast F. E., Rosenzweig J. E., 1970, Organizationa and Management, McGraw-Hill.

Katus J., 2002, Transformacja, globalizacja i europejska integracja, [w:] ESVA Polska, Europejskie Sympozjum Stowarzyszeń Dobrowolnych, Globalizacja a rozwój regionalny, Wyższa Szkoła Hotelarstwa i Turystyki, Częstochowa.

Katz B., Allen K., 1999, Help wanted: connecting inner-city job seekers with suburban jobs, "Brookings Review", no 17(4).

Kaźmierczak T. (red.), 2008, W poszukiwaniu strategii pobudzania oddolnego rozwoju społeczności wiejskich, Instytut Spraw Publicznych, Warszawa.

Kearns A., Paddison R., 2000, New Challenges for Urban Governance, "Urban Studies", vol. 37, no 5-6, s. 845-850.

Keating M., 1991. Comparative urban politics. Edward Elgar, Aldershot.

Keil R., 1998, Globalization makes states: perspectives of local governance in the age of the world city, „Review of International Political Economy”, vol. 5 issue 4, s. 616-646. 
Keller D. A., 2009, Switzerland and Zurich, Konferencja METREX, Wrocław.

Kelling J. (red.), 2011, Urban-rural relationships in metropolitan areas of influence. Best practice examples of metropolitan-rural cooperation, METREX.

Keohane R. O, Nye J. S., 2000, Introduction, [w:] Nye J. S. Jr., Donahue J. D. (red.), Governance in a Globalizing World, Brookings Institutional Press, Washington.

Kettl D. F., 2000, The Global Public Management Revolution. A Report on the Transformation of Governance, Brooklin Institution Press, Washington.

Kickert W. J. M., 1997, Public governance in the Netherlands: An alternative to AngloAmerican "Managerialism”, „Public Administration”, vol. 75.

Kickert W. J. M., 2002, Public governance in small continental European states, „International Journal of Public Administration”, No 12.

Kickert W. J. M., Klijn E. H., Koppenjan J. F. M. (red.), 1997, Managing Complex Networks, Sage, London

Kickert W., Koppenjan J. 1997, Public Management and Network Management, [w:] W. J. M. Kickert, E. H. Klijn, J. F. M. Koppenjan (red.), Managing Complex Networks, Sage, London, s. 35-61.

Kieżun W., 2002, Polski dorobek teoretyczny zarzq̨dzania publicznego „,Współczesne Zarządzanie", nr 4.

Kieżun W., 2004, 0 kosztach administracji, „MBA”, nr 1.

Klasik A., 1998, Rola metropolii w rozwoju regionalnym, [w:] J. Purchla (red.), Metropolitalne funkcje Krakowa, MCK, Kraków, s. 39-46.

Klasik A., Kuźnik F. (red.), 2001, Zarzqdzanie strategiczne rozwojem lokalnym i regionalnym, Wydawnictwo Akademii Ekonomicznej w Katowicach, Katowice.

Klausen J. E., Swianiewicz, P. 2007, Cities in city regions: governing the diversity, Faculty of Geography and Regional Studies, UW, Warszawa.

Klein J. L., Tremblay D. G., 2010, Social Actors and Their Role in Metropolitan Governance in Montreal: Towards an Inclusive Coalition?, „GeoJournal”, No 75 (6), s. 567-579.

Klimczuk A., 2009, Kapitał społeczny Polaków a rozwój społeczno-ekonomiczny, http://nbn-resolving.de/urn:nbn:de:0168-ssoar-314337.

Klimek P., 2012, Stowarzyszenie czy zwiq̨zek? Co samorzadom opłaca się bardziej?, „Finanse Komunalne”, nr 5, s. 13-20.

Knieling J., Kuerschner J., 2011, Territorial cohesion by supra-regional urban-rural partnerships. Exploration of different forms of cooperation between metropolitan cores and peripheral regions, the cases of the city of Amsterdam and the metropolitan region of Hamburg, [w:] Contested Regions: Territorial Politics and Policy, Regional Studies Association, Seaford. 
Knox P. L., 1995, World cities and the organization of global space, [w:] R. J. Johnston, P. J. Taylor, M. J. Watts (red.), Geographies of Global Change: Remapping the World in the Late Twentieth Century, Blackwell, Oxford, s. 232-247.

Knox P. L., Taylor P. J. (red.), 1995, World Cities in a World-System, Cambridge University Press.

Kobrin S. J., 1997, The architecture of globalization: state sovereignty in a networked global economy, [w:] Dunning J. H., Governments, Globalization and International Business, Clarendon Press, Oxford, s. 147-148.

Kobrin S. J., 2009, Globalization, transnational corporations and the future of global governance, [w:] Scherer A. G., Palazzo G. (red.), Handbook of Research on Global Corporate Citizenship, Edward Elgar, Cheltenham.

Kogucik J., Związki i porozumienia międzygminne - korzyści ze współpracy, http:// samorzad.infor.pl/drukowanie/387816.

Kohler-Koch B., Eising R. (red.), 1999, The Transformation of Governance in the European Union, Routledge.

Kołodziejski J., Parteka T., 2000, Perspektywy rozwoju metropolii Trójmiasta w XXI wieku, [w:] A. Kukliński, J. Kołodziejski, T. Markowski, W.Dziemianowicz (red.), Globalizacja polskich metropolii, EUROREG, Warszawa, s. 160-170.

Komisja Europejska, 2010, Drugie sprawozdanie o stanie miast europejskich, RWI, DIFU, NEA Transport Research and Training i PRAC, Bruksela.

Komorowski J., 2000, Współczesne uwarunkowania gospodarczo-przestrzenne internacjonalizacji miast polskich, „Zeszyty Naukowe Akademii Ekonomicznej w Poznaniu", Seria 2, Prace Habilitacyjne, z. 157.

Komunikat Komisji do Parlamentu Europejskiego, Rady, Europejskiego Komitetu Ekonomiczno-Społecznego oraz Komitetu Regionów z dnia 19 listopada 2009 r. w sprawie zwiększania znaczenia partnerstw publiczno-prywatnych, http://www. ppp.gov.pl/Poradnik_inwestora/Documents/Komunikat_KE_ws._wspierania_PPP_ 210111.pdf, 31.12.2012

Konferencja Zarządzanie rozwojem obszarów metropolitalnych, 2012, 17-19 maja, Gdynia.

Konstytucja Rzeczypospolitej Polskiej z dnia 2 kwietnia 1997 r., DzU 1997, nr 78, poz. 483.

Kooiman J., 2003, Governing as Governance, Sage Publications Ltd, London.

Kooiman J., 2008, (Współ)rzq̨dzenie socjopolityczne, „Zarządzanie Publiczne”, nr 3 (5), s. 138-151.

Kopaliński W., 2000, Słownik wyrazów obcych i zwrotów obcojęzycznych, Świat Książki, Warszawa. 
Korcelli-Olejniczak, E., 2004, Funkcje metropolitalne Berlina $i$ Warszawy w latach 1990-2002: współzależność pozycji w systemie miast Europy Środkowej, PAN. IGiPZ.

Korol J., Szczuciński P., 2006, Przestrzenne zróżnicowanie bezpośrednich inwestycji zagranicznych $w$ Polsce i ich wpływ na regionalny rozwój zrównoważony, „Zeszyty Naukowe Uniwersytetu Szczecińskiego", nr 450, s. 307-323.

Kosiński L., 1958, Zagadnienia struktury funkcjonalnej miast polskich, „Przegląd Geograficzny IG PAN", t. XXX, z. 2.

Kożuch B., 2003, Zarządzanie publiczne w zarysie, Fundacja Współczesne Zarządzanie, Białystok.

Kożuch B., 2004a, Zarządzanie publiczne, Wydawnictwo Placet, Warszawa.

Kożuch B., 2004b, Zarzq̨dzanie publiczne $w$ teorii i praktyce polskich organizacji, Wydawnictwo Placet, Warszawa.

Kożuch B., 2005, Kooperatywne zachowania organizacji publicznych, [w:] B. Plawgo, W. Zaremba (red.), Partnerskie współdziałanie w sektorze publicznym i prywatnym, Fundacja Współczesne Zarządzanie, Białystok.

Krugman P., Venables A., 1995, Globalization and the inequality of nations, „Quarterly Journal of Economics", No 110, s. 857-880.

Krzeczunowicz A., 2006, Globalizacja: geneza, zasięg, konsekwencje, Wydawnictwo Akademii Polonijnej „Edukator”, Częstochowa.

Kübler D., Schenkel W., Leresche J.-P., 2003, Bright Lights, Big Cities? Metropolisation, Intergovernmental Relations, and the New Federal Urban Policy in Switzerland, „Swiss Political Science Review”, No 9, s. 261-282.

Kübler D., Schwab B., 2007, New regionalism in five Swiss metropolitan areas: An assessment of inclusiveness, deliberation and democratic accountability, „European Journal of Political Research", No 46, s 473-502.

Kukliński A., 2000, Metropolia Warszawy wobec wyzwań procesów globalizacji, [w:] Kukliński A., Kołodziejski J., Markowski T., Dziemianowicz W. (red.), Globalizacja polskich metropolii, EUROREG, Warszawa, Oficyna wydawnicza „Rewasz”.

Kukliński, A. Kołodziejski J., Markowski T., Dziemianowicz W., 2000, Globalizacja polskich metropolii, EUROREG, Warszawa, Oficyna wydawnicza „Rewasz”.

Kunzmann K. R., 1998, World City Regions in Europe: Structural Change and Future Challenges, [w:] F. Lo, Y. Yeung (red.), Globalization and the World of Large Cities, United Nations University Press, Tokyo, New, York, Paris.

Kuraś B., 2008, Marszałkowie nie chca metropolii, http://wyborcza.pl/1,76842, 5875499,Marszalkowie_nie_chca_metropolii.html\#ixzz2FVNFaLxu, 9.01.2012.

Kuźniar R., 2000, Globalizacja, geopolityka, polityka zagraniczna, „Sprawy Międzynarodowe", $\mathrm{nr}$ 1, s. 9-16. 
Kuźniar R., 2003, Globalizacja i porządek międzynarodowy, „Sprawy Międzynarodowe", nr 1.

Kuźnik F. (red.), Studia regionalne w Polsce. Teoria, polityka, projektowanie, Wydawnictwo Akademii Ekonomicznej w Katowicach, Katowice.

Lackowska M., 2009, Zarządzanie obszarami metropolitalnymi w Polsce. Między dobrowolnościq a imperatywem, Wyd. UW, Warszawa.

Lafferty W. M. (red.), 2004, Governance For Sustainable Development. The Challenge of Adapting Form to Function, Edward Elgar Publishing.

Larsson G., 2006, Spatial Planning Systems in Western Europe: An Overview, IOS Press, Amsterdam.

Lasocka D., 2005, Samorządy w Unii Europejskiej, UKIE, Warszawa.

Lauder K. H. (red.), 2004, Public governance in the age of globalization, Ashgate, London.

Lauria M. (red.), 1996, Reconstructing urban regime theory: regulating urban politics in a global economy, Sage, Thousand Oaks.

Le Gales P., 2002, European Cities: Social Conflicts and Governance, Oxford University Press, Oxford

Lefevre Ch., 2003, Paris-ile-de-France region, [w:] W. Salet, A. Thornley, A.Kreukels (red.), Metropolitan Governance and Spatial Planning, Spon Press, London-New York.

Legeby F., Engström C-J., 2002, A Case Study of the Stockholm-Mälar Region, [w:] C. Bengs (red.), Facing ESPON, „Nordregio Report”, nr 1.

Legge 5 maggio 2009, n. 42, Delega al Governo in materia di federalismo fiscale, in attuazione dell'articolo 119 della Costituzione.

Legge 7 agosto 2012, n. 135, Gazzetta Ufficiale N. 189 del 14 Agosto 2012.

Lei n.o 10/2003 de 13 de Maio, Estabelece o regime de criação, o quadro de atribuições e competências das áreas metropolitanas e o funcionamento dos seus órgãos, Diário da República.

Lei n. ${ }^{\circ} 44 / 91$ de 2 de Agosto Áreas metropolitanas de Lisboa e do Porto, „Diário da República".

Lei n. ${ }^{\circ}$ 46/2008 de 27 de Agosto, Estabelece o regime jurídico das áreas metropolitanas de Lisboa e do Porto, Diário da República, 1. - série - № 165-27, http://www. aml.pt/web/index.php?\&iLevel1=gaml\&iLevel2=legislacao\&iContent=index.html.

Lei n.ํ4/1991 de 2 de Agosto, Áreas metropolitanas de Lisboa e do Porto, Diário da República. 
Lendzion J., 2004, Znaczenie obszarów metropolitalnych i ich otoczenia oraz współczesnych procesów metropolizacyjnych $w$ kształtowaniu polityki regionalnej Państwa, Ekspertyza wykonana na zlecenie Departamentu Polityki Regionalnej w MGiP, Gdynia.

Levine M. A., 1994, The transformation of urban politics in France: The roots of growth politics and urban regimes, „Urban Affairs Quarterly”, No 29, s. 383-410.

Levitt T., 1983, The globalization of markets, „Harvard Business Review”, May-June, s. 92-93.

Liberska B. (red.), 2002, Globalizacja. Mechanizmy i wyzwania, Polskie Wydawnictwo Ekonomiczne, Warszawa.

Lim G.C., 2005, Globalization, spatial allocation of resources and spatial impacts: A conceptual framework, [w:] H. W. Richardson, C.-H. C. Bae (red.), Globalization and urban development, Springer, New York, s. 13-28.

Lin N., 2001, Social Capital: A Theory of Social Structure and Action, Cambridge University Press, Cambridge.

Lis K., Sterniczuk H., 2005, Nadzór korporacyjny, Oficyna Ekonomiczna, Kraków.

Lisiński M., 2004, Metody planowania strategicznego, PWE, Warszawa.

Lisowski A., 2005, Janusowe oblicze suburbanizacji, [w:] Jażdżewska I. (red.), Współczesne procesy urbanizacji $i$ ich skutki, XVIII Konwersatorium wiedzy o mieście, Łódzkie Towarzystwo Naukowe, Łódź, s. 91-100.

Llei de l'Àrea Metropolitana de Barcelona, 03.08.2010.

Lo F., Yeung Y. (red.), 1998, Globalization and the world of large cities, United Nations University Press, Tokyo, New York, Paris.

Logan J., Molotch H., 1987, Urban Fortunes: The Political Economy of Place, University of California Press, Berkeley, Los Angeles.

Lovan W. R., Murray M., Shaffer R., 2004, Participatory Governance. Planning, Conflict Mediation and Public Decision-Making in Civil Society, Ashgate, Aldershof Burlington.

Lowery D., 2000, A Transactions Costs Model of Metropolitan Governance: Allocation versus Redistribution in Urban America, „Journal of Public Administration Research and Theory", No 10 (1), s. 49-78.

Lutrzykowski A., 2010, Metropolizacja - żywiołowy proces czy przedmiot polityki miejskiej, [w:] A. Lutrzykowski, R. Gawłowski (red.), Metropolie - wyzwanie polskiej polityki miejskiej, Wyd. Adam Marszałek, Toruń, s. 5-14.

Lutrzykowski A., Gawłowski R. (red.), 2010, Metropolie - wyzwanie polskiej polityki miejskiej, Wyd. Adam Marszałek, Toruń

Lyall C., Tait J., 2005, New Modes of Governance. Developing an Integrated Policy Approach to Science, Technology, Risk and the Environment, Ashgate, Aldershof. 
Ładysz I., 2009, Konkurencyjność obszarów metropolitalnych w Polsce, Wydawnictwo CeDeWu, Warszawa 2009.

MAC, 2012, Wyniki konsultacji dot. Zielonej księgi obszarów metropolitalnych, Warszawa.

MAC, 2013, Biała księga obszarów metropolitalnych, Warszawa.

Madanipour A., 1998, Social exclusion and space, [w:] A. Madanipour, G. Cars, J. Allen (red.), Social Exclusion in European Cities: Processes, Experiences and Responses, Jessica Kingsley, London, s. 75-94.

Magone J. M., 2003, Regional Institutions and Governance in the European Union, Greenwood Publishing Group.

Maik W., 2003, Pojęcie metropolii a problem badania funkcji metropolitalnych, [w:] I. Jażdżewska (red.), Funkcje metropolitalne i ich rola $w$ organizacji przestrzeni, XVI Konwersatorium wiedzy o mieście, Łódzkie Towarzystwo Naukowe, Łódź, s. 9-17.

Maik W., 2005, Procesy urbanizacji $w$ dobie globalizacji i społeczeństwa informacyjnego, [w:] I. Jażdżewska (red.), Współczesne procesy urbanizacji i ich skutki, XVIII Konwersatorium wiedzy o mieście, Łódzkie Towarzystwo Naukowe, Łódź.

Majer A., 2010, Socjologia i przestrzeń miejska, Wydawnictwo Naukowe PWN, Warszawa.

Makieła Z. (red.), 2009, Potencjalne metropolie ze szczególnym uwzględnieniem Polski Wschodniej, „Studia KPZK PAN”, t. CXXV, Warszawa.

Maldonado J. L., 2003, Metropolitan Government in Madrid, [w:] W. Salet, A. Kreukels, A. Thornley (red.), Metropolitan Governance and Spatial Planning, Spon Press, London-New York, s. 359-374.

Maliszowa B., 1981, Hierarchia ośrodków usługowych i ich program $w$ świetle podziałów terytorialnych kraju, „Biuletyn KPZK PAN”, z. 112.

Marin B., Mayentz R. (red.), 1991, Policy Networks: Empirical Evidence and Theoretical Considerations, Westview Press, Colorado.

Markowski T., 1999, Zarządzanie rozwojem miast, Wydawnictwo Naukowe PWN, Warszawa.

Markowski T., 2000, Globalizacja i metropolie, teoria i rzeczywistość - przypadek aglomeracji łódzkiej, [w:] Domański R. (red.), Nowe problemy rozwoju wielkich miast i regionów, „Biuletyn KPZK PAN”, z. 192, s. 125-140.

Markowski T., 2005, Przedmiotowa i podmiotowa konkurencyjność regionów, [w:] T. Czyż, H. Rogacki (red.), Współczesne problemy i koncepcje teoretyczne badań przestrzenno-ekonomicznych, Biuletyn KPZK PAN, z. 219, Warszawa, s. 24-37.

Markowski T., 2010, Zarządzanie metropolią przyszłości i jej wyróżniki - Modele zarządzania, Panel dyskusyjny - Modele rozwoju Pomorza, 4 marca, Gdańsk. 
Markowski T., 2011, Funkcjonowanie gospodarki przestrzennej - założenia budowy modelu zintegrowanego planowania i zarządzania rozwojem, [w:] T. Markowski, P. Żuber (red.), System planowania przestrzennego i jego rola $w$ strategicznym zarzq̨dzaniu rozwojem kraju, t. CXXXIV, KPZK PAN, Warszawa.

Markowski T., 2012, Problemy zarządzania w obszarach funkcjonalnych, Konferencja „Zarządzanie rozwojem obszarów metropolitalnych”, 17-19 maja, Gdynia.

Markowski T., Kaczmarek S., Olenderek J. (red.), Rewitalizacja terenów poporzemysłowych $w$ Łodzi, Studia KPZK PAN, t. CXXXII.

Markowski T., Kot J., Stawasz D., 2000, Przestrzenne aspekty globalizacji w Polsce, [w:] Kukliński A., Kołodziejski J., Markowski T., Dziemianowicz W. (red.), Globalizacja polskich metropolii, EUROREG, Warszawa, Oficyna wydawnicza „Rewasz”.

Markowski T., Marszał T., 2006a, Funkcje metropolitalne pięciu stolic województw wschodnich, www.mrr.gov.pl.

Markowski T., Marszał T., 2006b, Metropolie. Obszary metropolitalne. Metropolizacja. Problemy i pojęcia podstawowe, KPZK PAN, Warszawa

Markowski T., Stawasz D. (red.), 2007, Rewitalizacja a rozwój funkcji metropolitalnych miasta Łodzi, Wydawnictwo UŁ, Łódź.

Markowski T., Żuber P. (red.), 2011, System planowania przestrzennego i jego rola w strategicznym zarządzaniu rozwojem kraju, t. CXXXIV, KPZK PAN, Warszawa.

Marks G., Hooghe L., 2001, Multi-Level Governance and European Integration, Rowman \& Littlefield Pub Inc.

Marsh D., Rhodes R. A. W., 1992, Policy Networks in British Government, Clarendon, Oxford.

Marszał T., 2008, Rola polskich aglomeracji wobec wyzwań Strategii Lizbońskiej, Komitet Przestrzennego Zagospodarowania Kraju PAN, Warszawa.

Massey D. S., Gross A. B., Shibuya K., 1994, Migration, Segregation, and the Geographic Concentration of Poverty, „American Sociological Review”, No 59 (3), s. $425-45$.

Matczak A., 1992, Zmiany w strukturze funkcjonalnej miast Polski w latach 19731983, „Acta Universitas Lodzensis”, Folia Geographica, 17.

Matthews R. C. 0., 1986, The Economics of Institutions and the Sources of Growth, „The Economic Journal", Vol. 96, No. 384.

Mattoon R. H., 1995, Can alternative form of governance help metropolitan areas?, „Economic Perspectives”, vol. 19, issue 6.

Mączyńska E., 2003, Gospodarka i przedsiębiorstwa w warunkach globalnej zmiany, [w:] K. Jędralska, L. Żabiński (red.), Gospodarka w obliczu globalizacji. Przegląd wybranych zagadnień, PTE, Katowice. 
Mc Ginnis M. D. (red.), 1999, Polycentricity and Local Public Economies, University of Michigan Press, Ann Arbor.

McGrew A., 2009, Globalization and Global Politics, [w:] Baylis J., Smith S., Owens P. (red.) 2009, The Globalization of World Politics. An Introduction to International Relations, Oxford University Press, Oxford.

McLaverty P., 2002, Public Participation and Innovations in Community Governance, Ashgate.

McMahon, Patrice., 2004. Globalization and Global Governance: The implications for ethnopolitical conflict in Eastern Europe. Presented at the annual meeting of the International Studies Association 2004, Montreal, Quebec, Canada, Mar 17, 2004. http://www.allacademic.com/meta/p72488_index.html

Mendel T., 2000, Próba określenia wpływu poszczególnych grup interesów (stakeholders) na zarządzanie przedsiębiorstwami, „Zeszyty Naukowe Akademii Ekonomicznej w Poznaniu", nr 2.

Mendes C., Morgado S., 2008, Lisbon Metropolitan Area: centralities, urban growth and policies, $44^{\text {th }}$ ISOCARP Congress.

METREX, 2004, The Revised METREX Practice Benchmark of Effective Metropolitan Spatial Planning Practice. Metropolitan governance and the development of effective Integrated Metropolitan Strategies, http://www.eurometrex.org/Docs/ InterMETREX/Discussion/EN_Metro_Gov_Note2.pdf.

METREX, 2010, Intra-metropolitan polycentricity in practice - Reflections, challenges and conclusions from 12 European metropolitan areas, Final report of the METREX - ExPRET Group on Intra-Metropolitan Polycentricity, Glasgow.

Metropolia ciagle tylko na papierze, 2007, http://wiadomosci.gazeta.pl/kraj/1,343 09,4749957.html, 19.12.22012.

Metropolie będq oddolne, 2008, http://wyborcza.pl/1,85996,5430243,Metropolie_ beda_oddolne.html, 19.12.2008.

Miasto z marszałkiem kłóci się o wrocławskq metropolię, 2010, http://m.wroc law.gazeta.pl/wroclaw/1,106542,8645769.html, 26.01.2012.

Mieszkowska K., 2005, Zarządzanie obszarami metropolitalnymi - doświadczenia i nowe możliwości, [w:] T. Markowski (red.), Planowanie i zarządzanie w obszarach metropolitalnych, Biuletyn KPZK PAN, z. 221, s. 35-39.

Mikołajewicz Z. (red.), Uwarunkowania i strategie rozwoju regionalnego $w$ procesach integracji europejskiej, Wydawnictwo Uniwersytetu Opolskiego, Opole.

Mikuła Ł, 2009, Struktury organizacyjne planowania $i$ zarządzania $w$ aglomeracji poznańskiej, prezentacja na konferencji Miasto w aglomeracji - zarządzanie przestrzenią, Katowice.

Miller D. Y., Lee J. H., 2011, Making Sense of Metropolitan Regions: A Dimensional Approach to Regional Governance, „Publius”, vol. 41, No 1, s. 126-145. 
Miller D., 2002, The Regional Governing of Metropolitan America, Westview Press, Boulder.

Milward H. B., Wamsley G. L., 1985, Policy Subsystems, Networks and the Tools of Public Management, [w:] K. Hanf, Th. A. J. Toonen, Policy Implementation in Federal and Unitary Systems, Martinus Nijhoff Publishers, Dordrecht.

Mironowicz I, 2007, Czy potrzebne jest nam prawo aglomeracyjne?, „Urbanista”, nr 7.

Mitchell R. K., Agle B. R., Wood D. J., 1997, Toward a Theory of Stakeholder Identification and Salience: Defining the Principle of Who and What Really Counts, „Academy of Management Review”, vol. 22, No 4, s. 853-886.

Mitchell-Weaver C., Miller D., Deal jr, R., 2000, Multilevel Governance and Metropolitan Regionalism in the USA, „Urban Studies”, vol. 37, No 5/6.

Mitlin D., 2004, Reshaping Local Democracy, „Environment and Urbanization”, No 16(1), s. 3-8.

Mittelman J. (red.), 1996, Globalization: Critical Reflections, Lynne Rienner Publishers, Boulder.

Mollenkopf, J., Castells M., 1991, Dual city, Russell Sage, New York.

Moloch H., 1976, The City as a Growth Machine: Toward a Political Economy of Place, „The American Journal of Sociology', vol. 82, No 2, s. 309-332.

Monks R. A. G., Minow N., 2003, Corporate Governance, Blackwell Publishers, Cambridge.

Mooney G., Pile S., Brook C., 1999, On orderings and the city, [w:] S. Pile, C. Brook, G. Mooney (red.), Unruly Cities?, Routledge, Londyn, s. 345-362.

Morgado S., 2007, Developing Metropolitan Lisbon, 43 ${ }^{\text {rd }}$ ISOCARP Congress.

Morgado S., 2012, Lisbon experiences with metropolitan planning and management Konferencja „Zarządzanie rozwojem obszarów metropolitalnych”, 17-19 maja, Gdynia.

Moritz K., 2011, Powstał Gdański Obszar Metropolitalny. „Równi i solidarni”, http:// www.trojmiasto.pl/wiadomosci/Powstal-Gdanski-Obszar-Metropolitalny-Rownii-solidarni-n51425.html, 1.12.2012.

Mossberger K., Stoker G., 2001, The Evolution of Urban Regime Theory: The challenge of Conceptualisation, „Urban Affairs Review”, vol. 36, No 6.

Moszoro M., 2005, Partnerstwo publiczno-prywatne $w$ monopolach naturalnych w sferze użyteczności publicznej, Oficyna Wydawnicza SGH, Warszawa.

MRR, 2008, Zwiq̨zki międzygminne we Francji, Warszawa.

MRR, 2009, Założenia systemu zarządzania rozwojem Polski, Warszawa. 
MRR, 2010a, Krajowa Strategia Rozwoju Regionalnego 2010-2020: Regiony, Miasta, Obszary Wiejskie, Warszawa.

MRR, 2010b, Plan uporządkowania strategii rozwoju, Warszawa.

MRR, 2012a, Koncepcja Przestrzennego Zagospodarowania Kraju 2030, Warszawa.

MRR, 2012b, Założenia Krajowej Polityki Miejskiej do roku 2020, Projekt, 20 lipca, Warszawa.

MSWiA, 2007, Założenia do projektu ustawy metropolitalnej, projekt z dnia 4 lipca 2007 r., Warszawa.

MSWiA, 2007, Założenia do projektu ustawy metropolitalnej, projekt z dnia 4 lipca, Warszawa.

Murie A., Beazley M., Carter D., 2003, The Birmingham case, [w:] W. Salet, A. Kreukels, A.Thornley (red.), Metropolitan Governance and Spatial Planning, Spon Press, London-New York, s. 57-76.

Myrdal G., 1957, Economic Theory and Underdeveloped Regions, Duckworth, London.

Narayan D., 1999, Bonds and Bridges: Social capital and Poverty, World Bank, Washington.

Naschold F., von Otter C., 1996, Public sector transformation: rethinking markets and hierarchies in government, John Benjamins Publishing. Co., AmsterdamPhiladelphia.

National Contribution - Portugal, www.coe.int/t/.../CompendiumPortugal_en.pdf.

Navarro C., 2006, Spanish metropolitan areas and the case of Madrid, http://www. vrm.ca/documents/Carmen_Navarro.pdf, 25.07.2012.

Navarro C., 2011, Metropolitanization of Spanish urban areas: trends, challenges and the special case of Madrid, „European Political Science”, 11 November, doi: 10.1057/eps.2011.43.

Nelson A. C., Duncan J. B., 1995, Growth Management Principles and Practices, Planners Press, Chicago.

Nesadurai H., 2002, Globalisation and Economic Regionalism: A Survey and Critique of the Literature, „CSGR Working Paper”, No 108/02, Centre for the Study of Globalisation and Regionalisation, University of Warwick.

Newman P., Thornley A., 2005, Planning World Cities: Globalization and Urban Politics, Palgrave, London.

Niemiec W., Benczes, I., 2009, The economic dimensions of global and regional governance, Wydawnictwo Adam Marszałek, Toruń.

Niziołek M., 2008, Problemy ustroju aglomeracji miejskich, Wolters Kluwer Polska, Warszawa. 
Niżnik J., 2006, Multilevel governance: patterns and degrees of political integration: the EU eastern enlargement challenge, IFiS Publishers.

Norris D. F., 2001a, Prospects for Regional Governance under the New Regionalism: Economic Imperatives versus Political Impediments, „Journal of Urban Affairs”, No 23 (5), s. 557-71.

Norris D. F., 2001b, Whither Metropolitan Governance?, "Urban Affairs Review”, vol. 36, No 4, s. 532-550.

North D. C., 1990, Institutions, Institutional Change, and Economic Performance, Cambridge University Press, New York.

North D. C., 1991, Institutions, „Journal of Economic Perspectives”, vol. 5, No 1, s. 97-112.

Norton A., 1991, Civil Society in the Middle Way, „IPA Review”, vol. 44, No 3, s. 50-54.

Noworól A., 1998, Instrumenty zarządzania rozwojem miasta, Instytut Gospodarki Przestrzennej i Komunalnej, Kraków.

Oakerson R. J., 1999, Governing Local Public Economies: Creating the Civic Metropolis, ICS Press, Oakland.

Oakerson R. J., 2004, The study of metropolitan governance, [w:] R. C. Feiock (red.), Metropolitan governance. Conflict, competition and cooperation, Georgtown University Press, Waszyngton.

Oates W. E., 1972, Fiscal federalism, Harcourt Brace Jovanovich, New York.

Oduwaye L., 2006, Effects of Globalization on Cities in Developing Countries, "Journal of Sociological Sciences", No 12(3), s. 199-205.

OECD, 1993, Managing with Market-Type Mechanisms, PUMA, Paris.

OECD, 1999, Best practices in local development, Paris: LEED Notebook 27, OECD, Paris.

OECD, 2000, The reform of metropolitan governance, „Policy Brief”, OECD Observer, October

OECD, 2001a, OECD Territorial Reviews: Italy, Paris.

OECD, 2001b, Cities for Citizens: Improving Metropolitan Governance, OECD, Paris

OECD, 2001c, Territorial Outlook, Paris.

OECD, 2003, Managing Decentralisation: A New Role for Labour Market Policy, OECD, Paris.

OECD, 2004, OECD Principles of Corporate Governance, Paris.

OECD, 2005a, Building Competitive Regions: Strategies and Governance, OECD Publishing.

OECD, 2005b, Local Governance and the Drivers of Growth, Paris. 
OECD, 2006a, OECD Territorial Reviews: Competitive Cities in the Global Economy, OECD Publisher, Paris.

OECD, 2006b, OECD Territorial Reviews: France, Paris.

OECD, 2006c, OECD Territorial Reviews: Milan, Italy, Paris

OECD, 2007a, OECD Territorial Reviews: Competitive Cities, Paris.

OECD, 2007b, OECD Territorial Reviews: Randstad Holland, Netherlands.

OECD, 2007c, OECD Territorial Reviews: Madrid, Spain, Paris.

OECD, 2008a, Territorial Reviews: Poland, Paris.

OECD, 2008b, OECD Territorial Reviews: Portugal, Paris.

OECD, 2009, OECD Territorial Reviews: Copenhagen, Denmark, Paris.

OECD, 2010, OECD Territorial Reviews: Sweden, Paris.

OECD, 2011, OECD Territorial Reviews: Switzerland, OECD Publishing.

OECD, 2012, Definition of Functional Urban Areas (FUA) for the OECD metropolitan database, Paris.

Ohmae K., 2008, The End Of The Nation State. The rise of Regional Economies, HarperCollins, London.

Oliver J. E., 2001, Democracy in suburbia, Princeton University Press, Princeton.

Olsson A. M., Cars G., 2011, Polycentric spatial development: institutional challenges to intermunicipal cooperation, „Jahrbuch für Regionalwissenschaft”, t. 31, nr 2.

Olszewski E., 2009, Globalizacja a państwo i polityka, [w:] Kamińska K., Mrozowska S., Piwnicki G., Państwa-regiony-świat w kształtującej się rzeczywistości globalnej, Wydawnictwo Uniwersytetu Gdańskiego, Gdańsk.

Oner A.C., Mitsova D., Prosperi D., Vos J., 2010, Knowledge Globalization in Urban Studies and Planning: A Network Analysis of International Co-authorships, „Journal of Knowledge Globalization", vol. 3 (1).

Osborne D., Gaebler T. 1994; Rzqqdzić inaczej, Media Rodzina, Poznań.

Ossowicz T., 2005, Planowanie wrocławskiego obszaru metropolitalnego, referat na konferencji KPZK pt. Planowanie i zarządzanie w obszarach metropolitalnych, Łódź.

Ostrom E., 1983, A public choice approach to metropolitan institutions: structures, incentives and performance, „Social Science Journal”, No 20(3), s. 79-96.

Ostrom E., 1987, A Behavioral Approach to the Rational Choice Theory of Collective Action, „American Political Science Review”, vol. 92, No 1. 
Ostrom E., Parks R. B., 1999, Neither Gargantua nor the land of lilliputs, [w:] McGinnis (red.), Polycentricity and local public economies, University of Michigan Press, Ann Arbor, s. 284-305.

Ostrom V., 1972, Polycentricity, The American Political Science Association, Washington.

Ostrom V., 1989, The Intellectual Crisis in American Public Administration, University Alabama Press, Tuscaloosa.

Ostrom V., 1997, The Meaning of Democracy and the Vulnerability of Democracy, University of Michigan Press, Ann Arbor.

Ostrom V., Ostrom E., 1971, Public Choice: A Different Approach to Public Administration, „Public Administration Review”, No 31 (2), s. 203-16.

Ostrom V., Tiebaut Ch. M., Warren R., 1961, The Organization of Government in Metropolitan Areas: A theoretical Inquiry, "American Political Science Review", no 2, s. 831-842.

Owsiak S., 2005, Finanse publiczne. Teoria i praktyka, Wydawnictwo Naukowe PWN, Warszawa.

Painter J., 1997, Regulation, regime and practice in urban politics,[w:] M. Lauria (red.), Reconstructing urban regime theory: regulating urban politics in a global economy, Sage, Thousand Oaks, s. 122-43.

Park J. W., 2003, International Understanding of Local Governance and The Present Conditions and Problems of Local Governance in Busan, http://www.oecd.org/ dataoecd/59/38/6101980.pdf.

Park J.-W., International understanding of local governance and the present conditions and problems of local governance in Busan, Department of Public Administration, Silla University, http://www.oecd.org/dataoecd/59/38/6101980.pdf, 12.12.2011.

Parks R. B., Oakerson R. J., 1993, Comparative Metropolitan Organization: Service Production and Governance Structures in St. Louis (MO) and Allegheny County (PA), „Publius”, No 23 (1), s. 19 - 39.

Parks R. B., Oakerson R. J., 2000, Regionalism, Localism, and Metropolitan Governance: Suggestions from the Research Program on Local Public Economies, "State and Local Government Review", no 32, s. 169-179.

Parrado Diez S., 2006, Creating Economies of Scale, Promoting Inter Municipal Cooperation, SIGMA Conference: Public Administration Reform and Territorial Organisation: Empowering Local Governments in Ankara, 28 February - 1 March.

Parrado-Diez S., 2006, Creating Economies of Scale, Promoting Inter Municipal Cooperation, SIGMA Conference: Public Administration Reform and Territorial Organisation: Empowering Local Governments in Ankara, 28 February - 1 March. 
Parry G., Moyser G., Day N., 1992, Political Participation and Democracy in Britain, Cambridge University Press, Cambridge.

Parteka T., 2000a, Planowanie strategiczne $w$ równoważeniu struktur regionalnych, „Studia KPZK PAN”, t. 108.

Parteka T., 2000b, Wpływ globalizacji na zmiany struktury przestrzennej handlu, usług i transportu Trójmiasta, [w:] A. Kukliński, J. Kołodziejski, T. Markowski, W. Dziemianowicz (red.), Globalizacja polskich metropolii, EUROREG, Warszawa, Oficyna wydawnicza „Rewasz”, s. 160-170.

Parysek J., 2000, Polskie metropolie jako ogniwa procesu transformacji i przemian przestrzenno-strukturalnych (na tle metropolii europejskich), [w:] Z. Mikołajewicz (red.), Uwarunkowania i strategie rozwoju regionalnego w procesach integracji europejskiej, Wydawnictwo Uniwersytetu Opolskiego, Opole, s. 361-379.

Parysek J., 2003, Metropolie: metropolitalne funkcje i struktury przestrzenne, [w:] I. Jażdżewska (red.), Funkcje metropolitalne i ich rola $w$ organizacji przestrzeni, XVI Konwersatorium wiedzy o mieście, Łódzkie Towarzystwo Naukowe, Łódź, s. 19-40.

Parysek J., 2005, Miasta polskie na przełomie XX i XXI wieku. Rozwój i przekształcenia strukturalne, Bogucki Wydawnictwo Naukowe, Poznań.

Parysek J., 2008, Urbanizacja i niektóre współczesne idee, koncepcje i modele planowania rozwoju miast, [w:] J. Słodczyk, M. Śmigielska (red.), Współczesne kierunki i wymiary procesów urbanizacji, Wydawnictwo Uniwersytetu Opolskiego, Opole, s. 11-26.

Parysek J., Mierzejewska L. 2005. Two stages in Postwar Urbanisation in Poland: From Socialist to Postmodern Urbanisation, [w:] Y. Murajama, G. Du (red.), Cities in Global Perspective: Diversity and Transition College of Tourism, Rikkyo University with IGU Urban Commision, Tokyo, s. 72-82

Pemberton J.-A., 2009, Sovereignty: Interpretations, Palgrave Macmillan, New York.

Pemberton S., 2011, Exploring the changing governance of London - the politics of state rescaling, scale periodization and local political strategy, [w:] Contested Regions: Territorial Politics and Policy, Regional Studies Association, Seaford, s. 84-85.

Pereira M., Carranca M. A., 2009, Governance in the Lisbon Metropolitan Area: between the ambition of reinforcing the international rank and the will for deeper internal territorial cohesion, City Futures Conference, Madryd.

Perry J. (red.) 1996; Handbook of Public Administration, Jossey-Bass Public Administration, San Francisco.

Peters B. G., 1998, Getting by With Some Help from Our Friends: Partnerships as Institutions, [w:] J. Pierre, (red.), Partnerships in Urban Governance: European and American Experiences, Macmillan, London. 
Peters B. G., Pierre J., 1998, Governance Without Government? Rethinking Public Administration, „Journal of Public Administration Research and Theory”, No 8, s. 223-243.

Phares D., 2004, Metropolitan Governance without Metropolitan Government?, Ashgate.

Pieprzny S., Ura E., Ura M., 2005, Umowy o partnerstwie publiczno-prywatnym jako czynnik efektywności i sprawności działań samorzadu terytorialnego, [w:] E. Ura (red.), Sprawność działania administracji samorzq̨dowej, SEAP-Uniwersytet Rzeszowski-WSzH-P, Rzeszów, s. 503-516.

Pierre J., 1999, Models of urban governance: The institutional dimension of urban politics, „Urban Affairs Review”, No 34 (3): 372-96.

Pierre J., 2005, Comparative urban governance-Uncovering complex causalities, „Urban Affairs Review”, no 40 (4), s. 446-62.

Pierre J., Peters B. G., 2001, Governance, politics and the state, Macmillan, London.

Pietrzyk I., 2000, Kontrakty państwa z regionami jako narzędzie polityki rozwoju regionalnego, [w:] Z. Mikołajewicz (red.), Uwarunkowania i strategie rozwoju regionalnego $w$ procesach integracji europejskiej, Wydawnictwo Uniwersytetu Opolskiego, Opole, s. 327-345.

Pla Estratègic Metropolità de Barcelona, 2010, Barcelona Vision 2020, Strategic Metropolitan Plan of Barcelona Association, Barcelona

Planning and Compulsory Purchase Act, 2004, http://www.legislation.gov.uk/ukpga/ 2004/5/contents.

Plawgo B., Zaremba W. (red.), 2005, Partnerskie współdziałanie w sektorze publicznym i prywatnym, Fundacja Współczesne Zarządzanie, Białystok

Polak E., 2003, Globalizam i lokalizm jako bieguny funkcjonowania współczesnej cywilizacji, [w:] M. Barański, M. Stolarczyk (red.), Władze lokalne i regionalne $w$ warunkach globalizacji, Wydawnictwo Uniwersytetu Śląskiego, Katowice.

Polak E., 2009, Globalizacja a zróżnicowanie społeczno-ekonomiczne, Difin, Warszawa.

Pollitt C., 1990, Managerialism and the Public Services: The Anglo-American Experience, Blackwell, Oxford.

Popławski M., 2008, Proces projektowania głównych założeń reformy samorządu terytorialnego w Danii z dnia 1 stycznia 2007 r., [w:] J. Marszałek-Kawa, A. Lutrzykowski (red.), Samorząd terytorialny $w$ Polsce $i w$ Europie, Wydawnictwo Adam Marszałek, Toruń, s. 245-270.

Porter M., 1990, The Competitive Advantage of Nations, Macmillan, Basingstoke.

Porter M., 1998, Clusters and the new economics of competition, "Harvard Business Review", November-December

Porter M., 2001a, Porter o konkurencji, PWE, Warszawa. 
Porter M., 2001b, Regions and the new economics of competition, [w:] A. J. Scott (red.), Global City-Regions: Trends, Theory, Policy, Oxford University Press, Oxford, s. 139-157.

Portes A., 1998, Social Capital: Its Origins and Applications in Modern Sociology, „Annual Review of Sociology”, vol. 24, s. 1-24.

Potoczek A., 2005a, Administracja publiczna $w$ procesie zarzadzania rozwojem lokalnym i regionalnym, [w:] Rutkowski J., Stawasz D. (red.), Zarządzanie rozwojem lokalnym, Fundacja Współczesne Zarządzanie, Białystok, s. 11-20.

Potoczek A., 2005b, Planowanie przestrzenne jako instrument zarzadzania rozwojem jednostek samorządu terytorialnego, [w:] Kosiedowski W. (red.) Samorząd terytorialny $w$ procesie rozwoju regionalnego i lokalnego, Towarzystwo Naukowe Organizacji i Kierownictwa Stowarzyszenie Wyższej Użyteczności DOM ORGANIZATORA, Toruń, s. 117-126.

Potoczek A., Jachowicz S., 2005, Administracja publiczna w procesie zarządzania rozwojem lokalnym i regionalnym, Wydawnictwo Wyższej Szkoły SuwalskoMazurskiej im. Papieża Jana Pawła II, Toruń-Warszawa.

Preteceille E., 2000, Segregation, Class and Politics in Large Cities, [w:] A. Bagnasco, P. Le Gales (red.), Cities in Contemporary Europe, Cambridge University Press, Cambridge.

Program antykryzysowy dla Wrocławia, 2009, http://www.computerworld.pl/ news/344115/Program.antykryzysowy.dla.Wroclawia.html, 8.12.2012.

Projekt na posiedzenie Komisji Wspólnej Rzq̨du i Samorządu Terytorialnego $w$ dniu 28 maja 2008 r. ustawy o rozwoju miast, centrach rozwoju regionalnego i obszarach metropolitalnych.

Projekt z 15 września 2008 r. ustawy o polityce miejskiej i współpracy jednostek samorządu terytorialnego $w$ tym zakresie.

Projekt z 15 września 2008 ustawy o polityce miejskiej i współpracy jednostek samorządu terytorialnego $w$ tym zakresie.

Projekt z 8 maja 2009 r. ustawy o polityce miejskiej państwa i współpracy jednostek samorządu terytorialnego $w$ tym zakresie.

Projekt z grudnia 2012 r. ustawy o współdziałaniu w samorzq̨dzie terytorialnym na rzecz rozwoju lokalnego i regionalnego oraz o zmianie niektórych ustaw.

PROT-AML, 2002, Plano Regional de Ordenamento do Território da Área Metropolitana de Lisboa, Lizbona.

Provan K. G., Brinton M. H., 1995, A Preliminary Theory of Interorganisational Network Effectiveness: A Comparative Study of Four Community Mental Health Systems, „Administration Science Quarterly”, No 40, s. 1-33.

Prusek A., 1995, Strategia rozwoju regionów w warunkach gospodarki rynkowej. Wydawnictwo i Drukarnia „Secesja”, Kraków. 
Przygodzki Z., 2007, Zewnętrzne uwarunkowania konkurencyjności regionów, [w:] Chądzyński J., Nowakowska A., Przygodzki Z., Region i jego rozwój w warunkach globalizacji, CeDeWu.pl, Warszawa, s. 14-22.

Pszczołowski T., 1978, Mała encyklopedia prakseologii i teorii organizacji, Ossolineum, Wrocław-Warszawa-Kraków-Gdańsk.

Puga D., 1998, Urbanization patterns: European versus less developed countries, „Journal of Regional Sciences", vol. 38, No 2, s. 231-252.

Purchla J., Sepioł J., 1998, Metropolie a rozwój regionalny Polski, [w:] J. Purchla (red.), Metropolitalne funkcje Krakowa, t. 1, MCK, Kraków, s. 13-32.

Putnam R., 1993, Making Democracy Work, Princeton University Press, Princeton.

Putnam R., 1995, Demokracja w działaniu. Tradycje obywatelskie we współczesnych Włoszech, Wydawnictwo Znak, Kraków.

Putnam R., 2001, Social Capital: Measurement and Consequences, [w:] The Contribution of Human and Social Capital to Sustained Economic Growth and WellBeing, International Symposium Report edited by the OECD and HRDC.

Putnam R., 2008, Samotna gra w kręgle. Upadek i odrodzenie wspólnot lokalnych w Stanach Zjednoczonych, Wydawnictwa Akademickie i Profesjonalne, Warszawa.

Putnam R., Leonardi R., Nanetti R. 1993, Making Democracy Work: Civic Traditions in Modern Italy, Princeton University Press, Princeton.

Pyka R., 2010, Wspólnota aglomeracji Saint-Étienne Métropole, jako przykład postepujacego w Europie procesu metropolizacji, [w:] R. Pyka (red.), Sposób na metropolie. Idee a społeczne oczekiwania wobec projektu utworzenia śląskozagłebiowskiej metropolii, UM Katowice RSS MSNP US, Katowice.

Redondo J. L., 2010, Global Challenges and Strategic Spatial Planning in the Region of Catalonia, Bruksela.

Rees J., Harding A., 2013, CAEE. The case for agglomeration economies in Europe, ESPON \& University of Manchester, http://www.espon.eu/ export/sites/ default/Documents/Projects/TargetedAnalyses/CAEE/CAEE_Greater_Manchester_C ase_Study_Appendix_C2_FINAL.pdf.

Reese L. A., 2004, Same Governance, Different Day: Does Metropolitan Reorganization Make a Difference?, „Review of Policy Research”, vol. 21, No 4, s. 595-611.

Regulski J., Kocoń W., Ptaszyńska-Wołoczkowicz M., 1988, Władze lokalne a rozwój gospodarczy, PWE, Warszawa.

Reich R.B., 2000, Praca narodów: przygotowanie się do kapitalizmu XXI wieku, Wydawnictwo Adam Marszałek, Toruń.

Reiss-Schmidt S., 2004, Munich Region: From Government to Governance?, 40 ${ }^{\text {th }}$ ISoCaRP Congress, Genewa.

Rezolucja Lubelska, 2012, Lublin. 
Rhodes G., 1970, Government of London: The Struggle for Reform, LSE/Weidenfeld and Nicolson, London.

Rhodes R. A. W., 1988, Beyond Westminster and Whitehall: The Subsectoral Governments of Britain, London: Unwin Hyman, London.

Rhodes R. A. W., 1990, Policy Networks: A British Perspective, „Journal of Theoretical Politics", vol. 2, no 3, s. 293-317.

Rhodes R. A. W., 1996, The New Governance: Governing without Government, „Political Studies", Volume 44, Issue 4.

Rice P. G., Venables A. J., Pattachini E., 2006, Spatial Determinants of Productivity: Analysis for the Regions of Great Britain, „Regional Science and Urban Economics", No 36 (6), s. 727-752.

Richardson H. W., Bae C.-H. C. (red.), 2005, Globalization and urban development, Springer, New York.

Ringli H., 1997, Plan-making in the Zurich Region, [w:] P. Healey, A. Khakee, A. Motte (red.), Making Strategic Spatial Plans: Innovation in Europe, UCL Press Limited, s. 111-128.

Robertson R., 1992, Globalization: Social Theory and Global Culture, Sage, London, s. 8.

Rogers J., 2004, Institutional Failure, Blind Leadership and The Blame-Game National Pastime. The case of Argentina, „Transformation: An International Journal of Holistic Mission Studies", No 21/2, s. 129-137.

Romer P. M., 1986, Increasing returns and long-run growth, „Journal of Political Economy", No 94, s. 1002-1037.

Rosenthal S. S., Strange W. C., 2004, Evidence on the Nature and Sources of Agglomeration Economies, [w:] V. Henderson, J. Thisse, (red.), Handbook of Urban and Regional Economics, North Holland, Amsterdam.

Rosso E., 2004, Torino: policies and actions at a metropolitan level, Paper presented at the La Gouvernance Metropolitaine Conference, Montreal, 7-8 October.

Rot P., 2009, Metropolitalna rewolucja w drodze , „Gazeta Wyborcza”, 27 stycznia, s. 2.

RSA, 2011, Exploring the changing governance of London -the politics of state rescaling, scale periodization and local political strategy, [w:] Contested Regions: Territorial Politics and Policy, Regional Studies Association, Seaford.

Rusk D., 1993, Cities without Suburbs, Woodrow Wilson Center Press, Washington.

Rutkowski J. (red.), 2010, Partnerstowo publiczno-prywatne w Polsce i jego funkcjonowanie na przykładzie wybranych projektów, Wydawnictwo Uniwersytetu Łódzkiego, Łódź.

Rząd przyjął założenia do projektu ustawy metropolitalnej, 2007, http://wiadomosci. gazeta.pl/wiadomosci/1,114873,4608004.html, 19.12.2012. 
Sagan I., 2000, Miasto - scena konfliktów i współpracy, Wydawnictwo Uniwersytetu Gdańskiego. Gdańsk.

Sager F., 2005, Metropolitan Institutions and Policy Coordination: The Integration of Land Use and Transport Policies in Swiss Urban Areas, „Governance”, No 18, s. 227-256.

Salamon L. M., Anheier H.K., 1997, The Civil Society Sector, "Society", vol. 34, No 2, s. 60-65.

Salet W., 2006, Rescaling Territorial Governance in the Randstad Holland: The Responsiveness of Spatial and Institutional Strategies to Changing Socio-economic Interactions, „European Planning Studies”, vol. 14, No 7, s. 959-978.

Salet W., Kreukels A., Thornley A. (red.), 2003, Metropolitan Governance and Spatial Planning, Spon Press, London-New York.

Salsman R. M., 2012, Fiscal Austerity And Public Policy, "Forbes", http://www.forbes. com/sites/richardsalsman/2012/06/19/fiscal-austerity-and-public-policy/, 23.12.2012.

Saltzstein A. L., Copus, C., Sonenshein R. J., Skelcher C., 2008, Visions of Urban Reform: Comparing English and U.S. Strategies for Improving City Government, „Urban Affairs Review", No 44, s. 155-181.

Samorządy wojewódzkie krytycznie o projekcie ustawy metropolitalnej, 2008, http:// wiadomosci.gazeta.pl/wiadomosci/1,114873,5823873.html, 19.12.2012.

Samuelson P. A., 1954, The Pure Theory of Public Expenditure, „Review of Economics and Statistics", No 36 (4), s. 387-389.

Sarnecki P., 2007, Ustrój Unii Europejskiej i ustroje państw członkowskich, Wolters Kluwer Polska, Warszawa.

Sarnecki P., 2008, Ustroje konstytucyjne państw współczesnych, Wolters Kluwer Polska, Warszawa.

Sassen S., 1991, The Global City, Princeton University Press, Princeton, New York.

Sassen S., 1994, Cities in World Economy, Pine Forge Press, Thousand Oaks.

Sassen S., 1996, Loosing Control? Sovereignty in an Age of Globalization, Columbia University Press, New York, s. 25-30.

Sassen S., 1998, The impact of new technologies and the globalization of cities, [w:] F. Lo, Y. Yeung (red.), Globalization and the world of large cities, United Nations University Press, Tokyo.

Sassen S., 2000, Cities in the global economy, [w:] R. Simmonds, G. Hack (red.), Global city regions: Their emerging forms, Spon Press, London.

Sassen S., 2007, Globalizacja. Eseje o nowej mobilności ludzi i pieniędzy, Wydawnictwo UJ, Kraków. 
Scharpf F. W., 1997, Introduction: The Problem solving Capacity of Multi-level Governance, „European Journal of Public Policy”, No 4, s. 520-38.

Scherer A. G., Palazzo G., Baumann D., 2006, Global rules and private actors: Toward a new role of the transnational corporation in global governance, „Business Ethics Quarterly", No 16(4), s. 505-532.

Schindegger F., Tatzberger G., 2004, Territorial impact assessment (TIA.) A certain tool or a whole kind of tools, (contribution for first Interim Report of ESPON 3.1). Vienna: ÖIR - Austrian Institute for Regional Studies and Spatial Planning.

Schmitt P., Harbo L. G., Lehto V., 2011, An actor-oriented survey of territorial governance systems in the Nordic capital regions, „NORDREGIO Working Paper”, No 6.

Schneider M., 1986, Fragmentation and the growth of local government. Public Choice, No 48 (3), 255-263.

Schneider M., 1989, Intermunicipal competition, budget-maximizing bureaucrats, and the level of suburban competition, „American Journal of Political Science”, No 33 (2), 612-628.

Scholte J. A., 1997, Global Capitalism and the State, „International Affairs”, no 73 (3), s. 427-52.

Scholte J. A., 2005, Globalization: A Critical Introduction, Macmillan, London.

Schulte W., 2006, Sustainable Development of Metropolises and Achievements of Hamburg in this Field, Gdańsk.

Schulte W., b.r., How the Metropolis Hamburg cooperates with other Municipalities in the Metropolitan Region even in Cooperation with Private Companies, http:// www.urban.chcg.gov.tw/A97017R_Index/Upload/DownloadArea/1001118001 /1001118001002.pdf, 11.05.2012.

Schwab K., 2010, The Global Competitiveness Report 2010-2011, World Economic Forum, Geneva.

Scott A. J., 2001, Globalization and the Rise of City-regions, „European Planning Studies", vol. 9, No 7.

Seixas J., 2011, Catalysing governance in a paradoxical city: the Lisbon Strategic Charter and the uncertainties of political empowerment in the Portuguese capital city, „Urban Research \& Practice”, vol. 4, No 3, 264-284.

Seligman A. B., 1997, The Problem of Trust, Princeton University Press.

Shaffer S., 2004, Principles of American Metropolitan Governance, Llumina Press, Coral Springs.

Short J. R., 2004, Global Metropolitan: Globalizing Cities in a Capitalist World, Routledge, Londyn-New York.

Sierocińska K., 2011, Kapitał społeczny. Definiowanie, pomiar i typy, „Studia ekonomiczne", nr 1 (LXVIII), s. 69-86. 
Silva C. N., Syrett S., 2005, Metropolitan Governance and Regionalism: The Case of Lisbon, [w:] I. Sagan, H. Halkier (red.), Regionalism contested: institution, society and governance, Ashgate Publishing, Aldershot Burlington, s. 247-264.

Silva C. N., Syrett S., 2006, Governing Lisbon: Evolving Forms of City Governance, „International Journal of Urban and Regional Research”, vol. 30.1, s. 98-119.

Skarżyńska K., 2005, Czy jesteśmy prorozwojowi? Wartości i przekonania ludzi a dobrobyt i demokratyzacja kraju, [w:] M. Drogosz (red.), Jak Polacy przegrywaja, jak Polacy wygrywaja, GWP, Gdańsk, s. 69-92.

Skogstad G., 2003, Who Governs? Who Should Govern?: Political Authority and Legitimacy in Canada in the Twenty-First Century, „Canadian Journal of Political Science", No 36 (5), s. 955-974.

Skrzypek E., Zarządzanie wiedza i kapitałem intelektualnym $w$ warunkach globalizacji, http://www.instytut.info/images/stories/ksiazki_polecane/17_ksztalcenie ustaw iczne/07-Skrzypek.pdf, 13.09.2010.

Skwierczyński A., 2004, Struktura napływu bezpośrednich inwestycji zagranicznych w ujęciu przestrzennym, [w:] I. Michałków (red.), Kapitał zagraniczny. Wyzwania i szanse, Wyd. Wyższa Szkoła Ekonomiczna, Warszawa.

Slaughter A. M., 2004, Disaggregated Sovereignty: Toward the Public Accountability of Global Government Networks, "Government and Opposition", s. 159-190, http:// www.princeton.edu/ slaughtr/Articles/GovtOpp.pdf.

Smart A., Smart J., 2003, Urbanization and the Global Perspective, "Annual Review of Anthropology", vol. 32, s. 263-285.

Smętkowski M., 2001, Nowe relacje między metropoliq i regionem $w$ gospodarce informacyjnej, „Studia Regionalne i Lokalne”, nr 4(7).

Smętkowski M., Jałowiecki B., Gorzelak G., 2009, Obszary metropolitalne w Polsce: problemy rozwojowe i delimitacja, „Raporty i analizy EUROREG”, nr 1.

Smętkowski M., Wójcik P., 2009, Regiony w Europie Środkowo-Wschodniej: tendencje i czynniki rozwojowe, „Raporty i analizy EUROREG”, nr 3.

Soja E., 1992, Inside exopolis: scenes from Orange County, [w:] M. Sorkin (red.), Variations on a Theme Park: The New American City and the End of Public Space, The Noonday Press, New York, s. 94-122.

Soja E., 2000, Postmetropolis: Critical Studies of Cities and Regions, Blackwell, Oxford.

Solecki W. D., Leichenko R. M., 2006, Urbanization and the Metropolitan Environment. Lessons From New York and Shanghai, „Environment”, vol. 48, No 4, s. 8-23.

Sørensen E., Torfing J., 2004, Making Governance Networks Democratic, „Working Paper Series", No 1, Centre For Democratic Network Governance. 
Squires G. D., 2002, Urban Sprawl and the Uneven Development of Metropolitan America, [w:] G. D. Squires (red.), Urban Sprawl: Causes, Consequences and Policy Responses, Urban Institute Press, Washington, s. 1-22.

Staniek Z., 2005, Uwarunkowania i wyznaczniki efektywności systemu instytucjonalnego, [w]: W. Pacho (red.), Szkice ze współczesnej teorii ekonomii, SGH, Warszawa.

Stanisławski J., 1990, Słownik angielsko-polski, Wiedza Powszechna, Warszawa.

Staniszkis J., 2003, Kryzys państwa, „Rzeczpospolita”, nr 255.

Statut Górnośląskiego Zwiq̨zku Metropolitalnego, http://www.gzm.bip-e.pl/portal/ gzm/236/535/Statut.html.

Statut Stowarzyszenia Metropolia Poznań, http://www.aglomeracja.poznan. $\mathrm{pl} /$ aglomeracja/public/aglomeracja/pages.html?id=14745\&ch=14799\&p=2237 8\&instance=1144\&lang=pl\&lhs=aglomeracja\&rhs=publications.

Stawasz D., Drzazga D., Szydłowski C., 2011, Wybrane aspekty sprawności zarzq̨dzania w administracji publicznej, Wydawnictwo Uniwersytetu Łódzkiego, Łódź.

Stefaniuk J., 2007, Ustawa o zwiqzkach aglomeracyjnych - przegląd prac legislacyjnych dotyczacych delimitacji i funkcjonowania, http://www.regioportal.pl/pl24/ teksty4/ustawa_o_zwiazkach_aglomeracyjnych_przeglad_prac, 21.12.2012.

Steinmetz G. (red.), 1999, State/culture: state-formation after the cultural turn, Cornell University Press, Ithaca.

Stephens G. R., Wikstrom N., 2000, Metropolitan Government and Governance: Theoretical Perspectives, Empirical Analysis, and the Future, Oxford University Press, New York.

Stewart M., 1996, Too little, too late: The politics of local complacency, "Journal of Urban Affairs", No 18, s. 119-137.

Stewart M., 2003, Tackling the Challenge of Policy Integration, [w:] OECD Managing Decentralisation: A New Role for Labour Market Policy, OECD, Paris.

Stigler G. J., 1962, The tenable range of functions of local government, [w:] E.Phelps (red.), Private wants and public needs, W. W. Norton, New York.

Stiglitz J., 2004, Globalizacja, Wydawnictwo Naukowe PWN, Warszawa.

Stöhr W. B., 2003, Development from below: Vingt ans plus tard, [w:] J.-M. Fontan, J.-L. Klein, B. Lévesque (red.), Reconversion économique et développement territorial, Presses de l'Université du Québec, Québec, Ontario, s. 119-43.

Stoker G., 1998, Governance as Theory: Five Propositions, „International Social Science Journal", No 155, s. 17-28.

Stoker G., 2006, The Comparative Study of Local Governance: the need to go global, Hallsworth Conference, University of Manchester, 17-18 marca. 
Stone C. L, 1989, Regime politics, Governing Atlanta 1946-1988, University of Kansas Press, Lawrence.

Stopford J. M., Strange S., Henley J. S., 1991, Rival states, rival firms: competition for world market shares, Cambridge University Press, Cambridge, s. 1-2, 97-136

Storper M., 1997, The Regional World: Territorial Development in a Global Economy. Guilford Press, New York.

Strange S., 1988, States and Markets, Frances Pinter, London.

Strange S., 1996, The Retreat of the State: The Diffusion of Power in the World Economy, Cambridge University Press, Cambridge.

Strzelecki Z., 2011, Barometr Mazowsza. Zaufanie do instytucji życia publicznego na poziomie lokalnym, Mazowieckie Biuro Planowania Regionalnego w Warszawie.

Sullivan H., Skelcher C., 2002, Working across borders: collaborations in public services, [w:] G. Stoker, D. Wilson (red.), Government beyond the centre, Palgrave Macmillan, Basingstoke.

Swianiewicz P., 2003, Partisan Cleavages in Local Governments in Poland After 1990 [w:] T. Zarycki, G. Kolankiewicz (red.), Regional Issues in Polish Politics, London: School of Slavonic and East European Studies, University College London, Occasional Papers, No 60, s. 179-201.

Swianiewicz P., 2005, Nowe interpretacje teoretyczne polityki miejskiej, „Studia Regionalne i Lokalne", nr 4 (22), s. 5-25.

Swianiewicz P., 2006, Zarządzanie metropoliami: doświadczenia międzynarodowe, a rzeczywistość polska, „Samorząd Terytorialny” nr 1-2/2006, s. 29-44.

Swianiewicz P., 2008, Partnerska polityka publiczna na poziomie, „Dialog”, nr 4.

Swianiewicz P., Klimska U., 2005, Społeczne i polityczne zróżnicowanie aglomeracji w Polsce - waniliowe centrum, mozaika przedmieść, „Prace i Studia Geograficzne”, t. 35 , s. $45-70$.

Swianiewicz P., Krukowska J., Nowicka P., 2011, Zaniedbane dzielnice $w$ polityce wielkich miast, Dom Wydawniczy ELIPSA, Warszawa.

Swianiewicz P., Mielczarek A., Klimska U., 2004, Nierówne koalicje: liderzy miejscy w poszukiwaniu nowego modelu zarządzania rozwojem, Scholar, Warszawa.

Swyngedouw E., 1996, Producing futures: global finance as a geographical project, [w:] Daniels P., Lever W. (red.), The Global Economy in Transition, Longman, Harlow, s. 135-163.

Swyngedouw E., 1997, Neither global nor local: "glocalization" and the politics of scale, [w:] K. R. Cox (red.), Spaces of Globalization: Reasserting the Power of the Local, The Guilford Press, New York-London, s. 137-166.

Swyngedouw E., 2004, Globalisation or 'Glocalisation'? Networks, Territories and Rescaling, „Cambridge Review of International Affairs”, vol. 17, No 1. 
Szczerski K., 2003, Integracja europejska. Cywilizacja i polityka, Wydawnictwo Uniwersytetu Jagiellońskiego, Kraków.

Szkurłat E., 2003, Prestiż i specyfika miejsca jako kryterium metropolizacji polskich miast, [w:] I. Jażdżewska (red.), Funkcje metropolitalne i ich rola $w$ organizacji przestrzeni, XVI Konwersatorium wiedzy o mieście, Łódzkie Towarzystwo Naukowe, Łódź, s. 73-81.

Szlachta J., 1995, Problemy rozwoju wielkich miast UE na tle szerszej przestrzeni europejskiej, „Biuletyn KPZK PAN”, z. 169.

Sztompka P., 2007, Zaufanie. Fundament społeczeństwa, Znak, Kraków.

Szumska A., 2009, Czekamy na ustawę o aglomeracjach, http://wroclaw.naszemiasto.pl/ artykul/52325,czekamy-na-ustawe-o-aglomeracjach,id,t.html

Szymańska D., 2008, Urbanizacja na świecie, Wydawnictwo Naukowe PWN, Warszawa.

Śleszyński P., 2012, Delimitacja Miejskich Obszarów Funkcjonalnych stolic województw, PAN, Warszawa.

Świetlik M., Lubiatowski A., 2004, Cele, problematyka, tryb, „Wspólnota”, nr 13.

Taylor P. J., 2001, Specification of the world city network, „Geographical Analysis”, No 33, s. 181-194.

Taylor P. J., 2002, European Cities in the World City Network, [w:] H. van Dijk (red.), The European Metropolis 1920-2000, Proceedings of a Conference at The Centre of Comparative European History, Berlin.

Taylor P. J., 2003, European Cities in the World City Network, „GaWC Research Bulletin", No 105

Taylor P. J., 2004, World City Network. A Global Urban Analysis, Routledge, London.

Taylor P. J., Derudder B., Saey P., Witlox F. (red.), 2007, Cities in globalization: Practices, policies and theories, Routledge, London.

Taylor P. J., Ni P., Derudder B., Hoyler M., Huang J., Witlox F. (red), 2010, Global Urban Analysis: A Survey of Cities in Globalization, Routledge.

Telò M., 2001, European Union and New Regionalism. Regional Actors and Global Governance in a Post-Hegemonic Era, Ashgate, Aldershof-Burlington.

The Principal Agglomerations of the World, http://www.citypopulation.de/world/ Agglomerations.html.

Thornley A., 2003, London. Institutional turbulence but enduring nation-state control, [w:] Salet W., Kreukels A., Thornley A. (red.), Metropolitan Governance and Spatial Planning, Spon Press, London-New York.

Thrift N., 1994, Globalisation, regulation, urbanisation: The case of the Netherlands, „Urban Studies”, vol. 31, No 3, s. 365-380. 
Tiebout Ch. M. 1956, A Pure Theory of Local Expenditures, „Journal of Political Economy", No 64 (5), s. 416-24.

Tomas M., 2001, Local Government and Local Democracy. A Case Study: Barcelona, Barcelona.

Tomas M., 2002, Dealing with metropolitan governance. A case study: Madrid, VII Congreso Internacional del CLAD sobre la Reforma del Estado y de la Administración Pública, Lisboa, Portugal, 8-11 Oct.

Tomlinson J., 1999, Globalization and Culture, University of Chicago Press, Chicago.

Toniolo M., Pugliese T., 2003, Venice, [w:] W. Salet, A. Kreukels, A. Thornley (red.), Metropolitan Governance and Spatial Planning, Spon Press, London-New York, s. 244-263.

Tosics I., 2011, Sustainable land use in peri-urban areas government, planning and financial instruments, [w:] S. Pauleit, S. Bell, C. Aalbers (red.), Peri-Urban Futures: Land Use and Sustainability, Springer, Berlin.

Trafas K., Badania delimitacji obszarów metropolitalnych, http://www.malopolskie. $\mathrm{pl} /$ Planowanie/Pliki/seminarium_trafas.pdf.

Transportation Research Board, 1998, The Costs of Sprawl - Revisited, National Academy Press, Washington, http://onlinepubs.trb.org/onlinepubs/tcrp/tcrp _rpt_39-a.pdf, 2.03.2012.

Trojan J., 2005, Partnerstwo publiczno-prywatne a rozwój kapitału ludzkiego, [w:] B. Plawgo, W. Zaremba (red.), Partnerskie współdziałanie w sektorze publicznym i prywatnym, Fundacja Współczesne Zarządzanie, Białystok, s. 57-68.

Tumielewicz S., 2011, Założenia systemu zarządzania rozwojem Polski - strategie rozwoju, Ministerstwo Środowiska, Warszawa.

UK Presidency, 2005, Bristol Accord, The Office of the Deputy Prime Minister, London.

UNDP, 1997, Governance for Sustainable Human Development, New York.

UN-HABITAT, 2002, Global Campaign on Urban Governance, Concept Paper, Nairobi.

UN-HABITAT, 2010, State of the World's Cities 2010/2011 - Cities for All: Bridging the Urban Divide,

United Nations Population Division, 2008, An Overview of Urbanization, Internal Migration, Population Distribution and Development in the World, UN/POP/EGMURB, No 1.

United Nations, Department of Economic and Social Affairs, Population Division, 2012, World Urbanization Prospects: The 2011 Revision, CD-ROM Edition.

URBACT, 2011, CityRegions in progress. Practical guidelines for co-operations in agglomeration areas. 
Ustawa z dnia 27 marca 2003 r. o planowaniu i zagospodarowaniu przestrzennym, DzU, 2003, nr 80, poz. 717.

Ustawa z dnia 7 kwietnia 1989 r., Prawo o stowarzyszeniach, tekst jednolity, www. prawo.lex.pl.

Ustawa z dnia 7 marca 2007 r. o wspieraniu rozwoju obszarów wiejskich z udziałem środków Europejskiego Funduszu Rolnego na rzecz Rozwoju Obszarów Wiejskich, DzU ,2007, nr 64, poz. 427.

Ustawa z dnia 8 marca 1990 roku o samorządzie gminnym, DzU, 1990, nr 142, poz. 1591 z późn. zm.

Van der Burg A. J., Vink B. L., 2006, New Dutch spatial planning policy creates space for development, disP $164, \mathrm{nr} 1$.

Van der Burg A. J., Vink B. L., 2008, Randstad Holland towards 2040 - perspectives from national government, 44th ISOCARP Congress.

Vartanian T. P., Gleason P. M., 1999, Do Neighborhood Conditions Affect High School Dropout and College Graduation Rates?, „Journal of Socio-Economics”, No 28 (1), s. 21-41.

Venables A. J., 2009, Rethinking Economic Growth in a Globalizing World: An Economic Geography Lens, [w:] M. Spence, P. Clarke Annez, R. M. Buckley (red.), Urbanization and Growth, The International Bank for Reconstruction and Development, The World Bank, Washington.

VLP-ASPAN, 2004, Spatial planning in Switzerland.

Walliser A., Callejo C. B., 2004, Urban Outskirts in Madrid, [w:] G. Dubois-Taine (red.), European Cities: Insights on Outskirts, Peripheries des Villes Eurpeenes, Paris, s. 267-282.

Ward K., 1996, Rereading urban regime theory: Asympathetic critique, „Geoforum”, No 27, s. 427-38.

Waściński T. (red.), 2004, Globalizacja? za - przeciw, Wydawnictwo Uczelniane Politechniki Koszalińskiej, Koszalin.

Wawrzyniak B., 2000, Nadzór korporacyjny: perspektywa badań, „Organizacja i kierowanie", nr 2.

Wątpliwości z Bydgoszczy ws. metropolii, 2013, http://www.portalsamorzadowy. $\mathrm{pl} /$ prawo-i-finanse/watpliwosci-z-bydgoszczy-ws-metropolii,44020.html, 25.01.2013

Weber M., 2002, Gospodarka i społeczeństwo, PWN Warszawa.

Weiher G. R., 1991, The Fractured Metropolis: Political Fragmentation and Metropolitan Segregation, State University of New York Press, Albany.

Wellman B. Hampton K., 1999, Living Networked On and Offline, „Contemporary Sociology", vol. 28, No 6, s. 648-54. 
Wellman B., 2002, Little Boxes, Glocalization, and Networked Individualism, [w:] M. Tanabe, P. van den Besselaar, T. Ishida (red.), Digital Cities II, Springer-Verlag, Berlin.

Węcławowicz G., 1992, Centralne funkcje a rozwój aglomeracji warszawskiej, „Acta Universatis Lodziensis", Folia Geographica, 17, s. 67-77.

Wilkin J., 2012, Teoria wyboru publicznego. Główne nurty i zastosowania, Wydawnictwo Naukowe SCHOLAR, Warszawa.

Wilks S., Wright M., 1987, Comparative Government Industry Relations, Oxford University, Oxford.

Wojciechowski E., 2003, Zarzq̨dzanie w samorządzie terytorialnym, Difin, Warszawa.

Wojtyczek K., 2005, Polska w europejskim systemie konstytucyjnym, [w:] P. Sarnecki (red.), Prawo konstytucyjne RP, C.H.Beck, Warszawa.

Wolaniuk A., 1997, Funkcje metropolitalne Łodzi i ich rola w organizacji przestrzeni, Łódzkie Towarzystwo Naukowe, Łódź.

Wood C., 2005, Scope and Patterns of Metropolitan Governance in Urban America: Probing the Complexities in the Kansas City Region, „American Review of Public Administration", No 36 (3), s. 33-53.

Woods R., 2003, Urbanisation in Europe and China during the second millennium: a review of urbanism and demography, „International Journal of Population Geography", vol. 9, No 3, s. 215-227.

Woolcock M., 1998, Social Capital and Economic Development: Toward a Theoretical Synthesis and Policy Framework, „Theory and Society", vol. 27, No 2, s. 151-208.

Woolcock M., 2001, The place of social capital in understanding social and economic outcomes, „Canadian Journal of Policy Research”, No 2 (1), s. 11-17.

World Bank, 2000, Cities in transition: World Bank urban and local government strategy, The World Bank, Washington.

World resources 2002-2004: decisions for the earth: balance, voice and power, 2003, World Resources Institute, Washington.

Wójcicki M., 2009, Region Stuttgart, CBM UAM, Poznań.

Wójcik P., 2008, Dywergencja czy konwergencja: dynamika rozwoju polskich regionów, „Studia Regionalne i Lokalne”, nr 2, s. 41-60.

Wykaz LGD, http://ksow.pl/fileadmin/user_upload/ksow.pl/pliki/Leader/LISTA.pdf.

Wysocka E., 1994, Sieć osadnicza Polski w świetle integracji europejskiej, „Biuletyn KPZK PAN", z. 167.

Zachariasz I., 2004, W Niemczech, „Wspólnota”, nr 13

Zachariasz I., 2012, Opinia w sprawie „Zielonej księgi dotyczącej obszarów metropolitalnych" - dokumentu Ministerstwa Administracji i Cyfryzacji z kwietnia 2012 r., 
http://www.metropolie.pl/wp-content/uploads/2012/06/I.Zachariasz-opinia-nt. -Zielonej-Ksi\%C4\%99gi-MAC.pdf

Zajączkowska M., 2011, Założenia planowania przestrzennego i projektowania architektonicznego w Wielkiej Brytanii, „Przegląd Budowlany”, nr 3.

Zalega K., 2003, Systemy corporate governance a efektywność zarzq̨dzania spółkq kapitałową, SGH, Warszawa,

Zalewski A. (red.), 2005, Nowe zarządzanie publiczne w polskim samorzadzie terytorialnym, Szkoła Główna Handlowa, Warszawa.

Zasada M., 2012, „Koko metro spoko”, czyli co z ustawq metropolitalną, „Dziennik Zachodni", nr 111, 14.05.

Zawicki M., 2002, Nowe zarzq̨dzanie publiczne i zarzq̨dzanie przez współrzq̨dzenie zarys koncepcji zarzq̨dzania publicznego, „Zeszyty Naukowe”, Nr 598, Akademia Ekonomiczna w Krakowie, Kraków.

Zawicki M., 2011, Nowe zarządzanie publiczne, Polskie Wydawnictwo Ekonomiczne, Warszawa.

Zborowski A., 2005, Jak daleko polskiej urbanizacji do Europy?, [w:] I. Jażdżewska (red.), Współczesne procesy urbanizacji i ich skutki, XVIII Konwersatorium wiedzy o mieście, Łódzkie Towarzystwo Naukowe, Łódź, s. 57-74.

Zborowski A., Chaberko T., Grad N., Kretowicz P., Delimitacja Krakowskiego Obszaru Metropolitalnego, http://www.politykarozwoju.obserwatoria.malopolska.pl/Files. mvc/205/3._Delimitacja_Krakowskiego_Obszaru_Metropolitalnego.pdf, 6.08 .2012

Zorska A. (red.), 2002, Korporacje międzynarodowe w Polsce: wyzwania $w$ dobie globalizacji i regionalizacji, Difin, Warszawa.

Zorska A., 2000, Ku globalizacji?: przemiany w korporacjach transnarodowych i w gospodarce światowej, Wydawnictwo Naukowe PWN, Warszawa

Zorska A., 2001, Zmiany w procesie globalizacji a uczestnictwo krajów Europy Środkowej, [w:] Osiński J. (red.), Globalna gospodarka - lokalne społeczeństwa, Szkoła Główna Handlowa Oficyna Wydawnicza, Warszawa.

Zuboff S., 1988, In the Age of the Smart Machine: The Future of Work and Power, Basic Books, New York.

Zysnarski J., 2003, Partnerstwo publiczno-prywatne: Teoria i praktyka, Ośrodek Doradztwa i Doskonalenia Kadr, Gdańsk.

Żabiński L. (red.), 2002 Marketing globalny i jego strategie, Wydawnictwo AE, Katowice.

Żabiński L., 2003, Gospodarka polska wobec globalizacji: bariery i warunki sukcesu przedsiębiorstw na rynkach unijnych, [w:] K. Jędralska, L. Żabiński (red.), Gospodarka w obliczu globalizacji. Przegląd wybranych zagadnień, PTE, Katowice. 


\section{Strony internetowe}

http://birmingham.gov.uk/cs/Satellite?c=Page\&childpagename=SystemAdmin $\% 2 \mathrm{FP}$ ageLayout\&cid=1223092745907\&packedargs=currentType\%3DDate\%26event SearchType\%3Ddate\%26website\%3D1\&pagename=BCC\%2FCommon\%2FW rapper\%2FWrapper\&rendermode=live.

http://brandavenue.typepad.com/brand_avenue/2010/11/a-strong-greenbrand.html.

http://cartaestrategica.cm-lisboa.

http://dmp.zinnebeeld.nl/v1/cms/pdf_upload/Deltametropolis\%20Association.pdf. http://dmp.zinnebeeld.nl/v1/cms/pdf_upload/Deltametropolis,\%20connectivity,\%2 0competition,\%20cooperation.pdf.

http://en.wikipedia.org/wiki/Global_city.

http://en.wikipedia.org/wiki/List_of_metropolitan_areas_in_Sweden.

http://english.metropolregion.hamburg.de.

http://english.metropolregion.hamburg.de/bodies/1072126/secretariat.html.

http://english.metropolregion.hamburg.de/bodies/1072132/steeringcommittee.html.

http://english.metropolregion.hamburg.de/bodies/1072146/regionalconference.html.

http://fr.wikipedia.org/wiki/Communaut\%C3\%A9_urbaine.

http://m.wroclaw.gazeta.pl/wroclaw/1,106542,8645769.html.

http://pdu.stif.infohttp://pl.wikipedia.org/wiki/Lokalna_Grupa_Dzia\%C5\%82ania.

http://territori.scot.cat/cat/notices/2010/12/pla_territorial_parcial_de_la_regio_met ropolitana_de_barcelona_2634.php.

http://towarzystwobiznesowe.pl/kapital-spoleczny.

http://urbact.eu.

http://w3.bcn.es/V01/Serveis/Noticies/V01NoticiesLlistatNoticiesCtl/0,2138,1653_ 35144087_3_1382332054,00.html?accio=detall\&home=HomeBCN\&nomtipusMC $\mathrm{M}=$ Noticia.

http://webarchive.nationalarchives.gov.uk/+/http://www.advantagewm.co.uk/abo ut-awm/default.aspx.

http://webarchive.nationalarchives.gov.uk/+/http://www.communities.gov.uk/local government/local/localenterprisepartnerships. 
http://www.acturban.org/biennial/ElectronicCatalogue/Delft/delft.htm.

http://www.agma.gov.uk.

http://www.agma.gov.uk/about_us/index.html.

http://www.agma.gov.uk/agma/how_agma_works/index.html.

http://www.agma.gov.uk/local-enterprise-partnership/index.html.

http://www.agma.gov.uk/scrutiny/about_agma_scrutiny/index.html.

http://www.amb.cat.

http://www.amf.asso.fr/annuaire/?refer=region\&erg_n_id=14.

http://www.araw.pl.

http://www.cbm.amu.edu.pl.

http://www.ccdr-lvt.pt/content/index.php?action=detailfo\&rec=54.

http://www.ccdr-lvt.pt/pt/arco-ribeirinho-sul-oficialmente-lancado/1519.htm.

http://www.ccre.org.

http://www.cedru.com/en/what-we-do/development-and-land-use-

management/31-plano-regional-de-ordenamento-do-territorio-da-area-

metropolitana-de-lisboa.

http://www.centro.org.uk/LTP/LTP.aspx.

http://www.cities-localgovernments.org.

http://www.cmm.qc.ca.

http://www.ctm-madrid.es/servlet/CambiarIdioma?xh_TIPO=1.

http://www.currentconcerns.ch/index.php?id=837.

http://www.ekonomiaspoleczna.pl/x/615861.

http://www.eurocities.eu.

http://www.eurometrex.org.

http://www.funduszeeuropejskie.gov.pl/RPO/Aktualnosci/Strony/Jessica_240310.aspx.

http://www.greaterzuricharea.ch.

http://www.gzm.org.pl.

http://www.iledefrance.fr/english/the-regional-council/the-regional-councils-fieldsof-intervention/the-regional-councils-fields-of-intervention.

http://www.iledefrance.fr/lactualite/conseil-regional/conseil-regional/le-projet-desdrif-en-ligne.

http://www.investinmanchester.com. 
http://www.investinmanchester.com.

http://www.lboro.ac.uk/gawc.

http://www.london.gov.uk.

http://www.london.gov.uk/who-runs-londrnance/greater-london-authority/gla-

functional-bodies.

http://www.madrid.org.

http://www.madrid.org/iestadis/fijas/basicos/dguide.htm.

http://www.malardalsradet.se.

http://www.malardalsradet.se/?id=2587.

http://www.marketingmanchester.com.

http://www.metropoleruhr.de.

http://www.metropoleruhr.de/pl/strona-glowna/metropolia-ruhry/dane-ifakty.html.

http://www.metropoliagdansk.pl/stowarzyszenie-gom/inicjatywy-metropolitalne1990-2011.

http://www.metropolitanraum-zuerich.ch.

http://www.metropolregion-muenchen.eu.

http://www.milanomet.it/en.

http://www.milanomet.it/en/cosa-facciamo/activities.html.

http://www.milanomet.it/en/valorizzazione-territoriale/the-citt-di-citt-strategicproject.html.

http://www.milanomet.it/it/valorizzazione-territoriale/piano-territoriale-dicoordinamento-provinciale-3.html.

http://www.mlit.go.jp/kokudokeikaku/international/spw/general/italy/index_e.html.

http://www.nyidanmark.dk/pl-PL/Medborger_i_danmark_pl_pl/2\%20system\% 20rz\%C4\%85d\%C3\%B3w.html\#.

http://www.oecd.org/dataoecd/41/37/45511614.pdf.

http://www.oresundskomiteen.org/en.

http://www.paris-region.com/ard/paris-region-economic-developpement-

agency/the-economic-development-agency/our-remit.

http://www.paris-region.com/ard_uk/outils/nos_partenaires.asp.

http://www.partizipation.at/advocacy-planning.html.

http://www.pemb.cat/en/2020-vision. 
http://www.pemb.cat/en/what-is-the-plan/background-pemb.

http://www.pim.mi.it.

http://www.planninghelp.org.uk/planning-system/local-development-frameworks.

http://www.pocketinfo.net/2011/12/world-cities-2012.html.

http://www.provincia.mi.it/pianificazione_territoriale/piano_territoriale.

http://www.provincia.milano.it/export/sites/default/affari_sociali/immagini/ sn_milano2400.gif.

http://www.region-stuttgart.org/vrs/main.jsp?navid=67.

http://www.regiorandstad.com/eng_organisatie/dagelijksbestuur.php.

http://www.regio-randstad.nl/index_eng.php.

http://www.skane.se/sv/Webbplatser/skanese/English/Regional-self-

government/Swedish-Administrative-System.

http://www.som.szczecin.pl.

http://www.som.szczecin.pl.

http://www.stadt-zuerich.ch/prd/en/index/stadtentwicklung/aussenbeziehungen/ zuerich_regional/metropolitankonferenz.html.

http://www.stadt-zuerich.ch/prd/en/index/stadtentwicklung/aussenbeziehungen /zuerich_regional/rzu.html.

http://www.stat.gov.pl/gus/5840_13473_PLK_HTML.htm.

http://www.sweden.se/eng/Home/Society/Government-politics/Facts/Swedish-

System-of-Government.

http://www.transportforgreatermanchestercommittee.gov.uk.

http://www.tuttitalia.it/variazioni-amministrative/riordino-province-e-citta-

metropolitane/per-regione.

http://www.unfpa.org/pds/urbanization.htm.

http://www.unhabitat.org/content.asp?typeid=19\&catid=25\&cid=2097.

http://www.westmidlandsltp.gov.uk/default.php?id=249.

http://www.wmcouncils.gov.uk.

http://www.wmcouncils.gov.uk/what-we-do.

http://www.wmra.gov.uk.

http://www.woerdensberaad.nl.

http://www.xtec.cat/ jflorenz/comarca/rmb.htm. 


\section{SPIS TABEL}

Tabela 1. Globalizacja jako reterytorializacja: zmiana skali państw i miast...............35

Tabela 2. Cechy miasta globalnego według różnych autorów 44

Tabela 3. Procent ludności mieszkającej na terenach zurbanizowanych w latach 1950-2050

Tabela 4. Liczba ludności w miastach centralnych obszarów metropolitalnych i w strefie podmiejskiej (w tys.)

Tabela 5. Liczba ludności i gmin obszarów metropolitalnych wyznaczanych według różnych delimitacji ( $\mathrm{w}$ tys.) ...............................................................98

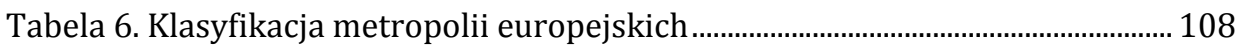

Tabela 7. Ranking metropolitalności polskich miast.......................................................... 110

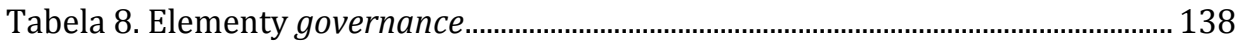

Tabela 9. Rodzaje strategicznych zachowań organizacji nastawionych na współdziałanie .............................................................................................. 142

Tabela 10. Pięć zasad good governance …….................................................................. 149

Tabela 11. System gospodarki przestrzennej w Portugalii .......................................... 195

Tabela 12. Regiony miejskie w Randstad (2002 r.) ...................................................... 206

Tabela 13. Podmioty metropolitan governance w regionie Sztokholmu.................. 218

Tabela 14. Współpraca gmin z interesariuszami przy tworzeniu dokumentów

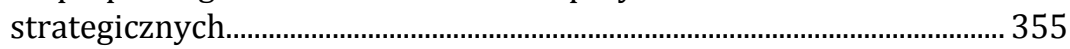

Tabela 15. Formy współpracy w zakresie transportu publicznego............................ 356

Tabela 16. Formy współpracy w zakresie gospodarki odpadami i gospodarki wodno-ściekowej.

Tabela 17. Formy współpracy w zakresie promocji, pozyskiwania inwestorów i funduszy

Tabela 18. Dziedziny współpracy podczas prac nad planem zagospodarowania przestrzennego obszaru metropolitalnego

Tabela 19. Odpowiedzi na pytanie dotyczące ujednolicenia systemu opłat za przejazdy komunikacja publiczną. 


\section{SPIS RYSUNKóW}

Rys. 1. Potencjalne i słabe MEGA w Polsce........................................................................................ 91

Rys. 2. Szersze strefy miejskie ośrodków metropolitalnych .................................................. 92

Rys. 3. Delimitacja obszarów metropolitalnych według UMP.................................................. 94

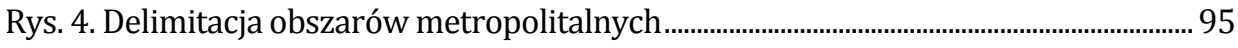

Rys. 5.Poznański Obszar Metropolitalny według różnych metod delimitacji..................... 97

Rys. 6. Funkcje przywódcze w obszarach metropolitalnych.................................................. 163

Rys. 7. Struktura organizacyjna kontraktów planistycznych (CPER)................................. 180

Rys. 8. Jednostki terytorialne w Randstad............................................................................2. 206

Rys. 9. Fingerplan z roku 1947 ......................................................................................... 230

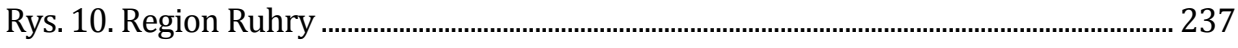

Rys. 11. Obszar Metropolitalny Monachium............................................................................. 238

Rys. 12. Granice regionu metropolitalnego Mediolanu....................................................... 249

Rys. 13. Zasięg terytorialny organizacji metropolitalnych w Barcelonie .......................... 256

Rys. 14. Obszar Metropolitalny Manchesteru ...................................................................... 275

Rys. 15. Struktura zarządzania w Wielkim Manchesterze .................................................... 276

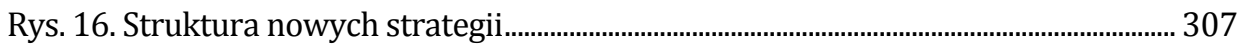

Rys. 17. Związki międzygminne na terenie Wrocławskiego Obszaru Metropolitalnego ....................................................................................................................... 323

Rys. 18. Związki międzygminne na terenie Wrocławskiego Obszaru Metropolitalnego

Rys. 19. Związki międzygminne na terenie Bydgosko-Toruńskiego Obszaru Metropolitalnego

Rys. 20. Związki międzygminne na terenie Lubelskiego Obszaru Metropolitalnego 324

Rys. 21. Związki międzygminne na terenie Lubelskiego Obszaru Metropolitalnego 325

Rys. 22. Związki międzygminne na terenie Łódzkiego Obszaru Metropolitalnego.... 325

Rys. 23. Związki międzygminne na terenie Łódzkiego Obszaru Metropolitalnego.... 326

Rys. 24. Związki międzygminne na terenie Krakowskiego Obszaru Metropolitalnego

Rys. 25. Związki międzygminne na terenie Krakowskiego Obszaru Metropolitalnego

Rys. 26. Związki międzygminne na terenie Warszawskiego Obszaru Metropolitalnego

Rys. 27. Związki międzygminne na terenie Warszawskiego Obszaru Metropolitalnego

Rys. 28. Związki międzygminne na terenie Górnośląskiego Obszaru Metropolitalnego. 
Rys. 29. Związki międzygminne na terenie Górnośląskiego Obszaru Metropolitalnego.

Rys. 30. Związki międzygminne na terenie Poznańskiego Obszaru Metropolitalnego.

Rys. 31. Związki międzygminne na terenie Poznańskiego Obszaru Metropolitalnego

Rys. 32. Związki międzygminne na terenie Szczecińskiego Obszaru Metropolitalnego.

Rys. 33. Związki międzygminne na terenie Szczecińskiego Obszaru Metropolitalnego.

Rys. 34. Związki międzygminne na terenie Trójmiejskiego Obszaru Metropolitalnego

Rys. 35. Związki międzygminne na terenie Trójmiejskiego Obszaru Metropolitalnego.

Rys. 36. Związki międzygminne na terenie Rzeszowskiego Obszaru Metropolitalnego.

Rys. 37. Związki międzygminne na terenie Białostockiego Obszaru Metropolitalnego.

Rys. 38. Związki międzygminne na terenie Białostockiego Obszaru Metropolitalnego.

Rys. 39. Członkowie stowarzyszeń w Trójmiejskim Obszarze Metropolitalnym......... 349

Rys. 40. Gotowość gmin do przekazania kompetencji instytucji metropolitalnej, a doświadczenia współpracy 


\section{Załącznik 1}

25 najlepiej usieciowionych miast Europy

\begin{tabular}{|c|c|c|}
\hline Pozycja & Miasto & Wskaźnik usieciowienia (GNC) \\
\hline 1 & Londyn & 1,00 \\
\hline 2 & Paryż & 0,78 \\
\hline 3 & Mediolan & 0,69 \\
\hline 4 & Madryd & 0,65 \\
\hline 5 & Bruksela & 0,63 \\
\hline 6 & Warszawa & 0,56 \\
\hline 7 & Zurych & 0,55 \\
\hline 8 & Amsterdam & 0,55 \\
\hline 9 & Dublin & 0,54 \\
\hline 10 & Rzym & 0,53 \\
\hline 11 & Lizbona & 0,52 \\
\hline 12 & Frankurt & 0,50 \\
\hline 13 & Sztokholm & 0,49 \\
\hline 14 & Praga & 0,49 \\
\hline 15 & Wiedeń & 0,48 \\
\hline 16 & Budapeszt & 0,48 \\
\hline 17 & Ateny & 0,48 \\
\hline 18 & Barcelona & 0,42 \\
\hline 19 & Bukareszt & 0,40 \\
\hline 20 & Oslo & 0,40 \\
\hline 21 & Berlin & 0,39 \\
\hline 22 & Helsinki & 0,39 \\
\hline 23 & Genewa & 0,38 \\
\hline 24 & Kopenhaga & 0,37 \\
\hline 25 & Hamburg & 0,37 \\
\hline
\end{tabular}

Źródło: [Taylor, Ni, Derudder, Hoyler, Huang, Witlox, 2010]. 


\section{Załącznik 2}

Obszary metropolitalne w krajach OECD wg PKB per capita

\begin{tabular}{|c|c|c|c|c|c|}
\hline Pozycja & $\begin{array}{c}\text { Obszar } \\
\text { metropolitalny }\end{array}$ & Kraj & Populacja (mln) & $\begin{array}{c}\text { PKB per capita } \\
\text { (tys. USD) }\end{array}$ & $\begin{array}{c}\text { Udział w PKB } \\
\text { kraju (\%) }\end{array}$ \\
\hline 1 & 2 & 3 & 4 & 5 & 6 \\
\hline 1 & San Francisco & USA & 4,2 & 62,3 & 2,2 \\
\hline 2 & Waszyngton & USA & 5,1 & 61,6 & 2,7 \\
\hline 3 & Boston & USA & 4,4 & 58,0 & 2,2 \\
\hline 4 & Seattle & USA & 3,2 & 54,4 & 1,5 \\
\hline 5 & Minneapolis & USA & 3,1 & 53,0 & 1,4 \\
\hline 6 & Nowy Jork & USA & 18,7 & 52,8 & 8,5 \\
\hline 7 & Denver & USA & 2,3 & 50,3 & 1,0 \\
\hline 8 & Filadelfia & USA & 5,8 & 50,5 & 2,5 \\
\hline 9 & Dallas & USA & 5,7 & 50,1 & 2,4 \\
\hline 10 & Atlanta & USA & 4,7 & 47,8 & 1,9 \\
\hline 11 & Houston & USA & 5,2 & 47,4 & 2,1 \\
\hline 12 & San Diego & USA & 2,9 & 46,8 & 1,2 \\
\hline 13 & Londyn & Wielka Brytania & 7,4 & 46,2 & 19,9 \\
\hline 14 & Chicago & USA & 9,4 & 45,6 & 3,7 \\
\hline 15 & Los Angeles & USA & 12,9 & 45,3 & 5,0 \\
\hline 16 & Detroit & USA & 4,5 & 44,0 & 1,7 \\
\hline 17 & Baltimore & USA & 2,6 & 43,3 & 1,0 \\
\hline 18 & Paryż & Francja & 11,2 & 42,7 & 27,9 \\
\hline 19 & Cleveland & USA & 2,1 & 42,2 & 0,8 \\
\hline 20 & Portland & USA & 2,1 & 41,8 & 0,7 \\
\hline 21 & St, Louis & USA & 2,8 & 40,9 & 1,0 \\
\hline 22 & Phoenix & USA & 3,7 & 39,9 & 1,3 \\
\hline 23 & Dublin & Irlandia & 1,6 & 38,9 & 47,6 \\
\hline 24 & Pittsburgh & USA & 2,4 & 38,6 & 0,8 \\
\hline 25 & Tampa Bay & USA & 2,6 & 37,8 & 0,8 \\
\hline 26 & Wiedeń & Austria & 2,2 & 37,6 & 33,7 \\
\hline 27 & Miami & USA & 5,4 & 37,2 & 1,7 \\
\hline 28 & Sztokholm & Szwecja & 2,2 & 36,7 & 31,5 \\
\hline 29 & Stuttgart & Niemcy & 2,7 & 36,4 & 4,3 \\
\hline 30 & Mediolan & Włochy & 7,4 & 35,6 & 17,2 \\
\hline 31 & Lyon & Francja & 1,6 & 35,2 & 3,4 \\
\hline 32 & Monachium & Niemcy & 6,1 & 35,2 & 9,6 \\
\hline 33 & Oslo & Norwegia & 1,7 & 35,0 & 36,5 \\
\hline 34 & Sydney & Australia & 4,2 & 35,0 & 23,5 \\
\hline 35 & Bruksela & Belgia & 3,8 & 35,0 & 44,4 \\
\hline 36 & Toronto & Kanada & 4,7 & 34,9 & 17,7 \\
\hline 37 & Helsinki & Finlandia & 1,8 & 34,0 & 42,1 \\
\hline
\end{tabular}


Obszary metropolitalne w krajach OECD wg PKB per capita c.d.

\begin{tabular}{|c|c|c|c|c|c|}
\hline 1 & 2 & 3 & 4 & 5 & 6 \\
\hline 38 & Frankfurt & Niemcy & 5,6 & 33,6 & 8,3 \\
\hline 39 & Kopenhaga & Dania & 2,4 & 33,5 & 49,5 \\
\hline 40 & Zurych & Szwajcaria & 2,5 & 33,4 & 33,1 \\
\hline 41 & Rzym & Włochy & 3,7 & 33,1 & 8,1 \\
\hline 42 & Randstad & Holandia & 7,5 & 32,9 & 51,3 \\
\hline 43 & Melbourne & Australia & 3,6 & 32,7 & 18,6 \\
\hline 44 & Vancouver & Kanada & 2,0 & 32,0 & 6,9 \\
\hline 45 & Turyn & Włochy & 2,2 & 32,0 & 4,6 \\
\hline 46 & Auckland & Nowa Zelandia & 12 & 31,2 & 36,1 \\
\hline 47 & Hamburg & Niemcy & 4,6 & 30,9 & 6,4 \\
\hline 48 & Tokio & Japonia & 34,2 & 29,3 & 30,4 \\
\hline 49 & Montreal & Kanada & 3,4 & 29,1 & 10,8 \\
\hline 50 & Madryt & Hiszpania & 5,6 & 29,0 & 16,7 \\
\hline 51 & Aichi & Japonia & 9,1 & 28,9 & 7,9 \\
\hline 52 & Birmingham & Wielka Brytania & 2,6 & 27,8 & 4,2 \\
\hline 53 & Leeds & Wielka Brytania & 2,1 & 27,5 & 3,4 \\
\hline 54 & Zagłębie Ruhry & Niemcy & 13,4 & 27,4 & 16,4 \\
\hline 55 & Lizbona & Portugalia & 2,7 & 27,1 & 37,9 \\
\hline 56 & Osaka & Japonia & 17,0 & 26,8 & 13,8 \\
\hline 57 & Manchester & Wielka Brytania & 2,5 & 26,6 & 3,9 \\
\hline 58 & Barcelona & Hiszpania & 4,9 & 26,0 & 13,1 \\
\hline 59 & Praga & Czechy & 2,3 & 25,6 & 34,7 \\
\hline 60 & Lille & Francja & 2,6 & 23,7 & 3,6 \\
\hline 61 & Budapeszt & Węgry & 2,8 & 23,5 & 45,6 \\
\hline 62 & Warszawa & Polska & 3,0 & 23,1 & 16,2 \\
\hline 63 & Fukuoka & Japonia & 5,1 & 22,3 & 3,4 \\
\hline 64 & Walencja & Hiszpania & 2,3 & 22,2 & 5,2 \\
\hline 65 & Busan & Korea & 7,9 & 21,9 & 18,9 \\
\hline 66 & Berlin & Niemcy & 6,0 & 21,3 & 5,7 \\
\hline 67 & Ateny & Grecja & 3,9 & 20,1 & 37,6 \\
\hline 68 & Seul & Korea & 23,5 & 19,1 & 46,6 \\
\hline 69 & Monterrey & Meksyk & 3,2 & 19,0 & 6,1 \\
\hline 70 & Neapol & Włochy & 3,1 & 17,1 & 3,4 \\
\hline 71 & Meksyk & Meksyk & 18,4 & 14,3 & 26,7 \\
\hline 72 & Guadalajara & Meksyk & 35 & 13,4 & 4,6 \\
\hline 73 & Puebla & Meksyk & 2,1 & 13,1 & 2,8 \\
\hline 74 & Daegu & Korea & 2,5 & 12,3 & 3,4 \\
\hline 75 & Kraków & Polska & 2,1 & 11,2 & 5,6 \\
\hline 76 & Istambuł & Turcja & 11,4 & 10,9 & 27,1 \\
\hline 77 & lzmir & Turcja & 3,4 & 10,0 & 7,3 \\
\hline 78 & Ankara & Turcja & 4,0 & 9,6 & 8,3 \\
\hline
\end{tabular}

Źródło: [OECD 2006]. 